
HEYE FOUNDATION VOL. XV

\title{
THE AMERICAN INDIAN IN GRADUATE STUDIES
}

A BIBLIOGRAPHY OF THESES AND DISSERTATIONS

Compiled by

FREDERICK J. DOCKSTADER

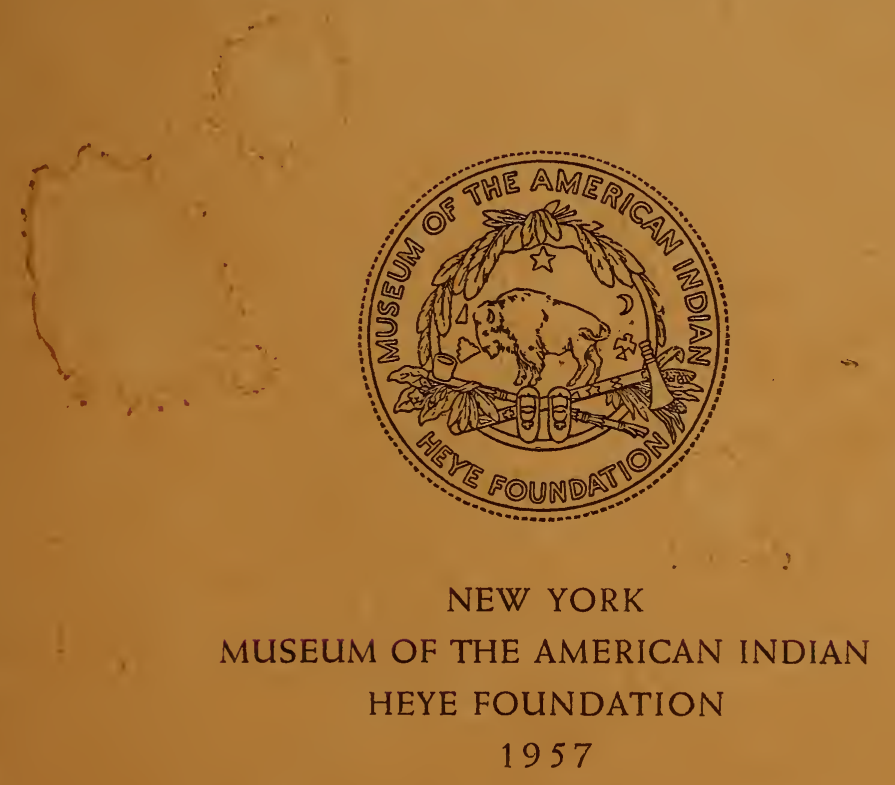





\author{
CONTRIBUTIONS FROM THE \\ MUSEUM OF THE AMERICAN INDIAN \\ HEYE FOUNDATION

$$
\text { VOL. XV }
$$

\title{
THE AMERICAN INDIAN IN GRADUATE STUDIES
}

A BIBLIOGRAPHY OF THESES AND DISSERTATIONS

Compiled by FREDERICK J. DOCKSTADER

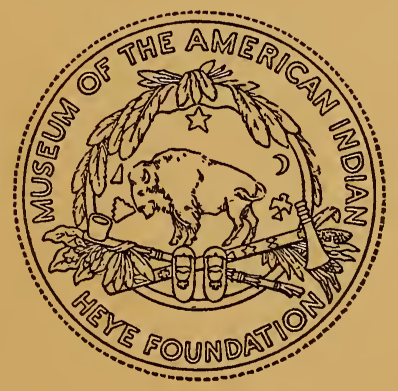

NEW YORK MUSEUM OF THE AMERICAN INDIAN HEYE FOUNDATION 
Library of Congress catalog card number 57-10880

Printed in Germany at J.J.Augustin, Glückstadt 


\section{FOREWORD}

The wealth of important data lying fallow in the many unpublished theses presented at the graduate levels in all academic disciplines has long been recognized.

When Dr. Dockstader joined our staff in September 1955, he had already compiled a considerable list of such theses covering the field of the American Indian.

This bibliography was, even then, so considerable that immediate and enthusiastic support was given to its continuation and completion.

His compilation is here presented in the knowledge that it will disclose many paths to hitherto obscure facets of research as regards the American Indian, and in the hope that such leads may make the tasks of future scholars less burdensome and more fruitful.

April 1957

E. K. BURnetT

Director 



\section{CONTENTS}

\section{PAGE}

FOREWORD

iii

Preface

vii

List of AbBreviations

xi

Roster of INSTITUTIONS

xiii

BIBLIOGRAPHY

1

ADDENDA

362

INDEX

365 



\section{PREFACE}

This bibliography lists those theses and dissertations which deal in any way with the American Indian, as presented for graduate degree requirements at colleges and universities in the United States, Canada and Mexico from 1890 to 1955. While every effort has been made to obtain as complete a listing as possible, it is fully realized that this volume at best represents perhaps three-fourths of the total number of such studies.

The selection has been deliberately extended beyond Anthropology to include all academic fields, since many of the most useful Indian studies have been prepared in several related disciplines, such as history, sociology, education, music, art, and literature.

The criterion has been the selection of all graduate studies which consider the Indian to the extent of at least one chapter-either by specific section, or scattered throughout in passim. The term Indian is here understood to include the aborigines of North, Central and South America, and the Eskimo. Archeological studies are included insofar as they consider Indian sites.

A total of 203 schools are included in this compilation. Some were checked in person by recourse to their libraries, others by examination of published abstract series or catalogues, while the balance were contacted by mail. In all, well over 400 schools were considered. Of these, 166 lacked relevant theses, 47 failed to respond to mailed inquiry, and 7 declined to coöperate in furnishing information. Since this latter group includes several sizable institutions, it can be understood why this list lacks completeness. School names are coded in the main body of the volume, and a full roster appears on pages xiii-xvii.

The bibliography does not attempt to be critical, since it was not possible personally to inspect all of the 3684 titles. It pretends only to gather these together for whatever reference value may accrue. As I have examined only approximately one-half of these theses in manuscript or in abstract form, it must be understood that many are judged wholly by title. Most of the more question- 
able titles have been checked for relevancy with Librarians, whose judgment is relied upon in such instances.

The value of these studies varies tremendously. Some are probably worthless, either because of out-dating, third-hand source material, or duplication of topic ad infinitum. Many, however, are excellent-and some contain surprising amounts of original information. On the MA level, particularly, there are many of unexpected quality; some, for example, present unusual personal experiences, or represent the unearthing of little-known local source materials. It is to aid in the exploration of these academic lodes that this volume is chiefly intended, and it is the hope of the compiler that prospectors will find the search rewarding. The list should also reveal to students and instructors alike what fields of Indian study have been over-worked or ignored.

$$
* * *
$$

For the most part the author's name is printed as given on the thesis title-page, although wherever possible middle names are added for a more complete record. There has not been a complete breakdown of degrees (MA, MS, M/ED, $\mathrm{PHD}, \mathrm{EDD}$, and so on); this information is not always available in published rosters. Wherever known, the specific degree is given; otherwise "MA" is understood as indicating work done on the Master's level, while "PHD" signifies that the study was presented for the doctoral degree. Titles are given just as they appear on the title page, or in published lists. I have retained original forms throughout, even in the face of apparent misspellings or peculiar grammar.

Dating is a victim of the erratic procedure followed by many of the published lists, which frequently fail to distinguish between seasonal commencement dates, thesis date, and awarding of the degree. Where possible the date appearing on the title-page of the thesis is used.

Pagination is indicated wherever possible, although this is extremely incomplete, since most university listings and library catalogue cards seem to regard thesis paging as an unimportant detail. The term "pages" is used arbitrarily, instead of the librarians' preferred "leaves," simply for consistency. Illustrative material is noted where known.

Details of publication are given for those theses which have been published, insofar as possible. This includes publication in whole or in part; no distinction is made in the listing, since this 
will be readily evidenced by pagination or upon inspection of the article. The published title is given only when it materially differs from that of the thesis, or to avoid confusion. References to abstracts are not included, since these are usually available only in the larger libraries; often the completed thesis is easier to obtain than the abstract.

In those instances where titles are ambiguous, I have tried to indicate areas or tribes involved by a brief annotation. Occasional comments relative to features of particular value or interest are added in order to clarify content. Tribal indication has not been judged necessary wherever made obvious by the title.

No attempt is made to indicate the availability of these studies, since this varies greatly from school to school. An inquiry directed to the library involved will readily elicit this information. For this purpose, addresses of all institutions included in the bibliography are given on pages xiii-xvii.

Many people have helped with this compilation. To list all to whom I owe a grateful acknowledgment would be to index a majority of the library personnel in most of the institutions included. I must, however, make particular mention of the encouraging coöperation of the Reference Librarians, whose courtesies and patience far exceeded my hopes. Indeed, without these, this list would be much less complete, and certainly far less useful.

As is true in most projects of this nature, a few key individuals have been more closely connected with its development in a personal way, and to ignore these associates would be ungrateful indeed. I am happy here to express my thanks for the assistance of Miss Gertrude Hill, Museum of New Mexico; Miss Jane Holden, Harvard University; Miss Wilma Kaemlein, University of Arizona; Miss Genevieve Porterfield, University of New Mexico; Dr. Douglas Schwartz, University of Oklahoma; Dr. Raymond H. Thompson, University of Kentucky; Mr. Wrayton Gardner, Western Reserve University; Sra. Carmen Cook de Leonard, Mexico D.F., Mexico; Miss Flora Diebert, University of Pennsylvania; Miss Winifred VerNooy, University of Chicago; Miss Ida-Marie Logan, Utah Agriculture College.

For typing and stenographic aid, Mrs. May A. Schneider warrants mention, and for help in organization, statistical analyses, proof-reading and general leg-work, I am grateful to my wife, Alice.

Frederick J. Dockstader 



\section{ABBREVIATIONS USED IN THIS VOLUME}

Acad. Academy

Admin. Administration

Amer. American

Anniv. Anniversary

Ännl. Annual

Annls. Annals

Anthro. Anthropological; Anthropologist ; Anthropology

Antiq. Antiquity

Archeol. Archaeological; Archaeologist; Archaeology

Assoc. Association

\section{Biog. Biography}

Bull. Bulletin

Bur. Bureau

Chi. Chicago

Cath. Catholic

col. color; colored

Coll. College

Collect. Collections

Comp. Comparative

Comm. Commission

Cong. Congress

Contr. Contributions

Dept. Department

Econ. Economics

Educ. Education

Educl. Educational

Eng. English

Ethnol. Ethnology; Ethnological

Found. Foundation

Geog. Geographic; Geographical

Hist. History ; Historical

Human. Humanistic

HRAF. Human Relations Area Files

Ill.; illus. Illustrated; Illustrations

Ind. Indian; Indians

Inst. Institute; Institution

Intl. International
Jour. Journal

Ling. Linguistics

Lit. Literature

Litho. Lithographed

M. Microfilmed

Mag. Magazine

Mem. Memoir; Memoirs

Mimeo. Mimeographed

Mono. Monograph

Mus. Museum

Nat. Natural

Natl. National

No. North; Northern

Nowest. Northwest

n. s. new series

Occas. Occasional

p. page; pages

Paps. Papers

Philol. Philology; Philological

Philos. Philosophy; Philosophical

pls. plates

Proc. Proceedings

Prov. Province; Provincial

pt. part

Pvtly. Privately

Prtd. Printed

Prtg. Printing

PuB. Published as ;

Published in

Pubs. Publications

Psych. Psychology; Psychological

Prehist. Prehistoric

Qtly. Quarterly

Rec. Records

Rel. Religion; Religions

Rept. Report

Repts. Reports

Res. Research

Rev. Review

Reprt. Reprint; Reprinted 
Sci. Science

Ser. Series

So. South; Southern

Soc. Social; Society

Sowest. Southwest

Sowestn. Southwestern

Spec. Special

Stud. Studies

Soeast. Southeast

Soeastn. Southeastern

Trans. Transactions
U;Univ. University

v.; vol. volume; volumes

var. various

\# Number

$\S \quad$ Chapter

* See page xiii

? See page xiii 


\section{ROSTER OF INSTITUTIONS}

All institutions represented in this bibliography are listed below. Code names used in the volume are presented in italics, followed by the total number of entries from that institution. In the last column are the complete names of the various schools, and their location. Schools marked * are known to be incompletely represented, due to inability to secure the needed information. Those marked? are probably not complete, although some data have been obtained. Unless so marked, it is believed that this list is reasonably complete in each instance.

Akron 2

Alabama 6

Alabama Poly. 6

Alaska 1

Alberta 1

Andover 4

Arizona 113

Ariz.-Flagstaf 7

Ariz.-Tempe 3

Arkansas 3

Asbury 1

Austin 1

\section{Ball 2}

Baylor 4

Birmingham-So. 2

Boston 1

Bowling Green 2

Bradley 2

Brigham Young 5

Brit. Columbia 10

Bryn Mawr 4

Buffalo 6

Butler 2

California 407

Canisius 2

Carver 2

Catholic 60

C. C.N.Y. 8

Cent. Washington

Chicago 159

Chico 1
University of Akron, Akron 4, Ohio

*University of Alabama, Tuscaloosa, Alabama

Alabama Polytechnic Institute, Auburn, Alabama

University of Alaska, College, Alaska

University of Alberta, Edmonton, Alberta, Canada

Andover Newton Theological Seminary, Newton Centre 59, Massachusetts

University of Arizona, Tucson, Arizona

Arizona State College, Flagstaff, Arizona

?Arizona State College, Tempe, Arizona

?University of Arkansas, Fayetteville, Arkansas

Asbury Theological Seminary, Wilmore, Kentucky

Austin College, Sherman, Texas

Ball State Teachers College, Muncie, Indiana

Baylor University, Waco, Texas

Birmingham-Southern College, Birmingham, Alabama

*Boston University, Boston, Massachusetts

Bowling Green State University, Bowling Green, Kentucky

Bradley University, Peoria, Illinois

*Brigham Young University, Provo, Utah

University of British Columbia, Vancouver 8, British Columbia, Canada

Bryn Mawr College, Bryn Mawr, Pennsylvania

?University of Buffalo, Buffalo 14, New York

Butler University, Indianapolis 7, Indiana

University of California, Berkeley 4, California

Canisius College, Buffalo 8, New York

Carver School of Missions, Louisville, Kentucky

* Catholic University of America, Washington 17, D.C.

College of the City of New York, New York 31, New York

Central Washington College of Education, Ellensburg, Washington

University of Chicago, Chicago 37, Illinois

Chico State College, Chico, California 
Cincinnati 11

Claremont 8

Clark 21

Colorado 48

Colorado $A \& M 6$

Colorado Coll. 3

Colorado State 20

Columbia 291

Cornell 23

Crozer 1

Denver 30

DePauw 1

Detroit 6

Divinity 1

Drake 5

Drew 1

Duke 6

Duquesne 2

East Texas 7

East. New Mex. 2

Emory 10

Florida 11

Florida State 8

Fordham 10

Fort Hays 4

Geo. Peabody 26

Geo. Washington 9 Georgia 3

Hardin-Simmons 7 Hartford 6

Harvard 106

Haverford 2

Howard 2

Hunter 5

Idaho 16

Illinois 26

Indiana 64

Iowa 79

John Carroll 2

Johns Hopkins 13

Kansas 50

Kansas City 7

Kans.-Emporia 7

Kans.-Pittsburg 6

Kansas State 1
?University of Cincinnati, Cincinnati 21, Ohio

Claremont Colleges, Claremont, California

Clark University, Worcester 3, Massachusetts

University of Colorado, Boulder, Colorado

Colorado Agricultural and Mechanical College, Fort Collins, Colorado

Colorado College, Colorado Springs, Colorado

?Colorado State College of Education, Greeley, Colorado

Columbia University, New York 27, New York

Cornell University, Ithaca, New York

Crozer Theological Seminary, Chester, Pennsylvania

?University of Denver, Denver, Colorado

DePauw University, Greencastle, Indiana

University of Detroit, Detroit 21, Michigan

Divinity School of the Protestant Episcopal Church, Philadelphia, Pennsylvania

?Drake University, Des Moines 11, Iowa

Drew University, Madison, New Jersey

?Duke University, Durham, North Carolina

?Duquesne University, Pittsburgh 10, Pennsylvania

East Texas State Teachers College, Commerce, Texas

Eastern New Mexico University, Portales, New Mexico Emory University, Atlanta, Georgia

University of Florida, Gainesville, Florida

Florida State University, Tallahassee, Florida

Fordham University, New York 58, New York

Fort Hays Kansas State College, Hays, Kansas

George Peabody College for Teachers, Nashville 5, Tennessee

?George Washington University, Washington 6, D. C. ?University of Georgia, Athens, Georgia

Hardin-Simmons University, Abilene, Texas

Hartford Seminary Foundation, Hartford 5, Connecticut

Harvard University, Cambridge 38, Massachusetts

Haverford College, Haverford, Pennsylvania

Howard University, Washington 1, D. C.

Hunter College, New York 21, New York

?University of Idaho, Moscow, Idaho

?University of Illinois, Urbana, Illinois

Indiana University, Bloomington, Indiana

State University of Iowa, Iowa City, Iowa

John Carroll University, Cleveland, Ohio

?Johns Hopkins University, Baltimore 18, Maryland

University of Kansas, Lawrence, Kansas

University of Kansas City, Kansas City 10, Missouri

Kansas State Teachers College, Emporia, Kansas

Kansas State Teachers College, Pittsburg, Kansas

?Kansas State College, Manhattan, Kansas 
Kent 1

Kentucky 10

Lehigh 1

Long Island 1

Louisiana 23

Louisville 2

Louisville Presb. 1

Loyola 8

\section{Manitoba 4}

Marquette 8

Maryland 4

Massachusetts 1

McGill 3

Mercer 1

Mexico 30

Mexico City 41

Mexico: EN 34

Miami 2

Michigan 25

Michigan State 3

Minnesota 20

Minnesota State 1

Mississippi 3

Miss. State 1

Missouri 9

Montana 38

Montana Coll. 1

Montréal 2

Mt. Allison 3

Nebraska 27

Nevada 1

New Brunswick 1

New Hampshire 1

New Jersey 1

New Mexico 117

New Mex. High. 4

New Mexico West.

New School 5

New York 46

New York-Albany 2

New York-Buffalo 2

Niagara 13

No. Carolina 22
Kent State University, Kent, Ohio

University of Kentucky, Louisville, Kentucky

Lehigh University, Bethlehem, Pennsylvania

Long Island University, Brooklyn 1, New York

Louisiana State University, Baton Rouge, Louisiana

University of Louisville, Louisville 8, Kentucky

Louisville Presbyterian Seminary, Louisville 2, Kentucky

Loyola University, Chicago, Illinois

University of Manitoba, Winnipeg, Manitoba, Canada

?Marquette University, Milwaukee 3, Wisconsin

University of Maryland, College Park, Maryland

University of Massachusetts, Amherst, Massachusetts McGill University, Montreal, Quebec, Canada

Mercer University, Macon, Georgia

*Universidad Nacional Autónoma, México D.F., México

Mexico City College, México 10 D.F., México

*Escuela Nacional de Antropología, Moneda 13, México D.F., México

Miami University, Oxford, Ohio

?University of Michigan, Ann Arbor, Michigan

?Michigan State College, East Lansing, Michigan

University of Minnesota, Minneapolis 14, Minnesota

Minnesota State Teachers College, Moorhead, Minnesota

?University of Mississippi, University, Mississippi

Mississippi State College, Starkville, Mississippi

University of Missouri, Columbia, Missouri

Montana State University, Missoula, Montana

Montana State College, Bozeman, Montana

Université de Montréal, Montréal, Québec, Canada

Mount Allison University, Sackville, New Brunswick, Canada

University of Nebraska, Lincoln 8, Nebraska

?University of Nevada, Reno, Nevada

University of New Brunswick, Fredericton, New Brunswick, Canada

University of New Hampshire, Durham, New Hampshire

?New Jersey State Teachers College, Upper Montclair, New Jersey

University of New Mexico, Albuquerque, New Mexico

New Mexico Highlands University, Las Vegas, New Mexico

New Mexico Western College, Silver City, New Mexico

New School for Social Research, New York 11, New York

New York University, New York 3, New York

New York State College, Albany 1, New York

New York State Teachers College, Buffalo 22, New York

Niagara University, Niagara Falls, New York

University of North Carolina, Chapel Hill, North Carolina 
University of North Dakota, Grand Forks, North Dakota

No.Dakota Agri. 3 ?North Dakota Agricultural College, Fargo, North

No. Texas 7

Northwestern 27

Notre Dame 14

Occidental 4

Ohio 8

Ohio State 27

Oklahoma 162

Oklahoma $A \& M 5$

Oregon 32

Oregon State 6

Ottawa 6

Pacific 4

Pennsylvania 98

Perna. State 12

Phillips 1

Pittsburgh 20

Princeton 2

Queen's 5

Radcliffe 4

Rhode Island 3

Rochester 3

St. Bonaventure 2

St. John's 3

St. John's Coll. 1

St. Louis 20

St. Mary's 5

Sam Houston 4

\section{Saskatchewan 1}

Seattle 1

S. F. Austin 1

Simmons 1

Smith 5

So. California 118

So. Carolina 2

So. Dakota 17

So. Dakota State 1

So. Methodist 15

Southwestern 3 Dakota

North Texas State Teachers College, Denton, Texas

?Northwestern University, Evanston, Illinois

University of Notre Dame, South Bend, Indiana

Occidental College, Los Angeles 41, California

Ohio University, Athens, Ohio

Ohio State University, Columbus 10, Ohio

University of Oklahoma, Norman, Oklahoma

3 Oklahoma Agricultural and Mechanical College, Stillwater, Oklahoma

University of Oregon, Eugene, Oregon

Oregon State College, Corvallis, Oregon

University of Ottawa, Ottawa, Quebec, Canada

College of the Pacific, Stockton, California

University of Pennsylvania, Philadelphia 4, Pennsylvania

Pennsylvania State College, State College, Pennsylvania

Phillips University, Enid, Oklahoma

?University of Pittsburgh, Pittsburgh 13, Pennsylvania

*Princeton University, Princeton, New Jersey

Queen's University, Kingston, Ontario, Canada

Radcliffe College, Cambridge, Massachusetts

Rhode Island College of Education, Providence, Rhode Island

University of Rochester, Rochester 20, New York

St. Bonaventure University, St.Bonaventure, New York

St. John's University, Brooklyn 6, New York

St. John's College, Cleveland, Ohio

?Saint Louis University, St. Louis 3, Missouri

St. Mary's University, San Antonio, Texas

Sam Houston State Teachers College, Huntsville, Texas

?University of Saskatchewan, Saskatoon, Saskatchewan, Canada

Seattle University, Seattle 22, Washington

Stephen F. Austin State College, Nacogdoches, Texas

Simmons College, Boston, Massachusetts

Smith College, Northampton, Massachusetts

University of Southern California, Los Angeles 7, California

?University of South Carolina, Columbia, South Carolina

University of South Dakota, Vermillion, South Dakota

?South Dakota State College, College Station, South Dakota

?Southern Methodist University, Dallas, Texas

Southwestern University, Georgetown, Texas 
Sowestn. Bapt. 1

Sowest. Texas $\tilde{7}$

Stanford 55

Stetson 1

Sul Ross 15

Syracuse 6

Temple 8

Tennessee 13

Texas 121

Texas $A \& I 3$

Tex. Christian 2

Texas Tech. 16

Texas Westn. 1

Toledo 1

Toronto 7

Trinity 5

Tulane 5

Tulsa 10

U.C.L.A. 13

Union 1

Utah 5

Utah Agri. 6

Vanderbilt 15

Virginia 15

Washington 55

Washington/SL 25

Wash. State 7

Wayne 7

Wellesley 1

West. Colorado 4

West. Ontario 3

West. Reserve 11

West Texas 3

West Virginia 1

West. Washington 1

\section{Whittier 2}

Wichita 6

Willamette 2

William-Mary 1

Williams 2

Wisconsin 37

Wittenberg 2

Wyoming 17

Yale 110
Southwestern Baptist Theological Seminary, Fort Worth, Texas

?Southwest Texas State Teachers College, San Marcos, Texas

Stanford University, Palo Alto, California

Stetson University, DeLand, Florida

Sul Ross State College, Alpine, Texas

Syracuse University, Syracuse 10, New York

Temple University, Philadelphia 22, Pennsylvania

?University of Tennessee, Knoxville, Tennessee

University of Texas, Austin 12, Texas

Texas College of Arts and Industries, Kingsville, Texas

?Texas Christian University, Fort Worth, Texas

Texas Technological College, Lubbock, Texas

Texas Western College, El Paso, Texas

University of Toledo, Toledo 6, Ohio

?University of Toronto, Toronto 5, Ontario, Canada

Trinity College, Hartford, Connecticut

Tulane University, New Orleans 18, Louisiana

University of Tulsa, Tulsa 4, Oklahoma

?University of California at Los Angeles, Los Angeles 24, California

Union Theological Seminary, New York 27, New York

?University of Utah, Salt Lake City, Utah

Utah State Agricultural College, Logan, Utah

?Vanderbilt University, Nashville 5, Tennessee

?University of Virginia, Charlottesville, Virginia

?University of Washington, Seattle 5, Washington

?Washington University, St. Louis 5, Missouri

State College of Washington, Pullman, Washington

Wayne University, Detroit 1, Michigan

Wellesley College, Wellesley, Massachusetts

?Western State College of Colorado, Gunnison, Colorado

?University of Western Ontario, London, Ontario, Canada

Western Reserve University, Cleveland 6, Ohio

West Texas State College, Canyon, Texas

?West Virginia University, Morgantown, West Virginia

Western Washington College of Education, Bellingham, Washington

Whittier College, Whittier, California

Municipal University of Wichita, Wichita, Kansas

Willamette University, Salem, Oregon

?College of William and Mary, Williamsburg, Virginia

Williams College, Williamstown, Massachusetts

University of Wisconsin, Madison 6, Wisconsin

Wittenberg College, Springfield, Ohio

University of Wyoming, Laramie, Wyoming

Yale University, New Haven, Connecticut 

Аввотt, Hazel Belle

MA 1924

Columbia

[1]

And what of the Indian? His literature and his treatment in our dramatic literature.

Not seen; copy missing from Library.

Abel, Annie Heloise Henderson MA 1900 Kansas

Indian Reservations in Kansas and the extinguishment of their title. 38p. Рuв: Kans. State Hist. Soc., Collect. VIII [1902] p72-109.

Abel, Annie Heloise Henderson PhD 1905 Harvard The history of events that resulted in Indian consolidation west of the Mississippi River. PuB: Amer. Hist. Assoc., Annl. Rept., I [1908] p233-450.

Abel, LeLand J. MA 1954

New Mexico

Pottery of the Mesa Verde and the Pueblo area north of the San Juan. 89p.

\section{Aberle, David Friend PhD 1950}

Columbia

The reconciliation of divergent views of Hopi culture through the analysis of life-history material. 431p. $M$. PUB: "Psychosocial analysis of a Hopi life-history." U/Calif., Comparative Psych. Mono., XXI \#1 [1951] 133p.

An effort to reconcile many differing interpretations of Hopi culture, based on Simmons' Sun Chief.

Abrams, H. Leon, JR. MA $1950 \quad$ Mexico City

A commentary on the Colonial section of the Codex Telleriano-Remensis with an appendix of comparative tables of events compiled from thirteen Colonial annals from the Valley of Mexico. 73p., facsimile illus.

Acosta Saignés, Miguel MA 1956 Mexico: $E N$ El comercio de los aztecas.

AcUÑa, HeCtor RubÉN $\quad$ MPH 1951

Yale

Public health administration of maternal and child services in the State of Coahuila, Mexico. 80p. 
A study of culture resistance: the veterans of World War II at Zuñi Pueblo. 200p. PuB: "Navaho and Zuñi veterans: a study of contrasting modes of culture change." Amer. Anthro., LI \#4 [1949] p547-461.

Adatr, Mildred LeE

MA 1938

Florida State

The establishment, growth, development, and functioning of the Federal day school on the Navajo Reservation since $1935.87 \mathrm{p}$.

Adams, Allen F. MA 1940

Sowest. Texas

The leader of the Volunteer Grays-the life of William G. Cooke, 1808-1847. 82p., illus.

Includes his Indian affairs career.

Adams, Blanche Valrea

MA 1930

Colorado

Colorado in the Civil War.

Much on Indian activity during the period; Ute chiefs took advantage of lack of military protection to raid towns.

Adams, Dorothy Inez MA 1928

California

North American Indian basketry hats. 22p., illus.

Discusses hats of 56 different tribes.

Adams, Forrest John MA $1930 \quad$ New Mexico

The normal mental growth of Indian sub-adults: Pueblo and non-sedentary subjects. 29 p.

Adams, Harold Edgar PhD 1929 Yale

Divorce in primitive societies: a study preliminary to a general survey of the evolution of divorce. 211p., many tables.

North and South American Indians included.

Adams, John ARthur MA 1934 Pittsburgh

The character of the British Indian trader in the upper Ohio Valley from 1725 to $1776.84 \mathrm{p}$.

Ottawa, Delaware, Miami, Shawnee, Catawba.

Adams, John Boman PhD 1946

Chicago

Contributions to the study of Maya art and religion. 131p. 
Adams, Mary C.

MRE 1948

Carver

Reasons for evangelical missions in South America. 56p.

Incidental references to Andean, Inca Indians.

Adams, Mary Elisabeth MA 1927 Chicago

The influence of the Indians on Georgia's adoption of the Federal Constitution. 59p.

Adams, Richard Newbold PhD $1950 \quad$ Yale

Muquiyauyo. 404p., pls.

Study of a Peruvian Indian community.

Adams, William Richard MA 1949

Faunal remains from the Angel Site. 56p., charts.

Indiana

Excavation in Vanderburgh County, Indiana.

Adis-Castro, Elias $\quad$ MA 1950

Indiana

$[22]$

The racial relationships of the Dominica Caribs. 83p.

Carib, Arawak, Oajana, Maya.

Adkins, Roy Lee MS/Ed 1955

No. Dakota

[23]

A study of the social composition and educational background of the Indian Service teachers in the Aberdeen area in 1954-1955. 70p.

Adkinson, Henry Magel MA 1897

Chicago

Conceptions of property among North American Indians. $31 \mathrm{p}$.

AdRIEN, FAther MA 1954

Ottawa

Les Micmacs de Restigouche. Rapport d'une enquête anthropologique. 114p.

Aginsky, Ethel G. MA 1933

Columbia

A critical review of Waldemar Jochelson's unpublished Aleutian Grammar, and an analysis of some text material. $64 \mathrm{p}$.

Agnew, MrRiam MA 1937

Denver

A contrast of Parkman's The Oregon Trail to similar works in the same period of the early West. 125p.

Agogino, George MA 1950

New Mexico

A study of the stereotype of the American Indian. 98p. 
Aguilar Piedra, Carlos H. MA 1956 Mexico: $E N$

Técnica de la orfebrería pre-hispánica. Puв: Acta Anthropologica II \#2 [1948] 139p.

Agutrre Tormes, Armando MA 1956 Mexico: $E N$

Problemas de la poblaciones totonacas, según el análisis de los datos censales y antropológicos.

Ahearn, Margaret Mary MA 1947

Clark

The Indians and the Government in the Northwest, 1783-1795. 123p.

The Old Northwest Territory.

AHLF, Mildred Gray MA 1911 California

[32]

Neve's Instructions of 1782 and the first Spanish Governors of California. 21p.

References throughout to Indians at missions.

Aiton, Arthur Scott MA 1918 California

The establishment of the Viceroyalty in New Spain. 123p.

Aiton, Arthur Scott $\quad$ PhD $1923 \quad$ California

Antonio de Mendoza, first Viceroy of New Spain. PuB: Duke U. Press [1927] 240p.

Early Spanish contacts with the Indians.

AKright, Ora Faye MA 1924

Kansas

Indian land cessions to the United States. 121p.

ALA, VIOLA MA 1949

So. Dakota

The problems related to the assimilation of the Indian in South Dakota. 101p.

alba Hermosillo, Carlos H. LD $1939 \quad$ Mexico

Estudio comparativo entre el derecho azteca y el derecho positivo mexicano. 130p. Р UB: Interamerican Ind. Inst. [1949] 140p.

Alberts, Robert Charles MS 1951 Wisconsin

A study of trade silver and Indian silverwork in the Upper Mississippi Valley. 137p. PuB: "Indian trade silver." Wisc. Archaeol., XXXIV \#1 [1953]. p 1-121.

Iroquois, Oneida, Menomini. 
The American Indian and his song. 50p.

Bannock, Shoshoni (mainly at Fort Hall Reservation).

Alden, Dauril MA 1953

California

The early history of Bahia, 1501-1553. 239p., maps.

Chapter on Indians of Brazil: Tupina, Tupinamba, "Tapuya".

Alden, John Richard PhD 1939

Michigan

Imperial management of Indian affairs in the South, 1756-1775. PUB: John Stuart and the Southern Colonial Frontier: A study of Indian relations, war, trade, and land problems in the southern wilderness, 1754-1775. U/Mich. Press [1944] 384p.

Especially concerned with Stuart's activities as Superintendent of Indian affairs.

ALdRICH, RICHARD L. MA $1936 \quad$ Arizona

A survey of prehistoric Southwestern architecture. 91p.

ALEgRÍa, Ricardo MA 1946

Chicago

Cacicazgo among the aborigines of West Indies.

Alexander, Edward Porter MA 1931 Iowa

The Earl of Bellomont, Colonial Governor of New York, Massachusetts and New Hampshire, 1698-1701. 178p.

Chapter on Iroquois.

Alexander, Elinor M. MA/LS $1945 \quad$ Columbia Federal public documents relating to the Pacific Coast region 1817-1850. 141p.

Allegrezza, Tore S. MA 1939 Colorado

Historical survey of the changing character of Indian schools. $121 \mathrm{p}$.

Aluen, Agnes Morgan PhD 1937 Clark

The sequence of human occupancy in the Middle Rio Verde Valley, Arizona.

Chapters on prehistoric and historic Indians of the area, especially Yavapai. Good selection of original photographs. 
Allen, Dorothy Eastman MM 1941 So. California

Indian music of Mexico up to the period of the Conquest and the culture which made it what it was. $454 \mathrm{p}$.

Allen, Eugene Vaughn MA 1939 Oklahoma $A \& M$ Development of law and legal institutions among the Creek Indians. 79p.

Allen, Henry Easton MA 1923 California

The destruction of the San Saba Mission, and the Parrilla expedition. 140p.

Apaches in missions, and attacks by Comanche, Wichita, Tonkawa, Texas, Bidai and other Caddo Indians.

Allen, Nannie Flo MA 1949 Oklahoma

A study of rhetorical style in selected messages of Principal Chiefs of the CherokeeNation between1860 and1880.174p.

Allen, S. T. MS $1941 \quad$ No. Texas

Early settlement of the Concho country. $98 \mathrm{p}$.

$\S 1$ Early missions to Indians. § 2 Indian struggles.

ALLEN, WinNie MA 1925

Texas

History of Nacogdoches, 1691-1830. 149p.

Two chapters on Indians and Indian affairs.

Aller, Diane Lee MA 1954 New Mexico

A survey of Southwestern Indian stone, shell, and bone sculptures. $77+126 \mathrm{p}$., illus.

Illustrated with examples of San Juan, Little Colorado, Gila, Salt and Rio Grande sculpture.

Allgood, Samuel Young MA 1927 Oklahoma

Benevolent activities of the United States among the Indians. $67 \mathrm{p}$.

Allshouse, John Clayton MA 1947 Oklahoma

The sculptural arts of the Pacific Northwest Coast Indians. 96p.

Alspach, Addison M. PhD $1933 \quad$ Iowa

Tomesha, a tone poem.

Tomesha: "Ground afire"; an Indian legend re-told in music. Death Vally, California, locale. 
Alsup, Frances McNeIll MA 1943

A history of the Panhandle of Texas. 241., maps.

U.C.L.A.

[58]

Chapter on the Indians of the Panhandle and their Reservations.

Altergott, Alexander, JR. MA 1932 So. California An economic history of the valley of the Mohaves. 132p., illus.

Ames, Susie May PhD 1940

Columbia

Studies of the Virginia eastern shore in the seventeenth century. PUB: Richmond: The Dietz Press [1940] 274p.

Brief sections on Indians as slaves; Indians in passim.

Amir, Raymond Gene MA 1954 California

Religious and political changes in a Guatemalan village. 55p., photos.

Magdalena Milpas Altas village; XX century.

Ammon, Soloman R. M/Ed 1935 So. California

History and present development of Indian schools in the United States. 104p.

Ammons, Nancy Caroline MA 1931 Oklahoma The Spanish Conquest of New Mexico in the sixteenth and seventeenth centuries. $96 \mathrm{p}$.

Amoss, Harold Lindsay, JR. MA 1947 New Mexico Variation in two culture traits in the Plains area. $97 \mathrm{p}$. Tipi and myth diversity.

Amoss, Harold Lindsay, JR. PhD 1951 California The Ute Mountain Ute: a study in differential borrowing.

Anderson, Arthur James O. MA 1931 Claremont A study of the ethnography of Mexico, based chiefly on the Mexican census of 1921. 103p.

Anderson, Arthur James O. PhD 1940 So. California Eclipse rituals and procedures of North American Indians in relation to their ceremonial patterns, from the point of view of social psychology. 366p.

Anderson, Barbara Louise MA 1955 Kans.-Emporia The Southwestern Indian in contemporary American 
literature, 1920-1955; an annotated booklist for adolescent readers. $67 \mathrm{p}$.

Anderson, Dorothy Ann MA $1949 \quad$ California

The Indian in colonial New England: an introductory study.

Anderson, Frank Gibbs PhD $1951 \quad$ New Mexico The Kachina cult of the Pueblo Indians. 3 vols.

ANDERSon, HaRry $\mathrm{H}$. MA 1954

So. Dakota

A history of the Cheyenne River Indian Agency and its military post, Fort Bennett, 1868-1891. 221p.

Anderson, Helmi Kraeman MA 1951 Mexico City Survey of techniques in mural painting from the primitive to the present day. 63p., illus.

While primarily concerned with contemporary mural work, preConquest techniques are included.

Anderson, Hobson Dewey PhD $1932 \quad$ Stanford

A social study of the Alaskan Eskimo. PuB: with W. C. Eells, Alaskan Natives: a survey of their sociological and educational status. Stanford U. Press [1935] 488p.

Considers education and health programs to find if curriculum applies to needs. Suggests outline for future use.

ANderson, Lowell Edgar MA $1953 \quad$ California

Factors influencing design in Navajo weaving.

ANDERSON, Robert PHD 1951 Michigan

A study of Cheyenne culture history, with special reference to the Northern Cheyenne. 279p. $M$.

Tongue River Reservation, Montana.

Andrade, Manuel José PhD 1933 Columbia Quileute. PUB: Handbook of American Indian Languages, III. Columbia U. Press [1933] p151-292.

A linguistic study.

Andrews, Anne Margaret MA 1942 So. California

The economic value of the buffalo. 
Siwahpa. 198p.

Fictional account of pioneer missionaries of Good Will Presbyterian Mission (called Wahpana Mission), So. Dakota. Siwahpa: name of reservation in this account.

Andrews, Dorothy Craighead MA 1931 Pennsylvania Preliminary geographical survey of the burial types of North American Indians, suggestions on the possible influences on the distribution. $261+23 p$.

\section{Andrews, Edward Wyllys IV PhD 1942 Harvard}

The archaeology of southwestern Campeche and its position in Maya history. PUB: Carnegie Inst. Wash., Contr. Amer. Anthro. Hist. \#40 [1943] 100p., illus.

Andrus, Thekra Nowatny MA 1950 Texas $A \& I$

Sam Houston and the Indians. 74p.

\section{Anger, Charles Leroy MA 1933}

Virginia

Thomas Cresap, a Maryland frontiersman.

Six Nations Indians considered, but only as incidental to frontier life; Cresap hated them, and author claims Maryland handled Indian affairs poorly.

Anson, Bert $\quad$ PhD 1953

Indiana

The fur traders in northern Indiana, 1796-1850. 322p. $M$.

Considerable attention given to Indian fur trading, WhiteIndian relations, Indian removal, etc.

Anthony, Albert Stephen PhD 1955 Harvard

A cross-cultural study of factors relating to male initiation rites and genital operations. 214p.

World-wide; considers HRAF data from 190 societies. Statistical analysis, with tribal distribution of traits.

Anthony, Ross Orlando MA 1930 So. California

A history of Fort Laramie. 133p., illus.

Includes relations between military and Sioux, and role of Fort Laramie in Sioux Wars of $1864-68$ and 1876.

Applebaugh, Pauline MA 1951

Mexico

[84]

Estudio de dioses, leyendas y costumbres indígenomexicanas pre-Colombianas. 
Guatemala and the United Fruit Company. 223p.

Appendix I: "The Guatemalan Indians" p208-215.

Appley, Daisy Marie MA 1923 Columbia

The United States Government and the American Indian since the Civil War. 51p.

Arbour, Colette MA 1950

Montréal

La diplomatie iroquoise. 106p., illus.

Archer, Kate Worthington MA 1925 California

The formation of the Territory of Idaho. 109p.

Includes section on missionary work among Nez Percés and Flatheads, as well as Indian wars in the area: Kutenai, Shoshone, Bannock, Coeur d'Alene, Pend d'Oreille, Tukuarika.

Armstrong, John Muton $\quad$ PhD $1949 \quad$ Yale

A Mexican community: a study of the cultural determinants of migration. $516 \mathrm{p}$., pls.

Chavinda, Michoacán; part Tarascan, mostly mestizo.

Armstrong, Marion Page MA 1954 No. Dakota Agri. These immortal few. 255p.

Teton Sioux.

Armstrong, Robert Gelston MA 1942 Oklahoma The acculturation of the Cheyenne and Arapaho Indians.

Arnold, Brigham Alicen PhD 1954 California Landforms and early human occupation of the Laguna Seca Chapala area, Baja California, Mexico.

ArNold, Dorothy Audora MA 1952 Tennessee Some recent contributions of the Cherokee Indians of North Carolina to the crafts of the Southern Highlands. $122 \mathrm{p}$.

Arnold, Dovie Mae MA 1938

Austin

American Indians in fiction.

Arntzen, Ruth M. MA 1936

Arizona

The influence of prehistoric religious ceremonies upon the living Indian tribes of the Southwest. 100p. 
Aschmann, Harold Homer PHD 1954 California central desert of Baja California.

Ash, Harry CURTIS MA 1932 Emory

Ethnology of the Indian tribes formerly occupying the Territory of Georgia. 140p.

Yuchi, Cherokee, Muskogee.

Ashby, Robert L. MA $1953 \quad$ Mexico City [100] Aztec human sacrifice; some psychological observations. $43 p$.

Ashton, Dudley $\quad$ PhD 1951

Iowa

An ethnologic approach to regional dance. $797 \mathrm{p}$.

Examines dance forms, world-wide. $\S 2$ "Regional dances of the First Americans". § 8 "Indian influences" (on Latin American dances).

Askins, Arthor Dale MA 1930

Ohio State

[102]

The history of the Santa Fé Trail.

Indian references scattered throughout.

Atherton, Lewis Eldon PhD $1937 \quad$ Missouri

The pioneer merchant in Mid-America. Рuв: U/Missouri Stud., XIV \#2 [1939] 135p.

$\S 5$ "Other business ventures: the Indian Trade".

Atherton, Lucien C. MA $1930 \quad$ California

The early history of the San Diego Presidial district, 1542-1782. 133p., pls.

Shoshoni and Yuma.

Atkeson, Mary Meek PhD 1919

Ohio State

[105]

A study of the local literature of the Upper Ohio Valley, with especial reference to the early pioneer and Indian tales, 1820-1840. Р \#2 [1921] 62p.

Atkin, William Tennyson MA 1932 California

The history of the fur trade in Snake River Valley to 1824. 113p. 
Attig, Chester Jacob PhD 1921

Chicago

[107]

The institutional history of the Northwest Territory, 1787-1802.

Treaty of Greenville (1795), and Indian Removal as affecting Kentucky and Ohio. Includes brief consideration of Great Lakes Indians in general.

Attwell, Walter G. MA 1938 Arizona

The excavation of Father Kino's second church and the [108] development of the missions of Pimería Alta. 200p.

Austin, Teresita MA 1943

Notre Dame

The early Ottawa Indian missions of the Grand River Valley, Michigan. 128p.

Austin, Wilfred Gordon

MA 1932

Stanford

An educational study of the Pima Indians of Arizona.

Aveleyra Arroyo de A., Luís MA 1956 Mexico: $E N$ El hombre de Tepexpan y sus problemas.

Avery, Essie JANE MA $1940 \quad$ Oklahoma $A \& M$ The social and economic history of the Quapaw Indians since 1833. 80p.

Avery, Orville Ellis MA 1940

Oklahoma

Confederate defense of Texas, 1861-1865. 121p.

Chapter "Defense against the Indians".

Ayers, Solon G. PhD 1952

Kansas

An investigation of terminal vocational education at Haskell Institute. 190p.

Bach, Arthur Lawrence MA 1937

No. Dakota

The United States Government Indian land policy. 90p.

Bach, Arthur Lawrence PhD 1942.

Iowa

Administration of Indian resources in the United States, 1933-1941. 293p.

Divides administration into four periods; 1778-1871, 1871-1887, 1887-1933 and 1933-1941; considers the latter in particular detail. 
BAdger, ANGeline MA/Ed 1938

An activity program for Indian children.

For Pima and Papago Indians, as worked out at Tucson [Indian] Training School at Escuela, Arizona.

Baerreis, David Albert PhD 1951 Columbia The preceramic horizons of northeastern Oklahoma. Pub: U/Mich. Mus., Anthro. Paps. \#6 [1951] 121p.

BAGBy, Lionel B. MA 1950 Mexico City Mesoamerican figures of the type called Chac Mool. 114 p., illus.

BaHAMonde, Wenceslao Oscar STM 1943 Hartford The religious aspects of the Spanish Conquest and Colonial period of Peru. 111p.

Bahar, Hushang Ma 1955

Montana Pend d'Oreille kinship. 89p.

Kalispel Indians.

Batley, Alfred Goldsworthy PhD 1934 Toronto The conflict of European and eastern Algonkian cultures, 1504-1700. A study in Canadian civilization. Р Uв: New Brunswick Prov. Mus., Mono., Ser. \#2 [1937] 206p.

BaIley, Alvin Keith PhD 1948 Yale

The strategy of Sheldon Jackson in opening the West for national missions 1860-1880. 492p.

Drawing upon original material, considers his pre-Alaskan career -especially among Chippewa, Choctaw, Zuñi.

Batley, Flora louise PhD 1947

New York [124] The beliefs and practices of the Navaho Indians pertaining to the reproductive cycle. 302p. Р бв: Harvard $U$., Peabody Mus., Paps., XL \#2 [1950] 108p.

BAILEy, Lois Ruth MA 1932

Stanford

The Indian problem in California, 1848-1860. 130p.

BaIley, Mary Hewett MA 1937

The history of Grady County, Oklahoma. 86p.

Oklahoma

Choctaw, Chickasaw; land allotments, accessions and treaties. 
An evaluation of the musical expression of the Southern California Indians. 91p.

BAILEY, WILFRID C.

MA 1942

Arizona

The distribution of circular pit houses in the Southwest. $184 \mathrm{p}$.

Includes extended comparisons with Plains, Plateau, Eskimo and Siberian structures. Examines 80 Southwest sites, 300-1100 $\mathrm{AD}$, and charts various traits.

Batrd, Helen Delphine MS/LS 1939 Columbia The use and accuracy of accounts of the Lewis and Clark expedition in children's literature published from 1806 through December 1938. 142p., illus.

Baker, Augusta MA 1926

Denver

Ute Indians. 283p., 15 color pls.

Baker, Louise Crafton MA 1926

Oklahoma [131]

A history of Tahlequah. $79 \mathrm{p}$.

Cherokee and White relations, 1690-1926.

Baker, Mary Anna MA 1910

California

[132]

Early Spanish colonization in California directed by Rivera y Moncada. 295p.

BaKer, VIOLET HanNaH MA 1925

California

Methodist missions in the Northwest (United States) before $1846.96 \mathrm{p}$.

Especially concerned with mission to the Flatheads.

Bakken, Charlotte Toelle MA 1949 Wisconsin

Preliminary investigations at the Outlet Site (DA 3). 157p. Puв: Wisc. Archaeol., XXXI \#2 [1950] p43-70.

Report of excavation at Lake Monona, Wisconsin.

Balcomb, Mary Florence MA 1924

Chicago

The social position of the Peruvian Inca under the Inca, the Spanish, and the Republic.

Baldus, Fred MA 1923

Chicago

[136]

John Eliot's work among the American Indians. 41p. 
Baldwin, Gordon Cortes

MA 1934

Arizona

[137]

The prehistoric Pueblo of Kinishba. Рणв: "The material culture of Kinishba." Amer. Antiq., IV \#4 [1939] p314 to 327 .

Baldwin, Gordon Cortes PHD 1941 So. California The archaeology of the Upper Salt River Valley, Arizona: its sequence and inter-relationships. $307 \mathrm{p}$.

Ballenger, Thomas Lee PhD $1938 \quad$ Oklahoma The development of law and legal institutions among the Cherokees. 218p.

Balling, Josephine Juanita MA 1933 So. California Life of Joel Palmer. 86p.

Palmer figured in pacification and Reservation settlement of Oregon Indians (1860s).

Ballotti, Geno A. MA 1955 The Southwest Indian in fiction.

Wyoming

Balyeat, Frank Allen PhD 1927

Stanford Education in Indian Territory. 279p.

Particularly concerned with Five Civilized Tribes of Oklahoma; compares education facilities offered Indian, Negro and White.

Bandy, Mary Esther MA $1939 \quad$ Colorado State The cliff dwellers of Mesa Verde National Park. 96p.

Banks, Eugene Pendleton $\quad$ PhD 1954 Harvard An inquiry into the structure of Island Carib culture. 263p., photos.

Banks, WiLliam $\mathrm{H}$. MA 1953

Tennessee

Ethnobotany of the Cherokee Indians. 216p.

BANNISTER, BRyant MA 1953 Arizona Tree-ring analysis as applied to the dating of Kin Kletso ruin, Chaco Canyon, New Mexico. 38p.

Bannon, John Francis PhD 1939

California [147] The Jesuits in Sonora: 1620-1687.

Pima Bajo, Opata. 
Baptist, Mary MS/Ed 1923

Mission schools in the Indian Territory. 78p.

Oklahoma

[148]

Missions 1820-1889 among Osage, Creek, Cherokee, Choctaw, Seminole, Cheyenne, Arapaho.

Baptiste, Paul Francis MA 1933 So. California Pedro de Valdivia and the founding of Chile. 130p., illus.

Recounts his unsuccessful attempt to conquer the Araucanians.

Barba de Piña Chan, Beatriz MA 1956 Mexico: EN Tlapacoya, un sitio preclásico de transición.

Barber, Carroll G. MA 1952

Arizona

Trilingualism in Pascua: the social functions of language in an Arizona Yaqui village. 127p.

Barclay, Harold Barton

MA 1954

Cornell

Some factors in a themal analysis of a culture with special reference to the Slave Indians. 106p.

Barker, Willette Spragg MA 1940 New York Masks of the American Indian. 68p., illus.

Barmann, Carlos MA 1922

Notre Dame

A sketch of missionary life in the Northwest Territory. $90 \mathrm{p}$.

Barnard, Helen Donovan

MA 1939

Texas

Early history of research in Texas archaeology by the Department of Anthropology, and the history of the Anthropology Museum of the University of Texas. 284p., illus.

Discusses research in the field of Indian studies.

Barnard, Herwanna Becker MA 1941 Oklahoma

The Comanche and his literature, with an anthology of his myths, legends, folktales, oratory, poetry and songs.

Barnes, Margaret Louise MA 1933

Oklahoma

Intruders in the Cherokee Nation, 1834-1907. 143p.

i.e., White homesteaders in Indian Territory; includes considerable original material. 
Barnes, Nellite. MA 1920

Kansas

American Indian verse-A study of characteristics. PUв:

"American Indian verse; Characteristics of style." U/

Kans., Bull., Human. Stud., II \#4 [1921] 63p.

All but Southeast area; extensive bibliography.

Barnett, Homer Garner PHD 1938 California The nature and function of the potlatch. PUB: Amer. Anthro., XL \#3 [1938] p349-358.

BARNOUW, VICTOR

PhD 1950

Columbia Acculturation and personality among the Wisconsin Chippewa. Р вв: Amer. Anthro. Assoc., Mem. \#72 [1950] $152 \mathrm{p}$.

Barre, Eltzabeth Freeman MA 1941 So. Carolina A study of the Indian in William Gilmore Simms' novels and short stories. $117 \mathrm{p}$.

Barrett, Lynn Murray MA 1924 California [162] McKenzie, McDonald and Ross in the Snake River country. $405 \mathrm{p}$.

Barrett, Rita ANgela MA $1936 \quad$ Columbia $[163]$ Motif development in early Peruvian textiles. 22p., illus.

Barrett, Samdel Alfred MA $1906 \quad$ California [164] The ethno-geography of the Pomo and neighboring Indians. 332p., maps. Puв: U/Calif., Pubs. Amer. Archaeol. Ethnol., VI [1908] 332p.

Barrett, Samuel Alfred PhD 1908 California Pomo Indian basketry. 308p., illus. Р бв: U/Calif., Pubs. Amer. Archaeol. Ethnol., VII \#3 [1908] p133-308, illus.

Barron, Leona Stamps MA 1939 Oklahoma The penetration of the Whites into the Chickasaw Nation, 1866-1907. 98p.

Barrow, Thomas WILEy MA 1948 Sul Ross

[161]

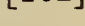
Another step westward. 75p., illus.

Mescalero Apache and other tribes. 
The ethno-botany of the Coahuila Indians of Southern California. PUB: U/Chi. Press [1900] 82p.

Barry, Gerald L. MA 1950

Alberta-Montana relationships. Рणв: The Whoop-up Alberta Trail. Edmonton, Alberta: Applied Arts Prod. [1953].

$\S 2$ is devoted to aboriginal inhabitants of the area.

Barter, Eloise Richards MA 1955 Arizona An analysis of the ceramic traditions of the Jewett Gap Site, New Mexico. 87p.

Barth, Arthor August

MA 1937

St. Louis

Guide to materials for the history of the Indian missions of the trans-Mississippi West (exclusive of De Smetiana) in the archives of St. Louis University. $106 \mathrm{p}$.

Barth, Florence Edith

MA 1914

California

The Terán expedition into Texas and Louisiana. Translation of the original documents with introduction and notes. $228 \mathrm{p}$.

Barth, Pius J. PhD 1945

Chicago

Franciscan education and the social order in Spanish North America (1501-1821). PuB: U/Chi. Press [1945] $431 \mathrm{p}$.

Bartlett, Florence Emily MA 1920 Colorado Coll. Administration of New Mexico in the seventeenth century. $61 \mathrm{p}$.

\section{Bartlett, Richard A. PhD 1953}

Colorado

The Great Surveys in Colorado: 1867-1879.

Indians considered as they were encountered by the King, Wheeler, Hayden and Powell surveys.

Barton, Walter C. MA $1939 \quad$ Colorado $A \& M$

The educational experiences inherent in the construction of a Sioux Indian home. $44 \mathrm{p}$.

Barton, William George MA 1919

Columbia

The Utah Indian War, known as the Black Hawk War of $1865-6-7$. 76p., maps.

Includes considerable unpublished original material. 
Baseheart, Harry Wetherald PhD 1953 Harvard

[178]

Historical changes in the kinship system of the Oneida Indians. 311p.

Bass, Mary Frances $\quad$ MS 1942 Alabama

A study of place names of Clarke County, Mississippi. Indian place names are included.

Bass, William Marvin III MS 1956

Indian crania from Moundville, Alabama. Illus.

Bastien, Pierre A. Rémy PhD 1956 Mexico: EN

La Pirámide del Sol de Teotihuacán. PuB: 29 th Intl. Cong. Americanists, Paps., pt. 1 [1951] p62-67.

Bates, Lana Louise MA 1930

California

Historical geography of California, 1513-1835. 103p.

Sections on native inhabitants and Indian missions.

Bates, Lorna Doone MA 1934

Iowa [183]

The Noble Savage in the works of Thoreau.

Bateson, Mildred Mellor MA 1925 Chicago Architecture among the American Indians. 97p., illus.

Batson, James Edward MA 1928

Texas

The beginnings of Kerr County, Texas. 173p.

Includes accounts of Indians and Indian raids.

Bader, George Philip MA 1923 Washington/SL The Plains during the first two years of the Civil War. $145 p$.

Baughman, James Wallace MA 1953 California [187] Ancient Peruvian painted textiles. 110p., illus.

BaUm, LaURa EdNa MA 1940

Oklahoma

Agriculture among the Five Civilized Tribes, 1865-1906. $148 \mathrm{p}$.

Bauman, Robert F. MA 1950

Toledo

Maumee Valley Indians on Walpole Island. PUB: “The migration of the Ottawa Indians from the Maumee Valley to Walpole Island." Nowest. Ohio Qtly., XXI [1949] p86-112. 
The development of the public land policy, 1783-1820, with special reference to Indians. $319 \mathrm{p}$.

Bayless, L. George MA 1940 Oklahoma $A \& M$ Early history of the Modocs, the war, and claims due to the war. $59 \mathrm{p}$.

Beaghler, Mary Jane

MA 1948

Mexico City

A new chronicle of the City of Mexico (1519-1564). 46p.

A fantasy based on historical material. Gives a unified picture of two contrasting cities of Mexico; one Aztec, the other Spanish, as seen through the eyes of a friar accompanying Cortés.

Beal, Merrill D. PhD 1945

A history of Yellowstone National Park. 241p.

Wash. State

Includes a section on Indians of the Yellowstone area.

Beals, Ellis H. MA 1928

Pittsburgh Arthur St. Clair in the history of western Pennsylvania.

$\S 3$ “St. Clair promotes peace and order" [1773-1775]. Includes Shawnee, Delaware, Six Nations.

Beals, Ralph Leon PhD 1931

California

The comparative ethnology of northern Mexico before 1750. PuB: Ibero-Americana, I \#2 [1932] p93-225.

Beardsley, Richard Krng PHD 1947 California Temporal and areal relationships in central California archaeology. Puв: U/Calif., Archeol. Survey \#24-25 [1954].

Beatty, Edward Corbyn O. PhD 1936

Chicago The social philosophy of William Penn. 529p.

Chapter on his relations with Indians.

Beatty, Richmond Croom PhD $1930 \quad$ Vanderbilt William Byrd of Westover. PUB: Houghton Mifflin [1932] 233p.

Indians as affecting Byrd's career; especially Bacon's Rebellion, Yamassee and Tuscarora Wars, and his views on interracial marriage.

Beatty, William C., JR. MA 1934 Colorado

The social and political organization of the non-Pueblo Indians of Arizona and surrounding areas. 136p., map. 
Beatty, William C., JR. PhD 1942 So. California The army of the Incas; a study in comparative military ethnology. $357 \mathrm{p}$.

Inca army compared with those of Aztecs and Tlascalans. Considers various weapons used.

Becker, Agnes Elizabeth MA 1910 Northwestern [201] The Indians as a factor in the American Revolution.

BECKER, WILLIAM J. MA 1931

Oklahoma The compounding of words in the Comanche language. Includes vocabulary and text.

Beckett, Charlie Mitchell MA 1949 Oklahoma $A \& M$ Choctaw Indians in Mississippi since 1830. 81p.

BeCKett, Ola LoRraine MA 1934 The Cherokee Phoenix and its efforts in the education of Oklahoma [203] the Cherokees. 73p.

Beckman, Peter PhD 1942 Catholic The Catholic Church on the Kansas Frontier (1850-1877). PUB: Cath. U. Press [1943] 168p.

$\S 1$ "The Indian missions."

Beckwith, Clarence G. PhD 1937 Michigan Early settlements in the Black Hills, 1874-1884. 248p.

Demonstrates how the settlement of the area influenced national Indian policy.

Beckwith, Evelina Gilbert MA 1950 No. Carolina A study of the physical equipment and teaching person[207] nel of the Indian schools of Robeson County.

"Croatan Indians."

Beckwith, Martha Warren MA 1906 Columbia

[208] Dance forms of the Moqui and Kwakiutl Indians. 43p. PUв: Proc., 15th Intl. Cong. Americanists, pt. 2 [1907] p79-114.

Beehler, LeaH MA 1927 Queen's [209] Haldimand and the Loyalists. 59p.

Mohawk. 
Beeley, Stephen MA 1946

Archaeology of the Utah Lake Site. $67 \mathrm{p}$.

Beers, Henry P. PhD 1935

Pennsylvania

The Western military frontier, 1815-1846. PUB: U/ Penna. Press [1935] 227p.

Behen, Dorothy M. F. PhD 1951

Chicago

[212]

The captivity story in American literature, 1577-1826: An examination of written reports in English, authentic and fictitious, of experiences of White men captured by the Indians north of Mexico. 429p.

Bemharz, Edwin Alanson PhD 1951 California

Felipe de Neve: Governor of California and Commandant General of the Interior Provinces. 243p.

Beitzer, Christian H. MS/Ed 1941 No. Dakota The historical development of the educational program on the Fort Berthold Indian Reservation. 108p.

Belcher, John Cheslow MA 1945 Louisiana A demographic analysis of Oklahoma villages.

Brief consideration of some Indian villages in the state: based largely on U.S. census data.

Belik, Mubeccel PHD $1950 \quad$ Northwestern

A comparative study of patterns of consumption and systems of social stratification.

Considers Tzintzuntzán.

Bell, James Christy $\quad$ PhD 1921

Columbia

[217]

Opening a highway to the Pacific, 1838-46. PUв: Columbia U., Stud. Hist. Econ. Public Law, XCVI \#1 [1921] 211p.

$\S 4$ "Missionary Colonists".

Bell, Robert Eugene PhD 1947 Chicago

[218]

Chronology in the Middle Mississippi Valley. 122p. PuB:

Griffin, Archaeology of Eastern United States. U/Chi. Press [1952] p345-351.

BeLL, VIRginta MA 1934

Geo. Peabody

[216]

[215]

Federal relations with the trans-Mississippi Cherokees, 1838-1907. 111p. 
Bellows, Esther Cornelia MA 1932 Oklahoma The history of Garvin County.

Considers Chickasaw history as part of the background.

Bender, Averam Burton PhD 1932 Washington/SL Government explorations and frontier defense in Texas, New Mexico and California, 1848-1861. 609p. Puв: The march of empire: Frontier defense in the Southwest, 1848 to 1860. U/Kans. Press [1952] 323p.

Bender, Jessie Frémont MA 1930

Oklahoma

Cheyenne and Arapaho Indians, 1861-1892. 211p.

Benedict, Laura Estelle W. MA 1904 Chicago The hunting pattern of mind as expressed in certain aspects of clan totemism among the North American Indians. $98 \mathrm{p}$.

Benedict, Ruth Fulton PhD $1923 \quad$ Columbia The concept of the guardian spirit in North America. Pub: Amer. Anthro. Assoc., Mem. \#29 [1923] 97p.

Beneke, Herman Henry MA 1912

Chicago A comparison of White boys and adult Indian groups. $142 \mathrm{p}$.

Bengston, Nels August PhD 1927 Clark Studies in the geography of Honduras.

$\S 3$ "The native races"; $\S 20$ "The social geography of Honduras" (Population; characteristics and problems-tribal isolation, mixture of Indian and foreign stocks).

Bennetr, Alice Bell MA 1941

No. Texas

Restoration and extension of Federal forts in the Southwest. $117 \mathrm{p}$., maps.

1865-1885. Chapter on Federal Indian policy, and extensive Indian content elsewhere.

Bennett, Estella JoRdan MA 1926 Colorado State A study of Dakota Territory of 1861 and Wyoming south of the $43 \mathrm{rd}$ parallel. $224 \mathrm{p}$.

Bennett, John Windiam MA 1940

Chicago

[224]

A preliminary study of the Kincaid component and its affiliations. 131p.

Study of a southern Illinois archeological site.

[228]

[229] 
Bennett, Miriam M.

MA 1936

Wayne

$[230]$

Two centuries of warfare between the Sioux and Chippewa Indians. $46 \mathrm{p}$.

Benson, Bernice Carter MA 1937 Oklahoma $A \& M$ The Creek Nation during the Reconstruction period. 56p.

Benson, Natalie S.

MA 1951

Columbia

The head vases of the Arkansas-Missouri region-their art and archaeology in relation to culture complexes in the Southeast. 45p., illus.

Berg, Clay Nelson, Jr.

MA 1948

Denver

$[231]$

$[232]$

A comparative study of the teaching methods of the Navajo, Cheyenne, and Manus Indians. 96p.

Berger, Max MS/Ed 1934

C.C.N.Y.

Education in early Texas, 1821-1835. 114p.

$\S 6$ "Education in Texas prior to 1821". Considers Indian education, missions.

BerLIN, HeINRICH MCH 1940

Mexico

Relaciones precolombinas entre Cuba y Yucatán. 20p. PUв: Revista Mexicana de Estudios Antropológicos, IV \#1-2 [1940] p141-160.

BERLIN, HEINRICH DL 1947

Mexico

Fragmentos desconocidos del Códice de Yanhuitlán y otras investigaciones mixtecas.

Bernal y García P., Ignacio MA 1949 Mexico: $E N$

[237] La cerámica de Monte Albán III. 162p. Puв: Mimeo.

Bernal y García P., Ignacio DL 1956 Mexico: EN La cerámica preclásica de Monte Albán.

Berreman, Gerald D. MA 1953 Oregon

$[233]$

$[235]$

A contemporary study of Nikolski: an Aleutian village. $391 p$.

Berreman, Joel Van Meter MA 1934

Oregon [240]

Tribal distribution in Oregon. 107p. Рбв: Amer. Anthro. Assoc., Mem. \#47 [1937] 67p.

BerRy, JANe Milhouse MA 1913

Columbia

The Indian policy of colonial Pennsylvania. 59p. 
Place names of Natchitoches Parish.

Includes a few Indian names.

Bersch, Vera Marie MA 1935

St. Louis

Evidence of the existence of prayer of petition among the North American Indians. 55p.

\section{Bessac, Susanne Leppmann MA 1955 California} The Eskimos' representational art in two dimensions.

Best, Agnes L. MA 1938

Iowa

A study of games and rhythms of the Indians of North America which may be correlated with social studies in the second grade.

Bettina, Albert Anthony Ed 1953 Bradley The development of vocational-industrial education in New Mexico. 191p. $M$.

Includes consideration of U.S. Indian schools and religious Indian schools.

Bettis, Florine Parnell MA 1952

Oklahoma

A nutritional study of a community of Kiowa Indians of western Oklahoma. $66 \mathrm{p}$.

Bewley, Mary MA 1938

New Mexico

The Indians of New Mexico in the Civil War. PUB: "A résumé of the pre-Civil War Indian situation in New Mexico." U/New Mex: Research, III \#1 [1939] p33-41.

Beyer, Richard Lawrence MA 1927

Iowa

Robert Hunter, a Governor of colonial New York.

Beyer, Richard Lawrence PhD 1929

Iowa $[250]$

Robert Hunter, Royal Governor of New York. 373p.

Considerable attention given Iroquois Indians.

Beynon, Abi Elizabeth PhD 1931 Washington The land problems of Mexico.

Early chapters consider Aztec land tenure systems and Spanish land policy. 
The history of the German settlements in Texas, 1831 to 1861. 405p., illus.

Chapter "Relations between German settlers and Indians".

BIGgar, HUGH JoHN MA 1951 Montana

The development of the lower Flathead Valley. 166p.

Indian content: § 2 "Before the Whites came"; § 3 "Exploration and fur trade, 1809-1871"; §4 "Missionaries and Indian Agents".

\section{Biggin, Dorothea Child MA $1930 \quad$ Alabama Poly} The Creek Wars in Alabama-1813-1814.

Billet, Viola Ellen MA $1937 \quad$ Northwestern Indian diplomacy in the Northwest Territory, 1783 to 1795. $97 \mathrm{p}$.

\section{Bingham, Edwin R. PhD 1950}

U.C.L.A.

Charles F.Lummis and his magazine. 430p. PuB: Charles F. Lummis, Editor of the Southwest, San Marino: Huntington Library [1955] 218p., illus.

Lummis' crusade in behalf of the Indians of California and the Southwest. His Indian interest is reflected throughout The Land of Sunshine.

Binkley, Frances Williams MA $1946 \quad$ Colorado The Hayden Survey.

Includes brief references to Mesa Verde and San Juan archaeological explorations, contacts with Ute and Sioux, etc.

Birge, Kingsley $\mathrm{H}$. PhD 1945

Political and societal status; a functional study. 508p.

Yale

Copper Eskimo, Oto, Tanaina, Kiowa and Yaruro.

Bischoff, William Norbert PhD 1950

Loyola

The Yakima Indian War, 1855-1856. 363p.

Bissell, Benjamin Hezekiah PhD 1923

Yale

The American Indian in English literature of the eighteenth century. A study of philosophical, sentimental, and picturesque exoticism. 307p., illus. Рuв: Yale U., Stud. Eng., LXVIII [1925] 229p.

Bixler, Raymond Walter MA 1924 Columbia Some Indian contributions to American civilization. 25p. 
Black, Doris Louise

MA 1938

Colorado

[262]

History of Grant County, South Dakota: 1861-1937.

Indians briefly considered, before and after settlement of the area.

Black, Emanuel MS/Ed 1937

C.C.N.Y.

The teacher in the Territories and outlying possessions of the United States. 148p.

$\S 2$ "Alaska" deals with native schools.

Black, Wilfred Watson PhD 1942

Iowa

[264]

Historians and the tradition of pioneer hardships.

Indian-White relations; stresses responsibility of historians for distorted pictures of Indian life and frontier life in general.

Black, William Harold

MA 1948

California

The relationship between Tupí-Guaraní shamans and chiefs. $73 p$.

Blackmar, Frank Wilson PhD 1889 Johns Hopkins

[266]

Spanish colonization in the Southwest. Рणв: Johns Hopkins U., Stud. Hist. Pol. Sci., Ser. 8 \#4 [1890] 79p.

Blatne, Harold Arlo PhD $1936 \quad$ West. Reserve

The Frontiersman in American prose fiction: 1800-1860. $138 \mathrm{p}$.

"The Indian was the chief attribute of the American frontier." Regards Cooper and Simms as romantic, not realistic.

BlaIR, Corinne Ann MA 1949

Tulsa

A history of Tallahassee Mission. 92p.

[268]

Creek.

Blatr, Eric Lee $\quad$ MA 1929

Texas

[269]

A study of the government, political organization, and population of the territory that now constitutes Grimes County, Texas, 1821-1836. 266p., maps.

Much on Indian population of the area.

Blatr, LEOLA RUth MM 1948

So. California

[270]

A study of the cultural heritage of the California children from the Indians. $156 \mathrm{p}$.

Particularly as concerns music and songs. 
Blake, Charlotte Erskine MA 1928 No. Dakota Agri

Pastimes of the Indian, cowboy, early and present day settlers in North Dakota. 68p.

Blake, Forrester Avery MA 1947 Denver Johnny Christmas. 292p. PuB : NY: Wm. Morrow [1948] $278 p$.

A novel with Indian characters and locale.

Blake, Gertrude Burleson MA 1932 Texas

$[273]$ The public career of General Hugh McLeod. 122p.

His career in Indian Wars.

Blanco, Evaline L. MA 1951 Mexico City

[274] The repartition of lands in the New World as found in the Recopilación de las Leyes de Indias. 79p.

Considers situation of original inhabitants.

Blasingham, Emily Jane PhD 1956

Indiana

$[275]$ The Illinois Indians, 1634-1800: A study in depopulation. 148p. PUв: Ethnohistory, III \#2 [1956] p193-224.

Bleasby, George PhD 1951

The Frontier in Cooper's Leatherstocking Tales.

Considers Indians included as individual characters in Cooper's works.

Bledsoe, Elizabeth MA 1931

History of the Cherokee Outlet, 1828-1893. 131p.

Blessing, Edith Stephens MA 1941 New Mexico The North American Indian as presented in early chronicles. 91p.

Bliss, Wescey Lloyd MA $1935 \quad$ New Mexico

[279]

Preservation of the murals of Kiva III, Kuaua Pueblo ruins. Illus. PUB : Amer. Antiq., XIII \#3 [1948] p218-223, illus.

Especially valuable for technical details connected with their excavation, removal and preservation.

Bitss, Wesley Lloyd PhD 1955

Arizona

[276]

The theory and practice of field archaeology. 735p. $M$.

A manual for archaeology which uses Amerindian excavations as case studies. Roughly: Part I, Techniques; Part II, Interpretation. 
Report on the Hayes Papers in the Bancroft Library with special reference to the attitude of the native Californians towards Statehood. 83p.

Indians are considered among the "Native Californians".

Blizzard, Winliam Leland MA 1935 Kansas [282] The frontier press of Colorado in the Ute Indian Uprising of 1879 . A case study in public opinion. $175 \mathrm{p}$.

Blodgett, Frederick Winslow MA 1951 California Guatemalan jaspé textiles: technique and motives. 91p.

Bloom, Lansing Bartlett MA 1902 Williams New Mexico under the Mexican Government, 1821-1846. $161 \mathrm{p}$.

\section{Bloom, Leonard PhD 1937}

Duke

The acculturation of the Eastern Cherokee. 167p. PUB: No. Carolina Hist. Rev., XIX \#4 [1942] p323-358.

Blount, Bertha MA 1919 California The Apaches in United States history, 1846-1886. 229p.

Blue, George Verne MA 1923

California Samuel Hancock's Thirteen Years on the Northwest Coast. 201p.

Particularly considers Chinook Indians.

Buunm, Elaine Ann MA 1948 Chicago An analysis of the Boulder Sites, a study of early Hopewell occupation in Illinois. 97p.

Blythin, Margaret Allewelt MA 1940 California [289] The Kern diaries, 1848-1849: a contribution to Western history. 151p., maps.

Ute raids and encounters with Arapaho and Kiowa.

Bobb, Bernard E. PhD $1949 \quad$ U.C.L.A. [290] The Viceregency of Antonio María de Bucareli y Ursúa 1771-1779. 356p.

Bucareli's concern over Apache and Comanche ravages and the inability of Royal forces to punish the Indians. 
The sequence of human occupance in Wayne County, Kentucky: an historical study. 256p.

Indians as incidental to Kentucky settlement.

Bogan, Phebe M. MA 1922 Arizona

[292]

The ceremonial dances of the Yaqui Indians near Tucson, Arizona. Pub: Yaqui Indian dances. Ariz. Archaeol. Soc. [1925] 69p.

BOGARD, JosEPH MA 1927

Consummation of the Cherokee-Creek removal. 92p.

Boggess, Arthur Clinton PhD 1906 Pennsylvania

Settlement of Illinois, 1778-1880. Pub: Chi. Hist. Soc. [1908] 267p.

As it affected the Indians of the area.

Boggs, Herschel JefFerson MA 1940

Texas

Drake

[293]

[294]

A history of Fort Concho. 94p., illus.

Chapters on Comanche warfare, and reasons for founding Fort Concho.

Boggs, Lois Margaret Hartman MA 1943 Florida State $[296]$

A translation of La Florida, Part I, Book II, by Garcilaso de la Vega, el Inca from the Editio Princeps, Lisboa, 1605 with collation of first and second Spanish editions, comparison with French version. 197p.

Boggs, Stanley H. MA 1936

Arizona

[297]

A survey of the Papago people. 139p.

Papago-Pima-Sobaipuri; Tarahumara, Tepehuane, Opata, and Zoque. Includes contemporary situation.

Boggs, Stephen Taylor PhD 1954 Washington/SL [298] Ojibwa socialization: some aspects of parent-child interaction in a changing culture. 221p. $M$.

BoHr, Joseph WILLIAM MA 1929

Catholic

Present status of Catholic education among the Indians of

[299] the United States.

Bollig, Richard Joseph PHD 1934 Catholic

History of Catholic education in Kansas, 1836-1932.

[300]

PuB: Cath. U. Press [1933] 131p.

Kickapoo, Ottawa, Potawatomi. 
Bolster, Mel H. MA 1952 Arkansas

Crazy Snake and the Smoked Meat Rebellion of 1909; a study of Creek unrest among fullbloods in Oklahoma. $155 \mathrm{p}$.

Bonner, Myrtle Studdard MA 1950 Alabama Poly Education and other influences in the cultural assimilation of the Cherokee Indians on the Qualla Reservation in North Carolina. 66p.

BonNey, India H. MA 1936

Louisiana

Mary Austin's interpretation of the American Indian.

Boon, LALLA RookH MA 1922 California

The history of the Santa Clara Valley: the Spanish period. 185p., pls., maps.

Chapter on Costanoan Indians.

BoorsteIn, EdITH MA $1953 \quad$ Long Island

The New Confederacy of the Iroquois: a unique example of an American secret society. 231p.

Deals with a White group interested in Indian lore, whose organization followed Indian patterns.

Boosinger, Elby Alex MA $1951 \quad$ Nebraska

The Cherokee Indians in the Revolutionary War. 95p.

Borah, Woodrow Wilson PhD 1940 California

Silk-raising in colonial Mexico. 281p. PuB: IberoAmericana, II \#20 [1943] 170p., illus.

Started in 1503; includes consideration of Indian labor, and mention of Indian silk-raising centers.

Bordenkircher, Mary Alice MA 1949 Kans.-Emporia [308] A historical study of the Mission schools in early territory now comprising Kansas. 62p.

Delaware, Iowa, Kaw, Kickapoo, Miami, Osage, Ottawa, Potawatomi, Sac-Fox, Shawnee.

Bortner, Doyle McClean MA $1937 \quad$ Penna. State Government Indian fur-trading posts, 1796-1822. 95p.

Bosch, James WiLey MA 1952

Stanford

Kwakiutl values as reflected in mythology. $163 \mathrm{p}$. 
The educational work done by the Franciscans among the Indians of Mexico in the sixteenth century. 44p.

Bostwick, Retta Estella MA $1930 \quad$ Penna. State The Indians and colonial Pennsylvania. 73p.

Bott, Elizabeth JANE MA 1949 Chicago A comparison of the social organization of the Emo and Ponemah Bands of Ojibwa Indians. 69p.

Bourne, Arthur Ross MA 1953 Occidental

Some major aspects of the historical development of Palm Springs between 1880 and 1938, and in addition a continuation of the historical changes in the Indian land problems and four cultural institutions until 1948. 135p.

Kawia.

Boutin, Hilda Thelma MA 1946

Seattle

Survival of superstition among the Indians of the Pacific Northwest. 95p.

Boutwell, Ruth MA 1936 Oklahoma

Adjustment of Osage Indian youth to contemporary civilization. $117 \mathrm{p}$.

Bowers, Alfred William MA 1929 Chicago The history and culture of the Mandan, Hidatsa, and Arikara in the upper Missouri Valley. 118p.

Bowers, Alfred Willitam PhD 1948

A history of the Mandan and Hidatsa. 235p. PUB: Mandan social and ceremonial organization. U/Chi. Press [1950] 512p.

BOWERs, LEO

MA 1940

Oklahoma $A \& M$

A history of the Sac and Fox Indians until after the opening of their Reservation in Oklahoma. 63p.

Bowker, Mabel EdNa PhD 1926 Boston The Indian policy of the United States from 1789 to [320] 1841. 344p., maps. 
Bowlby, JAMES W. MS 1937

Idaho

[321]

Famous missionary educators of the Oregon country. $27 \mathrm{p}$.

In briefly sketching careers of some of the more important missionaries, work among the Indians is considered.

Bowler, Mary JANE MA $1944 \quad$ Washington/SL The Sioux Indians and the United States Government, 1862-1878. 208p.

Bowman, Henry A. MA 1929

West. Reserve

[323]

The humor of primitive peoples. $317 \mathrm{p}$.

Includes Indian humor.

Box, Annie Lauretta Mattox MA 1952 Miss. State Mississippi as described by travelers, 1800-1861. 204p. $\S 4$ "The Red Man".

Box, Dorothy Mae MS $1947 \quad$ No. Texas A social and economic history of the El Paso area. 118p. Includes section on Indians of the El Paso area.

Boyce, Annie Mary MA 1939

Sowest. Texas

A Red Man's foster son. 172p., illus.

Life of Sam Houston. Cherokee.

Boyce, MarJorie Gray MA 1924 California

Franciscan complaints against the Governmental officials of New Mexico, 1760-1790; translation of original documents with introduction and notes. 184p.

Boyd, WILLIAM HaRLaNd MA 1937 California

Cimarron, 1886-1890; a proposed territory in "No Man's Land". 43p.

Kiowa, Comanche, Cherokee; land claims.

Boyer, Mary G. MA 1930

Arizona

The peoples-the Spaniards, the Indians, the Americans -and nature in the literature of Arizona. PUB: Arizona in literature. Glendale: A. H. Clark [1934] 574p.

An anthology, including missionary writings, ethnographies and recent fiction. 
Boyer, Raymond Henry

The Texas Indian problem, 1845-1860. 131p.

Boyle, Gail Elizabeth MA 1941

Chicago

Emigrant Indian tribal policies as indicated by intertribal councils, 1837-1853. 52p.

Brackett, WaLter Lee MA 1943

Tulsa

Place-names of five northeast counties of Oklahoma. $144 \mathrm{p}$.

1021 entries; 50 Indian names considered.

Bracy, Jesse Albert MA 1939

Colorado State

Colorado Indians and their removal. 221p.

Braden, Charles Samuel PhD 1926

Chicago

Religious aspects of the conquest of Mexico. 390p. Рuв: Duke U. Press [1930] 359p.

Braden, Norman Adelbert MA 1931 Kentucky

A brief study of the prehistoric Indian remains in Kentucky, with special reference to certain material from Trigg County, Kentucky. 23p.

Based largely on excavation of the Duncan Site.

Bradford, Clovis MA 1949

Sul Ross

$[336]$

History of Terrell County. 124p.

Texas: Jumano, Apache, Cherokee, Kiowa, Hasinai-Cenis.

Bradley, Glenn Danford PhD 1915 Michigan

$[337]$

The story of the Santa Fé. PuB: Boston: R. G. Badger [1920] 288p., illus.

Contains considerable Indian material relating to history of transportation, Indian-White relations in construction of the Santa Fé Railroad, and its influence.

Bradley, Viola McKee MA 1944 Alabama Poly [338]

The contrast of Cooper's The Last of the Mohicans and Simms' The Yemassee.

Bradshaw, Arline Louise

MA 1926

Chicago

The conflict between Georgia and the Cherokee Nation.

[339] $52 \mathrm{p}$. 
Brady, Ralph Hamilton

The Franciscans in Pimería Alta. 177p.

Pima-Papago revolt, Apache raids, Mission activities.

Bragg, Floyd Richard MA 1953

Colorado

[341]

Contributions of both modern and ancient cultures toward the extinction of the Caribou Eskimos. 131p.

BragG, WiLliam F., JR. MA 1953

Wyoming

Sacajawea's role in Western history. 88p.

Brainard, Margaret $\quad$ PhD 1935

Chicago

[343]

The Hopi Indian family: a study of the changes represented in its present structure and functions. 328p. $M$.

Brainerd, George Walton PhD 1937 Ohio State Animal remains from the Anderson Village Site, Fort Ancient, Ohio. 45p., illus.

Bram, Joseph PhD 1941

Columbia

An analysis of Inca militarism. Pणв: Amer. Ethnol. Soc., Mono. \#4 [1941] 85p.

Bramson, Emely K. MA 1940

Columbia

[344]

New York State and the Iroquois Indians. 92p.

Branch, Edward Douglas PhD 1928

Iowa

[345]

The hunting of the buffalo. 231p. PUB: NY: Appleton [1929] 239p.

Apache, Osage, Sioux, Blackfoot, Cree, Comanche, Cheyenne.

Branch, Marion Elizabeth MA 1941 Columbia

[348]

The Indian policy of the Jesuits in colonial Brazil, 1549-1755. 71p.

Branchard, Ralph Joseph MA $1953 \quad$ No. Dakota

[349]

A comparative study of the intermediate grades of two Indian schools and two public schools in Rolette County. $51 \mathrm{p}$.

Cree.

Brand, Donald Dilworth PHD 1933 California

[350]

The historical geography of northwestern Chihuahua. Ршв: Amer. Anthro., XXXVII [1935] p287-305. 
A preliminary study of cross-sexual joking relationships in primitive society. 20p.

Based on cross-cultural survey data. Appendix lists various tribal customs.

Brant, Charles Sanford PhD 1951 Cornell

[352]

The Kiowa Apache Indians: a study in ethnology and acculturation. $195 \mathrm{p}$.

Bratton, Ethel MaE

MA 1932

Texas

Sociological effects upon the Pawnee Indians of the interaction between White and Indian cultures. 105p.

Brayer, Herbert OLIver MA 1937 New Mexico

The Pueblo Indian land grants of the "Río Abajo", New Mexico. Рбв: U/New Mex. Bull., Hist. Ser., I \#1 [1938] 135p.

Brazelton, Audra NeIL

MA 1935

Missouri

Family life of the Osage Indians previous to $1872.106 \mathrm{p}$.

Brebner, Edith Alice MA 1934

Idaho $[356]$

A firsthand study of the Yakima Indians, with particular reference to the effect of Government supervision upon the personal, domestic, and social life of the Indian. 30p.

Breece, Helen M. MA $1932 \quad$ West. Reserve

The function of art in the culture of the American Indian. 103p., illus.

Breed, Noel Jerub MA 1926

California

[354]

[355]

The fur trade in Wyoming. 222p.

Breed, Noel Jerub PhD 1927

California

The early development of the Wyoming country, 1743 to 1852.315 p., map.

Some references to Cheyenne, Crow, Arapaho, etc.

BREkke, Lodise SophIA MA 1923 California

Sources of ancient Middle American history. 263p., illus., maps.

Mexican and Mayan manuscripts. 
Brennan, Michael F. MS/Ed 1952 New York-Buffalo

Part of a guide for teaching science in the Cattaraugus Indian school-weather and climate. 154p.

Brennen, Ethel Morrow MA 1942

Oregon Indians and Indian policy, 1849-1871. 92p.

Niagara

[362]

Brenner, Anita PhD 1934

Columbia

The influence of technique on the decorative style in the domestic pottery of Culhuacán. PUB: Columbia U., Contr. Anthro., XIII [1934] 94p., illus.

Brew, JoHN OTIS PHD 1941

Harvard

The archaeology of southeastern Utah and its place in the history of the Southwest. PUB: "Archaeology of Alkali Ridge, southeastern Utah." Harvard U., Peabody Mus., Paps., XXI [1946] 345p., illus.

Brewster, Mela Sedmlo

MA 1935

New Mexico

New Mexico weaving and the practical vegetable dyes $[365]$ from Spanish colonial times. 78p., illus.

Indians briefly, as related to New Mexico weaving.

Bridge, Beatrice Mary

MA 1938

Saskatchewan

The influence of the Iroquois in the development of New France, 1603-1665. 196p.

Iroquois, Huron, Algonkin.

Bridges, CorA Belle MA 1932 Oklahoma

[364]

The struggle of Oklahoma for statehood. 123p.

1890-1907. Part played by Indians, Indian leaders; attempt to form the State of Sequoyah.

Bridgwater, William R. PhD 1938

Yale

[366]

The American Fur Company. 229p.

Treats generally the relation of fur traders and Indians.

Briggs, Catherine Clover MA 1930 So. California

Beale's road across northern Arizona. 66p.

Indian troubles prevented success.

Bright, William Oliver PhD 1955

California

A grammar of the Karok language. 276p.

[369] 
The Bannack Indian War of 1878. 152p. PuB: Caxton [1938] 241p.

Bannock, Shoshoni, Paiute.

Brizee, Robert L. MA 1954 New Mexico The stereotype of the Indian in the New Mexico press.

Brockunier, Samdel Hugh PhD 1937 Harvard Roger Williams; a study of his life and career to 1657. 2 vols. PuB: The Irrepressible Democrat. NY: Ronald Press [1940] 305p.

His relations with natives in the Rhode Island area.

Brodbeck, Carlton Birtiner MA 1942

Virginia

The forts of seventeenth-century Virginia.

Much Indian material, including section on Powahatan Confederacy.

Brohough, Gustav O. MA $1906 \quad$ Wisconsin Sioux and Chippewa half-breed scrip and its application to the Minnesota Pine Lands. 69p.

Bromilow, Jessie Elizabeth $\quad$ PhD 1935 So. California Don Diego de Vargas and the reconquest of New Mexico, 1692-1704. Р ив: (Bailey, Jessie Bromilow) U/New Mex. Press [1940] 290p.

Brooks, Edward Howard

George Washington and the Fort Necessity Campaign, 1754. $124 \mathrm{p}$.

Imperial rivalry and the Indian; Jumonville and Fort Necessity; Indian resentment and reaction.

Brooks, Marian Stuart MA 1917

Oklahoma

A history of the Indian Territory during the Civil War.

Brophy, Kathleen McKee MA 1932 New Mexico The language of the Santa Fé trader. 106p.

Languages (English, Spanish, French, Indian) used by traders on the trail.

Brosnan, Cornelius James PhD 1930 California Jason Lee: a missionary's part in the founding of the 
Commonwealth of Oregon. PuB: Jason Lee, prophet of the new Oregon: NY: Macmillan [1932] 348p.

Includes his work among the Indians, and his unsympathetic attitude toward them.

Brough, Rosemary Joy MA 1953 Cornell

Lucky, the opportunist. A psychobiological personality [381] study of a Navaho singer. 158p.

Brown, Alice Clara MA/Ed 1932 Colorado An analysis of the intelligence of Indians. 83p.

A study based on data from students representing 45 tribes at Bacone College, Oklahoma.

Brown, Augustus Foss MA 1950 Pennsylvania Structure of interpersonal relations in Onondaga society.

Brown, Clyde Chestedrat MA 1934 Colorado

A survey history of Collingsworth County, Texas. 127p.

Chapters on "Indians of the Panhandle region" and "Indian Removal".

Brown, David H. MA 1929

Trinity

A history of transportation in the lower Connecticut Valley to 1844 . 60p.

Chapter "Early trails in the Connecticut Valley" deals with Indian trails.

Brown, Eugene N. MS/Ed 1952

The Niagara frontier as an aid in teaching American history. $106 \mathrm{p}$.

Iroquois Indians, especially Seneca.

Brown, Everett Sommerville MA 1908 California

Preface to a chronological index of Indian tribes in the Carondelet papers in the Academy of Pacific Coast History (Hubert Howe Bancroft Library).

Brown, James Haldane PhD 1952 Pittsburgh

Presbyterian beginnings in Ohio.

§ 3 "Presbyterian social influence in early Ohio" deals with Indian missions. 
Fort Hall and the Oregon Trail. 190p.

Indians in relations to the Fort and to travellers over the Trail.

Brown, Jessie Louise Preston

MA 1903 Columbia

[390] A bibliography of the Iroquois Indians. 54p.

Annotated.

Brown, Katherine Diana MA 1932 New Mexico

The policy of the United States Government in its relations with the Navajo Indians. 131p.

Brown, Lula Lemmon MA 1930

Colorado [392]

The Cherokee neutral-lands controversy. 81p.

Kansas area.

Brown, Lizzie May MA 1915

Minnesota [393]

Indian affairs in Illinois from 1815 to $1820.61 \mathrm{p}$.

Brown, Loren NunN PhD 1937

Oklahoma

[394]

The work of the Dawes Commission among the Choctaw and Chickasaw Indians. 301p.

Includes considerable original material.

Brown, Marion Agnes

MA 1917

California

Federal Indian policy in New Mexico, 1846-1851. 185p.

Brown, William Henry MA 1954

Illinois [396]

Comparative study of horse nomadism. $54 \mathrm{p}$.

Plains: Comanche, Crow, Kiowa, Blackfoot; also Chaco and Patagonia.

BrownING, JULIA MA 1933

Iowa

The frontier settlements of the early thirties. $102 p$.

$\S 3$ "The Indian barrier to the frontier": Winnebago, Sac, Fox.

Bruman, Henry John PhD 1940

Aboriginal drink areas in New Spain. 243p.

Bruner, Edward M. MA 1950

Ohio State

California

A level of aspiration study among the Ramah Navaho.

Bruner, Edward M. PHD 1954

Chicago [400]

A study of cultural change and persistence in a Mandan- 
Hidatsa village. M. P Uв: "Cultural transmission and cultural change." Sowestn. Jour. Anthro., XII \#2 [1956] p191-199.

Bruner, Frank G. PhD 1908

Columbia

The hearing of primitive peoples; an experimental study of the auditory acuity and the upper limit of hearing of Whites, Indians, Filipinos, Ainu and African Pigmies. PuB: Columbia U., Contr. Philos. Psych., XVII \#3 [1908] 113p.

Data from tests made at Columbian Exposition-includes many tribes.

Brunhouse, Robert Levers MA 1935 Pennsylvania

History of the Carlisle Indian School: a phase of Government Indian policy, 1879 to 1918. 158p.

Bryant, EdNa MA 1938

Wayne

Oratory of the United States Indian from 1600 to 1900. $302 \mathrm{p}$.

BRyant, Loy Young MA 1935

No. Carolina

The Pocahontas theme in American literature. 151p.

Buchanan, David Peavler MA 1923 Tennessee

The relations of the Cherokee Indians with the English in America prior to 1763 . 105p.

Buchanan, Ivy Luella $\quad \mathrm{PHD} 1930 \quad$ Washington [406] An economic history of Kitsap County, Washington, to 1889.

Chapters on Indian life, Indian wars, and various phases of Indian economic activities.

BUChanan, LoRna M. MA 1929

Washington

History of the fur industry in the Pribilof Islands. 106p.

Includes relations of Aleuts with seal industry.

BUCK, Carl R. MA 1940 Oklahoma $A \& M$

Economic development of the Chickasaw Indians, 1865 to $1907.47 \mathrm{p}$.

Buck, Lucrus Edman MA 1949 So. California

An inquiry into the history of Presbyterian educational missions in New Mexico.

$\S 4$ "Schools for Pueblo Indians". 
An introduction to North American antiquity. 110p.

Budge, Belva Adele M/Ed $1941 \quad$ Stanford

A source unit on the origin and meaning of California place names; original studies drawn from the period of the Spanish missions. 59p.

While primarily concerned with names of Spanish origin, a few Indian terms are included.

Buechner, Cecilia Batn MA $1929 \quad$ Notre Dame

The Pokagons of the lake shore Potawatomies of Indiana, Michigan, Illinois. 79p. PUB: Indiana Hist. Soc., Pubs. X\#5 [1933] p279-340.

A biographical sketch of an important family of Potawatomi Indians.

Buel, Frances E. MA 1943

So. Dakota

Sioux reaction to Government policy, 1868-1906. 87p.

Buford, Dora Edde MA 1932

Oklahoma

A history of the Indians under the Quapaw Agency.

Peoria, Miami, Ottawa, Wyandot, Quapaw, Seneca, Shawnee, Modoc.

Buker, Raymond Bates STM 1933 Andover Newton Catholic missions among the Indians in Maine. 51p.

Bunker, Robert M. MA 1954 New Mexico Authority as aid to community action: case studies from the American Revolution and from Pueblo Indian affairs. 152p.

Buntin, Arthur Roy MA 1952 Montana Battleground: narrative and evaluation of intertribal warfare on the buffalo plains of eastern Montana and in adjacent areas prior to $1880.351 \mathrm{p}$.

Buntin, Martha Leota MA 1931 Oklahoma History of the Kiowa, Comanche, and Wichita Indian Agency. 195p.

Includes considerable original material. 
The Pueblo Potter; a study of creative imagination in primitive art. PUв: Columbia U., Contr. Anthro., VIII [1929] 134p., illus.

Burbage, Edward A. MA 1950

Tulsa

The legend of Zeke Proctor. 66p.

Oklahoma Cherokee.

Burch, Marvin Chandler MA 1950 Texas A history of the Lower Trinity River region of Texas to 1836. 175p., illus.

$\S 2$ Indians of the region.

Burgess, Glen Dean MA 1937

Stanford

[422]

A program for teaching English to Indian children in elementary schools. $174 \mathrm{p}$.

Burgie, Amee George MA 1942 Sul Ross

Education of the Navajo Indians of the Southwest. 96p.

Burke, James Michael MA 1951 St. Louis

Diary of the Potawatomie Mission of St. Marys on the Lake by Father Maurice Gailland, S. J.: translated and edited with biography and notes, by James Michael Burke, S. J. 287p.

BURKHER, Howard H. M/Ed 1929

Butler

The effect of education upon the life of the Alaskan Eskimo. 150p.

Borlingame, Merrill Gildea MA $1928 \quad$ Iowa

The economic importance of the buffalo in the northern Plains region, 1800-1890. 190p.

$\S 3$ "The Indian and the buffalo".

Burlingame, Merrill Gildea PhD $1936 \quad$ Iowa The military-Indian frontier in Montana, 1860-1890. $317 \mathrm{p}$.

Burnett, Wesley J. MA 1940 California

The revolt of Tupac Amaru.

(1780-1781) Led by José Gabriel Condorcanqui, "Last of the Incas". 
The Indian policy of the United States Government, 1870 to 1906 , with particular reference to land tenure. $287 \mathrm{p}$.

Burns, Charles Foster MA 1932 Washington/SL Auguste and Pierre Chouteau, fur trading magnates. [430] $96 \mathrm{p}$.

Especially Osage; also Chickasaw, Kickapoo, Blackfoot, Cherokee.

BURns, Louis F.

MA 1950

Kans.-Emporia

The fur trading ventures of Auguste Pierre Chouteau and Pierre "Cadet" Chouteau. 50p. Osage.

Burns, Melton James MS 1954 Idaho Administration of Indian affairs in the allotment and citizenship period, 1887 to date. $119 \mathrm{p}$.

Burrell, Ruth Clay MA $1950 \quad$ West Texas Resource unit: the ancient life and arts of Texas Panhandle Indians. 81p.

Prehistoric Texans, Folsom Man, etc.

Burton, Harley True MA 1927 Texas

A history of the J A Ranch. 246p., maps. PUB: Austin: Von Boechmann-Jones Co. [1928] 147p., illus.

Two chapters on Indian wars and the Indian Scare of 1890.

Burton, Henrietta Kolshorn PhD 1936 Columbia The re-establishment of the Indians in their Pueblo life through the revival of their traditional crafts; a study in home extension education. Р Coll., Contr. Educ., \#673 [1936] 96p.

Particularly concerned with San Ildefonso; offers comparisons with Nambé.

Burton, RUth HewitT MA 1947

Penna. State

The role of the myth in primitive society.

Zuñi, Tsimshian, plus three non-Amerindian tribes.

BURTon, WARREN HepbURN MA 1955 Clark The agriculture problem of the Navajo Indian Reservation. $204 \mathrm{p}$. 
Bush, Minnie May MA 1909

Illinois

[438]

Indian trade in the Old Northwest, 1790-1820. 66p.

Bushnell, Clyde G. MAE 1948 Mexico

La influencia de los españoles en la Florida. 129p. Р चв: Mimeo.

Bushnell, John Hempstead PhD 1955 California San Juan Atzingo: an interpretation of folk culture in Central Mexico. 172p.

BuskIRK, WINFRed PHD $1949 \quad$ New Mexico [441] Western Apache subsistence economy. 443p.

Buswell, James Oliver III MA 1952 Pennsylvania An introduction to ethno-linguistics. 150p.

Emphasizes Indian material, especially Dakota; includes text and translations.

Buswell, LoIs E. MA 1934

Wisconsin

The oratory of the South Dakota Indians. 103p.

Butler, Charles Thompson, JR. MA 1948 Texas A west Texas rock shelter. 95 p.

Butler, Eva L. MA 1946 Pennsylvania A preliminary outline of Algonkian culture and use of maize in southern New England. PUB: Archeol. Soc. Conn., Bull., XXII [1948] p3-39.

Butler, Mary K. PhD 1936

Pennsylvania

Piedras Negras pottery. PuB: Piedras Negras, preliminary report No. 4. U/Penna. Mus. Pubs. [1935] 69p.

Guatemalan archaeology.

Butterfass, Theodore Ohliger MA 1929 Columbia The liquor traffic among the Indians of the New York state in the Colonial period. 110p.

Butterfield, Marvin Ellis PhD $1936 \quad$ Illinois The interpreters of Fernando Cortés: Doña Marina, and [447] Jerónimo de Águilar. PuB: "Jerónimo de Águilar, conquistador." U/Alabama Stud. \#10 [1955] 54p. 
Educational policies of the Federal Government toward the Sac and Fox Indians of Iowa, 1920-1921 and 1936 to 1937, with resulting changes in Indian educational attitudes: a study in the process of assimilation. $71 \mathrm{p}$.

Byrne, La URA LaURENSON

MA 1920

California

$[450]$

The Federal Indian policy in Utah, 1848-1865. 121p.

Byington, Mildred Johnson MA 1924 California Father Kino's early years in America: translation of original documents with an historical introduction. $165 p$.

Especially his work with California tribes.

Cain, Alice Virginia MA 1935 Sul Ross

[451]

A history of Brewster County. 238p.

Jumano, Apache and Comanche tribes in Texas.

Cain, Frances Smith MA 1940

Oklahoma

$[453]$

The Kickapoo Indians, 1832-1895. 110p.

Catn, H. Thomas MA 1946

Arizona

$[454]$

Petroglyphs of the state of Washington. 121p. PणB: Petroglyphs of central Washington. U/Wash. Press [1950] $57 \mathrm{p}$. , illus.

Caldwell, Joseph R. MA 1943

Chicago [455]

Cultural relations of four Indian sites on the Georgia coast. $58 \mathrm{p}$.

Caldwell, Norman Ward PhD $1936 \quad$ Illinois The French in the West, 1740-1750. Р ठв: "The French in the Mississippi Valley 1740-1750." U/Ill., Stud. Soc. Sci., XXVI \#3 [1941] 113p.

$\S 4$ "General Indian relations"; § 5 "Indian uprising of 1747 ".

Caldwell, Warren Wendell MA 1949 Stanford The archaeology of the Stanford-Palo Alto region. 55p.

\section{Cale, Ada Warren MA 1944}

Texas frontier problems, 1836-1860.

St. Mary's 
Calef, Wesley Carr PhD 1948 Chicago [459]

Land associations and occupance problems in the Uinta country. Pub: U/Chi. Press [1949] 173p.

Uintah, White River, Uncompahgre Utes in Colorado.

Caley, Percy B. PhD 1940

Pittsburgh

[460]

Dunmore: Colonial Governor of New York and Virginia, 1770-1782.

Indian troubles; Dunmore's War.

CaLHodn, Jay Robert MA 1952

Chicago

[461]

A study of symbolism in the religion of the Crow with special reference to the medicine-bundle. $69 \mathrm{p}$.

Calkin, Carleton Ivers $\quad$ PhD 1953 California

[462]

Moche figure-painted pottery: the history of an ancient Peruvian art style. $189 \mathrm{p}$., illus

Calkins, Thomas Vincent Ma/Ed 1928 Yale Service and tenure of teachers in the Alaska native schools. 81p.

Calkins, Thomas Vincent $\quad$ PhD 1931

Yale [464]

Education of the Alaskan native. 234p.

Callaghan, Margaret Cecilia MA 1943

Iowa [465]

Bibliography of reference and recreational materials on Alaska and the Far North for intermediate grades.

Callaghan, Mary Consuela PhD 1951 Pennsylvania Indianism in Peru-1883-1939. 240p.

Callahan, Rosalie A. MA 1955 Hunter [467] Changing Governmental policy towards the Indians, 1928-1955.

Cámara Barbachano, Fernando MA 1956 Mexico: $E N$ Cambios culturales entre los indios tzeltales de los altos de Chiapas.

Cambria, Claudia E. MA 1946 Columbia [469] The Indian reform movement in the United States from 1865 to $1887.76 \mathrm{p}$. 
Cameron, Una Beatrice

MA 1938

The history of San Gabriel Valley, California.

So. California

[470]

Includes life of Gabrielinos and Serranos in missions.

Camp, Roberta Marie MA 1937

Colorado

The admission of Oklahoma, 1889-1907.

Role of Indians in Oklahoma politics.

Campbell, Cuba Belle MA 1942 Oklahoma $A \& M$

[472]

Contributions of some Oklahoma Indians to costume design in the United States. 29p.

Campbell, Donald B. MA 1941

Montana

The Indian campaigns of General Nelson A. Miles in eastern Montana and the political organization and settlement of that section. 112p.

Sioux, Cheyenne, Nez Percé, Bannock, Shoshoni.

CAMpbell, Edith Gore MA 1931

Indiana

The Star Husband tale: a comparative study by the historic-geographic method. 131p.

Campbell, Exie Chauncey MS 1930 Oklahoma Shawnee, Oklahoma: a geographical study of an urban landscape.

Includes early history of Shawnee as an Indian village.

Campbell, Ruth West $\quad$ MA 1915

Columbia

[476]

The Jesuits and their methods of conversion in New France. 37p.

Considerable Indian material, especially chapter on the Indian mind in "Methods in converting".

Campbell, Thelma MA 1933

Cabeza de Vaca, the first historian of Texas. 120p.

Campbeld, Thomas Nolan Ma 1936

Texas

A study of ornamentation in the pottery of prehistoric east Texas, with special attention given to designs. 203p.

Campbell, Thomas NolaN $\quad$ PhD 1947 Harvard

The archaeology of the Texas coast and its relation to that of Mexico and the lower Mississippi Valley. 2 vols., illus. 
Campen, George H. MA 1939 New York

Robert Hunter, Governor of New York, 1710-1719. 57p.

Chapter "The French and the Indians".

Canby, Joel Shackelford $\quad \mathrm{PhD} 1950 \quad$ Harvard

Excavations at Yarumela, Spanish Honduras: recovery, description, and interpretation of a long ceramic sequence. Р вв: Intl. Congress Americanists, Paps., XXIX pt. 1 [1951] p79-85.

Canfield, Delos Lincoln PhD $1934 \quad$ Columbia Spanish literature in Mexican languages as a source for the study of Spanish pronounciation. Рणв: NY: Instituto de las Españas en los Estados Unidos [1934] 257p.

Part II "Spanish pronunciation as revealed in the orthography of the Indian languages of Mexico".

Cangialosi, Russell Donald MFA 1948 So. California An investigation into pre-Columbian sculptural forms in [483] relation to their possible application to the decoration of a contemporary living room. $36 \mathrm{p}$., pls.

Cano, Victor Migued MA 1929

So. Methodist

El imperio de los Incas. 62p.

An account of the Inca empire, its origin and development.

Cantor, Nathaniel $\quad$ PhD 1956

Columbia

Primitive property: a study of the relations between the general culture of several groups and their property rights. 119 p. $M$.

Includes North West Coast tribes, North Africa, and New Guinea in the survey.

Cappannari, Stephen Clement $\quad$ PhD 1950 California [486] The concept of property among Shoshoneans. 127p.

Cappious, Samuel Lloyd MA 1941

Washington A history of the Bitter Root Valley to 1914. 101p.

Flatheads.

CAPPS, HUGH O., JR. MA 1941 Denver

A study of flaked stone implements. 97p., pls.

Primarily concerned with Amerindian artifacts. 
CAPPS, INEZ HaRbour MA 1952

Montana

[489]

Social change among the White Mountain Apache Indians from the 1800 's to the present. $70 \mathrm{p}$.

Cardinal, Ezra Victor MA 1924

Catholic [490]

Catholic education among the Menominee and Ottawa Indians (1824-1950).

Carey, Henry Ames $\quad$ PhD 1931

Columbia

An analysis of the northwestern Chihuahua culture. PUв: Amer. Anthro., XXXIII \#3 [1931] p325-374.

Carle, Peggy MA 1941

Burial customs of the Indians of the Southwest.

Texas Tech. [492]

Carleton, William A. ThD 1945

Sowestn. Bapt. [493]

Not yours but you.

Life of Joseph Samuel Morrow, missionary to east Oklahoma tribes, especially at Atoka. Seminole, Choctaw, Chickasaw.

Carlile, Homer Ellis MA 1938 Oklahoma $A \& M$ The removal of the Eastern Cherokees. 96p.

Carlson, Frank MA 1903

Washington Chief Sealth. $47 \mathrm{p}$.

Was chief of Dwamish, Suquamish, Samahamüsh, Skopahmish, Stkamish, Sktahlmish tribes.

Carlton, Leslie MS 1939

No. Texas

Indians of southeast Texas. 91p.

Carmean, James Walter MA 1934

Wittenberg

[494]

Senator Benjamin Harrison and the Indian problem, 1881-1889. 58p.

West of Mississippi; Sioux, Apache, Kiowa, Cheyenne, Kickapoo.

Carmichael, Elizabeth H. MA 1933 Geo. Washington An analysis of the Indian unit as found in the elementary grades. $53 \mathrm{p}$.

Carmichael, Lois Mrluer MA 1944 Sowest. Texas The history of Uvalde County. 89p., illus.

Scattered references to Texas Indians throughout. 
Carmody, Julia Helen

Edward Winslow and Indian diplomacy and the diplomacy of King Philip's War. 76p.

Carnes, Mary Loyola MA 1922

California

The American occupation of New Mexico. 161p. Рив:

[501] New Mex. Hist. Rev., Pubs. Hist., VIII [1939] 166p.

Carpenter, Charlotte MA 1942

Sul Ross

Conditions that led to the establishment of Fort Sam

[502] Houston. 111p.

Comanche, Apache.

Carpenter, Edmund Snow MA 1948 Pennsylvania A brief review of certain Pennsylvania mounds.

Carpenter, Edmund Snow PhD 1950 Pennsylvania Intermediate period influences in the Northeast. $157 \mathrm{p}$. $M$.

Considers question of intrusion of Iroquois into Great LakesSt. Lawrence area.

CARr, Clifford E.

MA 1931

Detroit

Detroit in the American Revolution, with particular respect to Indian relations. $87 \mathrm{p}$.

Carr, Fletcher A. MA 1935

Arizona

[503]

[504]

The ancient Pueblo culture of northern Mexico. 119p.

A comparative study of the Chihuahua-Sonora area; traces relationship of these people with Southwestern U.S. and southern Mexico.

Carr, Helen Salisbury MA $1930 \quad$ California

[507]

The Indian uprising in Lower California, 1734-1737. 101p., illus.

Vaicura and Pericú.

Carr, Paul Omega MA 1927

Iowa [508]

The Treaty of Fort Stanwix, 1768. 121p.

Carr, Paul Omega PhD 1932

Iowa [509]

The defense of the Frontier, 1760-1775. 329p.

Carrasco Pizana, Pedro MA 1956 Mexico: EN

Los otomies: cultura e historia prehispánica de los pueblos Mesoamericanos. 
Carrasco Pizana, Pedro

Tarascan folk religion; an analysis of economic, social and religious interactions. PUB: Tulane U., Middle Amer. Res. Inst., Pubs. \#17 [1952] 63p.

Carriker, Francis Lemar

MA 1940

Oklahoma

Indians as British auxiliaries in the Old Northwest, 1777-1783. 161p.

Carrillo, Esperanza MA 1915 California The work of Fray Francisco Garcés in the Southwest. $134 \mathrm{p}$.

Expeditions into California and to the Hopi, 1774-1776.

Carroll, Mary Pius MA 1917 California Spanish colonization in Española, 1492-1517. 125p.

Carroth, Wincie Ann

MA 1937

Louisiana The significance of religion in the dance. Section on "Dance of the North American Indians".

Carson, Charles Aluen M/Ed 1924 A survey of an Arizona Indian school. 118p.

Pima Indian Boarding School. Compares day school, boarding school, and the Institute.

Carson, Jane Dennison PhD 1951 Virginia

Sir William Berkeley, Governor of Virginia: a study in Colonial policy.

His relations with the Indians in war, peace and trade.

Carson, Mearl Fielding MA 1950

Denver

A comparison of cultural traits of southeastern United [518] States and the Circum-Caribbean area. 114p., maps.

Carter, Bruce Gilbert MA 1932

Oklahoma

The history of Seminole County, Oklahoma.

Oklahoma Seminole. Includes much original material.

Carter, Edward R. MA 1951

Kansas

Adjustment of the Dakota Indians in Rapid City, South [520] Dakota. 106p.

Carter, George Francis PhD 1942 California Agricultural geography of the Southwest Indians. PUB: Viking Fund Pubs. Anthro. \#5 [1945] 140p. 
Carter, Patricia Hadaway

The Trail of Tears: an historical narrative. 495p.

1814-1838; brief summary of Cherokee tribal history before 1836.

Casagrande, Joseph Bartholomew PhD 1951 Columbia Comanche linguistic acculturation: a study in ethnolinguistics. 138p. M. Р Uв: Intl. Jour. Amer. Ling., XX-XXI [1954-1955] var. pp.

Studies effects of 250-year White contact on Comanche language and culture. Also offers observations on importances of changes.

CASEY, JACK TULL MA 1946

California

The Indians in the settlement of California (1769-1869).

Cash, Clara Marie

MA 1941

Colorado

Political history of the Arkansas Territory, 1819-1836.

Summary of pre-1819 history discusses Indian tribes living there.

Cassel, Herbert WILBdr MA 1933 California The Comanches on the Spanish frontier, 1770-1795. 117 ., maps.

Casseld, Raymond Kelly PHD 1947 Michigan The land use system of the Bajo Rio Bravo in the State of Tamaulipas, Mexico. 106p.

Chapter "Cultural environment" includes brief consideration of Indian inhabitants and aboriginal land tenure.

Cassutt, Dorothy Burd MA 1942

Denver Social aspects of the Indian Service. 182p.

$[528]$

Includes an appendix of documents.

Castañeda, Carlos Eduardo

MA 1923

Texas

A report on the Spanish archives in San Antonio, Texas. 349p. Pub: San Antonio: Yanaguana Soc. [1937] 167p.

Includes documents pertaining to Spanish-Indian relations.

Castañeda, Carlos Eduardo

$\mathrm{PHD} 1932$

Texas

Morfís History of Texas: a critical, chronological account of the early exploration, attempts at colonization, and the final occupation of Texas by the Spaniards, by Fr. Juan Agustín Morfí, O.F.M., missionary, teacher, and historian of his order, 1678-1779.651p. PUB: History 
of Texas, 1673-1779 by Fray Juan Agustín Morfí. Albuquerque: Quivira Soc. Pubs., VI[1935] 2 vols.

Translation with comments by Castañeda; Indians of Texas.

Caudill, Whitam Abel MA 1948 Chicago [531]

Psychological characteristics of acculturated Wisconsin Ojibwa children. 93p.

Cadghey, John WaLton MA 1926 California Early Federal relations with New Mexico. 131p.

Section on control of Navajo and Pueblo, and warfare with Apache and Comanche.

Caughey, John Walton PhD 1928 California Louisiana under Spain, 1762-1783. PuB: "Bernardo de Gálvez in Louisiana, 1776-1783." U.C.L.A., Pubs. Soc. Sci., IV [1934] 290p.

Cauvin, Mary Austin $\quad$ MA 1939

Louisiana The French Ursulines in colonial Louisiana, 1727-1824. Their school for Indians and Negroes.

CAYwood, Louis Richard MA $1933 \quad$ Arizona The archaeology of the Sulphur Spring Valley, Arizona.

Chadwick, William Sandy MA $1941 \quad$ Sul Ross A brief history of Panola County, Texas. 72p.

Caddo, Cherokee, Asinai.

Chaffee, Eugene Bernard MA 1931 California [537] Early history of the Boise region 1811-1864. 91p. Shoshoni.

Chalfant, Stuart A. MA 1951 Columbia [538] A comparative analysis of Arikara and Mandan religious and ceremonial organization. $84 \mathrm{p}$.

Chamberlatn, Alexander F. PhD $1892 \quad$ Clark The language of the Mississaga Indians of Skúgog. PUB: Phila: McCalla \& Co., [1892] 84p.

This was the first $\mathrm{PHD}$ in Anthropology to be granted in the United States. Since Clark University had no Anthropology Department at that time, the degree was earned in the Sociology Department. See also 841, 3336. 
Chamberlain, Robert Stoner $\quad$ PhD 1936 Harvard

Francisco de Montejo and the conquest of Yucatan, c.1473-1546. 377p. PUB: "The conquest and colonization of Yucatan, 1517-1550." Carnegie Inst. Wash., Pubs. \#582 [1948] 365p.

Summarizes Yucatecan prehistory, plus extensive consideration of the Spanish Conquest of the Maya.

Champe, John Leland $\quad$ PhD 1946

Columbia [541]

Ash Hollow Cave: a study of stratigraphic sequence in the central Great Plains. Puв: U/Nebr., Stud., n.s. \#1 [1946] 131p., illus.

Chandler, Anna Lewis $\quad$ MA 1949

Indiana

The Miami Indians. 84p.

Chaney, Margaret A.

MA 1928

Oklahoma

[540]

A tribal history of the Seminole Indians. 134p.

Emphasizes the Oklahoma Seminole.

Chang-Rodríg Uez, Eugento PhD 1955 Washington

[544] La literatura política de González Prada, Mariátegui y Haya de la Torre. 564p. $M$.

Includes consideration of Indian problems in Latin America, and Indianismo.

Chapman, Carl Haley MA $1946 \quad$ New Mexico

A study of the classification, distribution, and sequence of the archaeological cultures of Missouri. PUB: "A preliminary survey of Missouri archaeology." Missouri Archeol., X pts. 1-4 [1946-1948] 164p.

Chapman, Charles Edward PhD 1915 California The founding of Spanish California: the northwestward expansion of New Spain, 1687-1783. PuB : NY: Macmillan [1916] 485p.

Chapman, Martha Corbett

MA 1937 No. Carolina

[545]

Indian relations in colonial North Carolina, 1584-1754.

$[547]$

Cherokee.

Chapmann, Anne Mac-Kaye MA 1956 Mexico: $E N$ Raíces y consecuencias de la guerra de los aztecas contra Azcapotzalco. 
Chappel, Wilbur Walter MA 1943 So. Methodist Altamirano, el gran maestro Indio. 101p.

Ignacio Manuel Altamirano, Indian novelist, professor, and poet.

Chapple, Eliot Dismore $\quad$ PhD $1933 \quad$ Harvard

The theory of associations as applied to primitive and civilized communities, with special emphasis upon the functional approach. $380 \mathrm{p}$.

Compares Omaha Indian social organization with typical New England community.

Chard, Chester Stevens PHD 1953 California

[551]

Kamchadal culture and its relationships in the Old and New Worlds. Puв: Kroeber Anthro. Soc., Paps. \#8-9 [1953] 70p; 44p.

Includes Koryak, Chukchi, Eskimo, and North West Coast tribes.

Charles, Lucile Hoerr PhD 1943 Yale

[552]

Growing up through drama: the educational role of dramatization in primitive puberty rites. $412 \mathrm{p}$. РUв: Jour. Amer. Folklore, LXIX \#233 [1946] p247-262.

Cross-culture survey data. Includes Indians.

Chatfield, Jennifer MA $1948 \quad$ New Mexico [553]

The Pentecostal move at Sia Pueblo: individual deviation and group reintegration as a result of contact pressure. $78 \mathrm{p}$.

Chauvenet, William MA 1935 New Mexico

Erosion control in Chaco Canyon, New Mexico, for the preservation of archaeological sites. $60 \mathrm{p}$.

Chesky, JANE MA 1943

Arizona

The nature and function of Papago music. 137p.

Chewning, Elizabeth Key MA 1935 Texas

Comparison of the cultures of the Bushmen and Fuegians, with special reference to the mental aspects.

Indians of Tierra del Fuego.

Childears, Carolyn Lucille MA $1949 \quad$ Denver

An analysis of Indian place names in four Rocky Mountain states. $186 \mathrm{p}$.

Montana, Wyoming, Colorado, New Mexico. 
Childers, Floy Lydia MA 1939 Oklahoma $A \& M$ [558] A study of the costumes of the Indian tribes at the time of their removal to Oklahoma. $36 \mathrm{p}$.

Chisum, Emmett D. MA 1953

Wyoming

[559]

The construction of the Union Pacific Railroad through Wyoming, 1867-1869. 130p.

General references to the Indians and Indian raids during construction.

Che, Ting-Li $\quad$ MA 1951

Oregon [560]

A plan for Klamath Indian Reservations. 55p.

Community development, especially mixed-population towns on the reservation. Indian-White relations.

Choate, Julian Ernest, JR. PhD 1954 Vanderbilt The myth of the American cowboy: a study of the cattleman's frontier in history and fiction. $469 \mathrm{p} . M$.

Indians in passim, mostly as they affected or fought with the cowboy. Period 1890-1915.

Chowen, Richard Henry MA 1941 Northwestern The history of treaty making with the Potawatomi Nation of Indians. 111p.

Chowning, Martha Ans MA 1952 Pennsylvania Raven myths in northwestern North America and northeastern Asia. 179p.

Christensen, Carl Donald MA $1940 \quad$ Nebraska A partial evaluation of the Seventh Day Adventist Indian secondary schools in Bolivia and Peru. 92p.

Christensen, Ross Taylor PhD $1956 \quad$ Arizona An archaeological study of the Illescas-Jubones coast of northern Peru and southern Ecuador. 455p. $M$.

Christiansen, William V. MS/Ed 1955 Utah Agri The employers' opinions on Navajo student employees during the summer of $1954.94 \mathrm{p}$.

190 students from Intermountain School.

Churchill, Charles W. MA 1940 New York

Economic culture of the Pomo Indians of northern California. 71p., illus. 
Clapp, Elizabeth $\quad$ MA 1934

Wichita [568]

The Medicine Lodge Indian Treaty. 91p.

Comanche, Kiowa, Kiowa-Apache, Cheyenne, Arapaho.

Clardy, Ellen Sheridan MA 1935

The beginnings of an American Indian policy. 90p.

Clark, Bonnie Jean MA 1943

California [570]

Peruvian gauze techniques. $80 \mathrm{p}$. , pls.

Clark, Harold Edward PhD 1955 Indiana

Fenimore Cooper's Leatherstocking Tales: a problem in race. 260 p. $M$.

Discusses Cooper's presentation of Indian-White relationships and his arguments against racial equality.

Clark, Howard Glenn MA 1953

Pittsburgh

[569]

John Fraser, western Pennsylvania frontiersman.

Miami.

Clark, Ira Granville, JR. MA 1937 Oklahoma Attempts to form an Indian Confederation in Oklahoma, 1860-1890. 238p.

Clark, Ira Granville, JR. PhD 1947 California [574] The railroads and the tribal lands: Indian Territory, 1838-1890. 336p.

Clark, Joseph Stanley PhD 1940

Wisconsin The Ponca Indian Agency. 440p., map.

Considers Indian Bureau activities in one specific agency; Ponca, Pawnee, Nez Percé, Oto, Missouri and Tonkawa tribes.

Clark, Letitia Macelia MA 1910 Stanford The first expedition of Juan Bautista de Anza, 1773 to 1774. $80 \mathrm{p}$.

Indian raids, contacts between Whites and Indians.

Clark, Richard EliJah PhD 1915 Pennsylvania The effect of social forces upon religious rites and ceremonies. Pub: U/Penna. Press [1924] 81p.

$\S 7$ "Religion of Ancient Mexico"; § 8 "Religion of Ancient Peru". 
Clark, Robert Carlton MA 1901

Texas

$[578]$

The beginnings of Texas: Fort Saint Louis and Mission

San Francisco de los Tejas. Рub: Texas State Hist. Qtly.,

I \#3 [1902] p171-205.

Considerable on missions to Tejas Indians.

Clark, Robert Thomas, JR. PhD 1932 Stanford

Herder and the Noble Savage. Р

[579] thought. U/Calif. Press [1955] 501p.

Many examples to indicate Herder's concept of the Savage. Includes Iroquois peace plan, and White-Indian struggle.

Clarke, Eleanor Parker MA 1933

Arizona

Designs on the prehistoric pottery of Arizona. PUB: U/Ariz., Soc. Sci. Bull. \#9 [1935] 76p., illus.

ClaARKE-Smith, LINDA

MA 1907

Columbia

Primitive woman. A study of woman among the tribes of Australia and of the Iroquois Confederacy. 46p.

Clay, Donice Louise MA 1935 Oklahoma $A \& M$

A study of art among the Kiowa Indian school children. $91 \mathrm{p}$.

Cleary, Thomas Francis $\quad$ PhD 1932

Illinois

The history of the Catholic Church in Illinois from 1763-1844. 469p.

$\S 1$ "Indian missions in Illinois".

Clements, Forrest Edward MA 1925 California

Primitive concepts of disease in North America.

Clements, Forrest Edward PhD 1928 California

Primitive concepts of disease. PuB: U/Calif., Pubs. Amer. Archeol. Ethnol., XXXII \#2 [1932] p185-252.

Clements, Leon Eugene MA 1938 Colorado State Possibilities of rehabilitating the Oglala Sioux. 114p.

Cliff, Thelma Drake MA 1942 Oregon

A history of the Warm Springs Reservation, 1855-1900.

[583] $323 p$.

Clifford, Barbara Marr EdD 1941 New York Hiawatha, an Indian boy: An operetta based on Henry W. Longfellow's poem. 104p. 
Clifford, DoRothy MA 1942

Washington

[589]

American women playwrights before 1850 .

Discusses first Indian play (1794), Tammany, by Anne Kamble Hatton.

Clifford, MyrtLe MA 1932

Montana

[590]

Three women of frontier Montana. 41p.

One was Natowáp Tsis-Tseksin, daughter of Matose-Apiw, Chief of Bloods of the North.

Cline, Howard F. PhD 1947

Harvard

Regionalism and society in Yucatán, 1825-1847. 2 vols.

Life and culture of the Maya, their economy and land systems.

Cline, Omer W. MA 1948

East Texas

History of Mitchell County to 1900. 149p.

Texas. § 2 "Indian depredations, expeditions, and problems."

Clingan, Dorothy Edwina MA 1934 Yale The Iroquois Confederacy, 1682-1690. 120p.

Coan, Charles Florus MA 1915

California

[591]

The Federal Indian policy in the Oregon country, 1849-1855. 82p., maps.

Coan, Charles Florus $\quad$ PhD 1920

California [595]

The Federal Indian policy in the Pacific Northwest, 1849-1870. 494p.

Cobi, Jesse Ludowick

MA 1917

California

[592]

The establishment of Civil Government in Oregon, 1837-1845.

Several pages on laws of the Nez Percé.

Cobb, William Montague PhD 1932 West. Reserve Human archives. 208p.

Surveys "human material in U.S. and Canada now available for advancement of knowledge of physical anthropology and human growth". Concentrates on data in urban areas in modern times, but includes material on Indian skeletal remains.

Coburn, Miner Thompson MA 1934 Northwestern

A study of commercial Chicago from the rebuilding of Fort Dearborn to the River and Harbor Convention, 1816-1847.

Includes Indian relations of the area. 
Cocks, JomL Ellịs MS 1951

Florida

[599]

Colonial beginnings of Mexican textile industry. 122p.

About half of the thesis discusses Aztec use of textiles before the Conquest. Balance considers contemporary Mexican textile industry.

Codere, Helen Frances

PHD 1950

Columbia

Fighting with property; a study of Kwakiutl potlatching and warfare, 1792-1930. PUB: Amer. Ethnol. Soc., Mono. \#18 [1950] 136p., illus.

Cody, Edmund Raymond MA 1932

Idaho [601]

The early history of the Catholic Church in the Willamette Valley, 1838-1848. 66p.

Indians missions mentioned incidentally.

CoE, RoberT H. MA 1926

Tennessee

[600]

Benjamin Hawkins, Indian agent from 1796 to 1817.98p.

Coe, William Robertson II MA 1953 Pennsylvania The artifacts, caches, and burials of Piedras Negras, Guatemala. 174p., illus.

CoFfey, JoHn Lockhart MA 1925 Oklahoma $A \& M$ The Five Civilized Tribes and their influence in Oklahoma history. 110p.

Coffey, Lois Marie Re ynolds MA 1931 Oklahoma $A \& M$ A history of the Wichitas. 92p.

Coffin, Ernest Winliam PhD 1908

Clark [606]

On the education of backward races. PUB : Pedagogical Seminary, XV [1908] pl-62.

$\S 10$ "Our Indian problem" Pueblo, Southwest, Cherokee, Iroquois and Mission tribes.

Coghlan, Mary Daniel MA 1943

Fordham

The Anglo-Spanish conflict for supremacy of the southern frontier: 1600-1748. 111p.

Includes brief mention of Spanish-Anglo relations with Appalachi, Creek and Seminole.

Conn, Abye Albert MA 1906

Columbia [608]

Who are citizens of the United States? And who persons?

63 .

Very brief mention of Indian legal cases. 
Coine, Harriett Edythe

MA 1932

So. California

[609]

The play life of certain Indian tribes in California. 65p.

Cole, David L. MS 1954

Oregon

[610]

A contribution to the archaeology of The Dalles region. $176 \mathrm{p}$.

Coleman, Bernard PhD 1947

Catholic

Decorative designs of the Ojibwa of northern Minnesota. Pув: Cath. U., Anthro. Ser. \#12 [1947] 125p., illus.

Coleman, Lois Frierson $\quad$ MA 1939

So. Methodist

Aspects of Indian civilization; as revealed in representative Mexican novels. 73p.

Collett, Beryl Bishop MA $1922 \quad$ Stanford

The character of the California Indian as portrayed in California literature. 220p.

Collier, Donald PhD 1954

Chicago

Cultural chronology and change as reflected in the ce[614] ramics of the Virú Valley, Peru. Pбв: Chi. Mus. Nat. Hist., Fieldiana, XLIII [1955] 226p.

Collier, Malcolm Carr PhD 1951

Chicago [615]

Local organization among the Navaho. 113p. $M$.

Collins, Gladys Irene MA 1929

Oklahoma

A history of Spanish west Texas. 77p.

$\S 3$ Spanish relations with Indian tribes, 1535-1762.

Collins, Hazel Minnie MA 1917 California [617]

Rivera's inspection of the frontier Presidios of New Spain, 1724-1728. 115p.

Collins, JUNe McCormick MA $1946 \quad$ Chicago A study of religious change among the Skagit Indians of [618] western Washington. 135p.

Collins, June McCormick PhD $1949 \quad$ Chicago The influence of White contact on class distinction and [619] political authority among the Indians of northern Puget Sound. 104p. $M$. 
Collins, Lloyd R. MS 1951

Oregon

[620]

The cultural positions of the Kalapuya in the Pacific

Northwest. 155p.

Collins, Mary Delecta MA 1947

History of the "Song of Hiawatha". 109p.

Niagara

Colson, Elizabeth Florence PhD 1944 Radclife The Makah: a study of assimilation. 613p., maps. PUB : The Makah Indians. U/Minn. Press [1953] 308p.

Colton, Ray Charles PhD 1954 Maryland The American Civil War in the western Territories of New Mexico, Arizona, Colorado and Utah. 323p. $M$.

Plains; Navaho, Apache, Ute, Shoshoni, Bannock. Much on Indian activities, 1861-65.

Comin, Howard V., JR.

MA 1926

Drake

The development of Indian citizenship in the United States. $96 \mathrm{p}$.

Conn, Richard MA 1955

Washington

A classification of aboriginal North American clothing. $80 \mathrm{p}$.

Conneluy, John MA 1946

West. Reserve

Shungopavi: a story of intercultural relations. $438 \mathrm{p}$.

Based on personal experiences at Shungopovi Day School.

Connoluy, Florence MA $1940 \quad$ Arizona

[627]

The origin and diffusion of smudged pottery in the Southwest. 135p.

Connoluy, Gregory M.

MA 1935

Niagara

[622]

[623]

[624]

St. Isaac Jogues. 23p.

1607-1646. His work among the Huron and Iroquois tribes.

Connolly, Sarah Ward MA 1951

So. Methodist

[629]

Mary Austin's philosophy of the land.

Influence of the Indian "Earth Mother" on Mary Austin.

Connor, Daniel A.

MA 1949

Texas Westn.

Military operations in the Southwest, 1861-1865; and

[630] 
battles and movements of the Union and Confederate Texas, forces and campaigns against the Indians in northwest New Mexico and Arizona during the Civil War period. 161p., illus.

Connor, Sydney MA 1942

Yale [631]

The social organization of the Bering Sea region. $94 \mathrm{p}$.

Conroy, Margaret ANN MA $1952 \quad$ Niagara

Missionary effort in Huronia, 1634-1650. 130p.

Constas, Helen MA 1948

New School

Bureaucratic collectivism: A study of the Incas of Peru. $72 p$.

Contreras, Doris M. MA 1954 Mexico City Clavigero: un estudio de su Historia Antigua de México, sus fuentes históricas, con índice analítico de la obra. $73 \mathrm{p}$.

Career of Francisco Xavier Clavigero [1731-1787]; sources and development of his famed Historia, and problems of orthography.

Coogan, John Edward PhD 1934 Fordham

[635]

The eloquence of our American Indian: as reported in the writings of European missionaries concerning especially the tribes of the St. Lawrence Valley, the Great Lakes region, and the western Plains. 404p.

Cook, Ruth Cathly $\quad$ MA 1935

Minnesota

[636]

The results of a remediation program, which used the activity unit technique, on subject matter accomplishments and on certain attitudes of a group of third and fourth grade Indian children at the Red Lake Agency school. 257p.

Chippewa.

Cook, Sarah Louise MA 1930

New Mexico

[637]

The ethnobotany of the Jémez Indians. 28p., maps.

55 species of plants and uses.

Cook, William Adelbert MS/Ed 1911

Illinois

[638]

The American Indian; a study in race education. 191p. 
Cooke, Anne Milne MA 1937

Yale

The material culture of the Northern Ute. $118 \mathrm{p}$, illus.

Coonrod, Guy RAYMond MA 1947

Colorado [640]

Kansas Indian lands, 1803-1854. 100p.

Cooper, Arch Eldredge MA 1942 Chicago

[641]

Ecological aspects of the family hunting territory system of the northeastern Algonkians. 48p.

Cooper, Esther Fager MA 1924

Iowa [642]

Genesis and application of the Dawes Act. 293p.

Cooper, Leland Rogers MA $1948 \quad$ Minnesota

Culture aspects of the Nett Lake Indian Village. 121p.

[643]

Chippewa.

Coopwood, JulIa MA 1938 Texas

[644]

History of the La Bahía settlements during the administration of Captain Manuel Ramírez de la Piscina, 1750 to $1776.124 \mathrm{p}$.

Chapter on relations with the Karankawa, Apache, Aranama and Tamique of Texas.

Coose, LoIs MA 1941

The Texans' necessities of life, 1821-1845. 114p.

St. Mary's

Sections on Indian foods, Indian cultural gifts to Whites.

Cope, Alice Rue MA 1929

Pittsburgh [646]

Fort McIntosh.

Wyandot.

Cope, Leona MA 1917

California

[647]

Calendars of the Indians north of Mexico. 53p. PuB:

U/Calif., Pubs. Amer. Archeol. Ethnol., XVI \#4 [1919] p119-176.

Cope, Robert Samuel

$\mathrm{PHD} 1950$

Ohio State

Slavery and servitude in the colony of Virginia in the

[648] seventeenth century.

Includes considerable Indian slavery.

Copenhaver, Ellen G.

MA 1933

Columbia [649]

Life and culture of the Indians of southwestern Virginia. $82 p$., illus. 
Corbert, Anita Lawrence

MA 1903

Stanford

[650]

Influence of physiography upon the occupation and settlement of New Mexico and Arizona. 43p.

Chapter on Indians of the area.

Corbett, John Maxwell MA 1939 So. California Ball courts and ball games of the ancient American Indians. 79p.

Corbett, John Maxwell

$\mathrm{PHD} 1951$

Columbia

A comparative analysis of the cultural remains from early Ancón and early Supé, Peru. 128p., illus. M. PuB: with Gordon R. Willey, Early Ancón and early Supé culture, Chavin horizon sites of the central Peruvian coast. Columbia U. Press [1954] 180p., illus.

Corkern, Florence R. MA 1940 Texas An evaluation of Southwest books for primary children. [653] Section on Indian books.

Corneld, Ruth E. PhD 1930 Pennsylvania

[652]

A study of the geographical distribution of the fishing methods of the North American Indians. 59p.

CoRnett, Lloyd H., JR. MA 1954

Oklahoma

Leasing and utilization of land of the Cheyenne and [655] Arapaho Indians, 1891-1907. 284p.

Oklahoma Arapaho and Cheyenne.

Cornish, DUdley T. MA 1947 Colorado in Congress: the first five years, 1876-1881. Colorado

[654] Considers legislation applied to Indians and Indian affairs.

Correia, Delia Richards

MA 1935

California

Lasuén in California. 179p.

Missions in lower and upper California.

Corry, John Pitts $\quad$ PHD 1935

Pennsylvania

Indian affairs in Georgia, 1732-1756. РणB: U/Penna. Press [1936] 197p.

Costikyan, Hagor

STM 1936

Union

The Friends in the United States from the Revolution [659] to the Civil War, 1783-1865. 151p.

Brief mention of Quaker missions to the Indians. 
CotTer, JoHN LAMBerT

MA 1935

Denver

Yuma and Folsom artifacts. 161p., pls. Рणв: "The significance of Folsom and Yuma artifact occurrences in the light of typology and distribution." Phila. Anthro. Soc., Pubs., I [1937] p22-35, illus.

CoUlter, JosepH E. MA 1948 Catholic missions among the Potawatomi Indians.

Count, Earl Wendel $\quad$ PhD 1935 California $[662]$ The Earth-Diver: an attempt at an Asiatic-American correlation. $319 \mathrm{p}$.

Covey, Anna Hays MA 1935

Texas

$[661]$ The public career of Dixon Hall Lewis to 1844.

Alabama Senator, active in Indian affairs.

Covington, James Warren $\quad$ PHD $1949 \quad$ Oklahoma [664] Relations between the Ute Indians and the United States Government, 1848-1900. 310p.

Cowan, Clara Blanche ma 1941 Missouri Assimilation of the Cherokees (as revealed in a hundred [665] urban families). 141p.

Cox, Carol MA 1939

Denver

[666]

A study of Indian dwellings in the western area of North America. 158p.

Cox, Charles Raymond MA 1931 Oklahoma $A \& M$ Caddoan relations with the White race previous to 1801 . [667] $174 \mathrm{p}$.

Considerable primary source material; includes all major Caddoan tribes.

Cox, IsaAc J. $\quad$ PhD 1904 Pennsylvania $[668]$ The early exploration of Louisiana. PUB: Cincinnati U. Press [1906] 160p.

Considers early Indian-White explorer contacts.

Cox, Lionel Conrad MS/Ed 1938

Wyoming [669] A study of the intelligence of Indian and White children. 
Cultural relations between South America and the Old World with reference to possible contact across the Pacific Ocean. 136p.

Craig, Donald Munro The Yaqui problem, 1880-1939.

California

Craig, Edith MA 1943

Colorado $A \& M$

Needs of Indian girls for homemaking education. 100p.

Craig, Lucie Hinton MA 1929

The removal of the Chickasaw Indians. 109p.

Craig, Sarah Helen

MA 1933

Ohio State

Comparative study of the novels, dealing with the Southwest, of Gertrude Atherton and Mary Austin.

Crane, Fred Arthur PhD 1952

Yale

The Noble Savage in America, 1815-1860. 453p.

Crane, Katharine Elizabeth $\quad$ MA 1925

Smith

The Indian policy of the United States Government since 1871. $88 \mathrm{p}$.

Crane, Katharine Elizabeth PhD 1930 Chicago Indian relations in the Old Northwest before $1811.177 \mathrm{p}$.

Crane, Verner Winslow PhD 1915 Pennsylvania The Southern frontier, 1670-1732. PUB: Duke U. Press [1928] 391p.

The Indian frontier of South Carolina, 1670-1715.

Cravens, Dollye Hefner MA 1942 Oklahoma $A \& M$ Standard bearer of the Cherokees: the life of William Wirt Hastings. 42p.

Cresap, Bernarr PhD 1949

Vanderbilt

The career of General O. C. Ord to 1864.

Considers his activities in Seminole War, Washington and Oregon Indian campaigns, 1855-1858.

Crespi, Alberta R. EdD 1942

Fordham

Secondary school teachers in the Territories and possessions of the United States. 320p.

Considers Alaskan native schools, conditions and needs.

[677]

[678]

[679]

[676] 
Cresson, Francis M., JR.

MA 1937

Pennsylvania

[682]

Maya and Mexican sweat houses. 34p.

A comparative study of Mesoamerican architecture.

Crippen, Harlan Robert MA 1950

California

[683]

The Dakota Indians and New France, 1654-1760.

Crisweld, EliJah Harry $\quad$ PhD $1936 \quad M i s s o u r i$

Lewis and Clark: linguistic pioneers. PUB: U/Missouri Stud., XV \#2 [1940] 102p.

$\S 1$ "The New World of explorers ... the Indians". Includes the Lewis and Clark lexicon.

Crites, Kenneth Kipling MA $1953 \quad$ New Mexico

A study of teacher turnover on the Navajo Reservation.

Crocker, William Henry

MA 1953

Stanford

A systematic approach to the study of innovators, deviants and conformers through the use of personal documents. $322 \mathrm{p}$.

Uses Indian individual histories as case-examples.

Crockett, Grace LiLIan MA 1918 California [687]

Mange's Luz de Tierra Incógnita; a translation of the original manuscript, together with an historical introduction. $193 \mathrm{p}$.

Indians in Pimería Alta, 1694-1701.

Crockett, Joy MA 1923

Idaho

Operations of the Hudson's Bay Company in Old Oregon. 33p.

Mentions Indians only incidentally; emphasis is on organization, founding of trading posts, and other activities.

Croft, Kenneth MA 1949

Indiana

[689]

A guide to source material on extinct North American Indian languages. 8p. PUB: Intl. Jour. Amer. Ling., XIV \#4 [1948] p260-268.

Croft, Kenneth $\quad$ PhD 1953

Indiana

Matlapa and classical Nahuatl: with comparative notes on the two dialects. 122p. M. PUB: Intl. Jour. Amer. Ling., XIX-XX [1953-1954] var. pp. 
Cronk, Leslie M.

Indian education in terms of pupil and community needs. 111p.

Cronyn, George WiLliam MA 1917 Columbia

The frontier in American literature prior to the Civil War. 145p.

Includes general references to Indians.

Crook, Clifton Allen MA/Ed $1941 \quad$ Washington

A study of Indian education in Washington.

Period 1930-1941. Examines assumption by Washington of state responsibility for schools.

Crooks, Madricia Dale MA $1937 \quad$ Oklahoma

Dennis Wolfe Bushyhead and his influence on Oklahoma history. $126 \mathrm{p}$.

Contains much original manuscript material, letters and documents pertaining to Cherokee history.

Cross, Barney Edward MA $1935 \quad$ Colorado State

General John Simcoe as a disturbing factor in the Old Northwest. 113p.

Mohawk, Mingo, Shawnee, Cherokee, Chippewa, Huron, Six Nations.

Crossett, Lela MA $1928 \quad$ California [696]

New Mexico Pueblo Indians as described by the early explorers. 187p.

Crodch, WILLIAM Ward

MA 1932

Tennessee

Missionary activities among the Cherokee Indians, 1757-1838. 202p.

Croushore, James Henry PhD $1943 \quad$ Yale John William DeForest. A biographical and critical study to the year 1868. 397p., photos.

Background for his History of the Indians of Connecticut. Used firsthand data; much on Indians, and his technique of research.

Crowder, Mary William MA 1927 Oklahoma

Virginia's relations with the Indians, 1607-1763. 77p.

Algonquin, Five Nations, Mohawk. 
Crowe, Fletcher Standefer MA 1922 Washington/SL $[700]$ The National policy of frontier defense, 1815-1825. 95p. Includes Seminole, Creek, Arikara, Sioux, Choctaw.

Crown, Winton L. MA 1950

Fort Hays

A study of Indian raids in northwest Kansas, 1864-1878.

[701] $135 p$.

Cruden, Davina Ruth MA 1922

California [702]

Early fur trade in California. 286p.

Crump, Bonnie Lela Massey

PHD 1932 Columbia The educability of Indian children in Reservation schools. PuB: Durant, Okla: Soeastn. State Teachers Coll., Contr. Educ. \#3 [1932] 59p.

Five Civilized Tribes of Oklahoma only:

Culhane, Albert Edward MA 1934 Colorado A history of the settlement of La Plata County, Colorado. [704] Much on Ute Indians.

Culp, Ruby Lee MA $1934 \quad$ Geo. Washington The missions of the American Board and Presbyterian [705] Church among the Five Civilized Tribes, 1803-1860. $152 \mathrm{p}$.

Cummings, J. R. MA 1941 Medical practices of the Indian of the Southwest.

Cunningham, James Stewart $\quad$ PhD 1946 California [707] Spanish colonization in Patagonia, 1778-1783. 190p.

Araucanians, Patagonians, Pampas.

Cureton, Robert Elliott MA 1937 Atlanta [708] The Indian problem in colonial Georgia, 1733-1745.

Curley, Michael Joseph PhD 1940

Catholic [709]

Church and state in the Spanish Floridas (1783-1822). Puв: Cath. U., Stud. Amer. Church Hist., XXX [1940] 380 p., illus.

Currie, Althea Elizabeth MA 1930 Illinois The American Indian as portrayed by Montaigne, Voltaire, and Chateaubriand. 56p. 
Currie, Gordon C. MA 1947

Mt. Allison

[711]

Indian education in Nova Scotia. 59p.

Curtis, Martha Elizabeth PhD 1944

Cornell

A study of the relation of some science materials known to certain Algonkin Indians to present elementary science teaching.

Education of Indian child and trait complex of tribe as exemplified by study of Keshena Menomini.

Curry, Laura Kathleen MaE $1937 \quad$ Mexico La rebeldía entre los Indios de México. 68p.

[713]

A summary of Indian rebellions in Mexico.

CURRy, Raymond William MA 1942

Arizona Arizona in fiction. 213p.

1848-1942. Regards Indian as second in importance only to the cowboy.

CurRy, Robert A. MA 1955 Buffalo

New York Loyalists and the American Revolution. 245p. Frequent references to Indian role in the Revolution.

Custer, JoHn L. MA 1951

Excavation at Culhuacán. 190p., illus.

Mexico City

Account of the excavation of a pre-Conquest city underlying the present Barrio de San Francisco de Culhuacán.

Cutter, Donald Colgett $\quad \mathrm{PHD} 1950 \quad$ California Spanish exploration of California's central valley.

Effects of penetration into valley by Whites; refugee Indians from missions pursued. 45 explorations considered.

Dabney, Margaret Alice MA 1945 Kansas

Materials native to Oklahoma in art education.

Historical background on Indian tribes and Pueblo ruins; two maps show Five Tribes before and after removal. Not primarily Indian.

DaCey, William MA 1946 Clark

Geographic origins of art; a regional concept of classification. $141 \mathrm{p}$.

Includes environmental consideration of Indian art; examines differences between primitive and sophisticated art expressions. 
Dagley, Asa Wallace

The Negro of Oklahoma.

Negroes held as slaves by each of Five Civilized Tribes; freedmen adopted into tribes; their treatment, problems. Much on Indians.

DAhLGREN DE JoRdán, Barbro MA 1956 Mexico: $E N$ La Mixteca, su cultura e historia prehispánica. Р вв: U/Mexico: Collec. culturas mexicanas, II [1954] 399p.

DAlFuKU, Hiroshi PHD 1951

Harvard

A conceptual scheme of Southwestern archaeology in the light of the excavation of a Basket Maker III-Pueblo I site in the Jeddito Valley, northeastern Arizona. 181p., illus. Puв: Amer. Anthro., LIV \#2 [1952] p 191-200.

Dalager, Rudolph Levin MA 1930 So. California The Espejo expedition into New Mexico, 1582-1583. 88p.

Dale, Kenneth Ivan EdD 1949 Navajo Indian educational administration. $196 \mathrm{p}$.

Dale, Margaret Pressly $\quad$ MA 1933 Columbia

[722] The Crónica Mexicana by Hernando Alvarado Tezozomoc. $96 \mathrm{p}$.

DaLL, Dorothy MA 1936

Montana

The influence of Governor Isaac Ingalls Stevens on the opening of the Northwest. 88p.

Dalr ymple, Paul Clement

MA 1952

Syracuse

No. Dakota An historical geography of Monhegan Island, Maine. 109p., illus.

Based largely on Williams' History of Maine; Indian-White relations considered at length.

Daniels, James Manley MA 1948 Texas

La Junta de los Ríos and the despoblado, 1680-1760. Indians of the Big Bend region; missions.

Danson, Edward Bridge PhD 1952 Harvard An archaeological survey of west central New Mexico and east central Arizona. 2 vols., illus. 
Dargan, Lena Dingman

MA 1932

New Mexico

James S. Calhoun in New Mexico. 131p.

His career as Indian Agent, 1849-1852.

Dark, Philip John Crosskey $\quad$ PhD 1954

Methods in ethnohistory: with reference to Mixtec materials. 323 p., illus.

Darlington, Marion MA 1943

Columbia

A study of the poetry of the Indians of North America and its influence on modern American poetry. 296p.

Darnell, William Leonard MA $1930 \quad$ Texas The services of Francisco de Urdiñola in Nueva Vizcaya, 1575-1612.

Dart, Marguerite Mildred MA 1954 California The history of Lompoc Valley, California. 169p., photos. Chumash.

Daugherty, George Henry, JR. PhD 1925 Chicago Reflections of environment in North American Indian literature.

Excludes myths and tales. Considers songs and ritual orations of Indians in general, primarily Chippewa, Sioux, Pima and some Iroquois.

Daugherty, Richard D. PhD 1953 Washington Early man in the Columbia Intermontane Province. 376p. M. Рचв: U/Utah, Anthro. Paps. \#24 [1956] 123p.

Dávalos Hurtado, Eusebio MA 1956 Mexico: $E N$ La deformación craneana entre los Tlatelolca.

Davidson, Donald Curtis MA 1934 California The North West Company in Old Oregon and New Caledonia. $87 \mathrm{p}$.

Includes Cowlitz, Snake, Iroquois and other tribes.

Davidson, Gordon Charles MA 1908 California Report on the manuscripts of British Columbia in the Bancroft collection. 6p.

Includes manuscripts discussing Indians of British Columbia.

[736] 
Davidson, Gordon Charles PhD 1916 California

The North West Company. Р вв: U/Calif. Pubs. Hist., VII [1918] 349p.

Indian material relating to fur trade throughout.

Davidson, James Aluie PhD 1941

Baptist beginnings in western Pennsylvania.

Pittsburgh [741]

Some consideration of Baptist mission work among Indians.

Davidson, Robert Nathantel MA 1952 Stanford A study of the Ghost Dance of 1889. 49p.

Davidson, William David MA 1948

Duke

A method for studying religious cult and healing ceremonies and its application to a Guatemalan Indian curing ceremony. 145p.

Pokoman Indian curer was informant.

Davis, Caroline Leola MA 1937

Oklahoma

[742]

[743]

The history of the schools and the educational development of the Chickasaw Nation. 146p.

Davis, Doris Winona MA 1939 Washington The Land Ordinance of 1785.

$[745]$

Brief references to Indian titles, cessions and treaties.

Davis, Edward MA 1919

Oklahoma

Tribal land titles in Oklahoma. 50p.

[746]

Circa 1860-1914. Tribes of Indian Territory.

Davis, Edward PhD 1935

Texas

History of Federal relations with the Five Civilized Tribes of Indians since 1865. 544p.

Davis, Edward Motr, JR. PHD 1954 Harvard The culture history of the central Great Plains prior to the introduction of pottery. 386p., illus.

Davis, George Harland MS/Ed 1941 Oregon State A curriculum based on the functional needs of the Navajo.

Davis, Gladys Maude MA 1937 Colorado The Indians and Indian campaigns in the Panhandle of Texas. 135p., map.

[748]

[750] 
Davis, James Thomas

MA 1954

California

The Patterson Mound: a comparative analysis of the archaeology of Site Alameda 328.

Davis, John Benjamin MA 1929 Geo. Peabody

The life and works of Sequoyah. 102p.

Davis, JoHN WAYNe MA 1934

Colorado

A history of the Pipestone Reservation and quarry in Minnesota. 115p.

Davis, Lawrence J. MA $1944 \quad$ So. California The sociocultural changes in the Cheyenne River Sioux Indians as a result of contact with White civilization.

Davis, Robert YaRborodgh MA $1944 \quad$ Iowa A study of the San Juan Indian Mission. 147p.

Davis, William Lyle PhD $1943 \quad$ California $[756]$ Mission St. Anne of the Cayuse Indians, 1847-1848. $238 \mathrm{p}$.

Davlin, Joyce Katharyn MA 1956 Mexico: $E N$ $[757]$ Breve estudio de los entierros en Mesoamérica prehispánica.

Day, Arthur Grove MA 1942 Stanford North American ritual poetry in English translation.

DAy, Arthur Grove PhD 1944

Stanford

Types of North American Indian poetry in English translation. Рणв: The sky clears; poetry of the American Indian. Macmillan [1951] 204p.

Considers 38 Indian tribes, also several Mesomerican groups.

Day, MurLIN Webster MA 1937

Kentucky

[760]

Sir William Johnson and the Conspiracy of Pontiac. 74p.

Daywalt, William E. PhD 1948

U.C.L.A. [761]

A critical study of contemporary Mexican Indian pottery. 269p.

Also includes corollary study of work at several Indian Reservations in U.S. and British Columbia. 
Dazey, Elizabeth Thorne

MA 1948

California

[762]

The transition from childhood to adulthood among the Klamath Indians of Oregon.

Deale, Valentine B. MA 1939

Notre Dame

The history of the Potawatomi before 1722. 66p.

Dean, Chester L. MA 1935

So. California

The Federal Indian policy in Arizona, 1863-1886. 184p.

[764]

Dearborn, Frances R.

MA 1927

Iowa

Problems of North American Indians: a course of study in Indian history. 231p.

DeArmond, Louts Cushman PhD 1950 California Luis de Valdivia and defensive war in seventeenth century Chile. 264p., maps.

Araucanians.

Debo, Angie Elbertha

$\mathrm{PHD} 1933$

Oklahoma

History of the Choctaw Nation from the end of the Civil War to the close of the tribal period. PUB: Rise and fall of the Choctaw Republic. U/Okla. Press [1934] 314p., illus.

Debra, Mabel Mason MA 1928

Yale

$[763]$

[765]

A comparative study of life forms and their symbols in Indian ceramic design of the Southwest. 33p., illus.

DeBurgos, Francis MA 1927

Texas

The administration of Teodoro de Croix, Commander

[769] General of the Provincias Internas de Mexico, 1776-1783. Problems of Indian administration.

Decker, A. Mabel MA 1917

Columbia

[767] The treatment of the Indians during the Spanish conquest. $32 p$.

DeFlores, Patricia Firth

MA 1949

Stanford

Mexican costume: its development from pre-Columbian

[771] times to the present as an expression of the blending of cultures.

DeGaetano, Leo Vincent

MA 1948

New York

Indian policy in early New England. 109p.

$[770]$ 
DeGroat, Elizabeth MA 1950

Catholic

An analysis of the material culture of the Iroquoian

$[773]$ Indians.

DeHarport, David Lee MA 1945 Denver A racial classification of some Pueblo crania. 76p., illus.

De la Calle y Rodríguez, María MA 1956 Mexico: $E N$

Función de la indumentaria prehispánica en el centro y sur de México.

DeLaCruz, Margot Preece

MA 1954

Florida

The encomienda in Cuba. $72 \mathrm{p}$.

1503-1520. "Contributed to the disappearance of the Indians in Cuba."

Delaguna, Frederica Annis PhD 1933 Columbia A comparison of Eskimo and Palaeolithic art. PUB: Amer. Jour. Archeol., XXXVI \#4 [1932] p477-511; XXXVII \#1 [1933] p77-107.

Delaney, Geraldyn Ann MA 1932 Columbia The manuscript of Henry David Thoreau's Notes on the North American Indians, volumes XI and XII. (Transcribed and edited.) $352+102 \mathrm{p}$.

Delanglez, Jean $\quad$ PhD 1935

Catholic

The French Jesuits in lower Louisiana (1700-1763). PUB : Cath. U., Stud. Amer. Church Hist., XXI [1935] 547p. Indians considered throughout; especially mission posts among Arkansas, Yazoo, Choctaw, Alibamu.

Delmez, Albert Juares PhD 1949

Missouri

The history of the cultural missions in Mexican education.

[780] 317p. $M$.

Period 1923-1949. UNESCO especially considered. Indians mentioned throughout as "peasants", but no specific tribes mentioned.

Delorme, David P. PhD 1955

Texas

[781]

A socio-economic study of the Turtle Mountain band of Chippewa Indians, and a critical evaluation of proposals designed to terminate their Federal wardship status. $271 p$. 
Demetracopodlou, Dorothy S. PhD 1932 California The Loon Woman myth: a study in synthesis. PuB: Jour. Amer. Folklore, XLVI \#180 [1933] p101-128.

DeNier, Flora Lauretta MA 1928

California

Robert Livermore and the development of Livermore Valley to 1860.221 p., maps.

Various Miwok tribes of the area.

Denison, Natalie Morrison MA 1938 Oklahoma Presbyterian missions and missionaries among the Choctaw to 1907. 229p.

Denison, Velma MA 1932

Geo. Peabody

A brief history of the Chickasaws in Oklahoma. 125p.

Denman, Murrie MA 1953

So. Dakota

Art in the life of the Sioux Indian of South Dakota.

8 black and white plates of various Sioux designs and scenes are included.

Dennerlein, Gerald Edwin MA 1941 So. California History of the Ramona Land: the economic and social development of San Jacinto, California.

Especial reference to Luiseño and Soboba Indians.

Dennis, Elsie Frances MA 1928

Oregon

Slavery among the Indians in the Pacific Northwest. 64p.

$[786]$

Dennis, Mary E.

MA 1939

New Mexico

Plants and animals used as sources of dye, paint, and skin dressing in the Southwest. 50p.

Denniston, Douglas MA $1948 \quad$ New Mexico A group of paintings derived from Southwestern Indian art.

15 photographic reproductions.

Denoyer, Charles MA 1909

No. Dakota

[784]

The history of Fort Totten. 104p.

Dakota Sioux.

Dent, WiLlard L. MA 1949

East Texas

$[788]$

[789]

History of Stonewall County. 129p., illus.

$\S 2$ "Early exploration and the Indians"; § 3 "The Indian and the buffalo". Texas locale. 
Denton, DoRIs MA 1929

Kansas

[793]

Harmony Mission, 1821-1837. 57p.

Account of a short-lived mission to the Osage Indians of Kansas.

Denton, Flossie Hilton MA 1937 Geo. Peabody

Stories of the Cherokee Indians adapted to fourth grade [794] level. $128 \mathrm{p}$.

"A group of Cherokee stories never before collected."

Derden, Lucien JACK MA $1949 \quad$ So. Methodist The education of the shaman among the North American Indians. 90p.

Derr, Lucile Elizabeth MA 1927 California The administration of Esteván Miró in Spanish Louisiana 1784-1791, with an appendix of translations from the originals of Spanish documents, 1781-1791. 382p.

Creek, Choctaw, Chickasaw and Alibamu.

Derthick, Lawrence G. MA $1930 \quad$ Tennessee The Indian boundary line in the southern district of British North America, 1763-1779. 156p.

Desmond, Gerald R. PhD 1951 Gambling among the Yakima. Puв: Cath. U., Anthro. Ser. \#14 [1952] 58p.

De uel, Thorne PHD 1935

Chicago

The application of a classificatory method to Mississippi [799] Valley archaeology. PuB : with F. Cooper-Cole, Rediscovering Illinois: Archaeological explorations in and around Fulton County. U/Chi. Press [1937] p207-219.

DeVault, Earl S. MA 1940

Colorado State

[795]

$[796]$

The Sioux in South Dakota. 107p.

Devereux, George PhD $1936 \quad$ California The sexual life of the Mohave Indians: an interpretation in terms of social psychology. PUB: Human Biology, IX \#4 [1937] p498-527.

Dewar, John MA 1954 Mexico City [797] Mexican masks.

The mask in primitive cultures, and an artistic evaluation of the Mexican mask. 
Diamond, Herbert Maynard PhD 1917

Yale [803]

Religion, a factor in primitive economic adaptation. PUB: Religion and the Commonweal. NY: Harper \& Bro. [1928] 305p.

Dibble, Charles E. MCH $1938 \quad$ Mexico Un estudio del "Códice Xolot". 236p., illus. РuB : Códice Xolotl. U/Utah Press [1951] 166p., illus.

Dibble, Charles E. DA 1942 Mexico [805] Códice en Cruz. Pub: México, D.F.: Taller Numancia [1942] 164p., illus.

Dibble, Paul Gladstone MA $1930 \quad$ Chicago Christian influence among the Stockbridge Indians. 97p.

Dickerson, Oliver Morton PhD 1911 Illinois American Colonial Government 1696-1765; a study of the British Board of Trade in its relation to the American Colonies, political, industrial, administrative. PUB: Cleveland: A. H. Clark [1912] 390p., illus.

Cherokee, Creek, Miami, Mohegan, Six Nations. Includes annotated bibliography.

Dickerson, William Edwin S. MA 1952 Texas "The White Path." The ethnology of the AlabamaKoasati Indians of Texas. 179p.

Dickson, Evelyn Marthena Hogue MA 1946 Stanford Food plants of the western Oregon Indians. 218p.

Diesing, Pa Ul PhD 1952

An action program for the Fox Indians. 168p.

[806]

[807]

Dietricich, Sigismund de RÜDesherm PhD 1931 Clark Historical geography of the Thames River Valley, Connecticut.

Includes chapter on Pequot.

Dijour, Elizabeth MA 1931

Columbia

[808]

Preliminary study of Runasimi (Q'ešwa) of the Cuzqueño and Bolivian groups. 49p.

A linguistic study. 
Dinnen, Catherine Marie MA 1950 So. California A study of the early history of Fort Wayne, Indiana.

Relation of Fort to the Miami tribes; also Shawnee, Potawatomi, Chippewa, Ottawa.

Dionne, Gabriel MA $1947 \quad$ Ottawa

Histoire des méthodes missionnaires utilisées par les Oblats de Marie Immaculée dans l'évangélisation des indiens du "versant pacifique" au dix-neuvième siècle. $150 \mathrm{p}$.

DiPeso, Charles Corradino, JR. MA 1950 Arizona Babocomari, Indian village located on the Babocomari River: an archaeological site in southeastern Arizona. 416p. Pбв: Dragoon: The Amerind Found., \#5 [1951] 248p., illus.

DiPeso, Charles Corradino, JR. PhD 1953 Arizona The Sobaipuri Indians of the upper San Pedro River [816] Valley, southeastern Arizona. 405p. M. Р Uв: Dragoon: The Amerind Found., \#6 [1953] 285p., illus.

Ethnohistorical and archaeological study; Spanish contacts, 1450-1692, and their impact, intensively examined.

DitTert, Alfred E., JR. MA $1949 \quad$ New Mexico [817] The prehistoric population and architecture of the Cebolleta Mesa region, central western New Mexico. 113p.

Dixon, Helen Mrluer MA 1934 Texas The middle years of the administration of Juan María, Baron de Ripperdá, Governor of Texas, 1773-1775. 97p. Chapter on Indian affairs.

Dixon, KeIth A. MA 1952 Arizona

Hidden House, a cliff ruin in Sycamore Canyon, central [819] Arizona; a study based on notes by Clarence R. King and Museum collections. 178p. Рбв: Mus. No. Arizona, Bull. \#29 [1956] 90p., illus.

Dixon, Mabel Eastman MA 1924 Columbia Methods of dyeing among the aboriginal tribes of [820] America. 27p. 
Dixon, Roland Burrage

PHD 1900

Harvard

The language of the Maidu Indians of California. Рणв: Bur. Amer. Ethnol., Bull. \#40 pt. 1 [1911] p679-734.

Dobie, Dudley RichaRd MA 1932 Texas

The history of Hays County, Texas.

Including aboriginal inhabitants of the area.

Dockstader, Frederick J. MA 1941 Ariz.-Flagstaff European influences on Hopi Kachina ceremonials. 64p. illus., col. pls.

Dockstader, Frederick J. PhD 1951 West. Reserve White influences on the Hopi Kachina cult. 249p. P UB: The Kachina and the White man. Cranbrook Inst. Sci. [1954] 185p., illus., col. pls.

Dodge, FAye MA 1911

Kansas

The nature and extent of Indian agriculture in North America. 45p.

Dodson, Leonidas PhD 1927

Iowa [826]

Alexander Spotswood, a Governor of colonial Virginia, 1710-1722. Pub: U/Penna. Press [1932] 323p.

Chapter on "Indian relations". Iroquois, Algonquian, Dakota Sioux.

DOLCH, IsABeL Scherer MA 1922 Washington/SL Calendar of the Pierre Chouteau-Maffitt papers concerning the fur trade in the Southwest. 201p.

Considerable Indian material, especially on Sac, Fox, Osage, Potawatomi.

DoNaHUE, MaY MA 1923

Columbia

The economic life of the American Indians as seen in the Jesuit Relations, edition of Reuben Gold Thwaites, 1896-1901. 30p.

Donaldson, Clara Rosella Ma 1926

Akron [829]

A study of the United States Indian schools. 127p.

Donaldson, Jessie Louise

MA 1931

California

A stylistic study of variants of the mentor-grandmother

[830] myth. $37 \mathrm{p}$.

All North American tribes, including Eskimo. 
Dondore, Dorothy Anne

The Prairie and the making of middle America; four centuries of description. PUB : Torch Press [1926] 472p.

Literary descriptions of the West; much on Indians.

Donnelly, Jean Merl MA 1933

Arizona

[832]

John G. Neihardt-epic poet. 65p.

Neihardt's Cycle of the West: Plains Indians west of the Mississippi, chiefly Omaha.

Donnelly, Joseph Peter PhD $1940 \quad$ St. Louis The liquor traffic among the aborigines of the New Northwest, 1800-1860. 303p. $M$.

Oregon-Washington-Idaho area ; traces causes of failure in "civilizing" Indians to liquor traffic, with fur traders and homesteaders equally culpable.

Donnelly, William Patrick MA $1934 \quad$ St. Louis Father Pierre-Jean de Smet; United States Ambassador to the Indians. 138p. PuB : Cath. Hist. Soc., Hist. Records and Stud., XXIV [1934] p7-142.

Donohue, Arthur Thomas PhD 1932 Kansas The history of the early Jesuit missions in Kansas. 256p. $M$.

1836-1848. Role of Jesuits and their influence on Indian economics, religion and culture. Traces five missions among Potawatomi, Creek, Osage.

Donohugh, Agnes C. L. MA $1916 \quad$ Columbia Knowledge and interpretation in Salish culture. $36 \mathrm{p}$.

Dorain, Edith McEwen MA 1927 Columbia Indian warfare in early New England literature. 85p.

Dorman, Margaret MA 1932 New Mexico A study of the water-color paintings of modern Pueblo Indians. 34p.

Dorn, Donald D. MS/Ed 1954

No. Dakota

A comparative study of Indian and White children in the intermediate grades of the Cass Lake public schools. $88 \mathrm{p}$.

Minnesota Chippewa. 
Dorrance, Harold George MA 1953 Mexico City [840] The social position of the Indian woman in sixteenth century New Spain. 93p.

Dorsey, George Amos PhD $1894 \quad$ Harvard [841] An archaeological study based on a personal exploration of over one hundred graves at the Necropolis of Ancón, Peru. 2 vols., illus. with 116 photographs.

This was the first $\mathrm{PhD}$ awarded by a formally-organized Department of Anthropology in the United States. See also 539,3336 .

Dorson, Richard Mercer PhD 1943 Harvard [842] New England popular tales and legends. 774p. PUB: Jonathan draws the long bow. Harvard U. Press [1946] $274 \mathrm{p}$.

Includes brief section on Indian legends.

Dosch, Delmar R. MA 1947 Loyola [843] Father Pierre-Jean de Smet, S. J., Ambassador extraordinary to the Sioux Indians, 1862-1868. 94p.

Dossick, Jesse JoHN EDD 1941

Harvard

Education among the ancient Aztecs. 494p.

Douglas, Mary Elizabeth MA 1947

Oregon [845] Oregon Indian basketry types and distribution. $96 \mathrm{p}$.

Douglass, LiLlian $\quad$ MA 1932

Louisiana

Place-names of East Feliciana parish.

[846]

Includes a few Indian names.

Dove, Myrtle R. MA 1949

The history of Toyah, Texas. 82p., illus.

Sul Ross [847]

Comanche, Apache.

Dovell, Junius E. PhD 1947

No. Carolina [848]

A history of the Everglades of Florida. 598p.

Includes section on Seminoles; other tribes in passim.

Dowell, ETHEL Fowler MA 1932 The opening of Oklahoma Territory, 1889. 112p.

Dowlen, Louise Eleana MA 1937

Geo. Peabody

[850]

North American Indian poetry. 297p.

Columbia [849] 
Dowling, Alice Brown

MA 1932

Oklahoma

[851]

The significance of the destruction of the American bison in the Southwest. 67p.

Dowling, Joseph Albert MA 1951

New York [852]

Victor Raúl Haya de la Torre. 81p.

Career of the Peruvian Indianist political leader.

Downing, Beebs MA 1944

Geo. Washington

The social position of the Andean Indian in selected contemporary novels of Peru, Ecuador, and Bolivia. 67p.

Dozier, Edward P. MA $1949 \quad$ New Mexico

A tentative description and classification of Tewa verb structure. PUB: Intl. Jour. Amer. Ling., XIX [1953] p118-129.

Dozier, Edward P. $\quad$ PhD 1952

U.C.L.A.

The changing social organization of the Hopi-Tewa. 160p. PUв: "The Hopi-Tewa of Arizona." U/Calif., Pubs. Amer. Archeol. Ethnol., XLIV \#3 [1954] p259-376.

Dragoo, Donald Wayne MA 1949

Indiana

Origins of the Adena culture. 73p.

Drain, MaUd MA 1928

Oklahoma

The history of the education of the Creek Indians. 111p.

Drain, Myrtle $\quad$ MA 1928

Oklahoma

A history of the education of the Choctaw and Chickasaw Indians. 90p.

Draper, Catherine M. MA 1948 Montana

[853]

[854]

$[855]$

The influence of the horse on the life of the Great Plains Indians. $72 \mathrm{p}$.

Draughon, Byrd Love MA 1946

Oklahoma

$[856]$

[857]

[858]

Christian missions among the Chickasaws. 98p.

Drewes, Rudolph Herman

MA 1927

California

[861]

Pedro Fages, California pioneer. 104p.

Yuma tribes.

Dring, Lovilla Ruth MA 1934

New Mexico

Literary backgrounds of the Santa Fé Trail. 194p.

Extensive Indian consideration, especially as a hazard to travel.

[859]

[860] 
Driver, David Mruler PhD 1942 Columbia

The Indian in Brazilian literature. PuB: NY: Hispanic Inst. of U. S. [1942] 190p.

Driver, Harold Edson MA 1934 California [864] Wappo ethnography. Рuв: U/Calif., Pubs. Amer. Archeol. Ethnol., XXXVI [1936] p179-220.

Driver, Harold Edson PhD $1936 \quad$ California The reliability of culture element data. PuB: "Culture element distributions, Pt. VIII." U/Calif., Anthro. Rec., I \#4 [1938] p205-220.

Drucker, Philip PhD 1936

California

Diffusion in Northwest Coast culture in the light of some distributions. 140p.

DRUMmond, IsABeL N. MA 1930

Indiana

A study of the literary and artistic elements in the life of the Sioux. 137p.

Dubach, OtTo Frederick

РнМ 1905

Chicago

[865]

The treaty relations and government of the Cherokee. $33 p$.

DuBois, Cora Alice PhD 1932

California

[866]

Girls' adolescence observations in North America. 98p.

[867]

Duell, Prentice W. MA 1917 Arizona

A study of the Mission San Xavier del Bac, near Tucson, Arizona. PuB: Mission architecture as exemplified in San Xavier del Bac. Tucson: Ariz. Archeol. \& Hist. Soc. [1919] 135p., illus.

While primarily a civil engineering study, Pima-Papago-Apache are considered. A complete list of Southwestern missions and an exhaustive bibliography are included.

DUfF, WILson MA 1952

Washington

The Upper Stalo Indians; an introductory ethnography. 366p. Pणв: "The Upper Stalo Indians of the Fraser Valley, British Columbia." Victoria: British Columbia Provincial Mus. Mem. \#1 [1952] 136p.

Halkomelem, or Lower Fraser Indians. 
Duffen, William A. MA 1936

Arizona

[872]

The development of human culture in the San Pedro River Valley, Arizona. 108p.

Thesis expanded from its original aim of seeking connection between Sobaipuri and San Pedro River tribes into a developmental study of human culture in the area.

Duffy, Charles Anthony MA 1952 California

Peru under Fernando de Torres y Portugal, Conde del Villar, Viceroy, 1585-1589. 195p.

Missionary work and defense; Araucanian and Chiriguaná.

Dugan, E. J. MA 1938 Oklahoma $A \& M$ Education among the Creek Indians. 60p.

Duggleby, Donald Rex MA 1948

Indiana

Hoosiers travel the Oregon Trail, 1841-1853. 348p.

Duke, Mary Fender ma 1942

So. Methodist

The Indian in American literature since 1920. 135p.

Dulaney, Lulu Mae Ma 1927

Texas

The first administration of Sam Houston. 184p., illus. Chapter on his Indian relations.

DUNBar, LaIRD J. MA 1948

New Mexico

A study of the suffrage of the Arizona and New Mexico Indian. $76 \mathrm{p}$.

DUNCAN, John Livingston MA 1936 West. Ontario Church of England missions among the Indians in the diocese of Huron to 1850. 153p.

Six Nations: Sable, Muncey, Manitoulin I., Walpole I.

Duncan, Mary Beverly MA 1926

Columbia [880]

General Andrew Lewis. 42p.

Indian fighter in Virginia Border Wars.

Duncan, Winliam deBarenne MA 1933 Pittsburgh [881] Benjamin Franklin and the frontier.

Dunham, Douglas PhD 1950 Michigan

The French element in the American fur trade, 1760-1816. 272p. $M$.

Compares British and French Indian policies in northern half of U.S., Great Lakes to the Pacific. 
Dunham, Harold Hathaway PhD 1941 Columbia Government handout; a study in the administration of the public lands, 1875-1891. PUB: Ann Arbor: Edwards Bros. [1941] 364p.

Scattered Indian mention; particularly in the disposal of Reservation lands.

Dunlap, Amy MA 1937

New York [884]

The Indian population of the United States. 131p.

A thorough study containing data from many sources.

Dunlap, Ethel Minola MA 1930

Indian removals to Oklahoma after 1865. 81p.

Dunlap, Willtam CooK PhD 1933 Pennsylvania

Quaker education in Baltimore and Virginia. Early meetings with an account of certain meetings of Delaware and the Eastern Shore affiliated with Philadelphia. PUB: U/Penna. Press [1936] 574p.

Based on the manuscript sources. $\S 3$ "Education, civilization and care of the Indians."

Dunn, Adrian Ritchey MA 1951

No. Dakota

A history of old Fort Berthold. 121p.

[887]

Gros Ventre, Arikara, Mandan.

Dunn, William Edward MA $1910 \quad$ Stanford Apache relations in Texas, 1718-1750. Рuв: Texas State Hist. Assoc., Qtly., XIV \#3 [1911] p198-274.

Dunn, William Edward PhD $1917 \quad$ Columbia Spanish and French rivalry in the Gulf region of the United States, 1678-1702; the beginnings of Texas and Pensacola. Р ив: U/Texas, Stud. Hist. \#1 [1917] 238p.

Section on missions to the natives; other Indian references throughout.

Dunne, Peter Masten PhD 1935 California The Four Rivers: early Jesuit missions on the Pacific Coast. Pub: Pioneer black robes on the west coast. U/Calif. Press [1940] 286p., illus.

Sinaloa, Mexico: Indian missions throughout. 
Dunnells, Leslie Harold MA 1938 Colorado State

Indian life in Colorado; a collection of source material. $125 p$.

Basket Maker, Cliffdweller, Arapaho, Kiowa, Cheyenne, Ute.

Dupre Brown, Grace MAE 1941

La espada y la cruz en las Floridas Españolas. 116p.

Mexico

Durlach, Theresa Mayer PhD 1929 Columbia

The relationship systems of the Tlingit, Haida and Tsimshian. PuB: Amer. Ethnol. Soc., Pubs. XI [1928] $177 \mathrm{p}$.

DUtch, WilliaM, JR. MA 1949 DePauw John Tipton of Indiana, with special reference to his activities as Indian Agent of the United States. 234p. Potawatomi. 1786-1839.

Dutelle, Thomas E. MA 1951 Columbia [895]

Development of political leadership and institutions among the Klamath Indians. 100p.

Dutton, Bertha P. MA $1937 \quad$ New Mexico Łeyit Kin, a small house ruin, Chaco Canyon, New Mexico; preliminary report. РuB: U/New Mex. Bull., Mono. Ser., I \#6 [1938] 101p., pls.

Dutron, Bertha Pauline PhD 1952 Columbia The Toltecs and their influence on the culture of Chichén Itzá. 151p. $M$.

Dutron, Dewey Alva MA 1930

Denver

[894]

A study of the application of intelligence tests to the Indians of the Southwest. 105p.

Mainly Pueblo Indians.

Duvall, Claude A. MS 1926 Syracuse

The educational status of the Red Man in New York [899] State. 69 p.

\section{Dyer, Ruth Caroline}

MA 1945

California

The Indians' land title in California: a case in Federal equity, 1851-1942. 
DyK, WALTER MA 1931

Chicago

[901]

Verb types in Wishram, an American Indian language of the Northwest Coast. 72p.

DyK, WaLter PHD 1933

Yale [902]

A grammar of Wishram. 157p.

Easby, Elizabeth K. MA 1952

Columbia

$[903]$

The pre-Conquest art of Santarém, Brazil. 88p., illus.

EASTERLy, Joe a.

MA 1933

Texas

The life of Jonathan Hamilton Baker, 1832-1918. $187 \mathrm{p}$.

$\S 3$ on Baker's career as an Indian fighter in Texas.

Eastes, Helene Margarete MA.1934 Olahoma The Franciscans in New Mexico, 1540-1680. 114p.

Eaton, Mariam Boyd MA 1928 Tennessee

A history of the Cherokee Indians, 1763-1776. 85p.

Eaton, Rachel Caroline PhD 1919

John Ross and the Cherokee Indians. PUB: Muskogee, Okla: Star Printery [1921] 153p.

Eccles, William John PhD 1955

McGill

[904]

Frontenac and New France, 1672-1698. 537p.

Chapter "Frontenac and the Iroquois"; also includes Huron and Ottawa.

Edel, May Mandelbadm PhD $1939 \quad$ Columbia The Tillamook language. Рणв: Intl. Jour. Amer. Ling., -X \#1 [1939] pl-57.

EdelL, IRVIN MA 1942

New York

[905]

The Indian problem and its development in early Virginia, 1607-1676. 64p.

Edman, Grace Augusta

MA 1930

Texas

A compilation of Royal Decrees relating to Texas and other Northern Provinces of New Spain, 1719-1799. $509 \mathrm{p}$.

Translated and edited, with introduction and notes. Considerable Indian mention. 
Los Manitos: patterns of humor in relation to cultural values. $289 \mathrm{p}$.

Hispano humor, with comparisons to Navajo and Pueblo Indians.

EDWARDS, ELLEN LEE

MA 1952

New York

Ethnohistory of the Mackenzie Valley from Providence to Aklavik. 131p., maps.

Includes extensive consideration of the various Indians of the Mackenzie Valley area.

Edwards, Hugh L. MA 1945

East Texas

An annotated bibliography of Southwestern historical literature in the library of East Texas State Teachers College. 97p.

Edwards, Lawrence E. MA 1937 St. Louis

The De Smetiana of St. Louis University: a critical guide to the first three volumes of the writings of Father Pierre-Jean De Smet, including letters and other documents written between July 20,1838 , and November 10 , 1859. $137 \mathrm{p}$.

Much on his Indian activities.

Edwards, William Ellis PhD 1954 Columbia

The Helen Blazes Site of central-eastern Florida: a study in method utilizing the disciplines of archaeology, geology and pedology. 125p. $M$.

Report on 1949-51 excavations at Melbourne, Florida; dates site at 5500-4000 BC.

EgAN, Gerard R. MA 1951

Columbia

An investigation of the conduct of Major Marcus A. Reno in the Battle of the Little Big Horn, June 25, 1876. 63p.

EgGan, Frederick Russell PhD $1933 \quad$ Chicago The kinship and social organization of the Western Pueblos with special reference to the Hopi Indians. Рणв: Social organization of the Western Pueblos. U/Chi. Press [1950] 373p. 
Eggers, Florence MA 1935 Oklahoma $A \& M$

A study of the Plains Indians since the formation of the Indian Bureau. 76p.

Ehrlich, Clara Hilderman PhD 1939 Columbia Tribal culture in Crow mythology. Puв: Jour. Amer. Folklore, L \#198 [1937] p307-408.

Compares life of Crow as reflected in myths with that reported in ethnographies.

Eichenlaub, Gregory $\quad$ MA $1929 \quad$ Notre Dame [921] The removal of the Creeks and Cherokees from their Georgia lands. 48p.

Eidsmoe, Russell M. MA 1935 So. Dakota The progress of the Indians on the Reservations in South Dakota, 1877-1906. 104p.

Eikenberry, Alice M. MA 1929 Iowa [920] Expeditions up the Missouri River to 1819. 91p. $\S 5$ "Influences of the Indians on navigation".

Eiseley, Loren Corey MA $1935 \quad$ Pennsylvania A review of the paleontological evidence bearing upon the age of the Scottsbluff Quarry and its associated artifacts. 39p. Рuв: Amer. Anthro., XXXVII [1935] p306-319.

Eiseley, Loren CoRey PhD 1937 Pennsylvania Three indices of Quaternary time and their bearing upon the problems of American prehistory. A critique. 39p.

Eisenberg, Benzion MA 1948 Columbia The Fox Indians and the European struggle for the North American empire. 102p.

Eisenhader, Gladys MA 1953 Columbia

[921] 
Ekholm, Gordon Frederick PhD 1941 Harvard

Cultural patterns in the archaeology of northwestern Mexico. Puв: "Excavations at Guasave, Sinaloa, Mexico." Amer.Mus. Nat. Hist., Anthro. Paps., XXXVIII pt. 2 [1942] p23-139, illus.

Includes comparisons with Middle America and southwestern United States.

Ela, Mary Hazeltine MA 1903 Wisconsin [930]

The international relations of the Southwest Indians from 1793 to 1795 . $85 \mathrm{p}$.

Chickasaw, Choctaw, Cherokee, Muskogee.

Elefson, Verna MA 1927

Iowa

Indian Agencies on the Upper Missouri to 1850.

Elkin, Henry $\quad$ PhD 1940

Columbia

The northern Arapaho of Wyoming. Рणв: Linton, Acculturation in Seven American Indian Tribes. NY: Appleton-Century Co. [1940] p207-255.

Eller, Marian $\quad$ MA 1938

New Mexico

An investigation of drawings by Pueblo Indian children. $40 \mathrm{p} .$, Illus.

Ellingworth, Jesse J. MS 1955 Minnesota State A guidance program for Red Lake Indians. 29p.

Chippewa.

Elliott, Arthur Elwood PhD $1931 \quad$ Columbia

Paraguay; its cultural heritage, social conditions and educational problems. Рuв: Columbia U., Teachers Coll., Contr. Educ. \#473 [1931] 210p.

Includes considerable on Guaraní role in Paraguay. Missions and mission schools, race mixture, etc.

Eldiott, Helen Elizabeth MA 1942 Pennsylvania [936] An archaeological survey of Utah. 63p.

Ellis, Herbert Lee PhD $1956 \quad$ Columbia

The Indian policy of the Republic of Chile. 231p. $M$.

Araucanian Indians, from the founding of the Republic to 1949. 
Ellis, Joseph A. MA 1953

The crimes of the Putumayo. 85p.

Particular attention to Witoto; also Andoquera, Bora, Ocaina and Yuria. Period 1900s, during Columbian-Peruvian conflict.

Ellis, Robert Sydney PhD 1914

Clark

[939]

The attitude toward death and the types of belief in immortality; a study in the psychology of religion. Рuв: Jour. Rel. Psych., VII [1915] p466-510.

Australia, Oceania, Eskimo.

Ellison, William Henry PhD 1919 California $[940]$ The Federal Indian policy in California, 1846-1860. Miss. Valley Hist. Rev., IX [1922] p37-67.

Elmendorf, WiLliam W.

MA 1935

Washington

The soul-recovery ceremony among the Indians of the Northwest Coast. 85p.

Elmendorf, William W. PhD $1949 \quad$ California The structure of Twana culture.

Elmore, Francis Hapgood MA 1935 So. California Ethnobotany of the Navajo. Puв: U/New Mex. Bull., Mono. Ser., I \#7 [1943] 136p.

Elosua, JUAN MA 1951

New York

[943]

Frontier defense in the upper Middle West, 1815-1850. $100 \mathrm{p}$.

Elsbree, Oliver Wendell $\quad$ PhD 1928 Columbia The rise of the missionary spirit in America, 1790-1815. PUB: Williamsport Prtg \& Bdg Co. [1928] 187p.

$\S 1$ "Pioneer Protestant missionaries among the American Indian during 17th and 18th centuries."

Elson, Benjamin Franklin, JR.

MA 1954

Cornell Sierra Popoluca intonation. 212p.

A linguistic study of a Mexican dialect.

Elvin, Alexander $\quad$ MA 1939 Colorado $A \& M$

The application of the Wheeler-Howard Act to the educational, occupational, and social programs of the Phoenix Indian High School. 84p. 
The excavation and repair of the Quarai Mission. PuB: El Palacio, XXXIX \#25 [1935] p133-144.

Ely, Laurence Elbert

MA 1935

Texas

The Civil War history of the Cherokee Indians in the light of tribal factionalism. 117p.

Emerick, Richard Gibbs MA 1954 Pennsylvania Recent observations on some aspects of Havasupai culture. $206 \mathrm{p}$.

Emerson, John Norman PhD 1954

Chicago

[948]

The archaeology of the Ontario Iroquois. $279 \mathrm{p} . M$.

Engberg, La URel Arthur MA 1940

Colorado

Voting trends of South Dakota Senators.

One section reviews their votes on legislation dealing with Indian affairs.

Engel, Grace Margaret MA 1937

Columbia

Pocahontas in American literature. 82p.

Engle, Paul Emerson MA 1923

Wittenberg [954]

Missionary history of the Pacific Northwest to 1850. $118 \mathrm{p}$.

Considers mission work among the Northwest tribes.

Engler, Gladys Catherine MA $1940 \quad$ Columbia

[955]

The Indian in L'Abbé Prévost's Cléveland: fact or fancy. $51 p$.

Virginia Territory; compares modern ethnologists' point of view with that of French and Virginian historians.

Ennis, George Harrison MA 1949 Pennsylvania [956] A survey of the prehistory; of Concho Flat. 75p.

Report on an area in eastern Arizona, near Snowflake.

Ensley, Joseph WesLey MA 1931

Oklahoma [957]

Indian hostilities of the Southwest, 1865-1875. 129p.

Epperson, Freeman Henry MA 1952 East. New Mex.

History of Indian education in the United States, with special reference to the development of the boarding school to 1933. 75p. 
Eppig, Josephine M. MA 1932 Columbia

Thoreau's manuscript notes on the American Indian, Vol. 8. 437p.

Erasmus, Charles John MA $1950 \quad$ California [960] The economic life of a Mayo village. 192p.

Erickson, Evelyn E. MA 1934 Northwestern A study of the present movement in Peru to revive the Incaic civilization. $63 \mathrm{p}$.

Erickson, Martin Elmer $\quad$ PhD 1942 Washington Guatemalan literature of the last fifty years.

Considers part played by authors in treating the Indian, and abandonment of that interest since 1930 .

Ervin, Bertha Jewell MA 1932 Oklahoma $A \& M$ The development of education among the Cherokee Indians. 66p.

Esch, LyNd J. MA 1950

Indiana

[964]

A report on excavations at the Cahone Site in 1948. 93p., illus.

Esch, LYND J. $\quad$ PHD 1953

Indiana

A study of the reliability of cultural evidences for archaeological-ethnological cultural continuities in the eastern United States. 149p. $M$.

Esparza y Estrada, Graciela MREd 1950 Asbury Religious education in Mexico. 81p.

Espinosa, José Mandel $\quad$ PhD $1935 \quad$ California

Diego de Vargas and the reconquest of New Mexico, 1691-1704. Р Uв: Crusaders of the Rio Grande. Chi: Inst. of Jesuit Hist. [1942] 410p.

Espinoza Llanos, Niceforo E. PhD 1953 Maryland Exploratory analysis of some key influences of children in southern Indian communities of Peru with implications for education in rural schools. $227 \mathrm{p}$.

Essene, Frank J., JR. PhD 1947

California [969]

A comparative study of Eskimo mythology. 94p.

Compares east, west and central Eskimo with Indians of interior Canada, Northwest Coast tribes and northeast Asiatic peoples.

[967] 
Ring weavings. $43 \mathrm{p}$., pls.

Northwest Coast, Pueblo; also Mexico, Panama, South America.

Esteve-Abril, Ana Himilce MA 1944 No. Carolina

The controversy in sixteenth century Spain concerning the legal and social status of the Indian. $62 \mathrm{p}$.

Estrada, Antonia MA 1924

So. California

The private and social life of the Aztec tribe and its influence upon the inhabitants of Mexico at the present time. $62 \mathrm{p}$.

Evans, Cecelia Marie MA 1937

Denver Comparative Indian mythology. 178p.

[972]

Evans, Cliffrord, JR. PHD 1950 Columbia The archaeology of the Territory of Amapá, Brazil (Brazilian Guiana). 165p. $M$.

Outlines characteristics of three phases: Aruã, Mazagão, Aristé; compares with historical documentation.

Evans, Emory G. MA 1954

Virginia Government Indian policy, 1789-1809. 129p.

Evans, Harry L. PhD 1953 Florida Mexican silversmithing-a study of historical and contemporary contributions pertinent to industrial education. $358 \mathrm{p}$.

Primarily a study of contemporary Mexican craft; considers Indian as far as "Mexican" is Indian. Includes mention of ancient craftwork in silver.

Evans, Joshua T. MS 1938 Utah Agri.

The Northwestern Shoshone Indians. 108p.

(A) Under tribal organization and government. (B) Under the ecclesiatical administration of the Mormon Church as exemplified at the Washakie Colony, Utah.

Evans, Marie Padget M/Ed 1952

Florida

Mexican miniatures: a study of the educational contri[978] butions of miniatures in revealing customs, habits, and cultures of Mexico. 350p.

Toltec, Zapotec, Aztec and Spanish miniatures. 
Introduction to the observance of Navajo sandpainting.

Evans, Wilma Marie MA 1940

Iowa $[980]$

Fort Leavenworth, a frontier outpost. 91p.

Brief scattered references to Shawnee and Pawnee.

Evanson, Chellis Nathaniel PhD 1930

Iowa [981]

Sir Francis Nicholson, a Royal Governor in the Chesapeake Colonies during the period 1690-1705.

Ewald, Robert Harold PhD 1955

Michigan

[982]

San Antonio Sacatepéquez: culture change in a Guatemalan community. 331 . $M$.

Ewers, John CANField MA 1934

Yale

Painted robes and skins of the Plains Indians. 116p. PuB: Plains Indian painting. Stanford U. Press [1939] 84 p., illus.

Ewing, Russell Charles MA 1931

History of Pimería Alta, 1687-1767. 127p., illus.

California

[984]

Pima and Apaches.

Ewing, Russell Charles PhD 1934 California The Pima Uprising, 1751-1752 : a study in Spain's Indian policy. 354p. Рбв: "Investigations into the causes of the Pima Uprising of 1751." Mid-America, XXIII [1941] p139-151.

Ezell, Paul Howard PhD 1956

Arizona

The Hispanic acculturation of the Gila River Pimas. 460p. $M$.

Fagin, Nathan Bryllion PhD 1931 Johns Hopkins

William Bartram: interpreter of the American landscape. PUB: Johns Hopkins U. Press [1933] 229p.

$\S 3$ "Studies of the American Indians" presents much on Indians, especially Cherokee and Creek.

Fatrbanks, Charles Herron PhD 1954 Michigan

The excavation of Mound C, Ocmulgee National Monument, Macon, Georgia. 243p. $M$. 
The Noble Savage; a study in romantic naturalism. PuB: Columbia U. Press [1928] 536p.

Considerable on Indian as romantic literature.

Faigin, Helen PhD 1953

Radcliffe

Child rearing in the Rimrock community, with special reference to the development of guilt. 118p.

Fals-Borda, Orlando PhD 1955

Florida

A sociological study of the relationships between man and the land in the Department of Boyacá, Colombia. 277 p. $M$.

Includes Indian (Chibcha) land use; mainly a study of contemporary conditions.

FARMer, Freda M. MA 1953 Ball

The changing attitudes of American authors toward the Indians. $45 \mathrm{p}$.

Faron, Louis C. PhD 1954

Columbia

The acculturation of the Araucanian Picunche during the first century of Spanish colonization in Chile: 1536-1635. 205p. M. РUв: Ethnohistory, II \#2 [1955] p133-145.

Farreld, Willite Ewen

MA 1935 Oklahoma $A \& M$ Educational problems as confronted by the Quaker Agents on the Kiowa and Comanche Reservation. 61p.

Fatha uer, George Harry MA 1942 Chicago [995] Social organization and kinship of the northern Athabascan Indians. 115p.

Fathauer, George Harry PhD 1950 Chicago [994] [993] Mohave social organization, with special emphasis upon age-sex categories. $315 \mathrm{p} . M$.

Faulhaber, Johanna MA 1956

Mexico: $E N$

[991]

Algunos aspectos antropológicos de la población de Tepoztlán, Morelos.

Faulkner, Colleela

MA 1949

Oklahoma

The life and times of Reverend Stephen Foreman. 254p. Oklahoma Cherokee. 
Fadrot, Alvin G.

MA 1951

Colorado $A \& M$

[999]

Metal décor of the Navajo Indians. 61p.

FaUst, Harold S. STD 1943

Temple [1000]

The Presbyterian mission to the American Indian during the period of Indian removal (1838-1893). 472p.

Includes original material, presented from an exhaustive but biased viewpoint.

Faust, Richard Allen

MA 1935

Pennsylvania [1001]

A comparative study of anthropophagy among the tribes north of Mexico. 73p.

Fee, Dexter S. MA 1934

Montana [1002]

Government policy towards the principal Indian Nations of Montana, 1857-1873. 183p.

Feeney, Francis H. MA/Ed 1937

Arizona [1003]

Illiteracy in Arizona from 1870 to $1930.128 p$.

Considers the several races in the state, summarizes literacy records and includes statistical data, charts and tables.

Felding, Mary E. MA $1938 \quad$ Colorado State [1004]

History of legends of the Indians of northwest Missouri.

$93 \mathrm{p}$.

Sac-Fox, Iowa.

Fellows, Muriel H. MA $1936 \quad$ Pennsylvania [1005] Petrography in the New World. 19p., pls., maps.

Fenton, William Nelson PhD 1937 Yale [1006]

The Seneca Eagle Dance: a study of personality expression in ritual. 264p. PUв: "The Iroquois Eagle Dance: an offshoot of the Calumet Dance." Bur. Amer. Ethnol., Bull. \#156 [1953] 324p., illus.

Ferdón, Edwin Nelson, JR. MA 1943 So. California [1007] The archaeological excavation of Hermit's Cave, New Mexico. Р एв: School of Amer. Res., Mono. \#10 [1946] $29 \mathrm{p}$.

Fergus, Mabel Elizabeth MA 1913 Columbia [1008] Alexander McGillivray and William Augustus Bowles; two characters in the early history of the South. 35p.

Creek, circa 1750-1800. 
Ferguson, Elizabeth A.

The theory and practice of medicine among preliterate peoples. $398 \mathrm{p}$.

Considers shaman, healing and surgery among Andaman, Chukchi, Trobriand, Pondo, Navajo; appendix includes extensive treatment of Indian medical practices.

Ferguson, Marjorie MA 1931

New Mexico [1010]

The acculturation of Sandía Pueblo. 94p.

Ferguson, Ruby Alta MA 1927 California [1011] The historical development of the Russian River Valley 1579-1865. 161p., illus.

Pomo and Wappo; also intermarriage with Aleuts.

Fernández, Justino D.Hist. $1953 \quad$ Mexico [1012] Coatlicue. Estética del arte indígena antiguo. 236p. PUB: Mexico: Ediciones del IV centenario de la Univ. Nacl., XV [1954] 285p.

Fernández, María Teresa MA 1956 Mexico: $E N$ [1013] Fonémica del Ixtateco.

A linguistic study of Ixtateco, an Indian language of Oaxaca, Mexico.

Ferrer, Mary Joan MA 1944

Fordham [1014]

Life and manners of the Aztecs according to the early chroniclers. $96 \mathrm{p}$.

Feddge, Margaret Mary MA 1921

California [1015]

The Viceregal Administration of Luis de Velasco the Second, 1590-1595. 112p.

Covers New Spain and Española.

Feders, Marvin M. MA 1949

Columbia [1016]

A tentative approach to the theory of social evolution. 85p.

Pomo of Ukiah Valley community, California.

Finch, GaIl Harper MA 1936

Oklahoma [1017]

The Anglo-American régime in New Mexico, 1846-1861.

$131 p$.

Indians put on Reservations: Indian-White relations. 
Findly, Sarah Elizabeth MS/LS 1944 Michigan [1018] A subject index to the history of the Pacific Northwest and Alaska, as found in United States Government documents, Congressional serials, 47th Congress, 1881 to $1883.66 \mathrm{p}$.

Includes a section on Alaskan natives.

Fine, James O. MA 1951

No. Dakota [1019]

An analysis of factors affecting agricultural development on the Fort Totten Indian Reservation. 121p.

Sioux-mostly Wahpeton and Sisseton.

Fink, Marianne A. MA 1950

New Mexico [1020]

Personality differences of acculturating Navajo adolescent girls as revealed by the Rorschach tests. 149p.

Finley, Theodore Roosevelt MA 1938 Columbia [1021] Ignacio Manuel Altamirano as interpreter of traditional Mexican life and customs. 103p.

Fisch, Miriam Murray MA 1947

Washington [1022]

Medical-social treatment provided by Seattle agencies for ten Alaskan children.

Mainly Eskimo children.

Fischer, David C. MA/Ed 1954 No. Dakota [1023] The effect of relocation on Indian education in the three affiliated tribes-Gros Ventre, Arikara, and Mandanat the Fort Berthold Reservation. 131p.

Fischer, Harry Frederick MA 1933 Washington/SL [1024] The fur trade of the Arkansas Valley. 232p.

Fishback, Agnes Irene MA 1929

Hartford [1025] The Guaraní Indians of Paraguay. 92p.

Fisher, Amy McCaughey MA 1932

The Indian Reservation system since 1832. 45p.

Fisher, Don C. MA 1925

The Nez Percé War. $107 \mathrm{p}$.

Fisher, Edna Marie MA 1921 California [1028]

Medical knowledge and practice in New Spain during the sixteenth century. $171 \mathrm{p}$.

Section on medicine among the Aztec and Toltec tribes. 
Fisher, Ernest Brayton, JR.

Study of the concept and practice of salvation in the Muskhogean linguistic stock of North American Indians.

Fisher, Glen H. PhD 1952 No. Carolina [1030] Directed culture change in Latin America: the application of modern theories of culture change to an analysis of the Mexican pilot project in basic education in Santiago, Nayarit, Mexico. 334p.

Fisher, Margaret Welpley $\quad$ PhD 1935 Pennsylvania [1031] William Jones' Ethnography of the Fox Indians. PUB: Bur. Amer. Ethnol., Bull. \#125 [1939] 156p., illus.

Fisher, Marian Elizabeth MA 1950 New York [1032] A history of the Indians on Montauk, Long Island. 178p.

Fisher, Reginald G. MA 1929 New Mexico [1033] A plan for an archaeological study of the Pueblo Plateau. PUB: "The archaeological survey of the Pueblo Plateau." U/New Mex. Bull., Archeol. Ser., I \#1 [1930] 22p.

Fisher, Reginald G. PhD 1935 So. California [1034] The relation of North American prehistory to postglacial climatic fluctuations. 165p. Р Uв: School of Amer. Res., Mono. \#3 [1935] 92p.

Especially considers migrations into New World.

Fisher, Ruby Keefauver MA 1930 Indiana [1035] Literary and artistic expression of the Hopi Indians. $138 \mathrm{p}$.

Fitts, Mary Elizabeth MA 1937 Washington/SL [1036] The Apache and the United States Government, 1860 to $1886.132 \mathrm{p}$.

Fitz, Beolah MA 1935

New Mexico [1037]

The history of the Carlisle Indian School. $72 \mathrm{p}$.

Fitzgerald, Agnes E. MA 1937

Columbia [1038]

The problem of a social worker among Indians: with particular reference to the Chippewas of northern Wisconsin. 79p. 
FitzGerald, Mary Paul PhD 1936

St. Louis [1039]

The Osage Mission: a factor in the making of Kansas. 312p. PuB: Beacon on the Plains. Leavenworth: St. Mary's Coll. [1939] 297p., illus.

Considerable original material on Osage.

Flanagan, Gertrude Catherine MS 1938 Oklahoma [1040] A study of the dietary habits of three generations of the Eastern Cherokee Indians. 76p.

Flannery, Monica MA 1918

California [1041]

A comparative sketch of the mythology of the Siouan and Caddoan linguistic stocks. 59p.

Flannery, Regina MA 1931

Catholic [1042]

A study of the distribution and development of the Memegwecio concept in Algonquian folklore.

Flannery, Regina PhD 1938

Catholic [1043]

An analysis of coastal Algonquian culture. Рuв: Cath. U., Anthro. Ser. \#7 [1939] 219p.

Fleck, Byron Y. PhD 1950

Iowa [1044]

The West as viewed by foreign travelers: 1783-1840.

Includes scattered mention of Indians from foreign viewpoint.

Flekke, Marie MA 1935

The opening of the Black Hills in 1876. 78p.

New Mexico [1045]

Sioux.

Fleming, Bertha Belle MA 1930 Oklahoma $A \& M$ [1046] Legislative enactments relating to the Indians of Indian Territory from 1879 to $1889.93 p$.

Fletcher, Mildred Peronia MS 1949 So. California [1047] A guide for student teachers teaching a unit on the Los Angeles Indians. 179p.

Fletcher, Nancy Jane MA 1931 Geo. Peabody [1048] The removal of the Indians from Georgia. 53p.

Creek and Cherokee.

Fuey, Jo AnN MA 1953

Wyoming [1049]

John B. Kendrick's career in the United States Senate.

[1917-1933] Section on his work with Indian Affairs Committee. 
A preliminary survey of mammalian bone implements of the Anasazi region. 134p., illus.

\section{Flood, Edith Lyle MA 1938}

Oklahoma $[1051]$

Alexander Posey in Oklahoma history. 108p.

1873-1908; Creek secretary of "Sequoyah" Constitutional convention.

Flook, Edmund Robert MA 1940

California [1052]

Henry de Tonty, fur trader in the Mississippi Valley (1678-1704).

Flores-Fernández, Edmundo PhD 1948 Wisconsin [1053] Comparative analysis of the agrarian problems of Peru and Mexico.

Compares Peruvian feudal ayllu with Mexican revolution ejido; considers native Indian land systems.

Flowers, Marvin Paine MA 1931 Oklahoma $A \& M$ [1054] Education among the Creek Indians. 144p.

Fogerty, Robert Paul PhD 1942

Minnesota [1055] An institutional study of the Territorial Courts in the Old Northwest, 1788-1848.

Pt. 3 "The courts, soldiers and the Indians".

Foley, Rudolph Xavier PhD 1937

Fordham [1056]

The origins of the Indian Reorganization Act of 1934. $281 \mathrm{p}$.

Folmer, Henry PhD 1948

Chicago [1057]

Franco-Spanish rivalry in North America, 1524-1763. 346p. PUB: Glendale: A. H. Clark Co. [1953] 346p.

Many Indian references throughout.

Folsom, WILLIAM RickCoRds MA 1896

Williams [1058]

The French Posts in the Old Northwest, 1689-1763, and their control. 41p.

Iroquois, Fox, Algonquin tribes.

Fong, MaN-Hee MA 1940

So. California [1059]

A comparative study of personal names and naming systems among the Chinese and certain American Indian tribes. $93 \mathrm{p}$.

A general discussion; 17 Indian tribes considered. 
Forbes, Charles Gerald $\quad$ MA 1937

Oklahoma [1060]

History of the Blackfeet until 1907. 107p.

Forbes, Charles Gerald PhD 1939

Oklahoma [1061]

History of the origin and development of the oil industry in Oklahoma through 1915. 228p.

Considerable on Indians, Indian use of oil and Indian-White relations.

Forbes, W. Stanton MA 1953

Mexico City [1062]

Patterns of geometric expression in the architecture and culture of ancient Egypt and ancient Mexico. 172p., illus.

Forbis, Richard George

MA 1950

Montana [1063]

Religious acculturation of the Flathead Indians of Montana. 107p.

Forbis, Richard George PhD 1955 Columbia [1064] The MacHaffie Site. 215p. $M$.

A report on an excavation in Montana.

Force, Roland Winfield

MA 1952

Stanford [1065]

A comparison of Pueblo and European ghetto reactions to deprivation situations.

Ford, Charles Lafa yette

MA 1939

Oklahoma [1066]

Northern Plains trader frauds prior to $1880.97 \mathrm{p}$.

Dakota and neighboring tribes.

Ford, Frances ErLe MA 1934

Virginia [1067]

William Christian: a frontiersman of the Valley of Virginia. 80p.

Indian Commissioner in 1770s. Last chapter considers Cherokee relations in detail.

Ford, Herman MA 1932

Colorado [1068]

The history and economic development of Hale County, Texas. 108p.

Section on Indians of the area.

Ford, James Alfred $\quad$ PhD 1949

Columbia [1069]

Cultural dating of prehistoric sites in Virú Valley, Peru. Puв: Amer. Mus. Nat. Hist., Anthro. Paps., XLIII pt. 2 [1949] p29-89. 
A survey history of Carson County, Texas. 95p.

Chapter devoted to the problem of Indian removal.

Ford, Thomas Robert $\quad$ PHD $1951 \quad$ Vanderbilt [1071] Man and land in Peru, a study of agrarian change. P UB: U/Florida Press [1955] 176p.

Traces history and development of Spanish land tenure in Peru, including indigenous systems and changes as imposed by Spaniards.

Forde, Lois Elizabeth $\quad$ PhD 1951

Columbia [1072]

Elias Cornelius Boudinot. 265p. $M$.

Cherokee, 1860-1890. Carolinas, Georgia and Oklahoma.

Forest, Mary Rose MA 1946

California [1073]

Yuma, gateway to California, 1846-1877. 136p., pls.

Yuma Indians.

Forsberg, Helen MA 1935

Arizona [1074]

A study of the skeletal remains from the Pueblos of Kinishba and Tuzigoot in Arizona. 142p.

Physical anthropology of the sites; compares with data in Hooton's Indians of Pecos.

Forsee, Frances Aylesa MA 1931

Colorado [1075]

Policy of the United States Government towards the Sisseton Sioux Indians, 1871-1931. 115p.

Includes all-over view of Sisseton Sioux culture, as well as White-Indian relations.

Forst, John PHD 1935

New York [1076]

Indien und die Deutsche Literatur von 1900 bis 1923. 235p. PuB: Leipzig: R. Noske [1934] 94p.

A study of the Indian as presented in German literature.

Forster, James R. MA 1951

Mexico City [1077]

Gingerbread figurines of the Toltec-Mazapán period. $76 \mathrm{p}$., illus.

Forsyth, Edmund Clark ThM 1910 Missionary activities in the settlement and development of North America. 39p. 
Fortenberry, LUCHLle WiLlie MA 1937 Oklahoma [1079] The Navajo Indians, 1846 to $1869.99 \mathrm{p}$.

FosskuHL, Elizabeth MA 1949 Mexico [1080] Francisco Xavier Clavijero, historiador de la cultura de los mexicanos antiguos. 137p.

The career of the famous Mexican historiographer, many of whose studies pertained to pre-Columbian Mexico.

Foster, ArLouine B. MA 1934 Drake [1081] The Cherokee of the East. 153p.

Foster, George McClelland, JR. PhD 1941 California [1082] A primitive Mexican economy. Pub: Amer. Ethnol. Soc., Mono. \#5 [1942] 115p.

Popoluca Indians of Vera Cruz, Mexico.

Foster, Laurence PhD 1931 Pennsylvania [1083] Indian-Negro relationships in the Southwest. PUB: U/Penna. Press [1935] 86p.

Fox, Edith Mead MA $1945 \quad$ Cornell [1084] William Johnson's early career as a frontier landlord and trader. 137p.

Fox, George Edmund MA 1943 Geo. Washington [1085] The Choctaw Academy: an experiment in Indian education. 153p.

Fox, Hetty Marie $\quad$ MA 1936

Oklahoma [1086]

Tecumseh and his Indian Wars. 112p.

Fox, John Samuel MA $1936 \quad$ California [1087]

Early mining in New Spain: the background of the Zacatecas mining rush. 81p.

Cortés and the preëmption of Montezuma's mines.

Fox, John SAmuel PhD $1940 \quad$ California [1088]

The beginnings of Spanish mining in America: the West Indies and Castilla del Oro. 123p.

Indian labor; some mention of pre-Columbian goldwork and finds. 
Fox, Velda Mae

MA 1927

Iowa $[1089]$

The development of the Pocahontas story in American literature, 1607-1927.

Frachtenberg, Leo Joachim PhD 1910 Columbia [1090] Grammar of the Coos language of Oregon. PuB: Boas, "Handbook of American Indian Languages." Bur. Amer. Ethnol., Bull. \#40 pt. 2 [1922] p297-429.

Franklin, Mary Van MA $1949 \quad$ New Mexico [1091] A description of some of the adjustment problems of tuberculous Indians to sanitorium life. 85p.

Frantz, Charles MA 1951

Haverford [1092]

The urban migration and adjustment of American Indians since 1940. 155p.

Collection of data as background for better understanding of practical problems facing American Friends Service Committee, etc., in urban areas where American Indians are located.

Fraps, Clara Lee Tanner MA 1928

Arizona [1093]

Archaeological survey of Arizona. 72p., maps.

Fraser, Dorothy Electa MA 1941

Columbia [1094]

The cultural significance of an archaeological site on the middle Missouri River. 118p., illus.

Rygh Site, Campbell county, South Dakota.

Fraser, Jessie Melville MA 1926

Columbia [1095]

The loyalty of the Johnson family of New York State to the British Empire during the American Revolution. 42p.

Fraser, Richard Hobbs MA 1952

Oklahoma [1096]

A theoretical analysis of the Huron-Iroquois War, 1603-1649. 164p.

Fraser, Robert Stuart MA 1934

Denver [1097]

Studies in race intelligence of Indian pupils at Sherman Institute, Riverside, California. 88p.

Frazer, Shirley Mae MA 1936

Washington [1098]

The relation of costume and environment.

Indians in general, no specific tribe. 
Frazier, Jo Wood

MA 1931

Geo. Peabody [1099]

The removal of the Indians from Arkansas. 58p., illus.

Osage, Cherokee, Quapaw, Choctaw, Caddo.

Frederick, Aurora Leigh MA 1923 Washington/SL [1100] Indian land cessions in Missouri, 1804-1816. 168p.

Frederick, James Vincent

$\mathrm{PHD} 1937$

Oklahoma [1101]

The Holladay Overland Mail and Express Company. 284p. Р бв: Ben Holladay, the Stagecoach King. Glendale:

A. H. Clark [1940] 334p.

Much on Indian hazards, attacks, wars.

Frederikson, Otto Frovin PhD 1931

Kansas [1102]

The liquor question in Kansas before constitutional prohibition. 103p. PUB: "The liquor question among the Indian tribes in Kansas, 1804-1881." U/Kans., Bull., Human. Stud., IV \#4 [1932] 103p.

Freeburg, Roy Everett Walter

EDD 1946 Stanford

The use of musical resources of the Pacific-Southwest region for elementary education.

Extensive consideration of Indian music.

Freed, Ruth Helen Anderson $\quad$ MA 1948 So. California An analysis of the literary significance of certain legends of the Yosemite Indians. 203p.

Southern Miwok.

Freeman, Albert Thayer

MA 1922 So. California [1105] Christianity, the solution of the American Indian problem. $94 \mathrm{p}$.

Freeman, John Leiper, JR. PhD 1952 Princeton [1106] The New Deal for Indians: a study in Bureau-Committee relations in American Government. 545p. $M$.

Relations between Bureau of Indian Affairs and Congressional Committee on Indian Affairs, 1928-1945, including history of Bureau activities.

French, David Heath

MA 1940

Claremont [1107]

A comparative study of the mythologies of the Jicarilla, Lipan, Mescalero, and Chiricahua Apache Indians. 78p. 
Factionalism in Isleta Pueblo. PuB : Amer. Ethnol. Soc., Mono. \#14 [1948] 48p.

French, Frances Crouser

MA 1952

Louisiana [1109]

The Morton Shell Heap on Weeks Island, Louisiana.

\section{French, Kathrine Story $\quad$ PhD 1955}

Columbia [1110]

Culture segments and variation in contemporary social ceremonialism on the Warm Springs Reservation, Oregon. 163 p. $M$.

Tenino, Tyigh, Wasco tribes.

Frick, Paul Sumner MA 1954

Arizona [1111]

An archaeological survey of the central Santa Cruz Valley, southern Arizona. 138p.

Fried, JACOB $\quad$ PHD 1952

Yale [1112]

Ideal norms and social control in Tarahumara society. Pणв: Sowestn. Jour. Anthro., IX \#3 [1953] p286-295.

Friedu, Ernestine M. MA 1948

Mexico City [1113]

The legends of Quetzalcoatl. 38p.

Attempts to investigate truth or fiction of the accounts of Quetzalcoatl.

FriedL, Ernestine M. PhD 1950

Columbia [1114]

An attempt at directed culture change; leadership among the Chippewa, 1640-1948. 362p. $M$.

Attempts of British, French, Americans to instill different leadership patterns into Great Lakes Chippewa, so as to facilitate European control.

Friend, Llerena Beaufort PhD 1951 Texas [1115]

The Great Designer-Sam Houston in the American political scene. 731p.

Chapter on "The Indian interlude".

Frietsch, Mary Olivia EdD 1943

Cincinnati [1116]

History of the educational activities of the Sisters of Saint Francis, Oldenburg, Indiana.

Considers work of the Order among Montana Crows; two Reservation schools maintained. 
Fritschel, Erwin G. MA 1939

Colorado State [1117]

A history of the Indian mission of the Lutheran Iowa Synod, 1856-1866. 182p.

Crow, Cheyenne, Arapaho.

Fritz, Henry J. MA 1933

Catholic [1118]

A functional aspect of Plains Indian education.

Fritz, William Francis $\quad$ MA 1938

Texas [1119]

Mary Austin: interpreter of the Southwest.

Frost, Ralph Walter MA 1925

Tennessee [1120]

A history of the Cherokee Indians of the Tennessee region from 1783 to $1794.82 \mathrm{p}$.

Fuller, Clarissa Parsons

MA $1943 \quad$ New Mexico

[1121]

Frank H. Cushing's relations to Zuñi and the Hemenway Southwestern Expedition, 1879-1889. 104p.

Fuller, Clarissa Parsons PhD 1949 New Mexico [1122] A reëxamination of Bandelier's studies of ancient Mexico. 107p.

FULler, MorT $\quad$ MA 1934

The journal of John R. Bell. 403p.

Stanford [1123]

"The account of an expedition to the foot of the Rocky Mountains under the command of Major S. H. Long in the year 1820." Indians as encountered by the expedition.

Fuller, Robert Gorham PhD 1915

Harvard [1124]

Observations on a collection of crania from the prehistoric stone graves of Tennessee. 4 vols., 1008p.

Fullerton, Eula Edna MA 1931

Oklahoma [1125]

Some social institutions of the Cherokees, 1820-1906.

$108 \mathrm{p}$.

Some original material.

FunK, Esther $\quad$ MA 1946

So. California [1126]

A comparative study of ancient and modern Peruvian textiles. $328 \mathrm{p}$.

Fynn, Arthur John $\quad$ PhD 1899

Colorado [1127]

The Pueblo Indian as a product of environment. PUB:

NY: Little, Brown \& Co. [1907] 275p. 
GaAder, Alfred Bruce

MA 1937

Mexico [1128]

La contribución del indígena a la cultura de México.

131 .

GabBert, Jane Elizabeth MA 1934

California [1129]

Social organization of Indian tribes of southeastern United States. 98p.

Gabel, Norman Emil MA 1931

Arizona [1130]

Martínez Hill ruins; an example of prehistoric culture of the Middle Gila. 71p.

Gabel, Norman Emil PhD 1941

Harvard [1131]

A comparative racial study of the Papago. Рuв: U/New

Mex. Bull., Anthro. Ser. \#4 [1949] 96p., illus.

Comparisons include Hopi, Navajo, Yaqui and Zuñi.

GaCH, Michael MA 1946

Loyola [1132]

Indians of the north and northwest in the American Revolution, 1775-1783. 184p.

Gage, Daniel J. MA 1926

Wisconsin [1133]

Indian policy in the United States from 1858 to 1875 . $369 \mathrm{p}$.

Gallaher, ART, JR. MA 1951

Oklahoma [1134]

A survey of the Seminole freedmen. 152p.

Gallardo A., Luís MPH 1947

Public health in Bolivia. 98p.

Yale [1135]

Some material on Indians, scattered throughout.

Gallenz, Mathias Caspar MA 1929

The Micmacs-a survey of Micmac culture traits.

Galligan, Alice MA 1939

Columbia [1137]

Distribution of basketry techniques in South America. $96 p$. , illus.

Includes examples drawn from many tribes.

Galloway, Blanche MA $1930 \quad$ Washington/SL [1138] The relations with the Indian tribes of the MissouriArkansas region, 1803-1835. 139p. 
Prehistoric stone sculpture of the western United States. 496 p., many photos. $M$.

Galt, William Richard, JR. MA 1949

Florida State [1140] Spanish accounts of Lima in the sixteenth and seventeenth centuries. 95p.

Galvão, Eduardo Enéas G. PhD 1952

Columbia [1141]

The religion of an Amazon community; a study in culture change. $189 \mathrm{p} . M$.

Based on fictitious town, Itá, located on lower Amazon; finds the caboclo (mixed Indian-Portuguese stock) retain many Indian features, with strong Roman Catholic overlay.

Galvin, Eucharista PhD 1929

Chicago [1142]

The influence and conditions affecting the settlement of Minnesota, 1837-60.

Extensive material on Indian-White relations during settlement. Chippewa, Winnebago, Sioux.

Galvin, Mary Camillus M/Ed 1939

No. Dakota [1143]

The development of the Catholic elementary and secondary schools of North Dakota from the first beginnings to the present day. $143 \mathrm{p}$.

Indian mission schools included.

Gamble, JoHn IRvin MA 1952

Washington/SL [1144]

Kiowa dance gatherings and costumed dancers. 78p.

Gamio, Mandel MA 1911

Columbia [1145] Archaeological researches in Chalchihuites, State of Zacatecas, northern Mexico. 26p., pls.

Gamio, Manued $\quad \mathrm{PhD} 1922$

Columbia [1146]

Traduction of the introduction, synthesis and conclusions of the work The Population of the Valley of Teotihuacán. Р 18 p. text; 98 plates.

Gamio de Alba, Ana Margarita MCA 1941 Mexico [1147] El matrimonio prehistórico azteca. 27p.

Ganaway, Loomis Morton

MA 1935

Vanderbilt [1148]

The beginning of a Federal Indian policy in New Mexico, 1849-1852. $119 \mathrm{p}$. 
Indian trade in the United States, 1789-1822. 93p.

Garfield, Marvín H. MA 1932

Kansas [1150]

Defense of the Kansas frontier against Indians and outlaws, 1864-1869. 183p.

Garfield, Viola Edmundson MA 1931 Washington [1151] Change in the marriage customs of the Tsimshian. 62p.

Garfield, Viola Edmundson PhD 1939 Columbia [1152] Tsimshian clan and society. PUB: U/Wash. Pubs. Anthro., VII \#3 [1939] p167-340.

Garlock, Lawrence Elwood MA 1939

Iowa [1153]

Life and migrations of the Blackfeet Indians. 125p.

Garner, Beatrice MA 1954

Ute acculturation and dietary adaptation. 138p.

Garrett, James Elmer MA 1927

Denver [1155]

A comparison of the intelligence of Whites and Indians in the common schools of Oklahoma. 160p.

Creek, Cherokee, Choctaw, Chickasaw, Seminole.

Garth, Thomas Russeld, JR. MA 1940 California [1156] Atsugewi ethnography. Рив: U/Calif., Anthro. Rec., XIV \#2 [1953] 212p., illus.

Garvey, John Williams MA 1952

Loyola [1157]

The residence and mission of Ste. Marie-1639-1649; a thrilling chapter in the history of Huronia. 128p.

Garvin, Paul Lucian PhD 1947

Indiana [1158]

Kutenai grammar. 221p. Рuв: Intl. Jour. Amer. Ling., XIV, XVII [1948, 1951] var. pp.

Gatchell, Lillian MA 1935

Alabama [1159]

The Indian policy of the Continental Congress, 1775 to 1783. 75p.

Gates, Gladys Esther MA 1926

Oklahoma [1160]

The Wichita Indians from 1859 to 1868.41 p. 
Gates, Robert Lyon MA 1948

So. California [1161]

A history of the Kern County, California, mountain area.

$\S 2$ "Indians before the White man". Especially Tübatulabal; also Yokuts.

Gay, Dorothy Frances MA 1933

Arizona [1162]

Apache art. 56p., col. pls.

Gay, Mabel Theressa

MA 1925

California [1163]

The establishment of territorial government in Montana. $132 \mathrm{p}$.

Blackfeet, Crow, Assiniboine, Flathead, Nez Percé and Shoshoni.

GAYLER, LUCy Boutwell MA 1936

Oklahoma [1164]

A case study in social adjustment of one hundred Osage families. 100p.

Gayton, Anna Hadwick MA 1924

California [1165]

A survey of aerial sepulture. 61p., maps.

Section on platform and tree burials in North America.

Gayton, Anna Hadwick PhD 1928

California [1166]

The narcotic plant Datura in aboriginal American culture. $99 \mathrm{p}$.

Geary, Gerald J. PhD 1934

Catholic [1167]

The secularization of the California Indian missions, 1810-1846. Puв: Cath. U., Stud. Amer. Church Hist., XVII [1934] 204p.

Gebhard, Paul Henry PhD 1946

Harvard [1168]

Stone objects from prehistoric North America, with respect to distribution, type, and significance. 3 vols., $1314 \mathrm{p}$., illus.

An exhaustive, throughly illustrated classification of types drawn from all areas and archaeological periods.

Geiger, Maynard PHD 1937

Catholic [1169]

The Franciscan conquest of Florida, 1573-1618. PUB:

Cath. U., Stud. Hispanic-Amer. Hist., I [1937] 319p.

Gellatly, Marjorie Gail

MA 1940

Washington

Fourteen Northwest Coast Indian songs transcribed into musical notation. $79 \mathrm{p}$.

Data from Muckleshoot Reservation : Puyallup, Lummi, Yakima, Snoqualmie. 
Gentry, Dorothy Delores

The treatment of the American Indian in the American novel, 1929-1953. 294p.

Gerheim, Earl B. MA 1946

New Mexico [1172]

The Rh factor: recent developments and study of its incidence among the Indians of the Southwest. $68 \mathrm{p}$.

Gerken, Walter Diedrich MA 1902 Columbia [1173] The relation of the Iroquois to the struggle between the French and English in North America. 193p.

Gerow, Bert Alfred $\quad$ PhD 1950

California [1174]

Bloodclot Boy: an historical and stylistic study of a North American Indian hero tale. 161p.

Getty, Harry Thomas MA 1932

Arizona [1175] Cultures of the Upper Gila. 104p.

Getty, Harry Thomas PhD 1950

Chicago [1176]

Interethnic relationships in the community of Tucson. 245p. $M$.

Papago and Yaqui.

GIbBaRd, John Edgar MA 1937

Brit. Columbia [1177]

Early history of the Fraser Valley, 1808-1885. 308p. Salish.

Gibis, Jerome F. MA 1952

Mexico City [1178]

Some stylistic considerations on the ancient art of Mexico. 112p.

Combines disciplines of art and archaeology.

Gibbs, Mary Henry

MA 1932

Catholic [1179]

The Shawnee Indians.

Gibson, Charles II

MA 1947

Texas [1180]

The Inca concept of sovereignty and the Spanish administration in Peru. Рणв: U/Texas, Inst. Latin-Amer. Stud., Latin-Amer. Stud. 4 [1948] 146p.

Gibson, Charles II

PHD 1950

Yale [1181]

History of Tlaxcala in the sixteenth century. 580p.

Pбв: Yale U., Hist. Pubs., Miscellany \#56 [1952] 300p. 
Gibson, George Davis PhD 1940

California [1182]

Jesuit education of the Indians in New France, 1611

to $1658.146 \mathrm{p}$.

Gibson, LoRna FAITH MA $1956 \quad$ Indiana [1183]

Pame (Otomi) phonemics and morphophonemics. 67p.

PUB: Intl. Jour. Amer. Ling., XXII \#4 [1956] p242-265.

Giddings, James Lovis, JR. MA $1941 \quad$ Arizona [1184]

Dendrochronology in northern Alaska. 128p. PUB: $U /$ Ariz. Bull., XII \#4 [1941] 107p.

Giddings, James L., JR. PhD 1951 Pennsylvania [1185] The Arctic Woodland culture of the Kobuk River. 144p. Puв: U/Penna. Mus., Mono. [1952] 144p., illus.

Giddings, Ruth WaRner MA 1945

Folk literature of the Yaqui Indians. 209p.

Arizona [1186]

Yaqui of Potam [Sonora], Pascua and Barrio Libre [Arizona]. 64 tales included, alien influences examined.

Gilbert, Grace $\quad$ MS 1936

Kans.-Pittsburg [1187]

Indian missions in southeastern Kansas. $82 \mathrm{p}$.

Gilbert, Hope Elizabeth MA 1933

California [1188]

The relations of the Spaniards to the Tewa Indians, 1540-1696. 138p., map.

GILbert, Lois ElleN MA 1940

West. Reserve [1189]

Santos of the Southwest. 71p.

Considers efforts of Pueblo Indians in creating santos.

Gilbert, Willitam Harlen, JR.

New fire ceremonies in America. 118p.

Gilbert, William Harlen, JR. PhD 1934 Chicago [1191] Eastern Cherokee social organization. PuB: Eggan, Social Anthropology of North American Tribes. U/Chi. Press [1937] p285-338.

Gilbertson, Albert Nicolay PhD $1913 \quad$ Clark [1192] Some ethical phases of Eskimo culture. PUB: Jour. Rel. Psych., VI \#4 [1913] p321-274; VII \#1 [1914] p45-74.

GILL, Eloise Wise MA 1935

Louisiana [1193]

The changing attitude toward the Indian in American literature. 
A history of Indian missions in Mississippi. 180p.

Gillard, Kathleen Isabel $\quad$ PhD 1950 Geo. Peabody [1195] Michigan as recorded in its writings. 351p. Puв: Our Michigan heritage. NY: Pageant Press [1955] 259p., illus.

§ 1 "The Indian in Michigan history and literature."

GiLlett, Mary Myrtle MA 1950

New York [1196]

A survey of the programs of Christian education among the American Indians associated with the Board of National Missions of the Presbyterian Church in the United States of America. 33p.

Gillette, Charles Edgar MA 1949

Chicago [1197]

The non-Mississippi manifestations at the Fisher Site, Will County, Illinois. 84p.

GILLILAND, LESLIE JAMES

MA 1929

Conrad Weiser, Indian interpreter and frontier diplomat. 96p.

Six Nations.

Gillin, John Philip PhD 1934

Harvard [1199]

The Barama River Caribs of British Guiana, a physical and social study. PuB: Harvard U., Peabody Mus., Paps., XIV \#2 [1936] 274p.

Gillingham, Frank Truscott MA 1918 Pennsylvania [1200] Comparison between the tribes of northeastern Asia and northwestern America. 27p.

Gillmor, Frances MA 1931

Arizona [1201]

A biography of John and Louisa Wetherill. 177p. PUB: Traders to the Navajos. NY: Houghton Mifflin [1934] $265 \mathrm{p}$.

Gilmer, Nancy Caldwell MA 1952

California [1202]

Huarochiri in the seventeenth century: the persistence of native religion in colonial Peru., 166p.

Gilmore, Jesse Lee PhD 1952

California [1203]

A history of the Rogue River Valley-pioneer period, 1850-1862. 426p., maps. 
Gilmore, Melvin Randolph MA $1909 \quad$ Nebraska [1204] A study in the ethnobotany of the Omaha Indians. Рणв: Nebr. State Hist. Soc., Collect., XVII [1913] p314-357.

Gilmore, Melvin Randolph PhD 1914 Nebraska [1205] Uses of plants by the Indians of the Missouri River region. 154p. Рбв: Bur. Amer. Ethnol., 33rd Annl. Rept. [1919] p45-154, illus.

Gilmore, Melvin Starr MA 1932

Wash. State [1206]

The Iroquois at war. $136 \mathrm{p}$.

Gilmore, William R. MA 1952 The life and work of the Reverend Robert McGill Loughridge, missionary to Creek Indians. 153p.

GIRdNer, Alwin J. MA 1950 Arizona [1208] Navaho-United States relations 1846-1868. 187p.

GiRón, Louis Tellez MA 1937

Southwestern [1209] Aztec civilization and legends. 141p.

Girvin, Eb CARL MA 1941

Texas [1210] The ecology of the Indian Reservation, Polk County, Texas. 51p.

GITTINGER, Roy

$$
\text { PHD } 1917
$$

California [1211]

The formation of the State of Oklahoma (1803-1906). Pбв: U/Calif. Pubs. Hist., VI [1917] 256p.

Givens, Marjorie Burnside

MA 1936

California [1212] The geographical distribution of hand-loomed pile fabrics. 112p.

Peru, Mandan, Navajo, Choctaw, Tularosa Cave Site.

Gleeson, Mark Schubert MA 1951 Pennsylvania The events leading to the introduction of Christianity into Yucatan and their effects upon the Yucatecan Indians. $115 \mathrm{p}$.

Glenn, Nan Ashton MA 1937 New Mexico [1214] Probable origin of the modern Pueblos. 133p.

Glover, Willitam Bonny MA 1932 Texas [1215] A history of the Caddo Indians. 136p. 
Gluek, Alvin Charles, JR.

The struggle for the British Northwest: a study in Canadian-American relations. 504p. $M$.

Minnesota, northern Great Plains area, includes Indian Wars.

GOAD, Edgar Ford MA 1934

So. California [1217]

A study of the relations of the European invaders with the North American Indians east of the Mississippi (1492 to 1608$) .196 \mathrm{p}$.

Goad, Edgar Ford $\quad$ PHD 1939

So. California [1218]

A study of the life of Adolph Francis Alphonse Bandelier, with an appraisal of his contributions to American anthropology and related sciences. 230p.

Goddard, Geneva MA 1930

Kans.-Emporia [1219]

A study of the historical development and educational work of Haskell Institute. 82p.

Goddard, Pliny Earle PhD 1904

California [1220]

The morphology of the Hupa language. PUв: U/Calif., Pubs. Amer. Archeol. Ethnol., III \#1 [1905] 344p.

Goddard, Sara ANne MA 1930

New Mexico [1221]

The Zuñi language as a means of interpreting Pueblo Indian culture. $108 \mathrm{p}$.

Godley, Margaret Walton MA 1935

Emory [1222]

Georgia county place-names. 95p.

9 counties have Indian names; thesis includes a section "Linguistic aspects of Georgia county place-names" which discusses Indian names, towns and tribes.

Godward, WILHELmina MA 1927

California [1223]

The French régime in the middle Northwest. 200p.

Sioux, Cree, Chippewa, Ottawa, Huron, Potawatomi, Fox and Mandan.

Godward, Wilhelmina PhD 1930 California [1224]

The decline of British control on the middle Northwest, 1783-1815. 457p.

Sioux, Mandan, Potawatomi, Ottawa, etc.

Goethals, Amelia Maria MA 1937

Pre-Columbian plant cultivation and its significance. 
Gogain, John Mann PHD 1948

Yale [1226]

Culture and geography in Florida prehistory. Рuв: "Space and time perspective in northern St. Johns archaeology, Florida." Yale U., Pubs. Anthro. \#47 [1952] 147p.

Gogin, Eleanor Gertrude MA 1910

Columbia [1227] The Coureur de Bois: A social type in the colonial history of New France. 38p.

Brief consideration of Indian relations with the coureur de bois.

Goins, John Francis PHD $1954 \quad$ California [1228] Huayculi: the Quichua of Cochabamba Valley, Boliva. 312 p. $M$.

Gold, Douglas MA 1934

Montana [1229]

The intelligence and achievement of Blackfeet Indians. $74 \mathrm{p}$.

Golden, Bernard MA 1953

Columbia $[1230]$

The stepped-fret in Amerindian art. 64p., illus.

Goldenweiser, Alexander A. MA 1904 Columbia [1231] The rites of new religions among the native tribes of North America. 85p.

Especially Smohalla, Tecumseh, Wovoka, Tenskwátawa and Kanakûk.

Goldenweiser, Alexander A. PHD 1910 Columbia [1232] Totemism: an analytical study. PuB: Jour. Amer. Folklore, XXIII \#88 [1911] p179-293.

Golding, Helen MA $1952 \quad$ New Mexico West. [1233] Primitive art of the Southwest. 29p., photos.

Goldman, Irving PhD 1941

Columbia [1234]

The Alkatcho Carrier: historical background of crest prerogatives. Рणв: Amer. Anthro., XLIII \#3 [1941] p396-418.

GoldSCHMIdT, WaLter ROCHS Some archaeological sites in Titus County and their relation to east Texas prehistory. 131p. 
Gollin, Eugene S.

An examination of culture patterns in Ukiah Valley, California, in relation to attitude structures and behavioral manifestations. $76 \mathrm{p}$.

Concerns Pomo Indians of the area.

Golomshtok, EugENe A. MA 1923

California [1237]

Ethnology of the Atsugewi Indians. 100p.

Gonnsen, Reta Kizer MA 1949 Hardin-Simmons [1238] The religion of the Navajo Indians. 123p.

Goode, William Jostah PhD $1946 \quad$ Penna. State The sociology of primitive religion. 524p. PUB: Religion among the primitives. Glencoe, Ill: Free Press [1951] $321 \mathrm{p}$.

Includes study of Zuñi.

Goodman, Basil Harry MA 1951 Ariz.-Tempe [1240] An investigation of the adjustment of the Apache Indians to the public schools of the State of Arizona. 85p.

Goodwin, William Irving MA 1941 Massachusetts The development of vocational education in agriculture at Indian schools. $74 \mathrm{p}$.

Goodykoontz, Colin Brummit

MA 1914 California [1242] Spanish exploration of Louisiana and the adjacent borders of New Spain, 1762-1800: translation of documents, with introduction and notes. 239p.

Indians of the Louisiana area.

Gordon, Burton LeRoy PhD 1954

California [1243] Human geography and ecology in the Sinú country of Colombia.

Gordon, George Byron · PHD 1903 Harvard [1244] The serpent motive in the ancient art of Central America and Mexico. 2 vols. Pub: U/Penna. Mus., Dept. Archeol., Trans., I [1905] p131-163, illus.

Gordon, LaUra Ammonnette MA 1939 Oklahoma $A \& M$ [1245] The mission schools of the Five Civilized Tribes in Oklahom a. $43 \mathrm{p}$. 
Gordon, Mollie Elizabeth MA 1939 New Mexico [1246] The ethnobiology of the salmon food area of North America. 157p.

Gordos, Edward Andres MA 1949

Lehigh [1247]

Indian trade in Pennsylvania, 1730-1763. 224p.

Goree, Julius Weshey MA 1942

Participation of the Indians in the War of $1812.87 \mathrm{p}$.

Gorham, Mildred Ide MA 1917 California [1249] The development of the Coahuila-Texas frontier, 1670 to $1700.67 \mathrm{p}$.

Gormly, Mary MA $1948 \quad$ Mexico City [1250] The rise of the Aztecs to political supremacy (1325-1428). 31 p., maps, charts.

Gorton, Ernest Fay MA $1935 \quad$ Oklahoma $A \& M$ [1251] Education among the Osage Indians. 66p.

Gossett, Thomas Frank PhD 1953 Minnesota [1252] The idea of Anglo-Saxon superiority in American thought, 1865-1915. 416p. $M$.

Considers ethnology, and Anglo-Saxon concepts of relations between Whites and Indians. Includes period prior to 1865 .

Gould, ALPhin T. MA 1940

Montana [1253]

A hundred years on the Ishawooa. 168p.

Shoshoni, Crow, Sioux, Bannock, Blackfoot, Nez Percé.

Gould, Cassius W. PHD $1954 \quad$ Northwestern [1254]

An analysis of the folk-music in the Oaxaca and Chiapas area of Mexico. 314p.

Includes Indian influences on Mexican music.

Gould, RALF Fisher MA 1931

New Mexico [1255]

Psychological tests applied to American Indians. 39p.

Albuquerque Indian school pupils.

Grabber, Adeline MA 1952

Arizona [1256]

An interpretation of Canyon de Chelly National Monument; a study for children. 163p. 
Grace, Cyril W.

Internal and external factors affecting the social status of the Sioux Indians. 142p.

Grad, Mary Rosina MA 1949

Marquette [1258]

The Indians and French in the Illinois region under three Governments. 144p.

Graebner, Norman Arthur

MA 1940

Oklahoma [1259]

Apache depredations on the Mexican frontier, 1837 to 1853. $127 \mathrm{p}$.

Graeff, Arthur D. MA/Ed 1932

Conrad Weiser-Interpreter. 71p.

Temple [1260]

Iroquois; Delaware, Shawnee, and Catawba,.

Graham, Eleanora L. MA/Ed 1951 Colorado State [1261] An analysis of the errors made in the standardized achievement tests by Indian children in Grades 6, 7, and 8 in Becker County, Minnesota. 93p.

White Earth School, Ponemah Chippewa.

Graham, Robert Adelbert MA $1933 \quad$ Arizona [1262] The textile art of the prehistoric Southwest. 98p., illus.

Grajales Ramos, Gloria MCH 1949

Mexico [1263]

Cristianismo y paganismo en la altiplanicie mexicana. Siglo XVI. PUB: Mexico: Impresora Económica [1949] $126 \mathrm{p}$.

Granberry, JuLian MA 1955

Florida [1264]

A survey of Bahamian archaeology. 410p.

Grandjean, Dolly Beatrice MA 1939 California [1265] An analysis of Peruvian embroideries.

Grant, Rena Victoria PhD 1942 California [1266] Environment in the poetry of the West.

Mentions Indian influences on poetry; includes Indian terms.

Granzer, Loretta Mary MA 1937 Nebraska [1267]

Indian education at Haskell Institute, 1884-1937. 259p.

Gray, Robert A. MA 1950

West. Reserve [1268]

The Southern powderkeg: a study of the Creek and Cherokee Nations, 1763-1796. 250p. 
Gray, William Ramsay

MA 1942

Texas [1269]

Archaeology of the Craig rock shelters, upper Nueces

Valley, Edwards County, Texas. 79p.

Greaves, Halbert PhD 1942

Wisconsin [1270]

Public speaking in Utah, 1847-1869.

Mormon-Indian relations; speeches of Indians.

Green, Charles Lowell MA 1928

Iowa [1271]

The Indian Reservation system of the Dakotas to 1889.

Pub: So. Dakota Hist. Collect., XIV [1928] p307-416.

Green, Charles Lowell PhD 1939

Iowa [1272]

The administration of the public domain in South Dakota.

Period 1861-1939. Discusses background of land settlement: Indian land cessions and Reservation allotments.

Green, Edith Vivian MA 1930

Occidental [1273]

California during the Civil War period. $108 \mathrm{p}$.

Brief Indian mention, especially toward the end, in connection with mail routes and early settlement.

Green, Philip Jackson MA 1925

Alabama [1274]

Life and institutions of the Creek Indians to $1836.70 \mathrm{p}$.

Greene, Dorothea Clare

MA 1952

Ohio State [1275]

A survey of the arts of the Pueblo people and the New Mexican Spaniards. 206p., photos.

Greenfield, Edward W. MA 1946

Columbia [1276]

The life of Colonel Daniel Parke, Jr., Virginia gentleman-adventurer (1669-1710).

Considers Bacon's Rebellion as caused by Indian menace.

Greenfield, Richard Kenneth

MA 1948 Columbia

[1277]

George Washington's western land interests and activities in the West, 1748-1775. 88p.

Greengo, Robert Eugene MA 1951

California [1278]

Aboriginal use of shellfish as food in California. PuB: Kroeber Anthro. Soc., Paps. \#7 [1952] p63-114.

Greenholt, Homer Reginald

PHD 1937 Chicago [1279]

A study of Wilhelm Loehe, his colonies, and the Lutheran Indian missions in the Saginaw Valley of Michigan. 270p. 
Greenman, Emerson Frank PhD 1927 Michigan [1280] The earthwork enclosures of Michigan. 167p.

Greer, Scott A. PhD $1951 \quad$ U.C.L.A. [1281] The participation of ethnic minorities in the Labor unions of Los Angeles County. 413p.

Section on Indian laboring class in Los Angeles.

Greever, William St. Clair PhD 1947 Harvard [1282] The Santa Fé Railway and its western land grant. 536p. Pub: Arid Domain; the Santa Fé Railroad and its western land grant. Stanford U. Press [1954] 184p.

Indian land ownership and resources. Discusses Indian lien rights in Arizona and New Mexico, especially attempts to get Zuñi Reservation revoked.

Gregg, Adelaide Le Mert $\quad$ MA 1934 So. California [1283] A history of Santa Catalina Island from 1542 to 1919. 230p., maps.

Includes aboriginal inhabitants.

Gregg, Robert Danforth PhD 1932 Johns Hopkins [1284] The influence of border troubles on relations between the United States and Mexico 1876-1910. PUв: Johns Hopkins U., Stud. Hist. Pol. Sci., Ser., LV \#3 [1937] 200p.

Apache raids; Apache Indians in general.

Gregory, Catherine Elizabeth MA 1936 Illinois [1285] The Miami revolt, 1748-1752. 57p.

Gregory, Dedcalion, JR. MA 1947 William-Mary [1286] Colonial legislation affecting the Powahatan Confederation. 53p.

Especially Pamunkey.

Gregory, Parthenta Frances Ma 1927 Chicago [1287] The Choctaw Indians. 124p.

Grieder, Theodore G. MA 1928

Iowa [1288]

The influence of the American bison or buffalo on westward expansion. 109p.

$\S 5$ "The Indians and the buffalo." 
Griffen, William Bedrof MA 1955

Mexico City [1289]

A survey of present day Seri culture.

Griffin, James Bennett PhD 1936

Michigan [1290]

The cultural significance of the ceramic remains from the Norris Basin. 137p. PUв: W. S. Webb "An archaeological survey of the Norris Basin in eastern Tennessee." Bur. Amer. Ethnol., Bull. \#118 [1938] p253-386.

Griffin, John WaLLaCe

MA 1946

Chicago

The upper Mississippi occupations of the Fisher Site, Will County, Illinois. 181p.

Griffin, Joseph Aloysius PhD 1932

Catholic [1292]

The contribution of Belgium to the Catholic Church in America (1523-1857). Pub: Cath. U., Stud. Amer. Church Hist., XIII [1932] 235p.

\section{Griffith, William Joyce PhD 1942 California} The Spanish occupation of the Hasinai country, 1690 to 1737. Рuв: Tulane U., Mid. Amer. Res. Inst., Studies \#3 [1954] 147p.

Grimsley, Helen K. MA 1943

Ohio [1294]

The Mexican Indian in the novels of Mariano Azuela and Gregorio López y Fuentes. 46p.

Grise, George PhD 1950

Geo. Peabody [1295]

Kentuckians as pictured by American novelists. 244p.

Brief mention of Indians in novels about Kentucky.

Griswold, GiLleter Gary MA 1954 Aboriginal patterns of trade between the Columbia Basin and the Northern Plains. 172p.

Grissel, Lois ANNa MA 1946

Iowa [1297]

An analysis of a prehistoric village site near Cedar Rapids, Iowa. 30p.

Grivas, Theodore MA 1953 So. California [1298] Stephen Watts Kearny and the Army of the West.

Indian references scattered throughout. 
The social criticism of Hamlin Garland. 383p.

"The great importance of his social criticism consisted of his consideration of the American Indian problem."

Grossman, Henry MA 1940

New York [1300]

The economic and industrial organization of the American Indian in the twentieth century. 165p.

Grossman, Mitchell M. Van N. MA 1948 So. Methodist [1301] The introduction of slavery into the New World.

Examines European patterns of Indian slavery, and outcome of the practice in the New World.

Grotts, Pearl Irene MA 1942

Sociological aspects of the Crow Indian dances. 23p.

Grover, Elsie Jeanette MA $1913 \quad$ California [1303] The establishment of Territorial Government in Utah and the struggle for Statehood, 1849-1862. 95p.

Ute and Shoshoni.

Grunad, Herman MA 1923

Columbia $[1304]$

Indian relations since the Civil War. 58p.

Goenther, Amalia Helen MA 1929

Oklahoma $[1305]$

The Cheyenne and Arapaho Indian Reservation in Oklahoma. 118p.

GUENTHER, LINDA Y. MA 1937

Arizona [1306]

Gila polychromes. The origin and development of polychrome pottery in the Gila River drainage area. 53p.

Guess, Francis M. MA 1953

Mexico City [1307]

Report on excavations at Pueblo Viejo, Tamazulapan, Oaxaca. 118p., illus.

Guest, Anna Leie MA 1929

California [1308]

The historical development of southern Oregon, 1825 to $1852.122 \mathrm{p}$.

Takelma, Tututni and Umpqua.

GUild, ElLiott WiLLIAM MA 1931

Stanford [1309]

The sociological rôle of music in primitive cultures. $127 \mathrm{p}$.

$\S 5$ Music and group life among the North American Indians. 
Gunderson, Carl M. MA 1951

Montana [1310]

The history of the Milk River Valley. 149p.

GUNN, JACK Winton MA 1947

Texas [1311]

Life of Ben McCulloch. 120p., illus.

Chapters on his career as an Indian fighter and Indian scout.

Gunnerson, James Howard

MA 1950

Nebraska [1312]

The Dismal River aspect. 251p.

Summary of central Nebraska archaeology.

Gunst, Marie Louise MA 1930

Arizona [1313]

Ceremonials of the Papago and Pima Indians, with special emphasis on the relationship of the dance to their religion. $73 \mathrm{p}$.

Gunter, Addye L. MA 1953

Oklahoma [1314]

Health problems and practices of a group of Cherokee Indians. $106 \mathrm{p}$.

Gunther, ERna MA 1920

Columbia [1315]

Design units on Tlingit baskets. 31p.

GUNTHER, ERNA PHD 1928

Columbia [1316]

A further analysis of the first salmon ceremony. PUB:

U/Wash., Pubs. Anthro., II \#5 [1928] p133-173.

Gurney, William Harold MA 1948 Brit. Columbia

[1317] The work of Reverend Father V.M.R. Le Jeune, O.M.I.

$177 \mathrm{p}$.

Interior Salish.

Gustafson, Carl Stanley $\quad$ MA/Ed 1954 Wyoming [1318]

Stories for elementary school pupils to supplement

Wyoming history.

Includes some Indian stories, period 1811-1954.

Guthe, Alfred Kidder PhD 1956

Michigan [1319]

Late prehistoric occupation in southwestern New York: an interpretive analysis. 148 p. $M$.

Guthe, Carl Eugene PhD 1917

The lunar count of the Mayas. 259p. PuB: "A possible solution of the number series on pages 51 to 58 of the Dresden Codex." Harvard U., Peabody Mus., Paps., VI [1921] 31p. 
Gutiérrez Eskildsen, Rosario María DL 1944 Mexico Substrato y superestrato del español de Tabasco. 134p., illus.

A philological study of the development of Spanish in Tabasco. Indian influences are considered.

GUTKoski, Joseph Leo MA 1938

Columbia [1322]

Wyoming Valley lands controversy. 100p.

Mainly Six Nations; controversy between Pennsylvania and Connecticut, 1769-1807.

GuY, F. J. PhD 1932

The Catholic Church in Arkansas, 1541-1843.

Catholic [1323]

HaAg, William George, JR. PhD 1948 Michigan [1324] An osteometric analysis of some aboriginal dogs. $198 \mathrm{p}$. $M$.

Examines the origin and relationships between various canine groups, and the position of dogs in their cultural, temporal and human environment.

HaAs, Florence L. M/Ed 1931

Temple [1325]

Recreational activities of primitive and tribal people. $161 p$.

Cheyenne, Cherokee, Algonquin (Shawnee, Delaware), Tuscarora, Sioux.

Haas, Francis PhD 1954

Chicago [1326]

Education in New Mexico: a study of the development of education in a changing social order. $232 \mathrm{p}$.

HaAs, Mary Rosamond Swadesh PhD 1935 Yale [1327] A grammar of the Tunica language. 174p. PuB: Handbook of American Indian Languages, IV. NY : J. J. Augustin [1940] 143p.

Hack, John Tilton PhD 1940

Harvard [1328]

Geography and geology of the Hopi country, Arizona. PUB: "The changing physical environment of the Hopi Indians of Arizona." Harvard U., Peabody Mus., Paps., XXXV \#1 [1942] 86p., illus.

From geological-ecological backgrounds of the area, examines Hopi development in relation to their environment. 
Hackbarth, Robert Walter MA 1948 Colorado Coll. [1329] Council governments and councilar tendencies among primitive cultures, with special consideration of Aztec, Muskogian, and Iroquois government. 206p.

Hackett, Charles Wilson MA 1914

California [1330] The revolt of the Pueblo Indians of New Mexico in 1680. 55p. Puв: Texas State Hist. Assoc., Qtly., XV \#2 [1911] p93-147.

Hackett, Charles Wilson PhD 1917 California [1331] The uprising of the Pueblo Indians of New Mexico, 1680-1682. 524p. Рuв: U/New Mex. Press [1942] 2 vols.

HaCkstafF, Katherine D. MA 1931 Indian trade in colonial Virginia, 1607-1763. 82p.

Columbia [1332]

Haddox, Clara Gibson MA 1952

Geo. Peabody [1333] A study of the customs, folkways and folk dances of Mexico. 97p.

Includes Aztec and Maya.

Hadley, Barbara Ballou MA $1940 \quad$ California [1334] Aprism: A study in recent Peruvian political and social history.

Nativistic movement in Peru.

Hadley, Paul Ervin MA 1946

So. California [1335] The growth and development of Paraguayan culture.

Extensive material on Guaraní Indians.

Hadlock, Wendell Stanwood MA 1945 Pennsylvania [1336] War among the northeastern Woodland Indians. PuB: Amer. Anthro., XLIX [1947] p204-221.

Haeberlin, Herman KarL PhD 1915 Columbia [1337] The idea of fertilization in the culture of the Pueblo Indians. Р $\mathrm{Bb}$ : Amer. Anthro. Assoc., Mem. III \#1 [1916] $55 \mathrm{p}$.

Haefner, John Henry PhD $1943 \quad$ Iowa [1338] The West as seen through frontier biography.

Includes Indian-White relations as reported by hunters, trappers, soldiers, scouts, missionaries and teachers. 
Hagan, Winliam T.

The Black Hawk War.

Sauk, Fox, Sioux, Menomini. Keokuk, Black Hawk.

Hagberg, Elizabeth B. MA 1939 Arizona [1340] Southwestern Indian burial practices. 264p.

Brings together both prehistoric and historic data for comparative study.

\section{Hagerty, Leroy W. MA 1927}

Indian raids along the Platte and Little Blue River, 1864-1865. 141p.

Arapaho, Cheyenne, Sioux.

Haggard, Juan Villasana PhD 1942 Texas [1342]

The neutral ground between Louisiana and Texas, 1806-1821. 244p., maps. Рणв: Louisiana Hist. Qtly., XXVIII \#4 [1945] p1001-1128.

Chapters on Indian barriers to settlement, and Indian trade.

Haight, Charles Henry MA 1947 California [1343] Mexico in the life and writings of Alexander von Humboldt. $173 \mathrm{p}$.

20p. on his impressions of natives.

Hame, Berard MA 1929

Catholic [1344]

Property concepts of the Navaho Indians. PuB: Cath. U., Anthro. Ser. \#17 [1955] 55p.

Haines, Francis D. PhD 1938 California [1345]

Nez Percé Indians in Northwest history, 1805-1895. 382p. Puв: Red Eagles of the Northwest. Portland: Scholastic Press [1939] 361p. (Reprinted 1956 as The Nez Percés, U/Oklahoma Press.)

HaLe, KenNeth Locke MA 1956

Indiana [1346] The distribution of the Class II prefixes in Navaho. $67 \mathrm{p}$.

HaLey, John Curry MA 1940 Ollahoma [1347] The opening of the Kiowa and Comanche country. 120p.

Hall, Edward Twitcheld, JR. MA 1938 Arizona [1348] An archaeological survey of the Walhalla Glades, Grand Canyon, Arizona. PuB: Mus. No. Ariz., Bull. \#20 [1942] 32p. 
Hall, Edward Twitchell, JR. PhD 1942 Columbia [1349] Early stockaded settlements in the Governador, New Mexico; a marginal Anasazi development from Basket Maker III to Pueblo I times. Р вв: Columbia U., Stud. Archeol. Ethnol., II pt. 1 [1944] 96p.

Hall, Gladys Harriet MA 1926 California [1350]

History of American relations with Spanish Louisiana from 1790-1800, with an appendix of original documents. $236 \mathrm{p}$.

Choctaw, Creek, Chickasaw, Seminole and Cherokee.

HaLL, Marion MA 1933

So. California [1351]

The role of defense in the colonization of the South Carolina frontier. $147 \mathrm{p}$.

Indian attacks.

HaLl, RaLPh J. MA $1931 \quad$ Oklahoma $A \& M$ [1352] Bloomfield Indian School and its work. 67p.

First missionary school among Chickasaws for girls, founded 1852 .

HaLl, Robert Leonard MA 1951 Wisconsin

The late prehistoric occupation of northeastern Oklahoma as seen from the Smith Site, Delaware County.

HaLL, Tom ALdis MA 1934

Oklahoma [1354]

The socio-economic status of the Cherokee Indians. 135p.

Halliday, Constance Carolyn MA 1947 California [1355] Basketry hats of the east Asiatic region as part of a circum-Pacific distribution.

Hallowell, Alfred Irving PhD 1924 Pennsylvania [1356] Bear ceremonialism in the northern hemisphere. PUB: Amer. Anthro., XXVIII \#1 [1926] pl-175.

Halpern, Abraham Meyer PhD 1947 A grammar of the Yuma language. PuB: Intl. Jour. Amer. Ling., XII-XIII [1946-1947] var. pp.

HALPIN, JAMES T., JR. MA 1950 Syracuse [1358] The valley of Atlixco, Puebla, Mexico. 79p. 
Hamilton, George Henry

MA 1926 Brit. Columbia [1359]

Religious conceptions of native British Columbia tribes. $35 \mathrm{p}$.

Hamilton, John M. MA 1948

Arizona [1360]

A history of the Presbyterian work among the Pima and Papago Indians of Arizona. 260p.

Hamilton, William B., JR. PhD 1937

Duke [1361] American beginnings in the Old Southwest: the Mississippi phase.

Hamlin, Alfred Street MA 1918 California [1362] The Federal policy in relation to the Nevada Indian. $106 \mathrm{p}$.

Washo, Shoshonean, Bannock, Gosiute, Paiute.

Hamman, Rose-Elnor MA 1950

Colorado [1363]

A bibliography of the cultural development in northwestern Colorado. 50p.

Includes archaeology of Dinosaur Canyon National Monument, Ute Indians, and Indian-White contacts.

Hammelef, John Christensen PhD 1955 Michigan [1364] British and American attempts to coördinate the defense of the Continental Colonies to meet French and northern Indian attacks, 1643-1754. 265p. $M$.

Especially considers Indian attacks in the original 13 Colonies area.

Hammond, Frances Turner MA 1951 Indiana [1365] Girls' puberty observances in South America. 118p.

Hammond, George Peter PhD $1925 \quad$ California [1366] Don Juan de Oñate and the founding of New Mexico, 1595-1620. Puв: New Mex. Hist. Soc., Pubs. Hist., II [1927] 288p., maps.

Hammond, Roscoe Eldon MA 1918

Utah [1367]

The Anglo-Saxon settlement of the Far West, prior to 1905. $78 \mathrm{p}$.

Said to consider Indians of the area.

Hammond, Stelda Lou MA 1936

Wayne [1368]

Contribution of the American Indian and Negro to the folk-music of America. 97p. 
Hanan, Everetti Edward MA 1948

Iowa [1369]

The influence of the Indian on the life and literature of Thoreau. $77 \mathrm{p}$.

Handy, Mary Outvia MA 1949

Texas [1370]

A history of Fort Sam Houston. 140p., illus. РuB: Naylor Co. [1951] 111p.

Includes material on Indians, especially period of Geronimo's imprisonment at the Fort.

Hanke, Lewis Ulysses PhD 1935

Harvard [1371]

Studies in the theoretical aspects of the Spanish Conquest of America. 393p. PUB: "The first social experiments in America; a study in the development of Spanish Indian policy in the sixteenth century." Harvard $U$. Hist. Mono. V [1935] 99p.

$\S 1$ "Spanish Indian policy, 1493-1542." § 2 "Just war and the natives."

Hankins, John Erskine MA 1925

So. Carolina [1372]

Oratory of the American Indian; a descriptive and critical discussion of the oratory of the Indians of eastern and middle western America until the year 1830. $45 \mathrm{p}$.

Hanley, Maurus Richard MA 1929

Relations of the Spanish government to the American Catholic [1373] Indians.

Hanna, Mary Alice PhD 1917

Bryn Mawr [1374]

The trade of the Delaware district before the Revolution.

PUB: Smith Coll., Stud. Hist., II \#4 [1917] p239-348.

Brief references to Indian trade in passim.

Hanna, Murel Warmoth MA 1931 Arizona [1375] An archeological review of Middle Gila culture. 94p.

Hanna, Paul Shelley MA 1953 No. Dakota [1376] An analysis of the assimilations of White culture by Hidatsa Indians of North Dakota. 146p.

Hansborough, HeLen MA 1932 Cincinnati French exploration of the Mississippi Valley in the seventeenth century 1634-1699. 55p. 
Hansen, Clarence F.

MA 1916

Iowa $[1378]$

Psychological study of Indian conversions. $147 \mathrm{p}$.

Cheyenne, Crow, Winnebago, Makah, Navajo, Fox, Sac, Chippewa.

Hansen, Harvey Chester MS/Ed 1927 Oklahoma [1379] Correlation between verbal intelligence tests and nonverbal intelligence tests of Indian pupils. $41 p$.

Oklahoma Indians; no specific tribes mentioned.

Hansen, Harvey Chester EdD 1935

Oklahoma [1380]

Scholastic achievement of Indian pupils. 171p. PUB:

Pedagogical Seminary and Jour. Genetic Psych., L [1937] p 361-369.

Hansen, Helen Deli MA $1936 \quad$ Stanford [1381]

A history of the Federal Government's educational activities with the Indians in the United States. $121+46 \mathrm{p}$.

Hansen, Margaret Elizabeth MA 1949 Colorado State [1382] Removal of the Indians from Nebraska. 136p.

Hanson, George Emmandel MA 1924 California [1383] The early history of Yuba River Valley. 163p.

Central California Indian tribes.

Hanson, VIRGINIA MA 1937

Alabama: in legend and lore. 130p.

Birmingham-So. [1384]

Largely concerned with place-name sources, poetry of Indian names, etc. Section on Indian legends.

Harbour, Emma Estill $\quad$ PhD 1933

A brief history of the Red River country since 1803.

Chapter: "Indian removals and relations."

HARDIES, RoDERICK R. MA 1952

Columbia [1386]

Changes in Baffin Island Eskimo culture. 182p.

HaRding, HaRry B. MS 1940 Arizona [1387] A study of heterophile and related antibodies in various racial groups living in southern Arizona. 79p.

Includes Indians of the state.

Hardman, Marion Payzant PhD 1939

Minnesota [1388]

Terror in American prose fiction to 1835.

The Indian as an element of terror in novels. 
HaRley, Mary Parker

MA 1935

Georgia [1389]

Georgia Indian trade: the Trustee Period, 1733-1752.

$86 \mathrm{p}$.

Cherokee, Creek, Chickasaw, Choctaw, Yuchi.

Harmon, George Dewey PhD 1930 Pennsylvania [1390]

Sixty years of Indian Affairs, political, economic, and diplomatic, 1789-1850. РUB: U/No. Carolina Press [1941] 428p.

Harms, Tina Cecelia ma 1927

Kansas [1391]

A dictionary of characters in Cooper's Leatherstocking Tales.

Harney, Laura Brooks EdD $1939 \quad$ New York [1392] School and society in Matanuska Valley with appropriate Alaskan background. 150p.

Brief section on Alaskan Indians and Eskimos.

Harp, Elmer, JR. PhD 1953

Harvard [1393]

The cultural affinities of the Newfoundland Dorset Eskimo. Pub: "New World Affinities of Cape Dorset Culture," U/Alaska, Anthro. Paps., I \#2 [1953] p37-54.

Harp, Mirford Berger MA 1943 Oklahoma $A \& M$ [1394] A survey of Shawnee medicine men and their practices. $63 \mathrm{p}$.

Harper, Blanche Wurdack MA 1929 New Mexico Notes on the documentary history, the language, and the rituals and customs of Jémez Pueblo. 83p.

1541 to 1929 . Includes vocabulary material.

HaRPer, Euizabeth ANN MA 1951

Oklahoma [1396]

The trade and diplomacy of the Taovayas Indians on the northern frontier of New Spain, 1719-1835. Р Св: Sowestn. Hist. Qtly., XLI [1953] p181-201.

Harpster, John W. MA 1932 Pittsburgh [1397] A bibliography for a study of the Mayas. 227p.

Period 1520-1932. 1600 items listed.

Harrington, Mark Raymond MA 1908 Columbia [1398] Iroquois industries as shown by their archaeology. 48p. 
Comparative social organization of the western Eskimo and Aleut. 111p.

HaRris, JACK SARgent PHD 1940

Columbia [1400]

The White Knife Shoshoni of Nevada. PuB: Linton, Acculturation in Seven American Indian Tribes. N.Y.: Appleton-Century Co. [1940] p39-116.

Harris, John West, JR. PhD 1928

The glorification of American types in American literature from 1775 to 1825 .

Indians throughout; especially as examples in certain historical novels.

Harris, Otis Roscoe MA 1929

The Dawes Commission to the Five Civilized Tribes.

Harrison, Celeste Elizabeth MA 1930 Columbia [1403] The early history of the Spanish missions in Alta California 1769-1784. 53p.

Considerable Indian material throughout.

Harrison, Frances Kathry

MA 1950

Oklahoma [1402]

The Indians as a means of Spanish defense of West Florida, 1783-1795.

Harshberger, Emmett Leroy MA 1929 Ohio State [1405] A brief history of the Seminole Indians. 115p.

Harshberger, John W. PHD 1892 Pennsylvania [1406] Maize: a botanical and economic study.

Said to include Indian references.

HartJe, Robert G. MA 1950

Vanderbilt [1407]

The early military career of Earl Van Dorn.

In command at Pea Ridge; active in Kiowa-Comanche campaigns.

Hartiley, Lois Teal MA 1945

Penna. State [1408]

Pocahontas plays, 1808-1855.

Hartung, Jean Buehrer MA 1944

Denver [1409]

An investigation of the literature concerning the Spanish

Missions of California and Southwest. 79p.

Spanish missions to the Indians included. 
Harvey, Doris L. MA 1935 Arizona [1410] The pottery of the Little Colorado culture area. 73p., ill. Compared with San Juan, Upper Gila, Kinishba, etc.

Harvey, Theodore Vespasian Lee DB 1934 Chicago [1411] Missionary methods of the French Jesuits among the Hurons. 71p.

Harwood, Thomas Franklin MA 1954 Texas [1412] The Indian problem on the first frontier: Virginia, 1584-1622. 175p.

Haskelt, Marion Lowrie MA 1917 California [1413] Rubí's inspection of the frontier presidios of New Spain, 1766-1768. Translation of sources, introduction and notes. 75+92p. Puв: So. Calif. Hist. Soc., Pubs. V [1917] p33-43.

Mostly Apache, Mescalero, Tlascaltecan, Lipan, Comanche and Tejas.

Hassinger, Edward Wesley MA 1951 Minnesota [1414] A study of a minority group's social contacts; the lower Sioux community of Morton, Minnesota. 124p.

Hastings, Virginia Annette MA 1955 Pennsylvania [1415] The concept of moiety-a review and a new interpretation. 120p.

Of 42 moiety systems considered, about a third are Indian.

Hastings, Virginia Marston MA 1943 Arizona [1416] A history of Arizona during the Civil War, 1859-1865.

Considerable Indian, all Southwest tribes.

HathCOAT, LeONARD MA 1946

Arkansas [1417]

A pattern of high school education for the Chilocco Indian School. Р UB: Chilocco Print Shop [1946] 42p.

Hauck, Paul A. PhD 1953

Utah [1418]

Rorschach performances of the Ute Indians. PUB: U/ Utah Anthro. Paps. \#23 [1955] 15p.

Hadn, Edward Julius Ma $1949 \quad$ Notre Dame [1419] Recent trends in United States Indian policy; the Indian Reorganization Act of 1934. 122p. 
The succession of house types in the Pueblo area. 100p.

Haury, Emil Walter PhD 1934

Harvard [1421]

The archaeology of the Salt River Valley, Arizona: a study of the interrelations of two ethnic groups. Р एв: "The excavation of Los Muertos and neighboring ruins in the Salt River Valley, southern Arizona." Harvard U., Peabody Mus., Paps., XXIV \#1 [1945] 224p., illus.

HaUser, Sol Frederick

MA 1943

Columbia [1422]

A study of alcoholism in an American Indian tribe. 104p.

Mostly Pomo, with general references to other tribes.

\section{Haveme yer, Loomis PhD 1915}

The drama of savage peoples. PuB: Yale U. Press [1916] $274 \mathrm{p}$.

Indian mentioned in passim throughout the work.

HaWkEn, EDWARD Joy MA 1938

California [1424]

The military problem on the Powder River Road, 1865-1868. 154p., maps.

Sioux.

Hawkes, Ernest William $\quad \mathrm{PHD} 1915$ Pennsylvania [1425] Skeletal measurements and observations of the Point Barrow Eskimo, with comparisons with other Eskimo groups. PuB: Amer. Anthro., XVIII \#2 [1916] p203-244.

Hawley, Cecelia Lois MA 1932 New York [1426] Art reference material as an aid for teachers. 188p., illus.

$\S 9$ "Art of pre-Columbian Peru". § 10 "American Indian Art".

Hawley, Florence May MA 1928

Arizona [1427]

Pottery and culture relations in the Middle Gila. PuB: Amer. Anthro., XXXII \#3 [1930] p522-536.

Hawley, Florence May PhD 1934

Chicago [1428]

The significance of the dated prehistory of Chetro Ketl, Chaco Cañon, New Mexico. Pub: U/New Mex. Bull., Mono. Ser., I \#1 [1934] 80p., illus. 
Haynes, GUY H. . MA 1932

Texas Tech. [1429]

Excavation of Saddleback ruin. 44p.

Canadian River, Texas Panhandle.

Haywood, Charles PhD 1951

Columbia [1430]

Bibliography of North American folklore and folksong. PUB: NY: Greenberg [1951] 1292p.

Second part, The American Indians North of Mexico, p750-1159, contains an exhaustive listing of published material.

Hazard, Lucy Lockwood $\quad \mathrm{PHD} 1925 \quad$ California [1431]

The frontier in American literature. Рणв: NY: T. Y.

Crowell [1927] 308p.

$\S 6$ "The Puritan Community: attitude toward the Indian."

Healy, Ettie Mtriam MA 1922

California [1432]

The New Mexico missions in the middle eighteenth century (translation of original documents, with introduction and notes). 158p.

Emphasis on Pueblo, Hopi and Navajo.

Hearn, Lea Theresa MA 1948

Life of the aborigines along the Taunton River basin.

Clark [1433]

Massachusetts and Connecticut tribes.

Hearon, KarL JASPER MA 1930

California [1434]

The route of De Soto west of the Mississippi River. 90p.

His encounters with tribes of the Mississippi area.

Heath, Herschel PhD 1933

The Indians as a factor in the War of 1812. $362+5 \mathrm{p}$.

Hecker, Lena Bendenbender PhD 1935 Iowa [1436]

Constitutional status of education in Alaska. PUB: Social Science, XII \#1 [1937] p64-71.

Federal-Territorial educational systems compared; includes sections on facilities for Alaskan natives.

Heemstra, Gerrit MA 1928

New York [1437]

The educational mission for the American Indian. 98p.

Heffernan, William Joseph MA 1951 California [1438]

Edward M. Kern, artist and explorer. 167p., illus. Ров:

$E$. M. Kern, the travels of an artist-explorer. Kern County

Hist. Assoc. [1953] 112p., maps.

Klamath and Navajo. 
Hegrenes, Jack R.

The use of discontinuous traits in problems of divergence and discrimination in American Indian culture. $93 \mathrm{p}$.

Heidelberg, NeLl A. MA 1940

Louisiana [1440]

The frontier in Mississippi.

Indian land cessions, treaties, and removal.

Heilman, Robert Bechtold PhD 1935

Harvard [1441]

The English novel, 1760-1800, and the American Revolution. 2 vols. РuB: America in English fiction 1760:1800. The influences of the American Revolution. U/Louisiana [1937] 480p.

A brief section on the Indian in English literature.

Heinrich, Albert CarL M/Ed 1955

An outline of the kinship systems of the Bering Straits Eskimos. 211p.

Heizer, Robert Fleming PhD 1941 California [1443] Aboriginal whaling in the Old and New Worlds. PuB: Bur. Amer. Ethnol., Bull. \#133 [1943] p415-468.

Helmen, Vernon R. MA 1950

Indiana [1444] The cultural affiliations and relationships of the Oliver Farm Site, Marion County, Indiana. 59p., illus.

Helmer, Velma MA 1925

Kansas [1445]

The American Indian and mental tests. 112p.

Tests at Haskell Institute on 9th and 10th graders.

Hemsing, William Moyer MA $1953 \quad$ New Mexico [1446] The history and trends of Indian education in New Mexico under the administration of Federal and State Government. 220p.

Henderson, Adele MA 1926

Texas [1447]

Smith County, Texas: its background and history in ante-bellum days. 118 p., maps.

Chapter on early Indian life in the region.

Henderson, Gerald Mitchell MA 1952 Pennsylvania [1448] A neo-Eskimo house excavation at the Iyatayet Site on Cape Denbigh. 119p. 
Henderson, Katherine Bradford MA 1924 Texas [1449] The early history of Milam County. 206+21p., illus.

$\S 5$ "Indian affairs in central Texas."

Henderson, Lester Dale EdD 1935 Stanford [1450] The development of education in Alaska, 1867 to 1931.

Includes Indian education to the period when it was transferred to the Bureau of Indian Affairs.

Hendon, Lottie Bess MA 1929

Oklahoma [1451]

Indian affairs from 1867 to $1889.74 \mathrm{p}$.

Hendren, Samuel Rivers PhD 1895 Johns Hopkins [1452] Government and religion of the Virginia Indians. PUB: Johns Hopkins U., Stud. Hist. Pol. Sci., Ser. 13 \#11-12 [1895] 58p.

Hendron, J. W. MA $1935 \quad$ New Mexico [1453] A stratigraphic study of the pottery of Alameda Pueblo. Also offers comparisons with Kuaua and Puaray.

Hendry, Jean Clare MA 1952 Cornell [1454] Iroquois masks and maskmaking on the Onondaga Reservation. 111p., illus.

Henline, Ruth PhD 1947

Northwestern [1455]

Travel literature of colonists in America, 1754-1783; an annotated bibliography with an introduction and an author index.

Considers printed documents which record American travel in America; many of these contain Indian references.

Hennessee, Don A. MA 1951 Mexico City [1456]

Oaxaca: an annotated bibliography of anthropological material. $148 \mathrm{p}$.

Covers $400+$ years. Includes archaeology, ethnology, linguistics and physical anthropology.

Henning, Clarence Eugene MA/Ed 1940 Washington [1457] Development of secondary education in Alaska.

Includes work of Sheldon Jackson, mission schools, and the early days of the Federal school program.

Hennings, Lawrence Joseph MA 1931

Catholic [1458]

Las Casas and early American slavery. 
Henry, Adolphos Ebenezer

STM 1926

Divinity [1459]

Early sacrifices and primitive customs among the African peoples and American Indians.

Henry, Jules A. PhD 1935

Columbia [1460]

A Kaingang text. PUB: Intl. Jour. Amer. Ling., VIII [1935] p172-218.

Henry, William Earl PhD 1944 Chicago [1461] An exploration of the validity and usefulness of the thematic apperception technique in the study of culturepersonality relations. 140p. M. Pणв: Genetic Psychology Mono., XXXV, first half [1947] 135p., illus.

Navajo and Hopi.

Henshaw, Lillie Duvall MA 1935 Oklahoma [1462] A history of the Cherokee tribal schools since the Civil War. 312p.

Heppeld, Shirley J JNe MA $1949 \quad$ Penna. State [1463] The Indian War in Berks County, Pennsylvania, 1755 to $1758.120 \mathrm{p}$.

Herge, Henry Curtis EdD 1942

New York [1464]

Colonial Long Island. A collection of historical facts and folk material of early Long Island. 222p., illus.

$\S 1$ "Our Indian predecessors," § 2 "Indian legends."

Herman, Mary Woody MA 1950

California [1465]

An analysis of Delaware-European cultural borrowing in the seventeenth and eighteenth centuries. PUB: Kroeber Anthro. Soc., Paps. \#1 [1950] p45-77.

Herman, Mary Woody PhD 1953

California [1466]

Indian fur trade of New France in the seventeenth century. 207p.

Huron and Delaware tribes given primary attention.

Hernández Rodríguez, Rosadra MH 1954 Mexico [1467] El Valle de Toluca. Su historia. Época prehispánica y siglo XVI. 124p., illus.

Herron, Richard W. MA 1938

Cincinnati [1468]

The southern Indians as a factor in the relations of Spain and the United States, 1783-1795. 61p.

Cherokee, Choctaw, Creek and Chickasaw. 
Herzog, George - PhD 1938

Columbia [1469]

A comparison of Pueblo and Pima musical styles. PuB:

Jour. Amer. Folklore, XLIX \#194 [1937] p283-417.

Hess, RalPh Edward MFA 1950 So. California [1470] Arizona Indian music and suggestions for its use in the elementary school. 145p.

Hesselden, Elizabeth Clark MA 1931 New Mex.High. [1471] Pueblo Indian costume. 76p.

Hester, Joseph A., JR. $\quad$ PhD 1954

U.C.L.A. [1472]

Natural and cultural bases of ancient Maya subsistence economy. 231p.

Hewes, Gordon Winant $\quad$ PhD $1947 \quad$ California [1473] Aboriginal use of fishery resources in northwestern North America. 284p.

Hey, George Anderson MA 1939

Trinity [1474]

The policies of Senator Henry L. Dawes in solving the Indian problem. $67 \mathrm{p}$.

Massachusetts Senator largely responsible for the Allotment Act of 1887.

Hibben, Frank Commings PhD $1940 \quad$ Harvard [1475] The Gallina culture of north-central New Mexico. 2 vols., illus. PuB: "The Gallina Phase." Amer. Antiq., IV \#2 [1938] p131-136; AND "The Pottery of the Gallina Complex." Amer. Antiq., XIV \#3 [1949] p194-202.

Hickerson, Nancy Parrot MA $1950 \quad$ Indiana [1476] The institution of slavery in societies of North-western North America. 104p.

Hickox, Charles F., JR. MA 1953 Columbia [1477] Indian petroglyphs of Lincoln County, New Mexico and related areas. 54 p., illus.

Hicks, Mozelle MA 1942 Ariz.-Flagstaff [1478]

The influence of education on the life of the Apache Indians on the San Carlos Reservation. 104p. 
Hiemstra, William L. MA 1948

Mississippi [1479]

Presbyterian missions among the Choctaw and Chickasaw Indians, 1845-1862. 72p.

Higbee, RALPH Wilson MA 1951 California [1480] Design motives of Guatemalan narrow weavings. 216p.

Hilger, Mary INez PhD 1939

Catholic [1481]

A social study of one-hundred-fifty Chippewa Indian families on the White Earth Reservation of Minnesota. PUB: Cath. U. [1939] 251p.

HiLL, Esther V. MA 1930

Buffalo [1482]

Iroquois Indians and their lands since 1763. 207p.

HiLL, FAITH RACHEL MA 1942

Whittier [1483]

Education for Navajos: problems involved in working out a plan of education for the Navajo Indians. 104p.

Hull, Gertrude Frances MA 1938

Arizona [1484]

Turquoise: its history and significance in the Southwest. $211 \mathrm{p}$.

Considers mines and mining, prehistoric uses and importance. Includes charts of culture traits.

Hill, HeLen Thompson MA 1955

Tulane [1485]

Cross and prayer-stick in New Mexico.

"A study of the implications of past and present mission work among the Indians of New Mexico."

HiLl, Joseph ABner MA $1916 \quad$ California [1486] The Indian policy of the United States on the Southwestern frontier, 1830-1845. 172p.

Hill, Lawrence Francis MA 1921 California [1487] Federal Indian policy in Texas, 1845-1859. 147p.

Hill, Peter J. MA $1944 \quad$ New Mex. High. [1488] The Pueblo of La Isleta during the sixteenth and seventeenth century. 162p.

Hill, Willard Willitams $\quad$ PhD $1934 \quad$ Yale [1489] The agricultural and hunting methods of the Navaho Indians. PuB: Yale U., Pubs. Anthro. \#18 [1938] 194p. 
Himes, Norman Edwin PhD 1932

Harvard [1490]

The practice of contraception and its relation to some phases of population theory. $520 \mathrm{p}$. Illus.

Includes methods employed by many Amerindian tribes.

Hinchee, Charles L. MS/Ed $1935 \quad$ Northwestern [1491] A comparison of the Kwalwasser-Dykema test scores of certain White and Indian children. 53p.

Hindman, Sarah Eutzabeth MA 1932 Texas [1492] Materials used in the manufacture of east Texas pottery. Includes Indian pottery making.

Hinds, Roland MA 1936

Oklahoma [1493]

White intruders in the Creek Nation, 1830-1907. 123p.

Hintz, Mary Carol MA 1943

Sowest. Texas [1494]

Early history of Limestone County organized as a study for teaching a local history unit. 154p., illus.

Texas. Includes Indian affairs and legends of the area.

Hirsch, Charles Bronislaw PhD 1954 Indiana [1495] The experiences of the S.P.G. in eighteenth-century North Carolina. 390p. $M$.

Missionary work with Indians. Stresses value of little-known resource materials available.

Hoagland, Robert John MA $1930 \quad$ Columbia [1496] A comparison of the Indians of James Fenimore Cooper and those seen by Indian agents, travellers, and scientists. 45p.

Hockett, Charles Francis PhD 1939 Yale [1497] A descriptive grammar of the Potawatomi language. PUB: "Potawatomi." Intl. Jour. Amer. Ling., XIV [1948] var. pp.

Hodges, Dewey Whitsett MA $1929 \quad$ Oklahoma [1498] Colonel E. C. Boudinot and his influence on Oklahoma history. 60p.

Indian Territory, politics and government; Cherokee Removal.

Hodgson, Virginta Elatne MS 1953 So. California [1499] A social studies unit on the Pueblo Indians. $106 \mathrm{p}$. 
Hoebel, Edward Adamson

PHD 1940

Columbia [1500]

The political organization and law-ways of the Comanche Indians. Рuв: Amer. Anthro. Assoc., Mem. \#54 [1940] $149 \mathrm{p}$.

HoEl, WIILIAM BaKer MA 1938

Little Turtle, the Miami Chieftain. 56p.

Miami [1501]

Hoff, George Alfred MS/Ed 1943

No. Dakota [1502]

Indian school education in North Dakota. 210p.

Hoff, Patricta $\quad$ MA 1933

Columbia [1503]

The Government of the Indians during the Taft Administration. $60 \mathrm{p}$.

Hoffman, Bernard Gilbert $\quad$ PhD 1955 California [1504] The historical ethnography of the Micmac of the sixteenth and seventeenth centuries. 838p. $M$.

Hoffman, Edna Pearl MA $1935 \quad$ Florida State [1505] The problem of Seminole Indian removal from Florida. $104 \mathrm{p}$.

Hoffman, Nelson M. MA 1947 Continental Congressional Indian policy, 1775 to 1781. $156 \mathrm{p}$.

Hoffmann, Fritz Leo MA 1930

Texas [1507]

The first three years of the administration of Juan María, Baron de Ripperdá, Governor of Texas, 1770-1778. 140p., illus.

Two chapters on his Indian affairs.

Hoffmann, Fritz Leo PhD 1935 Texas [1508]

Diary of the Alarcón Expedition into Texas, 1718-1719.

Pub: Quivira Soc., V [1935] 124p., facs.

Describes encounters with Indian tribes during the trip.

Hohenthal, William Dalton, Jr. PhD 1951 California [1509] The concept of cultural marginality and native agriculture in South America. 250p.

A primary study of the Fulniô Indians. 
HoIJER, Harry 'PhD 1931

Chicago [1510]

Tonkawa: an Indian language of Texas. Р $\mathrm{BB}:$ Handbook of American Indian Languages, III. NY: Columbia U. Press [1933] p1-148.

Holcomb, GeORge RUHLE MA $1952 \quad$ Wisconsin [1511] The analysis of human remains from Aztalan. 80p.

Archaeological site in Jefferson County, southern Wisconsin.

Holden, Tom C. MA 1934

Texas Tech. [1512]

Pottery of Saddleback ruin. 80p.

Canadian River, Texas Panhandle area.

Holden, William Curry PhD 1928

Texas [1513]

Frontier problems and movements in west Texas, 1846-1900. 382p.

Indian attacks and relations with White settlers.

Holder, Preston $\quad \mathrm{PhD} 1951$

Columbia [1514]

The role of the Caddoan horticulturists in culture history of the Great Plains. 135p. $M$.

HoLDSWORTH, WILLIE MA 1937

Texas [1515]

A study of the intelligence and reading ability of Navajo Indians in the ninth and tenth grades. $95 \mathrm{p}$.

Hollenbach, Marion Grace MA 1942 So. California [1516] Dogs in native American culture. 200p.

Hollowell, Betty Barham MA 1948 Oklahoma $A \& M$ [1517] Development and use of native dyes in Navajo rug craft. $36 \mathrm{p}$.

Holmberg, Allan R. PhD 1946

Yale [1518]

The Sirionó: a study of the effect of hunger frustration on the culture of a semi-nomadic Bolivian Indian society. PuB: "Nomads' of the long bow; the Sirionó of eastern Bolivia." Smithsonian Inst., Inst. Soc. Anthro., Pubs. \#10 [1950] 104p., illus.

Holmes, Chrystal M. MA 1942

Iowa [1519]

A story for children based on the customs and habits of the Blackfoot and Crow Indians of a century or more ago. $274 \mathrm{p}$. 
The effect of climate and topography on certain types of cultural development in western United States. 123p.

A study of the uses of rural home conveniences-radio, running water, electricity, etc. The survey included some Indian homes.

Holmaren, Phim Samdel PhD $1950 \quad$ Nebraska [1521] Sioux and White relations. 267p.

Period 1805-1914.

Holt, Permelia Catharine MA 1929 California [1522] Hospitality customs of Indians of America north of Mexico. 32p., tables.

Holt, Permelia Catharine PhD 1942 California [1523] The relations of Shasta folklore. PuB: "Shasta ethnography." U/Calif., Pubs. Amer. Archeol. Ethnol., III \#4 [1946] p299-349.

Holter, Don Wendell PhD 1934

The beginnings of Protestantism in trans-Missouri. 184p.

Р

Includes Indian references, period 1823-1900.

Holzman, Ruth Florence MA 1924

Denver [1525]

Spanish-Indian language influence. $97 \mathrm{p}$.

Tewa Indians of upper Rio Grande Valley, New Mexico.

HoNigmann, JoHn JosepH MA 1943

War and social structure. 28p., charts.

Yale [1526]

Considers Indian warfare.

Honigmann, John Joseph PhD 1946

Kaska ethos: a study in methodology. Рणв: Yale U., Pubs. Anthro. \#40 [1949] 365p.

Hoop, Oscar WinsLow MA 1928

A history of Fort Hoskins. 30+70p., many documents.

Oregon [1528]

Coquille, Point Orford and Coos Bay tribes.

Hoopes, Alban Williamson PhD 1932 Pennsylvania [1529] Indian affairs and their administration, with special reference to the Far West, 1849-1860. Рuв: U/Penna. Press [1932] 264p. 
Hopcraft, Margaret Lindsay MA 1943 New Mexico [1530] Attitudes towards the Indian as found in American literature, 1700-1800. 115p.

Hopkins, David Alwin MA $1951 \quad$ Montana [1531] A brief history of Indian education on the Tongue River Reservation. 75p.

Cheyenne.

Hopper, Davis Madison MA $1933 \quad$ Sul Ross [1532] The diplomacy of President Jackson in the attempt to acquire Texas. 99 p., maps.

Texas Indians and Indian-White contacts.

Horcasitas, Fernando MA 1953-Mexico City [1533] An analysis of the Deluge myth in Mesoamerica. 67p.

Hornbaker, Horace Wayne MA 1940 So. California [1534] A historical study of the use of color in the decorative arts of the Indians of New Mexico, Arizona, and Colorado.

Horner, Eva May MA 1931

Chicago [1535]

The masked gods of the Navaho, and their appearance among the Pueblos and Apaches. 279p.

Horner, George Roland MA 1943 Columbia [1536] New Jersey pottery: description and analysis. 59p., illus.

Horton, Donald PHD $1943 \quad$ Yale [1537] Alcohol and anxiety: a cross-cultural study of the functions of alcohol in primitive societies. РUв: Qtly. Jour., Stud. on Alcohol, IV \#2 [1943] p199-320.

HoRTON, RALPH MA 1921

Chicago [1538] The relations between the Indians and the Whites in colonial Virginia. $47 \mathrm{p}$.

Hosea, Mrnnie Loyola MA 1930 California [1539] The Jesuits in New Spain in the 16th century. 121p.

Hoskins, Irene Elizabeth MA 1947 Hartford [1540] The Navaho Indians: a study of their physical and social characteristics and relation of these characteristics to educational policies. $217 \mathrm{p}$. 
Hoskins, Lewis Maloney

Class and clash in seventeenth century Mexico. 237p. $M$.

Indians mentioned only occasionally, but especially as participants in Tehuántepec Revolt of 1660 and 1692 Revolt in Mexico City.

Hodgh, Vera Alice MA $1931 \quad$ New Mexico [1542] The bibliography of the ethnobiology of the Southwestern Indians. $146 \mathrm{p}$.

Lists 265 plants, 65 animal species, and their uses.

Householder, Fred Walter MA 1909

Sources of the Texas Law of Married Women. 66p.

Texas [1543]

Chapter on the relation of Spanish law codes to the Indians.

Houston, Mary Ruth MA 1925 California [1544] The early history of Berkeley, California. 110p., illus.

Costanoan tribes.

Howard, David Hugh MA 1940

Flaked stone implements of southwest Wyoming. 81p., illus.

Howard, Edgar B. PhD 1935

Pennsylvania [1546]

Evidence of early man in North America, based on geological and archaeological work in New Mexico. Pub: U/Penna., Museum Journal, XXIV \#2-3 [1935] p61-175.

Howard, George Delvigne $\quad$ PhD $1945 \quad$ Yale [1547] Prehistoric ceramic styles of lowland South America, their distribution and history. 166p. PUB: Yale U., Pubs. Anthro. \#37 [1947] 95p.

Howard, Hellen Addison

MA 1933

So. California [1548] Recent versified transcriptions and imitations of the poetry of the American Indians. 68p.

Howard, James Henri MA 1950 The ethnography of the northern Ponca. 411p.

Howard, Josephine Theo MA 1940 Geo. Washington [1550] The mechanical aptitude of Indian boys in the Southwest $66 \mathrm{p}$.

Apache, Navajo, Pueblo. 
Howard, Robert RandolPH

$\mathrm{PHD} 1950$

Yale [1551]

The archeology of Jamaica and its position in relation to Circum-Caribbean culture. PuB: Amer. Antiq., XXII \#1 [1956] p45-59.

Howard, Sarah Gates MA 1902 Stanford [1552] The industrial policy of Spain in the West Indies, 1492-1550.

Library says, "No copy exists of this thesis."

Howatt, Edward Dalton MA 1932 Cuauhtémoc, last of the Aztec Emperors. 180p.

California [1553]

Howden, George

MA 1915

California [1554]

The expedition of Father Gaspar José de Solís into Texas, 1767-1768. 116p.

Primarily Tejas Indians; also Apache and Lipan.

Howe, Elizabeth Kent $\quad$ MS 1935

Kansas [1555] An assimilation study of high school girls. 57p.

At Haskell Institute.

Howe, Kenneth G. MA $1953 \quad$ Mexico City [1556] Mexico's population problems-its economic implications.

Howes, Edward Herbert MA $1947 \quad$ California [1557] The employment of Indian scouts by the United States Army in Arizona, 1865-1886.

Howes, Edward Herbert PhD 1955

California [1558]

Federal exploration and development of the 32nd parallel route west of the Rio Grande, 1846-1861. 404p.

Howson, JoAN MA 1941

Columbia [1559]

A protohistoric Arikara village: the Buffalo Pasture Site. $96 \mathrm{p}$. , illus.

A South Dakota site.

Hoyt, Charles Eugene MA 1952

Montana [1560]

The Good Friday service at the St. Ignatius Mission;

a study in culture change. $157 \mathrm{p}$.

Salish. 
Hoyt, Frankin MA 1948

So. California [1561]

A history of the desert region of Riverside County from 1540 to the completion of the railroad to Yuma in 1877.

Early part is Garcés' diary; there is considerable reference throughout to Indians, individually and as tribes.

Hoyt, William Dana, JR. $\quad$ PhD 1939 Johns Hopkins [1562]

Colonel William Fleming on the Virginia frontier, 1755-1783. 251p.

Huber, G. H. MA 1933

Buffalo [1563]

Indian policy of Pennsylvania. 176p.

Huckaby, George Portal MA 1936 Oklahoma $A \& M$ [1564]

The Osage Indians and their treaty relations with the Federal Government. 55p.

Huddlestun, J. R. MA 1954

Kansas City [1565]

Missouri River towns from a traveller's viewpoint, 1820-1850. 105p.

$\S 3$ "Cultural viewpoint," has section on races and nationalities, including Indian.

Hudson, Elizabeth May MA 1936 So. California [1566] Design contributions of the Pima Indians as evidenced in their basketry. 93p., pls.

Hudson, Emandel Bernard $\quad$ M/Ed 1940 Oregon State [1567] Community education on the Pyramid Lake Indian Reservation. $83 \mathrm{p}$.

Paiute.

Huenemann, Ruth L. PhD 1953

Harvard [1568]

The nutrition and care of Peruvian children from birth to three years of age.

Copy missing from library.

Huff, Martha Rebecca MA 1940

Texas [1569]

The Indian element in twentieth century SpanishAmerican novels. 134p.

Hughes, Anne Eugenia MA 1912

California [1570]

The beginnings of Spanish settlement in the El Paso district. PuB: U/Calif., Pubs. Hist., I \#3 [1914] p295392. 
Hughes, Charles Campbell

MA 1953

Cornell [1571]

A preliminary ethnography of the Eskimo of St. Lawrence Island, Alaska. 300p.

Hughes, Gregory Charles MA 1939

St. Louis [1572]

The Catholic missions and the fur trade in the transMississippi West, 1838-1864. 125p.

Mission work with the Plains Indians.

Hughes, Jack Thomas MA 1942 Texas [1573]

An archaeological report on the Harrell Site of northcentral Texas. $134 \mathrm{p}$.

Hughes, Paul Leroy MA $1949 \quad$ Indiana [1574]

The removal of the Shawnee Indians from Ohio. 125p.

Hughes, WILLIS BoLdT MA 1948

Oregon [1575]

Indian Messiahs in United States history. 170p.

Hughes, Willis Boldt $\quad$ PHD $1955 \quad$ Minnesota [1576]

The Army and Stephen Watts Kearny in the West, 1819-1846. 555p. $M$.

Considers Indians and Indian menace in detail.

HuLL, DoRothy MA 1916

California [1577]

Castaño de Sosa's expedition to New Mexico in 1590.

178p. Puв: Old Santa Fé, III \#12 [1916] p307-332.

Hulsizer, Allan Lynne PhD $1940 \quad$ Columbia [1578] Region and culture in the curriculum of the Navaho and the Dakota; a technique and its development into an educational program. Рणв: Pvtly. [1940] 344p.

Humphrey, Charles Manley MA 1933 Oklahoma $A \& M$ [1579] Removal of the Creek Indians to Oklahoma. $54 \mathrm{p}$.

Humphreys, Robert Hammton MA 1951 Texas [1580] The typology and distribution of North American paleoIndian projectile points. $85 \mathrm{p}$.

Hunsberger, Eugene Albert MA 1951 Indiana [1581] Indian affairs in North Carolina, 1663-1775. 70p. 
The intertribal relations of the Indian tribes of the Great Lakes region, 1609-1684. РणB: The Wars of the Iroquois. $\mathrm{U} /$ Wisconsin [1940] 209p.

Hunter, Helen Virginia MA 1940 Pennsylvania [1583] The ethnography of salt in aboriginal North America. PUв: U/Penna. [1940] 63p.

Hunter, William Arthur PhD 1955 Tulane [1584] An edition and translation of a Nahuatl version of the Calderonian auto sacramental El gran teatro del mundo. Original by Fr. Bartolomé de Alva, 1640-1645.

Huntington, Margaret Alice MA 1924 Illinois [1585] The treatment of the Indian in American literature previous to $1860.79 \mathrm{p}$.

Hurd, Gerdie Raymond MA 1937 Oklahoma $A \& M$ [1586] The Dawes Commission and its relation to the Five Civilized Tribes. 95p.

HuRt, Wesley Robert, JR. MA 1941 New Mexico [1587] Manzano; a study of community disorganization. 233p.

Examines the contacts of a Spanish-American community with surrounding Pueblo, Navajo and Apache.

Hurt, Wesley RoBert, JR. PhD 1952 Michigan [1588] A comparative study of the pre-ceramic occupations of North America. 605p. M. Рणв: Amer. Antiq., XVIII [1953] p204-222.

Hussey, JoHn Adam MA 1935

The Wolfskill Party in California. 210p.

California [1589]

Occasional references to encounters with Apache and Osage.

Hutchins, Bess MA 1923

The literature of Peru.

Virginia [1590]

In Spanish. Examines historical background of Inca Peru.

Hutchinson, Charles Ernest MA 1933 So. California [1591]

Development and use of transportation routes in the

San Bernardino Valley region, 1769-1900. 165p., maps.

California tribes; conflict with Whites. 
Hutchinson, Charles Ernest PhD 1941 So. California [1592] A study of processes of acculturation in the Indian Pueblos of the Rio Grande valley. 439p.

Hutchinson, William Thomas PhD 1927 Chicago [1593] The bounty lands of the American Revolution in Ohio.

Indian warfare and removal.

Hutton, Charles Elmer MA 1917 Oklahoma [1594] The location of the Indian tribes in Oklahoma. 155p.

Hutton, Mary SopHIA MA $1944 \quad$ Nebraska [1595] An early history of North Platte, Nebraska. 112p.

Sioux, Cheyenne, Winnebago.

Huyck, Mernice Howe MA 1930 New Mex. High. [1596] Navajo blankets, the literature of a nomadic people. 65 p., illus.

Hyde, Stuart Wallace PhD $1954 \quad$ Stanford [1597] The representation of the West in American drama from 1849 to 1917. 501p. $M$.

Includes brief consideration of the Indian and Indian characters in plays presented during the period.

Hymes, Dell Hathaway PhD $1956 \quad$ Indiana [1598] The language of the Kathlamet Chinook. $306 \mathrm{p} . M$.

Hymes, Virginia Wolf MA 1954 Indiana [1599] Athapaskan numeral systems. 63p. Рणв: Intl. Jour. Amer. Ling., XXI \#1 [1955] p26-45.

IDen, Thomas L. MA $1929 \quad$ West. Colorado [1600] A history of the Ute Indian cessions of Colorado. 145p., maps.

IdLE, DUNNING PHD $1946 \quad$ Illinois [1601] The post of the St. Joseph River during the French régime, 1679-1761. 318p.

Great Lakes tribes.

IMBERT, RUTH MA $1946 \quad$ Columbia [1602]

Goldsmithing techniques in pre-Columbian Central and South America. 79p., illus. 
Ingleman, Anna A. MA 1929

Kansas [1603]

Indian place names of Kansas.

Library cannot locate thesis.

Inouye, Frank T. MA 1946

Indian policies in the Old Northwest. $72 \mathrm{p}$.

Inouye, Frank T. PhD 1950

So. California [1605]

Sir William Johnson and the administration of the Northern Indian Department. 686p.

IsBell, Sarah RAChel MA 1928

Musical talent of Indians. 81p.

Chilocco Indian School, Oklahoma.

Isbister, JANE BaLLANTyNe MA $1939 \quad$ New York [1607] Virginia fur trade with the Indians to $1722.46 \mathrm{p}$.

Isch, Flora Mae Bellefle dr MA 1948 Montana [1608] The development of the upper Flathead and Kootenai country. $109 \mathrm{p}$.

§ 1: Land and Indians. § 2: Early fur traders. § 3: Indian-White relations, $1800-1900$.

IVERSON, ANDREAS MA 1922

Chicago [1609]

The Moravian mission among the North American Indians in the eighteenth and nineteenth centuries. $76 \mathrm{p}$.

IVEy, Rosalie MA 1942

Texas [1610]

A history of Fort Bliss. 152p.

Section on Indian troubles of the area.

JABLOW, JosePH PHD 1951

Columbia [1611]

The Cheyenne in Plains Indian trade relations, 1795 to

1840. Рub: Amer. Ethnol. Soc., Mono. \#19 [1951] 100p.

JACKS, HAZEL D. A. MA 1932

Wichita [1612]

Government relations with the Comanche Indians. 128p.

JACKS, LEO V. MA 1920

Catholic [1613]

The Jesuit missions of Lower California.

JaCkson, Beulah MaRy MA 1933

Geo. Peabody [1614]

The rise and development of harvest customs and festivals. $78 \mathrm{p}$.

Very brief consideration of early Creek festivals, and North American Indian Corn Dances in general. 
JACKSON, EARL MA 1934

Arizona [1615]

A survey of the Verde drainage. 111p.

Based on surface observations, plus excavations between Little Colorado drainage and Salt River Valley.

JACKSON, EveretT GEe MA $1940 \quad$ So. California [1616] An investigation of the design of the ceramic figurines produced by the chief cultures of pre-Columbian Mexico.

JACKson, George Anson MA $1939 \quad$ Yale [1617]

Mineralogy of Connecticut artifacts. Pub: Archeol. Soc. Conn., Bull. \#11 [1940] p3-56, illus.

JaCkson, Gladys MaE MA $1950 \quad$ Nebraska [1618] Indianismo: social revolution in Mexico. 192p.

JACKSON, JoHN WeSLEY MA $1938 \quad$ Iowa [1619]

State jurisdiction of Indian affairs in South Dakota. 120p.

Jackson, Leroy Freeman PhM 1909 Chicago [1620] The extinguishment of the land title of the eastern tribes of the Dakota Nation previous to the outbreak of 1862 . $45 \mathrm{p}$.
Jackson, Litulian Reeves
MA 1929
Indiana [1621]
The tale of the Dog Husband: a comparative study of a North American Indian folk tale. 180p.

JACKSON, ROBERT EARL MA 1922

The Federal Indian policy in Texas. 81p.

JACKSon, Thomas J. MS $1919 \quad$ So. Dakota State

Chicago [1622]

Indians and the agriculture of Crow Creek Indian Reservation, South Dakota. 66p.

Yankton Sioux. Experiences of the author as Government Farmer at Crow Creek; a more personal document than the conventional thesis.

JACKsON, W. R., JR. PHD $1954 \quad$ Illinois [1624] Early Florida through Spanish eyes. PuB: U/Miami, Hist. Amer. Stud., XII [1954] 179p.

Jackson, William Turrentine PhD 1940 Texas [1625]

The early exploration and founding of Yellowstone

National Park. 299p. 
The West in American literary magazines, 1851-1883.

Bibliography of 425 articles; many include the Indian.

Jacobs, Melville PhD 1931 Columbia [1627]

A sketch of Northern Sahaptin grammar. PUB: $U /$

Wash., Pubs. Anthro., IV \#2 [1931] p87-291.

Jacobs, Melvin Clay PhD 1938

Columbia [1628]

Winning Oregon; a study of an expansionist movement.

PUB: Caldwell: Caxton [1938] 261p.

$\S 1$ "The fur-trading and missionary period in Oregon."

JAcobs, Wilbur R. PHD 1947

U.C.L.A. [1629]

Presents to Indians along the Ohio and Northwest frontiers, 1748-1763. 358p. PUB: Diplomacy and Indian Gifts.

Stanford U. Press [1950] 208p., illus.

Jacobsen, Jerome Vincent $\quad$ PhD 1934 California [1630] Educational foundations of the Jesuits in New Spain. 299p. Pub: U/Calif. Press [1938] 292p.

Considers mission activities to Indians.

Jacobson, Daniel $\quad$ PhD 1954

Louisiana [1631]

Koasati culture change. 231p.

1750-1954.

JAebker, ORville JohN PhD 1954

Indiana [1632]

Henry Hamilton: British soldier and Colonial Governor. 458 p. $M$.

Officer during French and Indian War; directed Indian raids against colonies during Revolutionary War.

JAFFe, HaRold ALAN MA 1932

New York [1633]

The Indian policy, 1867-1887.60p.

JAFFe, Theresa H. MA 1932

Columbia [1634]

A study of the social conditioning of mourning customs. $49 \mathrm{p}$.

Winnebago, Zuñi, Tarahumara, Guiana, Bontoc Igorot.

Jakeman, Max Wells PhD $1938 \quad$ California [1635]

The Maya states of Yucatan, 1441-1545. PUB: The origin

and history of the Mayas. Los Angeles: Research Pub.

Co. [1945] 203p., illus.

Early Spanish-Maya relations. 
James, Alice Galuigan PhD 1945

Columbia [1636]

Village arrangement and social organization of some Amazon tribes. Pub: NY: Pvtly. Pub. [1949] 131p.

Various tribes of Brazil and Ecuador.

James, Bernard J. PhD 1955

Wisconsin [1637]

The analysis of an American Indian village: Chippewa. 365p. $M$.

James, Frances Godwin MA 1938

Yale [1638]

Puritan missionary endeavors in early New England.

$112 p$.

Indians considered throughout.

James, James Alton PhD 1894

Johns Hopkins [1639]

English institutions and the American Indian. PuB: Johns Hopkins U., Stud. Hist. Pol. Sci., Ser. XII \#10 [1894] 59p.

James, Marjorie Pauline MA 1935 So. California [1640] Dramatic elements in North American Indian rituals, with specific reference to the Northwest, Plains, and Southwest areas. 97p.

Jamieson, Elmer D.Ped. 1928

Toronto [1641]

The mental capacity of southern Ontario Indians. $216 \mathrm{p}$. Pणв: Jl. Educl. Psychol., XIX [1928] 313-328; 536-551.

Six Nations, Delaware, Chippewa, Munsee.

Jamison, HaRoLd BURTON MA 1915

Historical and critical estimate of Kit Carson. 194p.

JANTzen, Muldred ItTer MA $1934 \quad$ Pennsylvania [1643] The geographical distribution and chronological position of three identifiable motifs in Peruvian art: the bird, the fish, and the puma or cat. 51p.

Jarman, Clifford Newton MA $1940 \quad$ Colorado [1644] Indian relations in New Mexico during the Civil War.

JARRETt, Charlotte JeAN MA 1929 Oklahoma [1645]

The influence of General Stand Watie on the history of Oklahoma. 64p.

Cherokee. 
JefFers, Claribel MA 1947

So. Methodist [1646]

The conversion of the Aztec to Catholicism as revealed by early writers. $108 \mathrm{p}$.

Jeltz, Wyatt Franklin MA 1945 Kans.-Pittsburgh [1647] A study of the Choctaw and Chickasaw Indians as slaveholders. $151 \mathrm{p}$.

Jemison, Verna McDaniel MA 1932

Ollahoma [1648]

The Indian traders of the Southern Plains, 1845-1875.

Includes original material.

Jenkins, Glenelle MA 1940

Nebraska [1649]

Introduction to the ethno-history of the Omaha.

Jenkins, John Cooper MA 1951 Hardin-Simmons [1650] A history of Estacado. 152p.

Chapter on Indian depredations and campaigns of extermination in Texas.

Jenkins, Katharine Drew MA $1951 \quad$ California [1651] An analysis of the Saltillo style in Mexican sarapes.

Jenkins, Ruth Euizabeth MA 1932 New York [1652] An historical study of the dances of the Mexican Indians in the latter pre-Hispanic colonial and modern periods of Mexico. 41p.

Jenkins, Thelma Adams MA 1931

New Mexico [1653]

A study of cowboy diction, with a glossary of terms. 127p.

Includes Indian words.

Jenkins, William T. MA 1949

Vanderbilt [1654]

History of Sumner County, Tennessee, to 1800.

Considers Indian problem 1780-1800; especially 1787-1800.

Jenks, Albert Ernest $\quad$ PhD $1899 \quad$ Wisconsin [1655]

The wild rice gatherers of the Upper Lakes; a study in American primitive economics. PuB: Bur. Amer. Ethnol., 19th Annl. Rept., pt. 2 [1900] p1013-1137, illus.

JenKs, Edward LeE MA 1935

Oklahoma [1656]

The Federal military policy in western Oklahoma, 1865-1885. 135p.

Indian campaigns. Indian-White relations. 
Jennings, Jesse D. PhD $1943 \quad$ Chicago [1657]

The site Kaminal Juyú and its contribution to solution of certain problems of Central American prehistory. 119p. $M$.

Jennings, Vivian MA 1934

Texas [1658]

History of Sam Houston's Governorship of Texas. 189p. $\S 3$ "Indian affairs."

Jessup, Anne Elizabeth MA $1952 \quad$ Vanderbilt [1659] D. H. Lawrence and the American Southwest.

Considers Lawrence's interest in Indian religion, and his reaction to Aztec culture.

Jewell, Donald MA 1950

Claremont [1660]

A Navaho apperception list as a psychocultural approach. $96 \mathrm{p}$.

Joblin, Elgie Ellingham Miller MA 1946 Toronto [1661] The education of the Indians of Western Ontario. 159p. Pचв: Ontario Coll. Educ. Bull. \#13, Dept. Educ. Res. [1947] 138p.

Kettle Point, Sarnia, Walpole I., Moraviantown, Muncey.

Joffe, Natalte Frankel PhD $1940 \quad$ Columbia [1662]

The Fox of Iowa. Pub: Linton, Acculturation in Seven American Indian Tribes. N.Y.: Appleton-Century Co. [1940] p259-331.

JoHns, Vera LANE MA 1932

Oklahoma [1663]

The Cherokees and the Treaty of 1866. 95p.

Johnson, Amanda PhD $1925 \quad$ Chicago [1664]

The Michigan fur trade. PUB: Lansing: Michigan Hist.

Comm. [1925] 201p.

1634-1850. French-British-American régimes, and their relations with the Great Lakes tribes.

Johnson, Benjamin MA 1952 New York [1665]

The Doniphan Expedition during the Mexican War, 1846-1847. 123p.

Chapter on Navajo and Zuñi relations and treaties. 
Johnson, Edith MA 1926

So. California [1666]

Suplemento noticia del estado que guardan las misiones de California y Monterey, por Pedro Faxes, 1775. 105p. Translated and edited, with notes on California Indian life.

Johnson, Frank Davis MA 1939

Oklahoma [1667]

The Modoc Indians and their removal to Oklahoma. 109 p.

Modoc, Klamath, Quapaw.

Johnson, Georgia Belle Kuhn MA 1929 Tennessee [1668] Spain and the Cherokee Indians, 1783-1798. 55p.

Johnson, Grace Scott MA 1940

Oklahoma [1669]

James S. Calhoun, pioneer official of New Mexico. 105p.

1803-1852: Navajo, Pueblo, Apache, Cheyenne, Arapaho, Cayuga, Comanche, Ute.

Johnson, Harry Prescots $\quad$ PhD 1941 California [1670] Diego Martínez de Hurdaide.

In Sinaloa and Sonora, 1601-1626. "Perhaps first White to contact Yaqui Indians".

Johnson, Irmgard Weitlaner MA 1950 California [1671]

Twine-plaiting; a historical, technical, and comparative study. 168p., pls.

Guatemala, Mexico, Eastern United States (Woodland Ojibwa).

Johns on, JAMes Gurton MA 1921 California

[1672]

The Spanish régime in Georgia and South Carolina 1566-1702. Puв: U/Georgia Spec. Ser., Stud. I \#9 [1923].

Johnson, James Gurton PhD 1924 California [1673] The colonial southeast, 1732-1763; an international contest for territorial and economic control. 248p. Puв: U/Colo., Stud. XIX \#3 [1932] p163-225.

Much on Indians of the Southeast.

Johnson, John James MA $1943 \quad$ California [1674] The introduction of the horse into the Americas and its spread to Peru, 1493-1550. 92p. 
Johnson, Joseph EsRey

PHD 1943

Harvard [1675]

A statesman of colonial Pennsylvania: a study of the private life and public career of James Logan to the year 1726. 2 vols.

Slight Iroquois mention.

Johnson, KenNeth W. MA 1949

Kansas [1676]

Mexican Indian and the novels of Gregorio López y Fuentes. 138p.

Johnson, Mruo C. MA 1937

Minnesota [1677]

The history of education on the Fort Peck Reservation from 1885 to $1935.119 p$.

Yankton Sioux, Assiniboine.

Johnson, Oscar Elden MA 1950

Minnesota [1678]

Kinship in a contemporary Yanktonai-Dakota Indian community. 143p.

Johnson, Otis H. MA 1947

Oregon [1679]

The history of the Klamath Indian Reservation, 1864 to $1900.198 \mathrm{p}$.

Klamath, Modoc, Paiute.

Johnson, RaLPH WaLter MA 1952

California [1680]

The history of colonial Antioquía, 1541-1625. 157p., maps.

Colombian Indians.

Johnson, Roxana Galletly MA 1920 California [1681] Spanish activities in the Louisiana territory: an annotated bibliography of material in the University of California libraries. 200p.

Mostly Choctaw, Chickasaw and Creek.

Johnson, Ruthe DuvaL MA 1934 So. California [1682] The sociological significance of initiation rites among pre-literate peoples; an ethnological study. 61p.

Tuscarora, Apache, Kawia.

Johnson, Thomas Heskiul MA 1935 Texas [1683] Relations with the Indians on the Texas frontier, 1858 to $1859.135 \mathrm{p}$. 
JoHnson, WILLARD L. MA 1932

Drake [1684]

The religion of the Mesquakie Indians in Tama County, Iowa. $92+78$ p.

Johnston, James Hugo

PHD 1937

Chicago [1685]

Race relations in Virginia and miscegenation in the South, 1776-1860. 287p.

§ 11 "Indian relations."

Johnston, Mary Antonio

PHD 1948

Catholic [1686]

Federal relations with the great Sioux Indians of South

Dakota, 1887-1933.137p.PuB :Cath. U.Press [1948] 137p.

Johnston, ODA B. MA 1940

Iowa [1687]

History of Fort Armstrong, 1816-1836. 139p.

$\S 3$ "The Indian neighbors and the fur trade." Kaskaskia, Peoria, Kickapoo, Sac, Fox, Winnebago, Potawatomi.

JoNASSON, INGABORG MS/ED 1937

No. Dakota [1688]

The comparative intellectual abilities of full and mixed blood Indians (a study based on a testing experiment of 286 Indian students in attendance at the United States Indian Boarding School, Wahpeton, North Dakota, 1937). 71p.

JoNES, BeN MA 1932

Iowa [1689]

The economic, legal and educational status of the Mesquakie (Fox) Indian of Iowa. 72p.

JoNes, Ethel G. MA 1950

Mexico City [1690]

Cuauhtémoc: history of the creation of a national hero. $71 p$.

Jones, Henry Broadus PhD 1924 Chicago [1691] The Death Song of the "Noble Savage": a study in the idealization of the American Indian. 144p.

Mostly North American, but considers South and Central America. Historical essay on early writers and the death song.

Jones, J. PAUL MS 1949

No. Texas [1692]

The history of Hardeman County, Texas. 128p.

Kiowa, Comanche.

Jones, John Alan PHD 1950

Columbia [1693]

The rôle of the Sun Dance in Northern Ute acculturation. 102p. $M$. 
JoNes, Joseph JAY PHD 1934

Stanford [1694]

British literary men's opinions about America, 1750 to 1832. 271p. $M$.

Some consideration of 1750-1812 writings on Indian and treatment. Exotic and romantic appeal.

Jones, Lucy ThweatT MS 1925

Virginia [1695]

A comparative study of the American Indian in prose fiction, from Edgar Huntley to Ramona. 76p.

Jones, Onis Gaines MA 1935

Oklahoma [1696]

Chickasaw Governors and their administrations, 1856 to $1893.223 p$.

JoNeS, RoBert ROBERTS MA 1923

Iowa [1697]

An inquiry concerning the evidences for the existence of foreign contact in the development of pre-Columbian American culture. $66+34 \mathrm{p}$.

Jones, Volney HuRT MA 1931

New Mexico [1698]

The ethnobotany of the Isleta Indians. 55p.

103 plants considered.

Jones, W. Brayton, JR. MA 1941 New Hampshire [1699] The Indian Stream Republic. 91p.

King Philip-St. Francis Abnaki.

JoNes, WILLIAM MA 1902

Columbia [1700]

A study in the Chinook and Katlamat languages. 29p.

Jones, WiLliam PhD 1904

Columbia [1701]

Some principles of Algonkin word-formation. PUB:

Amer. Anthro., n.s., VI \#3 [1904] p369-411.

Joplin, Hatrie Seale MA 1917

Oklahoma [1702]

A history of the Creek Indians. 320p.

Jordan, Edith Marian MA 1935

Texas [1703]

History of Parker County, Texas. 145p.

Includes story of Cynthia Ann Parker, trial of Satanta and Big

Tree, and Indian depredations.

Judge, James Philip PhD 1950

Iowa $[1704]$

A social class and racial background comparison of some aspects of early child training practices in a rural Indian and White village. $108 \mathrm{p}$.

Sioux. 
Judson, George A. M/Ed. 1928

Arizona [1705]

A project in Arizona history.

Includes short bibliography on Navajo, Hopi, Papago.

Judson, Katherine Berry MA 1911 Washington [1706]

Fur trading forts of Old Oregon, 1810-1834. 198p.

Some mention of Flatheads; otherwise a general treatment of Indians of the area.

KaAP, Theodore F., JR. MA 1951

Arizona [1707]

A survey of the teaching of music in Indian schools of the Southwest with suggestions for improvement of such instruction. $94 \mathrm{p}$.

Arizona, New Mexico and Colorado schools.

KaHL, George Garry MA 1928

The Apaches in New Mexico, 1846-1861. 161p.

KaHN, Marion W. MA 1934

Columbia [1709]

The American Indian in the poetry of Philip Freneau and

Sarah Wentworth Morton. 40p.

KaLmykow, ALeXandRa MA 1947

Columbia [1710]

Administration of Alaska by the Russians on the eve of its transfer to the United States. 63p.

Especially mentions Kolosh [Tlingit] Indians; also refers to Aleut and Eskimo.

Kaplan, Bernice Antoville PhD $1953 \quad$ Chicago [1711] Social and technological change: Paracho, a case in point. 108p. $M$.

Study of Paracho village, Michoacán, Mexico.

Karinen, Arthur Eli MA 1948 California [1712] The historical geography of the Mendocino Coast. 163p. Yuki, Pomo, Sinkyone Indians.

Karpenstein, Katherine MA/LS 1939 California [1713] Illustrations of the West in Congressional documents, 1843-1863. 205p.

Includes reference to most Western Indians.

Kassel, E. MarILyN MA 1949

Oklahoma [1714]

An analysis of archaeological material attributed to the Chickasaws. 66p. 
Kaufman, Edmund George PhD $1929 \quad$ Chicago [1715]

The development of the missionary and philanthropic interest among the Mennonites of North America. PuB: Berne, Ind.: Mennonite Book Co. [1930] 416p.

Development of mission work among Indians; started 1880 in Oklahoma. Arapaho, Hopi, Cheyenne.

KaUfman, Howard Keva MA 1952

Indiana [1716]

Cheyenne Indian music and its cultural background. 312 .

Kavalyk, Nicholas John MA 1949 Columbia The Dutch fur trade in New Netherland, 1609-1664. 69p.

Kavanadgh, Thomas MaE 1950

Mexico [1718]

La obra misionera de Fray Antonio Margil de Jesús. 94p. Margil, the "patron saint of Texas", worked in the Texas and northern Mexico area circa 1700-1726.

Kayser, John Merrill MA 1940

Texas Tech. [1719]

Further study of Arrowhead ruin. 175p.

A Pueblo IV excavation at Glorieta, New Mexico.

Kearney, LeLia MA 1939

Catholic [1720]

French intrusion into New Mexico after 1680.

Keenan, Muriel MA 1936

The Office of Superintendent of Indian Affairs to 1840.

Kehoe, James Patrick MA 1937

History of the Catholic missionary activities among the

Indians of the Oregon country, 1838-1936. 121p.

Keirstead, Charles Wesley PhD 1936

Yale [1723]

The church history of the Canadian North-west. 550p.

Considerable Indian material; summarizes work of all major denominations active in the area.

KeIth, Harold Verne MA 1939

Oklahoma [1724]

Clem Rogers and his influence on Oklahoma history.

$101 p$.

Considerable mention of Cherokee.

Kellar, James H. MA 1953

Indiana [1725]

The atlatl in North America. 104p. PuB: Indiana Hist.

Soc., Prehist. Research Ser., III \#3 [1955] p281-352, illus. 
Keller, Frank Leuer

$\mathrm{PHD} 1949$

Maryland [1726]

Geography of the Lake Titicaca Basin of Bolivia: a comparative study of great landed estates and highland Indian communities. $113 \mathrm{p}$.

Aymará, Quechua, etc.

Keller, Jean P. PhD 1949

Washington [1727]

The Indian in the literature of Colombia. 401p.

Kelley, John Charles PhD 1947

Harvard [1728]

Jumano and Patarabueye: relations at La Junta de Los Rios. 247p., plates.

Kelley, Norman Sinclatr MA 1947 Columbia [1729] The Loyalists of the Mohawk Valley region. 93p.

Some Iroquois material included.

Kelley, Walter Keith MS/Ed $1938 \quad$ Colorado [1730] Educational policy of the Federal Government with reference to the perpetuation of indigenous culture. $84 \mathrm{p}$.

Kelly, Arthur Randolph PhD 1929

Harvard [1731]

The physical anthropology of a Mexican population in Texas: a study in race-mixture. 361 . Рणв: Tulane $U$., Middle Amer. Research Inst., Pub. \#13 [1947] 117p.

Considers Indian, Mexican, and Spanish-Indian mixtures.

Kelly, Charles G. MA 1952

Kansas [1732]

Welfare aspects of the Potawatomi Indian Agency program. 54p.

Kelly, Edna Arabella MA 1936

Kentucky [1733]

A brief history of the home life, education, and progress of the Hopi Indians. 187p.

Kelly, Gerald Lee MA 1954

Montana [1734]

The history of St. Ignatius Mission, Montana. 95p.

Considerable Indian material, especially Flathead tribes. Also considers Iroquois, Coeur d'Alene, Pend d'Oreille and Kutenai.

Kelly, Isabel Truesdell

MA 1927

California [1735]

A study of the carver's art of the Indians of northwestern California. Рणв: U/Calif., Pubs. Amer. Archeol. Ethnol., XXIV \#7 [1930] p343-360, illus. 
Kelly, Isabel Truesdell PhD 1932

Fundamentals of Great Basin culture. 65p.

Kelly, Mary James MA 1932

Notre Dame [1737]

Two decades of Catholic Church history in South Dakota country, 1839-1859. 52p.

Sioux tribes.

Kelly, Willtam Henderson PhD 1944 Harvard [1738] A preliminary study of the Cocopa Indians of Mexico; with an analysis of the influence of geographical position and physical environment on certain aspects of their culture. $459 \mathrm{p}$.

Also considers Kawia, Kamia, Papago, Yavapai, Paipai, and Yuman peoples.

Kemp, Edith Semat $\quad$ MA 1949

No. Carolina [1739]

A critical evaluation of the application of anthropological field techniques to the study of modern society. $91 \mathrm{p}$.

Considers four cultures as a basis; scattered Indian references throughout.

KeMP, Fred E. III MA 1954

Mexico City [1740]

Warfare in pre-Columbian Mesoamerica. 141p., illus.

Kemp, William Webb PhD 1914

Columbia [1741]

The support of schools in colonial New York by the Society for the Propagation of the Gospel in Foreign Parts. Puв: Columbia U., Teachers Coll., Contr. Educ. \#56 [1913] 279p.

Includes Indian missions and Indian schools; several New England areas considered.

Kenefick, Kathryn G. MA 1947 Northwestern [1742] Art in Indian life of the Southwest. 116p.

Kennard, Edward Allan PhD 1936 Columbia [1743] Mandan grammar. PUB: Intl. Jour. Amer. Ling., IX \#1 [1936] 43p.

Kennedy, Ella Brice Morris MA 1938 New Mexico [1744] The Indian in Southwestern fiction. Рuв: U/New Mex: Research I \#3 [1937] p212-225. 
Kennedy, Hope Frances

Juan de Ugarte. 87p.

California missions and Indians.

Kennedy, Kenneth Adrian MA 1954

California [1746]

The aboriginal population of the Great Basin. 87p.

Kennedy, Mary Jean $\quad$ PhD 1955

California [1747]

Culture contact and acculturation of the southwestern Pomo. 181p.

Kenny, Hamminl Thomas PhD $1951 \quad$ Maryland [1748] The origin and meaning of the Indian place-names of Maryland. 2 vols., 372p.

160 names defined; linguistics, phonology.

Kent, Kate Peck MA 1949

Arizona [1749]

An analysis and interpretation of the cotton textiles from Tonto National Monument. 99p.

Kent, Susan MA 1933

Columbia [1750]

The problem of local developments vs. chronological sequences in the archaeological Southwest. $49 \mathrm{p}$.

Kenyon, Carleton W. MA 1950

So. Dakota [1751]

History of Fort Randall. 132p.

Includes Sioux-White relations.

Kerr, Andrew Affleck PhD 1921

Harvard [1752]

Similarities in material culture between the Old and the New Worlds. 530p., illus.

Excellent parallels of many objects, compared with many areas. Considers Asia, Oceania, America; very little Europe or Africa.

Ketler, Ruth Marie MA 1933

The function of wealth among the Indians of North America. 103p.

Keur, Dorothy Louise PhD 1941

Columbia [1754]

Big Bead Mesa; an archeological study of Navaho acculturation, 1745-1812. PuB: Amer. Archeol. Soc., Mem. \#1 [1941] 90p. 
Key, JunE GUThrie MA 1953

Texas Tech. [1755]

Charles F. Lummis, Southwestern popularizer and romantic. $86 \mathrm{p}$.

Kidd, Alma Cochran MA 1954

Pacific [1756]

The West that's gone. 188p.

Cheyenne, Comanche.

KIDD, Kenneth EARL MA 1937

Toronto [1757]

Blackfoot ethnography. 225p.

Alberta (Canada) Blackfoot.

Kidder, Alfred Vincent

PнD 1914

Harvard [1758]

South-western ceramics. Their value in reconstructing the history of the ancient Cliff-dwelling and Pueblo tribes. An exposition from the point of view of type-distribution. PUB: "Pottery of the Pajarito Plateau and of some adjacent regions in New Mexico." Amer. Anthro. Assoc., Mem. II pt. 6 [1915] p407-462, illus.

Kidder, Alfred II PHD 1937

Harvard [1759]

Archaeological investigations in Venezuela. PuB: Harvard U., Peabody Mus., Paps., XXVI \#1 [1944] 178p.

Kidweli, Vivian Maxine MA 1931 Wash. State

Some suggested applications of Indian motifs to modern design. 76p., illus.

Chilcotin, Haida, Klikitat, Lillooet, Pueblo, Navajo, Hopi.

Kielman, Chester Valls MA 1952

The history and culture of the Five Civilized Tribes of American Indians. 323p.

Kiely, Joseph EdwaRd

MA 1933

Fordham [1762]

The Spaniard maligned: Spanish and English Indian contacts. 169 p.

Kiemen, Mathias C. PhD 1953

Catholic [1763]

The Indian policy of Portugal in the Amazon region, 1614-1693. Pचв: "Indian policy of Portugal in America, with special reference to the old state of Maranhão." Americas, V \#2, 4 [1948-1949] p131-471, 439-461.

KIKer, ERNest MA 1932

Education among the Seminole Indians. $57 \mathrm{p}$.

Oklahoma $A \& M$ [1764] 
Kulgore, Hattie

MA 1937

Oklahoma [1765]

The interests of the United States in Sonora and Lower

California, 1848-1900. 152p.

Indian raids and attempts to handle the Indian problem.

Krmball, Richard Roy MA $1950 \quad$ So. California [1766] Beginnings of literature based on the American frontier -descriptive bibliography.

14p. of bibliographical data on Indians in American literature.

Krmbrodgh, William C. MA 1942 Hardin-Simmons [1767] A history of Clay County. 161p.

Texas. Includes chapter on Indian affairs and campaigns.

Kinard, Margaret $\quad$ MA $1948 \quad$ Vanderbilt [1768] Frontier development of Williamson County, Tennessee.

Brief consideration of initial Indian occupancy.

King, Arden Ross PhD 1947

Aboriginal skin dressing in western North America.

King, Bernice Margaret MA 1935 Minnesota [1770] A study of form and expression in American Indian music, as exemplified in the songs of Jémez Pueblo. 270p.

King, DaLe S. MA 1931

Denver [1771]

Archaeology of the Central Highlands of eastern Colorado. $121 \mathrm{p}$.

KING, Gladys P. MA $1941 \quad$ Wisconsin [1772] Attempts to settle the Indian Territory, 1879-1885. $145 \mathrm{p}$.

King, Isabel Mae MA 1927

The Indian policy of Carondelet in Louisiana. 205p.

King, William Sherman MA 1950

Arizona [1774]

The folk Catholicism of the Tucson Papagos. 121p.

Kingsbury, Joseph Lyman PhD 1923

Chicago [1775]

The early history of Colorado.

Extensive consideration of Colorado Indians and early White contacts. 
Kingsbury, RaLPH MA 1940

So. California [1776]

The Napa Valley to 1850.

§ 2: Indian life, racial origins of Napa Valley Indians.

Kintery, PaUl PhD $1929 \quad$ Wisconsin [1777] The development of currency in early New York. 180p.

First chapter includes discussion of "Indian money"-Iroquois, Narragansett, Pequot.

Kinietz, William Vernon MA 1933

Chicago [1778] The ethnology of the Illinois Indian. 75p.

Kinman, Kathryn Mildored MA 1952 Mexico City [1779] Historiography of human sacrifice among the Aztecs and the Mayas. 104p.

Kinsey, W. Fred III MA $1953 \quad$ Columbia [1780] A comparison of the annual ceremonial cycle of the Creek and Iroquois Indians of the eastern United States. 140p.

Kirkland, Mary Mullineadx MSW 1954 So. California [1781] Factors in the culture of the Navaho Indians that may affect their acceptance of prenatal care. $56 \mathrm{p}$.

Kissling, Herbert Henry MA $1952 \quad$ Wyoming [1782] The evolution of the British North American fur trade, 1700-1821. 121p.

Kivett, Marvin Franklin MA $1951 \quad$ Nebraska [1783] The Woodruff ossuary, a prehistoric burial site in Phillips County, Kansas. Puв: Bur. Amer. Ethnol., Bull.\#154, pt. 3 [1953] p103-141, illus.

Kizer, Willifam M. MA 1940

So. Dakota [1784]

History of the Flandreau Indian School, Flandreau, South Dakota. 110p.

Sioux and Chippewa.

Kreeman, George Leland MA 1951 Mexico City [1785] The colonization policies of Hernán Cortés and Antonio de Mendoza. 75p.

Kuingensmith, Don Joseph MA 1941 Oklahoma A\&M [1786] History of the Ponca Indians of Oklahoma. 43p. 
Kuink, JaNe Seymour PhM 1902

Chicago [1787]

Relation to the medicine man to the educational system of the early races of North America. 50p.

Klopfenstein, Carl Grover PhD 1955 West. Reserve [1788] The removal of the Indians from Ohio, 1820-1843. 382p.

Knapp, Charles Merriam MA 1915 Columbia [1789] Sir William Johnson and Indian relations. 32p.

Six Nations.

KneEdler, HaRry Lane M/Ed 1940

Temple [1790] Charles Thomson. 114p.

$\S 2$ "Indian affairs". Bibliography lists manuscript sources.

Knepler, Abraham Eleazar PhD 1939

The education of the Cherokee Indians. 422p. PuB:

Yale [1791]

Chronicles of Okla., XX, XXI [1942-1943] p55-61, 378-401.

Knight, Marian Vera MA 1914

Smith [1792]

Craniometry of the southern New England Indians. 36p. Рuв: Conn. Acad. Arts Sci., Mem. IV [1915] p1-36.

Knisely, Charles Harvey MA 1933 Cincinnati [1793] The Moravian missions in Ohio. 45p.

1761-1824. Includes missions to the Delaware, Shawnee, Iroquois and Wyandot.

KNolL, JoHn ALFRed MS 1947

Idaho [1794]

The effect of prejudice upon the employment of Indians. $45 \mathrm{p}$.

Knoop, Anna Marie MA 1941 California [1795] The Federal Indian policy in the Sacramento Valley, 1846-1860. 176p.

Knowles, Nathaniel PhD $1939 \quad$ Pennsylvania [1796] The torture of captives by the Indians of Eastern North America. Pub: Amer. Philos. Soc., Proc., LXXXII \#2 [1940] p151-225. 
Koch, Lena Clark MA 1922

Texas [1797]

The Federal Indian policy in Texas, 1845-1860. 195p.

PUB: Sowestn. Hist. Qtly., XVIII-XIX [1925] var. pages.

Koentg, Myron Law MA 1933

Fort Union as a Missouri River Post. 86p.

Iowa [1798]

$\S 3$ "Indian neighbors of Fort Union." Sioux.

KоноштEк, FRED J. MA 1939

So. Dakota [1799]

A history of the Lake Traverse Indian Reservation. 51p.

Sisseton and Wahpeton Sioux.

KoLeCKI, JoHN Henry MA 1950

Niagara [1800]

Red Jacket, the last of the Senecas. 109p.

Koontz, Louis Knotт PHD 1920 Johns Hopkins [1801]

The Virginia frontier, 1754-1763. PUB: Johns Hopkins

U., Stud. Hist. Pol. Sci., Ser. 43 \#2 [1925] 186p.

French-Indian War period. Appendix presents many previously unpublished documents.

Koppel, Monte Hilliard PhD $1956 \quad$ New School [1802] Lima, Peru-A study in industrial-urban change. 149p.

Chapter on "Ethnic groups and language distribution" includes Indian languages and population statistics.

Koppert, Vincent Aloysids MA 1928

Catholic [1803]

Some myths of the Nootka Indians.

Koppert, Vincent Aloysids PhD $1930 \quad$ Catholic [1804] Contributions to Clayoquot ethnology. РuB: Cath. U., Anthro. Ser. \#1 [1930] 124p.

Korgen, MaLI MA 1947

Clark [1805]

Adjustment to environment by prehistoric Indians in Minnesota. 433p.

Korn, Lewis Johan MA 1934 Pennsylvania [1806] The distribution and analysis of "Lacrosse" in North America. 48p.

KoRN, PHILIP MA 1952

Columbia [1807]

A study of the attitudes of Thomas Jefferson and Andrew Jackson towards the American Indian. 90p. 
Korwan, Marion Evelyn

New England travel literature, 1600-1660. 85p.

Includes early accounts of White encounters with Indians.

Kottman, Wiltam Adolph MA $1905 \quad$ Columbia [1809] New Mexico, the land and its people. 32p.

Koughan, Florence Madelon MA 1931 California [1810] The development of the reindeer industry in Alaska, 1890-1929. 149p.

Kozin, Eugene M. MA 1947 New York [1811] The Indian Reorganization Act of 1934; an experiment in social engineering. $118 \mathrm{p}$.

Kramer, Fritz Louis MA 1953

California [1812]

Idaho town names. 197p., maps.

Many Indian place names.

KRAPP, RUTH LizetTe $\quad$ MA 1923

Cincinnati [1813] The Virginia frontier from 1700 to $\mathbf{1 7 7 6}$.

Brief mention of Indian menace, and the building of forts or towns as a barrier against them.

Kraus, Casper Christian MA 1931 Governor Spotswood's interest in frontier problems.

Ohio State [1814] Iroquois; events leading to the Treaty of Albany.

Krauskopf, Frances $\quad$ MA 1949

Indiana [1815]

The French régime in Indiana. 225p.

Kra uskopf, Frances PhD 1953

The French in Indiana, 1700-1760: a political history. 400p. $M$.

Miami, Wea, Vincennes area. Material on the Indians of the region scattered throughout the paper.

Kremens, John Benjamin MA 1941 Pennsylvania [1817] A survey of the roached hairdress among the Indians of. North America. 48p.

Kriegbaum, Lawrence L. MS 1920 Arizona [1818] The origin of primitive American agriculture, and its relations to the early agriculture of Arizona. 48p. 
Krieger, Alex Dony MA 1939

Oregon [1819]

Environment, population, and prehistory in the northwestern United States. 51+10p.

Krinkin, Alexandra Vega MA 1947 New York [1820] Acculturation and survival of Latin-American Indian culture patterns. $128 \mathrm{p}$.

Kroeber, Alfred Louis PhD $1901 \quad$ Columbia [1821] Decorative symbolism of the Arapaho. Рuв: Amer. Anthro., n.s., III [1901] p308-336.

Kroeber, Clifton Brown MA 1947 California [1822] García Hurtado de Mendoza, Viceroy of Peru, 1588-1596. 261p.

Quechua and Aymará.

KroH, Robert FrankLin MA 1951

Texas [1823]

Tom Green, shield and buckler. 222p., maps.

Includes his career as an Indian fighter in Texas.

Kshemsant, SUPRAPada MA 1952

No. Carolina [1824]

Longfellow's use of Indian sources in The Song of

Hiawatha. 99p.

Kubler, George Alexander MFA $1936 \quad$ Yale [1825] The religious architecture of New Mexico. 159p., illus.

Kubler, George Alexander PhD $1939 \quad$ Yale [1826] The religious architecture of New Mexico in the colonial period and since the American occupation. РणB: Colorado Springs: Taylor Museum [1940] 159p., illus.

History and descriptions of early mission churches in the various Pueblo villages, including the Hopi.

Kuehmsted, Eleanor Roberta MA 1941 So. California [1827] Navajo acculturation. $127 \mathrm{p}$.

KuIP ers, Cornelius C. MA $1934 \quad$ New Mexico [1828] Results of an intelligence test based on Indian culture.

KuLL, DoRothy M. MA 1952

Tennessee [1829]

A study of Tlingit Indian legends and folk tales from Sitka, Alaska. 121p. 
KuPPER, Elsie M.

The Long Island Indians; their relations with the White man. $47 \mathrm{p}$.

KyLe, Clara Ethel MA 1926

The re-conquest of New Mexico, 1680-1698. 127p.

Kyzer, Willye Maye MA 1952

Louisiana [1832]

A descriptive study of the speech of the Koasati Indians of Louisiana. $172 \mathrm{p}$.

LaBarre, Weston PhD 1937

Yale [1833]

The Peyote cult. Puв: Yale U., Pubs. Anthro. \#19 [1938] 188p.

Ladd, Carl E. PhD 1955

Kansas [1834]

The educational growth of Indian children in the Phoenix area, 1851 to 1952 , as measured by test results. 255p.

Lage, Patricia L. MA 1950

Arizona [1835]

History of Fort Huachuca, 1877-1913. 117p.

Arizona Apache.

LaING, Richard Davis MA 1950

Texas [1836]

The effect of the American frontier on military science and tactics. 154p.

Includes Indian warfare.

LAIRd, Thomas K. MA 1922

Iowa [1837]

Care and training of children among Australian and Eskimo tribes. $156 \mathrm{p}$.

LaManna, Virginia Carol MA 1934 New York [1838] A study of land frauds on the Western lands of the United States, 1875-1900. 54p.

Chapter on "The illegal use of Indian lands."

Lamar, Howard Roberts PhD 1951

Yale [1839]

Dakota Territory, 1861-1889; a study of frontier politics. $438 \mathrm{p}$.

Frequent Indian consideration.

LAMB, EDITH JANE MA 1917

California [1840]

The formation of the State of Nevada 1840-1864. 127p.

Bannock, Paiute, Snake, Washo. 
Lam B, Ursula Schaefer PhD 1949

California [1841]

Nicolás de Ovando, Comendador Mayor of Alcántara and Governor of the Indies.

Early 16 th century relations with Indians.

LAMBert, Bera Vtola MA 1952

Colorado [1842]

The career and times of Athanase de Mézières. 137p.

Indians of Texas-Louisiana; especially 1768-1780.

LAMBert, Joseph I. MA 1948

St. Mary's [1843]

The defense of the Indian frontier of Texas by the United States Army. 134p.

Lammers, Helen C. M/Ed 1947

Cincinnati [1844]

Selected stories from American Indian folklore for use with elementary school children. $179 \mathrm{p}$.

LANDERS, Emmett M. MA 1929

Hardin-Simmons [1845] A short history of Taylor County. 178p.

Texas. Chapter "Passing of the Indian".

Landes, Ruth PhD 1937

Columbia [1846]

Ojibwa sociology. Рuв: Columbia U., Contr. Anthro., XXIX [1937] 144p.

Landfried, Helen Marian MA 1944 Cincinnati [1847] The Indian campaigns in the Ohio country, 1787-1795. $44 \mathrm{p}$.

Iroquois, Shawnee, Miami, Wyandot, Delaware.

Landgraf, John Leslie PhD 1951

Columbia [1848]

Land-use in the Ramah Navaho area, New Mexico. 243p.

$M$ Puв: Harvard U., Peabody Mus., Paps., XLII \#1

[1954] 97p., maps.

Period 1871-1941; changes in land use.

LANDWEHR, RoBert Clement MA 1951

Stanford [1849]

Status personality and culture change. $69 \mathrm{p}$.

§ 3 Hopi; § 4 Salteaux.

Lane, Barbara Savadkin PhD 1953 Washington [1850] A comparative and analytic study of some aspects of Northwest Coast religion. $177 \mathrm{p} . M$.

Cowichan Indians of southern British Columbia. 
LANe, RoBert Brockstedt

PHD 1953

Washington [1851]

Cultural relations of the Chilcotin Indians of west central British Columbia. 342p. $M$.

Lang, GotTrRied Otto PhD 1954

Cornell [1852]

The Ute development program: a study of culture change in an underdeveloped area within the United States. 484p. $M$ PUв: "Whiterock Utes in transition." U/Utah, Anthro. Paps. \#15 [1953] 76p., illus.

Lang, Herbert Howard MA 1950 Texas [1853] Sources of conflict on the Anglo-American-Indian frontier, 1776-1876 - with emphasis on racial and cultural factors. $226 \mathrm{p}$.

Lange, Charles H., JR. MA 1941 New Mexico [1854] The Evans Site: a contribution to the archaeology of the Gallina region, northern New Mexico. $96+28 p$., illus.

Lange, Charles H., JR. PhD 1951 New Mexico [1855] An evaluation of economic factors in Cochití Pueblo culture change. $522 \mathrm{p}$, illus.

LANGE, EdwIN F. MS/Ed 1933 Primary and secondary education in New Netherland and colonial New York (1621-1783). 163p.

References throughout to Indian education, Dutch schools, slave schools, etc.

Lange, Elizabeth Jean March MA 1942 New Mexico [1857] A study of Zuñi myths as literature. 124p.

Langston, Kathryn LeE MA 1925 California [1858] The secularization of the California missions, 1813-1846. $291 \mathrm{p}$.

LaNphere, Mildred Talitha MA 1920 California [1859] The Indian policy in the Old Southwest from 1783 to 1795. 245p.

Cherokee, Creek, Choctaw and Chickasaw.

Lantis, David William MA 1948 Cincinnati [1860] The settlement of Alaska, past, present, future. 369p. 
Lantis, Margaret $\quad$ PhD 1939

California [1861]

Alaskan Eskimo ceremonialism. Рuв: Amer. Ethnol. Soc., Mono., XI [1947] 127p.

Lappin, Valeria Pearl MA 1941

Missouri [1862]

The mental and physical development of Indian children.

Oklahoma schools.

LaPrade, LuCine Hooper

MA 1920

California [1863]

The Cahuilla Indians. Рбв: (Hooper, Lucile) U/Calif., Pubs. Amer. Archeol. Ethnol., XVI \#6 [1920] p315-380.

LARSEN, Levi N. MA 1942

Some chapters in the history of Fort Buford. 153p.

Montana [1864]

Assiniboin, Sioux, Crow, Gros Ventre, Mandan, Arikara.

LARSON, JAMES RoBerT MA 1952

Fordham [1865]

The articulations between the social structure and religion among the Hopi Indians of Arizona. 238p.

LASSETTER, ROY, JR. MA 1938

Arizona [1866]

A dendrochronological investigation in the Clinch River drainage, Tennessee. $70 \mathrm{p}$.

Offers a chronology (1638-1938) and dating of log cabins and archeological sites.

Laub, Carl Herbert PhD 1929

Wisconsin [1867]

British regulation of Crown Lands in the West: the last phase, 1773-1775.

Virginia, Wautauga area-Lord Dunmore's War; Indians considered as a general group, no specific tribe.

Lauber, Almon Wheeler PhD 1913

Columbia [1868]

Indian slavery in colonial times within the present limits of the United States. Рuв: Columbia U. [1913] 352p.

Laughlin, William Sceva

PHD 1949

Harvard [1869]

The physical anthropology of three Aleut populations: Attu, Atka, and Nikolski.

LaUx, Donald James MA 1954

Oklahoma [1870]

A history of the Navajo, 1933-1953. 150p.

LaVRISCheFF, TIKHON I. EDD 1935

History of education in Alaska. 310p.

California [1871] 
Lawrence, Eleanor Frances

MA 1930

California [1872]

The Old Spanish Trail from Santa Fé to California. 148p., maps.

Shoshoni, Paiute, Bannock, Ute.

LaWson, MaRian MA 1939

Iowa $[1873]$

Cooper's Indians re-examined. $71 \mathrm{p}$.

Lawson, Mary E. MA $1940 \quad$ Colorado $A \& M$ [1874] Occupation of Indian girls after graduation at Sequoyah Orphan Training School, Tahlequah, Oklahoma. 62p.

Lawson, Murray Grant PhD 1942

California [1875]

Fur: a study in English mercantilism, 1700-1775.

French and Indian Wars awakened English Government to true role of Indian affairs and an Imperial system of regulation was inaugurated.

LAY, ChaRLES H.

MA 1950

Tulane [1876]

Spain's relations with the Indians in the Old Southwest, 1779-1791. 133p.

Layman, Cedric Denton MA 1922

Columbia [1877] The relation of the United States Government to the North American Indian. 75p.

(1789-1922).

Layman, Martha Elizabeth PhD 1942 Minnesota [1878] A history of Indian education in the United States. 475p. (1542-1942).

Layo, Fred F. MA 1950

Niagara [1879] The Sullivan-Clinton campaign of 1779. 115p.

Lea, Carol Beth MA 1947 Tex. Christian [1880] The Peruvian Indian as revealed in the novels of Ciro Alegría. 137p.

Lea, Emma Lane MA 1934 Geo. Peabody [1881] The Choctaw and Chickasaw Indians: a geographic study. 112p., maps.

Leach, Douglas Edward PhD 1952 Harvard [1882] The causes and effects of King Philip's War. 529p. (1675-1676) Wampanoag, Narragansett, etc. 
Leacock, Eleanor Burke

Some aspects of the philosophy of the Cheyenne and Arapaho Indians. 46p.

Leacock, Eleanor Burke PhD 1952 Columbia [1884] The Montagnais "hunting territory" and the fur trade. 89p. M. Puв: Amer. Anthro. Assoc., Mem. \#78 [1954] $59 \mathrm{p}$.

Leader, Herman Ale Xander PhD 1928 California [1885] The Hudson's Bay Company in California. 263p.

Indians only incidental.

Leasure, Clara E. MA 1948 Governmental organization and administration of Indian affairs in the United States. 75p.

Leathers, Nezzie Lee MA 1937

Oklahoma [1887] The Hopi Indians and their relations with the United States Government to 1906. 91p.

Leckie, Windtam H. PhD 1954 The military conquest of the Southern Plains Indians.

Ledbetter, WILLIAM GLeN MA 1935

Oregon [1889] Military history of the Oregon country, 1804-1859. 155p. Military operations against Rogue River and Yakima Indians.

\section{Ledemran, Jules Delmore MA 1899}

Columbia [1890] The administration of Governor George Clinton, in the province of New York, 1743-1753. 61p. $\S 4$ "Indian affairs". Six Nations.

Lee, Frederic Edward PhD 1916 Yale [1891] The influence of the Jesuits on the social organization of the North American Indians. 228p.

LEe, KNute H. MS/Ed 1953

No. Dakota [1892]

A comparison of the tenth, eleventh and twelfth grades of six schools in Sioux City, North Dakota, and Corson County, South Dakota. 60p.

Includes Indian children-Sioux.

Leechman, Douglas MA 1940

Ottawa [1893]

The popular concept of the "Red Indian" as revealed in literature. 131p. 
The "Red Indian" of literature: a study in the perpetuation of error. $276 \mathrm{p}$.

Especially eastern Canadian Indians.

Leeds, Josephine Frederica

MA 1929

Columbia [1895]

Longfellow's use of Indian lore. 83p.

Leftwich, Rodney L. EDD 1952 Arts and crafts of the Cherokee. 250p., photos. $M$.

Bradley [1896] Prehistoric to present, mainly Eastern Cherokee.

Leger, Mary Celeste PhD 1929

Catholic [1897]

The Catholic Indian missions in Maine: 1611-1820. 184p.

Puв: Cath. U., Stud. Amer. Church Hist., VIII [1929] $184 \mathrm{p}$.

Abnaki.

Leh, LeONARd LLEWELLyN MA 1929

Chicago [1898]

The shaman in aboriginal North American society. 121p. Puв : U/Colo., Stud., XXI \#4 [1934] p199-263.

Lehman, Philip Arthur MA 1929

Oregon [1899]

The religious, moral, and educational activities of the Hudson's Bay Company. 94p.

Some discussion of Company's efforts toward moral and spiritual education of Indians and its policy toward them.

Lehmer, Donald JAyne MA 1948

Chicago [1900]

The Jornada branch of the Mogollon. 99p. Рuв: $U /$ Ariz., Soc. Sci. Bull. \#17 [1948] 99p.

Lehmer, Donald Jayne PhD 1952

Harvard [1901]

The Fort Pierre branch in Plains prehistory. 145p., illus.

LeIDy, Edgar EARL MA 1929

Ohio State [1902]

The extinction of the Indian title in Ohio beyond the Greenville Treaty line. 76p.

Leinad, Alice MA $1934 \quad$ New Mexico [1903] Sanctuaries in the ancient pueblo of Chetro Ketl. 48p.

Leiter, CarL Richard MA/Ed 1954

Ball [1904]

The Big Miami Reserve, 1818-1840. 141p., maps.

Miami, Peoria; lands in Indiana and Ohio. 
Leland, Gunvald Elias MS/Ed $1944 \quad$ No. Dakota [1905] Recent education of Indians in Minnesota, with special emphasis upon the Chippewa. 82p.

Lemmon, Burton Carlyle MS 1941 Oregon State [1906] The historical development of the Chemawa Indian School. 87p.

Salem, Oregon.

Lemons, Wultam Everetr MA $1950 \quad$ Colorado [1907] John G. Neihardt's conception of the Plains Indian.

Lengert, Margaret Eleanor MA 1949 The history of Milam County. 225p., illus.

Texas [1908]

Chapter on Texas Indians and Indian problems.

Lennox, Herbert John PhD 1932 Samuel Kirkland's mission to the Iroquois. $275 \mathrm{p}$.

Leo Xavier MA 1945 Missionary labors in East Florida, 1565-1700. 130p.

Chicago [1909]

Timucua and other southeastern tribes.

Leonard, Charles Berdan MA 1922 California [1911] History of the San Joaquín Valley. 151p.

Indians as aboriginal inhabitants.

Leonard, Charles Berdan

PHD $1928 \quad$ California [1912] The Federal Indian policy in the San Joaquín Valley; its application and results. $420 \mathrm{p}$.

Leonard, Irving Albert PhD $1929 \quad$ California [1913] Don Carlos de Sigüenza y Góngora: his life and works, 1645-1700. Р вв: U/Calif., Pubs. Hist., XVIII [1928] 228 .

His historical writings include many Mexican Indian references.

Leopold, Herbert SAmuel MA $1943 \quad$ Columbia [1914] Padre José de Acosta (1539-1600): a study of his Historia Natural y Moral de las Indias. 224p.

Lerman, Norman Hart MA 1952

Washington [1915] An analysis of folktales of Lower Fraser Indians, British Columbia. 188p.

Mainly Tsawwassen and Nooksack. 
The fur trade of the middle Northwest, 1796-1818. 256p.

\section{Levan, Lawrence Robert MA 1951 Pennsylvania [1917]} Land tenure among the ancient Meso-Americans and its influence among the present Mexican system. $89 \mathrm{p}$.

Levardson, Norman Oley MA 1946

Cornell [1918]

A review of Alaska fur seal history and sealing methods. $88 \mathrm{p}$.

\section{Levie, Elmer Vivian MA 1925}

Chicago [1919]

The Alabama-Federal Government controversy of 1832 to 1834 ; the Creek Indian controversy. $77 \mathrm{p}$.

Lewis, Albert Buell PhD 1906 Columbia [1920] Tribes of the Columbia Valley and the coast of Washington and Oregon. Pणв: Amer. Anthro. Assoc., Mem. I [1906] p147-209.

Lewis, ANNa PhD 1930

Oklahoma [1921]

A history of the Arkansas River region, 1541 to 1800. $390 \mathrm{p}$.

Includes considerable Indian material.

Lewis, Donna May MA 1924

California [1922]

The Bents and the St. Vrains as pioneers in the trade of the Southwest. 157p., photos.

Relations with Cheyenne, Arapaho, Comanche and Ute.

LEwIS, ERNest MA 1951

No. Carolina [1923]

The Sara Indians, 1540-1768: an ethno-archaeological study. 344p.

Sara [Cheraw] and Eastern Siouan Indians.

Lewis, George Elmer PhD 1940

U.C.L.A. [1924]

The Indiana Company, 1763-1798. 267p. PuB: Glendale:

A. H. Clark [1941] 358p.

Effort of a group of Pennsylvania merchants and Indian traders (who had suffered losses in Pontiac's uprisings) to obtain restitution from the Indians involved: Oneida, Tuscarora, Onondaga, Seneca. 
LewIS, Oscar $\quad$ PHD 1942

Columbia [1925]

The effects of White contact upon Blackfoot culture, with special reference to the rôle of the fur trade. PUB: Amer. Ethnol. Soc., Mono., VI [1942] 73p.

Lewis, RALPH Kepler MA 1939

So. California [1926]

A comparison of the geometric design on pottery of the Middle-Mississippi Valley region with geometric design on pottery of the Southwest. 112., illus.

Lewis, Victor Truman MA 1940

East Texas Texas and the Nation, 1845-1860. 120p. Chapter on "Federal Indian policy in Texas".

LEWIS, WILLARD A. MA 1928 Hardin-Simmons Indian Reservations in Texas. 116p., maps.

LI, FANG-KuEI PHD 1929

Chicago [1929]

Mattole, an Athabaskan language. PuB: U/Chi. Press [1930] 152p.

Li, LIEN-CHIEH PHD 1943

Illinois [1930]

Rate of soil development as indicated by profile studies of Indian mounds. $58 \mathrm{p}$.

Libby, DoRothy Lee Rainier $\quad$ PhD 1952 California [1931] Girls' puberty observances among northern Athabascans. 229p. $M$.

Lichtenstein, Vernon E. MA 1930

Iowa [1932]

Friederich Gerstäcker's relation to American life and literature. $180 \mathrm{p}$.

Indians considered especially in $\S 2$; no particular tribes mentioned.

Lietz, Paul S. PhD 1940

Don Vasco de Quiroga and the second audiencia of New Spain. 219p.

Lightfoot, Eloise ArLene MA 1931

Stetson [1934]

The Seminoles of Florida. 41p.

Lilllard, Richard G. PhD 1943

Iowa [1935]

An interpretation of Nevada: Studies in Washoe journalism and humor. PuB: Desert challenge. Knopf [1942] $388 \mathrm{p}$.

Some on Nevada Indians; especially brief section on environment and its relation to Indian culture which developed. 
LIMón GutiérRez, Luís MA 1956 Clasificación biotipológica del grupo Mixteco.

Mexico: $E N$ [1936]

LINCOLN, JACKSON Steward MA 1933 California [ Indian dreams: their significance to the native and their relation to the culture pattern. $167 \mathrm{p}$.

Uses examples from Yuma, Navajo, Crow, Blackfoot, Menomini, Ottawa, Ojibwa, Kwakiutl, Wintu, Yavapai.

Lincoln, Mary Lodise MM $1950 \quad$ So. California [1938] Cherokee Outlet and its music. $117 \mathrm{p}$.

Lindemann, Marie Louise Händel MA 1950 New York [1939] A study of women in the Incan civilization. 210p., illus.

- Lindsay, Charles PhD $1930 \quad$ Nebraska [1940] The Big Horn Basin. PuB : U/Nebr.Stud., XXVIII-XXIX [1932] 274p.

Chapter on Indians and fur trade.

LINDSAY, IRENE MA 1930

So. Methodist [1941]

George Washington and the French and Indian War, 1753-1759. 103p.

Lindsay, Janet PaULine

Navajo public speaking. 153p.

Lindsey, MaRTHA JaNICE MA 1931 California [1943] Joseph Lane, first Territorial Governor of Oregon. 87p., illus.

His visits to Cayuse Indians and wars with Columbia, Snoqualmie, and Rogue River Indians.

LiNdSey, VirginIa LEE MA 1936

Oklahoma [1944]

History of the Western Cherokees. 92p.

Link, John Thomas PhD 1932

Nebraska [1945]

The toponomy of Nebraska. 186p.

Includes Indian names.

Link, MaURICE MA 1937

Loyola [1946]

Missionary labors and travels of Father Claude Jean Allouez, S. J., 1658-1689. 83p. 
Linton, RaLPH

Persistence of the Mound Builder's culture among recent Indian tribes. $29 \mathrm{p}$.

LINVILLE, R. N. MA 1905

Drake [1948] The Cheyenne and Arapahoe Indians of Oklahoma. 73p.

Lipkin, William PhD 1944

Columbia [1949]

Winnebago grammar. PUB: King's Crown Press [1945] $68 \mathrm{p}$.

Lister, Robert HiLl MA 1938

New Mexico [1950] Some aspects of Chihuahua archaeology. 93p., illus.

Lister, Robert HiLl PhD 1951

Harvard [1951] Archaeological cultures of western Mexico, with a report on excavations at Cojumatlán, Michoacán. Pणв: U/ New Mex., Pubs. Anthro. \#5 [1949] 106p., illus.

\section{Little, Margaret E. MA 1934}

Brit. Columbia [1952] Early days of the maritime fur trade, 1785-1794. 302p. Northwest Coast-lists all ships known to have visited, also many logs, journals and manuscripts.

Livingston, Walter Frank MS 1950

East Texas [1953] The Apaches of the Southwest. 116p.

LLoyd, JoHN B.

MA 1932

West. Colorado [1954] The Uncompaghre Utes. 166p., illus.

Lloyd, NANCy MA 1955 Arizona [1955] The Chumash; a study of the assimilation of a California Indian tribe. 238p.

Lloyd-Russell, Vincent $\quad$ PhD 1938 So. California [1956] The serpent, as the prime symbol of immortality, has its origin in the Semitic-Sumerian culture.

Brief American Indian mention: Shawnee, Maya, Inca, and Indian in general.

Lockett, Hattie Green MA 1933 Arizona [1957] The unwritten literature of the Hopi. РणB: U/Ariz., Soc. Sci. Bull. \#2 [1933] 101p., illus.

Lockett, Henry Claiborne

MS 1933 Arizona [1958] The prehistoric Hopi. 91p. 
Lockmiller, David A. MA 1928

Emory [1959]

Land grants of the Cherokee Nation. 69p.

Lockwood, Mary Margaret MA 1931

Arizona [1960]

Pioneer life as it is reflected in American literature. 127p.

Slight amount on Iroquois, Delaware, Mandan and Dakota tribes.

Loeb, Edwin Meyer MA 1921

Yale [1961]

Cannibalism. 128p.

Considers American Indians extensively.

Loeb, Edwin Meyer PhD 1922

Yale [1962]

The origin and evolution of human sacrifice. Рणв: "The blood sacrifice complex." Amer. Anthro. Assoc., Mem. \#30 [1923] 40p.

LOEHR, NORBERT P. MA 1940

St. Louis [1963]

Federal relations with the Jesuit Osage Indian Mission, 1847-1870. 122p.

Loetscher, Lefferts A. MA 1932 . Pennsylvania [1964] Robert J. Walker as Governor of Kansas Territory. $121 \mathrm{p}$.

Includes Indian relations.

Loewen, JACOB ABRAM MA 1954

Waunana grammar; a descriptive analysis. 141 p.

Chocó tribes of northwest Colombia.

LoNdon, MrLdREd H. MA 1940

Wichita [1966]

The Pawnee Indians and their relations with the Government to 1835 . 197p.

Long, Anton V. MA 1949

New Mexico [1967]

Senator Bursum and the Pueblo Indian Lands Act of 1924. 60p.

Long, Dorothy EmiLie $\quad$ MS 1953

Idaho [1968]

A comparison of the art and design of the basketry and costumes of the Nez Percé Indians with that of the Northwest Coast Indians. 125p.

Long, Frank J. MA 1942

The Selkirk Colony and the Minnesota fur trade.

Indians of Red River area; their help, disturbances, massacres. 
Indian education in Pennsylvania. 41p.

Longacre, Robert Edmondson PhD 1955 Pennsylvania [1971] Proto-Mixtecan. 333p. $M$.

Mixtec, Cuicatec, Trique, Amuzgo linguistic study.

LoNGBons, JoHN RoBerT MA 1954

Indiana [1972]

Political organization of central California Indians. 73p.

Includes Wintun, Patwin, Yuki, Maidu, Pomo, Wappo, Miwok, Mono, Nisenan and Tübatulabal.

Longenbaugh, Dillon A. MA 1941 Colorado $A \& M$ [1973] 4-H Club work for Indian boys and girls. $64 \mathrm{p}$.

LONGFEllow, JULIA Belle MA 1925

California [1974]

The New England fur trade 1602-1660. 78p., maps.

Occasional mention of Indian fur trade.

Longmore, Thomas WiLson PhD 1950 Michigan State [1975] Possibilities of agricultural colonization in Peru with reference to persons of European origin. 521p. $M$.

Also considers contemporary Indian situation.

Longtin, Ray C. MA 1948

Columbia [1976]

Travel literature on the Pacific Northwest before 1850 . $251 p$.

Some Indian mention.

Longyear, John Munro III PhD 1940

Harvard [1977]

Copan ceramics: their chronological and historical significance. PUB: "Copan ceramics; a study of southeastern Maya pottery." Carnegie Inst. Wash., Pubs. \#597 [1952] $114 p$., illus.

Loos, JoHn Lovis MA 1939

Nebraska [1978]

The career of William Clark. $107 \mathrm{p}$.

His career as Supt. of Indian Affairs.

Lopatin, Ivan JoHN PHD 1934

So. California [1979]

The cult of the dead among the natives of the Amur basin.

Compares with certain Amerindian tribes. 
The alienation and utilization of the Pawnee lands (1874-1921). 96p.

López Machorro, Elvira MHU 1955

Mexico [1981]

La verdad histórica como hazaña literatura. (Un estudio de la Historia de la conquista de México escrita por Antonio de Solís). РUв: Mexico: Impresora Galvé [1955] 130p.

Lorenzo Bautista, José Luís

MA 1956 Mexico: $E N$ [1982] Artefactos de Tlatilco.

Loris, ElatNe C. MA 1932

Louisiana [1983]

Place names of Pointe Coupée parish.

Louisiana; includes some Indian names.

Loseff, Eunice Devera MA 1953

So. California [1984]

A comparative study of names and naming patterns in selected cultures.

Several tribes; only Omaha mentioned by name.

Lossing, Laverna Lucy MA 1934 So. California [1985] A study of the character and rôle of music among the California Indians. 71p., illus.

Lothrop, Marian L. PhD 1926 California [1986] Mariano Guadalupe Vallejo, defender of the northern frontier of California. 253p.

Lothrop, Samuel KirkLand PhD 1921

Harvard [1987]

The ceramics of northern Costa Rica and western Nicaragua. PUв: "Pottery of Costa Rica and Nicaragua." Mus. Amer. Ind., Heye Found., Contr., VIII [1926] 2 vols., illus.

Lounsbury, Floyd G. PhD 1949 Yale [1988] Comparative Iroquoian morphology. Р $\mathrm{B}$ : "Oneida verb morphology." Yale U., Pubs. Anthro. \#48 [1953] 111p.

Love, Christene Moore MA 1940

Sam Houston [1989] The Spanish missions of Texas. 78p.

Lovrich, Frank MA 1952

So. Dakota [1990] The assimilation of the Indian in Rapid City. 99p. 
Lowe, James Thomas MS 1952

No. Texas [1991]

The Indian policy of the United States Government. 205p.

Lowenfels, Mtchael Sharon MA 1950 Pennsylvania

[1992]

Free drawing as a projective test in cross-cultural investigations. $96 \mathrm{p}$., illus.

Ojibwa children tested; includes facsimilies of their drawings.

LowIe, Robert HaRry PHD 1908

Columbia [1993]

The test-theme in North American mythology. Рणв:

Jour. Amer. Folklore, XXI \#81 [1908] p97-148.

Lowrey, ERnest J. MA 1932

Texas Tech. [1994]

Archaeology of Antelope Creek ruin. 55p.

On the Canadian River near Borger, Texas.

LOWREy, Flora MA 1945

So. Methodist [1995]

Peter Ellis Bean: a typical filibuster of early Texas history. 101p.

$\S 4$ "Bean as Indian Agent for the Mexican Republic".

Lowrimore, Burton Sherman PHD 1951 California [1996] The concept of dualism in American Indian folklore.

Loyola Mullaly, Mary MA 1930

Notre Dame [1997]

Some modern poets' interpretations of a vanishing race. $52 p$.

General Indian consideration.

Lozano, Dolores Dora

MA 1929

Texas [1998]

El Peregrino Indiano y algunas relaciones del siglo XVI de la Conquista de México. 94p.

An account of the Conquest of Mexico written by Antonio de Saavedra Guzmán, circa 1599.

LUCAS, JoHN MA 1924

Iowa [1999]

Career of Alexander Spotswood as a frontier builder.

$\S 2$ "Indian conflicts and the frontier defense". Tuscarora.

Ludas, Virginia CUMming MA 1947 California [2000] Some psychological aspects of primitive medicine. $69 \mathrm{p}$. Paiute and Sioux.

LuCy, M. KenNeth MA 1935 West. Colorado [2001] A description and interpretation of Mimbres pottery from the Mimbres Valley, New Mexico. 56p., illus. 
Ludwig, Fred

MA 1953

Arizona [2002]

An analysis of the inheritable morphological traits of the mandibular second premolar. 58p.

Includes Indians among those studied.

Luebben, Ralph August MA $1951 \quad$ New Mexico [2003] The Leaf Water Site, Chama Valley, New Mexico. 144p.

Luebben, Ralph August PhD 1955 Cornell [2004] A study of some off-reservation Navaho miners. 364p. $M$

Luhrs, Dorothy Louise MA $1937 \quad$ New Mexico [2005] The identification and distribution of the ceramic types in the Rio Puerco area, central New Mexico. 91p., illus.

Luhrs, Dorothy Louise PhD 1945 So. California [2006] An anthropological study of the sources of maladjustment among Eastern Pueblo adolescents. 215p.

Lundquist, Florence Baree MA $1934 \quad$ Pacific [2007] Education of the American Indian by the United States. $112 \mathrm{p}$.

LUNdy, James HaRwood MA 1941

Sul Ross [2008] The history of Jeff Davis County. 136p.

Apaches in Texas.

Luomala, Ellen Katharine MA 1934 California [2009] Turtle's War Party: a study in comparative mythology. $79 \mathrm{p}$.

Refers to most North American tribes.

Lurie, Nancy Oestreich PhD 1952 Northwestern [2010] The Winnebago Indians: a study in cultural change.

Period 1634-1950.

LUther, Vivian E. MA 1937 No. Dakota Agri. [2011] Ceremonials of the Sioux including their camp activities. $48 \mathrm{p}$.

Lydy, LLORA BeLLe MA 1926

Indiana [2012] Some European tales among North American Indians. $151 p$. 
Lyman, Jane LesLie

see Paine, Henrietta Nash and Jane Leslie Lyman.

Lynam, Anna Cathryn MA 1933

Iowa [2013]

Experiments in Indian administration, 1824-1871. 126p.

Shawnee, Piankashaw, Peoria, Kickapoo, Osage, Delaware.

Lynch, John Francis PhD $1953 \quad$ Washington [2014] Concepts of the Indian and Colonial society in Spanish writers on Guatemala: 1520-1620. 393p. $M$.

Lynch, Mary Clatre MA 1934

Marquette [2015]

Jesuit missionary activities in North America from 1572-1773. 114p.

Lynd, William Farson MA 1951

California [2016]

Fallen Timbers: the effect of a single battle on the course of American history. 125p.

Lynn, Anella PhD 1953

Catholic [2017]

Interracial marriages in Washington, D. C., 1940-1947.

Includes Indian interracial marriages.

Lyon, Eleanor Harriet MA 1939 Pennsylvania [2018]

Kiowa: phonology and noun morphology. 21p.

Lyons, Emory J. MA 1937

Fort Hays [2019]

Isaac McCoy: his plan of and work for Indian colonization. 115p. Pणв: Ft. Hays Kans. State Coll., Bull., XXXV \#17 [1945].

Miami, Potawatomi, Ottawa, Shawnee, Creek.

Lyons, Letitia Mary PhD 1940

Catholic [2020]

Francis Norbert Blanchet and the founding of the Oregon missions, 1838-1848. 200p. Р Uв: Cath. U., Stud. Amer. Church Hist., XXXI [1940] 200p.

McAhron, Albert Russell MA 1952 Notre Dame [2021] The material culture of the Southwestern Indian as seen by the early Spanish explorers, 1536-1634. 93p.

Mostly Pueblo Indians.

McAllester, David Park PhD $1949 \quad$ Columbia [2022] Peyote music. PuB: Viking F'und Pubs. Anthro. \#13 [1949] 104p. 
Kiowa-Apache social organization. PuB: Eggan, Social Anthropology of North American Tribes. U/Chi. Press [1937] p99-169.

McAllister, Stella MA 1910 Stanford [2024]

Missionary activities on the Gila and Colorado Rivers, 1768-1782. 79p.

McArthur, Daniel Evander MA 1918

Texas [2025]

The cattle industry in Texas, 1590-1918. 428p.

$\S 3$ "Indian depredations and wars".

MacArthur, K. D. MA 1927

The evolution of the fur-trade, 1760-1774.

Queen's [2026]

Thesis missing from library.

McBlatr, James MA $1949 \quad$ California [2027] The Indian question in the Ghent negotiations, August 8 -October 13, 1814. 87p.

\section{McBride, George McCutchen PhD $1921 \quad$ Yale [2028]} Land tenure in Latin America. PuB: Amer. Geog. Soc., Res. Ser. \#12 [1923] 204p., maps.

Pt. 1-Mexico (includes chapter on aboriginal land system). Pt. 2-Agrarian Indian communities of the Bolivian Andes.

McBride, Margaret Mary MA 1921 California [2029] The early Catholic missionaries in the Pacific Northwest 1774-1844. 102p.

McBrien, Russelt N. MA 1950

Colorado [2030] Fort Union and its wilderness empire. 146p.

Assiniboin, Sioux, Mandan, Blackfoot, Blood, Gros Ventre, Piegan.

McBryde, Felix Webster PhD 1940 California [2031] Native economy of southwestern Guatemala, and its natural background. 2 vols.

McBurney, Charles Reed MA 1948 Kansas [2032]

Cache Creek Indian Mission: a study in religious education among the Comanche, Apache, and Kiowa Indians of southwestern Oklahoma. 159p. 
MoCaffery, Walter Joseph

Francisco Palóu, his life and works. 218p.

Work with California Indians, ca. 1773-1789.

McCague, George Stephen MA 1939

Kent [2034]

United States Indian trade establishments. $82 \mathrm{p}$.

MoCaleb, Walter Flavius MA 1897

Texas [2035]

The Spanish missions of Texas. 102p. Р UB : Austin [1906]

McCall, Marion MA 1939

Pittsburgh [2036]

Field work in the Southwest with particular reference to the Chaco Canyon area. 58p.

McCanles, Lulu L. MA 1921 Stanford [2037]

Progress of the Indians of the Canadian Northwest under the Dominion. 126p.

McCann, Catherine Josephine PhD 1947 Pennsylvania [2038] Aboriginal urn burial in the southeastern United States. 110p. $M$.

Compares customs with Mexico, West Indies and Southwestern United States.

MoCann, Franklin Thresher $\quad$ PhD 1952 Columbia [2039] English discovery of America to 1585. PUB: NY: King's Crown Press [1952] 246p.

General discussion of Indians as found by explorers.

McCaskill, Joseph Clyde PhD 1934 Columbia [2040] The boys' adviser in the Government boarding schools for Indians. Рणв: Haskell Institute [1934] 120p.

McCaul, Donald Robert MA 1950 New Mexico [2041] A study of the origin and development of Northwest Coast dugouts. 120p., illus.

MoClanahan, Muriel H. PhD $1940 \quad$ Pittsburgh [2042] Aspects of Southwest regionalism in the prose works of Mary Austin.

Her Indian writings.

MoCleary, John P. MA 1948 Mexico City [2043] The behavior pattern of the Mexican. 18p. 
A history of the Indian missions of the Presbyterian Church in Kansas. 108p.

McClellan, Carolyn M. MA 1945 Washington/SL [2045] The Sioux Expedition, 1854-1856. 155p.

McClellan, Catharine PhD $1950 \quad$ California [2046] Culture change and native trade in southern Yukon Territory. 262p.

McClellan, Velma MA 1930

Miami [2047]

Indian conferences and Colonial union, with special reference to New York, 1664-1754. 104p.

McCloskey, Michael B. PhD 1952 The Missionary College of the Holy Cross, Querétaro, 1683-1733. P Uв: Acad. Amer. Franciscan Hist., Mono., [1957] 128p.

Training for Indian work.

McCluney, Eugene B. MA 1954 Tex. Christian [2049] History of the activity of the modern archaeologists in Texas concerning the Indian cultures. $137 \mathrm{p}$.

McClure, Florence E. MA 1954 Colorado State [2050] A study of one job placement program for young Navajo Indians with limited education. 68p.

McColudm, Dudley Foster PhD 1931 New York [2051] Spanish Texas. 238p.

Chapters on Texas Indians, various tribes.

McCollum, Floyd Livingston MS 1923 Kentucky [20こ2] Bones from Kentucky caves. 128p.

Mainly faunal bones; but includes information on prehistoric Kentucky Indian skeletons.

McConnaha, Robert Emmett MA $1939 \quad$ Nebraska [2053] A history of Nehawka, 1854-1916. 69p.

Omaha, Oto; Nebraska Indians in general.

McCord, Thomas T., JR. MA $1946 \quad$ New Mexico [2054] An economic history of the Mescalero Apache. 114p. 
McCorkle, Homer Thomas, Jr.

PHD 1954 California [2055

Community persistence and cultural change on Margarita Island, Venezuela. $M$. PUв: "The problem of aboriginal persistence." Sowestn. Jour. Anthro., XI \#3 [1955] p288-300.

Discusses aboriginal population of the island as found in the European-Negro-Indian Guayquerí community.

McCormack, William Charles MA 1950 Stanford [2056] Freedom and authority in primitive societies. $126 \mathrm{p}$.

Two chapters on Navajo social structure, religion and life cycle.

McCranie, Helen Eudora

MA 1933

Emory [2057]

The removal of the Cherokee Indians from Georgia. 49p.

McCreery, JANe Honour MA 1935 So. California [2058] The sequence of material culture traits in the Southwest. 35p., illus.

McCreery, Madelon Elizabeth MA 1940 So. California [2059] A study of the development of certain tribes on the western continent from a tribal to a confederacy form of government. 124p.

McCrossan, Joseph Marie PhD 1944 Pennsylvania [2060] The role of the church and the folk in the development of the early drama in New Mexico.

Considerable attention to Franciscan missions to the Indians.

McCulloch, Julia R. MA 1943

Ohio [2061] The stelae of the Maya. 96p.

McCullough, Halle David MA 1941 Wash. State [2062] Credit for Indians in the Pacific Northwest. 133p.

McCullough, Virginta Delph MA 1930 Ohio State [2063] The bird motif in Egyptian, Oriental and American mode. 15p., illus.

Pueblo, Mexican, Central America.

McCune, George HaLl PhD 1942 Minnesota [2064] The extension of the telegraph in the Northwest, 1850-1880.

Building the telegraph in Indian country; Indian-White relations; Indian removal by 1877. 
MacCurdy, George Grant PhD 1905

Yale $[2065]$

The Eolithic problem: evidences of a rude industry antedating the Palaeolithic. PUB: Amer. Anthro., n.s., VII [1905] p425-279.

McCurtatn, Edmund Green MA 1936 Oklahoma [2066]. The family backgrounds of 117 Indian problem-children. $132 \mathrm{p}$.

Various Oklahoma groups; about 20 tribes represented.

McCurtatn, Eloise Evans MA $1953 \quad$ Oklahoma [2067] Factors in the adjustment of one hundred Kiowa Indian youths. $97 \mathrm{p}$.

McDermott, Louisa MA 1904 California [2068] Ethnology and folklore of Selish proper. 128p.

Flathead Reservation region in northern Montana; includes Flathead and Pend d'Oreille tribes.

Macdonald, Isabel MA 1934

Detroit [2069]

The truth about the activities of Father Sebastian Rasle among the Abenaki Indians. 111p.

MacDonald, JoHn Gordon MA $1950 \quad$ Montana [2070] History of navigation on the Yellowstone River. 155p.

General references, not too extensive, to Crow, Sioux, Blackfoot.

McDonald, Kenneth Madison MA 1931 Alabama [2071] The removal of the Choctaw, Chickasaw and Cherokee Indians from Alabama. 129p.

McDonnold, Mattie MA 1942 Oklahoma [2072] Sam Houston's Texas administrations, 1836-1838, 1841-1844. 104p.

Considerable attention to Indian problems.

McElroy, Harold Lewis MA 1949 The Army frontier in Montana. 107p.

Much discussion of army campaigns against Plains Indians.

McFadden, Roberta Owens MS 1954 So. California [2074] A social study unit on the Southwest Indians. 72p. 
McFarland, WiLli-Lola

The diffusion of shell ornaments in the prehistoric Southwest. 251p.

Discusses shells found in excavations, identifies species and suggests geographic origins.

MacFarlane, Ronald Oliver PhD 1933 Harvard [2076] Indian relations in New England, 1620-1760: a study of a regulated frontier. $694 \mathrm{p}$.

Based on Massachusetts archives, discusses Indian policy in a controlled area.

MacFarLane, RUth MA 1926

Montana [2077]

The intelligence of Indians in the schools of Montana: data secured by an intelligence survey in Federal, State, and mission schools. $37 \mathrm{p}$.

McFeely, Frances MA 1949

California [2078]

Some aspects of folk-curing in the American Southwest 109 p.

Mostly Spanish-American; only incidentally Indian.

McGaffey, Laura Belle MA 1926

Kansas [2079]

The comment of travelers in colonial Spanish America, 1708-1824.

Includes general description of South American Indians, but no specific tribes mentioned.

McGee, Collins Linton MA $1922 \quad$ Mercer [2080] The activities of the missionaries among the Cherokee. $49 \mathrm{p}$.

McGee, John T. MA 1950

Present and past systems of land tenure in the Kippewa

Catholic [2081] area of Témiscaminque, Québec, Canada.

Including aboriginal land tenure patterns.

McGee, Lee Albert PhD 1932

Texas [2082]

History of Colorado Territory.

Early Indian troubles.

McGILL, Edith Louise $\quad$ MA 1927

California [2083]

The opening of Iowa to settlement and its development during the Territorial period. 212p.

Mostly Sioux, Algonquin and Iowa. 
McGinnis, Dorothy F.

MA 1949

Niagara [2084]

Myths and legends, and teaching American history. $110 \mathrm{p}$.

Includes American Indian legends.

McGlashan, Marian Lee MA 1928 California [2085] Manuel Gayoso de Lemos, Governor of Louisiana, 1797-1799. 100p., map.

His dealings with Creek, Choctaw, Chickasaw, Cherokee, etc.

McGoldrick, Eva Hartman MA 1935 Pennsylvania [2086] The dog and human relations among the aborigines of North America-north of the Rio Grande. 50p.

McGovern, JANet Blatr M. MA 1932 New Mexico [2087] A general survey of Isleta Indian Pueblo with especial reference to acute transitional conditions. 144 p., illus.

McGrain, Gertrude C. MA 1937

Michigan's role in the Black Hawk War. 55p.

Detroit [2088]

(1832). Sauk, Potawatomi, Ottawa.

McGrath, Ana Mae MS 1932

Antiquity of the American Indian. 67p.

McGregor, John Charles MS 1932

Arizona [2089]

The archaeology of the Little Colorado drainage area.

McGregor, John Charles PhD 1946 Chicago [2091]

Development and interrelationship of certain Southwestern cultures. 113p. Рणв: Southwestern Archaeology. NY: John Wiley \& Sons [1941] 413p.

McHugh, James J. MA 1922

Catholic [2092]

Educational aspects of the mission systems in Upper California.

McIntiRe, William G. PhD 1954 Louisiana [2093] Prehistoric settlements in coastal Louisiana. 130p.

500 sites in the area recorded.

McIntosh, Clifton Brooke PhD 1932 Virginia [2094] Aves sin nido and the beginnings of Indianismo. 148p.

Aves sin nido: a book by Clorinda Matto de Turner; the title refers to the Peruvian Indians. 
McIntosh, Frances

MA 1943

Oklahoma [2095]

Social and economic conditions of the Creek Indians.

McJimsey, George Davis

$\mathrm{PhD} 1939$

Columbia [2096]

Topographic terms in Virginia. РuB: Amer. Speech, Reprints \& Mono. \#3 [1940] 151p.

"Not a place-name study; names for topography." Includes some consideration of terms borrowed from Indian speech.

MCKAYE, VARA L. MA 1930

New Mexico [2097]

A critical bibliography of certain types of the literature of New Mexico.

Some Indian consideration.

McKee, Mary Annette

MA 1940

Washington [2098]

A study of Aztec costume from the time of the migrations in the eleventh or twelfth centuries to the Spanish conquest in 1519 A.D. 123p.

McKee, Samuel D. PhD 1935

Columbia [2099]

Labor in colonial New York, 1664-1776. PUB: Columbia U., Stud. Hist. Econ. Public Law \#410 [1935] 195p.

Brief mention of Indians as slave labor.

McKenna, Evelyn M. M/Ed 1951

Rhode Island [2100]

A brief survey of the treatment of Indians by the Federal Government since 1824 with special emphasis on the Navajo.

McKenna, Frances MA 1942

Kansas [2101]

Mary Hunter Austin, interpreter of the American Indian. $95 p$.

McKennan, Robert Addison PhD 1933 Harvard [2102] The Indians of the Upper Tanana, Alaska. 507p.

McKenzie, Fayette Avery $\quad$ PhD 1906 Pennsylvania [2103] The North American Indians of today and their contact with the White race. Рणв: The Indians in relation to the White population of the United States. Columbus 0: the author [1908] 117p.

McKeon, Jesse Chester MA $1934 \quad$ Penna. State [2104] A comparative study of the Indian policy of Spain, France and England in colonial America. 63p. 
McKern, Thomas Wilton

An anthropometric and morphological analysis of a prehistoric skeletal population from Santa Cruz Island, California. 102p.

McKinley, Harriet Fisher MA 1943 New Mexico [2106] The Ponca Indian Commission of 1880 and 1881. 79p.

McKinney, Keith H. MA $1949 \quad$ New Mex. High. [2107] Indians of the Western Plains. 105p.

MCKinney, Lillie G. MA 1934

New Mexico [2108] History of the Albuquerque Indian School. PuB: New Mex. Hist. Rev., XX [1945] var. pp.

McLadghlin, Mary Elatne MA 1949 Political and economic aspects of the Santa Fé Trail. 71p. Indians in relation to the Trail.

McLa dghuin, Madge MS 1938 Columbia [2110] The selection of anthropology books for the undergraduate liberal arts college. $122 \mathrm{p}$.

General anthropology; books on Indians included in bibliography.

McLaughuin, Merlyn PhD 1951 Colorado [2111] Imperial aspects of the North West Company in western Canada to 1870 .

A study of the rivalry between Hudson's Bay Co. and North West Co.; includes activities of both in the Indian trade.

McLaurin, Farrior MA 1938

Texas [2112] Some central Texas kitchen middens and campsites in the Marshall Ford Basin. 155p.

McLa URy, John Clark PedD 1904 New York An historical outline of efforts-both public and private - towards the education and civilization of the Indian, and of his present status. 228p.

Maclay, Howard Stanley PhD 1956 New Mexico [2114] Language and non-linguistic behavior: an experimental investigation. 101 p. $M$.

Compares Hoijer-Sapir and Whorf theories, using Navajo, Hopi and other Amerindian examples. 
MacLean, Harold Sterns

MA 1939 Oklahoma $A \& M$ [2115] Educational guidance for Osage Indians in the public schools. 57p.

MacLean, Joyce MS 1954

So. California [2116]

A verbal and pictorial presentation of Navajo culture.

McLean, Sadie Rosetta

MA 1929

Texas [2117]

The Second Congress of the Republic of Texas. 90p.

$\S 6$ "Indian Affairs of the Congress".

McLeod, Ruth Muldins MA 1936

Louisiana [2118]

The history of Natchitoches.

Natchitoches Indian village and its inhabitants are considered.

MacLeod, William Christie PhD 1924 Pennsylvania The origin of the state reconsidered in the light of the data of aboriginal North America. PuB: U/Penna. Press [1924] 109p.

McMillan, George Cameron MA 1955 Manitoba [2120] The struggle of the fur companies in the Red River region, 1811-1821. 201p.

Métis of the area; Red River Indians.

MoMullen, Edwin Wallace, JR. PhD 1950 Columbia [2121] English topographic terms in Florida, 1563-1874. 396p. M. Puв: U/Florida Press [1953] 227p.

Traces Florida topographic terms; those borrowed from Indian, French or Spanish inhabitants.

MoMullen, George R. MA 1951 Oklahoma $A \& M$ [2122] Federal policy in Indian education, 1870-1938. 123p.

MoMullen, Leon Russell MA 1932 California [2123] Two gateways to southern California: San Carlos Pass and Cajón Pass, 1772-1883. 111p., maps., illus.

Yuma, Kawia.

MoMurray, Doris Carlson MA $1951 \quad$ Nebraska [2124] The attitude towards the church in the Indianista novel.

MoMurray, Edna May Thomas MA 1935 So. Methodist [2125] The Indian medicine-man. $89 \mathrm{p}$.

Discusses techniques of healing, rites, herbs, degree of medical knowledge and tribal position. of the medicine man. 
The ideas of the good in the mythology of the Navaho Indians. 286p.

McNally, Imogene Elizabeth MA 1924 Pennsylvania [2127] West Indian and Southeastern culture contact. 112p.

MoNally, Mary Cechia MA 1926 California [2128] The establishment of Territorial government in Colorado. 173p., map.

Cheyenne, Arapaho, Ute, Sioux, Kiowa.

McNamara, Willitam M. PhD 1931

Catholic [2129]

The Catholic church on the northern Indiana frontier, 1789-1844. 89p. Рuв: Cath. U., Stud. Amer. Church Hist., XII [1931] 84p.

Includes Indian problems.

McNeEly, John Hamiton, JR. MA 1939 Geo.Washington [2130] History of tribal claims of the Dakota Sioux Indians against the United States. $127 \mathrm{p}$.

McNeIL, Mary Louise PhD 1952

Iowa $[2131]$

Costumbrismo in the social novel of the central Andean region. 231p. $M$.

Costumbrismo - descriptions of local customs, particularly Indian life.

MeNeinl, Parley H. MA 1940

Pre-historic Indians of Arizona. 128p.

MacNeish, Richard Stockton MA 1944

Chicago [2133]

The establishment of the Lewis focus. 58p.

The archaeology of southern Illinois.

MacNeish, Richard Stockton PhD 1948 Chicago [2134]

Prehistoric relationships between the cultures of the southeastern United States and Mexico in the light of an archaeological survey of the State of Tamaulipas, Mexico. 224p. $M$.

McNulty, Mary of Good Counsel MA 1935 Fordham [2135] Indian nationalism versus White aggression-Pontiac, Indian nationalist. $77 \mathrm{p}$.

Examines rise of Indian nationalism and emergence of Pontiac as a result of White treaty-breaking. 
McNutT, Charles $\mathrm{H}$.

MA 1954

New Mexico [2136]

A re-evaluation of the San Juan Basket Maker culture and possible relationships to certain non-ceramic groups.

MacPherson, Robert James MA 1902 Manitoba [2137] The influence of civilization on the North American Indian. $20 \mathrm{p}$.

Iroquois, Algonquian, Cree.

McQueen, James Mitchell MA 1907 Toronto [2138] The Iroquois as warriors and hunters. $64 \mathrm{p}$.

McQueen, Ray A. PhD 1942 Pittsburgh [2139] The role of Andrew Jackson in the acquisition of the Floridas.

Seminole, Creek.

McQuown, Norman Anton PhD $1940 \quad$ Yale [2140] A grammar of the Totonac language. 104+11p.

MoShane, Catherine Mary PhD 1939 California [2141] Hernando de Santarén: founder of the Jesuit missions of the Sierra Madre. $314 \mathrm{p}$.

Into Sinaloa in 1594; died in the Tepehuán Revolt of 1616. Includes Guasave, Xixime, Acaxee and Nébomes tribes.

McTaggart, John BRYan MA 1928 Ollahoma $A \& M$ A history of the Comanche tribe of Indians as influenced by the Federal Indian policy. 119p.

McVey, Cecil Harold MA 1951

Colorado [2143]

Fort Hays, Kansas. 90p.

Indian campaigns, 1865-1869. Sioux, Cheyenne, Kiowa, Arapaho and Kaw included in general consideration of "Indians".

McVicker, Harvey Grant MA 1905 Columbia [2144] The ancient cliff-dwellers of the Southwest. $37 \mathrm{p}$.

McWhirt, Martha J. MA 1936

Arizona [2145]

Incised decoration of the prehistoric pottery of the Southwest. 130p., pls.

Mackin, Margaret Cahalan MA 1934 Birmingham-So. [2146] The Creek Nation and the expansionists. 102p. 
Certain differences between Indian children and White children on the ninth and tenth grade levels. 120p.

Tests at Haskell Institute.

Maddox, John Lee PhD 1914

The medicine man. A sociological study of the character and evolution of shamanism. 370p. PUB: NY: Macmillan [1923] 330p.

Much on Indians scattered throughout.

Madeira, Percy Childs, JR. MA 1933 Pennsylvania [2149] Discussion of trans-Pacific influences on the material traits of certain of the higher pre-Columbian American cultures. $176+17 p$.

Madsen, Brigham Dwaine MA $1940 \quad$ California [2150] History of the upper Snake River Valley, 1807-1825. 116p., map.

Bannock, Shoshoni.

Madsen, Brigham Dwaine PhD 1948 California [2151] The Bannock Indians in Northwest history, 1805-1900. $327 \mathrm{p}$.

Madsen, Willitam PhD 1955

California [2152]

Christo-paganism: a study of Mexican religious syncretism. 166p. PUв: "Shamanism in Mexico." Sowestn. Jour. Anthro., XI \#1 [1955] p48-57.

Especially considers San Francisco Tecospa, a Nahuatl village in Mexico.

Magaret, Helene PhD 1940 Iowa [2153]

Father de Smet: a biography. Рuв: Farrar \& Rinehart [1940] 371p.

Period 1840-1873. Flathead, Sioux wars, Civil War, Gold Rush, etc.

Maggs, Helen Louise MA 1942 Syracuse [2154] Sir William Johnson's role in the French and Indian War. 129p. 
Maguire, Edward Francis

Frequent diseases and intended remedies on the frontier (1780-1850). 55p.

Includes Indian diseases and remedies, and epidemics historically recorded.

Mahan, Bruce Eluis MA 1920

Iowa $[2156]$

Old Fort Crawford, 1816-1856.

Mahan, Bruce Ellis PhD 1927

Iowa [2157]

Old Fort Crawford and the frontier. PUB: State Hist. Hist. Soc. of Iowa [1926] 349p.

Winnebago, Sioux, Ojibwa, Menomini.

Maher, M. Catherine Anthony MA 1951 St. John's [2158] A study of the Ollantay as an expression of Quechua culture. $61 \mathrm{p}$.

MaHLER, Joy MA 1948

Columbia [2159] An analysis of a stratigraphic textile series from Pachacamac, Peru. 25p.

MaHoney, Esther N.

MA 1936

Arizona [2160] The development and classification of Chihuahua pottery. $65 \mathrm{p}$.

Casas Grandes compared with the Valley of Mexico and the Middle Gila ware.

Mahoney, Marie Patricia MA 1935

American public opinion and Andrew Jackson's Indian

Clark [2161] policy, 1828-1835. 116+9p.

Mater, Harvey Edwin MA 1939

Washington

[2162]

Economic history of Pend Oreille County.

Establishing of Reservation and Indian school at Cusick, Washington.

Malan, Vernon Duane MA 1948 Montana [2163]

Language and social change among the Flathead Indians. $204 \mathrm{p}$.

MaLic, Elinor Eyre $\quad$ MA 1923

California [2164]

The political development of Montana, 1862-1889. 182p.

Mostly Flathead, Blackfeet, Crow and Sioux. 
David R. Atchison, Senator.

As Chairman of Commission on Indian Affairs, 1830-1854, Atchison had much to do with Indian removal.

Marin, James Cla dde PhD 1921

Kansas [2166]

The relation of Indian policy to westward expansion. Рбв: U/Kans., Bull., Human. Stud., II \#3 [1921] 108p.

MaLlory, GLadys MA 1939

Spanish beginnings in Arizona. 156p.

Considerable on Arizona Indians.

Malone, Henry Thompson MA 1949

Emory [2168]

Cherokee civilization in the lower Applachians, especially in north Georgia, before 1830. 191p.

Malone, Henry Thompson PhD 1952

Emory [2169]

A social history of the Eastern Cherokee Indians from the Revolution to Removal. 386p. PuB: Cherokees of the Old South. U/Georgia Press [1956] 238p.

Mandelbaum, David Goodman PhD $1936 \quad$ Yale [2170] Adjustment of the Plains Cree to a changing environment. PuB: "The Plains Cree." Amer. Mus. Nat. Hist., Anthro. Paps., XXXVII [1940] p155-316.

Mangiante, Rosal MA 1950

Arizona [2171]

History of Fort Defiance, 1851-1900. 100p. Navajo.

Mangin, Wriliam Patrick PhD 1954

Yale [2172]

The cultural significance of the fiesta complex in an Indian hacienda in Peru. [305p.]

Vicos, Peru.

Manion, Donald Keith MA 1949

Oregon [2173]

The changing relationships of the modeler to his material in China and the Valley of Mexico; a comparative study of the clay figurines produced during the first millenium of the Christian era. 73 p., illus.

Mann, Clara MS 1937

Oregon State [2174]

A study of Indian housing conditions of Wrangell Institute students to determine the type of home management house needed. 
Mann, Francis Walker, JR. MA 1935 So. California

Father Pierre-Jean de Smet, S. J.: his influence on the history of the trans-Mississippi West. 147p., illus.

Especially Potawatomi, Flathead, Yakima, Sioux.

Mannix, Margaret M. MA 1941 Marquette [2176] The contribution of Eusebio Francisco Kino, S. J., to the exploration and civilization of the American Southwest. 105p.

Manross, William Wilson PhD $1938 \quad$ Columbia [2177] The Episcopal Church in the United States, 1800-1840; a study in church life. Рणв: Columbia U., Stud. Hist. Econ. Public Law, \#441 [1938] 270p.

Chapter on missions and missionaries. Brief Indian content scattered elsewhere.

Manry, Corinne MA 1937

Texas [2178]

A history of the education of the Alabama Indians of Polk County, Texas. 110p.

Manseld, Adìle $\quad$ MA 1941

Sam Houston [2179]

A history of Trinity County. 73p.

Texas. Chapter "Indian history".

Mansfield, Portia Eda 1953

The Conchero dancers of Mexico. 290p. $M$.

New York [2180]

Considers pre-Hispanic origins and descriptions of conchero dance, including historical analysis, and its relation to the Aztecs.

Manson, Clara Sut MA 1936

Indian uprisings in Sonora, Mexico. 111p.

Mantor, Lyle Edwin $\quad$ PhD 1934

Iowa [2182]

The history of Fort Kearney.

So. California [2181]

Sioux, Pawnee.

Mapes, Eleanor Marie MA $1940 \quad$ Texas [2183]

The Indian in American poetry, 1840-1860. 125p.

Marble, Bessie Young MA 1937 Montana [2184]

The intelligence and achievement of White and Salish

Indian children. $62 \mathrm{p}$. 
March, David DeArmond MA 1941

Missouri [2185]

Cheyenne and Sioux Indian relations along the Oregon Trail, 1841-1858. 92p.

Marchand, James W. MA 1951 The sources of Herder's knowledge of America.

Vanderbilt [2186]

Emphasizes Herder's great interest and knowledge of Amerindian linguistics, ethnology and cultural-historical aspects.

Marchant, Alexander N. PHD 1940 Johns Hopkins [2187] The economic relations of Portuguese and Indians in the settlement of Brazil, 1500-1580. PUB : Johns Hopkins U., Stud. Hist. Pol. Sci., 60th Ser. \#1 [1942] 160p.

Marchington, Stanley Eugene MA 1955 Willamette [2188] Organization of the Klamath adult special education and training program for the Klamath Reservation. $421 p$.

Marentette, Mary Charles MA 1935

Detroit [2189] The old Jesuit Huron Mission, Sandwich, Ontario. 54p. Huron, Ottawa.

Margatn Araujo, Carlos R. MA 1956 Mexico: $E N$ [2190] Funcionalismo arquitectónico del México prehispánico.

Mariscal, Ernest Henry MAE $1941 \quad$ Mexico [2191] Anotaciones sobre la historia de Arizona. 129p.

Including the place of the Indian in that history.

MARJERRISON, Mary IsABeL MA 1935

Indiana [2192] A comparative study of the origin myths of the Indians of the Plains and Plateau area. 255p.

Marrs, GarLand JoHn MA 1949 New Mexico

Problems arising from the surface occurrence of archaeological material in southwestern Chihuahua, Mexico.

Marsh, Radph Henry MA 1941 The history of Polk County, Texas. 93p., illus.

Sul Ross [2194]

Kickapoo, Coushatta, Alabama.

Marsh, Roy Elmer MA 1921

California [2195].

The Federal Indian policy in New Mexico. 1845-60. 187p. 
Marshall, Cecil Eugene MA 1932

Iowa [2196]

The Spanish-Indian policy in the sixteenth century.

Marshall, Cecil Eugene PhD 1933

Iowa [2197]

The origins of a new society in New Spain, 1492-1580.

Development of the mestizo; considerable attention given to Indian assimilation.

MaRshaLl, ELLEN MA 1934

Texas [2198]

Some phases of the establishment and development of roads in Texas, 1716-1845. 117p., maps.

$\S 1$ "Indian paths and Spanish trails".

Marshall, Frances Jane MA 1925

Chicago [2199]

The influence of the southern Indians on the Revolutionary War. $42 p$.

Marshall, Henry R. MA 1935

Niagara [2200]

Fort Niagara under the French, English and the United States. 24p.

Marshall, Herbert Cladde MA 1940 Ollahoma $A \& M$ [2201] The North Carolina Cherokees. 29p.

Marshall, Thomas Mattland PhD 1914 California A history of the western boundary of the Louisiana Purchase, 1819-1841. Рणв: U/Calif., Pubs. Hist., II [1914] 266p., maps.

Marti, Anna Miluer Ma 1935

Oklahoma [2203]

A history of the Ghost-Dance religion among the Indians. $94 \mathrm{p}$.

Martig, RalPh Richard PhD 1934

The Hudson's Bay Company claims, 1846-1869. 245p.

$\S 5$ "The course of Empire: the Indians". Yakima, Cayuse, Colville, Spokane, Nez Percé, Walla Walla.

Martin, Evelyn Margaretta MA 1943 So. California [2205] Analysis of Indian ceremonial costumes of central Oklahoma. 111p., pls., photos.

Martin, Jeannette Rowell MA 1949

Indiana $[2206]$

The Rogue Indian wars, 1853-1855. 109p.

Takelma, Chastacosta, Tututni, Tututunne, Chemetunne. 
Helen Hunt Jackson in relation to her times. PUB: U/Louisiana Press [1939] 195p.

Her interests and activities in behalf of the Indians.

\section{Martin, Paul Sidney $\quad$ PhD 1929}

Chicago [2209]

The kiva: a survival of an ancient house type. 105p.

Martin, Ramona I. MA 1934

Wichita [2210] Government treatment of the Osages to $1830.163 \mathrm{p}$.

Martín, Sidney Walter PhD 1942 No. Carolina [2211] The Territorial period of Florida, 1819-1845.

White-Indian wars; relations with Creek and Seminole.

Martin, William B. MA 1903

Catholic [2212]

Religion among the Huron, Iroquois and Algonkian Indians.

Martín del Campo, Rafael MCB 1937 Mexico [2213] Los reptiles y batracios según los códices y relatos de los antiguos mexicanos. $512 \mathrm{p}$.

Martin-Vegue, George Boyd MA 1948 Florida State [2214] A study of the cultural history of pre-Spanish Perú. 71p., illus.

Marvin, Sallie Mather MA 1922

The poetry of the American Indian. 40p.

Oklahoma [2215]

Mary Cecil MA 1944

Ottawa $[2216]$

Jean-Pierre Aulneau of the Society of Jesus, missionary to western Canada. 105p.

Mary Clare MA 1955

Montana [2217]

The significance of the pipe to the Gros Ventres of Montana. 196p.

Marzano, Ruth Anne MA 1948

Chicago [2218]

An analysis of a series of crania from pre-historic Illinois with a critique of the racial classification of the area. 38p. 
Maser, Moreen O. MA 1939

New York [2219]

Realism in pre-Columbian art from Mexico to Peru. 172p., illus.

Masius, Vera MA 1945

Yale [2220]

Ceramic stratigraphy at South Indian Field, Florida. $60 \mathrm{p}$.

Mason, Charles Peter MA 1955 Cent. Washington [2221] Personality adjustment, mental maturity, and music aptitude of the three ethnic groups represented at Mt. Edgecumbe School, Mt. Edgecumbe, Alaska. 73p.

Athapascans, Haida, Tlingit, Tsimshian.

Mason, Gregory $\quad$ PhD 1938

The culture of the Taironas. 213p., pls., maps.

Mason, John Alden PhD 1911 California [2223] The ethnology of the Salinan Indians. Рбв: U/Calif., Pubs. Amer. Archeol. Ethnol., X \#4 [1912] p97-240.

Mason, Z. A. PhD 1954

Texas Tech. [2224]

The Baptist missionary movement on the Texas frontier, 1865-1885.

Mainly Indian raids and attacks; apparently little real "missionary work" was done.

Massey, Dorothy MA 1923

Wisconsin [2225] The Indian agencies at Peoria and Rock Island (a study in the Potawatomi and Sauk and Fox Indians). 88p.

Massey, Harold E. MA 1948

Southwestern [2226]

A history of Collin County. 128p.

Indians of Collin County, Texas.

Massey, William Clifford $\quad$ PHD 1955 California [2227] Culture history in the Cape region of Baja California, Mexico. 370p.

Masten, Bessie Isabel MA 1914 John Stuart, Indian agent. 33p.

Chicago [2228]

(1740-1811). Discusses his work in the Southeast. 
Masterson, James Raymond PhD 1936

Harvard [2229]

Records of travel in North America, 1700-1776.

Six chapters are devoted to travel records commenting on the Indian: race, economics, religion, culture, interracial marriage.

Mather, John R. PhD $1950 \quad J o h n s$ Hopkins [2230] Pleistocene climates and their effect on the New World migration of ancient man. Рणв: Sowestn Jour. Anthro., $\mathrm{X}$ \#3 [1954] p304-321.

Mathews, Ernest Dustin ThM 1950 Louisville Presb. [2231] Problems and processes of translating the ancient scriptures for the modern Maya of Yucatan. 172p.

Mathews, Lois Kimball MA 1904

Stanford [2232] A study of the spread of settlement in New England from 1620 to $1850.60 \mathrm{p}$.

Includes Indians in New England.

Matson, Gustave Albin $\quad$ PhD 1935 Washington/SL A procedure for the serological determination of blood relationships of ancient and modern peoples with special reference to the American Indian. 102p. Рणв: Jour. Immunology, XXX \#6 [1936] 2nd pt.

Blackfoot, Blood, Pueblo.

Matthews, George Hubert MA 1954 Pennsylvania [2234] A phonemic analysis of a Dakota dialect. 12p.

Matthews, Ruth Estelle MA 1941

Stanford [2235]

A study of Colorado place names. 429p.

Includes Indian place names and Indian personal names.

Mattson, Julia Edna MA 1951

No. Dakota [2236]

A survey of Indian pottery, arts, crafts, and symbolism west of the Mississippi River. 343p.

Maundrell, Charles Richard

MA 1941

Queen's [2237]

Indian health, 1867-1940.90p.

Maxwell, Amos DeZell $\quad$ MA 1950 Oklahoma $A \& M$ [2238] The Sequoyah Constitutional Convention. 141p. Рuв: Boston: Meador Pub. Co. [1953] 159p. 
Maxwell, Ida Elizabeth MA 1933 Geo. Peabody [2239] A study of the legends and stories of Arkansas Indians. $184 \mathrm{p}$.

Quapaw, Osage, Cherokee, Choctaw, Caddo, Iroquois, Chickasaw.

Maxwell, Moreau SANFord MA $1946 \quad$ Chicago [2240] A designation of the Dillinger focus, Carbondale, southern Illinois. 80p.

Maxwell, Moread Sanford PhD 1949 Chicago [2241] A proposed Woodland chronology in southern Illinois. 287p. PUв: "Woodland cultures of southern Illinois: archeological excavations in the Carbondale area." Logan Mus. Pubs. Anthro., Bull. \#7 [1951].

Maxwell, Thomas J., JR. MA $1953 \quad$ Missouri [2242] Agricultural ceremonies of the central Andes. Р Ethnohistory, III \#1 [1956] p46-71.

Mayer-Oakes, Willitam James PhD 1954 Chicago [2243] Fort Ancient relationships to the late prehistoric occupation of the upper Ohio Valley. M. PUB: Prehistory of the upper Ohio Valley: an introductory archeological study. Pittsburgh: Carnegie Mus. [1955] 296p., illus.

MAYERS, IsAaC BRown MA 1933

Claremont [2244]

Stonework of the Indians of southern California. 128p. +54 p. photos.

Mayhall, Mirdred Pickle PhD $1939 \quad$ Texas [2245] The Indians of Texas: the Atákapa, the Karankawa, the Tonkawa. 712p., many illus.

Mays, Elizabeth

Emory [2246]

The march of Andrew Jackson in the First Seminole War. 96p.

Mead, Mildred Ford MA 1941 Sam Houston [2247] Indians of Texas in legend and poetry. 105p.

Means, Georgia Sherwood MA $1933 \quad$ Columbia [2248] Economic penetration into western New York, 1608 to 1763. $46 \mathrm{p}$.

French-Indian relations, especially Iroquois. 
Chief Joseph, the Nez Percé. 63p.

Meany, Katherine C. MA 1931

Denver [2250] The Aztecs. 122p.

Mecham, John Lloyd

MA 1917

California [2251]

The Rodríguez expedition into New Mexico, 1581-1582. 106+166p. PUв: "The second Spanish expedition in New Mexico: an account of the Chamuscado-Rodríguez entrada of 1581-1582." New Mex. Hist. Rev., I \#3 [1926] p265-291.

Jumano, Piro, Tiwa and neighboring Pueblo tribes.

Mecham, JoHN Lloyd PhD 1923 California [2252] Francisco de Ibarra and the founding of Nueva Viscaya, 1554-1575. Рбв: Duke U. Press [1927] 265p.

Mechling, Winliam Hubbs PhD 1917

Harvard [2253]

The social and religious life of the Malecites and Micmacs.

Medicine-Crow, Joseph MA 1939

So. California [2254]

The effects of European culture contacts upon the economic, social, and religious life of the Crow Indians.

Meek, Wilbur Thornton PhD 1947

Columbia [2255]

The exchange media of colonial Mexico. PuB: King's Crown Press [1948] 114p.

$\S 2$ "Native media of exchange".

Meggers, Betty Jane PhD 1952

Columbia [2256]

The archeological sequence on Marajó Island, Brazil, with special reference to the Marajoara culture. 373p. $M$.

Mehler, Elsa Sauter MA 1916

Columbia [2257]

Religious and social customs of the Iroquois Indians. $27 \mathrm{p}$.

Meier, Alice Emma MA 1915

Illinois [2258]

The American Indian in German poetry. $60 \mathrm{p}$.

Meighan, Clement Woodward PhD 1953 California [2259] Ancient pottery figurines and their significance in the study of prehistory. $M$. 
Meigs, Peveril III $\quad$ PhD 1932

California [2260]

The Dominican missions of Lower California: a chapter in historical geography. 382p. РОв: "The Dominican frontier of Lower California." U/Calif., Pubs. Geog., VII [1935] p1-229.

Change of economy of Indians in mission area and decline of population.

Meinig, Donald William PhD 1953 Washington

$[2261]$

The Walla Walla country: 1805-1910. A century of man and the land. 365p. $M$.

Indians figure in wars, fur trade and missionary contacts.

Meindt, Mary Concessa MA $1950 \quad$ Duquesne

[2262]

Père Gabriel Druillettes, missionary extraordinary. 53p.

Abnaki and Montagnais.

Meixner, Robert Harmon MA 1948 Southwestern [2263] History of Padre Island. 110p.

Texas. Chapter "Padre Island and the Karankawa Indians".

Mekeel, Haviland Scudder PhD 1932 Yale [2264]

A modern American Indian community in the light of its past: a study in culture change. 218p., illus. Рणв: "The economy of a modern Teton Dakota community." Yale U., Pubs. Anthro. \#6 [1936] 14p., illus.

MELÉNDEZ, CoNCEPCIóN MA 1926

Columbia [2265]

El indianismo en la novela hispanoamericana. 56p.

Melom, Halvor GoRdon MA 1935

California [2266]

Francisco de Urdiñola; his life and legend, with emphasis upon his earlier career. $132 p$.

Apache, Mazapil, Guachichil.

Melrose, Andrew Rae MA 1923

Columbia [2267]

The Spirit Lake massacre. 44p.

Sioux uprising at Springfield, Minnesota, in 1857.

Mendelsohn, Irene AnNa MA 1927 So. California [2268] The Anglo-American colonization of Arizona before 1900. 82p., map.

General references, especially Apache and Yuma. 
Mendenhall, Raymond Eli PhD 1925 New York [2269] Quaker contributions to American education. 265p.

Chapter on "Quaker education among the Indians".

Menzi, Hermine MA 1926

Chicago [2270]

The relation of the Indians to the economic life of colonial New England. 62p.

Merriam, Alan P. PhD 1951

Northwestern [2271] Songs of the Afro-Bahian cults: an ethnomusical analysis.

Considers Indian influences on Negro music of Brazil.

Merrill, Pierce Kelton MA 1940

Oklahoma [2272]

The social and economic status of the Choctaw Indians. $121 p$.

Merriman, Howard Maxwell MA 1931 Cincinnati [2273] Frontier defense in the Northwest Territory. $41 \mathrm{p}$.

Merwin, Brdce W. MS 1924

Kansas [2274]

A study in curriculum building centered about a social science course based on the American Indian. 111p.

Merwin, Raymond Edwin $\quad$ PhD $1913 \quad$ Harvard The ruins of the southern part of the peninsula of Yucatan, with special reference to their place in the Maya culture. PUB: with G. C. Vaillant "The ruins of Holmul, Guatemala." Harvard U., Peabody Mus., Mem., III \#2 [1932] 103p., illus.

Meyer, Constance MA 1933

Northwestern [2276]

The local background of the Kansas-Nebraska Act.

Some Indian content.

Meyer, Leland Richard MA 1922

Syracuse [2277]

The people and institutions of the Mohawk Valley from the first settlement to the early nineteenth century. $198 \mathrm{p}$.

Iroquois.

Meyncke, Gretchen Dye MA 1927

Indiana [2278]

The "Orpheus" story among the North American Indians 141 . 
Michael, Henry N. PhD 1954

Pennsylvania [2279]

The Neolithic Age in eastern Siberia. 401p. $M$.

Brief section comparing eastern Siberia Neolithic cultures with Palaeo-Eskimo cultures, and with some recent North American archeological sites.

Migan, Mary Felixa MA $1946 \quad$ St. John's Coll. [2280] A survey of Father de Smet's work as Government envoy to the Indians of the West, 1851-1868. 123p.

MILAM, JoE B. MA $1931 \quad$ Oklahoma $A \& M$ [2281] The opening of the Cherokee Outlet. 174p.

Miles, Lewis Clarence $\quad$ MS 1936

Idaho [2282]

Chief Spokane Garry, early Indian educator. 44p.

Miles, Suzanne Whitelaw MA 1948 Chicago [2283]

A comparative analysis of the survivals of the ancient Maya calendar. $90 \mathrm{p}$.

Mrtes, Suzanne Whitelaw PhD 1955 Radcliffe [2284] The sixteenth century Pokom-Maya: a documentary analysis of social structure and archaeological setting. $161 p$.

Mrlford, Stanley James MA 1937 So. California [2285] The Twin War God cult of the living Pueblos. 95p., illus.

Mrller, Bessie MA $1930 \quad$ Emory [2286] A comparative study of the religion of the North American Indian. $42 \mathrm{p}$.

Muller, Carl Frederick MA 1929 Arizona [2287] Prehistoric irrigation systems in Arizona. 47p.

Muller, George Albert MA 1954 Mexico City [2288] Christian mediaeval and Indian influences on the Mexican attitude toward death. 68 p., pls.

Compares and contrasts mediaeval European and Aztec concepts of death.

Muller, Helen Markley MA 1954 West. Colorado [2289] Let me be a free man. 183p.

Fictional biography of Chief Joseph, Nez Percé. 
Miller, James Marshall The G kivas of Chetro Ketl. 187p.

Miller, Josephine Eugenta MA 1931 So. California [2291] The culture of the Florida Seminoles. 79p., illus.

Miller, Mary Emelyn MA 1919

Oklahoma [2292]

A history of the Indians in the Indian Territory from 1866 to 1889 . [64p.]

Muller, Merton Leland

PHD 1897

Chicago [2293]

A preliminary study of the Pueblo of Taos, New Mexico. PUB: U/Chi. Press [1898] 48p.

Miller, Mervyn MA 1932

Pacific [2294]

A history of the secularization of the missions of California. 101p.

California tribes.

Miller, Nathan PhD 1925

Yale [2295]

The child's position in simple societies. A sociological study. $517+30$ p. Puв: Brentano [1928] 307p.

Although examples used are primarily from Africa and Oceania, Amerindian references are scattered throughout.

MILLER, RAy E. MA 1929

Iowa $[2296]$

A strobophotographic analysis of a Tlingit Indian's speech. 49 p., illus.

Muller, Robert Alexander $\quad$ MA 1953 No. Carolina [2297] Latin American literature of discovery and exploration in the library of the University of North Carolina: a bibliography.

Circa 1492-1650.

Mrller, Wallace Elden PhD 1937 Northwestern [2298] Relations of church and state in Georgia, 1732-1776.

Indian-White relations, trade, missionaries to Indians.

Miller, Walter Benson PhD 1954

Harvard [2299] The authority system of the Fox Indians. 283p.

Miller, William Reynolds PedD 1902 New York [2300] A history of the development of education in the South- 
west, but more especially in Texas, from the time of the earliest settlement to the period of Reconstruction. 136p.

Considers schools and missions for Indians; includes northern Mexico.

Mtrligan, Edward Archibald MS/Ed 1948 No. Dakota [2301] The Standing Rock Sioux, 1874-1890. 177p.

Mullon, René Francis MA 1953

Columbia [2302]

Irrigation and the origin of the state in the Virú Valley of Peru. 115p.

Mrulon, René Francis PhD 1955

Columbia [2303]

When money grew on trees; a study of cacao in ancient Mesoamerica. 302p., maps. $M$.

Minls, George Thompson $\quad \mathrm{PhD} 1953 \quad$ Harvard [2304] Navaho art and culture; a study of the relations among cultural premises, art styles, and art values. 2 vols., illus.

MrLLS, JoHn EdwiN PhD $1955 \quad$ Washington [2305] The ethnohistory of Nootka Sound, Vancouver Island. 169p. $M$.

Mainly Moachat.

Muld, Lawrence Wilson MA $1931 \quad$ Ohio State [2306] A study of the Ute Indians. $109 \mathrm{p}$.

MrLLs, Lester W. MA 1934

Pacific [2307] The history of Elko, Nevada, a frontier town. 1868 to 1890. 112p.

Shoshoni.

Mtustead, Bertha Ellen MA $1930 \quad$ Fort Hays [2308] Christian missions among the Kansas Indians. 169p.

MishKIN, BernaRd E. MA 1935

Columbia [2309] A study of the recognition by an American Indian group of the facial expressions of emotion in an Indian and a White subject. 26p., photos.

Cheyenne at Tongue River Reservation.

Mishrin, Bernard E. PHD 1940

Columbia [2310]

Rank and warfare among the Plains Indians. PUB: Amer. Ethnol. Soc., Mono. \#3 [1940] 65p. 
Mishoff, Willard Oral PhD 1933

Iowa [2311]

The Indian policy of Sir William Johnson. 267p.

Mishod, Frank Henry MA 1942 Geo. Washington [2312]

The development of Federal schools for natives in Alaska, 1885-1941. 177p.

Mitcheld, Ernest GlynN MA 1949

Texas [2313]

History of Coleman County. 172p., illus.

Texas. Indian background and Indian raids.

Mitchell, Paul Beach MA 1952

The Sioux War of 1890-the end of Indian resistance.

Mitra, Pañchānana PhD 1930

Yale [2315]

History of anthropology in America. A study of method and research concepts. 315p. Р UB : A history of American anthropology. U/Calcutta, India [1933] 239p.

Indians as early source of ethnological interest; New Spain, explorers, scientists.

Mittelholtz, ERwin F. MS/Ed 1953

No. Dakota [2316]

A historical review of the Grand Portage Indian Reservation with special emphasis on Indian education. 168p.

Minnesota Chippewa.

Moder, Frances Grace MA 1927

Indiana [2317]

A study of Ojibwa art and literature. 98p.

Moedano Koer, Hugo MA 1956

Mexico: $E N$ [2318] Tollan.

Moeller, Lerae Britain MS 1954 So. California [2319] A general course for the study of contemporary primitive people. 123p.

Eskimo, Hopi, Navajo, Jívaro.

Moffitt, James W. PhD 1946

Oklahoma [2320]

A history of early Baptist missions among the Five Civilized Tribes. 175p.

MoHr, MarJorie OLSON MA 1953

So. California [2321]

A study of the Indian in selected works of Argentine romantic literature. $165 \mathrm{p}$. 
Mohr, Walter Harrison PhD 1931 Pennsylvania [2322]

Federal Indian relations, 1774-1788. PUB: U/Penna.

Press [1933] 247p.

Moke, Irene Alma PhD $1945 \quad$ Nebraska [2323]

Santa Fé, New Mexico, a study in urban geography. 209 p.

Considerable attention to Indian, especially Pueblo.

Monninger, Victor Cuinton MA 1917 Northwestern [2324] The Battle of Tippecanoe as a factor marking the beginning of the final disintegration of the confederated Indian power of the Old Northwest. $217 \mathrm{p}$.

Discusses role of the Knights of the Golden Circle.

Monteith, Alexander Ritchie MA 1934 So. California [2325] The place of Gaspar de Villagrá's La historia de la Nueva México in literature and history. 145p.

Montgomery, Clifford Marvin MA 1919 California [2326] Diary of the first Anza expedition to California: translation, with introduction and editorial notes. 108p.

(1774-1775) Mostly Yumas.

Montgomery, Esther D. MA 1927

Iowa [2327]

A study of the Indian in American fiction, 1820-50.

Montgomery, Guy $\quad \mathrm{PHD} 1921$

California [2328]

Studies in primitive folksong. Рuв: U/Calif., Pubs. Modern Philol., XI \#16 [1922] p285-292.

Contains texts of Chippewa and Teton-Sioux songs.

Monzón, ARturo MA 1956

Mexico: $E N$ [2329]

El calpulli en la organización social de los Tenochca.

Moody, Robert EarL PhD 1933

Yale [2330]

The Maine frontier, 1607 to $1763.462 \mathrm{p}$.

Several chapters on Indian treaties, trade and warfare. Mainly Penobscot.

Moor, Maurice Aluison PHD $1943 \quad$ Pennsylvania [2331] Seventeenth-century southeastern Algonkian ethnohistory. PUB: "Algonkian ethnohistory of the Carolina Sound." Jour. Wash. Academy of Sci., XXXIV \#6 [1944] p181-228. 
Mooney, John V.

PнM 1917

Catholic [2332]

The disposition of the Mission Indians after the secularization of the missions in California.

Moore, AUdis NedMeyer MA 1939

Oklahoma [2333]

The social and economic status of the Seminole Indians. $122 \mathrm{p}$.

Oklahoma Seminole.

Moore, Austin Leigh MA 1924

Early cattle days in Wyoming. 77p.

Columbia [2334]

Very brief consideration of Indian relations with cattlemen; some material on Indian land treaties.

Moore, Chydene Herman MS 1952 East Texas [2335] The opening of Oklahoma Indian lands. 91p., maps.

Moore, Frank William MA 1952 Excavations at Tetitla, Teotihuacán. 61p., illus.

Moore, GuY Rowley MA 1925

History of the Pawnee Indians. 140p.

Moore, Harvey Cleaver PhD 1950 New Mexico [2338] Anthropological method and theory in a study of costume. 135p., illus.

Includes Indian costume.

Moore, Helen Leonore MA 1925 So. California [2339] The Papago Indians of Arizona and Sonora. 92p.

Moore, Ila Cleo MA 1940

Oklahoma [2340]

Schools and education among the Kiowa and Comanche Indians, 1870-1940. 116p.

Moore, Jeanne Francis

MA 1954

Loyola [2341] The Choctaw Nation and the Dawes Commission. 68p.

Moore, Kenneth Burton

MA 1937

Montana [2342]

Government relations with the Dakota Sioux (1851 to 1876). 154p.

Moorhead, Max Leon PhD 1942

Rafael Carrera of Guatemala: his life and times.

[1839-1865] Carrera represented lower Indian classes. Indian uprising reflected era of nativism. 
Morales, Jerónimo A. MA 1952 Mexico City [2344] The peaceful conquest of Paraguay; the Jesuit missions and the question of sovereignty. 74p.

Missions to the Guaraní Indians.

Morgan, Blanche M. MA 1933 So. California [2345] General Crook's first administration in Arizona, 1871 to 1875. 122p., illus.

Morgan, ERnest West M/Ed $1940 \quad$ No. Carolina [2346] A racial comparison of education in Robeson County (North Carolina).

Includes White, "Croatan" Indian, Negro.

Morgan, Paul PhD 1954 Texas The treatment of the Indian in Southwestern literature since 1915: a study in primitivism. 454p.

Mortarty, Thomas Stephen MA $1941 \quad$ Catholic [2348] The concept of sacrifice among the Plains Indians of North America.

Morley, Clyde A. MA $1927 \quad$ Wisconsin [2349] A general survey of the schooling provided for the American Indian throughout our country's history with a special study of conditions in Wisconsin. 55p.

Morley, Helen Lucine MA 1930

A brief history of the Osage Indians. 96p.

Ohio State [2350]

Morley, Sylvanus Griswold MA 1908 Harvard [2351] The four principal Gods of the Maya codices and their name glyphs.

Morris, Harold White EdD 1954 Oregon State [2352] A history of Indian education in the United States. 146p.

MorRis, JoHN ALLEN MA 1938 No. Carolina [2353] The stories of William Gilmore Simms.

Morris, Mable Marie MA $1926 \quad$ Iowa [2354] The democratic influence in Charles Brockden Brown's treatment of the Indian. $72 \mathrm{p}$. 
Morrison, WIILIAM Brown MA 1925 Oklahoma [2356] Military posts and camps in Oklahoma. 123p. PuB: Okla. City: Harlow Pub. Co., [1936] 180p.

1820-1871. Tribal relations with Whites, including Apache, Comanche, Kiowa, Five Civilized Tribes.

Morrissey, JoHn P. MA 1933 Canisius [2357] How Spanish civilization superseded the Aztec civilization. 35p.

Morse, Marian Frances MA $1936 \quad$ Florida State [2358] Alexander McGillivray, who put not his trust in princes. $56 \mathrm{p}$.

Creek, circa 1739-1793.

Morse, Robert D. MA 1927 Oregon State [2359] The Hudson's Bay Company activities in the Oregon Territory, 1824-1846. 86p.

Morton, Donald George MA 1948 California [2360] Spanish exploratory and missionary activity in the province of Maynas: Audiencia of Quito, 1618-1686. 165p., maps.

Morton, OHLAND MA 1929

Oklahoma [2361] The political history of the Creek Indians since the Civil War. $122 \mathrm{p}$.

Moscote, Rafael Eutimio MA 1942 Columbia [2362] Spanish colonial policy and administration as revealed in Juan de Solórzano's Política indiana. 70p.

(1578-1621). The Audiencia of Lima, Perú.

Moser, Jean Rose MA 1941

Columbia [2363]

Settlement of western Maryland, 1748 to $1776.87 p$.

Encroachment on Shawnee, Delaware and Catawba briefly considered.

Mosley, J. P. MA 1935

Kansas [2364]

Land legislation in the Forty-first Congress, 1869-1871.

Pre-1869 Indian policy and land laws and clash between War and Interior Departments over Indian control. 
Mott, Marguerite

MA 1932

Washington/SL [2365]

Activities in the Northwest, 1848-1861, under the direction of the United States War Department. 157p.

MotT, MIIDREd INGRAM MA 1938

Chicago [2366]

The relation of historic Indian tribes to archeological manifestations in Iowa. $119 p$.

Mount, Marshall Ward MA 1952

Columbia [2367]

Alaskan Eskimo representational art; a reflection of the controls of a simple hunting society in an Arctic environment. 118p., illus.

Mowat, Charles Loch PhD 1938

Minnesota [2368]

East Florida under British rule, 1763-1783. PUB: U/

Calif., Pubs. Hist., XXXII [1943] 237p.

One chapter specifically on Cherokee; balance on lower Creeks.

Other tribes in passim.

Möykkynen, Kauko ERnest MA 1940

The influence of the Kalevala on Henry Wadsworth Longfellow's Song of Hiawatha. 103p.

Muckleroy, ANNa MA 1919

Texas [2370]

The Indian policy of the Republic of Texas. 202p. Рणв:

Sowestn. Hist. Qtly., XXV-XXVI [1922-1923] var. pp.

Mueller, Paul Eugene PhD 1956

Columbia [2371]

David Zeisberger's official diary, Fairfield, 1791-1795.

314p. $M$.

Translation of the manuscript; Detroit-Niagara area.

MULCAhy, Frederick C. MA 1947

Marquette [2372]

Removal of the Cherokee Indians from Georgia. 105p.

MÜLLER, FLoRenCIA MA 1956

Mexico: $E N$ [2373]

Estudio, análisis y reconstrucción históricos de la zona arquelógica de Chimalacatlán, Morelos.

Mulloy, William Thomas MA 1948

The Hagen Site, a prehistoric village on the Lower Yellowstone. Pub: U/Montana, Pubs. Soc. Sci. \#1 [1942] 106p., illus. 
A preliminary historical outline for the northwestern Plains. M. PuB: Griffin, Archeology of Eastern United States. U/Chi. Press [1952] p124-138.

Mulvey, Mary Doris PhD 1936 Catholic [2376]

French Catholic missionaries in the present United States (1604-1791). Р бв: Cath. U., Stud. Amer. Church Hist., XXIII [1936] 158p.

Considerable Indian material, especially Iroquois; Canada, Old Northwest, Illinois.

Mulvihill, Daniel Francis, JR. MA 1942 Columbia [2377] A metrical study of molar teeth in different racial groups. 19p., charts.

Compares New Britain Melanesians and Pt. Barrow Eskimo skulls.

Mulvihill, Daniel Joseph PhD 1954 Michigan [2378] Juan de Zumárraga, first Bishop of Mexico. 324p. $M$.

His career as Protector of the Indians is considered in detail. $\S 7$ "The Indian church".

Mundie, Catherine E. MA 1933

Canisius [2379]

A study of the relations between the Governments of the United States and the American Indian with special emphasis on the major policies pursued by the Federal Government. $59+11 \mathrm{p}$.

Munro, John B. PhD 1945 Ottawa [2380]

Language, legends and lore of the Carrier Indians. 320p.

Munroe, David Climite MA 1938 McGill [2381] The fur trade of New France, down to 1663. 129p., maps. Considerable Indian mention throughout.

Munson, Esther Miriam MA 1933 California [2382] Aboriginal economic geography of the Hopi. 158p.

Muntz, EarL Edward MA 1921

Primitive education. 131p.

Yale [2383]

General references to Indians throughout. 
Race contact: a study of the social and economic consequences of the contacts between civilized and uncivilized races. 664p. Рбв: NY: Century Co., [1927] $407 \mathrm{p}$.

One of three major sections is devoted to the American Indians.

MURDoch, Richard K. PhD 1947 U.C.L.A. [2385]

French intrigue along the Georgia-Florida frontier, 1793-1796. 344p. Puв: U/Calif., Pubs. Hist., XL [1951] $208 \mathrm{p}$.

Struggle for possession of Florida; includes Treaty of Augusta in 1773, between Gov. Wright and the Cherokee-Creek chiefs.

MUrphey, Sarah Elizabeth MA 1936 So. California A pre-Columbian housing program: a correlation of climatic zones and pre-Columbian house types. 264p.

\section{MURPHy, Henrietta PhD 1938}

Texas [2387]

Spanish presidial administration as exemplified by the inspection of Pedro de Rivera, 1724-1728.

Indian relations with the presidio.

MURPhy, Robert F. PhD 1954 Columbia [2388] The rubber trade and the Mundurucú village. $158 \mathrm{p} . M$.

Ethnohistory and acculturation of the Mundurucú, with special reference to their economic life.

Murphy, William Hymen MA 1932 Oklahoma $A \& M$ [2389] A history of the opening of the Wichita-Caddo-KiowaComanche-Apache Reservations. 50p.

Murray, Eloise MA 1934 Geo. Peabody [2390] Contribution of the American Indian to leisure time. 168p., illus.

General consideration: games, dances, art, crafts.

Murray, Jean Elizabeth MA 1924 Toronto [2391] A study of the native peoples who dwelt in the St. Lawrence region at the time of its discovery and earlier exploration. 109p. 
Murray, Jean Elizabeth

The fur trade in New France and New Netherland prior to $1645.231 \mathrm{p}$.

Canadian Iroquois extensively considered.

MURRay, Raymond H. MA 1945

So. Dakota [2393]

A survey of Indian policy in 1934 with special reference to the Dawes Act of $1887.85 \mathrm{p}$.

MURRAy, Richard Y. MA 1952

Arizona [2394]

The history of Fort Bowie. 311p.

Arizona Apache.

MURray, Robert J. MS/Ed 1953

No. Dakota [2395] History of education in the Turtle Mountain Indian Reservation, North Dakota. 140p.

Chippewa.

Murray, Stanley N. MA 1953

Wisconsin [2396]

A study of Indian land relations as illustrated through the history of the Lake Traverse Reservation Sioux. $242 p$.

MurRy, Margaret Whiting

MA 1937

Arizona [2397]

The development of form and design in the pottery at

Kinishba. 80p.

Myers, Minnie Hazel MA 1937

Tennessee [2398]

Tennessee's policy in the removal of the Cherokee. 113p.

Myron, Robert E. PHD 1953

Ohio State [2399] Hopewellian figurative sculpture. 229p., pls.

Nance, Winnie D. MA 1927 Texas [2400] A history of Archer County, Texas. 118p., maps.

Chapter on frontier Indian problems.

Nasatir, Abraham Phineas MA 1923

California [2401] The Chouteaus and the Indian trade of the West, 1764 to 1852.280 p.

Especially Missouri, Osage, Sioux.

Nasatir, Abraham Phineas PhD 1926 California [2402] Indian trade and diplomacy in the Spanish Illinois, 1763-1792. 373p. 
Land of the Kiamichi. 133p.

Kiamichi: region in southeast Oklahoma (McCurtain and Pushmataha Counties). Includes history of Kiamichi region and Choctaw Indians, 1820-1907.

\section{Nash, Philleo PhD 1937}

Chicago [2404]

The place of religious revivalism in the formation of the intercultural community on Klamath Reservation. Р UB: Eggan, Social Anthropology of North American Tribes. U/Chi. Press [1937] p377-442.

\section{NASTICH, Milena $\quad$ MA 1954}

Brit. Columbia [2405] The Lillooet: an account of the basis of individual status. $89 \mathrm{p}$.

Nathanson, Yale Samuel MA 1924 Pennsylvania [2406] Analysis of some Algonquin measurements.

\section{Neal, J. Allen MA 1955}

Ohio State [2407]

Colonel Henry Bouquet's expedition of 1762-1764: a study of British military tactics as used against the Indians of North America. 101p.

Especially Indians of Ohio.

Neal, Leola E. MA 1935

West. Ontario [2408]

Cultural isolation as a possible cause of schizophrenia. $55 p$.

Muncey Reserve (Canada).

Neds, Ivy Faye

MA 1929

Ohio State [2409]

Catholic missions among the Indian tribes of the Missouri and Columbia River valleys, 1825-1929. 82p.

Neighbors, Alice Atkinson

MA 1936

Texas

The life and public work of Robert S. Neighbors. 165p., illus.

Maj. Neighbors was Indian agent in the 1860 s in charge of Comanche removal from Texas to Oklahoma.

Neighbors, Kenneth Frankuin MA 1949 So. Methodist [2411] Robert S. Neighbors, Texas pioneer. 148p., illus.

His career as Indian Agent, Superintendent, and Indian fighter. 
Neil, Ana Gladys MA 1942

So. California [2412]

Spanish colonization and its influence on southern Arizona.

Nelson, Al B. PhD 1937

California [2413]

Juan de Ugalde and the Rio Grande frontier, 1777-1790. $257 \mathrm{p}$.

Includes Spanish warfare with Apache.

Nelson, Emma Viola MA 1932

The narrative method of the North American Indian folk tale as illustrated in the handling of plot, character, and setting. 58p.

Nelson, Harris Edward MA 1951

The transition from Standing Rock Indian Reservation to Carson County. 66p.

Nelson, Horatia Dodson MA 1932

Ohio State [2416]

Indian character and customs as portrayed in the novels of James Fenimore Cooper. 175p.

Nelson, Nels Christian MA 1908

California [2417]

The Ellis landing shellmound. Рбв: U/Calif., Pubs. Amer. Archeol. Ethnol., VII \#5 [1910] p357-426, illus.

Nelson, Russell Kermit MA 1939

Nebraska [2418]

A history of Abilene, Kansas, to 1890. 107p.

Mentions a Kaw chief, plus general references to danger from Indians; no specific tribes.

Neris-Papagia, John A. MA 1951 The jaguar complex in Mesoamerica. 101p.

Nesbitt, Padl Homer PhD 1938

Chicago [2420]

Starkweather Ruin: a Mogollon-Pueblo site in the Upper Gila area of New Mexico and affiliative aspects of the Mogollon culture. PuB: Logan Mus. Pubs. Anthro. Bull. \#6 [1938] 143p.

Nethery, Winlis J. MA $1940 \quad$ Oklahoma $A \& M$ [2421] The relations between the United States Government and the Teton Sioux Indians from 1868-1890. 108p. 
Nett, Betty R.

Osage kinship. PUB: "Historical changes in the Osage kinship system." Sowestn. Jour. Anthro., VIII \#2 [1952] p164-181.

NetTl, Bruno MA 1951

Indiana [2423] Musical culture of the Arapaho. 116p., scores, charts.

Nettl, Bruno PhD 1953

Indiana [2424]

American Indian music north of Mexico: its styles and areas. 239p. M. PuB: Jour. Amer. Folklore, Mem. \#45 [1954] 51p.

All areas; compared with Asiatic and European areas.

Neunoff, Dorothy Adele

MA 1922 Washington/SL

The Platte purchase. 103p.

Especially Sac, Fox, Iowa, Potawatomi; plus other tribes.

Neumann, Edwin Julius PhD 1951 Northwestern [2426] Hamlin Garland and the mountain West.

Considers Hamlin Garland's treatment of the Indian; his consideration of social problems rising from the assimilation of the Indian.

Neumann, Georg Karl PhD 1950

Chicago [2427]

Racial differentiation in the American Indian. $M$ PUB: Griffin, Archeology of Eastern United States. U/Chi. Press [1952] p13-34.

Neumann, Henriette Ruth

MA 1953

California [2428]

Implications of Federal withdrawal from Indian affairs in California. 227p.

NeVille, Frederica K. MA 1952

Louisiana [2429]

Clothing acculturation within three Indian tribes. $117 \mathrm{p}$.

Hopi, Teton, Cherokee after White contact.

NEWbERRy, Josephine M/Ed 1942

Texas [2430]

Legends and festivals associated with indigenous dances of Mexico. $98 \mathrm{p}$.

Newbold, Robert Clifford PhD 1954 Notre Dame [2431] The Albany Congress and Plan of Union of 1754. 301p. $M$.

Particular attention to Indian conferences, and White relations with the Six Nations. 
Newcomb, William WiLmon, JR.

PHD 1953 Michigan

[2432]

The culture and acculturation of the Delaware Indians. 297p. M. Рчв: U/Mich. Mus., Anthro. Paps. \#10 [1956] in press.

A detailed ethnohistorical study of the super-tribal society termed Pan-Indianism.

Newcombe, Alfred W. PhD $1933 \quad$ Michigan [2433] The organization and procedure of the S. P. G., with special reference to New England. 245p.

Some discussion relating to the Indians, mostly concerned with organization and purpose of the society.

NewComer, John F. MA 1951

New Mexico [2434]

Indigenous philosophy in the Valley of Mexico. 60p.

Newell, Whliam Benjamin MA 1934 Pennsylvania [2435] Crime and justice among the Iroquois Indians. $68 \mathrm{p}$.

Newkirk, Alfred Francis JD 1928

Illinois [2436]

Some phases of the descent law applicable to Indian allotments in Oklahoma. 30p. Р $\mathrm{B}$ : U/Ill., Coll. of Law Theses [1928]. 30p.

Newkirk, EdNa M.

The Indian policy during Grant's administration. 134p.

Newman, Marshall Thornton PhD 1941 Harvard [2438] An analysis of Indian skeletal material from northern Alabama and its bearing upon the peopling of the southeastern United States. PUB: "Preliminary report on the skeletal material from Pickwick Basin, Alabama." Bur. Amer. Ethnol., Bull. \#129 [1942] p393-507.

Newman, R. E. MA 1953 C.C.N.Y. [2439] Application of the Rorschach technique to an Otomí adolescent group. $79 \mathrm{p}$.

Otomí Indians of Mezquital Valley, Mexico.

Newman, Russell Wallace PhD 1949 California [2440] A comparative analysis of prehistoric skeletal remains from the lower Sacramento Valley. 85p. 
Newman, Stanley Stewart

PHD 1932

Yale [2441]

A grammatical sketch of Yokuts. PUв: Hoijer, "Linguistic structures of native America." Viking Fund Pubs. Anthro. \#6 [1946] p222-248.

Newton, Dwight Bennetr MA 1942 Kansas City

Techniques of overland freighting in the trans-Missouri West. 138p.

Chapter "Indian troubles".

Nicholas, Cora Savant MA $1948 \quad$ So. California [2443] History of Yuma Valley and Mesa with special emphasis upon the city of Yuma, Arizona.

Much on Yuma Indians.

Nichols, Cladde Andrew PhD $1930 \quad$ Columbia [2444] Moral education among the North American Indians. 104p. Р вв: Columbia U., Teachers Coll., Contr. Educ. \#427 [1930] 104p.

Nichols, David Benton MA 1942

Columbia [2445] The public life of William Clark. 44p.

Includes his career as Superintendent of Indian Affairs.

Nichols, Franklin Thayer PhD 1946 Harvard [2446] The Braddock expedition. 2 vols., 514p.

Considerable material on Indian affairs, Indian-White relations and the role of the Indian in the 1754-1755 campaign.

Nichols, Jeannette Paddock PhD 1924 Columbia [2447] Alaska; a history of its administration, exploitation, and industrial development during its first half century under the rule of the United States. Pणв: Cleveland:

A. H. Clark [1924] 456p.

Aleut Indians and Eskimo included.

Nicklin, Dorothy MA $1943 \quad$ Bowling Green [2448] The activities of General George Armstrong Custer in his work on the Plains frontier. 134p.

Nielsen, Jean Christian MA 1934

The operations of British fur trading companies in Idaho, 
with special reference to the Snake country expeditions. $136 \mathrm{p}$.

Emphasis on fur trading companies, but Indians are mentioned in passim.

Nigg, Clara IdA MA 1926

Kansas [2450]

A study of the blood groups among the American Indians. 55p. Рणв: Jour. Immunology, XI [1926] p319-322.

Study of fullbloods at Haskell, plus 457 Reservation Navajo.

Nigg, Clara IdA PhD 1929

Kansas [2451]

Study on isohemagglutination. PUB: Jour. Immunology, XIX \#1-2 [1930] 98p.

Statistics from Haskell Institute, Fort Defiance Navajo and doubtful fullbloods.

Nilsson, Marion William

MA 1928

Columbia [2452]

St. Louis, the emporium of the trans-Mississippi fur trade previous to $1834.85 \mathrm{p}$.

Indians in relation to fur trade.

Nixon, E. D. MA 1935

Colorado State [2453]

The Meeker massacre. $196 \mathrm{p}$.

Utes.

Noel, Virginta Pink MA 1924 Texas [2454]

The United States Indian Reservations in Texas, 1854-1859. 188p.

Noon, John Alfred PhD 1942

Pennsylvania [2455]

The League of the Iroquois on the Grand River. An acculturation study in government and law. PUB: "Law and government of the Grand River Iroquois." Viking Fund Pubs. Anthro. \#12 [1949] 186p.

Norby, Charles H. MA 1931

Iowa $[2456]$

The advance of the frontier, 1860-1870. 117p.

$\S 4$ "The Army frontier and the reduction of the Indian barrier".

Norkus, Nellie PhD 1954

Pittsburgh [2457]

Francis Farquier, Lieutenant-Governor of Virginia, 1758-1768: a study in colonial problems. 656p. $M$.

His part in conducting French and Indian War, aiding South Carolina in Cherokee War, Pontiac Uprising, Virginia-Indian relations in general. 
Norrington, Mary Edna MA 1924

Kansas [2458]

The beginning of the Church in Mexico, 1520-1600.

Extensive treatment of the Indian and oppression by the Church.

Norris, THeOdore MA 1939

New Mexico [2459]

The aboriginal utilization of the small cacti in the American Southwest. Pub: U/New Mex: Research, III \#1 [1939] p3-13.

North, William E. PhD 1936

Catholic education in southern California (1769-1935).

Includes Indian missions and mission education.

North, Woesha Cloud MA 1944.

Contemporary art activities of comparable American Indian cultures. $76 \mathrm{p}$.

Plains and Southwest; especially San Ildefonso and White Clay, South Dakota.

Northrop, Maxine BURnette MA 1938 Colorado State [2462] The Plains Indian in the history of Colorado. 206p.

Northrup, Richard Verne MA 1931 Ohio State [2463] The land interests and policy of Sir William Johnson. $86 \mathrm{p}$.

Includes his Indian activities in respect to land.

Norton, Katherine E. MA 1934 Detroit [2464]

History of the Saint Ignace Mission in Michigan from 1671 to $1706.37 \mathrm{p}$.

Huron, Algonquian, Ottawa, Iroquois, Sioux, Illinois.

Norton, Mary Aquinas PhD 1930

Catholic [2465]

Catholic missionary activities in the Northwest, 1818 to 1864. PUв: Cath. U. Press [1930] 154p.

Pembina-Chippewa, Sioux, Winnebago.

Nowland, Mary Julice $\quad$ MA 1940

United States Government relations with the Catholic Indian missions of the trans-Mississippi West, 1803-1882. 180p. 
Nowlin, Martha

MA 1932

Columbia [2467]

Thoreau's manuscript notes on the American Indian, volumes I, II, III, and IV. [391p.]

Noyes, Frances MA 1940

United States-Mexican border relations, 1872-1876.

Colorado [2468]

As affected by Indian raids; especially around the Tamaulipas zona libre.

NúÑez ChinchiLla, Jesús Mexico: $E N$ [2469]

Función y características arquitectónicas de las Pirámides Mesoamericanas.

NunN, Louise Virginia MA 1937

Columbia [2470]

A comparison of the social situation of two isolated Indian groups in northern North Carolina. 91p.

Rockingham and Person Counties; these people no longer retain any tribal association.

Nunn, William Curtis $\quad$ PhD 1938

Texas [2471]

Texas during the administration of E. J. Davis. 217p.

One-third of paper deals extensively with U.S. Indian policy.

Nurge, Ethel D. PhD 1955

Cornell [2472]

Culture change in contact situations: generalizations in syntheses by Malinowski, Linton and Barnett. 311p. $M$.

Based on Linton's Acculturation in Seven American Indian Tribes insofar as Indian material is concerned.

Ober, Elsie Theresa MA 1942

Columbia [2473]

Certain art cultures in relation to time, race, and space. 74p.

Mainly prehistoric periods; sections on Aztec and Polar Eskimo.

Oberg, Kalervo PhD 1937

Chicago [2474]

The social economy of the Tlingit Indians. PUB: U/Chi. Press [1940] litho.

O'Brien, Thomas Bruce MA 1935

Iowa [2475]

The frontier of settlement in $1850.88 \mathrm{p} .$, maps.

Includes considerable Indian material, particularly frontier movements and land cessions. 
O'Callaghan, Mary Agnes Meade PhD 1942 California [2476] The Indian policy of Carondelet in Spanish Louisiana, 1792-1797. 197p.

Nogales, Creek, Chickasaw.

O'Connell, Agnes Catherine MA 1930 California [2477] The historical development of the Sacramento Valley before 1848. 106p., maps.

O'Connor, Mary Helen MA 1942 Cornell [2478] Potawatomie land cessions in the Old Northwest. 106p.

ODELL, RUth PhD 1937

Nebraska [2479]

Helen Hunt Jackson and her times. PuB : NY : AppletonCentury [1939] 326p.

Odisho, Willtam Charles MA 1937 California [2480] The American colony in Oregon, 1834-1848. 134p., maps. Methodist, Presbyterian, Catholic missions.

Ogden, AdÈLE PHD $1938 \quad$ California [2481] The California sea-otter trade, 1784-1848. Р Uв: $U /$ Calif., Pubs. Hist., XXVI [1941] 251p.

OGden, Florence Ruth MA 1940 Texas [2482] Charles Fletcher Lummis: his life and works. $54 \mathrm{p}$. His Indian interest reflected throughout.

Ogle, Ralph Hendrick PhD 1940 Columbia [2483] Federal control of the Western Apaches, 1848-1886. Pбв: New Mex. Hist. Soc., Pubs. Hist., IX [1940] 260p.

O'Hara, BLanche MA 1934 A history of the Blackfeet Indians. 177p.

Orada, Ferdinand Eastlake PhD 1955 Columbia [2485] A comparative study of marginal societies. $184 \mathrm{p} . M$.

Yahgan, Yaruro, Naskapi, Western Shoshoni.

O'KaNe, HaRry WARD MA 1934 Northwestern [2486] The work of the Methodist Episcopal Church among the Potawatomie Indians. 85p. 
Reverend Modeste Demers, missionary in the Northwest. $87 \mathrm{p}$.

Cowichan, Chinook, among others.

Olguín Hermida, Guillermo DL 1939

Mexico [2488] Algunos aspectos del problema indígena. 68p.

Olinger, Barbara Ruth MA 1931

Kansas [2489]

The Southwest as treated in a selected list of American novels.

"Indians have proved to be the most attractive kind of material the region has afforded." 3 books on Navajos, 4 on Pueblos, plus others.

OLIver, Emmett SAMPson MA $1947 \quad$ Washington [2490] An analysis of guidance programs of Indian high schools in the United States. 101p.

Data from Haskell, Sherman, Phoenix, Santa Fé, Albuquerque, Chemawa, Stewart, Flandreau, Chilocco, Sequoyah.

Oliver, James Patterson MA 1955

Mexico City [2491] Architectural similarities of Mitla and Yagul: with a note on pottery.

Oliver, Louise D. MA 1943

The Mormons and Missouri, 1830-1839. 114p.

Kansas City [2492]

Scattered references to Indians, especially Delaware.

Oliver, Margaret W. MA 1936

Kans.-Pittsburg [2493]

The social custons of the Indians of the lower Columbia River region. $70 \mathrm{p}$.

Oliver, Winfred Allen MA 1931

The early history of the Mission of Espíritu Santo de Zúñiga and the Presidio of Nuestra Señora de Loreta, 1718-1751. 138p.

Chapters on native life and Indian troubles in the area.

Olsen, Olaf Severn PhD 1953

Colorado [2495]

A history of the Baptists of the Rocky Mountain region, 1849-1890.

Their missions to Indians of the region, including Ute, Paiute, Navajo, Pueblo. 
Olson, Ingeborg K. MA 1938

Colorado $A \& M[2496]$

The possibilities of an educational program for improving

Navaho weaving. 59p.

Olson, Marie Agnes MS $1933 \quad$ Kans.-Emporia [2497]

Landmarks in Kansas history.

Sections on "Kansas as Indian country"; "The Indian's last stand".

Olson, Olaf Ebert MA 1931 Washington [2498] History of education in the Territory of Alaska. 96p.

General treatment of Alaska; § "Natives of Alaska".

Olson, Ronald LeRoy MA $1926 \quad$ Washington [2499]

Some developments in the material culture of the Northwest Coast. $62 \mathrm{p}$.

Nootka, Kwakiutl, Haida.

Olson, Ronald LeRoy PhD $1929 \quad$ California [2500]

Unilateral institutions in native North America. PUB: "Clan and moiety in native America." U/Calif., Pubs. Amer. Archeol. Ethnol., XXXIII \#4 [1933] p351-422.

O'Meara, James Edward MA 1933 John Carroll [2501] Control of liquor traffic among the Indians of New France, and the work of the church to control it. $49 \mathrm{p}$.

O'Neale, Lita Morris PhD $1930 \quad$ California [2502] Yurok-Karok basket weavers. Р $\mathrm{Bв}$ : U/Calif., Pubs. Amer Archeol. Ethnol., XXXII \#1 [1932] p1-184, illus.

O'Neil, Marion MA 1923

California [2503] The North West Company on the Pacific slope. 112p.

O'Nem, Marion PhD 1940

California [2504] The North West Company on the Pacific slope. 327p.

Some Indian content relating to the North West Company.

O'NeILl, Kate Navin MA 1923 California [2505]

The Oñate Expedition into New Mexico: a translation of the original documents with an historical introduction and editorial notes. 193p.+translation. 
The Southern Ute of Colorado. Р Uв: Linton, Acculturation in Seven American Indian Tribes. NY: AppletonCentury Co. [1940] p119-203.

Opler, Morris Edward PhD 1933

Chicago [2507]

An analysis of Mescalero and Chiricahua Apache social organization in the light of their systems of relationship. Pub: Eggan, Social Anthropology of North American Tribes. U/Chi. Press [1937] p171-239.

Ord, Ellen Francis MA 1923 California [2508] The Rogue River Indian Expedition of 1856 (Diary of Capt. E. O. C. Ord, 3rd Art. U. S. Army, with introduction and editorial notes). 87 p., maps.

Orlans, George Harrison PhD $1926 \quad$ Illinois [2509] The influence of Walter Scott upon America and American literature before 1860. РणB: "The Indian in the metrical romance." U/Illinois Stud. [1929]; "The Romance ferment after Waverley." Amer. Lit., III [1932] p408-431.

Includes early Indian customs, legends and Indian narrative poetry.

O'Rourke, Thomas P. MA 1928

A study of the Memorial of Fray Alonso de Benavides. Pub: Amer. Cath. Hist. Soc., Rec., XXXIX [1928] p239-259.

O'Rourke, Thomas Patrick PhD 1927

Catholic [2511]

The Franciscan missions in Texas (1690-1793). PUB: Cath. U., Stud. Amer. Church Hist., V [1927] 107p.

Discusses work of missions with many tribes in Texas and northern Mexico. Also mentions Zacatecas and Querétaro training schools for friars.

ORR, Kenneth GoRdon MA 1942

Chicago [2512]

The Eufaula Mound, Oklahoma; contributions to the Spiro focus. 139p., Рбв: Oklahoma Pre., IV \#1 [1941] $15 \mathrm{p}$.

OrR, Kenneth Gordon $\quad \mathrm{PhD} 1944$

Chicago [2513]

Culture change at Kincaid: a study in statistical analysis. 293p. Рив: Faye-Cooper Cole and others, Kincaid, A prehistoric Illinois metropolis. U/Chi. Press [1951] p293-359. 
A study to determine the effectiveness of the Jay High School curriculum in meeting the needs of the Indian students. 36p.

Oklahoma Cherokee.

Osborne, Carolyn Mues MA $1941 \quad$ New Mexico [2515] An ethnological study of Michoacán in the sixteenth, seventeenth, and eighteenth centuries. $610 \mathrm{p}$.

Osborne, Homer Douglas MA 1942 New Mexico [2516] The Big Sandy Site, Henry County, Tennessee. 176p., ill.

Osborne, Homer Douglas PhD 1951 California [2517] Excavations near Umatilla, Oregon: the archaeology of the Columbia Intermontane province. PUB: Bur. Amer. Ethnol., Bull. \#166. In press.

Osgood, Cornelius Berrien PhD 1929

Chicago [2518]

The ethnology of the Northern Dene. PuB: "The ethnography of the Great Bear Lake Indians." National Mus. Canada, Bull., LXX [1931] p31-92.

OSTRANDER, Evah MA 1932 Chicago [2519] The American Home Missionary Society in Oregon, 1849-1870. 91p.

Indian missions frequently mentioned.

Otero, Michael A. PhD 1948 U.C.L.A. [2520] The American mission of Diego de Gardoqui, 1785-1789. $339 \mathrm{p}$.

Considers situation if United States went to war with the Indian: Spain promised not to interfere. Some mention of Southeast Indians.

Ott, Edward RUdolph PhD $1936 \quad$ Northwestern [2521] The influence of church and trade on French colonial policy as seen in the history of Detroit, 1700-1752.

Much on Indians, fur trade; Huron, Iroquois, Miami, Ottawa, Wea, Shawnee.

Ovnik, Catherine Mary MA/Ed $1950 \quad J o h n$ Carroll [2522] The missionary activities of Bishop Baraga among the Chippewa and Ottawa Indians. 76p. 
The establishment of the L'Arbre Croche Mission. 139p.

Ottawa primarily; some Huron.

Owens, Mary Lillitana PhD 1935

St. Louis [2524]

The history of the Sisters of Loretto in the trans-Mississippi West: an historical study of origins and westward expansion from 1812 to 1935 . 621p. $M$.

Scattered consideration of various Indian tribes throughout the area. Especially their first school (Osage). Valuable Indian bibliography.

OwL, Henry McClain MA 1929

No. Carolina [2525]

The Eastern Band of Cherokee Indians before and after removal. $180 \mathrm{p}$.

Oxendine, Cliffton MA 1934

Geo. Peabody [2526]

A social and economic history of the Indians of Robeson County, North Carolina. 63p.

Origin unknown: Cherokee, or White's Colony plus coastal Indians.

OXLEy, James RAy MA 1938

Phillips [2527]

Indian education in Oklahoma. 64p.

Paape, Charles William PhD $1946 \quad$ Illinois [2528] The Choctaw Revolt, a chapter in the intercolonial rivalry in the Old Southwest. 186p.

Packer, Ethel MA 1932

Columbia [2529]

Arizona-some adjustments to an arid environment. 57p., maps.

Includes material on aboriginal irrigation and farming techniques.

Padden, Robert Charles MA 1954 California [2530] Ecclesiatical conflict in New Spain, 1553-1574. 120p.

Mexican Indians.

Paddock, JoHn G. MA 1953 Mexico City [2531] The Mixe: an ethno-demographic study. 178p. Рuв: América Indígena, XIV \#4 [1954] p303-314.

Uses census data, descriptive material, and comparative data on other Oaxacan groups. 
Padelford, Philip Sidney

MA 1936

Washington [2532]

The Ordinances of 1784 and 1787.

As they affected Indian lands, cessions and treaties.

Page, A. Nayland MA 1953 Texas $A \& I$ [2533]

The United States Indian policy in relation to the Nez

Percé Indians of Idaho. 136p.

Patne, Charles Raymond Ma 1938

Oklahoma [2534]

The Seminole War of 1817-1818. 120p.

Panne, Gregory Lansing PhD 1924 Chicago

James Fenimore Cooper as an interpreter and critic of America. Рणв: "The Indians of the Leatherstocking Tales." Studies in Philology, XXIII [1926] p16-39.

Much on Cooper's Indians and his sources.

Paine, Henrietta Nash and JANE LESLIE LyMAN

MPH 1943

Yale [2536]

A survey of the public health work in the Republic of Guatemala. 324p., illus.

Indian in passim throughout.

Patnter, Burton Charles MA 1936

Pittsburgh [2537] The Delaware Indians and the American Revolution.

Paisley, Homer Samdel MA 1929

A short history of the Navahos. 87p.

Ohio State [2538]

Palerm Vich, ÁNgel MA 1956

Origen de la civilización urbana en Mesoamérica.

Palm, Mary Borgias PhD 1931

St. Louis [2540]

The Jesuit missions of the Illinois country, 1673-1763.

265p. PUB: Cleveland: Pvtly [1933] 138p.

Palm, Rufus Atwood, JR. MA 1930

New Mexico [2541]

New Mexico schools from 1581-1846. 82p.

Spanish mission schools, including Pueblo and Apache Indians.

Palmatary, Helen Constance MA 1936 Pennsylvania [2542] The ceramic art of the Tapajós Indians and its relation to pottery design in cultures to the north. 95p. PUB: "The pottery of Marajó Island, Brazil." Amer. Philos. Soc., Trans., XXXIX pt. 3 [1949] p261-470, illus. 
Der Einfluss der Neuen Welt auf den deutschen Wortschatz, 1492-1700.

The influence of the New World on German vocabulary. Includes lists of such words, including many Indian terms, tribal names, etc. Many early German travel descriptions.

Panyity, Patricia Helen MA 1949 Stylistic devices in Ojibway folk tales. $48 \mathrm{p}$.

California [2544]

Papen, Helen MA 1919

Spanish explorations in the interior of California, 1804-1821. 176p.

Park, Willard Zerbe PhD 1936

Yale [2546]

An analysis of Paviotso shamanism: a study in cultural relationships. 233p. PUв: "Shamanism in western North America." Northwestern U., Stud. Soc. Sci. \#2 [1938] $166 \mathrm{p}$.

Parker, Brder Logan MA 1925

Texas [2547]

Indian affairs and the frontier of Texas, 1865-1880. 134p. maps.

Parker, Elizabeth

MA 1939

California [2548]

The Creek Indians in Spanish Indian policy. 186p.

Parker, Franklin Dallas PhD 1951

Illinois [2549]

The histories and historians of Central America to 1850. 253p. $M$.

Considers books and writers of Central American history; includes Indian studies, especially Bernal Díaz del Castillo, Popol Vuh, Memorial de Sololá.

PARKer, Irene Louise

MA 1934

Fordham [2550]

Religion and astronomy, the dominant influences on the culture and civilization of the Mayas. 50p.

Parker, Isabel Margaret MA 1927 California [2551] Apache troubles in the Southwest. 158p., map.

Parker, Mary-Braeme PhD $1953 \quad$ Louisiana [2552] A study of the speech of the Nanticoke Indians of Indian River Hundred, Sussex County, Delaware. 331p. 
PARKer, Robert J. MA $1930 \quad$ California [2553] The Iroquois and the Dutch fur trade, 1609-1664. 101p., maps.

Parker, Robert J. PhD 1932 California [2554] The Iroquois and the Albany fur trade, 1609-1701. 191p.

Parkins, Almon Ernest PhD $1914 \quad$ Chicago [2555] The historical geography of Detroit. 356p. PuB: Mich. Hist. Comm., Univ. Ser., III [1918] 365p.

Various tribes of the area considered.

Parkins, Van Kirk VRigham MA 1935 Colorado Coll. [2556] A history of the Indian activities in the Pike's Peak region. 54p., map.

Parkman, Francis $\quad$ PhD 1930

Harvard [2557]

The French in Louisiana, 1699-1712.

French-Indian relations in Mississippi Valley area; especially Choctaw, Chickasaw, Creek.

Parks, Harry G. MA $1934 \quad$ Colorado State [2558] Removal of Indians from Kansas. 102p., maps.

Parks, Mance E. MA 1941

Sam Houston [2559] Federal forts established in Texas, 1845-1861. 82p.

Indian frontier background.

Parks, Mary Hitchcock MA 1937 Oklahoma [2560] A free association vocabulary of Pueblo Indians in the fifth and sixth grades. 65p.

New Mexico Pueblo Indians.

Parlati, Mary Aurelia MA 1952 Fordham [2561] The Indianista novel in Peru, Bolivia, and Ecuador.

Parmelee, Egbert Nelson MA 1905 Washington [2562] Early missions of Old Oregon. 111p.

Flathead and Cayuse.

Parrish, Cora Hoffinan MA $1948 \quad$ Oklahoma [2563] The Indian Peace Commission of 1867 and the Western Indians. $89 \mathrm{p}$. 
Parsell, Alfred P., JR. PhD 1948

New York [2564]

Social change and social control in an American Indian tribe. $317 \mathrm{p}$.

Yokayo Pomo of Ukiah, California.

Parsons, David $\quad \mathrm{PHD} 1940$

Oklahoma [2565]

The removal of the Osage from Kansas. 294p.

Parsons, James Jerome, JR. PhD 1948 California [2566] Antioqueño colonization in western Colombia: an historical geography. Рणв: U/Cal: Ibero-Americana, II \#32 [1949]

The Raza Antioqueña: Negro and Indian fusion with BasqueAsturian immigrants. Now an independent enclave.

Parsons, Phyllis R. MA 1950

Wyoming [2567]

The trans-Mississippi West in selected popular magazine literature, 1820-1870. An annotated bibliography. 82p.

Considerable Indian references.

Partoll, Albert John MA 1930

Montana [2568]

The Salish: Spartans of the West. 53+13p.

Paschal, Herbert Richard, JR. MA 1953 No. Carolina [2569] The Tuscarora Indians in North Carolina. 166p.

PAssin, Herbert MA 1941

Chicago [2570]

The place of kinship in Tarahumara social organization. $75 \mathrm{p}$.

Patterson, Dorothil Desmond MA 1942 Columbia [2571] Captain John Smith: an analysis of his ability as a historian. $87 \mathrm{p}$.

Includes section on Pocahontas.

Patton, Bessie Jane MA 1942 The Nez Percés Indians in the Northwest Territory.

Padl, Benjamin David PhD 1942

Ritual kinship: with special reference to god-parenthood in Middle America. 156 p. $M$.

Paul, Hateite Belde MA 1917 California [2574] The Garcés reports on the Southwestern Indians. 232p. 
Paul, Irven PhD 1946

Hartford [2575]

Acculturation in Chile; a study of the relations of evangelical Christianity to Christian culture with a view to the formulation of effective missionary principles and practices. $314 \mathrm{p}$.

$\S 2$ "Background and development of Chilean society"; Indians of Chile.

Paul, Mary Elizabeth MA 1932

Illinois [2576]

The Indians of the Illinois Territory from 1815 to 1818. $50 \mathrm{p}$.

Chippewa, Fox, Kickapoo, Menomini, Sauk, Winnebago, Potawatomi, Ottawa.

Paxson, Frances D. MA 1927

The Indian in American drama. 103p.

Iowa [2577]

Payne, Lois Estelle $\quad$ MA 1935

Stanford [2578]

A brief history of the education of the Indians of Oregon and Washington. 179p.

Paz, Lyda Averill MA 1937

Yale [2579]

A comparative study of Southwestern culture. 79p., illus., photos.

Subtitle: "Ethnographic study of the Koasati Indians". Also compares with Creek, Chickasaw, Alabama, Yuchi, Catawba, Cherokee, etc.

Pearce, Roy Harvey PhD 1945 Johns Hopkins [2580]

The Indian and the American mind, 1775-1800: a study in the history and impact of primitivistic ideas. PUB: The savages of America: a study of the Indian and the idea of civilization. Johns Hopkins U. Press [1953] 252p., illus.

Pearce, William Martin MA 1937 Texas Tech. [2581] A study of Arrowhead Site. 142p.

Glorieta, New Mexico.

Pearson, Alice Laurine

MA 1939

Colorado [2582] The Upper Peninsula of Michigan in literature.

A study of fiction and poetry, including Indian legends and historical background. 
Peckham, Edmund T.

The halibut fishery of the Pacific Northwest. 2 vols., 559p. $\S 1$ "The Indian fishery".

Penfold, Douglas John

MA 1951

West. Ontario [2584]

A study of the scholastic aptitude of the Indian children on the Caradoc Reserve. $47 \mathrm{p}$.

Caradoc Reserve (Canada): Chippewa, Muncey, Oneida.

Pepper, Pearl MA 1942

Alabama Poly. [2585]

The Creek Indian question in Alabama, 1832-1837.

Pérez San Vicente, Guadalupe

Diosas y mujeres aztecas. 228p.

Perham, Dorothy Elizabeth MA 1926

Wisconsin Indians since 1760. 68p.

MCH 1944 Mexico [2586]

Perkins, George O. MA 1954

The early history of Val Verde County. 152p., illus.

Chicago [2587]

Texas: Comanche, Lipan, Apache, Jumano.

Perkins, Jennie Caroline MA 1926

Alabama [2589]

The Cherokee Nation of Indians. 66p.

Perkins, Robert Nathal MA 1937 So. California [2590] Anglo-French relations in the Ohio Valley on the eve of the Seven Years' War. 1748-1756.

$\S 1$ "Description of Indians of the Ohio Valley-Indians as middle men-Intrigues with the Indians".

Perkinson, Mary O. M/Ed 1945

Kentucky [2591]

Development of weaving as a possible satisfying home industry among the Pueblo Indians of New Mexico. 118p.

Pershing, Benjamin Harrison PhD 1928 Chicago [2592] Winthrop Sargent: a builder in the Old Northwest. PUB : Ohio Archeol. Hist. Qtly., XXXV [1926] p583-602.

Pessoa, Maria Alice Moura

MA 1948

Columbia [2593] A bibliographic study of the Deluge Myth in the Americas. $68 \mathrm{p}$.

Pester, James LynN MA 1951

Washington [2594] The history of Indian education in the State of Washington. 260p., map. 
Petellin, Alexander Alvin MA 1938 Washington [2595] A course of study in hygiene for native children of Alaska. 82p.

Peters, Gladys Arlene MS 1934 Kansas [2596]

A study of certain interests and their relation to vocabularies in Indian high school students. 41p.

A study of Haskell Institute Indians; tribes unnamed.

Peters, John Leland MA 1938 Oklahoma [2597] The influence of the missionaries to the Cherokee Indians, 1800-1860. 90p.

Peterson, Alfred MA 1937 Arizona [2598] Development of design on Hohokam red-on-buff pottery.

Peterson, Charles L. MA 1954

Ohio [2599] A mural depicting the important themes of Longfellow's "The Story of Hiawatha". 32p.

Peterson, Ethel M. MA 1934 Oregon [2600] Oregon Indians and Indian policy, 1849-1871. 161p. Puв: U/Oregon Thesis Ser. \#3 [1939] 82p.

Peterson, Frederick A. MA $1949 \quad$ Mexico City [2601] The ancient Mexican fiesta of Toxcatl. 172p.

Peterson, Helen Hoff $\quad$ MA 1933

Ohio State [2602] The Moravians in the South.

In 1735 came to Georgia to convert Indians.

Petrullo, Vincenzo PhD 1934

Pennsylvania [2603]

The diabolic root: a study of peyotism, the new Indian religion among the Delawares. Р U/Penna. Press [1934] 185p.

\section{Pettit, Paul Brdce $\quad$ PhD 1949}

Cornell [2604]

The important American dramatic types to 1900: a study of the Yankee, Negro, Indian, and Frontiersman.

Pettitt, George Albert $\quad$ PhD $1940 \quad$ California [2605]

Primitive education in North America: its processes and effects. Pub: U/Calif., Pubs. Amer. Archeol. Ethnol., XLIII \#1 [1946] p1-182. 
Distinguishing characteristics of homemaking programs in Oklahoma Indian schools. 68p.

Pfaller, Louis L. MA 1950

Loyola [2607]

Catholic missionaries and the Fort Berthold Indians before 1889. $153 \mathrm{p}$.

Pfeil, Violet MA 1927

"The Spanish missions of Texas". A source book. 84p.

An annotated bibliography with comments on the source material and missions.

Phelan, John Leddy PhD 1951

California [2609]

The Franciscan City of God in the New World: a study of the writings of Gerónimo de Mendieta (1525-1604).

Especially his Historia eclesiástica indiana.

Phillits, Alpa Ruth MA 1930

Tennessee [2610]

British regulation of the Indian trade in the Old Southwest. 121p.

Philuips, Clifton J. PhD 1954 Harvard [2611]

Protestant America and the pagan world: the first half century of the American Board of Commissioners for Foreign Missions, 1810-1860. 2 vols.

$\S 4$ "The heathen at home".

Phillips, Henry DeWitt MA 1921

California [2612]

Paló's Noticias de la Nueva California: a translation of a portion of the work, with introduction and linguistic and historical notes. $109 \mathrm{p}$.

Phillips, Philis $\quad$ PhD 1939

Harvard [2613]

Introduction to the archaeology of the Mississippi Valley. 3 vols., 768 p., illus.

Pickering, John D. MA 1953

Chico [2614]

A survey of the incorporated schools of Alaska and selected Alaska Native Service schools with special emphasis on the industrial education program.

Pickett, Velma Bernice MA 1951

Cornell [2615]

Verb structure in Isthmus Zapotec. PUB: Intl. Jour. Amer. Ling., XIX, XXI [1953, 1955] var. pp. 
Pickett, William Poole MA 1941 Alabama Poly. [2616] The imperial and diplomatic significance of Indian trade in the struggle for the Old Southwest, 1670-1763.

Pierce, Burnett Cecil MA 1932 Colorado [2617] Titus County, Texas; its background and history in antebellum days.

Caddo tribes.

Pierce, Joe Eugene MA 1952 Indiana [2618] Degree of linguistic relationships among the Shawnee, Kickapoo, Ojibwa, and Sauk-and-Fox. 51p.

Pierson, Donald PhD 1939

Chicago [2619]

A study of racial and cultural adjustment in Bahía, Brazil. 245p. Рणв: Negroes in Brazil. U/Chi. Press [1942] 392p.

A study emphasizing the place of the Negro in interracial mixtures with Portuguese and Indians.

Pierson, Lloyd M. MA $1949 \quad$ New Mexico [2620] The prehistoric population of Chaco Canyon: a study in methods and techniques of prehistoric population estimation. $90 \mathrm{p}$.

Pike, Judith Johnstone MA $1953 \quad$ Trinity [2621] A study of place names in Middletown, Connecticut. $123 p$.

Section of Indian names, plus frequent references throughout.

Pilpel, Emily Marion MA 1929

Yale [2622]

A psychological analysis of some primitive mythologies, based upon Eskimo, East Siberian and Nigerian material. 38p. + appendix.

Piña Chan, Román MA 1956

Mexico: $E N$ [2623]

El horizonte preclásico del Valle de México. PuB: Las culturas preclásicas de la Cuenca de México. México: Fondo de Cultura Ecónomica [1955] 115p., illus.

Pineo, Peter Camden MA 1955

Brit. Columbia [2624]

Village migrations of the modern Kwakiutl. 89p. 
Place-names of New Hampshire. Physical features from origins to $1857.158 \mathrm{p}$.

Includes place-names of Indian origin.

Pirie, ZinLah MarJorie MA 1935

Claremont [2626]

The introduction of the mental hygiene program at Sherman Institute through a child guidance clinic. 110p.

Pitney, Elizabeth Halsted PhD 1940

Yale [2627] The physical size and growth of Pueblo Indian children. $167 p$. , illus.

Pittman, Richard Saunders

MA 1948 Pennsylvania [2628] Some recent trends in the methodology of descriptive grammar with an application of these to a description of Nahuatl. 53p.

Pittman, Richard Saunders

PHD 1953 Pennsylvania [2629] A grammar of Tetelcingo (Morelos) Nahuatl. 125p. $M$ PUB: Jour. Ling. Soc. Amer., XXX \#1 pt. 2 [1954] 67p. Includes verb charts, a verb index, and Nahuatl texts.

Platsance, Aloysius Frederick PhD 1954 St. Louis [2630] The United States Government factory system, 1796 to 1822. 638p.

A study of Federally-operated Indian Trading Posts.

Plaisted, Elizabeth MA 1916

Columbia [2631]

Indian relations during the last intercolonial war. $78 \mathrm{p}$.

Planer, Edward Thomas, Jr. MA 1934 California [2632] Spanish inland explorations in Alta California, 1790 to 1800. 276p., pls.

Pliego Segura, María Elena MHU 1952 Mexico [2633] Bernal Díaz del Castillo. 119p. Puв: Mexico: Taller Gráfica "El Escritorio" [1953].

Pockstaller, Theodore PhD 1919 California [2634] Juan María de Salvatierra S. J. and the establishment of the first permanent settlements in California (1697 to 1707).

Manner in which Salvatierra trained the Indians. 
Poinsatte, Charles Robert MA 1951 Notre Dame [2635]

A history of Fort Wayne, Indiana from 1716 to 1829 ; a study of its early development as a frontier village. 196p.

Many tribes considered, especially Miami.

Pollenz, Philippa MA $1947 \quad$ Columbia [2636] Some problems in the notation of Seneca dances. 89p.

Pollock, Floyd Allen $\quad$ PHD 1942 So. California [2637] Navajo-Federal relations as a social-cultural problem.

Particularly considers Collier program, Navajo reaction and cultural reasons for this reaction.

Pollock, Harry Evelyn Dorr PhD 1936 Harvard [2638] Round structures in aboriginal Middle America. 182p. PUв: Carnegie Inst. Wash., Pubs. \#471 [1936] 182p.

Ponce de Elizundia, Noemí MA $1951 \quad$ Mexico [2639] Estudio e importancia literaria de las leyendas mayas. $128 \mathrm{p}$.

Porter, Helen H. M/Ed 1955

Ohio [2640] The education of the American Indian. 115p.

Porter, Jean H. MA 1943 The frontier and Lord Dunmore's War. 89p.

Porter, Muriel Nón MA $1956 \quad$ Mexico: EN [2642] La pipa en México precortesiano. PUв: Acta Anthropologica, III \#2 [1948]

Porter, Muriel Nón PhD 1951

Columbia [2643]

The significance of Tlatilco in the study of the preclassic cultures of the New World. 149p. M Р Fund Pubs. Anthro. \#19 [1953] 104p., illus.

Posey, James BennetT MA 1928 Texas [2644]

A history of Cherokee County. 122p.

Much on Cherokee Indians in Texas.

Posey, Walter Brownlow PhD 1933 Vanderbilt [2645]

The development of Methodism in the Old Southwest, 1783-1824. Р ив: Tuscaloosa, Ala: Weatherford Prtg. Co. [1933] 151p.

§6 "Missionary efforts among the Indian". Creek, Cherokee, Choctaw. 
Yurok ritual. 307p. $M$.

\section{Post, Anita Calneh PhD 1932 \\ Southern Arizona Spanish.}

Stanford [2647]

Analyzes amount of Indian influence discernible, particularly in Nahuatl and Aztec tongues.

Post, George MS 1948

Blood group studies on the Arapahoe and Shoshoni

Wyoming [2648] Indian tribes of Wyoming. 66p.

Also compares with Blackfoot, Blood, Piegan.

Post, Richard Howell PhD 1936

Harvard [2649]

Anthropometric studies in bilateral asymmetry. 161p.

Maya.

Posthauer, Mary William MA $1948 \quad$ St. John's [2650]

La Araucana, its epical value.

Araucanian Indians of Chile.

Poston, Sidon MA 1946

The literature of the Red Lake Chippewa Indians. 31p.

Poteet, SybIL MA 1938

Texas Tech. [2652]

Occurrence and distribution of beveled knives. 46p.

Texas and eastern New Mexico.

Potter, Olive Mae MA 1924

California [2653]

The pre-Territorial history of the Iowa region, 1673 to 1838. 199p.

Poulson, Edward Thomas MA 1909

Louisville [2654]

Early missionary work of the French Jesuits in North America. 30p.

Powell, PhILIP Wayne PhD 1941 California [2655]

Military administration of the Chichimeca warfare in

New Spain, 1550-1595. PuB: Soldiers, Indians and Silver. U/Calif. [1952] 317p.

Powell, ShIRLEy J. MA 1954

So. Dakota [2656]

History of St. Mary's School. 69p.

Only private accredited Indian girl's school in United States.

Mostly Sioux. (Springfield, S. D.) 
Power, Harriet - MS/Ed 1943

Hunter [2657]

The educational growth of the Mexicans: changing concepts and their historical background. 42p.

Aztecs, early Spanish.

Power, Jessie Hazel MA $1920 \quad$ California [2658]

The Domínguez-Escalante expedition into the Great Basin, 1776-1777; translation of the original documents with introduction and editorial notes. 229p.

Powers, Margaret B. MA $1923 \quad$ Wisconsin [2659] The elimination of the Indians from Mississippi Territory. $73 p$.

Praus, Alexis Aless MA $1943 \quad$ Yale [2660]

The South Woodstock Site. 146p., illus. Рuв: Archeol.

Soc. Conn., Bull. \#17 [1945] 52p., illus.

Excavation of a site at Woodstock, Connecticut.

Presant, Joan Elizabeth MA 1954 Cornell [2661]

The Indian Affairs Branch of Canada: an aspect of acculturation. $102 p$.

PrewitT, Dorothy E. MA 1923

Iowa [2662]

North American Indians in English poetry. 87p.

Price, Florence F. MA/Ed $1945 \quad$ Hunter [2663]

Unit method of approach to the understanding of history in the intermediate grades. $57 \mathrm{p}$.

Includes sections on Indians.

Price, Ralph Beviere MA 1939 Colorado [2664] The Federal Government and emigrant roads through Northern Territories to the Far West, 1856-1866.

Slight Indian mention.

Prichard, Howard Oscar MA 1950 Duke [2665] The surpression of idolatry among the Indians of Peru. $153 \mathrm{p}$.

Priest, Loring Benson PhD 1937 Harvard [2666]

The reformation of the American Indian policy of the United States, 1865-1887. PuB: Uncle Sam's Stepchildren. Rutgers U. Press [1942] 310p. 
Priestley, Herbert Ingram PhD 1917 California [2667] José de Gálvez, Visitor-General of New Spain (1765 to 1771). Рuв: U/Calif., Pubs. Hist., V [1916] 450p.

Priestley, Samuel Edward G. PhD 1950 New York [2668] The agrarian problem in Mexico. 2 vols., 624p.

Indian land systems briefly mentioned. Contemporary Indians largely considered as "rural Mexicans".

Proffitt, Ida Mary MA 1925 Oklahoma [2669]

Relations between the Cherokee Nation and the United States, 1865-1906. 116p.

Provinse, John H. PhD 1934

Chicago [2670]

The underlying sanctions of Plains Indian culture: an approach to the study of primitive law. PuB: Eggan, Social Anthropology of North American Tribes. U/Chi. Press [1937] p341-374.

Pruett, Stella Mary MA 1940

Georgia [2671]

Troup and the Georgia-Creek controversy. 119p.

Przebeszvski, Felix B. MA 1942 Arizona [2672] Achievement in reading in Indian day school compared with that made in Indian boarding school. 32p.

Navajo Reservation schools.

Puckett, Newbell NILes MA 1921

Yale [2673]

The economic importance of fire in primitive life. 100p.

General survey, including references to the Indian.

Purdy, Leonora A. MA 1941

Buffalo Bill in truth and in fiction. 108p., illus.

Iowa [2674]

$\S 2$ "Indian Scout and 'Fighter" ". Indians throughout.

Purdy, Mary Lodise MA 1941

Design in Montana Indian art. 96p., illus.

Putney, Gladys J.

and Snell W. Putney PhD 1954

Oregon [2676]

A field evaluation of acculturation theory. $420 \mathrm{p}$.

Nahuatl-speaking village in Mexico.

Putney, Snell W.

see above. 
QUASS, IVAN D. MA 1938

Nebraska [2677]

The French in the Missouri River Valley up to the Louisiana Purchase. 115p.

Considerable Indian mention; tribes of the area.

Queton, Winona W. MA 1955 Oklahoma $A \& M$ [2678] Observation of behaviour changes of children living in coöperative dormitories at Fort Sill Indian School. 68p. Various tribes, but mainly Comanche, Kiowa and Navajo.

Quinn, Jean Williams MA $1949 \quad$ Texas Tech. [2679] Excavations at Arrowhead Ruin in 1941 and 1948. 167p. Glorieta, New Mexico.

QUynN, William Rogers MA $1923 \quad$ Virginia [2680] La literatura de las colonias Norteamericanas de España, las quales son ahora parte de los Estados Unidos.

Indians figure incidentally in the literature, but only in minor roles.

RaAsch, Elaine LuCy MA 1951

Illinois [2681] The character of the Mexican Indians as described by some sixteenth century Spanish writers. 56p.

RABOLD, RaPHAEL F. MA 1920

Catholic [2682] The California missions.

RABUN, JAMES W. MA 1937 Georgia and the Creek Indians. 227p.

No. Carolina [2683]

RADER, Alice Dresser

MA 1928

Kansas [2684] The American Indian in the American novel and short story. $163 p$.

Rader, Mary LiLlian

MA 1928

Tennessee [2685]

The Southern Indians in the Revolutionary War. 108p.

RadiN, PaUL PhD 1911

Columbia [2686]

The ritual and significance of the Winnebago medicine dance. PUв: Jour. Amer. Folklore, XXIV \#92 [1911] p149-208.

RAFFELD, HERBERT MA 1947

California [2687]

The Jesuit missions of Guayrá (1588-1633). 230p., maps.

Guaraní and Caingang. 
Ragsdale, Elsie Juanita MA 1931 Geo. Peabody [2688] Aspects of Indian culture as material for missionary study. 186p., illus.

Organized lessons for use in missionary study groups; general.

Rahill, Peter James PhD 1953

Catholic [2689]

The Catholic Indian missions and Grant's peace policy, 1870-1884. PUB: Cath. U. Press [1953] 396p.

RaIlsback, G. D. MA 1940 History of Stonewall County. 106p., maps.

Hardin-Simmons [2690]

Texas. Chapter on "Indians and buffalo".

RAINER, JoHN C. MS 1952

So. California [2691]

A study of adjustment problems and a handbook for Indian students in the high schools. $82 \mathrm{p}$.

Indians of Arizona and New Mexico.

RAINES, EARL L. MA 1940

Colorado $A \& M$ [2692]

A Sacajawea pageant unit as a core for the integration of instruction. 180p.

Ratney, Cecil DuBois MA 1932

Willamette [2693]

A study of the Salem Indian High School, comparing the cultural background, the intelligence scores, the percents of White blood, and the classroom grades. 90p.

Pacific Northwest tribes.

Rainey, Froelich Gladstone

MA 1953

Yale [2694]

Sources for the ethnography of Connecticut and southern New England Indians. PUB: "A compilation of historical data contributing to the ethnography of Connecticut and southern New England Indians." Archeol. Soc. Conn., Bull. \#3 [1936] p1-89.

Ratney, Fromlich Gladstone PhD 1935 Yale [2695] Puerto Rican archaeology. 362p., illus. Рणв: Scientific Survey of Puerto Rico and the Virgin Islands, XVIII pt. 1 [1940].

Ramage, Helen MA 1916 California [2696] The Wilkes Exploring Expedition on the Pacific slope, 1841. 197p.

Mostly encounters with Clallam, Cowlitz, Spokane, Nez Percé and Blackfeet Indians. 
RAMER, LeONARd Victor MA 1936

Iowa [2697]

The migrations of the Sauk and Fox Indians. 59p.

Ramón Llige, Adela MA 1956

Mexico: $E N$ [2698]

Estudio de las puntas arrojadizas de la altiplanicie de México.

Ramona, Mary MA 1928

Catholic [2699]

The ecclesiastical status of New Mexico, 1680-1875.

Puв: Cath. Hist. Rev., n. s., VIII \#4 [1929] p525-568.

Ramsey, Edna MaE MA 1913

Northwestern [2700]

Administration of the educational affairs of the Indians

by the Government from 1871-1891. 78p.

Ramsey, Helen Gladys MA 1941

The historical background of the Santa Fé Trail. 109p.

Indians only incidental.

Ranck, Mabel Alcy MA 1926

California [2702]

The Southern Indians in Oklahoma, 1808-1860. 202p.

Cherokee, Creek, Choctaw, Chickasaw and Seminole.

RaNdall, BetTy Uchitelle MA 1947 Columbia [2703] Elaboration of the Cinderella theme. 197p.

Northwest Coast folklore, compares themes with Grimm's.

RaNds, Barbara C. MA 1954 - New Mexico [2704] Ceramics of the Temple of the Inscriptions, Palenque, Chiapas, Mexico. 161p.

Rands, Robert Lawrence PhD 1952 Columbia [2705] Some evidences of warfare in classic Maya art. 234p. $M$.

Modifies usual belief of Maya as a peaceful folk; cites Bonampak and other visual evidence.

Raney, ANgelica MA 1952

A reëvaluation of the Indian policy of New Spain, 1519-1547, showing the part of Cortés in promoting its good features. $63 \mathrm{p}$.

RAPOPORT, ROBERT NormaN MA 1949

A study of Navaho religious acculturation. 191p. 
A study of changing Navaho religious values. 396p. PUB: "Changing Navaho religious values: a study of Christian missions to the Rimrock Navahos." Harvard U., Peabody Mus., Paps., XLI \#2 [1954] 152p.

Raschke, Catherine Aloyce EdD 1950 New York [2709] Mexico, our nearest Latin-American neighbor: a resource unit. $150 \mathrm{p} . M$.

Includes Mexican Indian culture as a resource.

Rather, Ethel Zivley MA 1903 Texas [2710] DeWitt's Colony. Рбв: U/Texas Bull. \#51 [1905] 96p. Chapter on relations of the Colony with the Indians.

RATHSBERger, HULdA JEANNE MA 1940 California [2711] Early French trade and settlement in California. 110p. Indian content incidental to fur trading.

RaUPe, Alice Browne MA 1939 Ollahoma $[2712]$

The Northern Indian Territorial refugees during the Civil War. 88p.

RAdZi, ERnest MA 1934

Wyoming [2713]

The fur men of the Missouri and its tributaries, 1822 to 1834. 66p.

Includes Indian trade, skirmishes, etc.

RAy, Verne Frederick MA 1933 Washington [2714]

The Sanpoil and Nespelem: Salishan peoples of northeastern Washington. 237p. PUв: U/Wash. Pubs. Anthro. \#5 [1932] 237p., illus.

Ray, Verne Frederick PhD 1938

Yale [2715]

Cultural relations in the Plateau of northwestern America. 224p., maps. Р Uв: Sowest. Mus., Pubs., F. W. Hodge Anniv. Pub. Fund, II [1939] 154p., maps.

Read, Lena Margaret MA 1926

Famous scouts of the West, 1825 to 1850.130 p.

California [2716]

Largely concerns Blackfeet, Apache and Ute. 
Reagan, Albert B. PhD 1925 Stanford [2717] Contributions to the geology of the Navajo country, Arizona, with notes on the archeology. 411p.

Records, Ralph Hyden PhD 1936

Chicago [2718]

Land as a basis for economic social discontent in Maine and Massachusetts to $1776.379 \mathrm{p}$.

Includes material on Indian land.

REDField, Robert PhD 1928

Chicago [2719]

A plan for a study of Tepoztlán, Morelos. 248p. PuB:

Tepoztlán: a Mexican village. U/Chi. Press [1930] 247p.

Redwine, BaIRd AlbIan MA 1931

Colorado [2720]

Indian relations in Arkansas. 121p.

Caddo, Cherokee, Osage, Quapaw.

Reed, Erik Kellerman PhD 1944

Harvard [2721]

An archaeological study of Mancos Valley, southwestern Colorado, and its position in the prehistory of the American Southwest. 255p., photos.

Anasazi culture.

Reed, Joe Dudley

MA 1941

New Mexico [2722]

The early basis of subsistence of the Indians in the Plains area. 100p.

Reese, Pauline MA 1938

Texas $A \& I$ [2723]

The history of Padre Island. Illus.

Several sections on Karankawa Indians of Texas.

Reetz, Charles Alvin MA 1949

Oregon [2724]

The cultural position of the Klamath semi-subterranean earth lodge in western North America. 114p.

Reeve, Frank Driver PhD 1937

Texas

[2725]

The Federal Indian policy in New Mexico, 1858-1880.

Pub: New Mex. Hist. Rev., XII-XIII [1937-1938] var. pp.

Reeves, Elton Traver

MA/Ed 1939

Washington

An historical study of the "Old Cataldo Mission" and its effect on education in the North West.

Flathead, Iroquois, Couer d'Alene, etc. Much data on Indianmission relations. 
Regan, Dora Frances MA 1948 Kans.-Pittsburg [2727] The Navajo arts, crafts, ceremonials, and education. $109 \mathrm{p}$.

Includes personal interviews plus library research.

Reichard, Gladys Amanda MA $1920 \quad$ Columbia [2728] Literary types and dissemination of North American myths. 46p.

Indian tribes in general.

Reichard, Gladys Amanda PhD 1926 Columbia [2729] Wiyot grammar and texts. Pub: U/Calif., Pubs. Amer. Archeol. Ethnol., XXII \#1 [1925] 215p.

Reid, Ida Christina PHM 1910

Chicago [2730]

The relation of the Apache Indians to the development of Arizona. 64p.

ReID, Robert LynN MA 1947

The early history of Fort Bliss. 119p.

Baylor [2731]

$\S 5$ "Indians".

Reifel, Benjamin PhD 1952

Harvard [2732]

Relocation on the Fort Berthold Reservation; problems and programs. $496 \mathrm{p}$.

ReImer, Arthur Louis MS/Ed 1947 So. California [2733] Mexican Indian folk music and its educational values.

Seven tribes: Aztec, Zapotec, Huichol, Tarascan, Otomí, Mazatec.

Reina, Ruben Elias MA $1950 \quad$ Michigan State [2734] Peru-survey of cultural areas in terms of acculturation. $148 p$.

Several Indian tribes of Peru, especially Inca.

Reiter, PaUl

MA 1933

New Mexico [2735]

The ancient pueblo of Chetro Ketl. 76p.

Reiter, Paul

PнD 1946

Harvard [2736]

Form and function in some prehistoric ceremonial structures in the Southwest. 323p., illus.

Reiter, Robert Louis MA 1953 California [2737]

The history of Fort Union, New Mexico. 
Reiter, Winifred Stamm MA $1933 \quad$ New Mexico [2738]

Personal adornment of the ancient Pueblo Indians. 98p.

Rendón Mayoral, Silvia MA 1956 Mexico: $E N$ [2739]

Examen de la decoración aplicada en las alfarerías de Cuautitlán, Estado de México, con una introducción al estudio de la cerámica popular mexicana.

Renner, George Thomas, JR. PhD 1927 Columbia [2740] Primitive religion in the tropical forests, a study in social geography. PUB: Pvtly. [1927] 111p.

Includes Yuracaré Indians and others of Amazonia; also Indians of Guiana.

RENNER, ROBERT V. MA 1952

Oregon [2741]

Archbishop Seghers and the Indian missions of Grand Ronde and Umatilla. 119p.

Rett, Donald James MA 1953

Penna. State [2742]

The afterlife among the preliterates.

Eskimo considered.

Reuter, Edward Byron PhD $1919 \quad$ Chicago [2743]

The mulatto in the United States, including a study of the rôle of mixed-blood races throughout the world. 417p. Рuв: Boston: Badger [1918] 417p.

Section on Indian mixed-bloods.

Reyburn, William David PhD 1952 Pennsylvania [2744] Cherokee verb morphology. 125p. Рणв: Intl. Jour. Amer. Ling., XIX-XX [1953-1954] var. pp.

Reyes, Stephen Antonin MA 1951 So. California [2745] Mexican customs and traditions as depicted in the works of Gregorio López y Fuentes.

Includes Mexican Indians.

Reynolds, Alfred WADE MA $1928 \quad$ California [2746]

The Alabama-Tombigbee Basin in international relations 1701-1763. 324p.

Choctaw, Chickasaw, Creek, Tohome, Mobile and Naniaba Indians. 
Some chapters in the history of the Bitter Root Valley. $104 \mathrm{p}$.

Flathead, Snake, Blackfeet, Piegan, Iroquois, Nez Percé, Sioux, Pend d'Oreille.

\section{Reynolds, JACK AdolPhe PHD 1941 Louisiana [2748]} Louisiana place-names of romance origin.

Includes section on Gallicized Indian names.

Rhodes, Benjamin F. MA 1920

Oklahoma [2749]

The opening of the Cherokee Outlet. $76 \mathrm{p}$.

Rice, Bernadine MA 1941

Texas [2750]

San Antonio, its early beginnings and its development under the Republic. $138 \mathrm{p}$.

$\S 4$ "Mexican and Indian invasions (1836-1846)".

Rice, Irene MA 1922

Yale [2751]

The policy of land distribution in Enfield, Connecticut, 1650-1750. 102p.

Brief section on "Purchases from the Indians".

Rice, Virginia Downs MA 1932

History of Bryan County before and after statehood.

Five Civilized Tribes of Oklahoma.

Rice, Boydie EtTa MS 1936

Kansas [2753]

A study of the relation between the degree of Indian blood and specific tribe and intelligence and scholastic marks of the American Indian. 77p.

At Haskell. 40 tribes, especially Cherokee, Creek, Choctaw, Chickasaw, Ottawa, Potawatomi, Sac-Fox.

Richards, Arthur Lee MA 1922

Chicago [2754]

The distribution of the lands of the Five Civilized Tribes. $71 \mathrm{p}$.

Richards, Elizabeth Ann MA 1946

Chicago [2755]

A comparative study of a series of crania from Dutch Harbor, Alaska. 143p.

Richards, Hons Coleman

MA 1936

Texas [2756]

The establishment of the Candelaria and San Lorenzo

Missions on the Upper Nueces. 75p., illus.

Lengthy consideration of Indians of the area. 
RichaRd, Robert L. MA 1951 Kansas

Indian removal in Florida, 1835-1842: a study of the causes and conduct of the Seminole War. 139p.

Richardson, Hazel Marie MA 1940

Oklahoma [2758] Shawnee Indians in Oklahoma. 88p.

Richardson, Jane Hanks PhD $1944 \quad$ Columbia [2759] Law and status among the Kiowa Indians. Pub: Amer. Ethnol. Soc., Mono., I [1940] 136p.

Richardson, Rupert Norval PhD 1928 Texas [2760] The Comanche Indians, 1820-1861. 537p., maps. Рuв: The Comanche barrier to Northern Plains settlement. Glendale: A. H. Clark [1933] 424p.

RICHERT, ROLAND MA 1939

Arizona [2761]

A comparative study of Southwestern milling stones. $67 \mathrm{p}$.

Rickard, Margaret Brown MA 1949 California [2762] The drainage of Mexico City during the colonial period. $116 \mathrm{p}$., maps.

Chapter on Aztec dikes and causeways.

Rickert, EmIL August MA 1929

The Moravian missions in North America.

Ohio State [2763]

Chapter on Indian missions. Several sections on Indians.

Ricketson, Oliver Garrison, JR. PHD 1933 Harvard [2764] Stratigraphy and its interpretation at Uaxactun, Guatemala. 3 vols. PuB: "Uaxactun, Guatemala, Group E, 1926-1931." Carnegie Inst. Wash., Pubs. Amer. Archeol. Ethnol. \#477 [1937] 314p., illus.

Includes physical anthropology, material culture, and survey of the geographical environment.

Ricketts, William Boyce MA 1941 California [2765] Exploration of the southwestern borders of the Louisiana Purchase, 1803-1807. 189p.

Spanish attempts to establish Indians as buffer against settlers. RICkEy, Don MA $1951 \quad$ Oklahoma $A \& M$ [2766] Firearms in the Indian wars, 1862 to $1891.117 \mathrm{p}$. 
Ricks, JoEL Edward

PHD 1930

Chicago [2767]

Forms and methods of early Mormon settlement in Utah and the surrounding region, 1847-77.

Indian-White relations, effect of Indian upon type of settlement, warfare.

Ridd, Dwight Nugent $\quad$ MA 1934

Manitoba [2768]

The second Riel Insurrection. 115p.

Métis of the area.

Ridd, JoHn ELwood MA 1934

Manitoba [2769]

The Red River Insurrection, 1869-1870. 109p.

Métis of the area.

Riddeld, Dorothy M. PHD 1954

The late Ica pottery of ancient Peru. 248p. $M$.

Max Uhle collection of Ica pottery at the U/Calif. Museum of Anthropology.

Riddeld, Francis Allen MA 1954 California [2771] Climate and the aboriginal occupation of the Pacific coast of Alaska. 99p.

Rider, Rowland Vance MA 1938

Syracuse [2772]

Socio-economic survey of the Onondaga Indian Reservation. $151 \mathrm{p}$.

Ridgway, Charles William MA 1951 Ariz.-Tempe [2773] A philosophy of curriculum for Papago Indian day schools. $57 \mathrm{p}$.

Ridout, Lionel Uthey MA 1940

California [2774]

Fermín Francisco de Lasuén and the economic development of the California missions. 193p., illus.

Slight Indian mention.

Rieder, Donald Frederich MA 1951 Pennsylvania [2775] Irrigation agriculture in the pre-Columbian Southwest and Meso-America. 68p.

Ries, Carol E. MA 1950

Arizona [2776]

Indigenous views of the European conquest of Mexico as encountered in the Crónicas and the Indigenista writers. $159 \mathrm{p}$. 
Ries, Madrice MA 1940

Louisiana [2777]

Historical anthropology of the conquest of Española.

Taino and Arawak; many maps.

Riggs, Robert Edward MA 1928

California [2778]

Aboriginal American contributions to architecture. 54p.

Mostly Maya.

Riggs, Venda Joy MA 1949

Indiana [2779]

Alternate phonemic analyses of Comanche. 12p. РणB:

Intl. Jour. Amer. Ling., XV [1949] p229-231.

Riley, Arthur Joseph PhD $1936 \quad$ Catholic [2780]

Catholics in New England to 1788. Рuв: Cath. U., Stud. Amer. Church Hist., XXIV [1936] 479p.

Riley, Carroll LaVerne PhD 1952 New Mexico [2781] The blowgun in the New World. PUB: Sowestn. Jour. Anthro., VIII \#3 [1952] p297-319; U/Colo. Studies, Ser. in Anthro. \#4 [1954] p78-89.

Riley, Glyndon M. MA 1939

West Texas [2782]

The history of Hemphill County. 135p.

Texas Cheyenne, Comanche, Kiowa.

RiLey, Robert Milton MS 1923

Kansas [2783]

A study of the performance of some American Indian students in selected intelligence and educational tests. $104 \mathrm{p}$.

Rinaldo, JoHn Beach MA 1937

Chicago [2784]

The Père Marquette Park Sites. 70p.

Rinaldo, John Beach PhD 1941

Chicago [2785]

An analysis of prehistoric Anasazi culture change. 271p. PUB: "An analysis of culture change in the AckmenLowry area." Chi. Mus. Nat. Hist., Fieldiana, XXXVI \#5 [1950] 14p.

Rioux, Marcel MA 1951

Montréal [2786]

Introduction à l'étude des Iroquois modernes. $92 \mathrm{p}$.

Ripley, June Evelyn MA 1950

Mexico City [2787]

A survey of published texts in Nahuatl: 1890-1950. $136 \mathrm{p}$. 
Rister, Carl Coke PhD 1925

Geo. Washington [2788]

Texas frontier defense, 1865-1881. Рuв: The Southwestern frontier, 1865-1881. Cleveland: A. H. Clark [1928] 311p.

Kiowa, Comanche, Cheyenne, Arapaho, Apache.

Ristuccia, Leon MA 1946

St. Bonaventure [2789]

A survey of the work of the friars among the California Indians (1769-1833). 66p.

Ritchie, Whiliam Augustus MS $1938 \quad$ Rochester [2790]

A perspective of northeastern archaeology. 100+125p., illus. PuB: Amer. Antiq., IV \#2 [1938] p94-112.

Ritche, William Augustus PhD 1944 Columbia [2791] The pre-Iroquoian occupations of New York State. PUв: Rochester Mus. Arts Sci., Mem. \#1 [1944] 416p., illus.

Ritzenthaler, Robert Eugene MA 1940 Wisconsin [2792] The cultural history of the Wisconsin Oneidas. PUB: "The Oneida Indians of Wisconsin." Milwaukee Public Mus., Bull., XIX \#1 [1950] p1-52.

Ritzenthaler, Robert Eugene PhD 1950 Columbia [2793] Chippewa preoccupation with health; change in a traditional attitude resulting from modern health problems. M. Рuв: Milwaukee Public Mus., Bull., XIX \#4 [1953].

Roach, William Lloyd PhD 1937

Stanford [2794]

The Federal endowment of education for Oklahoma.

Traces treaties, land accessions, and uses to which Indian Territory lands were put.

Robbins, Evelyn Good EdD $1949 \quad$ New York [2795] The handcrafts-a manual for teachers and prospective teachers of art. 210p., illus., col. pls.

Extensive consideration of Indian arts and crafts.

Robe, CeciL F. PhD 1943

Yale [2796]

The penetration of an Alaskan frontier; the Tanana

Valley and Fairbanks. 224p.

Describes Indians of the Tanana area.

Roberts, Alvin B. MA 1938

Iowa [2797]

The history of the Dickson Mound Builders. 60p.

Early occupants of the Fulton County area, Illinois. 
Roberts, Edward Graham PhD 1950

Virginia [2798]

The roads of Virginia, 1607-1840.

Pt. 3 considers effect of Indian hostility, and influences of early Indian trails.

Roberts, Elizabeth Ellinwood $\quad$ MA 1920 California [2799]

The Spanish missions at Yuma, 1779-1781. A translation of the original documents with introduction and notes. 401p.

Yuma Indians.

Roberts, ERnest EdWARd MS 1934 West Virginia [2800] Indian relations from 1783-1796. 66p.

Northwest Territory.

RoBerts, EUla May MA $1929 \quad$ Oklahoma [2801]

A history of the Kiowa and Comanche Indians in Oklahoma. 79p.

Roberts, Frank Harold Hanna PhD 1927 Harvard [2802]

The ceramic sequence in the Chaco Canyon, New Mexico, and its relation to the cultures of the San Juan Basin. 2 vols.

ROBERTS, JoAN MA 1939

Oklahoma [2803]

Missions and mining activities among the Creek Indians, 1832-1900. 102p.

Roberts, JoHN Mrton $\quad$ PhD 1947

Yale [2804]

The Navaho household: a comparative analysis of a small cultural unit. PणB: "Three Navaho households: a comparative study in small group culture." Harvard $U$., Peabody Mus., Paps., XL \#3 [1951] 87p.

Robertson, Elmer Arthur MA 1941

Nebraska [2805] Indian relations in the region of the Upper Platte Agency. 98p.

Robertson, Frank Delbert MA 1942 Arizona [2806]

A history of Yuma, Arizona, 1540-1920. 165p.

Brief mention of Yuma Indians in connection with early Spanish contacts, efforts of missionaries and fur trappers.

Robertson, RUTH EdNA MA $1911 \quad$ Stanford [2807] The diaries of the second and third expeditions of Father Garcés, 1770-1771.

Translated and edited. 
Robin, Enid Fenton

Indian girl, White girl. $77 \mathrm{p}$.

Columbia [2808]

Comparative study of Pomo and White girls; Ukiah, California.

Robin, Frederick Ellioti

MA 1941

Columbia [2809]

Culture contact and public opinion in a bi-cultural community. 149p.

Pomo in Ukiah, California.

Robinett, Florence Marie PhD $1954 \quad$ Indiana [2810] Hidatsa grammar. 132p. M. Рणв: Intl. Jour. Amer. Ling., XXI [1955] var. pp.

Texts included.

Robinson, Dorothy FuLwLer MA 1929 So.California [2811] A brief history of the Apaches from 1848 to 1864. 135p., illus.

Robinson, Frederick S. MA 1955

Niagara [2812]

The American frontier in the novels of James Fenimore Cooper. 11p.

Robinson, WALter StTTt, JR. MA $1941 \quad$ Virginia [2813] Indian policy of Virginia during the seventeenth century.

Robinson, Walter Stitt, JR. $\quad$ PhD $1950 \quad$ Virginia [2814] Indian policy of colonial Virginia. PUB: "The legal status of the Indian in colonial Virginia." Virginia Mag. Hist. Biog., LXI [1953] p247-259; "Indian education and missions in colonial Virginia." Jour. So. Hist., XVIII [1952] p152-168.

An elaboration of the same author's MA thesis, this considers all Virginia tribes of the period.

Robison, Houston T. MA 1943

Oregon [2815]

The Rogue River Indians and their relations with the Whites. $192 \mathrm{p}$.

Athapascan, Takelman, Hokan and Shastan tribes.

Rockefeller, Alfred, JR. PHD 1949 Northwestern [2816] The Sioux troubles of 1890-1891. 202p.

Rode wig, Margaret R. M/Ed 1954 Rhode Island

An historical study of the relation between the Narragansett tribe of Indians and the Colony and the State 
of Rhode Island and Providence Plantations as evidenced in the Acts, Resolves of and Petitions to the General Assemblies of the Colony and of the State after 1676 .

Rodnick, David PHD $1936 \quad$ Pennsylvania [2818] The Fort Belknap Assiniboine of Montana. 125p. РUв: U/Penna. [1938] 125p.

A study prepared for the Applied Anthropology unit of the U. S. Indian Service.

Rodríguez, Mario B. PhD 1950

Cornell [2819]

La novela social en El Perú, 1848-1948.

Includes the Indians of Peru.

Rodríguez Prampolint, Ida DCH 1948 Mexico [2820] Amadises de América. La hazaña de Indias como empresa caballeresca. Рuв: México: Taller Gráfica [1948] $172 \mathrm{p}$.

Roediger, Virginia More PhD 1937 Yale [2821]

Ceremonial costumes of the Pueblo Indians: their evolution, fabrication, and significance in the prayer-drama. 275p., illus. PUв: Ceremonial costumes of the Pueblo Indians. U/Calif. Press [1941] 251p., illus., col. pls.

Romisch, Phyllis J. MA $1951 \quad$ Columbia [2822] A distributional study of the interior arrangements of North American pit houses. 68p.

Western North America.

Rogers, Edward S. MA 1953

New Mexico [2823]

Aboriginal and post-contact traits of the MontagnaisNaskapi culture. 182p., illus.

Rogers, Harriet Evadna MA 1923 California [2824] The organization of the Territory of Arizona. 82p., illus.

Section on Apaches in Arizona.

Rogers, Mary Louise M/Ed 1943

Oklahoma [2825]

Curriculum planning for Cheyenne and Arapaho Indians.

Rogers, Melvin P. MA $1940 \quad$ Oklahoma $A \& M$ [2826] A history of the Pawnee Indians. 58p. 
Rogers, Spencer Lee

The distribution of material culture traits relating to agriculture in aboriginal North America. 63p.

Rogers, Spencer Lee PhD 1937

So. California [2828]

A comparison between aboriginal archery in western North America and eastern Asia. PuB: Amer. Anthro., XLII [1940] p255-269.

Based on a study of the Jessop archery collection of the San Diego Museum (California).

RoHRER, MILDREd Louise MA 1939

St. Louis [2829]

Names and namegiving among the North American Indians. $116 \mathrm{p}$.

Rojas, Lauro Antonio

MA 1936

California [2830]

Transcontinental trade of New Spain. 139p.

Indian content only incidental.

Rolland, Siegried B. PhD 1952 Northwestern [2831] Cadwallader Colden: Colonial politician, and Imperial statesman, 1718-1760.

Colden's Indian activities in the Pennsylvania area.

Romano, Octavio MA 1954

New Mexico [2832] Aspects of Rio Grande Pueblo cultural stability. 92p.

Romero Molina, JAVIER MA 1956

Mexico: $E N$ [2833] La población indígena de Tilantongo, Oaxaca.

Ronan, Margaret Theresa MA 1932

Montana [2834]

Memoirs of a frontierswoman (the life of Mary Catherine Ronan). 381p.

A biography of Margaret Ronan's mother. Pt. 3 "Life among the Flathead Indians".

Root, Winfred Trexler PhD 1912 Pennsylvania [2835] The relationships between Pennsylvania and the English Government, 1696-1760. Рणв: U/Penna., Pubs. Hist. [1912] 422p.

Slight Indian mention scattered throughout.

Roper, William James MA 1941 Brit. Columbia [2836] The achievements of Captain George Vancouver on the British Columbia coast. 130p.

Negotiations with Quadra at Nootka. 
A study of achievement of Indians. 218p., illus., tables.

U. S. Indian School at Albuquerque.

Rose, Yancey LaMar MA $1932 \quad$ Stanford [2838] Cultural assimilation in process: a descriptive study of a community in New Mexico. 221p.

Roseler, Alvin W. MA $1949 \quad$ St. Mary's [2839] The Indian policy of Sam Houston. 124p.

Rosenberg, Morris MA 1937

New Jersey [2840]

Mexican and Mayan archeology; a new source of supplementary content for the enrichment of the teaching of Spanish.

Rosenberry, Vivien Violet MA $1935 \quad$ Stanford [2841]

Designs of the Pueblo tribes of the Southwest. 134p., ill.

Rosene, Ruth Goodspeed MA 1951 Mexico City [2842]

The Discoverer, the Conqueror, and the Kings; a study of Colón and Cortés in their relations with the Crown of Spain. 143p.

Ross, Hubert Barnes PhD 1954

Columbia [2843]

The diffusion of the manioc plant from South America to Africa; an essay in ethnobotanical culture history. 135p. $M$.

Ross, Lenore C. MA 1952

U.C.L.A. [2844]

The arts and crafts of the California Indians. 187p.

Ross, Patricia Fent MA 1949

A study of the history of Azcapotzalco. 101p., map.

Includes dynastic chart, and map of Anahuac villages. From origin to present day.

Ross, VIRGINIA Louise MA 1939

Yale [2846]

Some pottery types of the highlands of western Mexico. 108p.

Study based on Lumholtz collections at the American Museum of Natural History. Guanajuato, Querétaro, Jalisco, Tepic and Michoacán. 
Ross, Winifred

The present-day dietary habits of the Papago Indians. $69 \mathrm{p}$.

Fieldwork 1940-41, at Sells and Ajo. Includes nutritional analysis of desert plants.

Rossman, Ruby Alma MA 1932

Geo. Peabody [2848]

Mathematics used by American Indians north of Mexico. 46 p., illus.

Rostlund, ERHARD

MA 1946

California [2849]

A distributional study of primitive fishing in California.

Rostlund, Erhard $\quad$ PhD 1951

California [2850]

A distribution study of fresh-water fish and fishing in aboriginal America north of Mexico. Pub: "Freshwater fish and fishing in native North America." U/Calif., Pubs. Geog., IX [1952] 314p., maps.

Roth, George Frederick, JR.

MS 1929 Cincinnati [2851] A study of the arts of the Maya Indians of Central America and a discussion of the application of Maya art to modern architectural design. 63p.

RothHar, Emma Florence MA 1929

Ohio State [2852]

A history of the Sioux Indians. 132p.

Roulston, Jessie Adams PhM 1910

Chicago [2853]

The effect of the Black Hawk War on the development of the Northwest. 47p.

Rouse, Benjamin Irving, Jr. PhD 1938 Yale [2854] Prehistory in Haiti: a study in method. 603p., illus. Puв: Yale U., Pubs. Anthro. \#21, 24 [1939, 1941] 202p., 196p., illus.

Rouse, Chrystine Meredith MA 1936 Pittsburgh [2855] Folk lore of Alabama:

Includes Indian folklore.

Rowe, Chandler Wllliam MA 1947

Chicago [2856]

The Wheatley Ridge Site, its relation to the Mogollon culture of southwestern New Mexico. 68p.

Rowe, Chandler William PhD 1951

The effigy mound culture of Wisconsin. 164p., illus. 
Rowe, John Howland PhD 1946

Harvard [2858]

An introduction to the archaeology of Cuzco. PUB: Harvard U., Peabody Mus., Paps., XXVII \#2 [1944] $69 \mathrm{p}$., illus.

Rowell, Mary King MA $1943 \quad$ Yale [2859] Contributions to Mohawk ethnography. 140p., map. PuB : Archeol. Soc. Conn., Bull. \#17 [1946].

Includes extensive bibliography.

Rowland, Donald Winslow PhD 1931 California [2860] The Elizondo expedition against the Indian rebels of Sonora, 1765-1771. 256p.

Seri and others.

Rowse, Edward Francis $\quad \mathrm{PhD} 1936$ Washington/SL [2861] Auguste and Pierre Chouteau. 281p.

Many [25] tribes mentioned; preëminent are Sauk, Fox, Osage.

Roy, Addie May MA 1931

Texas [2862]

History of Telegraph and Texas Register, 1835-1846. 149 p.

Chapter on reactions of this newspaper and its public towards the Indian policies of Sam Houston.

Rozelle, Ralph Lincoln MA 1951 So. California [2863] William Henry Jackson and his contribution to the history of the early West.

Illustrated with his photos. Ute, Shoshoni, Plains, Hopi, Pawnee, Mesa Verde.

Ruckman, Caroline Silsby MA 1926

Texas [2864]

The frontier of Texas during the Civil War. 138p., maps.

Considerable attention given to Indian problems.

Ruecking, Frederick Henry MA 1955

Texas [2865]

The Coahuiltecan Indians of southern Texas and northeastern Mexico. 404p.

RugGles, James Edgar MA 1931 Oklahoma [2866] Social and economic status of the Cheyenne Indians.

Runyan, Clarence S. MS $1939 \quad$ Montana Coll. [2867] Land utilization on the Crow Indian Reservation. 132p. 
RUPpÉ, REyNoLd JoSEPH, JR.

PHD 1953

Harvard [2868]

The Ácoma culture province; an archaeological concept. 405p., pls.

\section{RUSh, Esther JeANette MA 1955}

Tulane [2869]

The historical evolution of the concepts of Indigenismo in Mexico, 1916-1953., 123p.

Considers philosophical writings of Alfonso Caso, Manuel Gamio, Moisés Sáenz, José Vasconcelos.

Rushmore, Elsie Mttchell $\quad$ PhD $1914 \quad$ Columbia [2870] The Indian policy during Grant's administrations. Pणв: NY: The Marion Press [1914] 83p.

Ruskowski, Leo Francis PhD 1940

Catholic [2871]

French émigré priests in the United States (1791-1815). Pणв: Cath. U., Stud. Amer. Church Hist., XXXII [1940] 150p.

Discusses their work with various Indian tribes.

Russeld, Carma Alice Zimmerman MA 1932 California [2872] Indian missions in the Oklahoma region, 1819-1865. 78p. Cherokee and Osage.

Russell, Frank PhD 1898

Harvard [2873]

A study of a collection of Eskimo crania from Labrador, with observations on the prevailing system of craniometry. 105p.

RusseLL, J. C. MA 1930

Colorado State [2874]

Reputation of the Plains Indians as reported by hunters, trappers. 180p.

Russell, Jason Almus $\quad$ PhD 1929

Cornell [2875]

The Indian in American literature. (1775-1875). PUB: "Thoreau, the interpreter of the real Indian." Queens $U$. Qtly., XXXV \#1 [1927] p37-48; "Influence of Indian Confederations on the American colonies." Jour. Amer. Hist., XXII [1929] p27-124; "Narratives of Indian captivity." Education, LI \#2 [1930] p23-34.

Russeld, Kitty Audrey MA 1944 So. Methodist [2876] The development of education in Alaska.

Discusses dual education system, comparing natives of fifty years ago and today. 
Russeld, Luella Haney MS 1930 Arizona [2877]

The primitive religion of the Southwest: an interpretation. 146p.

Russell, Mattie $\quad$ PhD 1956

Duke [2878]

William Holland Thomas, White chief of the North Carolina Cherokees. 450p., illus.

Russeld, Nelson Vance PhD $1925 \quad$ Michigan [2879] The end of the British régime in Michigan and the Northwest. PuB: U/Mich., Alumni Qtly. Rev., XLIV \#19 [1938] p189-206.

Russelu, Rubye S. MA $1952 \quad$ Sul Ross [2880] Folklore of south Texas and Mexico. 117p.

Includes some Karankawa and other Indian legends.

Russeld, ShrRLey A. MA $1954 \quad$ Vanderbilt [2881] El Indio en la poesía modernista hispanoamericana.

Three modernist poets (Rubén Darío, José Santos Chocano, Ricardo Rojas) chosen as examples. Used Indian themes extensively.

RUTHERFoRd, AMy OAKLEY MA $1936 \quad$ California [2882] The early history of Victoria, British Columbia. 72p., maps.

Songeis.

Ruz L., Alberto MA 1956

Mexico: $E N$ [2883]

La costa de Campeche en los tiempos prehispánicos: prospección cerámica y bosquejo histórico.

Ryan, Cuthbert D. MS $1936 \quad$ Wisconsin [2884]

Wisconsin Indian legends. $47 \mathrm{p}$.

Menomini, Winnebago, Chippewa, Sioux, Sauk, Mascouten.

RYAN, G. F. $\quad$ MA 1930

Early Jesuit missionaries in New York State.

Niagara [2885]

Missing from library.

Sáenz Vargas, CéSAR MA $1956 \quad M e x i c o: E N$ [2886]

Quetzalcóatl en México y Centro América.

SAHLI, JoHN RANKIN MA 1935 Pittsburgh [2887] Seneca-American relations during the Revolution. 120p. 
A sketch of the Shoshone language. 155p.

St. John, LaUra MA 1941

California [2889]

The history of Spanish agriculture in the Caribbean in the sixteenth century. 84p.

Carib and Arawak agriculture included briefly.

Salazar Ortegón, Ponciano MA 1956 Mexico: EN [2890] Exploraciones y problemas de reconstrucción del Sistema I de Kabah, Yucatán.

Salter, Josephine Heath MA 1950 Ariz.-Flagstaff [2891] Analysis of need and resources for greater Indian emphasis at Arizona State College, at Flagstaff. 103p.

SALZ, Beate R. MA 1943

New School [2892]

Indianismo. $79 \mathrm{p}$.

Primarily Peru, Ecuador and Bolivia, but some Mexico.

Salz, Beate R. PhD 1950

New School [2893]

The human element in industrialization: a hypothetical case study of Ecuadorean Indians. 571p. PuB: Amer. Anthro. Assoc., Mem. \#85 [1955] 265p.

SALZMaNn, ZdenĔK MA 1949

Indiana [2894]

A method of analyzing numerical systems, based on South and North American Indian materials assembled by Theodore Kluge. 16p.

Sameth, Sigmund MA 1940

Oklahoma [2895]

Creek Negroes: a study of race relations. $98 \mathrm{p}$.

Samonte, Frank García MA 1940

Jesuit missions of the upper Amazon. 126p.

Samper, Alfred MA 1948

California [2896]

The domestic life of the Mexicans as shown in Historia general de las cosas de Nueva España by Fr. Bernardino de Sahagún. 130p.

Sample, Sarah Eleanor MS 1923

Kansas [2898]

The relation of native training to the education of the Indian. 59p.

General historical background; various unnamed tribes. 
SANDberg, Sigfred MA $1950 \quad$ New Mexico [2899] Anthropological investigation of the Correo Snake Pit.

In Valencia County, New Mexico, southwest quarter.

Sanborn, Ruth Ellen MA 1921

Indian problems in the Northwest, 1781-1789. 61p.

Sanders, Gledca S. MA $1933 \quad$ Oklahoma $A \& M$ [2901] The educational development of the Cheyenne and Arapaho Indians upon the Reservation. 70p.

\section{Sanderson, Dwight $\quad$ PhD 1924}

Chicago [2902]

The rural community: the natural history of a sociological group.

Examines and compares different types of rural groups, including several Amerindian.

Sandlin, Blan E. MA $1948 \quad$ Oklahoma $A \& M$ [2903] The social life of the Choctaw Indians, 1800-1900. 63p.

Sandoval, Leónidas Rodríguez PhD 1945 Catholic [2904] The socio-economic life of the Sierra Indians of Ecuador.

SANDSMaRK, Lawrence MA 1931

Montana [2905]

United States regulation of the fur trade. 118p.

Considerable Indian material but no specific tribes.

Sansom, LetTie E. MA 1952 Ariz.-Flagstaff [2906] The teaching of functional vocabulary to non-Englishspeaking Navajo children. 53p.

Sanz, Benjamin Gento MA $1950 \quad$ St. Bonaventure [2907] The first college for Indians in South America: San Andrés de Quito, Ecuador. 199p.

SAPIR, Edward PHD 1909

Columbia [2908]

The Takelma language of southwestern Oregon. PuB: Boas, "Handbook of American Indian Languages." Bur. Amer. Ethnol., Bull. \#40 pt. 2 [1922] p1-296.

Sarbescu, Sam Walter

MA 1955

Indiana [2909]

The Northwest Coast and Plateau mortuary complex and its cultural background. 108p. 
Sarot, Eden Emanuel PhD 1949

Princeton [2910]

Folklore of the dragonfly: a linguistic approach. 79 p. $M$.

Considers dragonfly theme around the world; includes Amerindian, especially Navaho.

Sarre, Alicia PhD 1945

La influencia español en la poesía lírica mexicana.

Stanford [2911]

Considerable Indian poetry and translation.

SASaki, Tom Taketo PhD 1950

Cornell [2912]

Technological change in a Navaho Indian farming community: a study of social and psychological processes.

SASSMAN, OREN MA 1941

Montana

[2913]

Metal mining in historic Beaverhead. 310p.

§ 1 "Beaverhead prior to 1862". Blackfoot, Pend d'Oreille, Shoshoni, Flathead, Nez Percé, Kutenai, Snake.

Satterthwaite, Linton, JR. PhD 1943 Pennsylvania [2914] Concepts and structures of Maya calendrical arithmetics. Puв: Phila. Anthro. Soc., Reprint Pubs. \#3 [1947] 168p., tables.

Sauer, Nellie Jane MA 1939 Texas Tech. [2915] American Indian words in the literature of the West and Southwest. 90p.

Savage, Frank MA 1949

Mexico City [2916]

Bartolomé de las Casas and his Apologetica historia sumaria. 99p.

Savage, Thomas J. MA 1946

Niagara [2917]

Forty years of missionary activity among the Indians in the State of New York, 164.2-1682. 11p.

Sayres, William Cortlandt PhD 1952 Harvard [2918] Zarzal: the ethnology of a rural Colombian community. 2 vols., illus.

Concerns a quasi-Indian group. Excellent photographs.

Scantling, Frederick H. MA 1940

Arizona [2919]

Excavations at Jackrabbit Ruin, Papago Indian Reservation, Arizona. 73p. Puв: The Kiva, V \#3 [1939]. 
Lacrosse coaching. $100 \mathrm{p}$.

Brief section on history and origin of Lacrosse.

Schaedel, Richard PaUd PhD 1952 Yale [2921] An analysis of central Andean stone sculpture. 371p., illus.

Schaefer, Ruth Elizabeth MA $1929 \quad$ Oregon [2922] The influence of Methodism in early Oregon. 92p.

Flathead, Nez Percé; Jason Lee's ill-fated Indian mission.

Schamfer, Waldemar D. MA $1935 \quad$ New Mexico [2923] Distribution of the human blood groups among the Pueblo Indians of New Mexico. 25p.

Schaeffer, Cladde Everett $\quad$ PhD 1940 Pennsylvania [2924] The subsistence quest of the Kutenai; a study of the interaction of culture and environment. 62p.

Schafer, Ann Eastlake MA 1941 Pennsylvania [2925]

The status of Iroquois women. $80 \mathrm{p}$.

Scheele, Raymond Lewis MA $1947 \quad$ Columbia [2926] The treatment of captives among the north east Indians of North America. 62p.

Scheele, Raymond Lewis PhD $1950 \quad$ Columbia [2927] Warfare of the Iroquois and their northern neighbors. 149p. $M$.

Schenck, Sara Moffatt MA 1925 California [2928] The stars in the culture of the American Indians. 70p.

Schenk, John Frederick MA 1932

Oregon [2929]

The Hudson's Bay Company in Oregon, 1821-1860. 121p.

Chinook, Klikitat, plus other scattered references.

Schetter, Adrienne Estelle MA 1933 California [2930]

The Indians on the Oregon Trail, 1845-1849; with emphasis on the Kansas, Pawnees, and Sioux, especially in 1846. 115p., illus. 
Navajo ritual poetry. 185p., illus. PUB: Beautiful on the Earth. Santa Fé: Dreis [1947] 155p., illus.

Based on Matthews, Wheelwright, etc., plus author's original material. Illustrated by author.

Schleiermacher, Christine MA 1941 Columbia [2932] The Dawes Act of February 8, 1887. 62p.

Schlomenack, Helen Holden MA 1940 Georgia [2933] The Seminole War, 1835-1842. 79p.

Schmidt, Erich Friedrich PhD 1929 Columbia [2934]

Time-relations of prehistoric pottery types in southern Arizona. Puв: Amer. Mus. Nat. Hist., Anthro. Paps., XXX pt. 5 [1928] p247-302.

Schmidt, Florence MA 1942 Montana [2935]

A study of the occupations of Blackfoot Indians. 112p.

SCHMITT, KARL, JR. MA 1942

Chicago [2936]

Patawomeke: an historic Algonkian site. 106p. PUB:

T. Dale Stewart, The historic Indian village of Patawomeke, Stafford County, Virginia.

SCHMITT, KaRL, JR. PHD 1947

Chicago [2937]

Archeological chronology of the Middle Atlantic states. 235p. Puв: Griffin, Archeology of Eastern United States. U/Chi. Press [1952] p59-70.

Schmitt, PaUL N. MS 1936 Kansas [2938]

A study showing that traditional grade classifications in Indian schools of the Southwest is impracticable and misleading. $33 p$.

Schock, Eldon Donald MA 1954

Idaho [2939]

The causes of the Nez Percé War as disclosed primarily by treaties in effect between the Nez Percés and the Federal Government prior to 1877 . 111p.

Scholes, France Vinton PhD 1943

Harvard [2940]

Church and State in New Mexico in the seventeenth century. Puв: New Mex. Hist. Soc., Pubs. Hist., VII [1937] 206p.; XI [1942] 276p.

Brief mention of Pueblo and Navajo, and the Inquisition in the Southwest. 
Scholes, Walter V.

PHD 1943

Michigan [2941]

The Diego Ramírez visita. 209p. M. Рuв: U/Missouri, Stud., XX \#4 [1946] 97p.

1551-1555 in Mexico City, Vera Cruz, Pánuco. Investigated Indian conditions; thesis includes study of Indian problems.

Scholl, Almah Wallace MA 1951 So. California [2942] The teaching oral language to non-English-speaking Indian children through health education. 124p.

Especially Papago.

Schramm, WiLbur Lang PhD 1932

Iowa [2943]

Studies in the longer narrative verse of America, 1775-1860. 135p. PUB: "Hiawatha and its predecessors." Philol. Qtly., XI \#4 [1932] p321-343.

Discusses several Indian romances, their influence on Hiawatha and the "noble savage".

Schroeder, Albert Henry MA 1940

Arizona [2944]

A stratigraphic survey of pre-Spanish trash mounds of the Salt River Valley, Arizona. 196p.

Schubert, Melvin Frank MA 1954 So. California [2945] An analysis of certain similarities between the city Dionysia and the Fort Hall Sun Dances. 111p.

Schuiling, John Thys MA 1938

Geo. Peabody [2946]

A study of community relationships in Minnesota Indian schools. 79p., maps.

Schulhof, Martha MA 1926

California [2947]

History of the administration of Bernardo de Gálvez in Louisiana, with an appendix of original documents. $307 \mathrm{p}$. Contains material regarding Indian slaves at Ste. Geneviève and St. Louis.

Schulman, Sam PhD 1954

Florida [2948]

A sociological analysis of land tenure patterns in Latin America. 420p. $M$.

Considers persistence of communal land tenure among Latin American Indian communities.

Schulte, Bedlah $\quad$ MA 1933

Occidental [2949]

Navajo Indian and Caucasian contact. 120p. 
Scholtz, Amelia Lodise MSW 1947

Washington [2950]

Indian unmarried mothers. $140 \mathrm{p}$.

No particular tribes; general.

Schulz, NaOMT MA 1930

Oklahoma [2951]

The American explorations of Oklahoma. 152p.

Includes Indian relations. Period circa 1806-1850.

Schutte, Tenjes Henry PhD 1924

Chicago [2952]

History of educational legislation in Pennsylvania, 1775 to 1850 .

Quaker educational facilities for Indians; early attempts to educate Indians.

Schutzel, ANN Ruth MA $1950 \quad$ Indiana [2953] A comparative analysis of law among the Cheyenne and Yurok. 90p.

Schuyler, Henry C. STL 1905

Catholic [2954]

Sebastian Rale, missionary in Maine (1694-1724). PuB:

Cath. Hist. Rev., I [1915] p164-174.

Schwartz, Douglas Wright PhD 1955

Havasupai prehistory: thirteen centuries of cultural development. 312p., illus.

Schwartz, Edmund ALbert MA 1943 So. California [2956] History of education in colonial Mexico. 115p.

Mostly Indians and mestizos; also Aztec and Inca.

Schwarzman, Richard C. MA $1949 \quad$ Occidental [2957] Frontier reminiscences of William H. Hedges. 225p.

Cherokee, Sioux.

Schweinsberger, Richard A. MA 1951 Indiana [2958] Family social structure and functions of the Muskhogean Indians of southeastern United States. 297p.

Schweitzer, Marianne A. MA $1945 \quad$ Yale [2959] Ethnography of the modern Mikasuki Indians of southern Florida. 101p.

Schweitzer, Marjorie Gardner MA 1954 Arizona [2960] A provisional analysis of Seri, a native language of Sonora. 95p. 
Scott, Elizabeth - MA 1946

Texas [2961]

A study of the chronicles of Indian captivity in the Southwest. 112p.

Scott, Isabel M. L.

MA 1951

Wyoming [2962]

Anglo-French conflict on the Pennsylvania frontier: the rôle of Colonel Henry Bouquet. 102p.

French-Indian War, Pontiac, etc., including original documentary material.

Scott, John Carver, JR. PhD 1953

Chicago [2963]

Race and culture contact in southeastern Alaska: a study of the assimilation and acculturation of the Wrangell Tlingit and White. 711p.

\section{Scott, Wallace Howard \\ MA 1949 \\ Montana [2964]}

The Custer Trail from Fort Abraham Lincoln to Powder River. 94p.

Sioux, Cheyenne.

Scruton, David Lagrove PhD 1954 Washington [2965]

Sex differential in memory retention of aboriginal behavior patterns. $138 \mathrm{p} . M$.

Muckleshoot Reservation, near Auburn, Washington.

Scull, Carolyn Beatrice MA 1914 California [2966]

The Ramón expedition, 1715-1716. A translation of the sources with introduction and notes. $172 \mathrm{p}$.

Mostly Tejas Indians.

Seaberg, Lillutan Marie MA $1955 \quad$ Florida [2967] The Zetrouer Site: Indian and Spaniard in central Florida. 209p.

A brief summary of Indian occupations of north central Florida to 1708 , and a detailed description of a Potano Indian mission site of circa $1680-1706$.

Seale, Lea Leslite PhD 1939

Louisiana [2968]

Indian place-names in Mississippi. 224p.

Origin, meanings of names derived from dialects of various Mississippi tribes; mostly Choctaw. Linguistic, not legendary treatment. 
A history of the Ponca Indian Agency in Oklahoma. 108p. Oto, Pawnee, Tonkawa.

Sears, Constance S.

MA 1953

New Mexico [2970]

Reflection of Hopi culture in Hopi folk tales. 146p.

Sears, William Hulse MA 1947

Chicago [2971]

Relationships of the pre-pottery manifestations of eastern United States. 152p.

Sears, William Hulse PhD 1950

Michigan [2972]

The prehistoric cultural position in the Southeast of Kolomoki, Early County, Georgia. 185p. $M$.

Secoy, Frank Raymond PhD 1951

Columbia [2973]

A functional-historical view of Plains Indian warfare: the process of change from the 17 th to the early 19 th century. 252p. $M$. PUB: "Changing military patterns on the Great Plains." Amer. Ethnol. Soc., Mono. \#21 [1953] 112p., maps.

Seeley, Charles Leonard

MA 1951 New Brunswick [2974] The disintegration of the Huron culture in the seventeenth century. $189 \mathrm{p}$.

Semmann, Harriet McGurn MA 1929

The Indian Agent, 1849-1927. 32p.

Seidel, Charles Barnard MA 1928

Louisville [2976]

Indian trade in the Old South from 1789-1812. 43p.

Cherokee, Creek, Arkansas, Choctaw, Natchitoches, Chickasaw.

Seixas, Genevieve Louise MA 1929

Smith [2977]

Government policy toward Indian education. $125 \mathrm{p}$.

Selmser, James L. BD 1955 Andover [2978]

The Dakota Indian: his culture and his religion.

Selzer, Leo Louis MA 1940

Colorado [2979]

A critical evaluation of Alaska as a territorial possession.

Human resources, Federal relations and control over natives. 
The policies of Hernán Cortés, as described in his letters. 376p. $M$.

Considers political, military, social, religious, economic policies; weapons used; White-Indian relations.

Senter, Donovan C. MA $1936 \quad$ New Mexico [2981] The calcanea of Kuaua Pueblo, New Mexico. 29p.

Calcaneus measurements of skeletons.

Service, Elman Rogers $\quad$ PhD $1950 \quad$ Columbia [2982]

Spanish-Guaraní acculturation in early colonial Paraguay: the encomienda from 1537 to $1620.172 p$. M. РUв: U/Mich. Mus., Anthro. Paps. \#9 [1954] 106p.

Setzer, José MA 1947 California [2983] Chemical analysis of Indian mounds. 83p., graphs.

Northern California.

Severance, Elsie Elliott MA $1935 \quad$ Whittier [2984]

Life and legends of the Navajos. 113p.

Seymour, Charles Francis MA 1906 California [2985]

Relations between the United States Government and the Mission Indians of southern California. 105p., maps.

Shoshonean and Yuman.

Seymour, Mattie Lee MA 1950

Texas [2986]

Euro-American influence in Alaska. 116p.

ShaCkelford, William JASPER MA 1951 Texas [2987]

Excavations at the Polvo Site in western Texas. 90p.

Shatffer, James BaLL PhD 1954 Columbia [2988] The Mogollon complex; its cultural role and historical development in the American Southwest. 223p. $M$.

Shaham, Milton Aaron MA $1932 \quad$ Pennsylvania [2989] Distribution of Eskimo mythical elements. 104p.

Shamberger, Elizabeth Strong MA 1928 New Mexico [2990] An educational history of Albuquerque. 56p.

$\S 2$ \& 3: United States Indian School. 
Shankel, George Edgar PhD 1945 Washington [2991] The development of Indian policy in British Columbia. $340 \mathrm{p}$.

Covers period 1840-1940.

Shannon, MacRae DaRwin MA 1937

Illinois [2992]

The Indian factor in Anglo-American relations in the Old Northwest, 1783-1796. 70p.

Shapiro, Dena Evelyn MA 1929

Chicago [2993]

Indian tribes and trails of the Chicago region; a preliminary study of the influence of the Indian on early White settlement. 92p., maps.

Sharp, Lawrence Raybourne MA 1940 Texas [2994] History of Panola County, Texas, to 1860. 212p., maps. Chapter on Indians and Indian troubles: Hasinai, Caddo, Cherokee.

SharP, Morrison PHD $1936 \quad$ Harvard [2995] The New England defense system in the seventeenth century.

Discusses organization, history and activities of the Trainbands; Indian activities only in passim.

Sharrow, Barnard G. MA 1948 Columbia [2996] British Colonial conceptions of American Indian origins. $55 \mathrm{p}$.

Shaul, Lawana Jean MA $1954 \quad$ Wyoming [2997]

Treatment of the West in selected magazine fiction, 1870-1900: an annotated bibliography. 123p.

Section on Indians.

Shaw, Helen Louise PHD $1929 \quad$ Bryn Mawr [2998]

British administration of the Southern Indians, 1756 to 1783. Pub: Lancaster Press [1931] 206p.

Excellent appendices list trade goods, invoices, and regulations. Primarily concerns Five Civilized Tribes.

SheA, Elizabeth M. M/Ed $1950 \quad$ Rhode Island [2999] The rôle of Benjamin Church in King Philip's War.

Shearer, Ernest Charles MA 1933 Colorado [3000]

A survey history of Potter County, Texas. 153p.

$\S 2$ "Prehistoric Panhandle"; § 3 "Indians and the buffalo". 
Sheehan, Lawrence J. MA 1932 Niagara [3001]

The Franciscan missions of California. 25p.

Sheehan, Thomas Whlliam MA 1915 - Columbia [3002]

The treatment of the Indians by the Spaniards within the present area of the United States. 174p.

Primarily Southwest and Louisiana.

Sheffield, Sarah Vantrease MA 1930 Geo. Peabody [3003] A study of Indian dances. 176p., illus., col. pls.

Physical Education Dept. General study, no specific tribes.

Shefrin, JACK Allew MA $1940 \quad$ Kansas City [3004] The Chisholm Trail. 202p.

Indian troubles; Chisholm with the Indians. Five Civilized Tribes.

Shelby, Charmion Clatr MA 1927 Texas [3005]

St. Denis's second expedition from Louisiana to the Rio Grande, 1716-1719, with illustrative documents, translated and edited. 118p., maps. Рणв: Sowestn. Hist. Qtly., XXVI-XXVII [1923-1924] p165-183, 190-216.

Indian references throughout.

Shelby, Charmion Clatr PhD 1935 Texas [3006] International rivalry in northeastern New Spain, 1700 to $1725.275 \mathrm{p}$.

Spanish-French relations, including Indians; on Texas-Louisiana frontier.

Shepard, Katherine MA 1936

New Mexico [3007]

The Miles-Crook controversy. 95p.

United States-Apache relations.

Sheppard, ERnest James MA $1926 \quad$ Illinois [3008]

Wampum and tobacco as media of exchange; or, did wampum and tobacco satisfy the requirements of a good medium of exchange? 53p.

Sherman, Paschal MA 1917

Catholic [3009]

The Indian policy of the United States.

Sherman, Paschal PhD 1920

Our Indian land law.

Catholic [3010] 
Shields, LiLlian B.

The Arapaho Indians, their association with the White man. $72 \mathrm{p}$.

\section{Shiels, William Eugene PhD $1933 \quad$ California [3012]}

The Jesuits on the Pacific slope. The Sinaloa Mission in the time of Father Tapia, 1591-1594. 269p. PUв: "Gonzalo de Tapia (1561-1594) founder of the first permanent Jesuit mission in North America." U.S. Cath. Hist. Soc., Mono. Ser., XIV [1934] 198p.

Includes letters from Father Tapia containing considerable material about Indians.

Shike, Virginia Catherine MA 1926

Drew [3013]

The Indian's endowment to North American civilization. $62 \mathrm{p}$.

Shimkin, Demitri Boris $\quad$ PhD 1939

California [3014] Some interactions of culture, needs, and personalities among the Wind River Shoshone. 179p. Р ив: U/Calif., Anthro. Rec., V \#4-5 [1947] p245-325.

Shimmeld, Lewis S. PhD $1900 \quad$ Pennsylvania [3015] Border warfare in Pennsylvania during the Revolution. P вв: U/Penna. Press [1901] 153p.

Includes Indian warfare.

Shiner, Joel Lewis PhD 1954

The McNary Reservoir, a study in Plateau archaeology.

Arizona [3016] 178p. $M$.

Columbia River, Washington-Oregon area.

Shipman, Fred WaLdo MA 1933

Clark [3017]

The Indian Council of 1793: a clash of policies. $121+5 \mathrm{p}$.

Area involved is the Old Northwest.

Shippen, Beulah A. MA 1940

Howard [3018] Indian slavery in Colonial times. 183p.

Shlanta, Boghdan A. MA $1938 \quad$ New Mexico [3019] A comparison of Navajo and Pueblo Indians in musical talent. 77p.

Shoaff, Frederic Barnett

MA 1903

Columbia [3020] Property among the North American Indians. 95p. 
Shong, Albert C. - MA 1901

Wisconsin [3021]

Indian policy in the Colonial period. Part I: New England. 100p.

Short, Emma Jean Brown MA 1934

Missouri [3022] The culture of the Osage Indians in Missouri. 111p.

Shortridge, Wilson Porter PhD 1919 Minnesota [3023] The transition of a typical frontier, with illustrations from the life of Henry Hastings Sibley, fur trader, first delegate in Congress from Minnesota Territory and first Governor of the State of Minnesota. PuB: Menasha: Banta [1922] 186p.

Chippewa and Sioux, upper Mississippi Valley, ca. 1825-1875.

Shreve, Margareit B. MA 1943 Modern Papago basketry. 177p. Puв: The Kiva, VIII [1943] p10-16.

Compares current work with Kissell [1916] study of Papago.

ShUKRy, LaIla SA YID PHD 1954

Cornell [3025] The rôle of women in a changing Navaho society. 337 p. $M$.

Shull, Natalie Henley MA 1950

Indiana [3026]

The arts of the Aztec Indians in the sixteenth century, based upon Historia general de las cosas de Nueva España by Fr. Bernardino de Sahagún. 82p.

Shutler, Dick, JR. MA 1950

California [3027]

The Dry Creek scraper, chopper, hammerstone complex, and its relationship to other pre-pottery cultures of the Southwest. 58p.

Sieber, Sylvester Anthony

MA 1942

Chicago [3028]

Problems of totemism among the northern, northeastern, and north Atlantic slope Algonkian Indians. 122p.

Siedlecki, Willitam Donald MA $1954 \quad$ Butler [3029] The ruination and expulsion of the Miami Indians. 70p.

Sievert, Henrietta Meta MA $1938 \quad$ Louisiana [3030]

Food lore of the North American Indian. 73p.

History of the food habits of the Indian and his influence on the present-day diet of the American White. 
A study of the Indiano in Spanish literature. $157 \mathrm{p}$.

\section{Silver, James Wesley $\quad$ PhD 1935}

Vanderbilt [3032]

Edmund Pendleton Gaines and frontier problems, 1801-1849. Рuв: Jour. So. Hist., I \#3 [1935] p320-344. Much on Cherokee, Choctaw, Creek, Seminole. Treaty of Ft. Jackson; Choctaw boundary.

Simmons, Eva Mary MA 1940

Oklahoma $[3033]$

Cherokee-Osage relations: $1803-1839.86 \mathrm{p}$.

Simmons, Leo William $\quad \mathrm{PhD} 1931$

Yale [3034]

The aged in primitive society. 4 vols. Puв: Yale U. Press [1945] 317p.

Data on 71 tribes, 26 Indian; summarized in many charts and tables.

Simmons, Patricta Caldwell

MA 1946 So. California [3035] A history of the Cucamonga Rancho.

$\S 1 \& 2$ : Indians as original inhabitants, and under first Mexican land grantees.

Simon, Beatrice V. MA 1950

McGill [3036]

Autobiographical writings of some North American Indians; a critical study of their origin and development. $199 \mathrm{p}$.

Simpson, Lesley ByRd

$\mathrm{PHD} 1928$

California [3037]

The development of the theory of forced native labor in the Spanish Colonies, with particular regard to Española and New Spain. PuB: "The Encomienda in New Spain. Forced native labor in the Spanish Colonies, 1492-1550." U/Calif., Pubs. Hist., XIX [1929] 298p.

Simpson, Robert Bonebrake PhD 1940 Clark [3038]

Studies in populational geography, Canandaigua Lake region, New York.

Section on "Aboriginal population of Canandaigua region." (Seneca.)

Simpson, Ruth DeEtte MA 1944

So. California [3039]

Evolution of the stone complexes in the Cochise, Mogollon, Hohokam, and Mimbres cultures. 383p., illus. 
Sims, Emmett McCammon

MA 1953

Ariz.-Tempe [3040]

Industrial arts program for the Apache Indian student in

Fort Thomas Union High School. 74p.

Sinclatr, Winliam John PhD 1904 California [3041]

The exploration of the Potter Creek Cave. Pणв: U/

Calif., Pubs. Amer. Archeol. Ethnol., II \#1 [1904] p1-28, illus., pls., maps'.

Singer, Ernestine H. Wieder MA 1935 Pennsylvania [3042] Analysis and distribution of netting techniques among the South American Indians. 52p.

Sinkbeil, Nina Leanore Dunn MA 1939 Colorado [3043]

A comparative study of marriage customs among the Indians of southwestern United States and the Negroes of West Africa. 239p.

Also examines rôle of women in Pueblo and non-Pueblo tribes.

Sipes, Richard GRey MA $1954 \quad$ Penna. State [3044] The ecology of the primitive community.

Crow tribe; 7 non-American cultures are also discussed.

Siskin, Edgar Elias $\quad$ PhD 1941

Yale [3045]

The impact of the Peyote Cult upon shamanism among the Washo Indians. 316p., illus.

Sizer, Miriam MA 1930

California [3046]

Early attempts to find a route to the Pacific by way of the Missouri River, 1673-1803. 150p., maps.

Comanche, Oto, Missouri, Osage, Iowa, Pawnee.

Sjoberg, Andrée Frances MA 1951 Texas [3047]

The Bidai Indians of southeastern Texas. 90p. Рбв: Sowestn. Jour. Anthro., VIII \#4 [1951] p391-400.

iskaggs, Opal MS 1943

Kentucky [3048]

A comparative study, with special reference to the human, of prehistoric mammalian osteological material obtained from a site on the Green River in Ohio County of Kentucky. 62p. Pणв: Webb "Indian Knoll, Site Oh2, Ohio County, Kentucky." U/Kentucky, Repts. Anthro., IV \#3 pt. 1 [1946] p333-355. 
SkaRland, Ivar

PHD 1949

Harvard [3049]

The geography of Alaska in Pleistocene and early Postglacial time: a study of the environment from an anthropological viewpoint. $192 \mathrm{p}$.

Skeels, Dell R. PhD 1949

Washington [3050]

Style in the unwritten literature of the Nez Percé Indians. $306+289$ p.

SkImIn, Edmond J. MA 1933

Niagara [3051]

The Catholic Church in pre-nineteenth century Mexico. $57 \mathrm{p}$.

Skinner, Carl Harrison EdD 1939

A plan of education for the Gila River Pima Indians.

Skinner, Frances MA 1937

Texas [3053]

The trial and release of Satanta and Big Tree: StateFederal relations during the Reconstruction era. 184p.

Sladghter, JaCQUelyn H. MS 1952 Wisconsin [3054] The decline of the Stockbridge Indians in Wisconsin. 58p.

Slentz, Helen Irene MA 1932

Oklahoma [3055]

The history of the Shawnee Indian Agency. 123p.

Sac and Fox, Shawnee, Potawatomi, Kickapoo, Iowa.

Slick, Sewell Elias PhD 1938

Pittsburgh [3056]

William Trent, Indian trader and land speculator. PuB:

William Trent and the West. Harrisburg: Archives Pub.

Co. [1947] 188p.

Period 1746-1787 in Pennsylvania, Virginia and Ohio.

Slusser, Mary Shepherd $\quad$ PhD $1950 \quad$ Columbia [3057]

Preliminary archeological studies of northern central

Chile. 264p. $M$.

Diaguita and El Molle cultures of Coquimbo, Chile.

Smead, Cophine Lewis MA 1947

Relations with the Plains Indians of Colorado. 135p.

Denver [3058]

Period 1859-1869.

Smiley, Terah L. MA 1949

Arizona [3059]

Architectural development of the Pueblo kiva. 171p. 
The dynamics of culture diffusion in the Plateau area with particular reference to slavery and trade. 595p.

Smith, Ann Gertrdde $\quad$ MA 1948

Texas [3061]

Social control in primitive societies. $87 \mathrm{p}$.

Sitth, Anne Mitne Milllspadgh - PhD $1940 \quad$ Yale [3062] An analysis of Basin mythology. 2 vols. [408p.] charts.

Essentially Ute, Paiute, Shoshoni and neighboring tribes.

Sitth, Blanche Baker MA $1943 \quad$ Sowest. Texas [3063] Legends and old tales of San Antonio and vicinity. 106p., illus.

Smith, Carlyle Shreeve PhD $1950 \quad$ Columbia [3064] The archaeology of coastal New York. Рбв: Amer. Mus. Nat. Hist., Anthro. Paps., XLIII pt. 2 [1950] p95-200, illus.

Smith, Charles Leonard MA $1930 \quad$ Ohio State [3065] The history of the United States Overland Mail to 1869. § 5: Federal-Indian problems and mail.

Smith, Clarence Ernest, JR. $\quad$ PhD $1950 \quad$ California [3066] Disease concepts and plant medicines in native South America. 137p.

Smith, Cleo D. PhD 1947

Kentucky [3067] Education in Mexico. 244p.

Although no tribes are mentioned by name, the Indian in general is discussed as part of thejproblem of educating backward people in Mexico.

Smith, Daniel Malloy MA $1950 \quad$ California [3068] James Seagrove, first Federal Agent to the Creek Indians, 1791-1796. 147p.

Smith, Della Fern MA $1930 \quad$ Ohio State [3069] The making of a scout; a critical study of "Kit"Carson's early career. $85 \mathrm{p}$.

His Indian scouting career. 
Smith, Desmond Mohler

MA 1942

So. California [3070]

The effect of the dessication of ancient Cahuilla Lake upon the culture and distribution of some of the Desert Indians of southern California. 144p.

Smith, Duane Douglas PhD 1936

Ohio State [3071]

The evolution of the legal concept of citizenship in the United States.

Chapter on Indian citizenship.

SMith, Dwight LaVerN $\quad$ PHD 1949

Indiana [3072]

Indiana land cessions in the Old Northwest, 1795-1809. $283 p$.

iSmith, Edna Eveland $\quad$ MA 1935

Iowa [3073]

Ceremonials of the Papago and Pima Indians, with special emphasis on the relationship of the dance to their religion. $66 \mathrm{p}$.

ismith, Elizabeth Parkes

MA 1927

Texas [3074]

The history and culture of the Pueblo of Pecos, New Mexico. 136p.

iSmith, Elma Rosamond

MA 1947

Arizona [3075]

Private schools for the Navajo Indians. 100p.

High schools.

Smith, George Jaye

MA 1948

The American Indian in Tulsa, a study in assimilation.

Tulsa [3076] $47 p$.

Smith, Hale Gildiam MA 1945

Chicago [3077]

The Crable Site, Fulton County, Illinois. 152p. PuB: U/Mich. Mus., Anthro. Paps. \#7 [1951] 53p.

Smith, Hale Grlliam PhD 1951

Michigan [3078]

The influence of European culture contacts upon the aboriginal cultures of north Florida. 262p. M. Рuв: "The European and the Indian." Florida Anthro. Soc. Pubs. \#4 [1956] 150p., illus.

، Smith, Henry Nash PhD 1940

Harvard [3079]

American emotional and imaginative attitudes towards the Great Plains and the Rocky Mountains, 1803-1850. PuB: Virgin Land. Harvard U. Press [1950] 305p.

Slight mention of Indian menace. 
Smith, JoHn Boyce, JR.

MA 1902

Columbia [3080]

Policy of the Northern and Middle Colonies toward the Indians in the seventeenth century. [120p.]

Smith, Lloyd D. MA 1900

Wisconsin [3081]

The Five Nations of Indians in their relation to the Colony of New York from 1700 to 1781. 78p.

SMith, McGRegor, JR.

MA 1952

Mexico City [3082]

Alien Gods. 191p.

Draft of a novel utilizing anthropological data; Mayans of late Second Empire and Aztecs just prior to Spanish Conquest.

Smith, Marc JaCK PhD 1946

Wisconsin [3083]

Joseph Brant; a Mohawk statesman. 303p.

Smith, Marian Wesley $\quad$ PhD 1938

Columbia [3084]

The war complex of the Plains Indians. PuB: Amer.

Philos. Soc., Proc., LXXVIII \#3 [1938] p425-464.

Smith, Marie Hobart MA 1950

New York [3085]

Higher education for the Indians in the American colonies. $83 p$.

Smith, Marion $\quad$ MA 1949

New York [3086]

The Jesuit reduction of Paraguay, 1607 to 1767. 131p.

Smith, Micah Pearce MA 1917

Columbia [3087]

The history of the Chickasaw Indians previous to 1861 .

Smith, Reuben William III MA 1952 California [3088] The Fort Kearney, South Pass, and Honey Lake Wagon Road. 119p., maps.

Crow and Shoshoni.

SMith, Robert L. MA 1951

New Mexico [3089]

A graphic interpretation of four Pueblo Indian Corn Dances.

Illustrated by Smith's paintings. Also 21 plates and 18 photos of dances, dancers, costumes. Sia, Santo Domingo, Jémez, San Felipe.

Smith, RoNald OLIver $\quad$ MA 1941

Washington [3090]

The Indian treaty policy of the Confederation, 1775-1789. 
Spanish exploration of the San Joaquín Valley. 74p.

California tribes.

Smith, WaLlace Joseph MA 1950

Washington [3092]

The fur trade in Colonial Pennsylvania. 136p.

Ottawa, Cayuga, among others.

Smith, Winnie Fitzgerald MRE 1955

Carver [3093]

A survey of Brazil: a study of the country, her history, her cultures and her religion. 112p.

Considers Indian tribes of Brazil briefly.

Smither, William Jonathan PhD 1952 Tulane [3094] The regional and social aspects of the contemporary Ecuadoran novel (1920-1950).

Considers Ecuadoran Indian. Appendix: "Bibliography of the Ecuadoran novel" is complete to 1952.

SNIDER, Janis Grant $\quad$ MS 1953

Idaho [3095]

A comparative study of the intelligence and aptitudes of Whites and Nez Percé Indians. 49p.

Snider, John Henry M/Ed 1932

Oklahoma [3096]

A study of Indian education in Pawnee County, Oklahoma. 97p.

Pawnee.

SNIPES, Bradshaw MA 1949

Haverford [3097]

Friends' relations with the Seneca Indians, 1838-1850. $106 \mathrm{p}$.

Quakers in Pennsylvania and New York.

Snow, Ira Jean $\quad$ MM 1946

So. California [3098]

A study of Five Civilized Indian Tribes of Oklahoma: a unit of work integrating music, art, English, and Oklahoma history in the junior high school. 349p.

Snow, Riley Eugene MA 1936

Colorado State [3099]

Removal of the Indians from Wyoming. 211p., maps.

Snyder, AdA F. Rich MA 1939

Buffalo [3100]

Indian policies and frontier campaigns during the American Revolution. 211p. 
Snyder, Evert Albert MA $1940 \quad$ New Mexico [3101]

Primitive uses of pine among the Indians of the American Southwest. 59p.

SNYDER, Geraldine D. MM 1944 Northwestern [3102]

Seneca Indian songs. $38 \mathrm{p}$.

Snyderman, George S. PhD $1948 \quad$ Pennsylvania [3103]

Behind the Tree of Peace: a sociological analysis of Iroquois warfare. PUв: Penna. Archeol., XVIII \#3-4 [1948] 93p.

Although no author is named in the publication, the entire issue is a summary of this dissertation.

SOLECKI, RALPH MA $1949 \quad$ Columbia [3104]

The archaeological position of historic Fort Corchaug, Long Island, and its relations to contemporary forts. 95p., illus. PuB: Archeol. Soc. Conn., Bull. \#24 [1950] p3-40.

Sollock, Dixie Pendergraft $\quad$ MA 1936 Arkansas [3105] Standards of living among the Cherokee Indians. 136p.

Somermier, Cornelia Eloise MA 1920 Kansas [3106] Racial differences in general intelligence with particular reference to the American Indian. 68p.

Haskell Institute, 65 tribes.

Sommer, Frank Henry III PhD 1950

Yale [3107]

Kwakiutl iconography. Prehistoric origins and development. 430p., illus.

SONDACK, ZeLDA MA 1933

L'Amérique sur la scène française au $18^{\mathrm{e}}$ siècle. $84 \mathrm{p}$.

$\S 4$ "Exoticisme Méridional" discusses Indians; additional Indians references elsewhere.

Sorensen, Ruth M. MS/Ed $1953 \quad$ Utah Agri. [3109]

Long ago Indian stories. $95 \mathrm{p}$, illus.

27 stories, mostly selected from Annual Reports of the Bureau of American Ethnology.

Soroos, RALPH MA 1936

Carl Schurz as Secretary of the Interior, 1877-1881.

Colorado [3110]

His Bureau of Indian Affairs work. 
Souter, Shelton MA 1924

[Andrew] Jackson in Florida. [118p.]

Emory [3111]

Southward, Claude MA 1929

A history of Comanche County. 147p.

Oklahoma [3112]

Oklahoma. Includes much on Southern Plains tribes and their influence.

Spaid, Stanley S. PhD 1950

Joel Palmer and Indian affairs in Oregon. 306p.

Oregon [3113]

Period: 1860s.

Spaulding, Albert Clanton PhD 1946 Columbia [3114]

Northeastern archaeology and general trends in the

Northern Forest Zone. Рuв: R. S. Peabody Found.

Archeol., Paps., III [1946] p143-167, 309-347.

Spaulding, Lucy Larcom MA 1941 California [3115]

Semi-fictional and fictional studies of figures in the

Western fur trade. $84 \mathrm{p}$.

Indian only incidental.

Spaulding, Philip T. MA 1955

Oregon [3116]

An ethnohistorical study of Akutan: an Aleut community. $179 \mathrm{p}$.

Spaulding, Robert Bruce MA 1953

Denver [3117]

Hopi Kachina sculpture. 122p., illus.

Speck, Frank Gouldsmith MA $1905 \quad$ Columbia [3118] A comparative study of the native mythology of the south-eastern United States.

Speck, Frank Gouldsmith $\quad$ PhD 1908 Pennsylvania [3119] The ethnology of the Yuchi Indians. Рuв: U/Penna. Mus., Anthro. Pubs., I \#1 [1909] 154p., illus.

Speck, Virginia Lee MA 1946

Montana [3120]

History of the Deer Lodge Valley to 1870. 151p.

Indians of the Montana-Idaho region.

Speelman, Margaret Pearson MA 1932 Kansas [3121]

A collection of folk stories of the American Indian. 335p.

Illustrated by Vincent Matt, fullblood Flathead. 
Speight, Frederick E. JR. J M/Ed $1938 \quad$ Temple [3122]

Pennsylvania and the French and Indian War to 1759.

Spell, Lota May Harrigan PhD $1923 \quad$ Texas [3123]

Musical education in North America during the sixteenth and seventeenth centuries. $127 \mathrm{p}$.

Includes Indian musical training.

Spellman, Charles Wilfred MA 1947 California [3124]

The Spanish missions of Florida, 1618-1763.

Spencer, Eloise JAUdoN MA $1936 \quad$ Denver [3125] Mythology and folk-tales of the Pike's Peak Indians. 97p.

Spencer, Frank Clarence PhD $1899 \quad$ Columbia [3126]

Education of the Pueblo child. A study of arrested development. Puв: Columbia U., Contr. Philos. Psych., VII \#1 [1899] 99p.

Spencer, Joseph EARLE PHD $1936 \quad$ California [3127] The Middle Virgin River Valley, Utah: a study in culture growth and change. 223p., illus., maps.

Section on Paiutes.

Spencer, Katherine MA 1943

Chicago [3128]

Reflection of social life in the Navaho origin myth. 132p. Puв: U/New Mex., Pubs. Anthro. \#3 [1947] 140p.

Spencer, Katherine $\quad$ PhD 1952

Chicago [3129]

Mythology and values: an analysis of Navaho chantway myths. 349p. $M$.

Spencer, Robert Francis MA $1940 \quad$ New Mexico [3130] A preliminary sketch of Keresan grammar. Р $\mathrm{BB}$ : Intl. Jour. Amer. Ling. XV [1946] p229-236.

SPERRY, JOHN D. MA 1952

Columbia [3131]

Eskimo kinship. 34p.

Speyer, Vivien Clatre MA $1948 \quad$ New York [3132]

Westward expansion during the Great Migration with emphasis on migration into the Old Northwest. 132p.

Scattered references to Indians of the area. 
The Prescott black-on-grey culture; its nature and relations, as exemplified in King's Ruin, Arizona. 126p.

West central Arizona area.

Spicer, Edward Holland $\quad$ PhD 1939

Chicago [3134]

Social organization and disorganization in an Arizona Yaqui village. Puв: Pascua: a Yaqui village in Arizona. U/Chi. Press [1940] 319p., illus.

SPICER, Rosamond Brown MA 1939

Chicago [3135] The Easter "Fiesta" of the Yaqui Indians of Pascua, Arizona. 206p.

Spielvogel, Rosalind BRueck

$\mathrm{PHD} 1955$

Wari: a study in Tiahuanaco style. 2 vols., illus.

Spier, Leslie PhD 1920

Columbia [3137]

The Sun Dance of the Plains Indians: its development and diffusion. PuB: Amer. Mus. Nat. Hist., Anthro. Paps., XVI pt. 7 [1921] p451-527.

Spier, Robert Forest Gayton PhD 1954 Harvard [3138] The cultural position of the Chukchansi Yokuts. 390p.

Spinden, Herbert Joseph PhD $1909 \quad$ Harvard [3139] Maya art. PUв: "A study of Maya art, its subject matter and historical development." Harvard U., Peabody Mus., Mem., VI [1913] 308p., illus.

Spindler, George D. PhD $1952 \quad$ U.C.L.A. [3140] The relation between social and psychological aspects of acculturation among the Menomini Indians. 331p.

SPINdLer, Mary Louise MA 1952

Stanford [3141]

The autobiographical approach to the study of acculturation of Menomini Indian women. 138p.

SPIRER, Jess $\quad$ MA 1933

Pittsburgh [3142]

The Hopi; with particular reference to their social organization. $44 \mathrm{p}$.

Spiva, Agnes Elizabeth MA 1929

Colorado [3143]

The Utes in Colorado, 1863-1880. 145p. 
Spoehr, Alexander $\quad$ PhD 1940

Chicago [3144]

Seminole kinship. 127p. PuB: Field Mus. Nat. Hist., Anthro. Ser., XXXIII \#2 [1942] p31-113.

\section{Spring, Charles $\quad$ M/Ed 1954}

Buffalo [3145]

A study of the Government boarding school on the Menominee Indian Reservation. 88p.

StaAck, Henry F.

MA 1925

Iowa [3146]

The frontier of settlement in Kansas, 1860-1870. 69p.

Scattered references to various tribes.

Stabler, Effie Phley $\quad$ MA 1929

Geo. Peabody [3147]

Amerindian elements in some typical American games.

91 ., illus.

Games common to most tribes; especial interest in Zuñi.

Stafford, Cora Elder $\quad$ PhD 1941

Paracas embroideries; a study of repeated patterns. PUB:

Columbia [3148]

NY: J. J. Augustin [1941] 107p., pls.

Stallings, William Sidney, JR. MS 1932 Arizona [3149] Pueblo archaeology of the Rio Grande drainage. 43p.

Stander, Golda C. MS/Ed 1933 C.C.N.Y. [3150]

The history of the founding of Jesuit educational institutions in the Colony of New York (1683-1860). 102p.

Jesuit Indian schools.

Stanford, Bessie WintFred MA $1939 \quad$ Rochester [3151] Fray Bernardino de Sahagún-early Americanist. 64p.

Stanislawski, Don PhD $1944 \quad$ California [3152] The historical geography of Michoacán. Puв: Amer. Anthro., XLIX [1947] p46-55.

Tarascan Indians.

Stanley, Lottie Lee $\quad$ MS 1954 East Texas [3153] Studies in the life of the Comanche Indians. 90p., illus.

Stanley, Samuel Leonard MA 1954 Washington [3154] Three ceremonial games in the Pueblo area. 100p. All tribes in area, but especially Hopi, Zuñi, Keres, Tano. 
La Salle's Colony in Texas. 140p.

Indian mention largely concerns Hasinai tribe.

Starkey, Lawrence Granville PhD 1948 Virginia [3156] A descriptive and analytical bibliography of the Cambridge, Mass., Press from its beginnings to the publication of Eliot's Indian Bible in 1663.

Considerable material on preparation and printing of Eliot's Indian Bible.

StaRkweather, John Edgene MA 1940 Stanford [3157] The family as an aspect of Piegan Blackfoot social organization. 141p.

Starr, Richard Boblett $\quad$ MA 1939

History and development of Antelope Valley.

$\S 2$ "The coming of the Indian" describes tribes of area.

StEARNS, JAMES EDGAR MA 1950

Florida [3159]

Andean Indian problems as shown in the novels of Jorge Icaza. 66p.

Contemporary Ecuador; social conditions; Inca, section on preColumbian period.

Steck, Francis Borgia PhD 1927

Catholic [3160]

The Jolliet-Marquette expedition, 1673. Рणв: Cath. U., Stud. Amer. Church Hist., VI [1927] 323p.

Includes many other early Spanish explorations, and consideration of Indians met.

Steckler, Marguerite Celeste MA 1932 Geo. Peabody [3161] The history of the Attacapa Indians for elementary school use. 114p., maps.

Steele, Adbrey Leroy MA 1938

Oklahoma [3162]

Quaker control of the Kiowa-Comanche Agency. 133p.

Steen, Sheila Craig MA 1951

Pennsylvania [3163]

The psychological consequences of acculturation among the Cape Bréton Micmac. 140+10p.

Stein, William Warner PhD 1955

Hualcan: an Andean Indian estancia. 454p. $M$.

Cornell [3164]

Quechua of Carhuaz district, Depto. Ancash [Peru]. 
Steinmacher, Dorotihea Elsean MA 1934 Pennsylvania [3165] An analytical study of Chimú ware, particularly of the stirrup handle type. 280p., illus.

Stenberg, Molly Peacock MA $1945 \quad$ Wyoming [3166] The Peyote Cult among Wyoming Indians. PUB: $U /$ Wyoming, Pubs., XII \#4 [1946] p85-156.

Stenberg, Richard Roluin PhD 1932 Texas [3167] American imperialism in the Southwest, 1800-1837.

Stephens, Harry R. MA 1941 So. Dakota [3168] The Government of the Indians of South Dakota. PUB: U/So. Dakota, Amer. Ind. Stud. \#8 [1942] 58p.

Stephenson, Robert L. MA 1942 Oregon [3169] Some problems involved in the typology of North American projectile points. 55p., illus.

Stern, Theodore MA 1941 Pennsylvania [3170] Pamunkey pottery making. PuB : Southern Indian Stud., III [1951] 78p., illus.

Stern, Theodore PHD $1948 \quad$ Pennsylvania [3171] The rubber-ball games of the Americas. Рив: Amer. Ethnol. Soc., Mono. \#17 [1950] 122p.

Sterns, Frederick Henderson $\quad$ PhD 1915 Harvard [3172] The archeology of eastern Nebraska, with special reference to the culture of the rectangular earth lodges. 2 vols., $266 \mathrm{p}$.

Pawnee emphasized in this study, which includes unusual documentary material. Cherokee and Arkansas tribes included.

Steven, CJ PhD 1954

Louisiana [3173]

Early American phonology.

Section on American Indian language.

Stevens, Wayne Edson PhD $1916 \quad$ Illinois [3174]

The Northwest fur trade, 1763-1800. Pub: U/Ill., Stud.

Soc. Sci., XIV \#3 [1926] 204p.

Much consideration of Great Lakes tribes. 
Stevenson, Helen Florence

MA 1940 New Mexico [3175]

Counting systems of North American Indians. 207p.

Stevenson, James F. MA 1948

Tulsa [3176]

Stand Watie in the Civil War. 74p.

Cherokee.

Steward, Julian Haynes PhD $1930 \quad$ California [3177]

The clown in native North America. PuB: "The ceremonial buffoon of the American Indian." Mich. Acad. Sci. Arts Letters, Paps., XIV [1931] p187-207.

Stewart, Dora Ann PhD 1931

Oklahoma [3178]

Government and development of Oklahoma Territory. Puв: Okla. City: Harlow Pub. Co. [1933] 434p.

Stewart, Elizabeth C. PhD $1936 \quad$ Johns Hopkins [3179] Mayan medical literature dealing with lung and throat troubles. 143p.

Stewart, Eugene Ramsey $\quad$ MA 1936

Oklahoma [3180]

The liquor traffic among the Southern Plains Indians, 1835-1875. 107p.

Stewart, Franklin LeRoy M/Ed $1940 \quad$ Oklahoma [3181] The administration and control of education among the Five Civilized Tribes in Oklahoma. 252p.

Stewart, Kenneth Malcolm MA 1940 California [3182] Spirit possession in native America. РUв: Sowestn. Jour. Anthro., II [1946] p323-329.

Stewart, Kenneth Malcolm PhD 1946 California [3183] The cultural affiliations of the Gila and Colorado River Yumans. 210p.

Stewart, LeRoy ERmine MA 1938

Oklahoma [3184]

A history of the Chickasaws, 1830-1855. 147p.

Stewart, Mary Ida MA 1931

Geo. Peabody [3185]

Legends of the Mississippi Indians in prose and fiction. $161 \mathrm{p}$.

Choctaw, Chickasaw, Natchez, Pascagoula, Biloxi. Original material said never to have been collected before. 
Stewart, Omer CaLl $\quad$ PhD 1939

California [3186]

Washo-Northern Paiute Peyotism: a study in acculturation. Puв: U/Calif., Pubs. Amer. Archeol. Ethnol., XL \#3 [1944] p63-140.

Stickler, JACK W. MA 1952

Kansas City [3187]

The Cree Indians, 1640-1880. 141p., maps.

Stigler, Robert Leath, JR. PhD 1954

Columbia [3188]

Negative painted pottery in South America. 173p. $M$.

Stimson, Anna Katherine MA 1946 Pennsylvania [3189] Contributions towards a bibliography of the medicinal use of plants by the Indians of North America. 55p.

Stites, Sara Henry PhD $1904 \quad$ Bryn Mawr [3190] Economics of the Iroquois. PUB: Bryn Mawr Mono., I \#3 [1905] 159p.

Stoker, Winfred Morris MA 1950

The history of Crockett County, Texas. 186p., illus.

Baylor [3191]

$\S 2$ discusses the Indian history of the area.

Stone, Jerome Wilson MA 1941 Arizona [3192]

The history of Fort Grant. 164p.

1860-1905. Relation to Apache problem, history of the Colyer, Howard and Crook activities.

STONER, VICTOR Rose MA 1937

Arizona [3193]

The Spanish missions of the Santa Cruz Valley. 142p.

1539-1822. Indian uprisings (especially Pima, Apache), mission growth, Golden Age, and decline.

Stormfels, Mabel C. MA 1934

Kansas [3194]

Land policy in Congress, 1867-1869.

Indian policy to 1867 ; land cessions and purchases of public lands obtained from Indians.

Story, Lewis WINGField MA 1952 Mexico City [3195]

Sixteenth century murals in New Spain; historical background and important examples. 149p., photos.

Spanish and Mexican backgrounds, problem of indigenous influence. 
San Blas Cuna acculturation: an introduction. PणB: Viking Fund Pubs. Anthro. \#9 [1947] 124p., illus.

\section{Stoutemyer, John Howard PhD 1910}

Clark [3197]

Religion and race education. PUB: Jour. Rel. Psych., VII [1915] p273-322, AND Jour. Race Development, V [1915] p438-466.

Brief one-sided treatment of missionary dealings with North and South American Indians. "A comparative study of mission methods."

Stratton, David Hodge

MA 1953

Colorado

[3198]

A history of Northern and Southern Baptists in New Mexico, 1849-1950. 154p.

Consideration of Laguna, Navajo and "Indians" in general.

Streib, Gordon Franklin PhD 1955 Columbia

[3199]

Patterns of communication among the Navaho Indians. 327 p. $M$.

Strickland, Rex Wallace MA 1929 So. Methodist [3200] History of Fannin County, 1836-1843. 134p.

Texas. "Indian warfare 1837-1839" and "Indian affairs at Warren, 1841".

Strickland, Rex Wallace PhD 1937

Texas [3201]

Anglo-American activities in northeastern Texas, 1803 to $1845.404 \mathrm{p}$.

Chapters on "Sibley's report on the Indians", "Indian defense" and "Indian wars".

StriEber, Mary Esther MA 1937

Texas [3202]

Cédulas relating to the early Spanish exploration of the shoreline of North America, 1512-1523. 95p.

Translation with introduction and notes.

Strong, Esther Boorman MA 1940

Yale [3203]

Relations of Government and Indian Christian missions in the United States, 1490-1940. 372p.

Strong, Esther Boorman PhD 1941

Yale [3204]

Wardship in American Indian administration. A political instrumentality for social adjustment. 364p., illus., charts. 
Strong, William Duncan PhD 1926 California [3205]

An analysis of aboriginal society in the southwestern United States. PUB: Amer. Anthro., XXIX \#1 [1927] p1-61.

Strott, Howard J. MA 1947

St. Louis [3206]

Ranger, Brave and Vaquero: the story of Colt's revolver in Texas from Independence to Secession. 169p.

Much Indian mention throughout.

Strouse, Dorothy Louise MA 1928

A study of archaeological maise. $32+42$ p., illus.

Struckman, Robert Powers MA 1947 Montana [3208]

"Sun Dance" and other stories. 134p.

Assiniboine, Gros Ventre fiction, based on authentic dance and setting.

Stubbs, Roy Manning MA 1948 Kansas City [3209]

English travellers in Western America, 1865-1900. 139p.

$\S 5$ : Negro, Chinese, Indian [Pueblo, Creek, Apache].

Studley, Lois Alyson MA 1936

Clark [3210]

A missionary history of the Northwest Coast of America, 1800-1835. 145p.

Skidegate-Kaigani; Flathead; Nez Percé.

StUmp, Vera MA 1922

California [3211]

The successors of Columbus to 1535 with a bibliographical guide to materials. 253p.

Central America, Gulf and eastern North America.

StURgeon, SHIRLEy H. MA $1943 \quad$ Northwestern [3212] Commerce in the Texan empresario colonies. $78 \mathrm{p}$.

$\S 1$ "Indian trade in early Texas".

Sturtevant, William Curtis $\quad$ PhD $1954 \quad$ Yale [3213]

The Mikasuki Seminole: medical beliefs and practices. $538 \mathrm{p}$.

SuÁREz, Ada MA 1951

Columbia [3214]

Cardinal Ximénes de Cisneros and the Indies. 66p.

Early 1500s-West Indies Indian groups. 
The Indian as treated by Cooper and Simms. 48p.

\section{Sullivan, Louis Robert PhD 1922}

Columbia [3216]

The frequency and distribution of some anatomical variations in American crania. Pub: Amer. Mus. Nat. Hist., Anthro. Paps., XXIII pt. 5 [1922] p203-258.

General Indian study.

Sullivan, M. Belle MA 1935

Wayne [3217]

Geographic aspects of Navajo life. 64p.

Sullivan, Mary Dorothy MA $1934 \quad$ Notre Dame [3218] A history of Catholic activity among the Blackfeet Indians in the United States. 118p.

Sullivan, Mary Louise MA 1932 Washington [3219] Eugene Casimir Chirouse, O.M.I., and the Indians of Washington. 131p.

Sullivan, Robert J.

MA 1936

Catholic [3220] The ethnology of the Ten'a Indians of Alaska.

Sullivan, Robert J. PhD 1942 Catholic [3221] The Ten'a food quest. Puв: Cath. U., Anthro. Ser. \#11 [1942] 142p.

Summers, George Alfred

MA 1937 Oklahoma $A \& M$ [3222] The leased district claims of the Choctaw-Chickasaw Nation. 98p.

Summers, Maud Gilchrist MA $1948 \quad$ New Mexico [3223] A study of Pueblo Indian textile design of the preColumbian period. 75 p., illus.

Sumner, Margaret LipPincotT MA 1952 Stanford [3224] Lodge-Boy and Thrown-Away: an analytic study of an American Indian folktale. 91p.

Susman, Amelia PhD 1943

Columbia [3225]

The accentual system of Winnebago. PUB: Columbia U/Press [1943] 149p.

A linguistic study. 
Suttles, Wayne Prescott $\quad$ PhD 1951 Washington [3226]

Economic life of the Coast Salish of Haro and Rosario Straits. 512p.

Sutton, Harvey H. MA 1939

Sowest. Texas [3227]

History of Menard County. 84p.

Indian missions and troubles in Texas.

SutTon, Lester V. MA 1950

No. Dakota [3228]

The historical development of the Lac Court Oreille Reservation. $96 \mathrm{p}$.

Chippewa.

Swadesh, Morris $\quad$ PhD 1933

Yale [3229]

The internal economy of the Nootka word. 156p.

Swank, George R. MA 1932

New Mexico [3230]

The ethnobotany of the Acoma and Laguna Indians. 75p. 233 plants considered.

Swanson, Earl H. MA 1951

Arizona [3231]

An archaeological survey of the Empire Valley, Arizona. $62 \mathrm{p}$.

Swantek, Clarence MA 1943

Notre Dame [3232]

The missionary labors of Reverend Francis Xavier Pierz in Michigan. 129p.

Among the Ottawa.

Swanton, John Reed PhD 1900

Harvard [3233]

The morphology of the Chinook verb. Рuв: Amer. Anthro., n.s., II [1900] p199-237.

Sweeney, Marian H. MA 1924

So. Dakota [3234]

Indian land policy since 1887 with special reference to South Dakota. $54+2 \mathrm{p}$.

Sweeney, Mary Frances MA 1938 Sowest. Texas The social and religious customs of the Spanish-Indian population of San Antonio, Texas. 100p.

SWINNEY, J. S.

MA 1935

Oklahoma $A \& M[3236]$

The development of education among the Choctaw Indians. $77 p$. 
The exploration and settlement of the Oregon country before 1818. 104p.

Early Indian occupants and contacts with the White settlers are included.

Sykes, Merlyn C. MA 1950

Bowling Green [3238]

A history of the attempts of the United States Government to re-establish self-government among the Indian tribes, 1934-1949. 169p.

Sylvester, Howard Eugene PhD 1954 Washington [3239] The American Museum, a study of prevailing ideas in late eighteenth-century America. 378p. $M$.

A magazine published by Mathew Carey, Philadelphia, 1787 to 1792. Much on life of times; especially an outlet for scholarly opinion. Considered Amerindian in many issues.

Symns, Edith Myrtle MA $1937 \quad$ So. California [3240] An investigation into the symbolic decorative motifs of Hopi Indian ceremonial costumes. 136p., col. pls.

TAChet, Consuelo A. MA 1933 So. California The early missionary conquest of Guatemala. 90p., illus.

Taliaferro, Eugene Albert MA 1926 California [3242] The development of Texas from 1715 to $1724.116+19 p$. Some mention of Indians.

Tampke, Edgar William MA 1927 The public career of Volney E. Howard. 102p.

$\S 5$ : His efforts at Indian removal and control. Period 1850s.

Tanquist, Mamie Ruth E. PhD 1933 So. California [3244] The ancient Jémez Pueblo of Unshagi, New Mexico. 184 p., illus.

Tapson, Alfred Joseph PhD 1952 California [3245] The Indian problem on the Argentine Pampa, 1735-1852.

TARR, JohN SAMUEL MA $1955 \quad$ Washington/SL [3246] The archaeological importance of the Cahokia mounds and village sites. $101 \mathrm{p}$. 
Tate, Alberta Torrence MA 1932

Columbia [3247]

Thoreau's manuscript notes on the American Indian, vol. IX. Edited with an introduction. 433p.

Tate, Alta Mae MA 1955

East. New Mex. [3248]

History of the Mescalero Apache Indian Reservation from the time of its establishment to $1954.82 \mathrm{p}$.

Tate, Vernon Dale MA 1930

California [3249]

The Juan Pérez expedition to the Northwest Coast, 1774. 110p., pls.

Refers to his reports on natives.

TAUB, Amos MA 1950

Arizona [3250]

Traditional poetry of the Yaqui Indians. 129p.

TAx, Sol PHD 1935

Chicago [3251]

Primitive social organization with some description of the social organization of the Fox Indians. PUB: Eggan, Social Anthropology of North American Tribes. U/Chi. Press [1937] p243-282.

TAYLOR, CARL N. MA 1929

The Bride of the Sun. 214p.

New Mexico [3252]

Fiction, Chaco Canyon locale.

TAYlor, Cora Alice MA 1906

Kansas [3253]

The social and religious status of Siouan women studied in the light of the history and environment of the Siouan Indians. 40p.

TAYlor, Elizabeth OURSLer MA 1934 Oklahoma A\& M [3254] Hostilities in Florida arising from the removal of the Seminole Indians. $78 \mathrm{p}$.

TAylor, Herbert CecIL, JR. PHD 1951

Chicago [3255]

Social change and cultural death; a diachronic study. 304p. $M$.

Pecos and Eskimo areas.

TAYLOR, OMA EARP M/Ed 1937 Oklahoma [3256]

A pragmatic problem of moral education on the Kiowa Indian Reservation. 136p.

Kiowa, Comanche, Apache, Delaware, Wichita, Caddo. 
TAYLOR, WALTER WILLARD, JR.

A study of archaeology: a dialectic, practical, and critical discussion with special reference to American archaeology and the conjunctive approach. 359p. Р вв: Amer. Anthro. Assoc., Mem. \#69 [1948] 256p.

Indian content included as archeological data.

Teaf, Frances Randall MA 1933 Pennsylvania [3258] Geographical distribution and correlation of kinship usages of the avoidance-familiarity types in North America. $21+5 \mathrm{p}$.

Teal, Raymond James MDS 1954

So. California [3259]

A cephalometric analysis of the Navajo Indian. 36p.

A dental survey of children "with acceptable occlusions."

Telling, Irving, JR. PhD 1952

Harvard [3260]

New Mexican frontiers: a social history of the Gallup area, 1881-1901. 549p.

Much on Navajo, Zuñi; slight Pueblo.

Temple, James W. MA 1942

Government relations with the Kiowa Indians. $126 \mathrm{p}$.

Templeton, Flossie Bewley MA 1939 Geo. Peabody [3262]

Indian children's interests as revealed by their drawings and paintings. $34 \mathrm{p}$., illus.

Sequoyah Indian Training School, Tahlequah.

Templin, Leslie George EdD 1946

Kansas [3263]

Education in the modern missionary enterprise. A study of the extent, significance, and purpose of education in the modern missionary work of the Protestant Churches.

Some material on Indian missions.

Terpening, Lucy Lee MA 1933 New York-Albany [3264] Educational value of the contributions of the American Indian to American literature. 55p.

Terreld, Peggy Joyce MA 1953

Texas Tech. [3265]

Colonel R. S. MacKenzie's campaigns against the Southern Plains Indians, 1865-1875. 101p. 
Terrill, Dora Bratton MA 1942 Kans.-Emporia [3266] A study of the religious elements in the works of Ignacio Altamirano. 44p.

Altamirano (1834-1893), a full-blood Indian from Guerrero, Mexico, wrote extensively of the customs of his people.

Terry, Robert J. MA 1954 New York [3267] The religious practices of the Aztecs. 94p.

Textor, Lucy Elizabeth MA $1895 \quad$ Stanford [3268] Official relations between the United States and the Sioux Indians. PuB: Stanford U., Pubs. Hist. Econ. \#2 [1896] 162p.

Theis, Ruth Kathry $\quad$ MA 1935

Pittsburgh [3269] The attitudes of the White people towards the Indians of the Upper Ohio Valley, 1749-1795. 125p.

Thomas, Alfred Barnaby MA 1924 California [3270] Spanish expeditions into the Colorado region, 1541-1776. 194p. Рuв: Colorado Mag., I \#7 [1924].

Pueblo, Apache, Ute, Comanche and Navajo.

Thomas, Alfred Barnaby PhD 1928 California [3271] Spanish expeditions northeast of New Mexico, 1696 to 1719. 250p. Рuв: After Coronado. U/Okla. Press [1935] $307 \mathrm{p}$.

Comanche, Apache.

Thomas, Mary Ursula PhD $1938 \quad$ St. Louis [3272] The Catholic Church on the Oklahoma frontier, 1824 to 1907. 346p. $M$.

Indian removal to Oklahoma; missions in Indian territory.

Thomas, Nancy Modena MA 1933

Oklahoma [3273]

Commerce in Texas from 1821-1845. 88p.

Chapter "Indian trade".

Thomas, Robert K. MA 1954 Arizona [3274]

The origin and development of the Redbird Smith movement. 220p.

Cherokee tribe, period 1890-1920. 
Sources of the Tradiciones Peruanas of Ricardo Palma. Inca-Quechua.

Thomas, Sidney Johnson MA 1933

Texas [3276]

The archaeological investigation of Fate Bell Shelter, Seminole Canyon, Val Verde County, Texas. 140p.

Thompson, Donald R. MA 1953

Denver [3277]

A history of Holy Rosary Indian Mission from its beginnings to the present. 132p., illus.

Sioux; many photographic excerpts from school yearbook.

Thompson, Francis Wilfred MA 1951 Brit. Columbia The employment problems and economic status of the British Columbia Indians: a survey of the extent to which the native Indians have become assimilated into the labour force and economic life of the Province. 60p.

Thompson, Raymond Harris PhD 1955 Harvard [3279] Modern Yucatecan Maya pottery: a study of the nature of archaeological inference. 400p., illus. РUв: Amer. Archeol. Soc., Mem. \#13. In press.

Thompson, Ruth MA 1912

Minnesota [3280]

The Sioux treaties at Traverse des Sioux and Mendota in 1851 and their outcome.

Thompson, Shemlagh MA 1947

California [3281]

A comparative study of mammalian faunas from archaeological sites in Marin and Sacramento Counties, California. 49p.

\section{Thompsón, Shemlagh PhD 1951}

A comparison of the criteria of age determination of human skeletons by cranial and pelvic morphology. 65p. California Indian skeletal material from archeological sites.

\section{Thompson, Strth $\quad$ PhD 1914}

Harvard [3283]

European borrowings and parallels in American Indian tales. 488p. Puв: "European tales among the North American Indian." Colorado Coll. Pubs. Language Ser., II [1919] p319-471. 
Thompson, Velva Evodene

MA 1925

California [3284]

The Territorial Government of the present State of Missouri. $113+13 p$.

Treaties with Osage, Sac and Fox.

Thompson, WiLliam BIRD MA $1947 \quad$ S. F. Austin [3285] A history of the Alabama and Coushattis Indians. 101p.

Thornton, Hurschel Vern MA $1929 \quad$ Oklahoma [3286] Oklahoma municipal history (Indian Territory). 99p.

Five Civilized Tribes; much on Indian, especially Cherokee and their cities.

Thornton, Sarah MA 1925

Oklahoma [3287]

Education of the Cherokee Indians. 59p.

Thorp, Rowena WeIrauch MA 1935 So. Methodist [3288]

The dress of the Plains Indian women and children. 64p.

Thrupp, Sylvia Lettice MA $1929 \quad$ Brit. Columbia [3289] A history of the Cranbrook District in East Kootenay. $97 \mathrm{p}$.

St. Eugene Indian Mission: Indian unrest. Period 1807-1900.

Tibesar, Antonine S. PhD $1952 \quad$ Catholic [3290]

Franciscan beginnings in colonial Peru (1531-1600).

Pбв: Acad. Amer. Franciscan Hist., Mono., I [1953] $162 \mathrm{p}$.

Early missionary efforts to the Indians stressed throughout.

Tichenor, Helen Elizabeth PhD 1941 California [3291] The opening of the southern missions of Baja California. $261 p$.

Especially concerns Juan de Ugarte and Jaime Bravo. Mentions the Pericue and Guaicuro Indians, and the attempt to protect the route to the Monqui Indian missions.

Trcknor, Earl Harold MA 1938 Alabama Poly: [3292] Andrew Jackson's campaign in Alabama during the Creek War of 1812.

Tidd, James Watson MA $1929 \quad$ Ohio State [3293] A brief history of the Nez Percés Indians. 92p. 
Tillson, Merl W.

PHD 1950

Denver [3294]

The frontiersman in American drama: An analytical study of characters and plays reflecting the phenomenon of Westward expansion. 342p.

Considers White frontiersman in opposition to Indians as characters or themes for dramatic productions.

Tippeconnic, JoHN W. MA 1942

Ariz.-Flagstaff [3295]

Comanche Indian customs with educational implications. $60 \mathrm{p}$.

TIRrell, Sarah R.

MA 1931

Yale [3296]

The land situation in North Carolina prior to the ratification of the Federal Constitution. 102p.

Indian-White relations throughout.

Titiev, Morris [Mischa] PhD 1934

Harvard [3297]

The social organization of the Hopi Indians. 330p., illus. Pणв: "Old Oraibi, a study of the Hopi Indians of Third Mesa." Harvard U., Peabody Mus., Paps., XXII \#1 [1944] 277p., illus.

Tobias, Edna Weedon MA 1936

Sul Ross [3298]

The history of education in Nueces County. 82p.

Karankawa Indians of Texas.

Tobie, Harvey Elmer MA 1927

Oregon [3299]

The Willamette Valley before the great immigrations. $210 \mathrm{p}$.

Extensive treatment of Indians.

Todd, Edgeley W. PhD 1952

Northwestern [3300]

Literary interest in the fur trade and fur trapper of the trans-Mississippi West.

1803-1850. While emphasis is on White trappers, some consideration is given Indian relations.

\section{Tohill, Louis Arthur PhD 1926}

Minnesota [3301]

Robert Dickson, British fur trader on the upper Mississippi: a story of trade, war and diplomacy. Рणв: Ann Arbor: Edwards [1927] 124p.

Chippewa, Sioux, Menomini, Winnebago; fur trade in Minnesota-Winconsin area. 
Tolan, Providencia $\quad$ MA 1952

Catholic [3302]

Catholic Indians. 50p.

General treatment.

Tolman, Robert G. MA 1948 Arizona [3303]

The Spanish mission as an economic institution in the Southwest. 193p.

Slight mention of tribes in mission areas.

Tomes, Vincent Gregory MA $1955 \quad$ New York [3304] The expulsion of the Society of Jesus from New Spain. $100 \mathrm{p}$.

Includes Jesuit missions to the Indians.

Tooker, Elizabeth J. MA 1953 Arizona [3305]

Papagos in Tucson; an introduction to their history, community life, and acculturation. $137 \mathrm{p}$.

Torgerson, Kenneth L. MS $1954 \quad$ Oregon [3306] The Modoc Indian War. 85p.

Torre-Bueno, Theodore MA $1952 \quad$ Columbia [3307] Mimbres pottery painting. 71p., illus.

Townsend, Charles Vernard MA 1939 Oklahoma $A \& M$ [3308] The opening of the Cheyenne and Arapahoe country. $55 \mathrm{p}$.

Townsend, Dallas Selwyn MA 1914 Columbia [3309] The Indians in American diplomacy: Article IX of the Treaty of Ghent. An historical monograph, 1814-1914. $134 \mathrm{p}$.

Townsend, Maurice Karlen MA 1950 Chicago [3310] The rehabilitation of the American Indian under the Indian Reorganization Act. 167p.

Tozzer, Alfred Marston PhD 1904 A comparative study of the Mayas and the Lacandones. P вв: NY: Macmillan [1907] 195p., illus.

Tracy, Elizabeth Andrea MA 1932 Smith [3312] The Indian in American drama, 1766-1856. 115p. 
Trammell, Cecil Byron

MA 1938

Oklahoma [3313]

Mescalero Indian relations in New Mexico, 1865-1885.

$119 \mathrm{p}$.

Travis, Vaud Ancil $\quad$ MA 1926

Forty years of the Cherokee Republic. 135p.

Oklahoma [3314]

This does not refer to the newspaper.

Treat, Payson Jackson PhD 1910

Stanford [3315]

The national land system, 1785-1820. Рбв: NY: E. B.

Treat \& Co. [1910] 426p.

Considerable on Indians and the land.

Treganza, Adan Eduardo PhD 1950 California [3316] The Topanga culture and southern California prehistory. $288 p$.

Treichler, PaUl F. MA 1932

Montana [3317] Custer, a play. $146 \mathrm{p}$.

A drama concerned with events prior to and including the Battle of the Little Big Horn, 1876.

Trelease, Allen William PhD 1955

Harvard [3318]

Indian relations and the fur trade in New Netherland, 1609-1664. 360p.

Tremayne, Frank Gilbert MA 1923

California [3319]

History of the Santa Clara Valley: the Mexican period.

227 p., pls.

Costanoan Indians.

Trenfel-Treantafeles, Jacqueline T. MA 1941

California [3320]

Spanish occupation of the upper Mississippi Valley, 1765-1770. 317p.

Includes section on Spanish Indian policy.

Trenholm, Windiam Seth MS $1939 \quad$ Mt. Allison [3321]

The Indians of eastern Canada during the seventeenth century. 41p.

Trent, Lloyd William MS/Ed $1945 \quad$ No. Dakota [3322] A supervisory survey of a small school system. 54p.

Cass Lake, Minnesota-Chippewa Indian Agency headquarters. 
Trevor, MarJorie C. MA 1954

Wyoming [3323]

History of Carter-Sweetwater County, to 1875. 133p.

1867-1875. Considerable references to Crow tribe.

Trexler, Harrison Anthony PhD 1914 Johns Hopkins

Slavery in Missouri 1804-1865. PUB: Johns Hopkins U., Stud. Hist. Pol. Sci. Ser., 32 \#2 [1914] 259p.

Brief section on Indian slavery.

Trimble, Martha Scott MA 1940

Hamlin Garland and his Western novels.

Colorado [3325]

Brief Indian mention, as included by Garland in some of the eleven novels considered.

Troiel, Marie Yvonne

MA 1924

California [3326]

Certain phases of the land problem in New Mexico and Arizona. 136p., illus.

Trodtman, Wriltam Fife MA 1947

Duke [3327]

The evolution of the Federal Indian Law. 114p.

Troxel, Kathryn Marie PhD 1950

Indiana [3328]

Fort Nisqually and the Puget's Sound Agricultural Company. 225p.

Nisqualli.

TSCHOPIK, HARRY, JR. PHD 1950

Harvard [3329]

The function of magic in an Aymará Indian community. 426p. PUв: "The Aymará of Chucuito. I. Magic." Amer. Mus. Nat. Hist., Anthro. Paps., XLIV pt. 2 [1951] p137-308, illus.

Tsuchiyama, Tamie PhD 1947 California [3330] A comparison of the folklore of the Northern, Southern and Pacific Athabaskans: a study in stability of folklore within a linguistic stock. 201p.

Tudisco, Anthony $\quad$ PhD 1950

Columbia [3331] America in eighteenth century Spanish literature. 217p. $M$.

Three basic themes: land, people and problems; discovery, conquest and colonization; the Indian. 
San Luis Jilotépeque: a study in social relations. 291p. Indian-White relations, mostly Maya-Quichol groups in Guatemala.

\section{Tunnell, Kathrine Greer MA 1931} Georgia's treaties with the Indians. 57p.

Emory [3333]

Turner, Elbert Daymond, JR. PhD 1949 No. Carolina [3334] The vocabulary of Bernal Díaz del Castillo's Historia Verdadera de la Conquista de la Nueva España.

Considers some Amerindian terms.

Turner, Festus Eugene MA 1951 Hardin-Simmons [3335] A history of Buffalo Gap. 125p., illus.

Extensive consideration of Texas tribes in one chapter.

Turner, Frederick JaCkson PHD 1890 Johns Hopkins [3336] The character and influence of the Indian trade in Wisconsin. PuB: Johns Hopkins U., Stud. Hist. Pol. Sci. Ser. 9 \#11-12 [1891] 94p.

Presented to the Department of History, this was the earliest $\mathrm{PHD}$ dissertation in the United States to give major attention to the American Indian. See also \#539 and \#841.

Turner, GLen MA 1950

Indiana [3337]

List of South American Indian languages. [75p.]

Turner, James E.

MA 1940

Oklahoma $A \& M$ [3338]

The development of the educational program at the Seneca Indian School. 50p.

Many tribes; general.

Turner, Rose ANDrÉE

MA 1923

California [3339]

Paló-Noticias de la Nueva California: a translation of a part of the work, with historical introduction and critical notes. $117 \mathrm{p}$.

\section{TURner, Ruth Elizabeth MA 1923 California [3340]}

Palóu-Noticias de la Nueva California: a translation of a part of the work, with historical introduction and critical notes. 109p. 
Place-names of Webster Parish-a linguistic historical study. 141p.

Only a few Indian names.

\section{Tussey, Edgar D. MA 1926}

The Apache Wars in Arizona, 1880-1887.

Iowa [3342]

\section{Tweddelu, Colin Ellidge MA 1947 Washington} An outline of the phonemics and morphology of the Snoqualmie-Duwamish (Coast Salish) dialects of central Puget Sound, Washington. 156p. Рбв: U/Wash., Pubs. Anthro., XII \#1 [1950].

Tweeddale, Constance MS 1939 . Mt. Allison [3344] Diet, disease and living conditions among Canadian Indians. $113 \mathrm{p}$.

Tyler, Samuel L. PhD 1951 Before Escalante; an early history of the Yuta Indians and the area north of New Mexico. 231p.

Tyner, Howard Q. MA 1949 Tulsa [3346] The Keetowah Society in Cherokee history. 147p.

UhLer, Sherman P. M/Ed 1934

Temple [3347] The Moravian church and the missions among the Delawares and the Indians of the north. 102p., maps.

Uhler, Sherman P. PhD 1950 Temple [3348] Pennsylvania's Indian relations to 1754 . 189p. РuB: Allentown, Penna: Pvtly Pub. [1951] 144p.

Uhlman, Ester Evangeline MS 1953 Idaho [3349] A comparative study of achievement and intelligence of Indians and Whites in the public schools of Lapwai, Idaho. 42 p.

Nez Percé.

Uldall, HaNs J. MA 1933 Columbia [3350] Maidu. 25p. Рив: Intl. Jour. Amer. Ling., XX [1954] p8-16.

A linguistic study. 

Social organization of the Papago Indians. 280p. PUB: Columbia U., Contr. Anthro., XXX [1939] 280p.

UNderwood, JoHN Elmer MA 1941 So. California [3352] The use of steatite by the North American Indian. 194p.

Underwood, WiLliam Henry MA 1931 Oklahoma [3353] A history of Atoka County. 118p.

Oklahoma Choctaw, early Indian-White relations, missions.

UnRuH, JoHN D. PhD 1939

Texas [3354] South Dakota in 1889. 219p.

Several sections consider Dakota Sioux.

Untereiner, Wayne Whitlock PhD 1952 Harvard [3355] Self and society: orientations in the value systems of two cultures. $465 \mathrm{p}$.

Pueblos of New Mexico compared with Anglo rural folk.

Useem, Ruth Marie Hill PhD 1947 Wisconsin [3356] The aftermath of defeat; a study of acculturation among the Rosebud Sioux in South Dakota. 390p.

Uzzell, Minter MA 1954

Tulsa [3357]

A freshman English program for Bacone College, 1948 to 1954. $216 \mathrm{p}$.

Indian school, no specific tribes.

Vaillant, George Clapp PhD 1927

Harvard [3358]

The chronological significance of Maya ceramics. 445p.

Valentine, Charles A. III MA 1952 Pennsylvania [3359] Towards a definition of Eskimo social organization. 182p.

Valle, Rafael Heliodoro DCH 1948 Mexico [3360] Cristóbal de Olid, conquistador de México y Honduras. 150p. Рбв: Taller Gráfica [1948].

VALLery, Hubert James MA 1942 A history of Indian education in Canada. 209p.

VAN AKen, MARK JAY MA 1950

California [3362]

Nuflo de Cháves and the founding of Santa Cruz de la Sierra. 182p.

Guaraní. 
Van Alstyne, Richard Warner MA 1924 So.California [3363] The Indian on the New England frontier, 1620-1675. 87p.

Pequot-King Philip.

VANDERBURG, JoANne MA 1953

Chilkat and Salish weaving. 119p., illus.

Washington [3364]

Van der Eerden, Mary LdCia MA 1943 Catholic [3365] Infant nutrition in Pueblo culture. Р $\mathrm{BB}$ : "Maternity care in a Spanish-American community of New Mexico." Cath. U., Anthro. Ser. \#13 [1948] 75p.

VANDER ZANDEN, JAMES W. MS 1954 Wisconsin [3366] Practices pertaining to dogs among the Indians of the United States. 173p.

VAN GeEm, Marion MA/LS 1940 Simmons [3367] Archaeology of the Pennsylvania Indian: a bibliography. 107 titles, annotated.

VAN HUIZEN, GEorge Harry MA 1950 Washington/SL [3368] The United States Government and the Sioux Indians, 1878-1891. 213p.

VANNAH, GUY LINwOOD STM 1925 Protestant missions among the American Indians. 39p.

VAN Norman, Carrie Elta MA 1931 Rochester [3370] Educational problems in the Indian schools under Governmental control. 124p.

Van Norman, Carrie Elta EdD 1941

Stanford [3371] An investigation of the concept of war in historical fiction written for children.

Two chapters on Indian warfare.

Van Stone, James WrLlard MA 1950 Pennsylvania [3372] Man and the grasslands: an anthropological critique of the theory of the Quaternary origin of the Western Prairies. 99p.

Van Stone, James Willard PhD 1954 Pennsylvania [3373] Archeological excavations at Kotzebue, Alaska. 172p. Рчв: U/Alaska, Anthro. Paps., III \#2 [1955] p75-156. 
The adolescent girl among primitive peoples. PUв: Jour. Rel. Psych., VI [1913] p375-421; VII [1914-15] p75-120.

General, but includes examples from North American Indian customs.

Van Well, Mary Stanislads PhD 1941 Marquette [3375] The educational aspects of the missions in the Southwest. 373p. Puв: Marquette U/Press [1942] 161p.

Chapters on "Indians before missionaries" and "Missions as an educational institution" (i.e., among the Indian tribes).

Vanzee, Pearl E. MA 1927

Iowa $[3376]$

The relations of the United States to the Ponca Indians.

VASSAR, Rena LeE MA 1953

California [3377]

The Fort Bidwell, California, Indian School: a study of the Federal Indian education policy. 176p.

Paiute.

Vaughan, Portia Loyetta MA 1939

Kansas [3378] An investigation of music as taught in a Government Indian school in Oklahoma. 189p.

No tribes mentioned; general.

VAwTER, JAMES ELLIOTT MA 1948

No. Carolina [3379]

Game activities of the Southeastern Indians of the United States in the 18th and 19th centuries. $142 p$.

Includes some original material.

Vázquez, Mario Carlos MA 1955

Cornell [3380]

A study of technological change in Vicos, Peru. 97p.

Velázquez, Pablo MA 1956

Mexico: $E N$ [3381]

La hechicería en Carapan, Michoacán.

Includes Mexican Indian witcheraft.

Verhey, ANne MA 1940

Iowa [3382]

Evaluation of and recommendations for constructive activities related to a unit on Indian life. 91p.

Viault, Elsie Rosine MA 1921

Columbia [3383]

Maize-its cultivation and preparation as a food by the Indians of the Southwest and the area east of the Mississippi. 25p. 
Villoro Toranzo, Luís MF 1949

Mexico [3384]

Los grandes momentos del indigenismo en México. 339p.

Villoro Toranzo, Luís DL 1950

Mexico [3385]

Los grandes momentos del indigenismo en México. 248p.

PUB: Fondo de cultura económica [1950]. 247p.

ViNogrande, ANN C. MA $1944 \quad$ Wisconsin [3386] The Indian policy of the Mexican Government since the Revolution. $89 \mathrm{p}$.

Vivian, Richard Gordon MA $1932 \quad$ New Mexico [3387] A re-study of the Province of Tiguex. 81p.

Voegelin, Charles Frederick PhD 1933 California [3388] A characterization of the Kern River Shoshonean language. $212 \mathrm{p}$.

Voegelin, Erminie Wheeler MA 1932 California [3389] Mythological elements common to the Kiowa and five other Plains tribes. 55p., maps.

Others are Crow, Arapaho, Gros Ventre, Blackfoot, Cheyenne.

Voegelin, Erminie Wheeler $\quad$ PhD $1939 \quad$ Yale [3390] Shawnee mortuary customs. Рणв: Indiana Hist. Soc., Prehist. Res. Ser., II \#4 [1944] p227-444.

Vogel, Cladde Lawrence PhD 1928

Catholic [3391] The Capuchins in French Louisiana (1722-1766). PUB: Cath. U., Stud. Amer. Church Hist., VII [1928] 201p.

Voget, Frederick William PhD $1948 \quad$ Yale [3392] The diffusion of the Wind River Shoshone Sun-dance to the Crow Indians of Montana. PUB: "Individual motivation in the diffusion of the Wind River Shoshone Sundance to the Crow Indians." Amer. Anthro., L [1948] p634-645.

Vogt, Evon Zartman, JR. PhD $1948 \quad$ Chicago Navaho veterans: a study of changing values. $394 \mathrm{p}$. Рбв: Harvard U., Peabody Mus., Paps., XLI \#1 [1951] 223p. 
Volwiler, Albert Tangeman PhD 1922 Pennsylvania [3394] George Croghan and the Westward movement, 1741 to 1782. PuB: Cleveland: A. H. Clark [1926] 370p.

Extensive consideration of Indian affairs.

Von Winning, Hasso Leopold MS 1954 So. California [3395] Pre-Columbian education among the Aztecs, Mayas, and Incas. 150p.

Vozbut, Edward Norbert

DDE 1955

Nebraska [3396]

Education for regional understanding with reference to the environment and problems of the Missouri Basin. 211 .

Pick-Sloan plan, with indirect references to its effect on Indian Reservations of the area.

VRETTOS, LouIs MA/Ed $1949 \quad$ Wyoming [3397] The education of Indians with special reference to the Shoshone Indian Reservation in Wyoming. $54 \mathrm{p}$.

WADDEL, WILLIAM S. MA 1931

So. Dakota [3398]

The military relations between the Sioux Indians and the United States Government in the Dakota Territory, 1860-1891. 67p.

Wadia, Maneck S. MA 1955

Indiana [3399]

Tesuque: a study in acculturation. $83 \mathrm{p}$.

Waggett, George M. MA 1944 Denver [3400] The Oblates in the Pacific Northwest, 1847-1878. 101p.

Wagley, Charles PhD 1941 Columbia [3401] Economics of a Guatemalan village. Pub: Amer. Anthro. Assoc., Mem. \#58 [1941] 87p.

The Mam village of Santiago Chimaltenango.

Wagner, Philip Laurence MA 1950 California [3402] Russian exploration in North America. 264p., maps.

Aleut, Eskimo, Athapascan, Kolosh; also Indians at Fort Ross, California.

Wagner, Philip Laurence PhD 1953 California [3403] Nicoya: historical geography of a Central American lowland community.

The Chorotega inhabited Nicoya in $\mathbf{1 5 0 0 .}$ 
Watles, Bertha Pfister

MA 1928

Virginia [3404]

Backward Virginians: a further study of the Win tribe.

A study of an isolated group living in the Blue Ridge foothills; mixed White-Negro-Indian.

Watnwright, Nicholas Biddle MA 1951 Pennsylvania [3405] George Croghan-Indian trader. 166p.

WaLdecker, Alice VIRginia MA 1945

Smith [3406] Administrative and legislative reforms in American Indian relations, 1928-1934. $151 \mathrm{p}$.

WaLdon, Freda MA 1931

Columbia [3407]

Alexander Henry, Esq., of Montreal, fur trader, adventurer and man of letters. $110 \mathrm{p}$.

Circa 1760-1776: includes material on his Indian relations and Indian fur trading activities.

Wales, E. Max

MA 1928

Indiana [3408]

The Hudson's Bay Company in the reign of Queen Anne.

Library cannot locate this thesis.

Walker, David Eugene MA 1942 Washington [3409] A survey of the establishment of educational institutions in Oregon preceding statehood.

Considers failure of attempts of Jason Lee to establish Methodist Indian school.

WaLker, Eva Mary MA 1936

North Dakota Indians. 236p.

Colorado State [3410]

Walker, Fintan Glenn MA 1932

Catholic [3411]

The progress of the Catholic Church on the southern Indiana frontier (1763-1834).

Walker, Frances Moorman

MA 1933

Virginia [3412]

Lord Dunmore in Virginia.

His Indian relationships; Lord Dunmore's War.

WALKER, RoBERT L. M/ED 1940

Oklahoma [3413]

The capacities and achievements of rural and city pupils in Choctaw, Oklahoma, Public School. 130p.

Choctaw; combines Indian and non-Indian pupils. 
WALKER, WILLARD B. MA 1953

Acculturation of the Great Whale River Cree. 81p.

WaLker, Winslow Metcalf MA 1928 California [3415] California Indian pipes, ancient and modern. 40p., pls.

Wall, Claude Leon MA 1952

Nevada [3416]

History of Indian education in Nevada from 1861 to 1951. 213p.

Washo, Northern Paiute, Southern Paiute, Shoshonean.

WaLL, Robert BILLE MA 1940

California [3417]

Frontier defense problems of the provincias internas del Poniente, 1786-1787. 99p.

Comanche, Navajo, Apache.

Wallace, ANna Ruth Haworth MA 1932 Indiana [3418] The son-in-law test among the North American Indians. [262p.]

Wallace, Anthony F. C. MA 1949 Pennsylvania [3419] A psychocultural analysis of the life of Teedyuscung, a Delaware Indian, 1700-1763. PuB: King of the Delawares: Teedyuscung, 1700-1763. U/Penna. [1949] 305p.

Wallace, Anthony F. C. PhD 1950 Pennsylvania [3420] The modal personality structure of the Tuscarora Indians, as revealed by the Rorschach test. Рणв: Bur. Amer. Ethnol., Bull. \#150 [1952] 120p.

WaLlace, Gerald Raymond

MA 1944

California [3421] The strategy of the fur traders in the Snake River Valley, 1824 to $1846.80 \mathrm{p}$.

Iroquois and others.

WALLACE, IsABEL WeIR MA 1918

Washington [3422]

History of education in Alaska. 42p.

Sitka Industrial School, Matlakatlah and "native schools".

Wallace, William James PhD $1946 \quad$ California [3423]

Hupa education: a study in primitive socialization and personality development. PUB: "Hupa child-traininga study in primitive education." Educl. Admin. \& Supervision, XXXIII [1947] 25p. 
A history of Limestone County, Texas, to 1873. 171p.

Extensive material on Indians of the region.

Walter, Virginta Melba MA 1931 California [3425]

Gonzalo Ximénes de Quesada and the conquest of Nueva Granada. 129p., maps.

Chibcha Indians of Colombia.

Walters, Padl Hugh MA 1944

Texas [3426]

Survey of the history of La Bahía del Espíritu Santo, 1721-1821. 148p.

§ 6 "Indian relations, 1721-1821". Texas region.

Walton, Edna Lou PhD 1921

California [3427]

Navaho traditional poetry. PUB: "American Indian poetry." Amer. Anthro., XXVII [1925] p25-52; "Navajo song patterning." Jour. Amer. Folklore, XLIII \#167 [1930] p105-118.

Walz, Vina E. PhD 1950

New Mexico [3428]

A history of the El Paso area, 1680-1692. 345p.

Manso, Jumano.

WARD, JEAN M. MA 1951

Columbia [3429]

The economic position of the Peruvian Indian peasant under the Inca and the Spanish colonial régimes. $38 \mathrm{p}$.

Ward, Mary Redempta MA 1921 California [3430] The Viceregal administration of Álvaro Manrique de Zúñiga, Marqués de Villamanrique, 1585-1590. 105p.

Considerable attention given to his attempts to ameliorate the living conditions of the natives in Mexico.

WARD, WILLIAM R. MA 1944 A history of Smith County, Texas. 249p., illus.

No. Texas [3431] Much on Indians.

Wardell, Morris L. PhD 1936

Chicago [3432]

A political history of the Cherokee Nation, 1838-1907. 490p. Р вв: U/Okla. Press [1938] 383p. 
Iroquoian Government. 109p., illus.

WARFIELD, Helen L. MA 1947

Claremont [3434]

The influence of media upon the development of thirddimensional expression of intangible ideas by preColumbian American Indian civilizations. 76p., illus.

Warner, Pauline Belle MA 1925

The Indian in American poetry of the nineteenth century. 170p.

Warner, RaLPh Emerson PhD 1935

The life and work of Ignacio Manuel Altamirano.

A Mexican Indian writer who wrote extensively of the life and customs of his people.

Warner, Robert Austin PhD 1935

Yale [3437]

The southern New England Indians to 1725. A study in culture contact. $366 \mathrm{p}$., maps, charts.

Exhaustive treatment of the subject; includes lengthy bibliography.

Warren, Virgil Alexander PhD $1933 \quad$ Virginia [3438] The use of Quechua by contemporary writers of the Andean regions. 119p.

Includes vocabulary.

Washburn, WILcomb Edward PhD 1955 Harvard [3439] Bacon's Rebellion, 1676-1677. 748p.

Chapter on "Early Indian troubles". Outlines differences of opinion between Bacon and Gov. Berkeley on Indian policy.

Wasley, WinLIam W. MA 1953

Arizona [3440]

The late Pueblo occupation of Point of Pines, eastcentral Arizona. 151p.

Wasserman, Maurice M. PhD 1954 Pennsylvania [3441]

The American Indian as seen by the seventeenth century chroniclers. 487 p. $M$.

Evaluates reliability of observances penned by early English colonists.

Waterman, Thomas Talbot $\quad$ PhD $1914 \quad$ Columbia [3442] The explanatory element in the folk-tales of the NorthAmerican Indians. PUB: Jour. Amer. Folklore, XXVII \#103 [1914] 54p. 
Waters, Marguerite Elizabeth MA 1933 So.California [3443] The myths, legends, and folklore tales of the Indians of Arizona. $108 \mathrm{p}$.

Watkins, Floyd C. PhD 1952 Vanderbilt [3444] James Kirke Paulding: humorist and critic of American life. $374 \mathrm{p}$.

1778-1860. Paulding was one of the earliest American authors to use Indians in fiction; suggests he anticipated others in use of Indian folklore.

Watkins, Frances Emma PhD 1942 So. California [3445] Crafts and industries of the American Indian women of California and the Southwest. 427p., maps.

WatKINS, Ira L. MA 1939 The history of Sterling County. 128p., map.

Texas Tech. [3446] $\S 1$ "Indian pre-history".

Watkins, Lucy RebecCA Mexican colonization on the United States border, 1848-1858. 140p.

Indians on Gila and Rio Grande Rivers.

Watrous, Blanche Greene PhD 1949 Northwestern [3448] A personality study of Ojibwa children. 264p.

Watson, Clifford G. MS/Ed 1952 New York-Buffalo [3449] Part of a guide for teaching science in the Cattaraugus Indian School-magnetism and electricity; machines. $146 \mathrm{p}$.

Watson, James BennetT MA 1945 Chicago [3450] The historical development of Hopi economy and its relations to other aspects of culture. $98 \mathrm{p}$.

Watson, James Bennett PhD $1948 \quad$ Chicago [3451] Cayuá culture change: a study in acculturation and methodology. 210p. Рuв: Amer. Anthro. Assoc., Mem. \#73 [1952] 144p., illus.

Watt, Jewell Krmball MS 1930 Kansas State [3452] A survey of Haskell Institute. 76p. 
WATtS, MiLdred

MA 1931

Geo. Peabody [3453]

Indian children's interests revealed by literary preferences and creative writings. $96 \mathrm{p}$.

Three Oklahoma schools, tested in 1931.

WAtTS, RoBert M. MA 1951

The masks of the Alaskan Eskimo. 49p., illus.

$\begin{array}{ccc}\text { WAUCHOPE, ROBERT } & \text { PHD } 1942 & \text { Harvard } \\ \text { The archaeology of Zacualpa, Department of Quiché, }\end{array}$

Columbia [3454] Guatemala: a study of interrelations of environment, technology, and human relations. 434p. PUB: "Excavations at Zacualpa, Guatemala." Tulane U., Middle Amer. Res. Inst., Pubs. \#14 [1948] 168p., illus.

Weaver, John M. MA 1948

Arizona [3456]

The history of Fort Lowell. 131p.

Apache, Yuma, Mohave.

Webb, Helene Amelia MA $1940 \quad$ Florida State [3457] The Seminoles in modern times. 111p., maps.

Webb, Walter Prescott PhD 1932 Texas [3458] The Great Plains; a study in institutions and environment. Puв: Boston: Ginn \& Co. [1931] 525p. illus., maps.

Weber, NANCy E. MA 1953

Hunter [3459]

A study of human blood groups. 58p.

Includes brief section on Amerindian groupings.

Webster, David Hutton PhD 1904

Harvard [3460]

Primitive social control. A study of initiation ceremonies and secret societies. 240p. PUB: NY: Macmillan [1908] $227 \mathrm{p}$.

Considerable Indian material.

Wedel, Waldo Rudolph PhD 1936 California [3461] Some historical and ethnic aspects of Nebraska archaeology. PUB: "An introduction to Pawnee archaeology." Bur. Amer. Ethnol., Bull. \#112 [1936] 122p., illus.

Weed, Alice Lucme MA 1934

Hartford [3462]

A study of Navajo Indians: treats of the characteristic traits in the cultural background. 137p. 
Weeks, Richard Carrier

MA 1948

Chicago [3463]

Problems of Baptist Indian missions in the Old Northwest, $1817-1840$. 80p.

Weinan, Clarence Wolsey PhD 1943 Columbia [3464] An introduction to the ceramics of Tres Zapotes, Vera Cruz, Mexico.144p. Рбв: Bur.Amer. Ethnol., Bull. \#139 [1943] 144p., illus.

Weickselbadm, Norman MA 1937

Ohio [3465]

The Catholic Indian School controversy, 1889-1891; a conflict of ideas. 148p.

Weinburg, Frances Toor

MA 1922

California [3466]

Relations of the Spaniards with the Moquis, 1540-1780. $167 \mathrm{p}$.

WEISSER, ELIZABETH

MA 1930

Denver [3467]

A diagnostic study of Indian handwriting. 159p., illus.

Albuquerque Indian School; Chilocco Indian School.

Welborn, Cla dd Alson MA 1932

Indian campaigns in the Northwest, 1865-1877. 110p.

Oklahoma [3468]

Dakota Sioux.

Welch, DoRothy E. MA 1929

West. Reserve [3469]

Citizenship of the American Indian, 1887-1929. 110p.

Survey showing effects of Burke and Dawes Acts.

WeLCH, Floyd Duckworth MA 1926 Washington/SL [3470] The work of Indian Agents in the Louisiana Purchase, 1804-1820. 134p.

Wellin, Edward $\quad$ PhD 1955

Harvard [3471]

Processes of directed culture change: studies of health action in Peru. 176p.

Indians of Peru included.

Wells, Helen G. MA 1942

So. California [3472]

Navaho of the Painted Desert in American fiction. 137p.

Wells, James Ralph PhD 1932 Washington/SL [3473]

The origin of immunity to diphtheria in isolated communities of Polar Eskimos. 102p. 
WeLls, Lewis B. MS 1937

Iowa [3474]

Comparative study of long bones of Indians buried in Dickson and other mounds of Fulton County, Illinois.

Wells, Marion A. MA 1932

Columbia [3475]

Thoreau's manuscript notes on the American Indian, volume VII. (Edited.) 424p.

Wells, William Alva MA 1936

Oklahoma [3476]

Osceola and the Second Seminole War. 186p.

Wells, WILlie Scruggs MA $1952 \quad$ West Texas [3477]

Indian music and its place in the curriculum of the modern school. 100p.

Welpley, Charles MA 1933

Geo. Washington [3478]

Pottery decoration among the Indians of the southwestern United States. 28p., pls.

WeLSH, Louise MA 1932

Oklahoma [3479]

The development of law and order in the Cherokee Nation, 1838-1907. 144p.

Weltisth, Gene PhD 1950

Columbia [3480]

The interrelation of technique and design in North American basketry. 132p. $M$.

Wend, Elizabeth Scudder MA 1937 New York-Albany [3481] The culture of the Iroquois Indians: its value for the schools of New York State. 180p.

Wendorf, Denver Frederick, JR. PhD 1952 Harvard [3482] Archaeological studies in the Petrified Forest National Monument, Arizona. Puв: Mus. No. Ariz., Bull. \#27 [1953] 203p., illus.

Werner, Gustave Adolph PhD 1923 California [3483] Don Pedro de Alvarado and the conquest of Guatemala. $243 p$.

Werner, Marion Beatrice

MA 1929

California [3484] The history of Juneau, Alaska. 208p., illus. Tlingit. 
Wesley, Edgar Bruce

MA 1925

Washington/SL [3485]

The fur trade of the Southwest. 177p.

Emphasis is on Osage, but many other tribes in the area are also mentioned throughout.

Wesley, Edgar Bruce PhD 1929 Washington/SL [3486] Frontier defense, 1815-1825. 301p. Рчв: Guarding the frontier; a study of frontier defense from 1815 to 1825. U/Minn. Press [1935] 217p., illus.

Some 35 tribe smentioned. Mostly on Caddo, Cherokee, Creek, Seminole, Osage, Sauk, Fox.

West, Albert Glenn $\quad$ MA 1941

Wash. State [3487]

A brief report on a thesis consisting of sixteen portrait paintings in oil of representative members of Indian tribes native to the Inland empire. 17p., illus.

Text contains report on methods, plus short biography of each subject. Colville, Nez Percé, Yakima.

West, Paul Montravile MA 1930 Geo. Peabody [3488]

Myths and legends of the Indians of Mississippi. 201p.

West, Phebe MA/Ed 1938

Washington [3489]

An educational program for an Aleut village. 129p.

Primarily concerned with Attu, but also considers Atka.

West, RALPH L. MA 1950

Wayne [3490]

The adjustment of the American Indian in Detroit: a descriptive study. $80 \mathrm{p}$.

Wetzler, Lewis William $\quad \mathrm{PHD} 1949 \quad$ California [3491]

A history of the Pima Indians. 384p. $M$.

Weyant, E. David MS/Ed $1939 \quad$ Wyoming [3492]

A program of health education for the community school at Nondalton, Alaska. 57p.

Emphasis on Eskimo.

Weyer, Edward Moffat, JR. PhD $1930 \quad$ Yale [3493]

The Eskimos: a study in adaptation to environment. 494p., illus. Рणв: The Eskimos: their environment and folkways. Yale U. Press [1932] 491p. 
Weyland, RUdolph HaRry MA 1945 Oklahoma $A \& M$ [3494] A study of the musical talent among Indian children from the Pawnee Indian Agency jurisdiction, Pawnee, Oklahoma. 56p.

Wharton, Reba Gaskin MA 1912 The Gadsden Treaty. 141p.

California [3495]

Yuma, Pima, Maricopa, Navajo, Apache and Comanche.

WheAT, JoE BeN MA 1949

Arizona [3496]

An archeological survey of the Addicks Dam Basin, southeast Texas. 171p. PUB: "The Addicks Dam Site." Bur. Amer. Ethnol., Bull. \#154 [1953] p143-252.

Wheat, Joe Ben PhD 1953

Arizona [3497]

A study of the Mogollon culture prior to A.D. 1000. 563p. Puв: Amer. Anthro. Assoc., Mem. \#82 [1955] $242 \mathrm{p}$.

WhEeler, Arline Z. MA 1955 Kansas [3498] Securing social adjustment among Indian girls at Stewart, Nevada. $56+11 p$.

WHEELER, RoLLIN W. MA 1933

Colorado State [3499] A history of the Indian Agencies in Arizona. 152p.

Wheelis, Martha Virginia MA 1945 Baylor [3500] The Texas Indians. 565p., many illus.

Whelan, Mary Elizabeth MA 1921 The Brazilian race problem. 56p.

Columbia [3501]

Some attention to Indian racial intermixture, but largely concerned with White-Negro mix.

Whitaker, Arthur Preston PhD 1924 Harvard [3502] The expansion of the Old Southwest, 1783-1791. PuB: "Spanish intrigue in the Old Southwest: an episode, 1788-1791." Miss. Valley Hist. Rev., XII [1925] p155176.

White, Alice Marsden MA 1943 Yale [3503] An exploratory study of the speech development of children in various societies. 140p.

Cross-cultural survey; Indians included. 
White, Berenice TupPer

The effect of the geography of Arizona on the art expression of the peoples of that region. 205p.

Chapter "Art expression of the Indians".

WHITE, JACK E. MA 1955

Kansas [3505]

Variation in height and weight of male Haskell Indian students over a 25 year period. $24 \mathrm{p}$.

White, John Browning PhD $1953 \quad$ Nebraska [3506]

Published sources on Territorial Nebraska; an essay and bibliography. 305 p.

1854-1867. Lists articles, reports, etc., on Indian tribes and Indian incidents.

White, Leslie A.

PHD 1927

Chicago

$[3507]$

Medicine societies of the Southwest. Pub: "A comparative study of Keresan medicine societies." Proc., 23rd Intl. Cong. Americanists [1928] p604-619.

White, Lonnie J.

MA 1955

Texas Tech. [3508]

Indian raids on the Kansas frontier, 1865-1875.

White, M. CATHERINe MA 1940

Montana

David Thompson-journals relating to Montana and adjacent regions, 1808-1812. 542p. PणB: Montana State U. Press [1950].

White, Mary Afra PhD 1940

St. Louis

Catholic Indian missionary influence in the development of Catholic education in Montana, 1840-1903. 230p. $M$.

White, Paul Raymond MA 1953

Trinity [3511]

Texas during the Civil War, 1861-1865. 115p.

Indian raids, fighting with Kickapoo. Small section on Indian relations.

White, Theodore Lawrence $\quad$ PhD $1953 \quad$ Texas [3512] The Marquis de Rubí's inspection of the eastern Presidios on the northern frontier of New Spain. 249p.

Whiteford, ANDRew Hunter MA 1943 Chicago

A frame of reference for the archaeology of eastern Tennessee. 103p. Pणв: Griffin, Archeology of Eastern United States. U/Chi. Press [1952] p207-225. 
Beacons of Wilderness; or, Jesuit missions of Montana. $135 \mathrm{p}$.

Missions to the Indians of Montana.

Whitenack, Charles E. MA 1932 Wisconsin [3515] The Federal Government and its relations with the Indians of the Old Northwest. (1783-1811.) 110p.

Whiteside, Myrtle Flossie MA 1938

Sul Ross [3516] Life of Laurence Sullivan Ross. 120p.

Extended treatment of his activities as a leader in Texas Comanche wars. Mention of Cynthia Ann Parker and Nocona.

Whiting, Beatrice Blyth PhD 1942 Yale [3517] The role of sorcery in social control; a study of theHarney Valley Paiute. Puв: "Paiute sorcery." Viking Fund Pubs. Anthro. \#15 [1950] 110p.

Whitman, William III PhD 1937 Columbia [3518] The Oto. Pणв: Columbia U., Contr. Anthro., XXVIII [1937] 132p.

Whitmore, Gladys Evelyn $\quad$ MS 1941 So. California [3519] A survey of the curricula of the Indian high schools of the United States. 100p.

WhitNer, Robert LeE MA 1948

Wash. State [3520] The nomination of the Nez Percé Agency personnel by denominational groups, 1871-1879. 112p.

WhitNey, RoBert ELLSWORTH MA 1955 Nebraska [3521] The Battle of Wounded Knee. 124p.

Sioux, 1891.

Whitten, Frederick Easton

MA 1950 Kansas City [3522] The Platte Purchase and its significance in frontier history. 76p.

Indian problems, Indian raids and depredations. Iowa, Sac-Fox.

Wicke, Charles R. MA 1954

Mexico City [3523]

The ball court at Yagul, Oaxaca: a comparative study. 
Wiese, Bernard R:

MA 1955

So. Dakota [3524]

The interpretation of the Indian in American historiography. 100p.

Wike, Joyce ANNabeu

MA 1941

Washington [3525]

Modern spirit dancing of Northern Puget Sound. 145p.

Wike, Joyce ANNABel PhD 1951

Columbia [3526]

The effect of the maritime fur trade on Northwest Coast Indian society. 107 p. $M$.

Wilcox, Lloyd PhD 1942

Wisconsin [3527]

Group structures and personality types among the Sioux Indians of North Dakota. 200p.

Wilcox, Wilma E. MA 1928

Iowa [3528]

Early Indian schools and education along the Missouri.

Wild, George Posey $\quad$ PhD 1941

Oklahoma [3529]

History of education of the Plains Indians of southwestern Oklahoma since the Civil War. 358p.

WILder, CARleton S. MA 1940

Arizona [3530]

The Yaqui Deer Dance: a study in cultural change. $157 \mathrm{p}$.

Wiley, Alma Pearl MA 1930

California [3531]

Marcus Whitman in the Oregon country. 105p.

His mission work among the Indians.

Wirey, Francis A. PhD 1941 Jedediah Smith in the West.

California [3532]

His Indian observations sent to Supt. Indian Affairs; Indian relations.

WILFORD, LLOYD ALDEN $\quad$ PHD 1937 Harvard [3533]

Minnesota archaeology, with special reference to the Mound area. Рणв: "A tentative classification of the prehistoric cultures of Minnesota." Amer. Antiq., VI \#3 [1941] p231-249.

Wilken, Robert Leo PhD $1953 \quad$ New Mexico [3534]

Father Anselm Weber, O.F.M., missionary to the Navaho, 1898-1921. 395p. $M$ Р Рв: Milwaukee: Bruce Pub. Co. [1955] 255p.

Also his work among Zuñi, Jémez, Santo Domingo and Rio Grande Pueblos. Much unpublished material included. 
Folk medicine in present day Mexico. 24p.

From pre-Conquest days to present time.

Wilkinson, John F. MA/Ed 1935 Arizona [3536] The Papago Indians and their education. 152p.

WiLlets, JANe Esther MA 1948 Pennsylvania [3537] Correlated changes in Ottawa kinship and social organization. 132p.

WILLEy, GoRdon RANDOLPH MA 1936 Arizona [3538] A survey of methods and problems in archeological excavation, with special reference to the Southwest. 140p. History of archeological excavation throughout the world; uses American Southwest as example.

WILLEy, GORDON RANDOLPH

PнD 1942

Columbia [3539] Excavations in the Chancay Valley. Рणв: Columbia U., Stud. Archeol. Ethnol., I \#3 [1943] p125-196.

\section{Williams, Albert Calvin MA 1939}

Texas [3540]

The route of Cabeza de Vaca in Texas: a study of historiography. $99 \mathrm{p}$.

Williams, Angela Mahola MA 1930

Indiana [3541] A study of Menomini art and literature. 162p.

Williams, Bernice Davis MA 1947

Mexico [3542] La historia del primer convento franciscano en México. Especially concerned with Franciscan missions to the Tlaxcala and Nahua peoples.

WiLliams, EdwaRd K. MA 1948 Jefferson's theories of language. 89p. Briefly considers his American Indian vocabularies.

\section{Willtams, Frances Sellers MA/Ed 1933 Temple [3544]} American dances for the American secondary schools. 184p.

"Dances of the American Indian along the frontier, with some mention of the Blackfeet, Makah, Pueblo." Also Algonquin and Sioux dance $s$. 
Williams, George Dee

PHD 1929

Harvard [3545]

Race mixture in Yucatán. 310p.

An analysis of racial characteristics of Yucatecan natives; physical anthropology statistics.

WiLliams, Gerald MA 1937

Oklahoma [3546]

The Colorado Indian problem, 1858-1876. 89p.

Cheyenne, Arapaho, Kiowa, Comanche, Southern Sioux, Ute.

WILLIAMS, J. W. MA 1939

No. Carolina [3547]

Emigration from North Carolina, 1789-1860.

Passing references to the Indian struggle to resist the onslaught of the Whites.

WiLLtams, James R. MA $1948 \quad$ Ariz.-Flagstaff [3548] Tribal education of the Hopi Indian child. 99p., illus.

Emphasizes the place of music in that training.

Winliams, Mary Clay MA 1922

Columbia [3549]

The opening of the Oklahoma Territory. $54 \mathrm{p}$.

WiLLIAMs, RAY A. MA 1934

So. Dakota [3550]

The prognostic value of the Detroit mechanical aptitude test battery in the vocational education of the American Indian. $21+2 \mathrm{p}$.

Flandreau Indian Vocational High School. Mostly Sioux; some Chippewa.

Williams, Ronald Irving EdD 1941 New York [3551] Art in Mexico. A text emphasizing the techniques of Mexican art for the use of the College teacher. 163p., ill.

Considerable attention is given to Mexican Indian art, pre- and post-Columbian. Profusely illustrated.

Williams, Stephen PhD 1954

Yale [3552]

An archeological study of the Mississippian culture in southeast Missouri. $327 \mathrm{p}$., illus.

Willis, William Shedrick PhD 1955

Columbia [3553]

Colonial conflict and the Cherokee Indians, 1710-1760. 293p. $M$.

WILlison, JoHn L. MA $1950 \quad$ Kans.-Emporia [3554]

Custer's Last Stand; a study of the Battle of the Little Big Horn. 65p. 
Willoughby, Nona Christensen MA 1950 California [3555] Division of labor among the Indians of California. 80p.

\section{Willson, Lawrence Sidney PhD $1944 \quad$ Yale [3556]} The influence of early North American history and legend on the writings of Henry David Thoreau. 329p. $\S 5$ "The traveler among the aborigines".

WiLson, Euizabeth Imogene MA 1953 St. Louis [3557] Calendar of the papers of John Dougherty, 1832-1863, in the archives of the Missouri Historical Society in the Jefferson Memorial at St. Louis. 113p.

As Indian Agent, Dougherty was an able and influential force among the Kansa-Missouri-Iowa tribes.

Wilson, Eugene B. MA 1950

Kansas [3558] American Indian games. 70p.

Wilson, Gilbert Livingstone PhD 1916 Minnesota [3559] The agriculture of the Hidatsa Indians; an Indian interpretation. Рuв: U/Minn., Stud. Soc. Sci. \#9 [1917] $129 \mathrm{p}$.

Based on personal narrative, Fort Berthold Reservation, North Dakota.

WiLson, Osburn C. MA $1932 \quad$ Vanderbilt [3560] The development of Florida Territory, 1821-1845.

Section on Indian War of 1835; Creek and Seminole.

Wilson, Raleigh Archie PhD 1949

Iowa [3561]

Negro and Indian relations in the Five Civilized Tribes from 1865 to $1907.263 p$.

Wilson, Raymond Glenn MA 1940

Place-names of six northeast counties of Oklahoma. $186 \mathrm{p}$.

1361 entries; 114 Indian names.

Wilton, AnNa Keener MA $1943 \quad$ New Mexico [3563]

Zuñi pottery making. 15p.

"Text supplements writer's mural painted at Gallup Court House." 
Wimer, Alfonso C. $\quad$ MA 1947

Life of the military in Texas: 1687-1731. 116p.

Discusses Indian wars, religion and customs.

WINGER, BJORN MA 1930

Indiana [3565]

A classification of motifs in Eskimo folk-literature. 177p.

Wingert, Paul Stover PhD $1949 \quad$ Columbia [3566] American Indian sculpture; a study of the Northwest Coast. Puв: J.J. Augustin [1949] 144p., illus.

WiNkLer, ERNEST WiLliaM MA 1901

Texas [3567]

The history of the Cherokee Indians in Texas. 138+19p.

Р ив: Texas State Hist. Assoc., Qtly., VII [1903] p95-165.

WINN, JoHN C. MS/Ed 1955

Utah Agri. [3568]

A comparative study of the Mexican-Indian students in the Carbon County schools. 93p.

Winn, May B. MA 1942

So. California [3569]

Marriage rites and customs of the Indians of Arizona.

Winter, Carl George MA 1931

California [3570]

A history of the discovery and exploration of Keewatin district, Northwest Territories, Canada, to the year 1800 . 144p., maps.

Hudson Bay Eskimo and Chipewyan Indians.

Winter, Elizabeth Harrell MA $1940 \quad$ Sul Ross [3571] Music in Texas since 1920. 43p.

Chapter "The Texas Indian and music".

WINTER, RoBERT E. MA 1952

Mexico City [3572]

Report on the excavations at Yatachio. 129p., photos.

PuB: Mesoamerican Notes, \#3 [1953] p1-50.

Wisdom, Charles Wirlis MA 1930

Arizona [3573]

Elements of the Piman language. 97p.

Wise, Freman NaLdo MA 1939

Illinois [3574]

The Indian problem in the province of Pennsylvania, 1750-1763. 112p.

Wise, Murray Monroe MA 1937

The religious conquest of Chibcha Indians. 97p.

Early Catholic missions in Colombia. 
Wise, Sidney F.

MA 1952

Queen's [3576]

The northern Indians in the American Revolution. 211p.

Withers, Allison Clement MA 1946

Arizona [3577]

Copper in the prehistoric Southwest. $75 \mathrm{p}$.

Gathers available reports of copper finds; analyses, traces sources of most.

Withers, ARNold Moore MA 1941

Arizona [3578]

Excavations at Valshni Village, Papago Indian Reservation, Arizona. 85p. Р вв: Amer. Antiq., X \#1 [1944] p33-47.

An evaluation of Papaguería culture, circa 800-1250 A.D.

Witherspoon, Alan C. MA 1934

The old mission of Michilmackinac. 58p.

Detroit [3579]

Chippewa, Ottawa, Menomini, Miami, Huron.

Witherspoon, Evelyn Gladney MA 1942 Columbia [3580] The serpent motive in Mayan and Aztec art. 49p., illus.

Witr, DoRothy Louise MA 1949 Washington/SL [3581] The Cheyenne and the United States Government, 1864-1870. 234p.

Wiтtногт, Јонм MA 1946

Pennsylvania [3582]

Green Corn ceremonialism in the Eastern Woodlands. Рбв: U/Mich., Mus. Anthro., Occas. Contr. \#13 [1949] $91 \mathrm{p}$.

Woerner, Davida PhD 1941

Columbia [3583]

Education among the Navajo; an historical study. Puв: Columbia U. [1941] 227p.

Woertz, Mildred Siemer MA 1951

California [3584] The rôle of the Chickasaw Nation on the Spanish-American frontier. 91p.

Wogain, Daniel Spelman PhD 1940

No. Carolina [3585]

The Indian in Mexican poetry. 314p.

Nineteenth and twentieth century.

WoLf, Key MA/Ed 1931

Oklahoma [3586]

Federal aid for the education of Indian children in the public schools of Oklahoma.99p. 
Wolf, MorRis PHD 1919

Columbia [3587]

Iroquois religion and its relation to their morals. PUB:

Columbia U. Press [1919] 111p.

WoLfe, Roy Israel MA 1947

Toronto [3588]

A study of the dermatoglyphics of the Six Nations Indians of southern Ontario. With a note on world distribution of indices of pattern intensity, interpreted in the light of Griffith Taylor's zones and strata theory. 146p.

WolfF, Elizabeth $\quad$ MA 1935

Wayne [3589]

The policy of the United States in removing the Indians from the Old Northwest by treaties. 144p.

WoLFF, HANS MA 1947

Indiana [3590]

Bibliography of bibliographies of North American Indian languages still spoken. 18p. Рбв: Intl. Jour. Amer. Ling., XIII \#4 [1947] p268-273.

WolfF, Hans $\quad$ PhD 1949

Indiana [3591]

Comparative phonology of the Siouan languages. 111p.

Р Uв: Intl. Jour. Amer. Ling., XVI-XVII [1950-1951] var. pp.

Wolff, Mabel Pauline PhD 1929

Bryn Mawr [3592]

The Colonial Agency of Pennsylvania, 1712-1757. РuB:

Lancaster: Intelligencer Prtg. Co. [1933] 243p.

Shawnee-Delaware, in passim. French-Indian War period and relations.

Wolfson, Harry MA $1932 \quad$ C.C.N.Y. [3593]

The history of Indian education under the Federal Government from 1871-1930. 156p.

Wonderly, WiLliam L. PhD 1947

Michigan [3594]

The Zoque phonemic and morphological structure. 276p. PUB: Intl. Jour. Amer. Ling., XVII-XVIII [1951-1952] var. pp.

Wood, Dion Carlos MA 1935

Oklahoma [3595]

The Creek Indians and internal relations in the Southeast (1775-1805). 72p. 
Wood, LoRen E.

MS/ED 1953

No. Dakota [3596]

A study of the educational status of the Chippewa Indians in the Cass Lake High School, Cass Lake, Minnesota. $41 \mathrm{p}$.

Wood, LuciLe Howell MA 1942

Prehistoric man in North America. 86p.

West. Reserve [3597]

Wood, Richard Coke PhD 1950

A history of the Calaveras region of California.

Some mention of Miwok and other Indians of the vicinity; period 1806-1950.

Wood, William W., JR. MA $1950 \quad$ No. Carolina [3599] The Eastern Cherokee veteran of World War II. 154p.

Woodbury, Richard Benjamin PhD 1949 Harvard [3600] Prehistoric stone implements of northeastern Arizona; a study of the origin, distribution and function of the stone tools, ornaments and weapons of the Jeddito District. 2 vols. Pøв: Harvard U., Peabody Mus., Paps., XXXIV [1954] 240p., illus.

Woods, Carter Albert $\quad$ PhD 1931

Yale [3601]

A critical analysis of the culture-area concept: an investigation based upon a study of the immaterial culture of the Indians of the United States. PUB: "A criticism of Wissler's North American culture area." Amer. Anthro., XXXVI \#4 [1934] p517-523.

Woodward, Dorothy PhD 1935

Yale [3602]

The Penitentes of New Mexico. 340p., photos.

§ 2 "Ethnological considerations" evaluates limited degree of Indian participation in Penitente rites.

Woodward, Isatah Alfonso MA 1939 The Indian problem in colonial Georgia, 1745-1763.

Woodward, Mary Twigg MA $1949 \quad$ Brit. Columbia [3604] Juvenile deliquency among Indian girls: an examination of the causes and treatment of a sample group, and the resulting social implications. 93p.

Northwest Coast Indians, Canada. 
Woodward, SARa Alice

MA 1933

Columbia [3605]

The second Seminole War with especial reference to the attitude of Congress. $42 \mathrm{p}$.

Woodward, Walter Carleton MA 1908 California [3606] A report on the manuscripts on Oregon in the Bancroft collection. 15p.

Some of these include the Oregon Indians.

WoOLLEy, LEaH MA 1923

Columbia [3607]

The Quest of the Sundown Trail, with a discussion of the work of John G. Neihardt and his epic Cycle of the West. $102 \mathrm{p}$.

Worcester, Donald Emmet MA $1940 \quad$ California [3608] The Apache Indians of New Mexico in the seventeenth century. 59p.

Worcester, Donald Emmet PhD 1947 California [3609] Early history of the Navaho Indians. 275p.

Wormington, Hannah Marie PhD 1953 Radclife [3610] The archeology of upper Colorado Plateau area in the northern periphery of the southwestern United States. 334p., illus. PUв: "A reappraisal of the Frémont culture with a summary of the archaeology of the northern periphery." Denver Mus. Nat. Hist., Proc. \#1 [1955] 200p., illus.

WoRTHYLAKe, MaRy MA $1954 \quad$ West. Washington [3611] A survey of certain northwest Indian cultures with adaptation for primary grade reading materials in the social studies.

Wright, Agnes Elodie MA 1931 California [3612] The beginnings of Monterey, 1542-1785. 76p., illus.

Costanoan Indians.

Wright, Barton Allen MA 1954 Arizona [3613] Excavation of Catclaw Cave, lower Colorado River. 74p.

Wright, Chester Welty

MA 1940

Texas Tech. [3614]

Types, distribution, and occurrences of flint gravers in Texas. 57p., illus. 
Wright, QUentin Everly MA 1954

California [3615]

The settlement of southeastern Oregon. 134p., maps.

Brief mention of Snakes and Paiutes.

Wyatt, Fay Savage

MA 1923

California [3616]

The Jesuit missions and missionaries of the Northwest.

245p., illus., maps.

Flathead, Coeur d'Alene, Pend d'Oreille, Colville, Yakima, Nez Percé, Okanagan.

Wycoco, Remedios Santiago PhD 1951

The types of North-American Indian tales. 293p.

Wylite, OpaL LUCILle MA 1950

A mural depicting an incident in the life of Chief Logan. 21p. illus.

Wyllys, Rufus Kay PhD 1932

California [3619]

The French in Sonora (1850-1854). The story of French adventureres from California into Mexico. Рбв: U/Calif., Pubs. Hist., XXI [1932] 320p., illus.

Wyly, Robert Fletcher MA 1940

Oklahoma [3620]

Samuel Houston Mayes and the Cherokee Nation, 1895 to $1899.85 \mathrm{p}$.

Wynn, Dudley Taylor PHD 1940

New York [3621]

A critical study of the writings of Mary Hunter Austin (1868-1934). 412p.

YAEGER, RANDOLPH O. PHD 1954 Indian enterprises of Isaac McCoy, 1817-1846. 621p.

Indian Agent and missionary; his activities in Oklahoma and Kansas.

YaRborodgh, James Martin MA 1938 Oklahoma $A \& M$ [3623] The transition of the Chickasaw Indians from an organized Nation to a part of a State. 71p.

YaRbrodgh, YANCY PARKer MA 1936 The life and career of Edward Burleson (1798-1851). $111 p$.

Considerable mention of Cherokee-Comanche removal from Texas; Cherokee-Mexican alliance, and Burleson's role in Indian warfare. 
Yeager, Hildegarde PhD 1947

Catholic [3625]

The life of James Roosevelt Bayley, first bishop of Newark and eighth archbishop of Baltimore, 1814-1877. Pणв: Cath. U., Stud. Amer. Church Hist., XXXVI [1947] 512p.

Recounts his activities in Indian Affairs, 1849-1852.

YeATs, HeLEN MAE 1940

Mexico [3626]

Leyendas de los índios mexicanos. 107p.

Yegerlehner, JoHn Foster MA 1954

Indiana [3627] The first five minutes of Shawnee laws in multiple stage translation. 28p.

A linguistic study.

Yerxa, Dorothy IdA MA 1926

California [3628]

The administration of Carondelet in Louisiana, with an appendix of original documents. 290p.

Section on his Indian policies.

Yoder, PhILLIP D. MA 1951

The history of Fort Whipple. 120p.

Arizona [3629]

Apache in Arizona.

Yorba, ERNest JoHn MA 1943

So. California [3630]

The Indian in contemporary Mexican literature as portrayed in the works of Gregorio López y Fuentes.

YoRK, DoRothy Jean MA 1955

Utah Agri. [3631] The early development of the Pocatello-Fort Hall region.

I. Indian era (Bannock-Shoshoni); II. Coming of the White man.

Yost, Ada Martha MA 1932

Idaho [3632]

Surviving folk ceremonials among the Shoshone Indians at Fort Hall. 65p.

Yost, Byron Augustus MA 1941

Kansas [3633]

The last Apache War. 127p.

Young, ARch Bryant, JR. MA 1939 A social history of early Globe, Gila County, Arizona.

Apache; Indian environment delayed settlement. 
The distribution of rectangular pit-houses in the Southwest. $256 \mathrm{p}$.

Young, Levi Edgar MA 1910

Columbia [3636]

Spanish explorations up the Pacific Coast to 1603. 31p., maps.

$\S 2$ "Indians of California" includes Hupa legend of Gard.

Young, Mary Elizabeth $\quad$ PhD 1955

Corneli [3637]

Redskins, ruffleshirts and rednecks: Indian allotments in Alabama and Mississippi, 1830-1860. 305p. $M$.

Young, Otis E., JR. PhD 1952

Indiana [3638]

The West of Philip St. George Cooke. 395p. Puв: The first military escort on the Santa Fé Trail, 1829. Glendale:

A. H. Clark [1952] 222p.

Sac, Fox, Pawnee, Apache, Sioux.

Young, Willitam Donald MA 1952

Stanford [3639]

The Indian character in American plays, 1808-1860.

YUENGER, JoHN W. MA 1950

Marquette [3640]

The growth of centralization in Colonial Indian affairs. $97 \mathrm{p}$.

YUHAUSe, Joseph MA 1941

Iowa [3641]

French exploratory routes, Québec to Fort Crèvecoeur, 1673-1730. 112p.

Scattered references to various tribes.

ZACKEM, MATHILDE Z. MA 1943

Michigan's aid in the Black Hawk War. 78p.

Zакол, Нiroto

Wayne [3642]

Klamath culture change. 280p.

ZeBio, Albert, JR. MA 1949

The Oregon Trail, 1832-1840. 215p.

Brief section on Indians along the Trail.

ZeCh, Albert Frederick MA 1939 So. California [3645]

Historical development of Fort Snelling (Minnesota).

Indians scattered throughout; mostly Sioux. 
Zeigen, Robert S. ' MA 1952

Utah [3646]

The family in matrilineal society; a functional comparative analysis of five preliterate cultures. $156 \mathrm{p}$.

Includes considerable Indian material, mentioning Hopi, Mandan, Haida, and Canela of Brazil.

Zeigler, Terry Bannerman MA 1944 Florida State [3647] The influence of the Indians of the Old Southwest on the Treaty of San Lorenzo. 104p.

1795 treaty with Spain over the West Florida-Mississippi Territory region.

Zelditch, Morris, JR. PHD $1955 \quad$ Harvard [3648] Authority and solidarity in three Southwestern communities. 335p.

Navaho of Ramah area.

Zeleny, Carolyn MA $1939 \quad$ Yale [3649] Governmental treatment of the Indian problem in Canada. 233p.

Zeller, Gertrude Nothstine MA 1932 Ohio State [3650] History of the Pawnee Indians. 98p.

Zens, Mary Serena MA 1936

So. Dakota [3651]

The educational work of the Catholic Church among the Indians of South Dakota. 62p.

Zigmond, Maurice Louis PhD 1941

Yale [3652]

Ethnobotanical studies among California and Great Basin Shoshoneans. 296p., map.

Zimmerman, Curtis Prang MA $1935 \quad$ Wash. State [3653] Studies in the Indian trade of the Colonial period. $76 \mathrm{p}$.

Zimmerman, Franklin B. MA 1953 So. California [3654] Survey of the rôle of music in Sonoran Uto-Aztekan culture. 228p.

Zimmerman, Harry EARL MA 1934 Kans.-Pittsburg [3655] The Indian's ability to learn mathematics (algebra and geometry) according to degree of Indian blood. 57p.

Study of marks given to 525 pupils. 
ZINGG, RoberT Mowry

PHD 1933

Chicago [3656]

A reconstruction of Uto-Aztekan history. 274p. PUB:

U/Denver, Contr. Ethnography, II [1939] 274p.

Zinn, Edith Grace MA $1946 \quad$ Penna. State [3657]

North, Central, and South American Indian design motifs and their occurence in the cultures of other races.

Zook, Lester Martin PhD $1954 \quad$ Penna. State [3658]

A study of agricultural colonization with a view to a particular proposal for the lower Mixteca region in southern Mexico. 355p.

ZwICK, GWen WILSON MA 1940

Oklahoma [3659]

Prohibition in the Cherokee Nation, 1820-1907. 130p.

\section{ADDENDA}

Atkinson, Darrell D. MS/Ed 1955 Utah Agri. [3660] Educational adjustment of Ute Indians as compared to the mixed-bloods, and native Whites at Union High School, Roosevelt, Utah. 57p.

Birmingham, Olive Kimbalu MA 1933 Brigham Young [3661] The art of the Arizona Southwestern Indian.

Carlisle, Rose Jeanne MA $1939 \quad$ New Mexico [3662] A Southwestern dictionary. 398p.

Includes Indian terms and references to Indians.

Cason, Ina Wirson MA 1939

New Mexico [3663] The Bent brothers on the frontier. $92 \mathrm{p}$.

Extensive Indian material; particularly in their rôle ás traders and Indian agents.

Christensen, Ross Taylor MA 1947 Brigham Young [3664] A preliminary report of archaeological investigations near Utah Lake, Utah, 1946. 
Falls, Anna E. MA 1929 New Mexico [3665]

The place of private and church schools in the education of the State. 84p.

Considers Indian mission schools in New Mexico.

Fielding, R. Kent MS $1952 \quad$ Brigham Young [3666] Establishing the value of Indian lands in the West, 1850-1900.

Fitzgerald, H. Alvah MS $1930 \quad$ Brigham Young [3667 Progressive opinion of the origin and antiquity of the American Indian.

Fleck, Martin MA $1939 \quad$ New Mexico [3668] Notes on the origin and development of Zea Mays. 96p.

GADdis, FANNy WoodHuLL MA 1917 California [3669] A catalogue of a collection of manuscript documents relative to Southwestern history, with an introduction. $233 p$.

Many of these documents pertain to the Indian.

Gardner, Esthfr Dalton MA 1941 New Mexico [3670] A study of the life and works of Charles Fletcher Lummis. $179 \mathrm{p}$.

Grove, Alvin Russelu, JR. MA 1937 New Mexico [3671] The distribution and utilization of Agave in the American Southwest. 74p.

Hanson, William F. MS $1937 \quad$ Brigham Young [3672] The lure of Tam-mam Nacup, Springtime festival of the Utes.

Hepler, Robert D. MA 1941 New Mexico [3673] William Watts Hart Davis in New Mexico. 205p.

McCarrell, Fred PhD 1934 The development of the training school.

Geo. Peabody [3674]

Consideration given early Pueblo education by Franciscans in their mission schools. 
McDonald, Maura MA 1942

New Mexico [3675]

Contributions of the Dominican sisters of Grand Rapids, Michigan, to education in New Mexico. 103p.

Their mission schools for Indians.

Marshall, Thomas Maitland MA 1910 California [3676] A report on certain material for the history of Arizona and New Mexico. 51p.

Includes documents which pertain to the Indians of the area.

Panneld, Herman Clay MA 1934

Colorado [3677]

Vocational opportunity in New Mexico.

Employment and labor activities of Pueblo Indians, Anglos and Spanish-Americans.

Shallenberger, Ivah MA $1936 \quad$ New Mexico [3678] La historia de la Nueva México, by Gaspar de Villagrá; a synthesis. $86 \mathrm{p}$.

SILverBerg, JAMES MA 1949

Wisconsin [3679]

The cultural position of the Kickapoo. 106p.

Smith, Owen Dale MA 1932

Denver [3680]

A comparison of the performances of full-blooded Indians, sedentary and nomadic, on achievement and on language and non-language intelligence tests.

Based on tests given at Santa Fé and Albuquerque Indian Schools.

Stratton, Alice BeLL MA 1903

Wellesley [3681]

The relations between the United States Government and the Sioux Indians. 59p.

Valliant, Maude Drake MA 1932 The history of the railroads of the Southwest.

Includes references to Indian problems and Reservation lands.

Vollmar, Edward PhD 1939

St. Louis [3683]

History of the Jesuit Colleges of New Mexico and Colorado, 1867-1919. 168p.

Not seen; said to include mention of Indian missions operated by the Jesuits.

Wilson, Houston Clyde

MA 1953

Texas [3684]

The Kickapoo Indians: an ethno-history. 212p., maps. 


\section{INDEX}

Acculturation; culture change 936 $\begin{array}{llllllll}61 & 91 & 93 & 122 & 160 & 285 & 298 & 302\end{array}$ $\begin{array}{lllllll}316 & 343 & 352 & 353 & 400 & 425 & 449\end{array}$ $\begin{array}{lllllll}468 & 489 & 520 & 523 & 531 & 553 & 586\end{array}$ $\begin{array}{lllllll}618 & 619 & 622 & 626 & 665 & 754 & 771\end{array}$ $\begin{array}{lllllll}806 & 810 & 823 & 824 & 855 & 922 & 927\end{array}$ $\begin{array}{llllll}932 & 982 & 986 & 1010 & 1030 & 1063\end{array}$ $\begin{array}{lllllll}1071 & 1083 & 1091 & 1192 & 1114 & 1151\end{array}$ $\begin{array}{llllll}1154 & 1164 & 1176 & 1202 & 1213 & 1240\end{array}$ $\begin{array}{llllll}1257 & 1304 & 1326 & 1376 & 1378 & 1386\end{array}$ $\begin{array}{llllll}1400 & 1439 & 1465 & 1520 & 1555 & 1560\end{array}$ $\begin{array}{llllll}1587 & 1592 & 1631 & 1662 & 1693 & 1711\end{array}$ $\begin{array}{lllllll}1733 & 1747 & 1754 & 1802 & 1820 & 1827\end{array}$ $\begin{array}{llllll}1849 & 1852 & 1855 & 1891 & 1925 & 1955\end{array}$ $\begin{array}{llllll}1990 & 2006 & 2010 & 2037 & 2046 & 2055\end{array}$ $\begin{array}{llllll}2067 & 2087 & 2103 & 2113 & 2137 & 2152\end{array}$ $\begin{array}{llllll}2163 & 2170 & 2197 & 2221 & 2254 & 2264\end{array}$ $\begin{array}{llllll}2384 & 2388 & 2404 & 2415 & 2429 & 2432\end{array}$ $\begin{array}{llllll}2472 & 2506 & 2513 & 2564 & 2575 & 2661\end{array}$ $\begin{array}{llllll}2676 & 2691 & 2707 & 2708 & 2734 & 2793\end{array}$ $\begin{array}{llllll}2808 & 2809 & 2823 & 2832 & 2838 & 2893\end{array}$ $\begin{array}{llllll}2946 & 2949 & 2963 & 2973 & 2982 & 2986\end{array}$ $\begin{array}{llllllll}3011 & 3014 & 3025 & 3076 & 3078 & 3134\end{array}$ $\begin{array}{lllllll}3140 & 3141 & 3163 & 3186 & 3196 & 3245\end{array}$ $\begin{array}{lllllll}3255 & 3269 & 3283 & 3305 & 3318 & 3355\end{array}$ $\begin{array}{lllllll}3356 & 3380 & 3393 & 3399 & 3414 & 3419\end{array}$ $\begin{array}{llllllll}3437 & 3451 & 3471 & 3490 & 3498 & 3526\end{array}$ $\begin{array}{lllllll}3527 & 3530 & 3537 & 3561 & 3599 & 3623\end{array}$ 3643 see also Adjustment problems; Culture disintegration; Race, White-Indian relations Acosta, José de 1914

Adolescence; puberty rites 552762 $\begin{array}{llllll}869 & 1020 & 1365 & 1931 & 2006 & 2439\end{array}$ 33743604 see also Children; Initiation

Adjustment problems $1091 \quad 1164$ American Fur Company 368 $\begin{array}{llllll}1240 & 2006 & 2221 & 2678 & 2691 & 3204\end{array}$ $\begin{array}{lllll}3355 & 3490 & 3498 & 3660\end{array}$

Africa $227122952843 \quad 3043$

Agave 3676

Age; treatment of the aged 3034 Agencies see Reservations
Agriculture $188 \quad 437 \quad 521 \quad 825 \quad 1019$ $\begin{array}{lllllll}1053 & 1071 & 1225 & 1241 & 1489 & 1509\end{array}$ $\begin{array}{llllll}1514 & 1623 & 1818 & 1973 & 1975 & 2242\end{array}$ $\begin{array}{llllll}2529 & 2668 & 2775 & 2827 & 2889 & 2912\end{array}$ 3328355935823658 see also Irrigation; Maize

Águilar, Jerónimo de 448

Aklavik 913

Akutan 3116

$\begin{array}{llllll}\text { Alabama } & 180 & 254 & 663 & 1384 & 2071\end{array}$ $\begin{array}{lllll}2438-2585 & 2746 & 2855 & 3292 & 3637\end{array}$ Alarcón, Fernando de 1508

Alaska 73263425463464465551 63168110181022118411851392 $\begin{array}{llllll}1436 & 1448 & 1450 & 1457 & 1571 & 1710\end{array}$ $\begin{array}{llllll}1810 & 1829 & 1860 & 1861 & 1869 & 1870\end{array}$ $\begin{array}{llllll}1918 & 2046 & 2102 & 2174 & 2221 & 2312\end{array}$ $\begin{array}{lllllll}2367 & 2447 & 2498 & 2614 & 2755 & 2771\end{array}$ $\begin{array}{llllll}2796 & 2876 & 2963 & 2979 & 2986 & 3048\end{array}$ $\begin{array}{lllllll}3220 & 3221 & 3373 & 3422 & 3454 & 3484\end{array}$ 3492

Albany Congress; Plan of Union 2431 Alcohol; alcoholism 14221537 see also Liquor

Alegría, Ciro 1880

Allotments 2436 see also Dawes Act; Land Titles

Allouez, Claude Jean 1946

Alva, Bartolomé de 1584

Alvarado, Pedro de 3483

Amazon (region) $1141 \quad 1636 \quad 1763$ 27402896 see also Brazil

American Board of Commissioners for Foreign Missions 2611

American Friends Service Committee 1092 2519

American occupation; colonization 50165010172146216622682480 3167

Amur Basin 1979 
Anthropology 1218145617392110 Archeological sites, contd. 231523382777

Antioquía 2566

Anza, Juan Bautista de 57623262566

Apologetica historia sumaria 2916

Aprism; aprismo 5441334 see also Haya de la Torre

ARCHEOLOGY; general archeological studies 8094108118155196218 $232 \quad 280 \quad 364 \quad 410444 \quad 455457479$ $\begin{array}{llllllll}488 & 491 & 503 & 504 & 506 & 518 & 545 & 551\end{array}$ $\begin{array}{llllllll}554 & 565 & 627 & 660 & 721 & 722 & 729 & 736\end{array}$ 748799841925936951965974 $\begin{array}{llllll}1033 & 1034 & 1093 & 1124 & 1139 & 1168\end{array}$ $\begin{array}{llllll}1178 & 1225 & 1226 & 1280 & 1297 & 1319\end{array}$ $\begin{array}{llllll}1398 & 1420 & 1545 & 1546 & 1547 & 1551\end{array}$ $\begin{array}{lllllll}1580 & 1588 & 1616 & 1617 & 1697 & 1714\end{array}$ $\begin{array}{lllllll}1750 & 1758 & 1771 & 1805 & 1818 & 1819\end{array}$ $\begin{array}{llllll}1930 & 1987 & 2049 & 2052 & 2058 & 2065\end{array}$ $\begin{array}{llllll}2089 & 2091 & 2093 & 2119 & 2127 & 2132\end{array}$ $\begin{array}{llllll}2144 & 2193 & 2209 & 2214 & 2222 & 2230\end{array}$ $\begin{array}{llllll}2233 & 2259 & 2279 & 2284 & 2287 & 2366\end{array}$ $\begin{array}{llllll}2386 & 2427 & 2613 & 2623 & 2717 & 2736\end{array}$ $\begin{array}{llllll}2761 & 2790 & 2791 & 2846 & 2937 & 2955\end{array}$ $\begin{array}{lllllll}2971 & 2983 & 2988 & 3049 & 3064 & 3114\end{array}$ $\begin{array}{lllllll}3169 & 3172 & 3205 & 3207 & 3223 & 3257\end{array}$ $\begin{array}{lllllll}3279 & 3281 & 3282 & 3367 & 3372 & 3434\end{array}$ $\begin{array}{lllllll}3461 & 3497 & 3512 & 3533 & 3538 & 3552\end{array}$ $\begin{array}{llllll}3597 & 3600 & 3601 & 3610 & 3614 & 3635\end{array}$ 3656

Archaeological dating; chronology

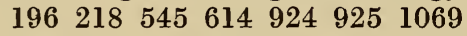
$\begin{array}{llllll}1226 & 1428 & 1588 & 1750 & 1977 & 2058\end{array}$ 206520892241225623752802 293429373358

Dendrochronology 14611841866 Pedology 916

Stratigraphy 54191622202764 2944

Archeological sites; areas, periods Ackmen-Lowry 2785

Ácoma 2868

Addicks Dam 3496

Adena 856

Alameda 1453

'Alameda 328' 751

Alkali Ridge 364

Amapá 974

Anasazi $1050 \quad 1349 \quad 2721.2785$ 3497

Ancón 652841

Anderson Village 344

Angel 21

Antelope Creek 1994

Aristé 974

Arrowhead Ruin 17192581 2679

Aruã 974

Ash Hollow Cave 541

Atlixco 1358

Azcapotzalco 2845

Aztalan 1511

Babocomari 815816

Bahamas 1264

Big Bead Mesa 1754

Big Sandy 2516

Bonampak 2705

Boulder 288

Buffalo Pasture 1559

Cahokia Mound 3246

Cahone 964

Campeche 802883

Catclaw Cave 3613

Cebolleta Mesa 817

Cedar Rapids 1297

Chaco Canyon $146 \quad 554 \quad 896$ 14282036262028023252

Chalchihuites 1145

Chancay 3539

Chavín 652

Chetro Ketl 1428190322902735

Chichén Itzá 897

Chihuahua 35049150619502160 2193

Chimalacatlán 2373

Chimú 3165

Clinch River 1866

Cochise 30393497

Cojumatlán 1951

Concho Flat 956

Copán 1977

Coquimbo 3057

Correo Snake Pit 2899

Crable 3077

Craig Rock Shelter 1269

Cuautitlán 2739

Culhuacán 363716

Cuzco 2858

Diaguita 3057 
Archeological sites, contd.

Dickson Mound 27973474

Dillinger Focus 2240

Dinosaur Natl. Monument 1363

Dismal River 1312

Dorset 1393

Dry Creek 3027

Duncan 335

Effigy Mounds 2857

Ellis Landing 2417

El Molle 3057

Empire Valley 3231

Eufaula Mound 2512

Evans 1854

Fate Bell Shelter 3276

Fisher 11971291

Folsom 660

Ft. Ancient 3442243

Ft. Corchaug 3104

Ft. Liberté 2854

Ft. Pierre 1901

Frémont 3610

Gallina 14751854

Gila River 1130

$1175 \quad 1306$ 13751427

Governador 1349

Great Basin 17361746

Guasave 929

Hagen 2374

Harrell 1573

Helen Blazes 916

Hermit's Cave 1007

Hidden House 819

Hohokám 1421259830393497

Holmul 2275

Hopewell 2882399

Ica 2770

Indian Knoll 3048

Ixtateco 1013

Iyatayet 1448

Jackrabbit Ruin 2919

Jeddito 7223600

Jewett Gap 170

Jornada 1900

Kabah 2890

Kaminal Juyú 1657

Kincaid 2292513

Kin Kletso 146

King's Ruin 3133

Kinishba $137 \quad 138 \quad 10742397$
Archeological sites, contd.

Kobuk River 1185

Kolomoki 2972

Kotzebue 3373

Kuaua 27914532981

Laguna Seca Chapala 94

La Junta de los Ríos 7281728

Leaf Water 2003

Lewis Focus 2133

Łeyit Kin 896

Little Colorado 14102090

Los Muertos 1421

McNary Reservoir 3016

MacHaffie 1064

Mancos Valley 2721

Marajó Is. 22562542

Marajoara 22562542

Marshall Ford Basin 2112

Martínez Hill 1130

Mazagão 974

Mesa Verde 414328022863

Middle Mississippi 19262613

Mimbres Valley 2001

Mitla 2491

Moché 462

Mogollón 1900242028562988 30393497

Monte Albán 237238

Morton Shell Heap 1109

Mound Builders 1947

Moundville 180

New York 2791

Nicoya 3403

Nikolski 239

Norris Basin 1290

Oaxaca 14562833

Ocmulgee 988

Oliver Farm 1444

Onondaga 1454

Outlet (DA 3) 134

Pajarito Plateau 1758

Palenque 2704

Palo Alto 457

Paracas 3148

Pachacamac 2159

Patawomeke 2936

Patterson Mound 751

Pecos 3074

Père Marquette Park 2784

Petrified Forest 3482 
Archeological sites, contd.

Pickwick Basin 2438

Piedras Negras 446603

Point of Pines 34403497

Polvo 2987

Potter Creek Cave 3041

Puaray 1453

Pueblo Plateau 1033

Pueblo Viejo 1307

Puerto Rico 2695

Quarai 948

Rio Grande 3149

Rio Puerco 2005

Rygh 1094

Sacramento Valley 2440

Saddleback Ruin $1429 \quad 1512$

Salt River Valley 13814212944

San Juan River 421362802

San Pedro River Valley 816872

Santa Cruz Valley 1111

Santarém 903

Scottsbluff Quarry 924

Sinú 1243

Smith 1353

Sobaipuri 815816872

South Indian Field 2220

South Woodstock 2660

Spiro 2512

Starkweather Ruin 2420

Sulphur Spring Valley 535

Supé 652

Tamaulipas 2134

Tamazulapan 1307

Teotihuacán 11462336

Tepexpán 111

Tepoztlán 9972719

The Dalles 610

Tiguex 3387

Tiahuanaco 3136

Titus County 1235

Tlapacoya 150

Tlatilco 19822643

Tlaxcala 2001181

Tollan 2318

Tonto Natl. Monument 1749

Topanga 3316

Tres Zapotes 3464

Tula 897

Tularosa Cave 1212

Tuzigoot 1074
Archeological sites, contd.

Uaxactun 2764

Umatilla 2517

Unshagi 3244

Utah Lake 2103664

Uto-Aztekan 36543656

Valshni Village 3578

Verde River $47 \quad 1615$

Vicos 3380

Virú 61410692302

Walhalla Glades 1348

Wari ; Huari 3136

Wheatley Ridge 2856

Woodruff Ossuary 1783

Yagul 24913523

Yarumela 481

Yatachio 3572

Yucatán 2890

Yuma-Folsom 660

Zacualpa 3455

Zetrouer 2967

Archery 2828

Architecture; construction 42184

68281710621903219022092469

$\begin{array}{llllll}2491 & 2638 & 2736 & 2762 & 2778 & 2851\end{array}$

28993059 see also Dwellings

Mission architecture $108 \quad 870 \quad 1825$

1826

Argentina 70723213245

Arizona 47110138151199292329

$\begin{array}{lllllll}369 & 516 & 535 & 580 & 623 & 630 & 650\end{array}$

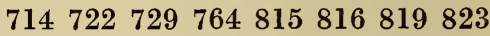

$\begin{array}{lllllll}824 & 855 & 870 & 872 & 878 & 956 & 1074\end{array}$

$\begin{array}{llllll}1093 & 1111 & 1130 & 1175 & 1176 & 1240\end{array}$

$\begin{array}{llllll}1306 & 1313 & 1348 & 1360 & 1375 & 1387\end{array}$

$\begin{array}{llllll}1410 & 1416 & 1534 & 1557 & 1615 & 1705\end{array}$

$\begin{array}{lllllll}1818 & 2002 & 2132 & 2167 & 2191 & 2268\end{array}$

$\begin{array}{llllll}2287 & 2339 & 2345 & 2412 & 2442 & 2529\end{array}$

$\begin{array}{llllll}2647 & 2691 & 2717 & 2730 & 2773 & 2824\end{array}$

$\begin{array}{lllllll}2919 & 2934 & 2944 & 3133 & 3134 & 3135\end{array}$

$\begin{array}{lllllll}3183 & 3192 & 3193 & 3231 & 3305 & 3326\end{array}$

$\begin{array}{llllll}3342 & 3440 & 3443 & 3495 & 3499 & 3504\end{array}$

$\begin{array}{llllll}3569 & 3600 & 3629 & 3634 & 3661 & 3676\end{array}$

Arkansas $232 \quad 525 \quad 1024 \quad 1099 \quad 1138$

$\begin{array}{llll}1323 & 1921 & 2239 & 2720\end{array}$

Army of the West 12981576

Art 17244357419582611718719

$\begin{array}{lllllllll}777 & 786 & 790 & 867 & 903 & 933 & 978 & 983\end{array}$

$\begin{array}{llllll}1012 & 1035 & 1162 & 1178 & 1233 & 1230\end{array}$

$\begin{array}{llllll}1244 & 1275 & 1426 & 1534 & 1566 & 1643\end{array}$ 
Art, contd.

$\begin{array}{llllll}1742 & 1760 & 1968 & 2063 & 2219 & 2304\end{array}$ $\begin{array}{lllllll}2317 & 2367 & 2419 & 2461 & 2473 & 2675\end{array}$ $\begin{array}{lllllll}2705 & 2841 & 2851 & 3026 & 3098 & 3107\end{array}$ $\begin{array}{lllllll}3139 & 3434 & 3478 & 3480 & 3504 & 3541\end{array}$ $\begin{array}{lllll}3551 & 3580 & 3657 & 3661 & \text { see also }\end{array}$ Painting; Sculpture; various crafts Arts and crafts $95 \quad 435 \quad 1398 \quad 1896$ $\begin{array}{llllll}2236 & 2390 & 2727 & 2795 & 2821 & 2844\end{array}$ 289730263445 see also various crafts

Asia; Asiatic influences 6621200 $\begin{array}{lllllll}1355 & 1752 & 2063 & 2173 & 2424 & 2828\end{array}$ Astronomy 132025502928

Atchison, David R. 21652166

Atherton, Gertrude 674

Atka 18693489

Atlatl 1725

Attu 18693489

Audiencia 193323602362

Aulneau, Jean-Pierre 2216

Austin, Mary H. 3036296741119 204221013621

Australia 9391837

Authority; group control 4161112 $\begin{array}{llllll}2056 & 2299 & 2564 & 3061 & 3460 & 3648\end{array}$ 3517

Aves sin nido 2094

Azcapotzalco 2845

Azuela, Mariano 1294

Bacon's Rebellion $198 \quad 1276 \quad 3439$

Baffin Island 1386

Bahia 4022712619

Baker, Jonathan H. 904

Bandelier, Adolph F. 11221218

Baraga, Frédéric 2522

Barter see Trade

Bartram, William 987

Basketry 13165845113713151355 $15661968 \quad 2502 \quad 3024 \quad 3480$

Bayley, James R. 3625

Beale, Edward F. 369

Bean, Peter E. 1995

Bear Ceremonialism 1356

Belgium 1292

Bell, John R. 1123

Bellomont, Earl of 44

Benavides, Fr. Alonso de 2510

Bent, Charles 19223663
Bering Straits 6311442

Berkeley, Gov. William 5173439

Bibliography; bibliographical studies

$\begin{array}{llllllll}45 & 68 & 171 & 281 & 360 & 387 & 390 & 465\end{array}$

$\begin{array}{lllllll}653 & 689 & 739 & 914 & 915 & 1018 & 1363\end{array}$

$\begin{array}{llllll}1397 & 1430 & 1455 & 1456 & 1542 & 1681\end{array}$

$\begin{array}{lllllll}1705 & 1766 & 2097 & 2110 & 2297 & 2567\end{array}$

$\begin{array}{lllllll}2593 & 2608 & 2694 & 2787 & 2997 & 3094\end{array}$

$\begin{array}{lllllll}3156 & 3189 & 3211 & 3367 & 3506 & 3557\end{array}$

359036063669

Big Horn Basin 1940

Big Miami Reserve 1904

BIOGRAPHY; biographical studies of Indians

Altamirano, Ignacio Manuel 549 10213266

Black Hawk 133920882853

Big Tree 17033053

Boudinot, Elias Cornelius 1072 1498

Bushyhead, Dennis Wolfe 694

Carrera, Rafael 2343

Chief Joseph 22492289

Chief Logan 3618

Chief Sealth 495

Chief Spokane Garry 2282

Crazy Snake 301

Cuauhtémoc 15531690

Condorcanqui, José Gabriel 428

Foreman, Stephen 998

Garcilaso de la Vega, El Inca 296

Hastings, William Wirt 679

Haya de la Torre, Victor Raúl 752 1334

Kanakûk 12311575

Keokuk 1339

King Philip 500169918822999 $3363 \quad 3436$

Little Turtle 1501

Lucky 381

Malinche (Doña Marina) 448

McGillivray, Alexander 10082358

Matose-Apiw 590

Mayes, Samuel Houston 3620

Natowáp Tsis-Tseksin 590

Nocona 3512

Osceola 3476

Pocahontas 40410891408

Pokagon family 412

Pontiac 760 
Biography, contd.

Posey, Alexander 1051

Quadra 2836

Ramona 787

Red Jacket 1800

Rogers, Clem V. 1724

Ross, John 907

Ross, Laurence Sullivan 3516

Sacajawea 3422692

Satanta 17033053

Sequoyah 752

Smohalla 12311575

Stand Watie 16453176

Tecumseh 10861231

Teedyuscung 3419

Tenskwátawa $1231 \quad 1575$

Túpac Amaru 428

Wovoka 12311575

Bison 773474174268511288

Bitter Root Valley 4872747

Black Hills 2061045

Blanchet, Francis Norbert 2020

Blood groups; typing 11721387 $\begin{array}{llllll}2233 & 2450 & 2451 & 2648 & 2923 & 3459\end{array}$

Blowgun 2781

Bolivia 564812853113512281518 $\begin{array}{llllll}1726 & 2028 & 2131 & 2561 & 2892 & 2921\end{array}$ 34383451

Bounty Lands 1593

Bouquet, Col. Henry 24072962

Bowles, William A. 1008

Braddock Expedition 2446

Bravo, Jaime 3291

Brazil 4034886390397411411636 $\begin{array}{llllll}2187 & 2242 & 2256 & 2271 & 2388 & 2542\end{array}$ $\begin{array}{llllll}2619 & 2687 & 2740 & 2896 & 3093 & 3501\end{array}$ see also Amazon

British Board of Trade 807

BRITISH (in America; general studies) $\begin{array}{ll}16 & 4051173121612241441 \quad 1639\end{array}$ $\begin{array}{llllll}1694 & 1762 & 1782 & 1875 & 2039 & 2200\end{array}$ $\begin{array}{llllll}2449 & 2554 & 2590 & 2962 & 2996 & 3301\end{array}$ see also Canada

British Colonial Indian Affairs 41 69241312447547658708797 $\begin{array}{llllll}910 & 1286 & 1364 & 1538 & 1581 & 1605\end{array}$ 178918682104227023112610 263128132814281729983018 302130803081330133483363 343735533574360336403653
British Colonial Government 44 $\begin{array}{lllllll}249 & 250 & 460 & 480 & 517 & 807 & 826\end{array}$ $\begin{array}{llllll}1632 & 1673 & 1867 & 1890 & 2368 & 2831\end{array}$ 2835287934123592

British Guiana 11991634

Brown, Charles Brockden 2354

Bucareli y Ursúa, Antonio María de 290

Burial customs see Mortuary

Burke Act 3469

Burleson, Edward 3624

Bursum, Sen. Holm O. 1967

Byrd, William 198

Cabeza de Vaca, Alvar Núñez 477 3540

Cacao 2303

Cactus 2459

Calendar 66471190132016141780 2061217222832914

Calhoun, James S. 7301669

$\begin{array}{lllllll}\text { California } & 32 & 57 & 104 & 125 & 127 & 132\end{array}$ $\begin{array}{llllllll}182 & 196 & 213 & 221 & 270 & 281 & 304 & 314\end{array}$ $\begin{array}{llllllll}411 & 451 & 457 & 470 & 524 & 546 & 567 & 609\end{array}$ $\begin{array}{lllllllll}613 & 657 & 702 & 717 & 734 & 751 & 783 & 787\end{array}$ $\begin{array}{lllllll}821 & 861 & 864 & 900 & 940 & 1011 & 1047\end{array}$ $\begin{array}{llllll}1073 & 1104 & 1161 & 1167 & 1273 & 1278\end{array}$ $\begin{array}{llllll}1281 & 1283 & 1383 & 1403 & 1409 & 1544\end{array}$ $\begin{array}{llllll}1561 & 1589 & 1591 & 1666 & 1712 & 1735\end{array}$ $\begin{array}{lllllll}1745 & 1776 & 1795 & 1858 & 1885 & 1911\end{array}$ $\begin{array}{llllll}1912 & 1955 & 1972 & 1985 & 2033 & 2092\end{array}$ $\begin{array}{lllllll}2123 & 2244 & 2294 & 2326 & 2332 & 2428\end{array}$ $\begin{array}{lllllll}2440 & 2460 & 2477 & 2481 & 2545 & 2612\end{array}$ $\begin{array}{lllllll}2632 & 2634 & 2682 & 2711 & 2774 & 2789\end{array}$ $\begin{array}{llllll}2808 & 2809 & 2844 & 2849 & 2850 & 2983\end{array}$ $\begin{array}{lllllll}2985 & 3001 & 3035 & 3041 & 3070 & 3091\end{array}$ $\begin{array}{lllllll}3158 & 3281 & 3282 & 3316 & 3319 & 3415\end{array}$ $\begin{array}{llll}3555 & 3598 & 3612 & 2652\end{array}$

Cambridge Press 3156

CANAdA $122 \quad 209 \quad 386 \quad 814913 \quad 1157$ $\begin{array}{llllll}1177 & 1216 & 1317 & 1723 & 1782 & 1803\end{array}$ $\begin{array}{lllllll}1893 & 1894 & 1952 & 2037 & 2111 & 2120\end{array}$ $\begin{array}{llllll}2137 & 2216 & 2237 & 2305 & 2391 & 2408\end{array}$ $\begin{array}{lllllll}2518 & 2661 & 2768 & 2769 & 2786 & 2823\end{array}$ $\begin{array}{llllll}3036 & 3321 & 3344 & 3361 & 3407 & 3414\end{array}$ 3576360436413649 see also New France

Alberta 1691757

British Columbia $738 \quad 739 \quad 871$ 117713591850185119152305 
Canada, contd. 240526242836288229913278 32893605

Newfoundland 1393

North West Territories 9132037 3570

Ontario $951 \quad 1641 \quad 166121893588$ Quebec 2081

Yukon 2046

Canadian Reserves see Reservations

Canandaigua Lake 3038

Cannibalism 100119611962

Canyon de Chelly 1256

Cape Denbigh 1448

Captives, Treatment by Indians 1796 2926 see also Indian Captivities

Capuchins 3391

Caribbean 4314451451810881551 $\begin{array}{lllllll}1552 & 1841 & 2038 & 2127 & 2854 & 2889\end{array}$ 30373214

Carondelet, Héctor de $387 \quad 1773$ 247636283641

Carson, Kit 16423069

Caso, Alfonso 2869

Cass Lake School 839

Castilla del Oro 1088

Catlinite 753

Cattle industry 20252334

Census 662152531 seealso Population

Ceremony; Ceremonials 97292318 5155385771110131313951535 $\begin{array}{llllll}1634 & 1640 & 1780 & 1861 & 1962 & 2011\end{array}$ $\begin{array}{lllllll}2172 & 2430 & 2493 & 2573 & 2601 & 2646\end{array}$ $\begin{array}{llllll}2686 & 2727 & 2736 & 2821 & 3135 & 3154\end{array}$ $\begin{array}{lllll}3240 & 3507 & 3632 & 3672 & \text { see also }\end{array}$ Dance; Religion, Indian; Shaman Adolescence, Puberty C. 552762 869136519313374

Agriculture C. 2242

Bear C. 1356

Eclipse rites 67

First Salmon C. 1316

Harvest C. 1614

New Fire C. 1190

Initiation C. 8416823460

Soul-recovery C. 941

Chac Mool 119

Chamuscado-Rodríguez Expedition 2251

Chateaubriand, François René de 710
Cháves, Nuflo de 3362

$\begin{array}{llll}\text { Cherokee Nation } 51 & 157 & 339 & 1268\end{array}$ $\begin{array}{llllll}1959 & 2589 & 2669 & 3432 & 3479 & 3620\end{array}$ 3659 see also Indian Tribes

Cherokee Outlet 277193822812749

Cherokee Phoenix 204

Cherokee Republic 3314

Chicago 5982993

Chickasaw Nation 16674432223584 3623 see also Indian Tribes

Child-bearing 17813365

Children 8117129270298422531 58276283993396899010221261

$\begin{array}{llllll}1491 & 1568 & 1704 & 1834 & 1862 & 2066\end{array}$

$\begin{array}{lllllll}2147 & 2184 & 2295 & 2584 & 2595 & 2626\end{array}$

$\begin{array}{llllll}2627 & 2678 & 3262 & 3288 & 3365 & 3423\end{array}$ $\begin{array}{lllll}3448 & 3453 & 3494 & 3586\end{array}$

Chile-149 $766 \quad 937 \quad 2575 \quad 2650 \quad 3057$

Chinese 1059

Chipped implements see Stone

Chirouse, Eugene Casimir 3219

Chisholm Trail 3004

Chocano, José Santos 2881

Choctaw Nation 7673222 see also Indian Tribes

Chouteau, Auguste \& Pierre 430431 82724012861

Christian, William 1067

Church, Benjamin 2999

Church and State $709 \quad 1963 \quad 2298$ $246626892940 \quad 3203 \quad 3520$

Cimarrón Territory 328

Citizenship $608 \quad 624 \quad 30713469$

Claims against U.S. see Land

Clans $223 \quad 115225003297$

Clark, William 19782445

Clavigero, Francisco Xavier 6341080

Cléveland 955

Climate 2771

Clinton, Gov. George 1890

Clowns 3177

Coatlicue 1012

CoDEx 22132351

Códice en Cruz 805

Dresden 1320

Telleriano-Remensis 6

Xolotl 804

Yanhuitlán 236

Cody, William F. 2674

Colden, Cadwallader 2831 
College of the Holy Cross 2048

$\begin{array}{llllll}\text { Colombia } & 938 & 991 & 1243 & 1680 & 1727\end{array}$ $\begin{array}{llllll}1965 & 2222 & 2566 & 2918 & 3425 & 3575\end{array}$

Colonial Union 2047

Colorado $12 \quad 175 \quad 282 \quad 333 \quad 557 \quad 623$ $\begin{array}{llllll}656 & 704891 & 1363 \quad 1534 & 1600 & 1771\end{array}$ $\begin{array}{lllllll}1775 & 2082 & 2128 & 2235 & 2453 & 2462\end{array}$ $\begin{array}{llllll}2506 & 2556 & 3058 & 3125 & 3143 & 3270\end{array}$ $32713545 \quad 3610 \quad 3683$

Colorado River 2024

Colt, Samuel 3206

Columbia Valley 1920

Columbus, Christopher 28423211

Confederacy; Indian confederation 573581593205921192875

Confederate States of America 113

Conferences 2047

Congress see United States, Congress

Connecticut $385698 \quad 811 \quad 1433 \quad 1617$ 2621266026942751

Connecticut River Valley 385

Constitution (Indian tribal) 1051 21192238

Constitution (U. S.) 1914363296

Continental Congress $1159 \quad 1364$ 15063090

Contraception 1490

Contributions to White culture 261 $270 \quad 305 \quad 645 \quad 1128 \quad 1465 \quad 17602390$ $\begin{array}{llllll}2709 & 2733 & 2778 & 2851 & 3013 & 3030\end{array}$ 314732643295

Cooke, Philip St. George 3638

Cooke, William G. 11

Cooper, James Fenimore 276338571 $\begin{array}{llllll}1391 & 1496 & 1873 & 2416 & 2535 & 2812\end{array}$ 3215

Copper 3577

Cortés, Hernando $448 \quad 1087 \quad 1785$ 270628422980

Costa Rica 1987

Costumbrismo 2131

Costume $\quad \begin{array}{llllll}13 & 472 & 558 & 625 & 771 & 775\end{array}$ $\begin{array}{llllll}1098 & 1144 & 1355 & 1471 & 1769 & 1817\end{array}$ $\begin{array}{llllll}1968 & 2098 & 2205 & 2338 & 2429 & 2738\end{array}$ 282132403288 see also Textiles Cotton 1749

Coureur de bois 1227

Courts (Territorial) 1055

Cowboys 271561714165323343206

Crafts see Arts and Crafts
Credit 2062

Creek Nation 231126814932146 see also Indian Tribes

Cresap, Thomas 82

Crime 2435

Croghan, George 33943405

Croix, Teodoro de 769

Crónica Mexicana 725

Crook, Genl. George 234530073192

Cuba 235776

Cucamonga Rancho 3035

Culture diffusion 866213427153060 31373392

Culture disintegration; extinction 341297430293054

Currency; media of exchange 1777 22552303 see also Trade

Cushing, Frank Hamilton 1121

Custer, George Armstrong 24483317 3554

Custer Trail 2964

Cycle of the West 8323607

Dakota Territory 2281839

DANCE; dancing $101208292 \quad 515$ $\begin{array}{llllll}1144 & 1302 & 1313 & 1333 & 1652 & 2180\end{array}$ $\begin{array}{llllll}2390 & 2430 & 2636 & 2686 & 3003 & 3073\end{array}$ 3089352535303544 see also Ceremony; Religion, Indian

Calumet Dance 1006

Conchero Dance 2180

Corn Dance 16143089

Deer Dance 3530

Eagle Dance 1006

Ghost Dance 74212312203

Green Corn Dance 3582

Sun Dance 1693294531373208 3392

Darío, Rubén 2881

Davis, Gov. E. J. 2471

Davis, William Watts Hart 3673

Dawes Act 39443264210511402

147415862341239329323462

Dawes, Sen. Henry L. 1474

Death 939169119792288 see also Mortuary

Death Song 1691

Deer Lodge Valley 3120

De Forest, John William 698

Delaware 88613742552 
Demers, Modeste 2487

Democratic influences 2354

Dendrochronology see Archeological dating

Dental studies 200223773259

Dermatoglyphics 3588

Detroit 505252125553490

De Witt's Colony 2710

Díaz del Castillo, Bernal 25492633 3334

Dickson, Robert 3301

Dikes; irrigation causeways 2762

Diphtheria 3473

Diplomacy 8925550083411981390 $\begin{array}{llllll}1396 & 1532 & 1629 & 2402 & 2468 & 2520\end{array}$ $\begin{array}{llllll}2563 & 2590 & 2831 & 3309 & 3432 & \text { see }\end{array}$ also Politics

Disease 5845852155306633443473

Divorce 1511511543

Dogs 1324151620863366

Domínguez-Escalante Expedition 2658

Dominica 22

Doniphan Expedition 1665

Dougherty, John 3557

Dragonfly 2910

Drainage 2762

Drama 1552588589140814231597 $\begin{array}{lllllll}1640 & 2060 & 2577 & 2604 & 2692 & 3177\end{array}$ $32943312 \quad 3317 \quad 3639$

Dreams 1937

Drink; beverage 398 see also Liquor

Druillettes, Gabriel 2262

Dualism 19962285

Dunmore, Lord 4603412

Dutch 92717171856239225533318

Dwellings $64 \quad 128 \quad 176 \quad 666 \quad 682 \quad 1420$ $\begin{array}{llllll}2174 & 2386 & 2638 & 2724 & 2822 & 2897\end{array}$ 31723.635 see also Architecture

Dyes; pigments $365789820 \quad 1517$

\section{Eclipse 67}

Ecology; environmental studies 98 $\begin{array}{lllllll}521 & 527 & 641 & 650 & 719 & 735 & 1098\end{array}$ $\begin{array}{llllll}1127 & 1210 & 1243 & 1266 & 1328 & 1472\end{array}$ $\begin{array}{llllll}1473 & 1520 & 1738 & 1805 & 1819 & 1935\end{array}$ $\begin{array}{lllllll}1936 & 2031 & 2170 & 2367 & 2386 & 2529\end{array}$ $\begin{array}{lllllll}2722 & 2740 & 2771 & 2924 & 3044 & 3049\end{array}$ $\begin{array}{llllll}3253 & 3455 & 3458 & 3493 & 3504 & 3396\end{array}$ see also Geography
Economics 24597787112216307 $\begin{array}{llllllll}325 & 406 & 408 & 426 & 441 & 485 & 486 & 511\end{array}$ $\begin{array}{lllllllll}567 & 633 & 776 & 781 & 787 & 803 & 807 & 828\end{array}$ $\begin{array}{llllllll}835 & 851 & 859 & 960 & 1082 & 1300 & 1354\end{array}$ $\begin{array}{lllllll}1390 & 1406 & 1472 & 1473 & 1556 & 1655\end{array}$ $\begin{array}{lllllll}1689 & 1753 & 1810 & 1855 & 2031 & 2054\end{array}$ $\begin{array}{llllll}2058 & 2062 & 2095 & 2109 & 2162 & 2187\end{array}$ $\begin{array}{llllll}2248 & 2254 & 2260 & 2270 & 2272 & 2333\end{array}$ $\begin{array}{llllll}2382 & 2388 & 2474 & 2526 & 2591 & 2673\end{array}$ $\begin{array}{llllll}2718 & 2722 & 2772 & 2774 & 2866 & 2904\end{array}$ $\begin{array}{lllllll}2924 & 2941 & 3008 & 3020 & 3070 & 3105\end{array}$ $\begin{array}{llllll}3190 & 3226 & 3278 & 3303 & 3401 & 3429\end{array}$ 34503658 see also Trade; Labor $\begin{array}{llllll}\text { Ecuador } & 565 & 853 & 1636 & 2131 & 2242\end{array}$ $\begin{array}{llllll}2360 & 2561 & 2892 & 2893 & 2904 & 2907\end{array}$ 309431593438

Edgar Huntley 1695

Ed Ucation (general studies) 110142

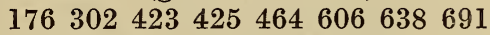
$\begin{array}{lllllll}711 & 874 & 968 & 1030 & 1054 & 1251 & 1437\end{array}$ $\begin{array}{llllll}1450 & 1457 & 1478 & 1540 & 1578 & 1689\end{array}$ $\begin{array}{llllll}1764 & 1791 & 1899 & 1905 & 2527 & 2640\end{array}$ $\begin{array}{lllllll}2657 & 2898 & 3052 & 3067 & 3096 & 3181\end{array}$ 32873536

Classroom "Unit Studies" on Indians 2454987187657941047 $\begin{array}{llllll}1103 & 1426 & 1470 & 1498 & 1844 & 2074\end{array}$ 208422742319266326882692 273327952840289130983264 329533823477348135443551

Colonial Indian education 1856 3085

Curricula for Indian education 73 $\begin{array}{lllllll}117 & 361 & 422 & 582 & 636 & 672 & 712\end{array}$ $\begin{array}{llllll}749 & 1707 & 2514 & 2595 & 2606 & 2672\end{array}$ 277328252906293829423123

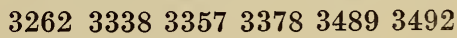
3519

Federal Education (U.S. Office of Indian Education) $10214 \quad 349$ $\begin{array}{lllllll}449 & 516 & 703 & 724 & 829 & 947 & 958\end{array}$ $\begin{array}{llllll}1023 & 1381 & 1392 & 1436 & 1446 & 1483\end{array}$

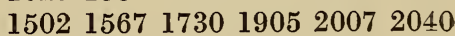
$2122 \quad 21882312261426722700$ 290129773370337733783593

Guidance 9342040211524902626 2691

History of Education 4662744 780857858963145014571462 153116771871187821132178 
Education, contd.

231623402349235223952498

257825942876295632363298

336134163422352835293583

Indian Schools :

Albuquerque $\quad 1255 \quad 2108 \quad 2837$ 299034673680

Bacone College 3823357

Bloomfield 1352

Carlisle 4021037

Cattaraugus 3613449

Chemawa 1906

Chilocco 141716063467

Choctaw Academy 1085

Flandreau 17843550

Ft. Bidwell 3377

Ft. Sill 2678

Ft. Thomas 3040

Haskell $114 \quad 1219 \quad 1267 \quad 1445$ $\begin{array}{lllll}1555 & 2450 & 2451 & 2596 & 2753\end{array}$

310634523505

Mt. Edgecumbe 2221

Phoenix 947

Pima Boarding School 516

Red Lake 636

St. Mary's 2656

Salem High School 2693

San Andrés de Quito 2907

Santa Fé 3680

Seneca 3338

Sequoyah 18743262

Sherman Institute 10972626

Sitka Industrial School 3422

Tucson Training School 117

Wrangell Institute 2174

Indian Tribal Education (i.e., traditional training) 204233552 $\begin{array}{llllll}795 & 844 & 990 & 1085 & 1118 & 1462\end{array}$ $\begin{array}{llllll}1704 & 1733 & 1787 & 1837 & 2282 & 2295\end{array}$ 238326052727289831263256 3295339534233548

Mission Education $148 \quad 173 \quad 234$ $\begin{array}{lllllll}299 & 300 & 308 & 311 & 415 & 490 & 534\end{array}$

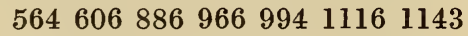

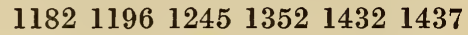

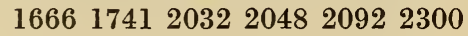
246025242541265629523150 326332773347337534093465 351036513665367436753683

Private Education 21133075
Education, contd.

State Education Administration $\begin{array}{llllll}349 & 693 & 899 & 1240 & 1326 & 1446\end{array}$ $1661 \quad 18921970211523002346$

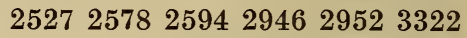
339734133416356835863596

Teachers; Personnel 23207263 $463 \quad 6816851047 \quad 14263551$

Vocational Education 114246976 12412496261430403422

Egypt 10622063

El gran teatro del mundo 1584

Eliot, John 1363156

Elizondo Expedition 2860

El Paso 3251570

El Peregrino Indiano 1998

Employment see Labor

Empresario 3212

Encomienda 776294129823037

Eolithic 20652279

Escalante, Silvestre Vélez de 2658 3345

Española 51410152777

Espejo Expedition 723

Estacado 1650

Ethics; ethos $1192 \quad 1371 \quad 1527 \quad 1883$ $24443256 \quad 3587$

Ethnobiology 12461542

Ethnobotany $145 \quad 168 \quad 445 \quad 637 \quad 712$ $\begin{array}{lllllll}789 & 809 & 943 & 1166 & 1204 & 1205 & 1225\end{array}$ $\begin{array}{llllll}1406 & 1517 & 1542 & 1655 & 1698 & 2125\end{array}$ $\begin{array}{llllll}2303 & 2459 & 2843 & 2847 & 3066 & 3101\end{array}$ 31893230365236683671 see also Agriculture; Maize

Ethnography; ethnologies 656699 $\begin{array}{llllllll}130 & 195 & 297 & 318 & 352 & 440 & 496 & 542\end{array}$ $\begin{array}{llllllll}639 & 643 & 649 & 773 & 778 & 800 & 808 & 864\end{array}$ $\begin{array}{lllllll}871 & 891 & 920 & 928 & 950 & 959 & 1021\end{array}$ $\begin{array}{llllll}1025 & 1031 & 1043 & 1081 & 1136 & 1153\end{array}$ $\begin{array}{llllll}1156 & 1179 & 1237 & 1274 & 1287 & 1289\end{array}$ $\begin{array}{llllll}1433 & 1504 & 1523 & 1527 & 1549 & 1571\end{array}$ $\begin{array}{lllllll}1582 & 1662 & 1757 & 1761 & 1778 & 1804\end{array}$ $\begin{array}{llllll}1863 & 1920 & 1923 & 1948 & 1953 & 1954\end{array}$ $\begin{array}{lllllll}1958 & 2068 & 2107 & 2149 & 2151 & 2168\end{array}$ $\begin{array}{llllll}2201 & 2207 & 2222 & 2223 & 2245 & 2250\end{array}$ $\begin{array}{llllll}2291 & 2293 & 2301 & 2306 & 2380 & 2390\end{array}$ $\begin{array}{lllllll}2405 & 2499 & 2515 & 2518 & 2531 & 2568\end{array}$ $\begin{array}{lllllll}2572 & 2579 & 2694 & 2714 & 2715 & 2758\end{array}$ $\begin{array}{llllll}2786 & 2792 & 2818 & 2823 & 2859 & 2865\end{array}$ $\begin{array}{llllll}2903 & 2918 & 2955 & 2959 & 2970 & 2978\end{array}$ 
Ethnography, contd. $\begin{array}{llllll}2984 & 3011 & 3022 & 3047 & 3074 & 3119\end{array}$ $\begin{array}{llllll}3128 & 3138 & 3153 & 3183 & 3187 & 3196\end{array}$ $\begin{array}{lllllll}3217 & 3220 & 3221 & 3295 & 3329 & 3344\end{array}$ $\begin{array}{llllll}3410 & 3437 & 3450 & 3481 & 3493 & 3518\end{array}$ Ethnography of the Fox Indians 1031 Ethnohistory $3 \quad 75 \quad 92 \quad 112 \quad 131 \quad 167$ $\begin{array}{llllllll}217 & 218 & 219 & 230 & 286 & 360 & 378 & 414\end{array}$ $\begin{array}{llllllll}504 & 510 & 543 & 562 & 587 & 604 & 605 & 721\end{array}$ $\begin{array}{llllllll}731 & 763 & 765 & 767 & 785 & 800 & 906 & 913\end{array}$ $\begin{array}{lllllll}926 & 949 & 985 & 986 & 1032 & 1060 & 1079\end{array}$ $\begin{array}{llllll}1080 & 1096 & 1114 & 1120 & 1122 & 1153\end{array}$ $\begin{array}{lllllll}1160 & 1188 & 1214 & 1215 & 1234 & 1258\end{array}$ $\begin{array}{lllllll}1268 & 1274 & 1345 & 1395 & 1405 & 1467\end{array}$ $\begin{array}{llllll}1488 & 1504 & 1514 & 1521 & 1600 & 1635\end{array}$ $\begin{array}{llllll}1645 & 1649 & 1679 & 1702 & 1708 & 1728\end{array}$ $\begin{array}{lllllll}1761 & 1779 & 1786 & 1799 & 1830 & 1870\end{array}$ $\begin{array}{lllllll}1887 & 1944 & 1958 & 1966 & 2054 & 2059\end{array}$ $\begin{array}{llllll}2130 & 2142 & 2151 & 2168 & 2169 & 2203\end{array}$ $\begin{array}{llllll}2284 & 2293 & 2305 & 2331 & 2337 & 2350\end{array}$ $\begin{array}{lllllll}2355 & 2361 & 2366 & 2373 & 2375 & 2388\end{array}$ $\begin{array}{llllll}2389 & 2396 & 2415 & 2432 & 2462 & 2484\end{array}$ $\begin{array}{llllll}2515 & 2525 & 2526 & 2537 & 2538 & 2556\end{array}$ $\begin{array}{lllllll}2572 & 2576 & 2587 & 2589 & 2697 & 2702\end{array}$ $\begin{array}{lllllll}2730 & 2758 & 2760 & 2777 & 2792 & 2801\end{array}$ $\begin{array}{lllllll}2811 & 2826 & 2845 & 2852 & 2883 & 2936\end{array}$ $\begin{array}{lllllll}2955 & 2967 & 2973 & 2974 & 3011 & 3029\end{array}$ $\begin{array}{lllllll}3033 & 3047 & 3054 & 3074 & 3087 & 3098\end{array}$ $\begin{array}{lllllll}3116 & 3143 & 3161 & 3184 & 3187 & 3196\end{array}$ $\begin{array}{lllllll}3228 & 3248 & 3253 & 3260 & 3274 & 3285\end{array}$ $\begin{array}{lllllll}3286 & 3293 & 3297 & 3305 & 3308 & 3309\end{array}$ $\begin{array}{lllllll}3314 & 3336 & 3345 & 3346 & 3384 & 3385\end{array}$ $\begin{array}{lllllll}3410 & 3432 & 3437 & 3450 & 3457 & 3461\end{array}$ $\begin{array}{llllll}3466 & 3491 & 3557 & 3567 & 3608 & 3609\end{array}$ 3623365036563684 seealso History

Ethnozoölogy $21 \quad 344 \quad 396 \quad 789 \quad 859$ $\begin{array}{llllll}1050 & 1244 & 1246 & 1316 & 1324 & 1356\end{array}$ $\begin{array}{lllllll}1516 & 1542 & 1643 & 1674 & 1810 & 1956\end{array}$ $\begin{array}{lllllll}2052 & 2063 & 2086 & 2213 & 2419 & 2481\end{array}$ $\begin{array}{lllllll}2849 & 2850 & 2910 & 3048 & 3281 & 3366\end{array}$ 3580

Exploration $\begin{array}{lllll}129 & 172 & 175 & 217 & 221\end{array}$ $\begin{array}{llllllll}257 & 289 & 369 & 477 & 530 & 576 & 668 & 717\end{array}$ 72392310571123113812171242 $\begin{array}{llllll}1366 & 1377 & 1434 & 1438 & 1508 & 1554\end{array}$ $\begin{array}{llllll}1558 & 1577 & 1591 & 1625 & 1628 & 1670\end{array}$ $\begin{array}{llllll}1842 & 1952 & 2021 & 2039 & 2045 & 2167\end{array}$ $\begin{array}{llllll}2176 & 2229 & 2251 & 2266 & 2297 & 2325\end{array}$ $\begin{array}{llllll}2326 & 2360 & 2391 & 2505 & 2545 & 2574\end{array}$ $\begin{array}{llllll}2632 & 2658 & 2664 & 2696 & 2716 & 2765\end{array}$
Exploration, contd. $\begin{array}{llllll}2807 & 2836 & 2842 & 2860 & 2863 & 2890\end{array}$ $\begin{array}{lllllll}2951 & 2966 & 3005 & 3046 & 3091 & 3160\end{array}$ $\begin{array}{lllllll}3202 & 3211 & 3237 & 3249 & 3270 & 3271\end{array}$ $\begin{array}{llllll}3339 & 3340 & 3402 & 3441 & 3509 & 3532\end{array}$ 35403619363636383641 see also Transportation; Travel Accounts

Factionalism 9491108

Fages, Pedro 8611666

Family; family life 298343355356 64166511641481173320662804 289729583157

Farquier, Gov. Francis 2457

Fertility 1337

Fiesta; festivals 2172260131353672 Fire 11902673

Firearms 2766

Fish; fishing $654 \quad 1246 \quad 1278 \quad 1316$ $\begin{array}{llllll}1443 & 1473 & 1643 & 2583 & 2849 & 2850\end{array}$ Flaked implements see Stone

Flathead Valley 253

Fleming, Col. William 1562

$\begin{array}{lllllll}\text { Florida } & 439 & 709 & 848 & 892 & 916 & 1169\end{array}$ $\begin{array}{lllllll}1226 & 1404 & 1505 & 1624 & 1910 & 1934\end{array}$ $\begin{array}{llllll}2121 & 2139 & 2211 & 2220 & 2291 & 2368\end{array}$ $\begin{array}{llllll}2385 & 2757 & 2959 & 2967 & 3078 & 3111\end{array}$ $31243254 \quad 3560$

Folklore; mythology; legends 5764 $\begin{array}{llllllll}86 & 105 & 156 & 310 & 404 & 420 & 436 & 474\end{array}$ $\begin{array}{llllllll}563 \quad 662 & 782 & 794 & 830 & 842 & 920 & 953\end{array}$ 96997310041041104210891104 $\begin{array}{llllll}1107 & 1113 & 1174 & 1186 & 1209 & 1333\end{array}$ $\begin{array}{llllll}1384 & 1430 & 1464 & 1523 & 1533 & 1621\end{array}$ $\begin{array}{llllll}1803 & 1829 & 1844 & 1857 & 1895 & 1915\end{array}$ $\begin{array}{llllll}1956 & 1957 & 1993 & 1996 & 2009 & 2012\end{array}$ $\begin{array}{llllll}2068 & 2078 & 2084 & 2126 & 2192 & 2239\end{array}$ $\begin{array}{llllll}2247 & 2278 & 2328 & 2380 & 2414 & 2430\end{array}$ $\begin{array}{lllllll}2509 & 2544 & 2586 & 2593 & 2622 & 2639\end{array}$ $\begin{array}{lllllll}2703 & 2728 & 2733 & 2745 & 2829 & 2855\end{array}$ $\begin{array}{lllllll}2880 & 2884 & 2886 & 2910 & 2928 & 2970\end{array}$ $\begin{array}{lllllll}2984 & 2989 & 3028 & 3050 & 3062 & 3063\end{array}$ $\begin{array}{lllllll}3102 & 3109 & 3118 & 3121 & 3125 & 3128\end{array}$ $\begin{array}{llllll}3129 & 3185 & 3224 & 3275 & 3283 & 3330\end{array}$ $\begin{array}{lllllll}3389 & 3442 & 2443 & 3444 & 3493 & 3535\end{array}$ $\begin{array}{lllll}3556 & 3565 & 3617 & 3626 & 3636\end{array}$

Foods $\begin{array}{llllll}398 & 445 \quad 645 \quad 809 & 1001 & 1040\end{array}$ $\begin{array}{llllll}1154 & 1246 & 1278 & 1406 & 1583 & 1655\end{array}$ $\begin{array}{lllllll}1961 & 2459 & 2722 & 2843 & 2847 & 2924\end{array}$ $\begin{array}{lllll}3030 & 3221 & 3344 & 3365 & 3383\end{array}$ 
Forts; Trading Posts 227309374 Freneau, Philip 1709

$1058 \quad 1706 \quad 2559 \quad 3104$

Ft. Abraham Lincoln 2964

Frogs 2213

Ft. Armstrong 1687

Ft. Bennett 71

Ft. Bidwell 3377

Ft. Bowie 2394

Ft. Bliss 16102731

Ft. Buford 1864

Ft. Concho 295

Ft. Corchaug 3104

Ft. Crawford 21562157

Ft. Crèvecoeur 3641

Ft. Dearborn 598

Ft. Defiance 2171

Ft. Grant 3192

Ft. Hall 38936313632

Ft. Hays 2143

Ft. Hoskins 1528

Ft. Huachuca 1835

Ft. Kearny 21823088

Ft. Laramie 85

Ft. Leavenworth 980

Ft. Lowell 3456

Ft. McIntosh 646

Ft. Necessity 377

Ft. Niagara 2200

Ft. Nisqually 3328

Ft. Randall 1751

Ft. Ross 3402

Ft. St. Joseph 1601

Ft. St. Louis 578

Ft. Sam Houston 5021370

Ft. Snelling 3645

Ft. Totten 791

Ft. Union 179820302737

Ft. Wayne 8132635

Ft. Whipple 3629

Ft. Thomas High School 3040

4-H Club 1973

Franklin, Benjamin 881

Fraser, John 572

Freedmen 1134

FRENCH $456 \quad 710 \quad 779 \quad 882 \quad 889 \quad 1057$

$\begin{array}{lllllll}1058 & 1173 & 1223 & 1258 & 1364 & 1377\end{array}$

$\begin{array}{lllllll}1411 & 1601 & 1720 & 1815 & 1816 & 2104\end{array}$ $\begin{array}{llllll}2200 & 2248 & 2376 & 2385 & 2521 & 2557\end{array}$ $\begin{array}{llllll}2590 & 2654 & 2677 & 2711 & 2871 & 2962\end{array}$ 3108339136193628 see also New France; Literature, French

Frontenac, Comte de 908

Frontier $276 \quad 397 \quad 458 \quad 526 \quad 561 \quad 678$ 69288112491259133813961412

$\begin{array}{llllll}1431 & 1440 & 1486 & 1513 & 1562 & 1629\end{array}$

$\begin{array}{llllll}1756 & 1766 & 1768 & 1801 & 1813 & 1836\end{array}$

$\begin{array}{lllllll}1839 & 1853 & 2076 & 2129 & 2155 & 2157\end{array}$

$\begin{array}{lllllll}2224 & 2307 & 2456 & 2475 & 2547 & 2635\end{array}$

$\begin{array}{llllll}2796 & 2957 & 3023 & 3079 & 3146 & 3260\end{array}$ $\begin{array}{lllll}3458 & 3522 & 3547 & 3584 & 3663\end{array}$

Frontier Defense 221509700944 $\begin{array}{llllll}1150 & 1351 & 1364 & 1404 & 1424 & 1683\end{array}$ $\begin{array}{llllll}1836 & 1843 & 1986 & 1999 & 2073 & 2456\end{array}$ $\begin{array}{llllll}2641 & 2788 & 2864 & 2995 & 3015 & 3032\end{array}$ 3100341734863508 see also Forts; Military Affairs; Warfare

Frontier Life $264 \quad 1431 \quad 1960 \quad 2834$ 3564 see also Settlement

Frontiersmen; Scouts 2675721067 $\begin{array}{llllll}1338 & 1642 & 2604 & 2716 & 2957 & 3069\end{array}$ 32943532

Fur Trade $16 \quad 83 \quad 106 \quad 162 \quad 309 \quad 358$ $\begin{array}{llllllll}368 & 407 & 430 & 431 & 702 & 738 & 740 & 827\end{array}$ $\begin{array}{llllll}882 & 1024 & 1052 & 1466 & 1572 & 1601\end{array}$ $\begin{array}{lllllll}1607 & 1628 & 1664 & 1706 & 1717 & 1782\end{array}$ $\begin{array}{llllll}1875 & 1884 & 1916 & 1918 & 1925 & 1940\end{array}$ $\begin{array}{llllll}1952 & 1969 & 1974 & 2026 & 2030 & 2111\end{array}$ $\begin{array}{llllll}2120 & 2261 & 2359 & 2381 & 2392 & 2401\end{array}$ $\begin{array}{llllll}2449 & 2452 & 2481 & 2521 & 2553 & 2554\end{array}$ $\begin{array}{llllll}2630 & 2711 & 2713 & 2861 & 2874 & 2905\end{array}$ $\begin{array}{lllllll}3023 & 3092 & 3115 & 3174 & 3300 & 3301\end{array}$ $\begin{array}{llllll}3318 & 3407 & 3408 & 3421 & 3485 & 3526\end{array}$ see also Trade

Gailland, Maurice 424

Gaines, Edmund Pendleton 3032

Gallup 3260

Gálvez, Bernardo de 5332947

Gálvez, José de 2667

Gambling 798

Games; recreation 245271465609 65179813251806239031473154 $\begin{array}{llll}3171 & 3379 & 3523 & 3558\end{array}$

Gamio, Manuel 2869

Garcés, Francisco 51315612574 2807

Garcilaso de la Vega 296

Gardoqui, Diego de 2520

Garland, Hamlin 129924263325 
Geography; ethnogeography $47 \quad 79$ $\begin{array}{llllllll}94 & 164 & 182 & 226 & 350 & 474 & 475 & 521\end{array}$ $\begin{array}{lllllll}650 & 654 & 727 & 811 & 928 & 1212 & 1226\end{array}$ $\begin{array}{lllllll}1243 & 1328 & 1643 & 1712 & 1726 & 1738\end{array}$ $\begin{array}{lllllll}1809 & 1881 & 1945 & 2260 & 2261 & 2323\end{array}$ $\begin{array}{llllll}2382 & 2555 & 2566 & 2740 & 3038 & 3049\end{array}$ 31523217325834033504 see also Ecology; Land

$\begin{array}{lllll}\text { Geology } & 916 & 1328 & 1546 & 1617\end{array}$ 2717

Geometry 10621926

Georgia 1999339455658708921 $\begin{array}{llllll}988 & 1048 & 1222 & 1389 & 1672 & 2057\end{array}$ $\begin{array}{llllll}2168 & 2298 & 2372 & 2385 & 2671 & 2683\end{array}$ 297233333603

Georgia-Creek controversy 2671

German $252 \quad 107622882543$ see also Literature, German

Gerstäcker, Friedrich 1932

Ghost Dance see Dance

Gifts to Indians 1629

Gila River 2024

God-parents 2573

Gold 291602

Government, Indian tribal 43331 $\begin{array}{lllllll}484 & 579 & 593 & 633 & 1329 & 1452 & 1500\end{array}$ $\begin{array}{lllllll}1696 & 2056 & 2059 & 2119 & 2238 & 2302\end{array}$ $\begin{array}{lllll}2455 & 3017 & 3238 & 3433 & 3623\end{array}$

Grand River Valley 109

Grant, Ulysses S. 24372870

Green Corn Dance see Dance

Green, Tom 1823

Guardian spirit 224

Guatemala $61 \quad 87 \quad 446 \quad 603 \quad 743 \quad 962$ $\begin{array}{llllll}982 & 1480 & 1657 & 2014 & 2031 & 2275\end{array}$ $\begin{array}{llllll}2343 & 2536 & 2764 & 3241 & 3332 & 3401\end{array}$ 34553483

Guilt 990

Haiti 2854

Haldimand, Gov. Frederick 209

Hamilton, Gov. Henry 1632

Hancock, Samuel 287

Handwriting 3467

Harrison, Benjamin 497

Hats 131355

Hatton, Ann Kamble 589

Hawkins, Benjamin 602

Hayden Survey 175257
Health; nutrition 87324710221040

$\begin{array}{llllll}1135 & 1154 & 1314 & 1518 & 1568 & 2006\end{array}$ $\begin{array}{lllllll}2237 & 2536 & 2595 & 2626 & 2793 & 2847\end{array}$ $\begin{array}{llllll}2942 & 3030 & 3105 & 3259 & 3344 & 3365\end{array}$ 347134733492 see also Disease; Medicine

Hearing ability 401

Hedges, William H. 2957

Hemenway Expedition 11211421

Henry, Alexander 3407

Herder, Johann Gottfried von 579 2186

Historia antigua de México 634

Historia de la conquista de México 1981

Historia eclesiástica Indiana 2609

Historia general de las cosas de Nueva Espã̃a 28973026

Historia natural y moral de las Indias 1914

Historia verdadera de la conquista de la Nueva España 3334

Historians; historical writing 264 $\begin{array}{llllll}1080 & 1913 & 1914 & 1981 & 1998 & 2175\end{array}$ $\begin{array}{lllllll}2325 & 2510 & 2549 & 2571 & 2633 & 2897\end{array}$ 29163151

$\begin{array}{lllllll}\text { History } & 386 & 474 & 530 & 634 & 687 & 725\end{array}$ $91495498414641493 \quad 14942084$ $\begin{array}{llllll}2191 & 2315 & 2325 & 2549 & 2555 & 2566\end{array}$ 26092612352436693676 see also Ethnohistory

History of Texas, 16\%3-1779 530

History of the Indians of Connecticut 698

Hoijer-Sapir language theory 2114 Holladay Overland Mail and Express Co. 1101

Home making $672 \quad 2174 \quad 26062804$

Honduras 48119773360

Honey Lake 3088

Horse 39685916742973

Hospitality customs 1522

Houston, Sam 8132687711151658 207228392862

Howard, Volney E. 3243

Hualcán 3164

Huarochiri 1202

Huayculi 1228

Hudson's Bay Company 6881885 $\begin{array}{llllll}1899 & 2111 & 2204 & 2359 & 2929 & 3408\end{array}$ 
Humboldt, Alexander von 1343

Humor 32335191219353177

Hunter, Gov. Robert $249 \quad 250 \quad 480$

Hunting 223347641148917251884 $2138 \quad 2367 \quad 2924 \quad 3221$

Hurdaide, Diego Martínez de 1670

Huronia 6321157

Ibarra, Francisco de 2252

Icaza, Jorge 3159

Idaho $90 \quad 487 \quad 537 \quad 1812 \quad 2449 \quad 2533$ 274733493631

Idolatry 2665

Illinois $\begin{array}{llllll}275 & 288 & 294 & 393 & 412 & 583\end{array}$ $\begin{array}{llllll}1197 & 1258 & 1291 & 1778 & 2133 & 2218\end{array}$ $\begin{array}{llllll}2402 & 2513 & 2540 & 2576 & 2797 & 3077\end{array}$ Illiteracy 1003

Immortality 9392742

Implements, flaked see Stone

Indian Bible 3156

Indian captivities; accounts of 212 26028752961

Indian Peace Commission 2563

Indian Reorganization Act 467947 $\begin{array}{lllll}1056 & 1106 & 1419 & 1811 & 2393 \quad 3310\end{array}$

Indian Stream Republic 1699

Indian Territory (Oklahoma) 148 $\begin{array}{lllllll}157 & 166 & 328 & 378 & 574 & 849 & 1046\end{array}$ $\begin{array}{llllll}1272 & 2292 & 2361 & 2712 & 3286 & 3549\end{array}$

Indian TrIBES

Eastern Woodlands 13363582

Five Civilized Tribes 188604705 $\begin{array}{llllll}747 & 930 & 1245 & 1402 & 1468 & 1586\end{array}$ $1761 \quad 18592085232026592702$ 274627542998303230763098 318132863561

Plains $\begin{array}{llllll}186 & 426 & 541 & 623 & 635 & 748\end{array}$ 8599199831066111812961514 $\begin{array}{llllll}1611 & 1640 & 1648 & 1888 & 1907 & 2107\end{array}$ 219223102348237524482462 $2670272228742973 \quad 30583079$ $\begin{array}{llll}3084 & 3137 & 3458 & 3529\end{array}$

Pueblo $4 \quad 14 \quad 70 \quad 354 \quad 416 \quad 419 \quad 435$ $\begin{array}{llllllll}506 & 532 & 650 & 696 & 774 & 912 & 933\end{array}$ $\begin{array}{llllll}1033 & 1065 & 1127 & 1172 & 1214 & 1221\end{array}$ $\begin{array}{llllll}1275 & 1330 & 1331 & 1337 & 1420 & 1469\end{array}$ $\begin{array}{llllll}1471 & 1499 & 1587 & 1592 & 1758 & 1760\end{array}$ 180919672006202120632144 214521952233225122852495
Indian Tribes, contd. 256025912627273828212832 284129232940301930593089 312631493154322332603365 344036743677

Six Nations $\begin{array}{lllll}699 & 879 & 880 & 1198\end{array}$ 17892311305630813588

Abnaki 16991897206922622954 Ácoma 28683230

Aleut $26 \quad 239 \quad 407 \quad 463 \quad 464 \quad 1011$ $\begin{array}{llllll}1305 & 1399 & 1710 & 1860 & 1869 & 1870\end{array}$ 191824472481249825952614 28762979311634023489

Algonquin 44564169910421043 170120832137221223312406 292729363028

Alibamu $779 \quad 796 \quad 808 \quad 2178 \quad 2194$ 2247257932853500

Amuzgo 1223667121971

Apache $167 \quad 286 \quad 340 \quad 441489532$ $\begin{array}{llllll}623 & 888 & 984 & 1036 & 1107 & 1162\end{array}$ $\begin{array}{llllll}1240 & 1259 & 1284 & 1478 & 1535 & 1550\end{array}$ $\begin{array}{llllll}1554 & 1587 & 1682 & 1708 & 1835 & 1843\end{array}$ 195320322054219522662268 234523892413248325072551 $\begin{array}{llllll}2716 & 2730 & 2788 & 2811 & 3007 & 3040\end{array}$

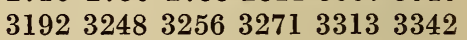
341734563500360836293633 Appalachi 607

Arapaho 932226558919321117 $\begin{array}{llllll}1305 & 1341 & 1715 & 1821 & 1883 \quad 1948\end{array}$ 242326482788282529013011 330833893546

Araucanian $707 \quad 766 \quad 873937993$ 2650

Arawak 126427772889

Arikara $317 \quad 538 \quad 887 \quad 1023 \quad 1559$

Arkansas 7792976

Assiniboin $1677 \quad 2675 \quad 2818 \quad 3208$

Atákapa 224531613500

Athapascan $995 \quad 1599 \quad 1929 \quad 1931$ 222133303402

Atsugewi 11561237

Aymará $1726 \quad 1822 \quad 3329$

Aztec $7 \quad 37 \quad 86 \quad 100 \quad 548 \quad 599 \quad 804$ 805944972978101310141028 $\begin{array}{llllll}1147 & 1209 & 1250 & 1329 & 1333 & 1408\end{array}$ $\begin{array}{lllllll}1553 & 1646 & 1659 & 1690 & 1779 & 2098\end{array}$ 225022882357247325862657 
Indian Tribes, contd. 273327622956302630823267 33953580

Bannock $371473 \quad 623 \quad 13621840$ 18722150215129453631

Bella Coola 1851

Bidai 5030473500

Biloxi 3185

Blackfoot $\quad 590 \quad 1060 \quad 1153 \quad 1229$

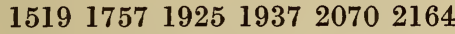
223324842675271629353036 3157321833893544

Blood 2233

Caddo 506671041109912151514 188822392389261727203180 325635003516

Caingang 14602687

Cakchiquel 3455

Canela 3646

Carib 221441199126417272889

Carrier 123518512380

Catawba 12602579

Cayuá 3451

Cayuga see Iroquois

Cayuse 75619432562

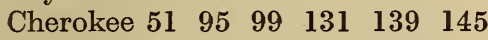
$\begin{array}{lllllll}157 & 204 & 219 & 277 & 285 & 293 & 302\end{array}$ $\begin{array}{lllllll}306 & 326 & 339 & 392 & 405 & 420 & 494\end{array}$ $\begin{array}{lllllll}522 & 547 & 665 & 679 & 694 & 697 & 794\end{array}$ $\begin{array}{lllllll}868 & 880 & 906 & 907 & 921 & 949 & 963\end{array}$ $\begin{array}{llllll}987 & 998 & 1040 & 1072 & 1081 & 1099\end{array}$ $\begin{array}{llllll}1120 & 1125 & 1191 & 1268 & 1314 & 1354\end{array}$ $\begin{array}{llllll}1389 & 1462 & 1498 & 1645 & 1663 & 1668\end{array}$ $\begin{array}{llllll}1724 & 1791 & 1843 & 1896 & 1938 & 1944\end{array}$

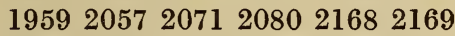
220122382239228123682372 239824292514242525792589

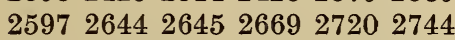
2748.28722878295729763033

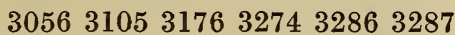
331433333346343234793500 $\begin{array}{lllll}3553 & 3567 & 3620 & 3624 & \text { see also }\end{array}$ Five Civilized Tribes

Cheyenne $7593222 \quad 233473 \quad 655$ $\begin{array}{llllll}891 & 1117 & 1305 & 1341 & 1378 & 1531\end{array}$ $\begin{array}{llllll}1611 & 1715 & 1883 & 1948 & 2184 & 2309\end{array}$

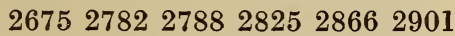
$2953 \quad 29643308338934103546$ 35813599

Chibcha 99117273575
Indian Tribes, contd.

Chickasaw $166 \quad 394 \quad 408 \quad 673 \quad 744$ 785796858860135213891479 $\begin{array}{lllllll}1647 & 1696 & 1714 & 1881 & 2071 & 2239\end{array}$ 247625792976308731843185 322235843623 see also Five Civilized Tribes

Chilcotin 18511760

Chimú 3165

Chinook $901902 \quad 1598 \quad 17002487$ 292932333299

Chipewyan 3570

Chippewa $123 \quad 160 \quad 230 \quad 298 \quad 313$ $\begin{array}{lllllll}375 & 531 & 611 & 636 & 643 & 781 & 839\end{array}$ $\begin{array}{llllll}880 & 934 & 1038 & 1114 & 1261 & 1378\end{array}$ $\begin{array}{llllll}1481 & 1637 & 1661 & 1784 & 1846 & 1849\end{array}$ $\begin{array}{llllll}1905 & 1937 & 1992 & 2157 & 2316 & 2317\end{array}$ 236523952522254425842618 265127932884302332283301 3448355035793596

Chiriguaná 873

Chitimacha 3161

Chocó 1965

Choctaw 123203394767779784 $\begin{array}{llllll}796 & 858 & 1085 & 1212 & 1287 & 1389\end{array}$ $\begin{array}{llllll}1479 & 1647 & 1881 & 2071 & 2239 & 2272\end{array}$ 234123552403252826452903 297631853222323633533413 see also Five Civilized Tribes

Chorotega 3403

Chumash 7341955

Ciboney 1264

Clayoquot 1804

Coahuiltecan 2865

Cochití 1855

Cocopa 1738

Coeur d'Alene $1734 \quad 2062 \quad 2720$ 3616

Comanche 50156202418523526 $\begin{array}{llllll}994 & 1347 & 1407 & 1500 & 1612 & 1756\end{array}$ $\begin{array}{llllll}1843 & 1888 & 2032 & 2142 & 2340 & 2389\end{array}$ $\begin{array}{llllll}2410 & 2411 & 2760 & 2779 & 2782 & 2788\end{array}$ $28013153 \quad 3162 \quad 318032563271$ 329534173500351635463624

Coos 1090

Cowichan 18502487

Cree 3492137217031873414

Creek 49231254268293301796 $\begin{array}{lllllll}835 & 857 & 874 & 921 & 987 & 1008 & 1051\end{array}$

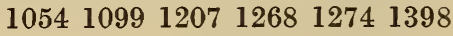


Indian Tribes, contd.

$\begin{array}{llllll}1493 & 1579 & 1614 & 1702 & 1780 & 1919\end{array}$ 201920952139214621942211 235823612368247625472579 258526452671268328032895 297630683111329233333500 3595 see also Five Civilized Tribes

Croatan 2072346

Crow 4619201116111713021378 151919372070216422542675 286730363044308833233389 3392

Cuicatec 1971

Cuna 3196

Dakota $442 \quad 520 \quad 683 \quad 1205 \quad 1271$ $\begin{array}{llllll}1578 & 1620 & 1678 & 2978 & 3468 & \text { see }\end{array}$ also Sioux

Delaware $1260 \quad 1465 \quad 1466 \quad 1788$ 179318471960201324322492 25372603325633473419

Dené 2518

Eskimo $73 \quad 244 \quad 341 \quad 425 \quad 463 \quad 464$ $\begin{array}{lllllll}551 & 631 & 777 & 830 & 928 & 969 & 1022\end{array}$ $\begin{array}{llllll}1192 & 1386 & 1392 & 1393 \quad 1399 & 1425\end{array}$ $\begin{array}{llllll}1442 & 1448 & 1571 & 1710 & 1810 & 1837\end{array}$ $\begin{array}{llllll}1861 & 1870 & 2279 & 2319 & 2367 & 2377\end{array}$ 244724732498259526142622 274228732876297929893131 325533593402345434733492 349335653570

Flathead 4871063173420682163 216421752562267527202834 292232103299

Fox $\begin{array}{llllll}319 & 449 & 810 & 926 & 1031 & 1339\end{array}$ $\begin{array}{llllll}1378 & 1662 & 1684 & 1687 & 1689 & 2044\end{array}$

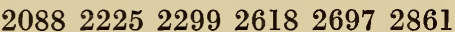
30363055325135223642

Fraser R. 1915

Fulniô 1509

Gabrielino 470

Goajira 2222

Gosiute 1362

"Great Bear Lake" 2518

Gros Ventre $887 \quad 1023 \quad 2217 \quad 2675$ 32083389

Guaicuro 3291

Guaraní 9351025133523442687 29823362

Guayquerí 2055
Indian Tribes, contd.

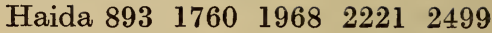
32103646

Hallkomelem 871

Hasinai 129331553500

Havasupai 9502955

Hidatsa $317 \quad 318 \quad 400 \quad 1376 \quad 2810$ 34103559

Hopi $5 \quad 208 \quad 343 \quad 513 \quad 626 \quad 823 \quad 824$ $\begin{array}{lllllll}855 & 918 & 1035 & 1131 & 1328 & 1461\end{array}$ $\begin{array}{llllll}1550 & 1705 & 1715 & 1733 \quad 1760 & 1849\end{array}$

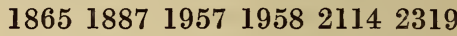
$2382 \quad 242927172970 \quad 3117 \quad 3142$ 324032973450346635483646

Huichol 2733

Hupa $122020623423 \quad 3636$

Huron $366 \quad 628 \quad 632 \quad 1096 \quad 1157$ $12231411 \quad 1466218922122523$ 2654292729743579

Illinois $275 \quad 1778 \quad 22402241$

Inca 135200345428484633961

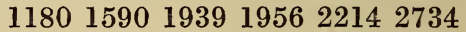
292129563159327533953429

Iowa $20442083 \quad 30553522$

Iroquois $89305 \quad 346361366383$ $\begin{array}{lllllll}390 & 504 & 581 & 593 & 628 & 635 & 773\end{array}$ $\begin{array}{llllll}899 & 908 & 951 & 1096 & 1173 & 1206\end{array}$ $\begin{array}{llllll}1260 & 1329 & 1398 & 1454 & 1482 & 1582\end{array}$ $\begin{array}{llllll}1729 & 1777 & 1780 & 1793 & 1814 & 1847\end{array}$ $\begin{array}{llllll}1889 & 1909 & 1924 & 1988 & 2137 & 2138\end{array}$

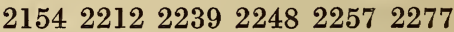
237623922435245525532554 265427202786292529273190 33473433344934813587

Isleta $1108 \quad 1488 \quad 1698 \quad 2087$

Jémez $\begin{array}{lllll}637 & 1395 & 1592 & 1770 & 3089\end{array}$ 32443534

Jívaro 2319

Jumano 1728205122513428

Kágaba 2222

Kaingang see Caingang

Kalapuya 6203299

Kalispel 1211734206220683616

Kamia 1738

Kansa 20442930

Karankawa $644 \quad 2245 \quad 2263 \quad 2723$ 28803500

Karok 3702502

Kaska 1527

Kaskaskia 1687 
Indian Tribes, contd.

Kathlamet 15981700

Kawia 1683141682173818632123

Keres 31303507

Kickapoo 453497168720132044 219426183055350035113679 3684

Kiowa $247418 \quad 497 \quad 582 \quad 891994$ $\begin{array}{lllll}1144 & 1347 & 1407 & 1843 \quad 1888 & 2018\end{array}$

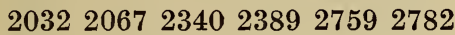
278828013053316231803256 326133893546

Kiowa-Apache 3522023

Klamath 560 $762 \quad 895 \quad 1438 \quad 1667$ 16792188240427243643

Klikitat $1760 \quad 2929 \quad 3299$

Koasati 8081631183221942247 257932853500

Kutchin 913

Kutenai 11581608173420622924

Kwakiutl $208 \quad 3106001851 \quad 1937$ 249926243107

Lacandón 3311

Laguna 31983230

Lillooet 176018512405

Luiseño 787

Maidu $821 \quad 19723350$

Makah 62213783544

Malecite 1222253

Mam 3401

Mandan 3173184005388871023 121212231224174319603410 3646

Manso 3428

Mascouten 2884

Matlapa 690

Mattole 1929

Maya $17 \quad 80 \quad 86 \quad 360 \quad 591 \quad 603 \quad 682$ $1320.1333 \quad 1397 \quad 1472 \quad 1635 \quad 1779$ 195619772031206122312275 228323512550263926492705 277828402851291430823139 317932793311333233583395 345535453580

Mayna 2360

Mayo 960

Mazatec 2733

Menomini 490712133919372157 288431403141314533013541 3579
Indian Tribes, contd.

Mesquakie see Fox

Miami 41454257281312851501 184719042019263530293056 3579

Micmac 25 $122 \quad 1136 \quad 1504 \quad 2253$ 3163

Mikasuki 29593213

Mimbres 7681230123320013039 3307

"Mission" 23322985

Mississaga 539

Miwok 78311041972

Mixe 2531

Mixtec 236721731193619713658

Modoc 191414166716793306

Mohave 598019963456

Mohawk 699285930363083 see also Iroquois

Mono 19723062

Monqui 3291

Montagnais $18842262 \quad 28232927$

Montauk 1032

Moqui see Hopi

Mundurucú 2388

Munsee 2584

Muskogee $99 \quad 1029 \quad 1329 \quad 2958$

Nahuatl 6901584215226282629 267627873542

Nambé 435

Nanticoke 25523347

Narragansett $1771 \quad 1882 \quad 2817$

Naskapi 24852823

Natchez 3185

Natchitoches 2976

Navajo $9 \quad 1074 \quad 124233 \quad 391399$ $\begin{array}{lllllll}423 & 437 & 532 & 566 & 615 & 623 & 685\end{array}$ $\begin{array}{lllllll}724 & 749 & 912 & 943 & 979 & 990 & 999\end{array}$ $\begin{array}{llllll}1009 & 1020 & 1079 & 1131 & 1201 & 1208\end{array}$ 121212381344134613781438 $\begin{array}{lllllll}1461 & 1483 & 1489 & 1515 & 1517 & 1535\end{array}$ $\begin{array}{lllllll}1540 & 1550 & 1578 & 1587 & 1596 & 1660\end{array}$ $\begin{array}{lllllll}1665 & 1705 & 1754 & 1760 & 1781 & 1809\end{array}$ $\begin{array}{lllllll}1827 & 1828 & 1848 & 1870 & 1937 & 1942\end{array}$ 200420502056210021142116 212621712195230423192450 245124952496253826372672 270727082717272128042906 291029122931294029492984 301930253075312831293198 
Indian Tribes, contd.

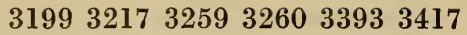
342734623472353435833609 3648

Nespelem 2714

Nez Percé 473596102713451378 196820622249228925332572 292229393050309532103293 $3488 \quad 3520 \quad 3616$

Nisqualli 3328

Nogales 2476

Nootka 18031804196823052499 28363229

Okanagon 3616

Omaha $550 \quad 832 \quad 1204 \quad 1205 \quad 1649$ 2053

Oneida 178166125842792 see also Iroquois

Onondaga 3832772 see alsoIroquois Opata 147297

Osage 31635579383510391099

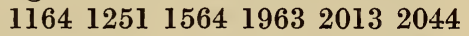
211522102239235024222524 $272028612872 \quad 3022 \cdot 3033$

Oto 205329693518

Otomi 510118324392733

Ottawa 1091894144907601223 122419372019208821352189 $25222523 \quad 323235373579$

Paiute $13621567 \quad 167918401872$ 200024952546306231273186 337734163517

Pamunkey 12863170

Papago 1172973405558161131 $\begin{array}{llllll}1176 & 1313 \quad 1360 & 17051738 & 1774\end{array}$ $\begin{array}{lllll}2339 & 27732847 & 2919 & 2942 & 3024\end{array}$ 30733305335135363578

Pascagoula 3185

Patagonian 707

Patarabueye 1728

Patwin 1972

Pawnee 3531205196619802337 282629302969309631723461 34953650

Pecos 30743255

Pend d'Oreille see Kalispel

Penobscot 2330

Peoria 414168719042013

Pequot 81117773363

Pericú 5073291
Indian Tribes, contd.

Piankashaw 20132044

Picunche 993

Piegan 3157

Pima $110 \quad 117 \quad 297 \quad 340 \quad 516 \quad 984$ $\begin{array}{llllll}985 & 986 & 1313 & 1360 & 1469 & 1566\end{array}$ $30523073 \quad 34913573$

Pima Bajo 147

Piro 2251

Pokoman 743

Pokom-Maya 2284

Pomo 164165567101110161236 14221747256428082809

Ponca $575 \quad 1205 \quad 1549 \quad 1786 \quad 2106$

Popoluca 1082

Potano 2967

Potawatomi 412424562661763 $\begin{array}{llllll}835 & 894 & 1223 & 1224 & 1497 & 1687\end{array}$ 201920882175222524782486 3055

Quapaw 112414109916672239 2720

Quechua 8121228172618222158 316432753438

Quiché 3455

Quichol 3332

Quileute 76

Rogue River $\quad 1889 \quad 1943 \quad 2508$ 2815

Runasimi 812

Sac see Sauk

Sahaptin 1627

Salinan 2223

$\begin{array}{lllll}\text { Salish } 836 & 942 & 1063 & 1177 & 1317\end{array}$ 156020682184256827143226 33433364

Sandía 1010

San Felipe 3089

San Ildefonso 43515922461

San Juan 755

Sanpoil 2714

Santo Domingo 30893534

Sara 1923

$\begin{array}{llllll}\text { Sauk } & 319 & 449 & 1339 & 1378 & 1687\end{array}$ 204420882225261826972861 2884303635223642

Seminole $519 \quad 543 \quad 607 \quad 848 \quad 1134$ $\begin{array}{llllll}1405 & 1505 & 1764 & 1934 & 2139 & 2211\end{array}$ 224622912333253427572933 311131443254345734763605 
Indian Tribes, contd.

Seneca $414 \quad 1006 \quad 1788 \quad 1800 \quad 2636$ 28873038309731023338 see also Iroquois

Seri 128928602960

Serrano 470

Shasta 1523

Shawnee 414475108611791260 $\begin{array}{llllll}1394 & 1574 & 1788 & 1793 \quad 1847 & 1956\end{array}$ 201320192618275830553347 33903627

Shoshoni 450473486537623977 $\begin{array}{llllll}1303 & 1362 & 1400 & 1872 & 2150 & 2307\end{array}$ 248526482888294530143062 308832993388339233973416 $36313632 \quad 3652$

Shuswap 1851

Sia $553 \quad 3089$

Sioux $\begin{array}{lllllll}36 & 71 & 85 & 176 & 230 & 322 & 375\end{array}$ 412443586754786791800843 $\begin{array}{llllll}867 & 1019 & 1041 & 1075 & 1257 & 1339\end{array}$ $\begin{array}{llllll}1341 & 1414 & 1502 & 1521 & 1623 & 1677\end{array}$ $\begin{array}{lllllll}1678 & 1686 & 1688 & 1704 & 1737 & 1784\end{array}$ $179817991892 \quad 199020002011$ 204420452070213021572164 217521842234226422672301 231423292342239624152421 242924612465281628522884 $2930295729643023 \quad 30363168$

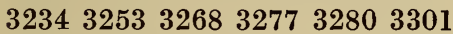
$\begin{array}{llllll}3356 & 3368 & 3398 & 3410 & 3521 & 3527\end{array}$ 354635503554359136513681 see also Dakota

Sirionó 1518

Skagit 618

Slave 152

Snoqualmi 1943

Sobaipuri 297815816872

Soboba 787

Songeis 2882

Stalo 871 (Halkomelem)

Stockbridge 8063054

Taino 2777

Tairona 2220

Takelma 13082908

Tanana 21022796

Taos 15922293

Taovayas 1396

Tapajós 2542

Tarahumara $297 \quad 1112 \quad 16342570$
Indian Tribes, contd.

Tarascan $91 \quad 511 \quad 1234 \quad 2733 \quad 3152$

Tejas 5015542247

Ten'a 32203221

Tenino 1110

Tenochca 2329

Tepehuán 297

Tesuque 3399

Tewa 85485511881525

Tigua 2251

Tillamook 909

Timucua 1910

Tlalteloca 737

Tlaxcala 2003542

Tlingit $893 \quad 1315 \quad 1710 \quad 1829 \quad 1968$ 222122962474296333643402 3484

Toltèc 89797810281077

Tonkawa 501510224529693500

Totonac 302140

Trique 1971

Tsimshian 436893115111522221

Tübatulabal 11611972

Tunica 1327

Tupí-Guaraní 265

Tuscarora 198168219992569 see also Iroquois

Tututni 1308

Twana 942

Tyigh 1110

Tzeltzal 468

Umpqua 1308

Ute $\begin{array}{lllllll}65 & 130 & 177 & 459 & 623 & 639 & 664\end{array}$ $\begin{array}{llllll}704 & 891 & 1154 & 1303 & 1363 & 1418\end{array}$ $\begin{array}{lllll}1693 & 1852 & 1872 \quad 1954 & 2195 & 2306\end{array}$

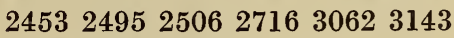
$\begin{array}{llll}3345 & 3546 & 3660 & 3672\end{array}$

Uto-Aztekan 3654

Vaicura 507

Wampanoag 1882

Wappo 86410111972

Wasco 1110

Washo 13621840193530453062 $3186 \quad 3416$

Waunana 1965

Wea 2044

Wichita $50 \quad 418 \quad 605 \quad 1160 \quad 1840$ 188819352389318032563500

"Win" 3404

Winnebago $1205 \quad 1378 \quad 1634 \quad 1687$ 
Indian Tribes, contd. 194920102157246526862884 32253301

Wintun 19371972

Wishram 901902

Witoto 938

Wiyot 2729

Wyandot $4146461788 \quad 1793 \quad 1847$ 1889

Yahgan 2485

$\begin{array}{llllll}\text { Yakima } & 259 & 356 & 798 & 1889 & 2062\end{array}$ 217534883616

Yamassee 198

Yaqui 151292671117611861670 3134313532503530

Yaruro 2485

Yavapai 4717381937

Yazoo 779

Yokuts 1161244130623138

Yuchi 99138925793119

Yuki 1972

$\begin{array}{lllll}\text { Yuma } 861 & 1073 & 1357 & 1561 & 1738\end{array}$

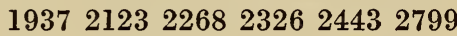
280631833456

Yucaré 2740

Yurok 250226462953

Zapotec 97826152733

Zoque 2973594

$\begin{array}{llllll}\text { Zuñi } 9 & 123 & 436 & 1121 & 1131 & 1221\end{array}$ 123912821634166518573147 326035343563

Indian Wars see Warfare

Indian-White Relations see Race

Indiana $83 \quad 412 \quad 813 \quad 875 \quad 894 \quad 1116$ $\begin{array}{llllll}1444 & 1815 & 1816 & 2129 & 2635 & 3411\end{array}$

Indiana Company 1924

Indianismo; the Indian in LatinAmerican literature 466544962 $\begin{array}{lllllll}1569 & 1618 & 1676 & 2094 & 2124 & 2265\end{array}$ $\begin{array}{lllllll}2321 & 2561 & 2776 & 2869 & 2881 & 2892\end{array}$ $\begin{array}{llllll}3031 & 3384 & 3385 & 3630 & \text { see also }\end{array}$ Literature; Religion, Nativism

Initiation $84 \quad 1682 \quad 3460$ see also Adolescence

Intelligence; mentality 14382556669 7038368391097115512291380 1515164116881862207721472184 2221258427532837309531063349 341335683655 see also Tests
International relations 9302746

Interracial relations see Race

Iowa $4491117 \quad 1297 \quad 166216841689$ $\begin{array}{lll}2366 & 2653 \quad 3557\end{array}$

Iroquois Confederacy 581593

Irrigation $2287 \quad 2302 \quad 25292775$

Ishawooa 1253

J. A. Ranch 434

Jackson, Andrew $1532 \quad 1807 \quad 2139$ $\begin{array}{llll}2161 & 2246 & 3111 & 3292\end{array}$

Jackson, Helen Hunt 22082479

Jackson, Sheldon 1231457

Jackson, William Henry 2863

Jamaica 1551

Jefferson, Thomas 18073543

Jesuit Relations 828

Jewelry see Ornament

Jochelson, Waldemar 26

Jogues, Isaac 628

Johnson, Sir William 76010841095 16051789215423112463

Jolliet-Marquette Expedition 3160

Jones, William 1031

Journalism; magazines, newspapers

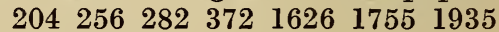
$\begin{array}{llll}2567 & 2862 & 2997 & 3239\end{array}$

Juneau 3484

Juvenile delinquency 3604

Kachina $70 \quad 82382415353117$ see also Masks; Religion; Ceremony

Kalevala 2369

Kamchadal 551

Kansas 2205300308392640701 79383510391102115011871603 $\begin{array}{lllllll}1783 & 1964 & 2044 & 2308 & 2418 & 2497\end{array}$ $\begin{array}{llllll}2558 & 2565 & 3146 & 3508 & 3557\end{array}$

Kansas-Nebraska Act 2276

Kearny, Genl. Stephen Watts 1298 1576

Keetowah Society 3346

Keewatin 3570

Kendrick, Sen. John B. 1049

Kentucky $291335 \quad 12952052$

Kern, Edward M. 1438

Kiamichi 2403

King, Clarence R. 8193133

Kino, Eusebio Francisco 108451 2176 
Kirkland, Samuel 1909

Kiva 220922903059

Kluge, Theodore 2894

Knights of the Golden Circle 2324

La Araucana 2650

La Bahía del Espíritu Santo 644 3426

Labor; employment problems 87307 566128113001552179418742004 $\begin{array}{llllll}2050 & 2099 & 2893 & 2935 & 3037 & 3278\end{array}$ $\begin{array}{llllll}3380 & 3445 & 3455 & 3555 & 3677 & \text { see }\end{array}$ also Slavery

Labor unions 1281

Labrador 2873

Lacrosse 18062920

La Florida del Inca 296

La historia de la Nueva México 2325 3678

La Junta de los Ríos 7281728

Lake Cahuilla 3070

Lake Titicaca 1726

LAND; Land policy, problems 115

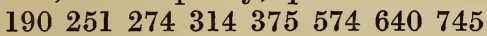
$\begin{array}{llllll}883 & 1045 & 1084 & 1272 & 1277 & 1282\end{array}$ $\begin{array}{llllll}1322 & 1474 & 1482 & 1593 & 1838 & 1867\end{array}$ $\begin{array}{lllllll}1967 & 2364 & 2396 & 2436 & 2532 & 2718\end{array}$ $\begin{array}{llllll}3010 & 3056 & 3194 & 3234 & 3308 & 3315\end{array}$ 33263549 see also Dawes Act; Reservations

Land cessions $35 \quad 745 \quad 1100 \quad 1272$ 160019802335242524782532 $2749275127542794 \quad 30723194$ 35223666

Land claims 2130

Land grants 354128219593637 3682

Land titles $2 \quad 392 \quad 745 \quad 746 \quad 900$ $16201902 \quad 32223666$

Land use; tenure 251429459527 $\begin{array}{llllll}655 & 991 & 1071 & 1726 & 1848 & 1917\end{array}$ 198020282081286729483296 3297

Land Ordinance 7452532

Lane, Gov. Joseph 1943

La Salle, Robert Cavalier de 3155

Las Casas, Bartolomé de 14582916

Last of the Mohicans 338

Lasuén, Fermín Francisco de 657 2774
Law; legislation $3749 \quad 139596 \quad 608$ $\begin{array}{llll}878900971 & 1046 \quad 10551286 & 1500\end{array}$ $\begin{array}{llllll}1543 & 1619 & 1639 & 1689 & 1967 & 2364\end{array}$ $\begin{array}{lllllll}2435 & 2455 & 2670 & 2759 & 2814 & 2952\end{array}$ $\begin{array}{llllll}2953 & 3010 & 3053 & 3071 & 3327 & 3406\end{array}$ 34793627

Lawrence, D. H. 1659

League of the Iroquois 2455 see also Iroquois Confederacy

Leatherstocking Tales 2765711391 2535

Lee, Jason 38029223409

Le Jeune, V.M.R. 1317

Lewis, Genl. Andrew 880

Lewis, Dixon Hall 663

Lewis and Clark Expedition 129 684

Life histories $5 \quad 381 \quad 686 \quad 3036 \quad 3141$ 3419

Lima 1140

LINGUISTICS; language $26 \quad 76 \quad 151$ $\begin{array}{llllllll}202 & 236 & 296 & 370 & 442 & 523 & 539 & 684\end{array}$ 689804805812854901902909 946101310901146115811831220 $\begin{array}{llllll}1221 & 1222 & 1327 & 1346 & 1357 & 1395\end{array}$ $\begin{array}{llllll}1460 & 1497 & 1510 & 1525 & 1584 & 1590\end{array}$ $\begin{array}{lllllll}1598 & 1599 & 1627 & 1700 & 1701 & 1743\end{array}$ $\begin{array}{llllll}1832 & 1929 & 1949 & 1965 & 1971 & 1988\end{array}$ $\begin{array}{lllllll}2018 & 2114 & 2140 & 2163 & 2231 & 2234\end{array}$ $\begin{array}{llllll}2283 & 2296 & 2351 & 2380 & 2441 & 2552\end{array}$ $\begin{array}{lllllll}2596 & 2612 & 2615 & 2618 & 2628 & 2629\end{array}$ $\begin{array}{lllllll}2729 & 2744 & 2779 & 2787 & 2810 & 2888\end{array}$ $\begin{array}{llllll}2894 & 2906 & 2908 & 2910 & 2942 & 2960\end{array}$ $\begin{array}{lllllll}3130 & 3173 & 3199 & 3225 & 3229 & 3233\end{array}$ $\begin{array}{lllllll}3330 & 3334 & 3337 & 3341 & 3343 & 3350\end{array}$ $\begin{array}{lllllll}3388 & 3438 & 3543 & 3573 & 3590 & 3591\end{array}$ 359436273662 see also Place Names; Speech; Vocabulary

Indian influences on non-Indian $\begin{array}{lllll}\text { languages } & 379 & 482 & 1321 & 1525\end{array}$ 165317482096254326472840 291529683173333433413438 Teaching English to Indians 2906 2942

Liquor 398447833110225013180 see also Alcohol

LiteratuRE (general studies) 127 $\begin{array}{llllllll}28 & 68 & 105 & 129 & 183 & 212 & 260 & 278\end{array}$ $\begin{array}{llllllll}329 & 404 & 522 & 579 & 588 & 613 & 635 & 675\end{array}$ $\begin{array}{llllllll}692 & 698 & 778 & 831 & 832 & 837 & 862 & 876\end{array}$ 
Literature, contd.

$\begin{array}{llllllll}953 & 959 & 987 & 989 & 992 & 1089 & 1119\end{array}$

$\begin{array}{llllll}1171 & 1193 & 1195 & 1252 & 1299 & 1338\end{array}$

$\begin{array}{lllllll}1369 & 1401 & 1409 & 1431 & 1441 & 1455\end{array}$

$\begin{array}{llllll}1496 & 1530 & 1626 & 1646 & 1691 & 1694\end{array}$

$\begin{array}{lllllll}1713 & 1755 & 1766 & 1824 & 1893 & 1894\end{array}$

$\begin{array}{llllll}1907 & 1960 & 2042 & 2097 & 2101 & 2110\end{array}$

$\begin{array}{llllll}2186 & 2208 & 2231 & 2289 & 2326 & 2327\end{array}$

$\begin{array}{lllllll}2347 & 2354 & 2426 & 2467 & 2479 & 2482\end{array}$

$\begin{array}{lllllll}2489 & 2509 & 2580 & 2582 & 2728 & 2834\end{array}$

$\begin{array}{lllllll}2875 & 2897 & 2915 & 3036 & 3098 & 3115\end{array}$

$\begin{array}{lllllll}3185 & 3247 & 3264 & 3300 & 3371 & 3444\end{array}$ $\begin{array}{llllll}3453 & 3475 & 3524 & 3556 & 3607 & 3621\end{array}$ see also Indian Captivities

Fiction 7896141161192267272 276303329549549561571612 629674714853117112941295 $\begin{array}{llllll}1318 & 1388 & 1391 & 1441 & 1519 & 1569\end{array}$ $\begin{array}{llllllll}1676 & 1695 & 1744 & 1873 & 1880 & 2042\end{array}$ 210121242131226522892327 235324162489253525612582 267426842812281929973082 309431153159318532083215 232533253371344434723621 3630

Literature, French 7109553108

Literature, German 57910761932 2186

Literature, Indian 11567358671035 $\begin{array}{llllll}1104 & 1186 & 1857 & 1957 & 2158 & 2317\end{array}$ $\begin{array}{llllll}2325 & 2639 & 2651 & 2728 & 3036 & 3050\end{array}$ 3079317931853541

Literature, Spanish 296466482544 $\begin{array}{lllllll}549 & 612 & 725 & 853 & 962 & 1021 & 1294\end{array}$ $\begin{array}{llllll}1525 & 1569 & 1590 & 1676 & 1727 & 1880\end{array}$ $\begin{array}{llllll}1913 & 1914 & 1981 & 1998 & 2014 & 2124\end{array}$ $\begin{array}{llllll}2131 & 2265 & 2321 & 2362 & 2510 & 2561\end{array}$ $\begin{array}{lllllll}2639 & 2647 & 2680 & 2681 & 2745 & 2776\end{array}$ $\begin{array}{lllllll}2819 & 2820 & 2840 & 2916 & 3031 & 3094\end{array}$ $\begin{array}{llllll}3159 & 3266 & 3275 & 3331 & 3436 & 3438\end{array}$ 3630

Livermore, Robert 783

Loehe, Wilhelm 1279

Logan, James 1675

Longfellow, Henry Wadsworth 588 62118241895236925992943

Long Island 103214641830

López y Fuentes, Gregorio 1294 $1676 \quad 2745 \quad 3630$

Loughridge, Robert McGill 1207
Louisiana $242533534668 \quad 779796$ $\begin{array}{llllll}846 & 1109 & 1242 & 1342 & 1350 & 1681\end{array}$ $\begin{array}{llllll}1773 & 1832 & 1983 & 2085 & 2093 & 2118\end{array}$ $\begin{array}{lllllll}2476 & 2557 & 2748 & 3341 & 3391 & 3628\end{array}$

Louisiana Purchase 220226772765 3470

Lummis, Charles Fletcher 2561755 24823670

Luz de tierra incógnita 687

McCoy, Isaac 20193622

McCulloch, Ben 1311

McDonald, John R. 162

Mackenzie, Alexander 162

Mackenzie Valley 913

MacKenzie, Col. R. S. 3265

McLeod, Genl. Hugh 273

Magdalena Milpas Altas 61

Magic 3329 see also Witchcraft

Maine 4157271897233027182954

Maize $445140632073383 \quad 3668$

Mange, Juan Mateo 687

Manioc 2843

Maranhão 1763

Margarita Is. 2055

Margil de Jesús, Antonio 1718

Marginal societies 15092485

Mariátegui, José Carlos 544

Marriage 11471151154316852017 $\begin{array}{llll}2950 & 3043 & 3569\end{array}$

Maryland $82 \quad 886 \quad 1748 \quad 2363$

Masks; masked rites 153802824 145415353454 see also Ceremony; Kachina; Religion

Massachusetts 14332718

Matanuska Valley 1392

Mathematics; numerical systems $\begin{array}{llllll}1320 & 1599 & 2848 & 2894 & 2914 & 3175\end{array}$ 3655

Matto de Turner, Clorinda 2094

Maumee Valley 189

Mechanical ability 1550

MEDICINE; Indian medication 381 70674310091028139417872000 $\begin{array}{llllll}2078 & 2125 & 2148 & 2155 & 2686 & 3066\end{array}$ $\begin{array}{llllll}3179 & 3189 & 3213 & 3507 & 3535 & \text { see }\end{array}$ also Shaman; Disease; Health Medical care by Whites 10221091 1135178125363473

Medicine bundle 461 
Meeker, N. C. 2453

Memegwecio 1042

Memorial de 16302510

Memorial de Sololá 2549

Memory 2965

Mendieta, Gerónimo de 2609

Mendoza, Antonio de $33 \quad 341785$

Mesoamerica $119 \quad 360 \quad 510 \quad 690 \quad 757$

$\begin{array}{llllll}1088 & 1113 & 1244 & 1397 & 1533 & 1584\end{array}$

$\begin{array}{lllllll}1602 & 1657 & 1740 & 1820 & 1917 & 1987\end{array}$

$\begin{array}{lllllll}2063 & 2219 & 2303 & 2419 & 2469 & 2539\end{array}$

$\begin{array}{lllllll}2549 & 2573 & 2638 & 2775 & 2851 & 2886\end{array}$ $2948 \quad 3403 \quad 3657$

Messiah 1575

Metate 2761

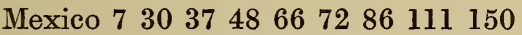

$\begin{array}{llllllll}181 & 192 & 195 & 216 & 251 & 284 & 307 & 311\end{array}$ $\begin{array}{llllllll}363 & 440 & 479 & 482 & 511 & 548 & 549 & 599\end{array}$ $\begin{array}{llllllll}612 & 634 & 682 & 713 & 716 & 721 & 725 & 731\end{array}$ $\begin{array}{llllllll}737 & 761 & 769 & 770 & 775 & 780 & 802 & 844\end{array}$ $\begin{array}{lllllll}897 & 960 & 966 & 972 & 976 & 978 & 1012\end{array}$ $\begin{array}{llllll}1014 & 1015 & 1021 & 1053 & 1062 & 1077\end{array}$ $\begin{array}{llllll}1080 & 1112 & 1122 & 1128 & 1178 & 1181\end{array}$ $\begin{array}{llllll}1209 & 1244 & 1259 & 1263 & 1294 & 1333\end{array}$ $\begin{array}{lllllll}1343 & 1456 & 1458 & 1467 & 1541 & 1553\end{array}$ $\begin{array}{llllll}1556 & 1616 & 1618 & 1651 & 1652 & 1676\end{array}$ $\begin{array}{lllllll}1690 & 1718 & 1738 & 1785 & 1913 & 1981\end{array}$ $\begin{array}{lllllll}2028 & 2043 & 2152 & 2173 & 2180 & 2190\end{array}$ $\begin{array}{llllll}2213 & 2219 & 2250 & 2255 & 2288 & 2318\end{array}$ $\begin{array}{lllllll}2329 & 2357 & 2473 & 2378 & 2430 & 2434\end{array}$ $\begin{array}{llllll}2439 & 2458 & 2488 & 2601 & 2623 & 2642\end{array}$ $\begin{array}{lllllll}2643 & 2657 & 2668 & 2676 & 2681 & 2698\end{array}$ $\begin{array}{llllll}2709 & 2733 & 2776 & 2787 & 2840 & 2845\end{array}$ $\begin{array}{llllll}2846 & 2869 & 2880 & 2911 & 2956 & 3051\end{array}$ $\begin{array}{lllllll}3067 & 3266 & 3360 & 3384 & 3385 & 3386\end{array}$ $\begin{array}{lllllll}3430 & 3436 & 3447 & 3535 & 3542 & 3585\end{array}$ 362636303658 see also New Spain

Baja California 94985071613 $\begin{array}{llll}1765 & 2227 & 2260 & 3291\end{array}$

Campeche 80

Chiapas 46812542704

Chihuahua 3504915061950

Coahuila 82865

México 2739

Michoacán $91 \quad 1711 \quad 1951 \quad 2515$ 31523381

Morelos 99723732719

Nayarit 1030

Oaxacal013 1254130714562833

Puebla 1358
Mexico, contd.

Querétaro 2048

Sinaloa $890 \quad 929 \quad 1670 \quad 2141$

Sonora $147506 \quad 1670 \quad 1765 \quad 2141$ 218123392860296036193654

Tabasco 1321

Tamaulipas 52721342468

Teotihuacán 1812336

Tlaxcala 1181

Vera Cruz 10823464

Zacatecas 1145

Mexico City 1922762

Mézières, Athanase de 1842

Michigan $\begin{array}{lllll}109 & 412 & 505 & 1195 & 1279\end{array}$ $\begin{array}{llllll}1280 & 1664 & 2088 & 2464 & 2555 & 2582\end{array}$ $\begin{array}{llll}2879 & 3232 & 3642 & 3675\end{array}$

$\begin{array}{llllll}\text { Migrations } 91 & 189 & 331 & 1034 & 1153\end{array}$ $\begin{array}{lllllll}2098 & 2230 & 2624 & 2697 & 3132 & 3597\end{array}$

Miles, Genl. Nelson A. 4733007

Military campaigns see Warfare

Milk Valley 1310

Milling stones 2761

Mining $\begin{array}{lllll}1087 & 1088 & 1484 & 1583 & 2004\end{array}$ 28032913

Minnesota $375611636 \quad 643 \quad 753839$ $\begin{array}{llllll}934 & 1142 & 1261 & 1414 & 1481 & 1805\end{array}$ $\begin{array}{llllll}1905 & 1969 & 2316 & 2946 & 3023 & 3322\end{array}$ 35963645

Miró, Esteván 796

Missions; missionaries see Religion

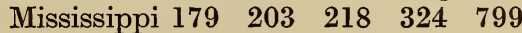
$\begin{array}{llllll}1052 & 1194 & 1361 & 1377 & 1434 & 1440\end{array}$ $\begin{array}{lllll}2659 & 2968 & 3185 & 3637\end{array}$

Missouri 232545915100411001138 $\begin{array}{llllll}1565 & 2452 & 2492 & 2677 & 2713 & 3022\end{array}$ $\begin{array}{llll}3284 & 3324 & 3552 & 3557\end{array}$

Mixed bloods; mestizos, métis 91375 $\begin{array}{lllllll}1141 & 2055 & 2120 & 2197 & 2526 & 2566\end{array}$ $\begin{array}{lllllll}2619 & 2693 & 2743 & 2753 & 2768 & 2769\end{array}$ 291829563235340435013655 3660 see also Race

Mohawk Valley 17292277

Moieties 14152500

Monhegan Is. 727

Montaigne, Michel E. de 710

Montana $169 \quad 417 \quad 427 \quad 473 \quad 557 \quad 590$ $\begin{array}{llllll}1002 & 1063 & 1064 & 1116 & 1163 & 1253\end{array}$ $\begin{array}{lllllll}1608 & 1734 & 2073 & 2077 & 2164 & 2217\end{array}$ $\begin{array}{llllll}2374 & 2675 & 2818 & 3120 & 3392 & 3509\end{array}$ 35103514 
Montejo, Francisco de 540

Moral education $1899 \quad 2444 \quad 3256$ 3587

Morfí, Juan Augustín 530

Morrow, Joseph Samuel 493

Morton, Sarah Wentworth 1709

Mortuary; burial customs 79492 60375711651340163419792038 29093390 see also Death

Mounds 503751988193019472857 $3246 \quad 3474 \quad 3533$

Muquiyauyo 20

Murals $7227982425993195 \quad 3618$ see also Painting

Museums; museum collections 155 $2770 \quad 2828 \quad 2846$

Music $3948 \quad 57127 \quad 156270555588$ $\begin{array}{llllll}1103 & 1170 & 1254 & 1309 & 1368 & 1430\end{array}$ $\begin{array}{lllllll}1469 & 1470 & 1606 & 1707 & 1716 & 1770\end{array}$ $\begin{array}{lllllll}1938 & 1985 & 2022 & 2221 & 2271 & 2328\end{array}$ $\begin{array}{lllllll}2423 & 2424 & 2733 & 3019 & 3098 & 3102\end{array}$ $\begin{array}{llllll}3123 & 3378 & 3477 & 3494 & 3548 & 3571\end{array}$ 36543672

Myths; mythology see Folklore

Nacogdoches 53

Names; namegiving 105919842829

Napa Valley 1776

Narcotics 1166 see also Peyote

Natchitoches 2118

Nebraska 13121341138215951945 $\begin{array}{llll}2053 & 3172 & 3461 & 3506\end{array}$

Negro $14272010831368 \quad 14591685$ $227123462604 \quad 26192895 \quad 3043$ 340435013561 see also Slavery; Race

Neighbors, Maj. Robert S. 24102411

Neihardt, John G. 83219073607

Neolithic 2279

Nets; netting 3042

Nett Lake Village 643

Nevada $1362 \quad 1400 \quad 1840 \quad 1935 \quad 2307$ 34163498

Neve, Felipe de 32213

New Confederation of the Iroquois 305

New England $69 \quad 445 \quad 772 \quad 837 \quad 842$ $\begin{array}{llllll}1433 & 1638 & 1792 & 1808 & 1974 & 2076\end{array}$ $\begin{array}{llllll}2232 & 2270 & 2433 & 2694 & 2780 & 2995\end{array}$ $\begin{array}{lll}3021 & 3363 & 3437\end{array}$
New France $366 \quad 476 \quad 683 \quad 908 \quad 1182$ $\begin{array}{lllll}1227 & 1466 & 2381 & 2392 & 2501\end{array}$

New Hampshire 2625

New Jersey 1536

New Mexico 63221246248284327

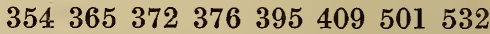
$\begin{array}{lllllllll}554 & 557 & 623 & 630 & 650 & 696 & 723 & 729\end{array}$ 7308178788969059129671007 $\begin{array}{llllll}1017 & 1148 & 1275 & 1326 & 1330 & 1331\end{array}$ $\begin{array}{llllll}1349 & 1366 & 1432 & 1446 & 1453 & 1475\end{array}$ $\begin{array}{lllllll}1477 & 1485 & 1525 & 1534 & 1546 & 1577\end{array}$ $\begin{array}{lllllll}1587 & 1644 & 1669 & 1708 & 1719 & 1720\end{array}$ $\begin{array}{lllllll}1809 & 1825 & 1826 & 1831 & 1848 & 1854\end{array}$ $\begin{array}{lllllll}2003 & 2005 & 2006 & 2060 & 2097 & 2195\end{array}$ $\begin{array}{llllll}2251 & 2293 & 2323 & 2325 & 2420 & 2505\end{array}$ $\begin{array}{lllllll}2541 & 2560 & 2581 & 2591 & 2679 & 2691\end{array}$ $\begin{array}{lllllll}2699 & 2725 & 2737 & 2838 & 2856 & 2899\end{array}$ $\begin{array}{llllll}2940 & 2990 & 3074 & 3198 & 3244 & 3260\end{array}$ $\begin{array}{lllllll}3271 & 3313 & 3326 & 3355 & 3388 & 3602\end{array}$ $\begin{array}{llllll}3608 & 3665 & 3673 & 3675 & 3676 & 3677\end{array}$ 36783683

New Netherland 1717

New Northwest (Washington, Oregon, Idaho, Montana, etc.) 563726736 83395410181296134514761640 $\begin{array}{llllll}1819 & 1920 & 1976 & 2029 & 2037 & 2062\end{array}$ $\begin{array}{llllll}2064 & 2150 & 2207 & 2365 & 2487 & 2493\end{array}$ $\begin{array}{llllll}2572 & 2693 & 2715 & 2726 & 3400 & 3468\end{array}$ 36113616 see also Old Northwest; North West Coast; Pacific

New Spain $33 \quad 34 \quad 174 \quad 398 \quad 546 \quad 617$ $\begin{array}{lllllll}818 & 840 & 911 & 985 & 1028 & 1087 & 1242\end{array}$ $\begin{array}{llllll}1396 & 1413 & 1539 & 1630 & 1933 & 2197\end{array}$ $\begin{array}{lllllll}2530 & 2655 & 2667 & 2706 & 2830 & 2941\end{array}$ $\begin{array}{llllll}3006 & 3037 & 3151 & 3195 & 3304 & 3345\end{array}$ 3512 see also Mexico; Spanish

New York $249250346 \quad 447460714$ 89992710321095131914641729 $\begin{array}{llllll}1741 & 1777 & 1830 & 1856 & 1890 & 2047\end{array}$ $\begin{array}{lllllll}2099 & 2248 & 2277 & 2885 & 2917 & 3038\end{array}$ $\begin{array}{lllllll}3064 & 3081 & 3097 & 3104 & 3150 & 3481\end{array}$

Niagara 386

Nicaragua 1987

Nicholson, Gov. Francis 981

Nikolski 2391869

"Noble Savage" $183 \quad 579 \quad 675 \quad 989$ $1691 \quad 1893 \quad 1894 \quad 2580$

Nondalton 3492

North Carolina 302547149515812201 2297234624702526256932963547 
North Dakota 27134988711431271 1376150216881892239534103527

Northeast 5046352926

North West Coast (Canada-U.S. Pacific Coast area) 56788866941 $\begin{array}{lllllll}1139 & 1170 & 1359 & 1850 & 1851 & 1952\end{array}$ $\begin{array}{lllllll}1968 & 2041 & 2499 & 2503 & 2504 & 2703\end{array}$ $\begin{array}{lllllll}2909 & 3210 & 3226 & 3249 & 3525 & 3526\end{array}$ 35663604

North West Company 7387402111 25032504

Northwest Territory $107 \quad 154 \quad 255$ 2800 see also Old Northwest

Notes on the North American Indian $7789592467 \quad 3247 \quad 3475$

Noticias de la Nueva California 2612 33393340

Nueva Granada 3425

Nueva Viscaya 7332252

Numerical systems; counting see Mathematics

Oceania 939175222952377 see also Pacific; Trans-Pacific contacts

$\begin{array}{llllll}\text { Ohio } 16 & 344 & 388 & 1574 & 1593 & 1629\end{array}$ $\begin{array}{llllll}1788 & 1793 & 1847 & 1902 & 2243 & 2407\end{array}$ $2590 \quad 3269$

Oil 1061

Oklahoma $118126215220247 \quad 301$ $\begin{array}{llllllll}319 & 332 & 367 & 420 & 471 & 472 & 475 & 493\end{array}$ $\begin{array}{llllllll}519 & 543 & 558 & 573 & 582 & 604 & 679 & 703\end{array}$ $\begin{array}{lllllllll}718 & 720 & 746 & 785 & 849 & 885 & 963 & 998\end{array}$ $\begin{array}{llllll}1051 & 1054 & 1061 & 1155 & 1211 & 1245\end{array}$ $\begin{array}{llllll}1305 & 1353 & 1385 & 1498 & 1579 & 1594\end{array}$ $\begin{array}{lllllll}1645 & 1656 & 1667 & 1724 & 1786 & 1874\end{array}$ $\begin{array}{llllll}1948 & 2032 & 2205 & 2238 & 2333 & 2335\end{array}$ $\begin{array}{llllll}2356 & 2403 & 2436 & 2512 & 2527 & 2606\end{array}$ $\begin{array}{llllll}2702 & 2752 & 2758 & 2794 & 2801 & 2872\end{array}$ $\begin{array}{lllllll}2951 & 2969 & 3098 & 3112 & 3178 & 3181\end{array}$ $\begin{array}{llllll}3272 & 3286 & 3353 & 3378 & 3413 & 3453\end{array}$ $\begin{array}{llllll}3529 & 3549 & 3562 & 3586 & \text { see also }\end{array}$ Indian Territory

Old Northwest(Michigan, Wisconsin, Illinois, Indiana, etc.) 31438512 67769510551058113212231224 $\begin{array}{lllllll}1582 & 1604 & 1629 & 1916 & 2273 & 2465\end{array}$ $\begin{array}{lllllll}2478 & 2532 & 2592 & 2800 & 2853 & 2879\end{array}$ $\begin{array}{llllll}2900 & 2992 & 3017 & 3072 & 3132 & 3174\end{array}$ $\begin{array}{lllll}3301 & 3515 & 3589 & 3642 & \text { see also }\end{array}$ Northwest Territory
Old Southwest (Alabama, Arkansas, Mississippi, etc.) 93013612528 26102616264535023647 see also Southeast

Old Spanish Trail 1872

Olid, Cristóbal de 3360

Ollantay 2158

Oñate, Juan de 13662505

Oratory $51 \quad 156 \quad 403 \quad 443 \quad 635 \quad 1270$ 13721942 see also Literature; Speech

Ord, Capt. E.O.C. 6802508

Oregon 140240321362380389594 $\begin{array}{lllllllll}595 & 596 & 601 & 610 & 688 & 694 & 738 & 809\end{array}$ $\begin{array}{lllllll}845 & 909 & 1090 & 1110 & 1308 & 1628\end{array}$ $\begin{array}{lllllll}1706 & 1722 & 1889 & 1943 & 2020 & 2359\end{array}$ $\begin{array}{llllll}2422 & 2480 & 2517 & 2519 & 2562 & 2578\end{array}$ $\begin{array}{llllll}2600 & 2741 & 2908 & 2929 & 3113 & 3237\end{array}$ $\begin{array}{llll}3299 & 3531 & 3606 & 3615\end{array}$

Oregon Trail 389875218529303644

Origins, Indian $410 \quad 736 \quad 924 \quad 925$ $\begin{array}{llllll}1034 & 1214 & 1546 & 2065 & 2089 & 2190\end{array}$ $\begin{array}{llllll}2192 & 2230 & 2539 & 2996 & 3128 & 3597\end{array}$ 3667

Ornament; jewelry 2738

Ovando, Nicolás de 1841

Pacific; Pacific Coast 45595890 $\begin{array}{llllll}1103 & 1139 & 2503 & 2504 & 2583 & 2696\end{array}$ $277130123046 \quad 3636$ see also Oceania; Trans-Pacific contacts

Padre Is. 22632723

Painting; drawing $187 \quad 789838933$ 97898319923221326233073487

Paleolithic 77720652279

Paleontology 924

Palma, Ricardo 3275

Palmer, Joel 1403113

Palóu, Francisco $2033 \quad 26123339$ 3340

Panama 9703196

Pan-Indianism 2432 see also Indianismo; Religion, Nativism

Papaguería 3578

Paraguay 9351025133523442982 3362

Parke, Col. Daniel 1276

Parker, Cynthia Ann 17033516

Parkman, Francis 27

Parrilla Expedition 50 
Paulding, James Kirke 3444

Pea Ridge 1407

Pedology 916

Penitentes 3602

Penn, William 197

Pennsylvania $194 \quad 241 \quad 312503 \quad 572$ $\begin{array}{llllll}741 & 1247 & 1463 & 1563 & 1675 & 1970\end{array}$ $\begin{array}{lllllll}2831 & 2835 & 2962 & 3015 & 3092 & 3097\end{array}$ $\begin{array}{llllll}3122 & 3348 & 3367 & 3405 & 3574 & 3592\end{array}$

Pensacola 889

Pérez, Juan 3249

Personality $160 \quad 1020 \quad 1106 \quad 1461$ $\begin{array}{llllll}1849 & 2221 & 3014 & 3420 & 3423 & 3448\end{array}$ 3527

Peru 345428462466564565570614 $\begin{array}{llllllll}633 & 652 & 841 & 852 & 853 & 873 & 938 & 961\end{array}$ $\begin{array}{llllll}968 & 1053 & 1069 & 1071 & 1125 & 1140\end{array}$ $\begin{array}{llllll}1180 & 1202 & 1212 & 1265 & 1334 & 1568\end{array}$ $\begin{array}{llllll}1590 & 1643 & 1674 & 1802 & 1822 & 1880\end{array}$ $\begin{array}{llllll}1975 & 2094 & 2131 & 2158 & 2159 & 2172\end{array}$ $\begin{array}{llllll}2214 & 2219 & 2242 & 2362 & 2302 & 2561\end{array}$ $\begin{array}{llllll}2665 & 2734 & 2770 & 2819 & 2858 & 2892\end{array}$ $\begin{array}{lllllll}2921 & 3136 & 3148 & 3164 & 3165 & 3290\end{array}$ $\begin{array}{llllll}3329 & 3380 & 3429 & 3438 & 3471 & 3539\end{array}$ 36573667

Peyote; Peyote Cult 183320222603 304531663186

Philosophy $19726012521371 \quad 1883$ $\begin{array}{lllllll}2126 & 2434 & 2580 & 2773 & 3079 & 3355\end{array}$ 3434

Photography 2863

Physical Anthropology 111180225 33540159773777499710741124 $\begin{array}{llllll}1131 & 1172 & 1199 & 1387 & 1425 & 1511\end{array}$ $\begin{array}{llllll}1540 & 1731 & 1783 & 1792 & 1862 & 1869\end{array}$ $\begin{array}{llllll}1936 & 2002 & 2052 & 2105 & 2218 & 2233\end{array}$ $\begin{array}{llllll}2377 & 2406 & 2438 & 2440 & 2450 & 2451\end{array}$ $\begin{array}{llllll}2627 & 2648 & 2649 & 2755 & 2764 & 2873\end{array}$ $\begin{array}{lllllll}2923 & 2981 & 3048 & 3216 & 3259 & 3282\end{array}$ $\begin{array}{lllllll}3311 & 3473 & 3474 & 3505 & 3588 & 3597\end{array}$ 36673680

Pick-Sloan Plan 3396

Pictographs; petroglyphs 4541005 1477

Pierz, Francis Xavier 3232

Pike's Peak 25563125

Pimería Alta 108340687984

Pine 3101

Pipe 221726423415

Pipestone Natl. Monument 753
Place Names $179 \quad 242 \quad 332 \quad 411 \quad 557$ $\begin{array}{llllll}846 & 1222 & 1384 & 1603 & 1748 & 1812\end{array}$ $\begin{array}{llllll}1945 & 1983 & 2121 & 2235 & 2621 & 2625\end{array}$ $\begin{array}{llll}2748 & 2968 & 3341 & 3562\end{array}$

Plateau $2192 \quad 290930603062$

Platte Purchase 24253522

Pleistocene 22303049

Poetry $57 \quad 156 \quad 158 \quad 588 \quad 621 \quad 732 \quad 758$ $\begin{array}{lllllll}759 & 832 & 850 & 1266 & 1548 & 1709 & 1824\end{array}$ $\begin{array}{llllll}1895 & 1997 & 2183 & 2215 & 2247 & 2258\end{array}$ $\begin{array}{llllll}2328 & 2369 & 2582 & 2599 & 2650 & 2662\end{array}$ $\begin{array}{lllllll}2881 & 2911 & 2931 & 2943 & 3250 & 3427\end{array}$ 34353585

Point Barrow 14252377

Política Indiana 2362

Politics $4361 \quad 199265484497544$

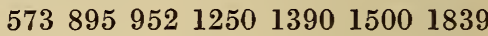
$\begin{array}{lllllll}1972 & 2059 & 2109 & 2119 & 2164 & 2276\end{array}$ $\begin{array}{lllllll}2361 & 2364 & 2437 & 2520 & 2831 & 2842\end{array}$ $\begin{array}{llllll}2980 & 3017 & 3023 & 3204 & 3432 & 3433\end{array}$ 34793520

Ponca Indian Commission 2106

Population; $30 \quad 66 \quad 98 \quad 215 \quad 275 \quad 817$ 88499711461556174618192531 $\begin{array}{lllll}2620 & 2771 & 2833 & 3038 & \text { see also }\end{array}$ Census

Popul Vuh 2549

Portugal; Portuguese $1141 \quad 1763$ 21872619

Potlatch 159600

Pottery; ceramics 4170232237238 $\begin{array}{llllllll}363 & 419 & 446 & 462 & 478 & 481 & 580 & 614\end{array}$ $\begin{array}{lllllll}627 & 761 & 768 & 978 & 1077 & 1290 & 1306\end{array}$ $\begin{array}{llllll}1410 & 1427 & 1453 & 1492 & 1512 & 1536\end{array}$ $\begin{array}{lllllll}1547 & 1616 & 1758 & 1926 & 1977 & 1982\end{array}$ $\begin{array}{lllllll}1987 & 2001 & 2005 & 2145 & 2160 & 2173\end{array}$ $\begin{array}{llllll}2220 & 2236 & 2259 & 2397 & 2491 & 2542\end{array}$ $\begin{array}{lllllll}2598 & 2704 & 2739 & 2770 & 2802 & 2846\end{array}$ $\begin{array}{lllllll}2883 & 2934 & 3133 & 3136 & 3165 & 3170\end{array}$ $\begin{array}{llllll}3188 & 3279 & 3307 & 3358 & 3434 & 3464\end{array}$ 34783563 see also Arts and Crafts Powder River 14242964

Powhatan Confederacy 3741286

Prada, González 544

Prayer 243

Presidio $104 \quad 617 \quad 1413 \quad 2387 \quad 2494$ 3512

Prévost, L'Abbé 955

Pribilof Is. 407

Proctor, Zeke 420 
Property $24485486 \quad 600 \quad 1344 \quad 1753$ 3020

Providence Plantation 2817

Provincias Internas del Poniente 3417

$\begin{array}{lllllll}\text { Psychology } 5 & 67 & 100 & 152 & 160 & 223\end{array}$ $\begin{array}{llllllll}225 & 381 & 382 & 399 & 531 & 553 & 686 & 801\end{array}$ $\begin{array}{llllll}990 & 1006 & 1020 & 1192 & 1236 & 1255\end{array}$ $\begin{array}{llllll}1378 & 1439 & 1461 & 1518 & 1537 & 1660\end{array}$ $\begin{array}{lllllll}1704 & 1937 & 2000 & 2043 & 2114 & 2221\end{array}$ $\begin{array}{llllll}2295 & 2304 & 2309 & 2408 & 2434 & 2439\end{array}$ $\begin{array}{llllll}2622 & 2626 & 2893 & 2912 & 2965 & 3014\end{array}$ $\begin{array}{lllllll}3061 & 3140 & 3163 & 3262 & 3355 & 3374\end{array}$ $\begin{array}{lllllll}3419 & 3420 & 3423 & 3434 & 3448 & 3453\end{array}$ 34673527 see also Intelligence; Personality; Tests

Pueblo Lands Act 1967

Puget's Sound Agriculture Co. 3328

Puritan 1638

Putumayo River 938

Pyramids 1812469

Quaternary 9253372

Quetzalcóatl 11132886

Quiroga, Vasco de 1933

RACE; race relations 22548638774 $\begin{array}{llllll}1131 & 1685 & 1731 & 2197 & 2218 & 2229\end{array}$ $\begin{array}{llllll}2384 & 2427 & 2473 & 2619 & 3106 & 3545\end{array}$ 3568 see alsoAcculturation; Adjustment problems; Mixed-bloods; Negro

Negro-Indian relations 10832346 2619289534043561

White-Indian relations 122699 113811761188125213041373 $\begin{array}{llllll}1465 & 1521 & 1538 & 1830 & 1853 \quad 2017\end{array}$ 207621032346280528092815 294629492963299230113197 324532693318340434373526

Railroads $\begin{array}{lllll}337 & 559 & 574 & 1282 & 1561\end{array}$ 3682

Râle, Sebastian 20692954

Ramírez de la Piscina, Capt. Manuel 644

Ramírez, Diego 2951

Ramón Expedition 2966

Ramona 7871695

Recopilación de las Leyes de Indias 274

Red River 2120

Reindeer 1810
Religion; religious studies see also Church and State

Catholic 205299300415490583 $\begin{array}{llllll}601 & 660 & 1143 & 1292 & 1323 & 1572\end{array}$ $\begin{array}{llllll}1646 & 1722 & 1737 & 1774 & 1897 & 2029\end{array}$ 212923762409246024652466 248025012521260726892699 $\begin{array}{llllll}2780 & 3051 & 3218 & 3272 & 3302 & 3400\end{array}$ 341134653510360236253651 Dominican 22603675

Franciscan 173311327340905 116920482060251126093001 329035423674

Jesuit $147348476 \quad 779828835$ 89011821411153916131630 189119632015214121892216 234425402654268728852896 301230863150330435143616 Christian influences 80612132152 Conversions 13781646

Protestantism 152426113369

Baptist $741 \quad 2224 \quad 2320 \quad 2495$ 31983463

Church of England 879

Episcopal 2177

Friends; Quakers 659886994 2269295230973162

Lutheran 11171279

Methodist $133 \quad 2480 \quad 2645 \quad 2922$

Methodist Episcopal 2486

Mennonite $\mathbf{1 7 1 5}$

Moravian 1609179326022763 3347

Mormon $977 \quad 12702492 \quad 2767$

Pentecost 553

Presbyterian $388 \quad 409705 \quad 784$ $\begin{array}{lllll}1000 & 1196 & 1360 & 1479 & 2044\end{array}$ 2480

Seventh-Day Adventist 564

Indian Religions; religious activities $\begin{array}{lllllll}17 & 61 & 67 & 70 & 86 & 97 & 120\end{array}$ $\begin{array}{lllllll}224 & 243 & 315 & 461 & 511 & 515 & 538\end{array}$ $\begin{array}{llllllll}553 & 577 & 618 & 743 & 803 & 823 & 824\end{array}$ $\begin{array}{llllll}939 & 941 & 1029 & 1063 & 1141 & 1202\end{array}$ $\begin{array}{llllll}1231 & 1238 & 1239 & 1263 & 1313 & 1337\end{array}$ $\begin{array}{llllll}1356 & 1359 & 1452 & 1535 & 1684 & 1774\end{array}$

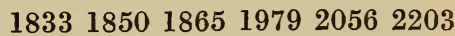
221222422253225422572285 228622882348235124042550 257325862603266527072708 
Religion, contd.

Indian Religions, contd.

274027422821287729783045

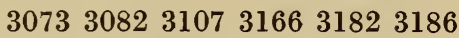

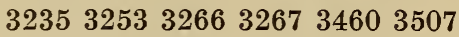
352535823587 see also Ceremony; Dance; Medicine; Religion, Nativism; Shaman

Missionaries; missionary activities among Indians $90 \quad 120 \quad 136 \quad 154$ $\begin{array}{lllllll}321 & 373 & 380 & 493 & 628 & 632 & 635\end{array}$ $\begin{array}{lllllll}697 & 784 & 834 & 915 & 945 & 954 & 1078\end{array}$ $\begin{array}{llllll}1207 & 1411 & 1495 & 1554 & 1628 & 1638\end{array}$ $\begin{array}{llllll}1715 & 1718 & 1722 & 1745 & 1899 & 1909\end{array}$ 191019462015201920202024 202920332069208021412153

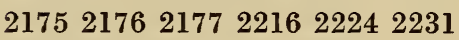
226222802360237123762378 246524872510251925222575 259726072612263426452654

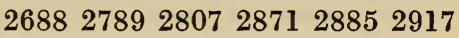
295432103214321932323241 326332903339334033913400 35103531353436163622

Missions; Indian mission activities and relations $\begin{array}{lllll}18 & 50 & 78 & 108 & 109\end{array}$ $\begin{array}{lllllll}123 & 133 & 171 & 205 & 268 & 334 & 348\end{array}$ $\begin{array}{lllllll}388 & 409 & 415 & 424 & 451 & 476 & 553\end{array}$ $\begin{array}{lllllll}578 & 583 & 601 & 657 & 659 & 705 & 741\end{array}$ $\begin{array}{lllllll}755 & 768 & 784 & 793 & 806 & 814 & 835\end{array}$ $\begin{array}{lllllll}860 & 870 & 879 & 890 & 892 & 905 & 935\end{array}$ $\begin{array}{llllll}945 & 948 & 1000 & 1039 & 1105 & 1117\end{array}$ $\begin{array}{llllll}1157 & 1167 & 1187 & 1194 & 1213 & 1263\end{array}$ $\begin{array}{llllll}1279 & 1292 & 1360 & 1403 & 1409 & 1432\end{array}$ $\begin{array}{lllllll}1479 & 1485 & 1524 & 1538 & 1560 & 1572\end{array}$ $\begin{array}{llllll}1609 & 1613 & 1630 & 1666 & 1715 & 1723\end{array}$ $\begin{array}{llllll}1734 & 1737 & 1745 & 1793 & 1825 & 1826\end{array}$

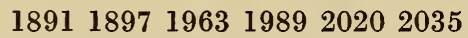
204420602177218922602269

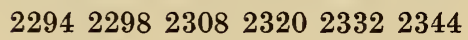
240924582460246424662480 248624942495251125232530 254025622608261126652682 268927082720272627412756 276327742799280328722922 294030013012305130863097

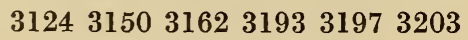
321832723277329133023303 330433693411351435313542 357335793616
Religion, contd.

Missions, contd.

Cache Creek 2032

Candelaria 2756

Dominican missions 2260

Espíritu Santo de Zúñiga 2494

Grande Ronde 2741

Guayrá 2687

Harmony 793

Holy Rosary 3277

Huron 2189

L'Arbe Croche 2523

Michilmackinac 3579

Old Cataldo 2726

Osage 10391963

St. Anne 756

St. Eugene 3289

St. Ignace 2464

St. Ignatius 17341560

St. Marys on the Lake 424

Ste. Marie 1157

San Francisco de los Tejas 578

San Lorenzo 2756

San Sabá 50

San Xavier del Bac 870

Sinaloa 3012

Tallahassee 268

Umatilla 2741

Yuma 2799

Secularization of Missions 1167 185822942332

Nativism; revival of Indian traditions 12311575213523432404 see also Peyote; Sun Dance; Ghost Dance

Relocation policy see U.S., Bureau of Indian Affairs

Removal 3167293333494522673 88592110001048109913821505 $\begin{array}{llllll}1574 & 1579 & 1593 & 1667 & 1788 & 2057\end{array}$ $\begin{array}{lllllll}2071 & 2161 & 2165 & 2169 & 2757 & 3029\end{array}$ $\begin{array}{lllll}3099 & 3243 & 3254 & 3272 & 3589\end{array}$

Reno, Maj. Marcus A. 917

Reptiles 2213

Reservations; Indian Agencies 2 $\begin{array}{lllllll}418 & 437 & 753 & 883 & 922 & 931 & 1026\end{array}$ $\begin{array}{llllll}1210 & 1271 & 1272 & 1305 & 1732 & 1904\end{array}$ $\begin{array}{llllll}1928 & 2162 & 2225 & 2389 & 2454 & 2805\end{array}$ 34993520

Caradoc (Canada) 2584 
Reservations, contd.

C'ass Lake 3322

Cheyenne-Arapaho 13052901

Cheyenne River 71754

Colville 3488

Crow 2867

Crow Creek 1623

Cusick 2162

Devil's Lake 3527

Ft. Belknap 2818

Ft. Berthold $214 \quad 887 \quad 10232607$ 27323559

Ft. Hall 2945

Ft. Peck 1677

Ft. Sill 2678

Ft. Totten 7911019

Grand Portage 2316

Kiowa 3256

Kiowa-Comanche 3162

Klamath $560 \quad 1679 \quad 2188 \quad 2404$

Lac Court Oreille 3228

Lake Traverse 17992396

Menomini 3145

Mescalero Apache 3248

Muckleshoot 11702965

Muncey (Canada) 16612408

Navajo 437

Nez Percé 3520

Onondaga 2772

Papago 29193578

Pawnee 3494

Pipestone 753

Ponca 5752969

Potawatomi 1732

Pyramid Lake 1567

Qualla 302

Quapaw 414

Red Lake 636934

Rock Island 2225

Sac-Fox 319

San Carlos 1478

Shawnee 3055

Shoshone 3397

Standing Rock 23012415

Tongue River $\mathbf{1 5 3 1}$

Turtle Mountain 7812395

Upper Platte 2805

Warm Springs $587 \quad 1110$

White Earth 1481

Rh factor 1172 see also Blood groups Santarén, Hernando de 2141

Sacramento Valley $\mathbf{1 7 9 5}$
Rhode Island 3732817

Rice 1655

"Río Abajo" 354

Ripperdá, Baron de 8181507

Rites and rituals see Ceremony

Rivera y Moncada, Pedro 132617 2387

Roach headdress 1817

Rogue River 1203

Rojas, Ricardo 2881

Ronan, Mary Catherine 2834

Rorschach test see Tests

Ross, Alexander 162

Rubber trade 2386

Rubí, Marquis de 14133512

Russia 17103402

Russian River 1011

Saavedra Guzmán, Antonio de 1998

Sacrifice; human sacrifice $100 \quad 1459$

$17791962 \quad 2348$

Sáenz, Moisés 2869

Sahagún, Berdno. de 289730263151

St. Clair, Arthur 194

St. Denis, Louis de 3005

St. Lawrence Is. 1571

St. Lawrence River 2391

St. Vrain, Céran 1922

Salt 1583

Salvatierra, Juan María de 2634

Salvation 1029

San Andrés de Quito 2907

San Antonio Sacatépequez 982

San Blas Is. 3196

San Francisco Tecospa 2152

San Gabriel Valley 470

San Joaquín Valley 191119123091

San Juan Atzingo 440

San Luís Jilotépeque 3332

Sandpainting 979

Santa Catalina Is. 1283

Santa Clara Valley 304

Santa Cruz Is. 2105

Santa Cruz de la Sierra 3362

Santa Fé 18722323

Santa Fé Trail $102 \quad 379 \quad 862 \quad 2109$ 27013638

Santarém 903 
Santiago Chimaltenango 3401

Santos 1189

Sargent, Winthrop 2592

Schurz, Carl 3110

Science 3617123449

Scott, Sir Walter 2509

Scouts see Frontiersmen; Warfare,

Indian Scouts

Sculpture; carving 5456119232483

$\begin{array}{llllll}1139 & 1454 & 1735 & 2061 & 2173 & 2244\end{array}$

239929213107311734343566

Seagrove, James 3068

Sea-otters 2481

Secularization see Religion, Missions

Seghers, Charles John 2741

Selkirk Colony 1969

Senate; Senators see U.S. Congress Sequoyah Constitution 10512238

Serpent 1244195622132580

Settlement; White settlers on the frontier 5229439752411421772 $\begin{array}{lllllll}1860 & 2363 & 2475 & 2711 & 2767 & 2993\end{array}$ $\begin{array}{lllll}3146 & 3237 & 3547 & 3615\end{array}$

Sex $84 \quad 124 \quad 351 \quad 801 \quad 996 \quad 1490 \quad 1781$ 2965

Shaman; shamanism 265381795 $\begin{array}{llllll}1394 & 1898 & 2148 & 2152 & 2546 & 3045\end{array}$ 3182 see also Medicine; Religion, Indian

Shell 542075

Shungopovi 626

Siberia 128551197922792622

Sibley, Gov. Henry H. 30233201

Sierra Popoluca 946

Sigüenza y Góngora, Carlos 1913

Silk raising 307

Silver 38976999

Simcoe, Genl. John 695

Simms, William Gilmore 161338 23533215

Sisters of Loretto 2524

Sisters of St. Francis 1116

Sitka 1829

Skins; hides; skin dressing 789983 1769

Slavery; Indians as slaves 60648

$\begin{array}{llllll}1134 & 1301 & 1458 & 1868 & 2099 & 2187\end{array}$

$\begin{array}{lllll}2947 & 3018 & 3037 & 3324\end{array}$

Indians as slave-holders $720 \quad 788$

$1134 \quad 1476 \quad 1647 \quad 3060$
Smet, Pierre-Jean de $834 \quad 843 \quad 915$ 215321752280

Smith, Jedediah 3532

Smith, Capt. John 2571

Snake River Valley 1061623421

Social control see Authority

Social customs $73 \quad 356 \quad 489511591$

$\begin{array}{llllll}972 & 1481 & 1540 & 2095 & 2253 & 2254\end{array}$

$\begin{array}{lllllll}2493 & 2526 & 2903 & 2904 & 3061 & 3128\end{array}$ $\begin{array}{llllll}3204 & 3235 & 3255 & 3305 & 3355 & 3498\end{array}$

Social organization $43 \quad 67 \quad 121 \quad 135$ $\begin{array}{llllllll}179 & 199 & 216 & 223 & 298 & 313 & 317 & 318\end{array}$ $\begin{array}{lllllllll}343 & 351 & 383 & 489 & 550 & 553 & 615 & 626\end{array}$

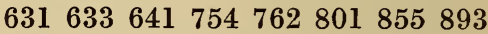
$\begin{array}{lllllll}895 & 918 & 942 & 995 & 996 & 1016 & 1110\end{array}$ $\begin{array}{llllll}1114 & 1125 & 1129 & 1152 & 1191 & 1199\end{array}$ $\begin{array}{llllll}1234 & 1236 & 1239 & 1274 & 1399 & 1442\end{array}$ $\begin{array}{lllllll}1526 & 1636 & 1678 & 1711 & 1781 & 1846\end{array}$ $\begin{array}{lllllll}1865 & 1891 & 1984 & 2010 & 2023 & 2056\end{array}$ $\begin{array}{llllll}2172 & 2284 & 2295 & 2310 & 2329 & 2405\end{array}$ $\begin{array}{lllllll}2422 & 2436 & 2485 & 2493 & 2507 & 2570\end{array}$ $\begin{array}{llllll}2573 & 2719 & 2804 & 2832 & 2902 & 2912\end{array}$ $\begin{array}{llllll}2925 & 2946 & 2950 & 2958 & 3014 & 3034\end{array}$ $\begin{array}{lllllll}3043 & 3103 & 3131 & 3134 & 3140 & 3142\end{array}$ $\begin{array}{llllll}3157 & 3183 & 3205 & 3251 & 3258 & 3297\end{array}$ $\begin{array}{lllllll}3332 & 3351 & 3359 & 3418 & 3423 & 3526\end{array}$ $\begin{array}{llllll}3527 & 3537 & 3555 & 3646 & 3648 & \text { see }\end{array}$ also Clan; Moities; Acculturation

Social status; position 135258619 $\begin{array}{llllll}620 & 1257 & 1354 & 2272 & 2333 & 2405\end{array}$ $\begin{array}{llll}2470 & 2759 & 2866 & 3253\end{array}$

Social workers 1038

Soil studies 1930

Solís, Antonio de 1981

Solís, Gaspar José de 1554

Solórzano, Juan de 2362

Song of Hiawatha 58862118242369 25992943

Sorcery see Witchcraft

Sosa, Castaño de 1577

Soto, Hernando de 14342118

South America 1137136515091547 $\begin{array}{llllll}1602 & 1820 & 2843 & 2948 & 3042 & 3066\end{array}$ 318833373657 see also countries

South Carolina 13511672

South Dakota 233678206262443 $\begin{array}{lllllll}520 & 786 & 800 & 922 & 952 & 1045 & 1094\end{array}$ $\begin{array}{llllll}1271 & 1272 & 1559 & 1619 & 1623 & 1686\end{array}$ $\begin{array}{lllllll}1737 & 1784 & 1892 & 1990 & 2656 & 3168\end{array}$ $\begin{array}{lllll}3234 & 3354 & 3356 & 3651\end{array}$ 
Southeast (the Carolinas, Georgia, Florida, Tennessee, Alabama, etc.) $\begin{array}{llllll}518 & 607 & 678 & 1008 & 1083 \quad 1129 & 1361\end{array}$ $\begin{array}{llllll}1468 & 1673 & 1859 & 1876 & 2038 & 2127\end{array}$ $\begin{array}{llllll}2134 & 2199 & 2331 & 2438 & 2579 & 2602\end{array}$ $\begin{array}{lllllll}2685 & 2958 & 2976 & 2998 & 3032 & 3118\end{array}$ $\begin{array}{llllll}3379 & 3383 & 3502 & 3584 & 3595 & 3603\end{array}$ see also Old Southwest

South Pass 3088

Southwest (Arizona, New Mexico, Texas, etc.) $42546897 \quad 128141$ $\begin{array}{llllllll}199 & 227 & 266 & 364 & 423 & 492 & 513 & 521\end{array}$ $\begin{array}{llllllll}627 & 674 & 706 & 722 & 789 & 790 & 827 & 838\end{array}$ $\begin{array}{llllllll}851 & 898 & 914 & 1103 & 1119 & 1139 & 1189\end{array}$ $\begin{array}{llllll}1233 & 1262 & 1340 & 1409 & 1484 & 1486\end{array}$ $\begin{array}{lllllll}1542 & 1550 & 1640 & 1659 & 1707 & 1742\end{array}$ $\begin{array}{lllllll}1744 & 1750 & 1755 & 1758 & 1922 & 1926\end{array}$ $\begin{array}{lllllll}1953 & 2021 & 2036 & 2042 & 2058 & 2074\end{array}$ $\begin{array}{llllll}2075 & 2078 & 2091 & 2176 & 2300 & 2347\end{array}$ $\begin{array}{lllllll}2459 & 2489 & 2551 & 2574 & 2736 & 2761\end{array}$ $\begin{array}{lllllll}2775 & 2841 & 2877 & 2915 & 2938 & 2961\end{array}$ $\begin{array}{lllllll}2988 & 3027 & 3043 & 3101 & 3167 & 3205\end{array}$ $\begin{array}{lllllll}3303 & 3375 & 3383 & 3445 & 3485 & 3507\end{array}$ $\begin{array}{lllllll}3538 & 3577 & 3648 & 3662 & 3669 & 3671\end{array}$ 3682

SPANISH (in America; general studies) $\begin{array}{lllllll}439 & 526 & 529 & 889 & 1057 & 1140\end{array}$ $\begin{array}{lllllll}1293 & 1404 & 1468 & 1552 & 1587 & 1624\end{array}$ $\begin{array}{llllll}1668 & 1681 & 1762 & 1876 & 1986 & 2104\end{array}$ $\begin{array}{llllll}2167 & 2297 & 2357 & 2385 & 2402 & 2520\end{array}$ $\begin{array}{llllll}2658 & 2681 & 2889 & 2911 & 3002 & 3031\end{array}$ 30913202333134663502 see also New Spain

Spanish Conquest $63 \quad 120 \quad 334$ $\begin{array}{llllll}484 & 540 & 770 & 892 & 1188 & 1371\end{array}$ $\begin{array}{llllll}1981 & 1998 & 2098 & 2633 & 2776 & 2842\end{array}$ 298032413334336034253483 3757

Spanish Colonial Government 709 796818873971101511801373 $1507 \quad 16721822183119332085$ 219623622387247625482655 2667294734173230

Spanish Colonization I20 132266 $\begin{array}{lllllll}411 & 514 & 530 & 533 & 616 & 540 & 644\end{array}$ $\begin{array}{lllllll}707 & 993 & 1350 & 1570 & 1680 & 1785\end{array}$ 201420512079236224122982 32903320336234293447

Spanish Language see Literature, Spanish
Speech $18322296 \quad 255231993503$ see also Linguistics; Literature; Oratory

S. P. G. see Religion

Spotswood, Gov. Alexander 826 18141999

State of Sequoyah 367

Steatite 3352

Stelae 2061

Stevens, Gov. Isaac I. 726

STONE; stone art 5445410051139 198220612244276129213352 3566 see also Pictographs

Flaked Implements 48811681545

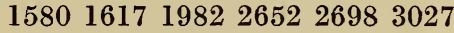
$\begin{array}{lllll}3039 & 3169 & 3600 & 3614 & \text { see also }\end{array}$ Weapons

Stuart, John 412228

Sullivan-Clinton campaign 1879

Sun Dance see Dance

Superstitions 315

Sycamore Canyon 819

Symbolism 4611821195622363240

Taft, William Howard 1503

Tahlequah 131

Tallahassee 368

Tam-mam Nacup 3672

Tammany 589

Tanana Valley 21022796

Tapia, Gonzalo de 3012

Taunton River 1433

Telegraph 2064

Telegraph and Texas Register 2862

Tennessee 11201124129016541768 $2398 \quad 2516 \quad 3513$

Terán Expedition 172

Termination see U.S., Bureau of Indian Affairs

Terror 1388

Tests; aptitude and ability 898933 $\begin{array}{llllll}1255 & 1261 & 1379 & 1445 & 1550 & 1660\end{array}$ $\begin{array}{llllll}1688 & 1828 & 1834 & 1892 & 1992 & 2077\end{array}$ $\begin{array}{lllllll}2309 & 2560 & 2596 & 2672 & 2693 & 2753\end{array}$ $\begin{array}{llllll}2783 & 3262 & 3453 & 3467 & 3494 & 3550\end{array}$ 3680 see also Education; Intelligence; Psychology

Kwalwasser-Dykema 1491

Rorschach 1020141824393420 
Texas 5253113155185221234252 $\begin{array}{llllllll}269 & 295 & 325 & 326 & 328 & 330 & 336 & 384\end{array}$ $\begin{array}{lllllllll}421 & 433 & 434 & 444 & 452 & 458 & 477 & 478\end{array}$ $\begin{array}{llllllll}479 & 496 & 499 & 502 & 529 & 530 & 536 & 578\end{array}$ $\begin{array}{llllllll}592 & 616 & 630 & 644 & 645 & 663 & 728 & 750\end{array}$ $\begin{array}{lllllllll}792 & 808 & 818 & 822 & 847 & 877 & 888 & 889\end{array}$ 9049119141068107011151210 $\begin{array}{llllll}1235 & 1249 & 1269 & 1342 & 1370 & 1429\end{array}$

$\begin{array}{lllllll}1447 & 1449 & 1487 & 1492 & 1494 & 1507\end{array}$ $\begin{array}{llllll}1508 & 1510 & 1512 & 1513 & 1532 & 1543\end{array}$

$\begin{array}{lllllll}1554 & 1570 & 1573 & 1650 & 1658 & 1683\end{array}$ $\begin{array}{lllllll}1692 & 1703 & 1731 & 1767 & 1797 & 1624\end{array}$ $\begin{array}{lllllll}1843 & 1845 & 1908 & 1927 & 1928 & 1989\end{array}$ $\begin{array}{llllll}1994 & 1995 & 2008 & 2025 & 2035 & 2049\end{array}$ $\begin{array}{lllllll}2051 & 2072 & 2112 & 2117 & 2178 & 2179\end{array}$ $\begin{array}{llllll}2194 & 2198 & 2224 & 2226 & 2245 & 2247\end{array}$ $\begin{array}{lllllll}2263 & 2313 & 2400 & 2410 & 2411 & 2454\end{array}$ $\begin{array}{lllllll}2511 & 2547 & 2559 & 2588 & 2608 & 2617\end{array}$ $\begin{array}{llllll}2644 & 2690 & 2723 & 2839 & 2864 & 2710\end{array}$ $\begin{array}{lllllll}2731 & 2750 & 2756 & 2782 & 2788 & 2865\end{array}$ $\begin{array}{lllllll}2880 & 2966 & 2987 & 2994 & 3000 & 3047\end{array}$ $\begin{array}{lllllll}3063 & 3155 & 3191 & 3200 & 3201 & 3206\end{array}$ $\begin{array}{lllllll}3212 & 3227 & 3235 & 3242 & 3243 & 3265\end{array}$ $\begin{array}{lllllll}3273 & 3276 & 3298 & 3335 & 3424 & 3428\end{array}$ $\begin{array}{lllllll}3431 & 3446 & 3500 & 3511 & 3540 & 3567\end{array}$ 3614

Texas, Republic of 23702471

Textiles (the finished product) 163 18728311261212126212651480 $\begin{array}{llllll}1596 & 1651 & 1749 & 2159 & 3148 & 3223\end{array}$ see also Weaving

Tezozomoc, Hernando Alvarado 725

The American Museum 3239

The Oregon Trail 27

The Population of the Valley of Teotihuacán 1146

The Yemassee 338

Thirteen Years on the North West Coast 287

Thomas, William Holland 2878

Thompson, David 3509

Thomson, Charles 1790

Thoreau, Henry David 183778959 $\begin{array}{llllll}1369 & 2467 & 2875 & 3247 & 3475 & 3556\end{array}$

Tierra del Fuego 556

Tilantongo 2833

Timber; lumber $\mathbf{3 7 5}$

Tipton, John 894

Tobacco 3008 see also Pipe

Tonto Natl. Monument 1749
Tonty, Henry de 10522118

Toluca 1467

Torres y Portugal, Fernando de 873

Torture 1796

Totemism 22312323028

Toxcatl 2601

Trade; commerce $16 \quad 103 \quad 438 \quad 807$ $\begin{array}{llllll}1149 & 1247 & 1332 & 1374 & 1389 & 1396\end{array}$ $\begin{array}{llllll}1777 & 1924 & 2062 & 2111 & 2255 & 2303\end{array}$ $\begin{array}{llllll}2359 & 2388 & 2402 & 2442 & 2449 & 2501\end{array}$ $\begin{array}{lllllll}2521 & 2610 & 2616 & 2830 & 2929 & 2976\end{array}$ $\begin{array}{lllllll}2998 & 3008 & 3060 & 3180 & 3212 & 3273\end{array}$ 33363653 see also Fur Trade; Economics

Inter-tribal trade 786612471296 139616111851204620752134 23033060

Trader frauds 1066

Traders 168337943043110661084 $\begin{array}{llllll}1201 & 1648 & 1922 & 2861 & 2874 & 3056\end{array}$ $\begin{array}{lllll}3394 & 3405 & 3407 & 3622 & 3663\end{array}$

Tradiciones Peruanas 3275

Trading Posts see Forts; U.S., Federal Trading Posts

Trails; Indian transportation routes 385219827982993

Trans-Pacific contacts 67012001355 169717522149 see also Oceania; Pacific

Transportation; White travel routes $\begin{array}{lllllll}217 & 369 & 385 & 875 & 1101 & 1558 & 1591\end{array}$ $\begin{array}{llllll}1872 & 2070 & 2109 & 2123 & 2198 & 2229\end{array}$ $\begin{array}{lllllll}2442 & 2664 & 2701 & 2798 & 2930 & 3004\end{array}$ 30463065308832093644 see also Exploration; Railroads

Travel Accounts; diaries, journals

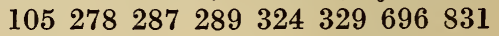
$\begin{array}{llllll}862 & 875 & 987 & 1013 & 1044 & 1123 \quad 1140\end{array}$ $\begin{array}{llllll}1195 & 1295 & 1338 & 1343 & 1455 & 1496\end{array}$ $\begin{array}{llllll}1565 & 1624 & 1808 & 1932 & 1976 & 2021\end{array}$ $\begin{array}{llllll}2039 & 2079 & 2229 & 2297 & 2543 & 2567\end{array}$ $\begin{array}{llllll}2807 & 2874 & 3108 & 3209 & 3300 & 3339\end{array}$ 334034413556 see also Exploration

Treaties $562 \quad 868 \quad 1564 \quad 2939 \quad 3090$ $\begin{array}{llll}3280 & 3333 & 3589\end{array}$

Albany 1814

Augusta 2385

Ft. Jackson 3032

Ft. Stanwix 508 
Treaties, contd.

Gadsden 3495

Ghent 20273309

Greenville 1071902

Medicine Lodge 568

Mendota 3280

San Lorenzo 3647

Traverse des Sioux 3280

Treaty of 1866,1663

Treatment of captives 2926

Tree-ring dating see Archaeological dating; Dendrochronology

Trent, William 3056

Tribal land claims see Land Claims; Land Titles

Troup, George McIntosh 2671

Tuberculosis 1091

Tucson 117617743305

Tulsa 3076

Turquoise 1484

Twin War Gods 2285

Tzintzuntzán 216

Ugalde, Juan de 2413

Ugarte, Juan de 17453291

Ukiah Valley $1016 \quad 1236 \quad 1422 \quad 2564$ 28082809

UNESCO 780

United Fruit Company 87

UNITED STATES

Administration of Indian Affairs, Federal: $55 \quad 116 \quad 356432 \quad 1503$ 152918861912201324833168 32043310 3327. State: 1563 161919192398242825472720 3168

Bureau of Indian Affairs 116528 $919 \quad 1106 \quad 1450 \quad 1721 \quad 3110$ see also Education

Relocation policy 102310922732

Supt. of Indian Affairs 411721 $1978 \quad 2410 \quad 2411$

Withdrawal policy; Termination 7812428

Congress 6561018110617132364 302331943605

Federal Trading Posts 3091149 203426302905

Govt. Documents 4510181713 see also Bibliography
United States, contd.

Govt. Indian Policy 190320362 391395402413429450467469 $\begin{array}{lllllll}569 & 594 & 595 & 676 & 700 & 764 & 772\end{array}$ $\begin{array}{llllll}940 & 975 & 1002 & 1075 & 1133 & 1148\end{array}$ $\begin{array}{lllllll}1362 & 1419 & 1486 & 1487 & 1506 & 1604\end{array}$ $\begin{array}{lllllll}1633 & 1795 & 1797 & 1807 & 1811 & 1852\end{array}$ $\begin{array}{llllll}1859 & 1912 & 1927 & 1991 & 2142 & 2161\end{array}$ 216621952364237923932437

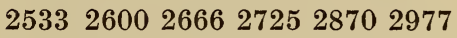
300930903194323432383310 35203589 see also Church and State; Education; Land

Govt. Indian Relations 88219393 $497 \quad 664 \quad 677 \quad 747824 \quad 1026 \quad 1036$

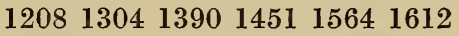
$\begin{array}{llllll}1686 & 1877 & 1919 & 1966 & 2100 & 2210\end{array}$ 232223422379242125472563 263726692800280529002939 297929853261326833683376 339834063515358136053681 see also Land; Removal; Warfare

Indian Agents 602834843894 119816691995201922282280 241024112445297530683470

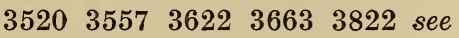
also Forts ; Reservations

Interior Dept. 23643110

Senate; Senators $663 \quad 952 \quad 1049$ 14742165

War Dept. 23642365 see also Warfare

U.S. Overland Mail 3065

Urdiñola, Francisco de 7332266

Ursulines 534

Utah 36445062393697712701303 $\begin{array}{llll}2767 & 3127 & 3660 & 3664\end{array}$

Valdivia, Luís de 766

Valdivia, Pedro de 149

Vallejo, Mariano Guadalupe 1986

Values $\begin{array}{llllll}310 & 485 & 486 & 600 & 912 & 1344\end{array}$ $2126 \quad 2304 \quad 312933553393$

Vancouver, Capt. George 2836

Van Dorn, Earl 1407

Vargas, Diego de 376967

Vasconcelos, José 2869

Velasco II, Luís de 1015

Venezuela 17592055

Verde Valley 47 
Veterans, World War 933933599

Vicos 2172

Villages; village arrangement 1636 16372719

Villagrá, Gaspar de 23253678

Virginia 60374460517648649699 $\begin{array}{lllllll}826 & 880 & 886 & 910 & 955 & 1067 & 1276\end{array}$ $\begin{array}{llllll}1332 & 1412 & 1452 & 1538 & 1562 & 1607\end{array}$ $\begin{array}{lllllll}1685 & 1801 & 1813 & 2096 & 2457 & 2798\end{array}$ $\begin{array}{lllll}2813 & 2814 & 2936 & 3404 & 3412\end{array}$

$\begin{array}{lllll}\text { Vocabulary } & 2543 & 2560 & 2596 & 2647\end{array}$ 291533343543 see also Linguistics; Place Names

Voltaire 710

Voting 878952

Walker, Gov. Robert J. 1964

Walla Walla 2261

Walpole Is. 1898791661

Wampum 17773008

Wardship 3204 see also Citizenship

WARFARE; Indian Wars in general 20083712061526179618362138 $\begin{array}{llllll}2310 & 2705 & 2766 & 2927 & 2973 & 3084\end{array}$ $\begin{array}{lllll}3103 & 3301 & 3371 & 3564\end{array}$

Civil War 12113186231248378 623630767949127314071416 164427122864305331763511 War of 1812 - 12481435

French and Indian War 11731364 163218011941215429623122 Indian Raids and Depredations $\begin{array}{llllll}701 & 1259 & 1284 & 1341 & 2468 & 2483\end{array}$ $25513508 \quad 3511$

Indian Revolts and Uprisings 507 7131086

Apache Wars 33423633

Baja California 507

Bannock War 371

Berks County War 1463

Chichimeca War 2655

Choctaw Revolt 2528

Huron-Iroquois War 1096

King Philip's War 5001882 29993363

Lord Dunmore's War 460500 186726413412

Meeker Massacre 2453

Mexico City Revolt 1541

Miami Revolt 1285
Warfare, contd.

Modoc War 19116673306

Pima-Papago Revolt 340

Pima Uprising 985

Pueblo Revolt $63 \quad 376 \quad 967 \quad 1330$ $\begin{array}{lllll}1331 & 1831 & 2688 & 2699 & 3428\end{array}$

Red River Insurrection 2769

Riel Insurrection 2768

Rogue River Wars 22062508

Sioux Wars 231428163398

Smoked Meat Rebellion 301

Sonora 2181

Spirit Lake Massacre 2267

Tehuántepec Revolt 1541

Tepehuán Revolt 2141

Utah Indian War 177

Ute Uprising 282

Yakima War 259

Indian Scouts (U.S. Army) 1557

Inter-tribal Wars 230345417548 $\begin{array}{llllll}600 & 1096 & 1336 & 1582 & 1740 & 2927\end{array}$ 2974

Mexican War 12981665

Revolutionary War $201306 \quad 416$ $\begin{array}{llllll}505 & 715 & 1095 & 1132 & 1441 & 1593\end{array}$ 163217292169219925372685 2887301531003576

Seven Year's War 2590

U.S. Army $1557 \quad 1576 \quad 18432073$ 25082483

U.S. Military Campaigns and military activities $211 \quad 427 \quad 473$ $\begin{array}{llllllll}511 & 630 & 680 & 695 & 750 & 766 & 957\end{array}$ $\begin{array}{llllll}1298 & 1424 & 1463 & 1576 & 1656 & 1847\end{array}$ $\begin{array}{lllllll}1853 & 1879 & 1888 & 1889 & 2045 & 2073\end{array}$ 234523652407241324462448 248330073265339834683564

Military Battles with Indians

Black Hawk War 17713392088 28533642

Creek War 2543292

Fallen Timbers 2016

Little Big Horn 3554

Nez Percé War 10272939

Seminole War 68022462534 27572933325434763605

Tippecanoe 2324

Wounded Knee 3521

Washakie Colony 977 
Washington $406 \quad 454 \quad 618 \quad 619 \quad 680$ 6939019022162257825942714 2965301632193343

Washington, D.C. 2017

Washington, George 37712771941

Water travel; canoes 2041

Wautauga 1867

Weapons 2001725276627813206 3600

Weaving (the technique) 74283365 $570599970 \quad 1517167124962591$ 30423364 see also Textiles

Weber, Anselm 3534

Weiser, Conrad 11981260

Welfare work 1732

Wetherill, Louisa \& John 1201

Whaling 1443

Wheeler-Howard Act see Indian Reorganization Act

Whitman, Marcus 3531

Whorf, Benjamin Lee 2114

Wilkes Exploring Expedition 2696

Willamette Valley 2207

Williams, Roger 373

Winslow, Edward 500

Wisconsin $134 \quad 531 \quad 1038 \quad 2349 \quad 2587$ $\begin{array}{llllll}2792 & 2793 & 2857 & 2884 & 3054 & 3336\end{array}$
Witcheraft; sorcery 33813517

Wolfskill Party 1589

Women; girls 8581589590840869 $\begin{array}{llllll}1543 & 1781 & 1939 & 2586 & 2808 & 2820\end{array}$ $\begin{array}{lllllll}2925 & 2950 & 2965 & 3025 & 3141 & 3253\end{array}$ $\begin{array}{llllll}3288 & 3374 & 3445 & 3604 & 3646\end{array}$

Wood $1454 \quad 2041 \quad 3101 \quad 3117 \quad 3566$ see also Timber

Wrangell Institute 2174

Wyoming $228 \quad 358 \quad 359 \quad 447 \quad 449 \quad 932$ $\begin{array}{llllll}1318 & 1322 & 1545 & 1625 & 2334 & 2648\end{array}$ $\begin{array}{lllll}3099 & 3166 & 3323 & 3397\end{array}$

Wyoming Valley controversy 1322

Ximénes de Cisneros 3214

Ximénes de Quesada, Gonsalvo 3425

Yellowstone Natl. Park 1931625

Yellowstone River 20702374

Yosemite Natl. Park 1104

Yuma 2443

Zacatecas Mining Rush 1087

Zarzal 2918

Zeisberger, David 2371

Zumárraga, Juan de 2378

Zúñiga, Âlvaro Manrique de 3430 


SMITHSONIAN INSTITUTION LIBRARIES

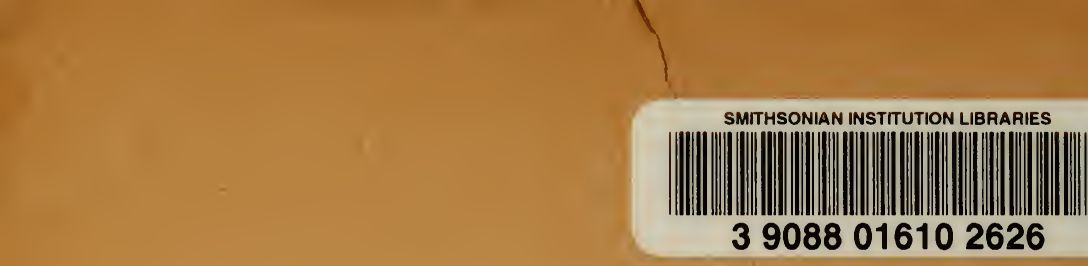

